Miriam M. Müller

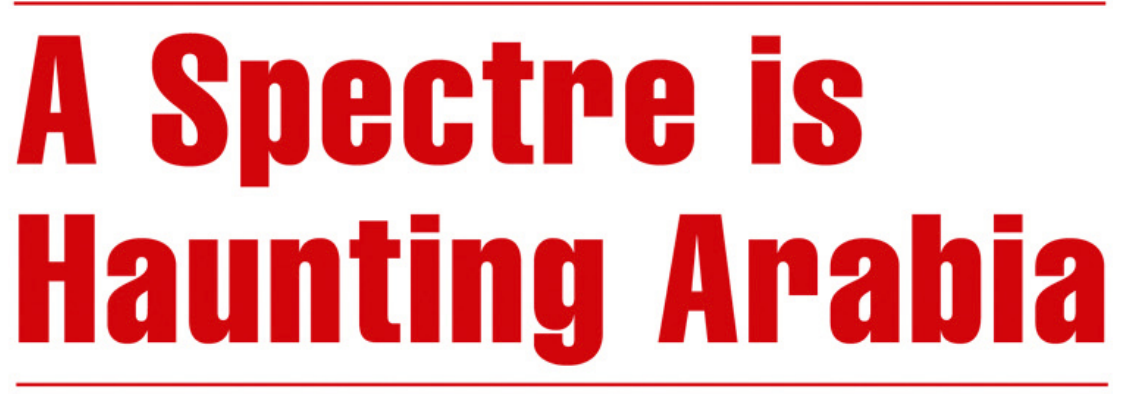

How the Germans Brought

Their Communism to Yemen

[transcript] Political science 
Miriam M. Müller

A Spectre is Haunting Arabia

Political Science | Volume 26 
This book is dedicated to my parents and grandparents.

I wouldn't be who I am without you.

Miriam M. Müller (Joint PhD) received her doctorate jointly from the Free University of Berlin, Germany, and the University of Victoria, Canada, in Political Science and International Relations. Specialized in the politics of the Middle East, she focuses on religious and political ideologies, international security, international development and foreign policy. Her current research is occupied with the role of religion, violence and identity in the manifestations of the »Islamic State«. 
Miriam M. MÜLler

\section{A Spectre is Haunting Arabia}

How the Germans Brought Their Communism to Yemen

[transcript] 
My thanks go to my supervisors Prof. Dr. Klaus Schroeder, Prof. Dr. Oliver Schmidtke, Prof. Dr. Uwe Puschner, and Prof. Dr. Peter Massing, as well as to my colleagues and friends at the Forschungsverbund SED-Staat, the Center for Global Studies at the University of Victoria, and the Political Science Department there.

This dissertation project has been generously supported by the German National Academic Foundation and the Center for Global Studies, Victoria, Canada. A Dissertation Submitted in (Partial) Fulfillment of the Requirements for theJoint Doctoral Degree (Cotutelle) in the Faculty of Political and Social Sciences ofthe Free University of Berlin, Germany and the Department of Political Scienceof the University of Victoria, Canada in October 2014.

\section{(C) $(1) \Theta$}

This work is licensed under the Creative Commons Attribution-NonCommercial-NoDerivs 4.0 (BY-NC-ND) which means that the text may be used for noncommercial purposes, provided credit is given to the author. For details go to http://creativecommons.org/licenses/by-nc-nd/4.o/.

To create an adaptation, translation, or derivative of the original work and for commercial use, further permission is required and can be obtained by contacting rights@transcript-verlag.de

\section{(C) 2015 transcript Verlag, Bielefeld}

\section{Bibliographic information published by the Deutsche Nationalbibliothek}

The Deutsche Nationalbibliothek lists this publication in the Deutsche Nationalbibliografie; detailed bibliographic data are available in the Internet at http://dnb.d-nb.de

Cover-Layout: Kordula Röckenhaus, Bielefeld Proof-Reading: Mike Barber, MA Political Science

Typeset: Christian Schmal, Zauberfeder Verlag Printed by Majuskel Medienproduktion GmbH, Wetzlar Print-ISBN 978-3-8376-3225-5 PDF-ISBN 978-3-8394-3225-9 


\title{
Content
}

\author{
Abbreviations (German and English) | 11 \\ Preface $\mid 13$
}

\section{A. ANALYTICAL FRAMEWORK}

Chapter 1. Then and Now: Why the Past of Yemen's South and the GDR's Role in it matter $\mid 19$

1. An Analysis of the GDR's Foreign Policy - A Fruitless Endeavor? | 22

2. Puzzle, Hypotheses, and Structure - How the Research Question generates the Analytical Approach | 26

\section{Chapter 2. State of Research: The Selection of Sources for an Interdisciplinary Project $\mid 31$}

1. History of a Divided Germany's Foreign Policy: Asymmetric Endeavors and Availability of Sources | 31

2. Secondary Sources in Focus I: Germany's Divided History and Foreign Policy $\mid 33$

3. Secondary Sources in Focus II: Cold War Studies, the Middle East and Modern Yemen | 36

4. Primary Sources: Between Archival and Personal Depths $\mid 40$

\section{Chapter 3. Analytical Approach: An Interdisciplinary Analysis of Foreign} Policy | 47

1. Foreign Policy - Where the Nation State ends $\mid 48$

2. How to assess Foreign Policy: Tools and Criteria $\mid 55$

3. Foreign Policy ends at the other State's Sovereignty $\mid 5^{8}$

4. The major Hypothesis: The GDR's Foreign Policy as a Policy of State- and Nation-Building | 68 


\section{B. ANALYSIS}

\section{PART I - The GDR as a Foreign Policy Actor}

\section{Chapter 4. Squeezed between Bonn and Moscow:}

The GDR's Foreign Policy - An Overview $\mid 77$

1. Political Prologue: The Cards are shuffled anew - Two German States and the Rules of the Cold War $\mid 78$

2. Priorities from the "Phase of Recognition" to the "High Times of Diplomacy" 80

\section{Chapter 5. Phase I - Between Internal Consolidation and International Recognition $\mid 85$}

1. The Soviet Union and the Warsaw Pact: In the Beginning there was Moscow $\mid 85$

2. Bonn - A Permanent Benchmark? The GDR's Attempt to promote itself as the "Alternative Germany" | 90

3. On the "Road to Recognition": The Turning-Point of East German Foreign Policy | 94

\section{Chapter 6. Phase II: From No.2 of the Eastern Bloc to just another}

\section{Isolation: The "Policy of Self-Assertion" | 97}

1. Keeping the Distance to Bonn - Oscillating between "Rapprochement" and "Dissociation" $\mid 98$

2. Growing Distance to "Brother Moscow": "Steadfast Friendship" in Danger? | 101

3. The Double-Edged Sword of International Recognition and the End of the GDR $\mid 103$

\section{Chapter 7. The "Three Spheres of Foreign Policy Making": Party, State,} and Society $\mid 109$

1. On the Political System of the GDR and its Social Reality $\mid 110$

2. Ideological Principles and Foreign Policy in "Socialist Germany" | 122

3. Foreign Policy Actors, Competencies and the Decision-Making Process: The “Three Spheres Approach" | 125

4. Summary: Competencies and Influences over Time | 151 


\section{Chapter 8. The GDR and the "Arab World": A Small State's "Fill-In}

Policy" | 157

1. The Middle East between Washington and Moscow - Pawn or Player? | 158

2. The GDR's "Policy of Recognition" translated to the Middle East $\mid 167$

3. The GDR and the Middle East: During the "High Times of Diplomacy" | 172

4. Means to an End - The GDR's Foreign Policy Strategies in the Arab World | 175

5. Conclusion: the GDR in the Middle East - A Showcase of East German Foreign Policy Strategies $\mid 183$

\section{Chapter 9. Forging a National Identity in Yemen's South - Social Change between Foreign Interference and a Fragmented Nation $\mid 187$}

1. On the Relevance of Identities for this Study $\mid 187$

2. From Tribal Lands to a Divided Yemen: A History of Foreign Interference 190

3. Determining a Yemeni identity in the South $\mid 195$

4. Ideological Templates: Political Influences from the Middle East and Europe 209

5. Synthetic Politics in Yemen's South: A Marxist State from Scratch | 221

\section{Chapter 10. Methodological Prelude: Connecting the Case Study, the Foreign Policy Phase Analysis and the State- and Nation-Building Approach 229}

1. Two Germanys, two Yemens and the Cold War: How East-Berlin "lost" the North and "won" the South 229

2. Phases of the GDR's Involvement in South Yemen: Internal Developments determine External Foreign Policy Engagement | 235

3. Factionism, Alliances and Executions as a Political Means - The Unstable Milieu of South Yemeni Politics $\mid 236$

4. The Major Hypothesis: The GDR's Foreign Policy as a Policy of Socialist State- and Nation-Building $\mid 238$ 
Chapter 11. Phase 1: The Phase of Sampling and Creation from 1963 to 1969/70 - A Constitutional Draft and the Road to Recognition | 245

1. The Revolutionary Phoenix from Aden's Ashes: Opting for a Socialist State 245

2. Soviet Engagement in South Yemen:

When Aden shed its Geostrategic Invisibility Cloak | 250

3. The Phase of Sampling: From First Contact to

Socialist Nation- and State-Building $\mid 252$

4. Conclusion: East-Berlin's new ally by the Red Sea $\mid 261$

Chapter 12. Phase II: The Phase of Establishment and Expansion 1969/70 to 1978 - Incorporating Marxism-Leninism in a Tribal Society | 265

1. Internal Developments: The First Steps towards a Socialist State | 265

2. Soviet Interests and Fields of Engagement:

From Suspicion to "Best-Friends-Forever" | 270

3. The Phase of Expansion: The GDR as the Director of "Civilian Matters" of Socialist Nation- and State-Building in South Arabia | 275

4. Conclusion: South Yemen as the Model Case of a Possible East German Foreign Policy| 293

Interlude: South Yemen - A "Rough State" in the Region and in the World | 297

1. Aden - Actor and Pawn in the Cold War Game 297

2. Between Conspiracy Theories and Security Policy:

East Berlin, Aden and International Terrorism | 302

Chapter 13. Phase III: The Phase of Continuity and Consolidation from 1978 to 1986 - German Guidance and Yemeni Emancipation | 307

1. Aden hovering between the Peak and Abyss of its Political and Economic Development $\mid 307$

2. Aden - A Soviet "First-Priority Goal" in the Arab World | 312

3. Consolidation and Continuity of East German Socialist Nation- and State-Building: How the GDR's foreign policy tied in with the YSP's approach $\mid 316$

4. Conclusion: East-German Engagement Swings from Enthusiasm to Disillusion | 326 
Chapter 14. Phase IV: The Phase of Neglect from 1986 to 1990 - The "Ice Age" of relations and the End of Socialist State-Building $\mid 329$

1. Internal Developments: The Last Throes of a Wounded and Dying State $\mid 330$

2. "Soviet dilemma at the Gate of Tears": Between Influence, Imposition and Lack of Control | 335

3. The Caesura of 1986 and its Aftermath during the Phase of Rejection: SED-State or Honecker-Centered Policy? | 341

4. Conclusion: Belated and Unfortunate Self-Confidence: East-Berlin wanders off the Soviet Course | 351

\section{FINDINGS}

\section{Chapter 15. On the External and Internal Empirical "Limits" of East German Foreign Policy | 357}

1. External Determinants of East German Foreign Policy | 357

2. Internal Limits of Foreign Policy: Between Economic Exhaustion, "Double Standards" and Political Friction $\mid 363$

\section{Chapter 16. South Yemen as the Model Case of a Possible East German Foreign Policy $\mid 369$}

1. Best Friends with Benefits: Soviet and East German Engagement in South Yemen as Part of a Regional Strategy in the Region $\mid 370$

2. Advocacy for an East German Foreign Policy in its own Right $\mid 373$

3. The GDR in South Yemen: A Phase Analysis of Foreign Policy | 375

4. South Yemen as the Exceptional Case and an Approximation to the "Ideal Type" of East German Foreign Policy | 379

\section{Chapter 17. Moscow, East Berlin and the "Hawks of Hadramawt" - Nation} Building or Neo-Colonialism in Southern Yemen? | 383

1. How to explore the "Limits of Foreign Policy" $\mid 383$

2. The GDR's Policy of Socialist State- and Nation-Building: Motives and Strategies $\mid 385$

3. The Impact of Socialist Nation-Building on South Yemen and its Society: A truly Marxist State in the Arab World? 388

4. South Yemen: Subject or Object of Foreign Policy? 391

\section{ANNEX}

I. Bibliography $\mid 397$

II. Archival Documents $\mid 425$ 



\section{Abbreviations (in German and English)}

\section{AASK - Afro-Asiatisches Solidaritätskomittee}

ADN - Allgemeiner Deutscher Nachrichtendienst

AGM - Arbeitsgruppe des Ministers (des MfS)

AHB - Außenhandelsbetrieb

ASR - Akademie für Staats- und Rechtswissenschaft der DDR

(Potsdam-Babelsberg)

ATUC - Aden Trades Union Congress

AzAP-BRD - Akten zur Auswärtigen Politik der Bundesrepublik Deutschland

BCD - Bewaffnung und Chemischer Dienst (MfS); Verw. 1972-1989

BKK - Arbeitsgruppe Bereich Kommerzielle Koordinierung

BStU - Bundesbeauftragte(r) für die Unterlagen des Staatssicherheitsdienstes

der ehem. DDR

CC - Central Committee of the SED (German: Zentral Komitee)

CSCE - Conference on Security and Cooperation in Europe

DEWAG - Deutsche Werbe- und Anzeigegesellschaft

DzAPR-DDR - Dokumente zur Außenpolitik der Regierung der DDR

FDJ - Freie Deutsche Jugend; English: Free German Youth

FLOSY - Front for the Liberation of Occupied South Yemen

GDR - German Democratic Republik

(Ger: Deutsche Demokratische Republik, DDR)

HIM - Hauptamtlicher Inoffizieller Mitarbeiter (category for inofficial employees of the MfS)

HIM/A - Hauptamtlicher Inoffizieller Mitarbeiter/Aufklärung (category for inofficial employees of the MfS)

HIME - Hauptamtlicher Inoffizieller Mitarbeiter im besonderen Einsatz

(category for inofficial employees of the MfS)

HVA - Department of Surveillance (Ger: "Hauptverwaltung Aufklärung”)

IMB - Inoffizieller Mitarbeiter der Abwehr und Feindverbindung /zur

unmittelb. Bearbeitung im Verdacht der Feindtätigkeit stehenden Personen ab 1979 (English: category for inofficial employees of the MfS)

IMS - Inoffizieller Mitarbeiter zur Sicherung 
und Durchdringung eines Verantwortungsbereiches; bis 1968: GI bzw. GHI ((category for inofficial employees of the MfS)

ITA - Ingenieurstechnischer Außenhandel; Waffenhandelsfirma

JSP - Jemenitisch Sozialistische Partei (English: Yemeni Socialist Party)

KoKo - Kommerzielle Koordinierung - Sonderbereich des Ministeriums für

Außenhandel

MAN - Movement of Arab Nationalists

MfAA - Ministerium für Auswärtige Angelegenheiten

(Eng: Department of Foreign Affairs)

MfS - Ministerium für Staatssicherheit; English: Ministry for State Security

NLF - National Liberation Front (of the PDRY)

OPK - Operative Personenkontrolle - Konspirativer Vorgang zur Aufklärung

und Überwachung von Personen

OTS - Operativ Technischer Sektor

PDB - Personendatenbank der DDR (des MdI)

PDU - People's Democratic Union (of South Yemen)

PDRY - People's Democratic Republic of Yemen

PFLP - Popular Front for the Liberation of Palenstine

PK - Kontaktperson (MfS, VA)

SED - Sozialistische Einheitspartei Deutschlands;

English: United Socialist Party

SFD - Staatlicher Funkdienst (MfS)

SPC - Supreme People's Council

VRD - Verwaltung Rückwärtige Dienste (MfS und NVA)

YSP - Yemeni Socialist Party (Ger: JSP - Jemenitisch Sozialistische Partei)

ZK - Zentral Komitee 


\section{Preface}

"To the desert, and the Bedouin, the coming of the British was a small whim of God. There is something enduring about the huge sand dunes, the endless empty horizons, the foul water and solitary wandering camels and the sublimely arrogant Bedouin soul. The Romans, the Abyssinians, the Turks, the British have all in their turn come, and in their turn have gone. Whoever comes next will leave as shallow an imprint." ${ }^{1}$

Alfree, "The Hawks of Hadramaut", 1967

Of all the possible successors it was the politically dwarfish German Democratic Republic (GDR) following in the footsteps of the giant that was the British Empire. Even though officially without a mission to colonize, or the means to do so, the GDR and its leading party SED ${ }^{2}$ without doubt aimed to leave a substantial "imprint" in Yemen, or more precisely, its southern region. The GDR's foreign policy in the People's Democratic Republic of Yemen (PDRY) ${ }^{3}$ was designed to reproduce its very own state- and nation-building process, the "planned development of Socialism." ${ }^{44}$ Until its accession to the Federal Republic of Germany in 1990, ${ }^{5}$ the GDR had been expanding this strategy step by step and, with the Kremlin's approval, maintained intensive contacts to the South Yemeni regime throughout the existence of the PDRY.

So why does the impact of a demised state's foreign policy on another longgone state and nation even matter? First, as this analysis will show, the GDR's engagement in South Yemen's state-building process is highly underrepresented

1 | Alfree, 1967, 192.

2 | Sozialistische Einheitspartei Deutschlands.

3 | The People's Republic of South Yemen renamed itself in 1970.

4 | German: planmäßiger Aufbau des Sozialismus. Schroeder, 2013, $110 \mathrm{ff}$.

5 | For example, a visit by a South Yemeni delegation of the Ministry of Interior in the GDR in August 1989, in: Bericht über den Aufenthalt einer Delegation des Mdl in der VDRJ, July 25 to August 1 1989, in: BStU MfS HA VII7954, 43ff. 
in today's foreign policy history narratives of the PDRY, the GDR and the USSR alike $^{6}-$ mostly due to remaining gaps in archival research. As a consequence, this case study also aims to complement recent research on the role of the Arab states in the Cold War. Second, current analyses and assessments by the Western media on the Yemeni transition process after 2011 and the abrupt termination of the internationally mediated National Dialogue in the wake of large-scale armed conflict in Yemen in early 2015, ${ }^{7}$ tend to ignore the complexity of Yemen's social and political structure and the resulting conflicts. Especially since the launch of Saudi Arabia's "Decisive Storm" operation against the Houthi movement, Western media and self-declared experts appear to be in favor of more accessible but regularly oversimplified explanations for the current escalation of violence in Yemen. The popular focus on the Sunni-Shiite nature of the struggle, swiftly reinterpreted as a "proxy war" between Riad and Teheran, is only one example among many.

Almost invisible in Western media coverage of Yemen is the history of half the country: the deceased Marxist state in the south and its remnants in today's Yemeni society. ${ }^{9}$ In Yemen, the new interpretation of a separate southern identity has been gestating for almost a decade now. Waving the PDRY flag and commemorating the anniversaries of British withdrawal from Aden in 1967 or secession from the north in $1994,{ }^{10}$ the identity of the Southern Movement draws from integrative symbols and memories of the former PDRY. This case study claims that South Yemen's state-building process and its actual manifestation as a state cannot be explained in a comprehensive way without taking into consideration Moscow's and East Berlin's intensive engagement and presence there. Whether the East German "imprint" has to be considered just as "shallow" as the preceding foreign powers' is another question of this analysis. This book is not about today's struggle for peace and stability in Yemen. First and foremost, it is an historic case study of the German Democratic Republic's activities in South Yemen, the only Marxist state that ever existed in Arabia ${ }^{11}$ and at times the closest and most loyal ally to the Soviet Union in the region. However, this book also aims to raise awareness of the roots of one of today's major internal divides in Yemen, the identity rift between north

6 I Usually, the GDR's activity is mentioned in relation to the presence of other states of the Eastern Bloc in South Yemen, such as the ČSSR. Halliday, 1990, 207. The same may be said for overviews on the GDR's foreign policy. Wentker, 2007, 286.

7 | Steinvorth, 2015; Stenslie, 2015.

8 | Avenarius, 2015.

9 | "Yemeni" is an onomatopoeic approximation to the Arab adjective "yemenī".

10 | Madabish, Divisions within Yemen's Al-Hirak delay announcement of Southern independence, in: Al-Sharq Al-Awsat, December 1 2014; Augustin, 2015, 53.

11 | Historic Term; "Arabia [...] is that great peninsula formed by the Arabic Gulph [sic!], the Indian Ocean, and the Persian Gulph[sic!]," in: Niebuhr, 1792, 5. 
and south. The main transition mechanism, the National Dialogue, was the first attempt to acknowledge the different interests of the major factions, but it failed to equally include and bind all parties, among them the Southern Movement. Hoping against hope that Yemen as a state will survive this crisis, Yemenis with the will and the ability to build a new Yemen will have to achieve the impossible: the integration of all social forces into the process of political transition, so that each and every one of them can claim this process as their own. We remember former President Ali Abdallah Saleh's ${ }^{12}$ famous quote: ruling Yemen was "like dancing on the heads of snakes."13 Today, Saleh wants the world to believe that he is the only leader able to get Yemen back on track. ${ }^{14}$ But by perpetuating his system of patronage and corruption, Saleh has turned out to be very much part of the problem. Thus, with the serpent charmer Saleh gone, the key for Yemen's transformation is not only to leave the old basket and flute behind, but the decision of each and every snake to be part of this transformation, to shed its skin and become a very different kind of political animal for the sake of a common goal: a happy Yemen.

12 | Arabic: Alī Abdallah Săleḥ; The Party's leading figure Saleh had already been head of state in the northern Yemen Arab Republic (YAR) since 1978 and had kept his power position in unified Yemen as well.

13 | Clark, 2010.

14 | Schiavenza, Yemen's Wily Puppet Master. Ali Abdullah Saleh, ousted in the Arab Spring protests, has re-emerged as the country's most influential man, March 292014. 

SECTION A. ANALYTICAL FRAMEWORK 



\title{
CHAPTER 1. Then and Now:
}

\section{Why the Past of Yemen's South and the GDR's Role in it matter}

\author{
" “ God, the nation, revolution, unity!”1 \\ National Motto of Unified Yemen since 1994 \\ "[Ismail] knew not to unite with the north and he was right, \\ look what happened since 1990. [...] The truth is we really \\ lost our leadership in 1986 after that we went downhill. \\ how we united, i dont know? The fact is if [Ismail and the \\ former leaders of the Left] were still alive; we'd be better \\ off! [sic!]"2
}

Yemeni BLOGGeR LIVING IN THE U.S. COMmenting ON A SOUth

YEMENI PROTEST IN WASHINGTON IN 2009

The case of South Yemen is exceptional in more ways than one. After ousting the British from their Crown Colony in 1967, the South Yemeni regime seized power to erect a new, socialist state from scratch. The radical South Yemeni leaders aimed at eradicating both the remnants of British occupation, but also the traditional socio-political structures of Yemeni society. At times in their state's history, especially during the years of economic growth in the late 1970s and early 1980 s, it appeared as if they had succeeded. However, the Marxist experiment turned out to be rather short-lived. After the "1986 crisis", an inner-party struggle of the Yemeni Socialist Party (YSP) followed by a bloody civil war, the majority of the revolutionary leaders were dead, exiled, or imprisoned. The PDRY never recovered from this political and economic blow. Yemeni unification in 1990 was followed by another civil war, this time between the former north and south. In the end, "Marxist Arabia" disappeared from the map without a trace. ${ }^{3}$ During Yemeni unification, the former Yemen Arab Republic (YAR) of the north simply expanded its former political system with minor adjustments. The YAR's major

1 | World Heritage Encyclopedia, National Motto.

2 | South Yemeni Protest in Washington, YouTube Photography and Comments, July 72009.

3 | On the role of artificial borders and the construction of social realty through their demarcation on maps: Willis, in: Al-Rasheed, 2004. 
party, the General People's Congress (GPC) led by its President, Ali Abdallah Saleh, ${ }^{4}$ claimed power. Ever since, Yemeni school children have started their school day by shouting the motto of a supposedly unified nation:

$$
\text { “ الله، الوطن، الثورة، الوحدة”, - God, the nation, revolution, unity!”5 }
$$

This motto must be considered part of the GPC's, or rather Saleh's, wider policy to overcome the country's fragmented and stratified nature to create a unified national Yemeni identity. ${ }^{6}$ Thus, the re-emergence of a distinct southern identity about a decade later in January 2007 came as a surprise to the majority of external and even some internal observers. Due to feelings of discrimination and marginalization, former South Yemeni military personnel had initiated protests on the occasion of the anniversary of the "1986 massacre", as they would call the incident. The appeals of retired officers for equality and compensation drew especially the young, and the loose congregation of protestors mutated into what is called the Southern Movement today, or just "The Movement": Al-Hirak. ${ }^{7}$ Fragmentation at this point had not been overcome and after the Arab Upheavals of 2011 and Ali Abdallah Saleh's downfall the year after, the "Southern Question" emerged as one of the main obstacles to Yemen's current transformation process. ${ }^{8}$ Waving the PDRY-flag today, a significant part of Al-Hirak has been advocating for secession from the Republic. ${ }^{9}$ Supported by a weakened $\mathrm{YSP}^{10}$ and former PDRY functionaries, the secessionists challenge and thus endanger not only Yemen's national unity today, but also its possible post-crisis transformation. How and why did this separate and clearly artificially constructed identity survive? Where are its origins and who had an active part in its formation? The historic references to the PDRY used by Al-Hirak, glorification of day-to-day life in former South Yemen,

4 | Arabic: Ali Abdallah Saleh; The Party's leading figure Saleh had already been head of state in the northern Yemen Arab Republic (YAR) since 1978 and had kept his seat in unified Yemen as well.

5 | World Heritage Encyclopedia, National Motto.

6 | On the history of socio-political fragmentation in Yemen: Dresch, 1993 and 2000.

7 | Arabic: Al-Hirak, Augustin, 2015 and Day, 2012, Rise of the Southern Movement, $227 \mathrm{ff}$. Even though Day's analytical approach to Yemen's modern history has to be rejected as overly simple, his account on the events of the last two decades offers an elaborate summary of recent political developments in the country.

8 Among others like the Houti conflict in the north. On the dynamics of the Houti Conlfict: Brandt, 2013.

9 | Thousands rally for Southern Independence in Yemen, October 122013 (AFP), in: ahram. org; Clash between Yemen troops. Southern Separatists wound four, January 272014 (AFP) Divisions within Yemen's Al-Hirak delay announcement of Southern independence, in: Al-Sharq Al-Awsat, December 12014.

10 | The Yemeni Socialist Party replaced the National Front as the new "vanguard party" of the PDRY in 1978. 
and still active insider relations and networks of former YSP functionaries ${ }^{11}$ give rise to demand a more diverse and intensive research on and analysis of the PDRY's history and especially its development as a socialist state.

South Yemen's unique history as a Marxist state in the Arab world and its reemergence as an "imagined community"12 par excellence during Yemen's ongoing transition alone render South Yemen an interesting object of International Relations study. ${ }^{13}$ However, to explore the early years of state- and nation-building in the separate south and the formation of a separate identity, a thorough account of external involvement in the process is needed: the emergence of a state led by a Soviet-style vanguard, including the process of "Socialist state- and nationbuilding" would never have taken place without external influence of East Germany and the Soviet Union. After the British had left and taken their money with them, the conflict-ridden and impoverished fledgling state needed large-scale support to realize the regime's ideological project, which was readily granted by the Soviet Union and its right hand in the international sphere, the GDR. As a consequence of the interdependence between Moscow's, East-Berlin's and Aden's actions, this case study not only offers a foreign policy analysis of East German engagement, but at the same time includes the internal developments in South Yemen as an essential determinant. "The GDR in South Yemen" is a unique case study in many respects: South Yemen's recent history provides an intriguing venue for foreign policy engagement by one of the most contested, ignored, and neglected international actors in 20 th century history: The German Democratic Republic. ${ }^{14}$

11 | Like for example Ali Salem Al-Beidh (Arabic: 'Alī Sālem al-Bīḍ), Augustin, 2013.

12 | Anderson, 1983, 35.

13 | In this analysis the discipline of "International Relations" (capitals) is differentiated from the actual relationships between states, or "international relations".

14 | Gareis, 2006, 49; Schmidt/Hellmann/Wolf, 2007, 30. 


\title{
1. An Analysis of the GDR's Foreign Policy - A Fruitless ENDEAVOR?
}

\author{
"The efforts of small states to reach their goals have to be \\ considered foreign policy nonetheless." 15 \\ HERMANN WENTKER
}

Due to profound controversies on the scope, quality, and content of East German foreign policy in academic discourse and political praxis, an extensive debate on the GDR's foreign policy in general is inevitable for the analysis of any case study of East German foreign policy engagement. Furthermore, studies of the GDR's foreign policy regularly fail to clarify the role and position of the GDR's foreign activities in relation to its political system and ideology as part of the SED's "Policy of survival". To do justice to the interdependence between the system of Real Socialism and East German foreign policy, this analysis explicitly includes the interdependence between the domestic and international sphere while accounting for its two major determinants, the Soviet Union and the "other Germany".

To this day, German and Cold War studies discourse cannot even agree on the question of whether the GDR was able to pursue an independent foreign policy in its own right. ${ }^{16}$ The German Federal Republic's ${ }^{17}$ international activities, on the other hand, have been considered a comprehensive, full-fledged foreign policy ever since the Treaties of Bonn and Paris came into force in 1955 and diplomatic relations with the Soviet Union were established. According to Helga Haftendorn, "the Federal Republic of Germany claimed its place as an equal member among the community of peoples"18 at this point, even though it hadn't achieved full sovereignty, yet. Further along the way, the West German intellectual Ralf Dahrendorf diagnosed a "sturdy state existence" with a "considerably big scope of action"19 in the mid-1970s. Contrastingly, Siegfried Bock, a high-ranking East German diplomat, in hindsight does not consider the GDR "a normal actor in international relations", as it was "not able to claim the same scope of action and options as other states." ${ }^{20}$ These opinions clearly demonstrate the huge gap between West and East German self-perceptions, with West Germany expressing far more confidence in their international actions than their Eastern counterparts.

However, the impact of the GDR's foreign policy during its existence and after cannot simply be denied in one sweeping blow. At least in certain countries

\footnotetext{
15 | Wentker, 2007, 3.

16 | Wippel, 1996, 27; Schmidt/Hellmann/Wolf, 2007, 30; Wentker, 2007, 10.

17 | Federal Republic of Germany (FRG); German: Bundesrepublik Deutschland.

18 | Haftendorn, 2001, 56.

19 | Dahrendorf, Ralf, in: Wentker, 2007, 1.

20 | Bock, Siegfried, 1999, in: Wentker, 2007, 3.
} 
and regions, East Germany's international performance had and still has a considerable influence on the foreign policy of the Federal Republic of Germany and its bilateral relations. In 1990, East Germany officially terminated foreign relations and dismissed its diplomatic personnel. In certain cases, however, reunified Germany drew from relations and connections established by the GDR, that is, in those countries where former West Germany for one reason or the other had not been involved. This long-term impact of East German international engagement so far has widely been neglected in academia, but clearly has to be regarded part of a wider discourse on how to handle the fact of German separation in history and political science in general.

One of the major controversies here is whether the two separate German histories between 1945 and 1990 should be written as one and if so, how this could be done. Initially, this question was addressed by Kleßmann in the late 1980 s. ${ }^{21}$ He tried to include the history of both German states in his narrative of German postwar history. This concept was resumed about a decade and a half later, and from there, a new discourse beyond bipolar-system thinking has evolved, including a demand for an "integrated postwar history" in German studies. ${ }^{22}$ Obviously, the discipline is bound to at least partly revise its analytical approach to Germany's divided past. And while the dictatorial character of the political system of the GDR calls for a conscious debate about the interrelation between the SED dictatorship and the GDR's policy output, it is not an excuse or justification for ignoring the impact of the GDR's existence and performance as a state in the international system in its entirety. Studies considering the GDR as a mere object of history exiled to the "footnotes" ${ }^{23}$ without doubt have proven inadequate in explaining the direct and indirect impact of the GDR on other actors within the international community of states.

This is especially true for the effects on the Federal Republic of Germany. The controversy over the exclusive focus on the German Federal Republic with regard to German postwar history has not yet come to a conclusion. But without doubt, the mutual reference of the two German states had its part in the formation of two separate German identities and thus on both states' performance in the international sphere: Ever since their "zero hour" in 1945, both German states defined their new identity as states claiming to be the "better Germany", while inevitably referring to their antipode. As a consequence, the long-term goal of research on German history should not only be to include East German history, but to even overcome the rather restrictive interpretation of the "parallel history of Germany” by Kleßmann. Current discourse suggests using an approach to German history that includes differences and similarities, as well as the interconnected

21 | Kleßmann, 1988.

22 | Möller, in: APuZ 3/2007, 7.

23 | Heym, Stefan, 18 March 1990 and Wehler, 2008, 362. 
character of the two German states, to identify the long-term impact of separation on unified Germany and thus unified Germany's foreign policy. This analysis explicitly positions itself within this debate and advocates for a more open and especially more public debate about Germany's divided past and reunited future in not only academia, but also politics. In 2010 Klaus Schroeder asked:

"Are the Germans off their heads? Even though they have been reunited for over twenty years, they keep emphasizing what separates them, not what they have achieved together." ${ }^{24}$

If Germany intends to achieve not only a structural unification, but a joint reunion, reconciliation, and merger of the two societies in the long run, "the Germans' doubled history cannot be overcome separately," 25 as Weidenfeld noted in the early 1990s. This especially holds true for German foreign policy history, as the double existence of two German states in the international realm is not a matter of interpretation, but a fact witnessed by the international community of states for over forty years and thus cannot be ignored any longer.

Regarding the GDR's foreign policy, the “other Germany” in the West emerged as one of the two major determinants shaping the East German international scope of action. The second determinant, the Soviet Union, for the most part claimed full control over East German international actions. But even though there did not exist an East German foreign policy independent from Moscow, this did not necessarily result in the non-existence of East German foreign policy making in general: regardless of its degree of autonomy, any policy directed by an internationally recognized state towards the international community of states to further its national interest has to be considered foreign policy. Undeniably, relations between the GDR and the Western allied forces exemplify the limits of the SED's room for maneuver. But East Berlin nonetheless sought and found ways to realize its national interest in day-to-day politics in the international realm. Despite the boundaries of the GDR's foreign policy being clearly marked, East Berlin discovered other, more modest ways to assert its political interests abroad. The GDR offered education and training for political cadres of Socialist-friendly states and became heavily engaged in the organizations of the United Nations even before its admission as a full member. Other venues for East German foreign policy were the CSCE Process in the early $1970{ }^{26}$ and East German engagement in the Middle East ${ }^{27}$ from the early 1960 s. Furthermore, some of the so-called

24 | Schroeder, 2010, 7.

25 | Weidenfeld, 1993, 15.

26 | Müller, in: DA 4/2010, 610.

27 | The author opts for a wide understanding of the term "Middle East" and follows Steinbach who defines it geographically as the "Arab world between Egypt and the Indian 
developing countries ${ }^{28}$ provided an extraordinary scope of action for East Berlin. Firstly, Moscow explicitly opened the door for East German activities in the "Global South." ${ }^{29}$ Secondly, Western Germany as the legal successor of the "Third Reich" had consented to political obligations to the state of Israel..$^{30}$ This approach resulted in severe political pitfalls and restrictions for Bonn in the Near and Middle East. In conclusion, the "developing world," and particularly the Arab states from the mid1960 s to the mid-1970s, became the main venue of East Germany's "patchwork policy." Acknowledging the Soviet Union and the Federal Republic of Germany as the two major foreign policy determinants of the GDR, this case study aims to deliver a foreign policy analysis of East German engagement in South Yemen. It follows Hermann Wentker's argument in which he differentiates between the phases of development of the relationship between the GDR and the Soviet Union, and between East and West Germany: Not only did Bonn and Moscow undergo significant changes during this time, as the GDR itself changed as well and thus these dependencies were not static either.

Finally, this analysis explicitly includes the dictatorial character of the GDR's political system as an integral part of any policy analysis of the GDR. Unfortunately, analytical tools designed to understand the functioning of democratically constituted states turn out to be rather inadequate when confronted with the organization of the GDR's political system. In spite of its name, the German "Democratic" Republic, the GDR had never been designed as a democracy, as Walter Ulbricht emphasized during his exile in Moscow in 1945: "It only has to look democratic while we keep everything in our hands." ${ }^{31}$ The SED's unconditional claim to power was even formalized in the GDR's constitution of 1968: "The German Democratic Republic is a Socialist state of workers and farmers [...] led by the working class and its Marxist-Leninist party." ${ }^{32}$ The party's influence was explicitly designed to penetrate every aspect of society and its political structures with the SED's version of Socialism. For example, educational policy was based

Ocean, the Persian Gulf and Iran, including Afghanistan and Pakistan," in: Steinbach, in: Schmidt/Hellmann/Wolf, 2007, 494.

28 | A critical account of the term "developing states": Sindjoun, Luc, in: Badie/BergSchlosser/Morlino, 2012, 640-645. On "modernization theory": Badie/Berg-Schlosser/ Morlino, 2012, 1609-1613.

29 | "Global South" is part of the "Postcolonial Project" and is the critical and competing conceptualization of what has been called the "Third" or "Developing World" to avoid the First-World/Second-World Dichotomy and to emphasize the agency of these countries, in: Bullard/Anheier/Juergensmeyer, 2012, 725-728.

30 | Meuschel, in: Kleßmann/Misselwitz/Wichert, 1999, 117.

31 | Ulbricht, Walter, May 1945, in: Leonhard, Wolfgang, 1961, 365. Leonhard as a former member of the "Ulbricht Group" quotes Ulbricht from his memory.

32 | Constitution of the GDR of 1968, Article 1. 
on the concept of "collective education" to form "socialist personalities." 33 The long-range objective of this policy, also called "educational dictatorship," was the creation of the "new socialist human" ${ }^{34}$ who would willingly concentrate all his efforts on the establishment of a communist utopia.

As a consequence, any analysis that aims to go beyond official statements of the leading party, the SED, and political and academic studies of the time has to guard against relativizing the system's dictatorial character. This argument opposes those who insist on the existence of social and political spheres remaining untouched by the state's penetration and who argue for an analysis decoupled from the traditional concept of dictatorial regimes. ${ }^{35}$ Furthermore, any study of the GDRs foreign policy today has to presuppose a self-image of the state and its functionaries colored in socialist ideology. Especially with regard to foreign policy and the Party's monopoly on any cross-border relations, it is almost impossible to imagine any space within GDR's society occupied with international questions untouched by state interference. Thus, it does not suffice to describe the GDR's legal system, constitution, and official statements to assess the true motives behind the GDR's foreign policy. Rather all of these have to be critically questioned and compared to constitutional reality and political day-to-day life, while relying on primary sources as much as possible, to allow a fruitful conclusion on the GDR's performance in the international system.

\section{Puzzle, Hypotheses, and Structure - How the Research Question Generates the Analytical Approach}

The case study first and foremost is a foreign policy analysis. However, it aims to include a critical perspective on the "limits of foreign policy" from both a (1) normative-ethical and a (2) descriptive-empirical perspective, while (3) expanding the analytical perspective. In doing so, the analysis is able to draw conclusions on (4) the exceptional case as a possible model or "ideal type" of the GDR's foreign policy towards the "Global South".

(1) In international law the principles of "equal sovereignty" and "non-intervention" have to be considered the basis for the international community of nation states and thus the international state system as it has been established after WWII. ${ }^{36}$ The two principles firstly define the reach and influence of a state's foreign policy as ending at

33 | "Bildung und Erziehung", in: Kleines politisches Wörterbuch, 1973, 116-118.

34 | Ulbricht, Walter, 10 Gebote für den neuen sozialistischen Menschen, July 10 1958, in: Protokoll der Verhandlungen des V. Parteitages der SED, 1959.

35 | E.g. Sabrow, 2007, 19-24.

36 | Charter of the United Nations, Article 2 (4) and (7); Giddens, 1983, 263; Welsh, Limiting Sovereignty, in: Welsh, 2004. 
the boundaries of another state's sovereignty and secondly declare any infringement of these boundaries illegal. Apart from questions concerned with military interference of one state into the territory of another, which can be summarized under the label of "humanitarian intervention", ${ }^{37}$ infringement of sovereignty can also be caused by other means of intervention and imposition. What is the relationship between one state's foreign policy and the sovereignty of another? Where does foreign policy end and intervention begin? To what extent can the foreign policy agent influence internal developments of the recipient state? This is where the normative-ethical "limits of foreign policy" may be discovered and explored.

(2) This normative-ethical dimension is complemented by an extensive empirical analysis of East German foreign policy engagement in South Yemen to identify the "limits" of foreign engagement in concrete terms. How do the two determinants of foreign policy, the national and the international, limit a state's foreign policy? What determines the success or failure of a foreign policy strategy? Thus, the analysis intends not only to describe GDR's foreign policy in South Yemen, but to evaluate its success with regard to its goals and motives, assess the importance of the country for the GDR's foreign policy and finally to comment on the impact of the GDR's actions in South Yemen.

(3) To fully understand a phenomenon's limits, one has to include more than just a single perspective on this boundary: No analysis of foreign policy can ignore the recipient or host (state) of foreign policy. Thus, the approach expands the traditional analytical perspectives of foreign policy analysis that usually focus exclusively on the foreign policy agent. This perspective is inspired by the critical stance of the "postcolonial project" usually referred to as postcolonialism..$^{38}$ This interdisciplinary field is occupied with the "forces of oppression and coercive domination that operate in the contemporary world." ${ }^{39}$ Halliday emphasizes the benefits of postcolonial perspectives for studies concerned with the Middle East:

“This [...] 'anti-hegemonic' approach stresses that we need not just look at the differences of social and political composition, or interest (e.g. in regard to trade or oil), but also to know how Middle Eastern states, and their peoples, regard international relations, not least to explain why they make the choices they do. Too often external analysis ignores not just history and context, but the roots of protest and the perspective of regional actors." 40

37 | Orford, 2003; Walzer, 1977; Shue and Wheeler, both in: Welsh, 2004, 11-28 and 29-51.

38 | Postcolonial research relies heavily on the post-structuralist perceptions of Michel Foucault and Jacques Derrida and thus is closely connected with other so-called "critical" fields of study in the social sciences in general and the discipline of International Relations (IR) in particular. On the boundaries of the discipline: Lockman, 2010, 207 and Young, 2001, 63ff.

39 | Young, 2001, 11.

40 | Halliday, 2006, 32. 
To remedy this shortcoming, studies committed to the "postcolonial project" not only aim to deconstruct these structures of domination, but also to recover agency of the "subaltern"41 (Latin: the subordinate). As a consequence, the 'host state' of foreign policy is not merely considered a dependent but also an independent variable, not a mere statistic of but an explanatory for East German policy design, implementation, policy change, and outcome. To grasp the motives, formulation, and implementation of East German activities in South Yemen, a thorough analysis of the socio-political conditions in South Yemen before and during the GDR's presence is an inevitable precondition.

(4) In relation to the big picture of the GDR's foreign policy, its activities in South Yemen were by no means the rule but the exception. How can this exceptional case be of any use beyond its own narrative? The research process on East German foreign policy engagement in South Yemen successively produced the major hypotheses of this study: The case of South Yemen may not only be considered the "exception to the rule", but also a model suggesting a theoretical "ideal type" ${ }^{\prime 2}$ of the "general," ${ }^{43}$ a "utopia" of East German foreign policy toward the Global South.

\section{From the Big Picture to the Small Picture and Back Again - Structuring the Argument}

The following section briefly summarizes the overall structure of the analysis and at the same time is intended to give the reader guidance to the overall approach. Divided into three Sections, the study follows the traditional structure of Introduction, Analysis, and Conclusion. Section A, "Analytical Framework", introduces the topic and puzzle and provides the reader with an overview of the project's theoretical presumptions. It includes subchapters on method, hypotheses, and theory. After an overview of the state of research on the interdisciplinary topic, as well as secondary and primary sources used, the major analytical categories are introduced: Foreign Policy, the Nation State, Sovereignty, and Identity. In the process, these categories will be connected by interrelated hypotheses to provide a comprehensive theoretical basis for the analysis.

Section B, "Analysis", is the main section of the analysis and offers a full-scale analysis of the internal and external determinants of the GDR's foreign policy in general and its activities in South Yemen in particular. It is divided into two parts, whereas Part I is occupied with “The GDR as a Foreign Policy Actor” and

41 Inspired by Antonio Gramsci's Prison Notebooks, Gayatri Spivak reframes the notion of the "Subaltern", in: Spivak, 2009.

42 | Weber, 2002, 10.

43 | Following Søren Kierkegaard's notion of the general, the exception defines the normal situation as well as itself. Comp. Kierkegaard, Søren, in: Schmitt, 2005 (1922), 15. 
Part II with "The GDR in Yemen”. Part I of Section B sketches the role of the two major determinants of East German foreign policy, the Soviet Union and the Federal Republic of Germany and points out the priorities directing East German foreign policy decisions. To be able to interpret East German foreign policy in South Yemen and reach conclusions about its generics and peculiarities, this is followed by an introduction to East German foreign policy history, its objectives and turning points, before and after its international diplomatic recognition in the early 1970s, the major turning point in East German foreign policy. Part I concludes with an analysis of the political system of the GDR based on the "three spheres approach", which differentiates between the three spheres of the SED state and thus foreign policy making: Party, state and society. This final subchapter aims to firstly differentiate between constitutional ideal and political reality of the SED state, secondly to point out the most relevant foreign policy actors in general and for the GDR's engagement in South Yemen in particular, and thirdly to serve as a point of reference for the concept of "socialist state- and nation-building" to interpret concrete East German foreign policy in South Yemen.

Taking into consideration the results of Part I, Part II of Section B firstly analyzes the role of the Middle East in the GDR's international activities. It presents three major strategies of East German foreign policy in the region and how they tie in with East German foreign policy in general. Secondly, Part II provides the reader with a unique study of the political milieu in Aden during the years leading up to South Yemen's independence to assess the impact of foreign powers in the country in the following decades, first and foremost the GDR. Lastly, the GDR's activities in South Yemen are analyzed using a phase analysis, based on the assumption that the foreign policy of any state, regardless of its political system, is an "interactive process" 44 that changes over time as a reaction to internal and external influences.

East German foreign policy in South Yemen is approached as a state- and nation-building policy of socialist connotation. Changes to and continuity of this policy are explored with reference to the major turning-points and catalyst events of East German-South Yemeni relations, of which four phases between 1967 and 1990 can be identified. Each of the analyzed phases of East German foreign policy is based on the same analytical scheme. First of all, the phase is determined by initial and finishing turning-points and catalyst events, followed by a brief overview of political developments in South Yemen. Change and continuity of politics and society serve as a points of reference and independent variables, that is, they are explanatory for any foreign policy activities of foreign powers in the country. Then Soviet interests and policies during the phase are sketched briefly to allow for an assessment of Moscow's major fields of engagement and, more importantly, Moscow's level of engagement. The short summary of Soviet

$44 \mid$ Haftendorn, 1989, 33. See also: Weißbuch zur Sicherheit Deutschlands of 1994 and Weißbuch zur Sicherheitspolitik. 
interest and activity on the Gulf of Aden is considered the framework of action for the GDR's foreign policy. East-German engagement in the Yemeni policy fields varied in intensity over time and the motives and reasons for these changes in intensity are identified. The conclusions of each phase analysis draw extensively from the introductory summary of Moscow's policy and South Yemen's internal political developments, as both are considered the major determinants of the GDR's activities on the ground.

The major goal of the phase analysis is to conclude with a comprehensive overview of East German engagement in South Yemen, including an assessment of its evolution over time, its relation to the GDR's overall foreign policy, and the impact of Soviet interests. Based on these results, Section C, "Findings" reconsiders the study's initial question and major hypotheses in three concluding chapters to provide the reader with a comprehensive overview of the study's major findings and conclusions. The first concluding chapter summarizes the empirical, concrete internal and external limits of East German foreign policy in general. The second chapter is occupied with the limits of East German foreign policy in South Yemen in particular. The first two concluding chapters on East German foreign policy serve as the framework to answer whether the major hypothesis of the study can be upheld: Can the case of South Yemen be considered both an exceptional case and a model pointing towards a Weberian ideal type ${ }^{45}$ of East German foreign policy? Finally, the last "Findings" chapter reflects on the normative limits of foreign policy with regard to the autonomy of the host state.

45 | Weber, 2002, 10. 


\title{
CHAPTER 2. State of Research:
}

\author{
The Selection of Sources for an Interdisciplinary Project
}

The lion's share of the project's scholarly achievement is the review and evaluation of comprehensive archival material, which has been uncharted territory so far. However, the interpretation of the findings of this research is only possible by including the research of several different fields. Consequently, and apart from the process of developing a fruitful approach to process the archival documents, one of the major challenges of this study was the selection of secondary literature on the various fields and topics relevant for this analysis. In the end, several monographs but also articles proved to be the most relevant for the theoretical approach and method of this study. In this chapter, a short account of the state of research on East German foreign policy, based on the most influential authors, is followed by brief statements on the non-theoretical monographs and articles most influential and relevant to this project. This includes the GDR's foreign policy and divided Germany's foreign policy history, Cold War Studies and the Middle East, and lastly the history of modern Yemen and its current transformation process.

\section{History of a Divided Germany's Foreign Policy: Asymmetric Endeavors and Availability of SOURCeS}

With regard to the history of German foreign policy, the notion of "asymmetry of research" between East and West is more valid than in other policy fields, even more so for the two Germanys' foreign policy in the Arab world, where countless studies on Bonn's activities have been published over the last three decades. ${ }^{1}$ The question whether East Germany had the ability to pursue a foreign policy wasn't even formulated in the West before the Berlin Wall was erected and the existence of East Germany could be denied no longer. ${ }^{2}$ Actual academic interest of West German

1 | See for example: Abu Samra, 2004; Berggötz, 1998; Bippes, 1997; Braune-Steininger 1988; Engler, 2007; Hünseler, 1990; Küntzel, 2009; Müllenmeister, 1998; Weingardt, 2002.

2 | Woitzik, 1967, in: Scholtyseck, 2003, 54. 
researchers in this foreign policy did not arise before the "Grundlagenvertrag" of $1972,{ }^{3}$ as the hostile relationship of neglect between the two Germanys had festered and engulfed academia as well. The two German signatures under one treaty meant the mutual de facto recognition towards the GDR of the "other Germany" and the attitude of West German research was about to change profoundly. While countless studies on the GDR's political and social system were published, more and more researchers occupied themselves with East Berlin's foreign policy as well. When the GDR joined the Federal Republic though, this newfound dedication disappeared over night. East Berlin's diplomatic staff was dismissed with almost no exemptions, its foreign ministry, the 'Ministerium für Auswärtige Angelegenheiten' (MfAA), was dissolved and with it the GDR's foreign policy history. ${ }^{4}$

Research tentatively reclaimed the field for further exploration in the late 1990 s. Benno Eide Siebs' study of $1999^{5}$ offers a first overview of the GDR's international activities after 1976, which neatly complements Ingrid Muth's study of 2001 on East-Berlin's Foreign Policy between 1949 and $1972 .{ }^{6}$ While Muth focuses on political structures and decision-making processes, Siebs presents a phaseoriented foreign policy analysis focusing on the content of the GDR's activities. Both studies rely on secondary literature published until the early 2000 s, but distinguish themselves by including a wider range of newly researched archival material, mostly from the Political Archive of the Foreign Office ${ }^{7}$ and the German Federal Archive. ${ }^{8}$ Several studies focusing on singular aspects of the GDR's international activities followed suit, like an anthology on the GDR's relations to the Western states, edited by Ulrich Pfeil and published in 2001. Two years later, Joachim Scholtyseck published a concise overview on the state of research on the GDR's foreign policy in reunified Germany and provided the first comprehensive summary of East German foreign policy development after reunification. ${ }^{9}$ Only a few years later Hermann Wentker published his "Außenpolitik in engen Grenzen" of $2007,{ }^{10}$ the most comprehensive overview of the state of research on the GDR's foreign policy so far. Caution is recommended for studies published in the GDR

3 | Kriele, in: Hacker, 1989, 33.

4 | Von Bredow, 2006, 183.

5 | Siebs, Benno-Eide, Die Außenpolitik der DDR 1976-1989. Strategien und Grenzen, Paderborn, 1999.

6 | Muth, Ingrid, Die DDR-Außenpolitik 1949-1972, Inhalte, Strukturen, Mechanismen, Berlin, 2000.

7 | Politisches Archiv des Auswärtigen Amtes (PA AA), Berlin.

8 | Bundesarchiv (BA), branch Berlin.

9 | Scholtyseck, Joachim, Die Außenpolitik der DDR, Enzyklopädie Deutscher Geschichte, Band 69, Oldenburg, 2003, esp. 51-60.

10 | Wentker, Hermann, Außenpolitik in engen Grenzen. Die DDR im internationalen System, 1949-1989, München, 2007. 
by East German social scientists and historians, which usually "put the foreign relations in the right light"11 in accordance with the SED's political preferences. Similar sensitivities are needed when dealing with West German publications during German separation, as they were highly politicized as well. Before the de facto recognition of the GDR, interest in the "other" Germany in general and its foreign policy in particular was considerably low. East Berlin's actions were considered a mere expression of Soviet interests. Due to rapprochement between the two Germanys in the 1970s, this attitude changed profoundly and academia enthusiastically turned towards this "new field". Nonetheless, these works remained part of the world they described. Political opinion oftentimes was mixed with "objective" analysis and East German publications naturally served as either a negative or positive blueprint. In addition to that, no sources without East German and Soviet approval could be used at the time. Nonetheless, contemporary studies remain an indispensable reference for the perceived interests and scope of action and thus are explicitly included in this analysis.

\section{Secondary Sources in Focus I: Germany's Divided History and Foreign Policy}

The topic of this study is located at the intersection not only of several disciplines but also fields of research. Apart from current debates on German separation, reunification, and history of German foreign policy, a good grasp of the determinants, players and ideologies of the Cold War is needed. Before beginning with the research for this study, the author had been working on the topic of German divided history in general and German foreign policy in particular for several years.

With regard to the Federal Republic of Germany's foreign policy, Helga Haftendorn's work provides an extraordinarily comprehensive interdisciplinary analysis before and after reunification. Apart from her contributions to this study's approach to foreign policy, her most recent study, "Coming of Age: German Foreign Policy Since 1945,"12 published in German in 2001 and in 2006 in English, serves as an introduction to the history of German foreign policy and as an indispensable guide to Germany's role during the Cold War. Even though this analysis contends with the GDR's international activities, Haftendorn's monograph initiated countless new trails of thought and led to much greater understanding of East German foreign policy.

11 | Scholtyseck, 2003, 53; Siebs, 1999, $19 \mathrm{ff}$.

12 Haftendorn, Helga, Coming of Age: German Foreign Policy Since 1945, Oxford, 2006; Haftendorn, Helga, Deutsche Außenpolitik zwischen Selbstbeschränkung und Selbstbehauptung. 1945-2000, Stuttgart/München, 2001. 
Among the monographs and encyclopedias on this topic, "The Handbook of Communism,"13 published by Stéphane Courtois, offered a combination of indepth analysis and distinguished interpretation in a very condensed format. In concise articles, Courtois and his research team introduce the communist ideology from its beginnings to its Real Socialist excesses. One of the contributors to the "Handbook," Klaus Schroder, also published the most comprehensive study on the political system and reality of the GDR, "The SED State" in 1998. With the second edition of 2013 , the monograph has established itself as a classic of German studies. ${ }^{14}$ It established the major determinants of the GDR's political system to interpret the relationship between party and state in the GDR. This was complemented by Matthias Judt's annotated and edited collection of selected document, published in 1998 , which presents pivotal original documents in the context of short but well-researched articles. ${ }^{15}$

Ingrid Muth's monograph on the GDR's foreign policy before 1972 is not only the first comprehensive study of the GDR's foreign policy apparatus, but without doubt also one of the most thorough and knowledgeable analyses of the structures and "praxis" of the GDR's foreign policy of its first two decades of existence. Due to Muth's two decades of active service for the GDR's MfAA, however, the reader is advised to keep a certain critical distance when reviewing her findings. While her work is not purposefully biased, she still explicitly remains within the logic of the political system of the GDR. ${ }^{16}$ On the one hand, there are good arguments to do so, the most important among them to be able to understand the nature of decisionmaking as well as to assess success and failure. On the other hand, this "inside" perspective does not generate conclusions beyond the ideological justifications or political bloc restraints of the GDR's foreign policy: Muth's institutional analytical view still treats East Berlin's foreign policy as separate from its dictatorial reality.

Hermann Wentker's monograph of 2007 remains the most extensive overview on East German foreign policy research. Strockmann rightly criticizes the book as a mere recycling of the various studies published before. ${ }^{17}$ However, this is also Wentker's most important achievement. Even though he does not include a significant amount of new archival material beyond edited document collections, ${ }^{18}$ his monograph provides research on the GDR's foreign policy with a thorough and well-researched summary, interpretation, and assessment of secondary literature on the subject. In addition to that, Wentker introduces an

13 | Courtois, Stéphane (Ed.). Das Handbuch des Kommunismus. Geschichte. Ideen. Köpfe, München, 2010.

14 | Schroeder, Klaus, Der SED-Staat, Der SED-Staat. Geschichte und Strukturen der DDR, München, 2013.

15 | Judt, Matthias (Ed.), DDR-Geschichte in Dokumenten, Bonn, 1998.

16 | Muth, 2001, 9.

17 | Storckmann, 2012, 28, FN 107.

18 | E.g. Akten zur Auswärtigen Politik der Bundesrepublik Deutschland. 
efficient approach to grasp the material and further understanding of the GDR's position in the international system at the same time: Wentker focuses on the dichotomy of heteronomy and autonomy of the GDR's foreign policy, depending on three determinants: the Soviet Union, West Germany, and internal political developments. ${ }^{19}$ In this study on the GDR in Yemen, Wentker's fruitful approach is reconsidered and adapted according to the findings of the analysis.

With his 2013 monograph on the GDR's military relations to the third world, ${ }^{20}$ Klaus Storckmann finally is able to step out of the cycle of seemingly endless academic repetition and recycling in the field of the GDR's international military engagement. Based on extensive archival research and three elaborate case studies of Egypt, Mozambique, and Ethiopia, Storckmann presents the meticulous work of an historian. He explicitly focuses on the "coordination process between the GDR and Soviet leadership"21 and successfully embeds his findings in the microlevel of his case studies on the one hand and, on the macro-level of the Warsaw Pact and GDR's policy towards the "Third World" on the other. Unfortunately, Storkmann's analysis merely oscillates between the two levels described, and as a consequence often misses opportunities to draw further conclusions from his findings with regard to the general Cold War setting and regional implications. But even though Storckmann's study may not be considered comprehensive with regard to the role of the GDR's military relations within the wider framework of foreign policy, Storckmann clearly departs from the well-trodden paths of academic and semi-academic research which had generally relied on exaggerations of the Western media and personal memories than archival findings. ${ }^{22}$ Storckmann sketches a clear and thorough framework of the GDR's policies in the Global South and provides significant insights on the decision-making processes of the GDR's foreign policy. ${ }^{23}$ As a consequence, and despite the apparent lack of involvement by the GDR's military in South Yemen, Storckmann's book adds considerable substance to this analysis.

Finally, the rising number of case studies on the GDR's activities in the Global South all in all does not substantially contribute to the discourse and state of research, as these are mostly limited to indexing archival material and sometimes interpreting it with regard to the respective country. A prominent example for this phenomenon is Haile Gabriel Dagne's slim volume on "The Commitment of the

19 | Introduction, Wentker, 2007.

20 | Storckmann, Klaus, Geheime Solidarität. Militärbeziehungen und Militärhilfen der DDR in die "Dritte Welt", Berlin, 2012.

21 | Ibid. 15.

22 | Ibid. 23; 27.

23 | Ibid. 55-179. 
German Democratic Republic in Ethiopia. A study based on Ethiopian Sources"24 of 2006 . While the subtitle clearly is the primary strength of Dagne's analysis, it is also its biggest weakness, as the Ethiopian sources leave the reader with more gaps, that is, more questions than answers about the East German presence in Addis Abeba. Also, Dagne fully ignores the complex interaction between East German activities abroad and its two major determinants - Moscow and Bonn - and falls short of interpreting the GDR's engagement in Ethiopia in the wider framework of the Cold War in general and East German foreign policy in particular. As a consequence, case studies like Dagne's are considered merely episodically in this analysis.

\section{Secondary SOURCES in Focus II: Cold War Studies, the Middle East and Modern Yemen}

While the Cold War has been depicted as half a century of both conflict as well as strained peace, ${ }^{25}$ current research tends to locate its assessments of the global competition between the Soviet Union and the United States of America somewhere in the middle. Despite significant progress over the past two decades, Greiner in 2008 rightly emphasizes vast uncharted territory in Cold War research and the academic discourse - especially with regard to the Soviet Union and its closest allies. ${ }^{26}$ With respect to this analysis, the profound change of perspective after Odd Arne Westad's publication of the "The Global Cold War"27 in 2005 is most relevant for the evolution of the Cold War discourse: According to Westad, the conflict created the idea of the "Third World" 28 by globalizing the narrative of the Cold War. Part of this development is the newly emerging perspective that comprehensive interpretations of the Cold War as a political phenomenon are only possible when the rigid surface of findings based on the bipolar perspective is scarified. This may be achieved by shifting the analytical focus to 'smaller actors' in the conflict as Greiner suggests ${ }^{29}$ and is exactly what Anne Applebaum achieved with her well-researched and even better-written narrative "Iron Curtain: The Crushing of Eastern Europe. 1944-1956" of 2013. Celebrated by the media and academia alike, ${ }^{30}$ Appelbaum's book presents an intriguing account of Soviet

$24 \mid$ Dagne, Haile Gabriel, The Commitment of the German Democratic Republic in Ethiopia. A study based on Ethiopian sources, Berlin, 2006.

25 | Gaddis, 1987; Soutou, 2011 (2011).

26 | Greiner, in: Greiner/Müller, Walter, 2008, 16.

27 | Westad, Odd Arne, The Global Cold War. Third World interventions and the making of our times, Cambridge, 2005.

28 | Westad, 2005, 275ff.

29 | Greiner, in: Greiner/Müller, Walter, 2008, 7 and 16.

30 | Levgold, 2013; Lieven, 2013. 
domination of Eastern Europe by focusing on the "recipient countries" of Soviet neo-colonial aspirations. Just like her, Fred Halliday focuses on the "small" actors within the Cold War context in one of the subchapters of his regional study "The Middle East in International Relations: Power, Politics and Ideology", in which he sketches the role of the Middle East during the Cold War and beyond. The impact of his writings on this analysis are elaborated upon further below. In addition to that, two other monographs turned out to be indispensable in interpreting the role of the Middle East in the Cold War: Youssef Choueiri's "Arab Nationalism: A History" published in 2000 and Tareq Ismael's monograph on “The Communist Movement in the Arab World" published in 2005. ${ }^{31}$ Based on the two major ideological concepts of the Arab world in the 2 oth century, both studies provide an excellent overview of the region's position and role in a bipolar world.

To merely access the highly complex history of modern Yemen is a task of several years of study. At that point, the researcher usually is able to realize that he or she has not progressed much toward understanding the multilayered and oftentimes contradictory social and political identities and loyalties of Yemen's actors, as a colleague put it during a conference. Nonetheless, the researcher has to begin somewhere. Paul Dresch's "A History of Modern Yemen" spans the full 2oth Century history of Yemen and has already become a "classic" for researchers of modern Yemen since its publication in 2000. Dresch's work distinguishes itself by its thorough historical analysis, dense writing style and inclusion of a wide range of Arab literature on the topic. He recounts the story of Yemen as more of a separated than divided history which inevitably to Yemeni unification in the early 1990s. His approach clearly has a focus on the statefounding and -building period until the early 1970s. As a consequence, Dresch's depiction of South Yemeni society and the political power constellation of the 1950 , in addition to his assessment of the revolutionary years of the 1960 s, are indispensable for the foundations of the argument of this study.

Robert Burrowes' "Historical Dictionary of Yemen" ${ }^{32}$ closes the huge gap in encyclopedias of the modern Middle East in the English language. Though the "Dictionary of Yemen" still has to live through several reviews and expansions - especially after the final downfall of Ali Abdallah Saleh in 2012 - it offers the most comprehensive and easiest access to a wide range of topics, events, and especially political actors in Yemen's modern history. The brief overview of the most important references used by Burrowes offers a solid starting point for any researcher new to the topic ${ }^{33}$ and the majority of monographs introduced by him have been used in the research for this study. Apart from its informative character, the "Dictionary" has to be considered a comprehensive comment on most of

31 | Choueiri, Youssef M., Arab Nationalism. A History, Oxford, 2000; Ismael, Tareq Y., The Communist Movement in the Arab World, New York, 2005.

32 | Burrowes, Robert D., Historical Dictionary of Yemen, Plymouth, 2010.

33 | Burrowes, 2010, 461-465. 
political developments in Yemen. Bearing this very personal approach in mind, Burrowes' interpretation of events and development is an invaluable companion to any analysis of modern Yemen history.

The current state of research on South Yemen has to be considered rather underwhelming, as current research is concentrated among a very small circle of researchers ${ }^{34}$ and the most recent piece of work on the PDRY is rather a popular than an academic book. The majority of thorough, well-informed studies so far have been published by Marxist scholars. As a consequence, the danger of simply transferring ideologically inspired opinions to this analysis remains. Keeping this in mind, this study, however, will not and cannot dispense with this research the PDRY simply remains a niche topic, in which today mostly socialist-oriented researchers take interest. Of the older of these studies, especially Robert Stookey's "South Yemen: A Marxist Republic in Arabia"35 of 1982, Joseph Kostiner's "The Struggle for South Yemen"36 of 1984, Helen Lackner's "P.D.R.Yemen: Outpost of Socialist Development in Arabia" ${ }^{\prime 37}$ of 1985, and Tareq and Jacqueline Ismael's "The People's Democratic Republic of Yemen: Politics, Economics and Society"38 published the year after, contributed to this study.

Without doubt, it is mostly authors who embrace some version of socialism and/or who lived through Real Socialism's failure that provide us with the most thorough and balanced analyses of the role of the Soviet Union in the Cold War and the socialist movements in the Middle East. The most prominent - but also moderate - example among authors writing on South Yemen is Fred Halliday with his "own particular version of historical materialism." ${ }^{39}$ Halliday's works have to be reviewed with a critical eye, especially in regard to the role of the Soviet Union in the region, as he usually tends to explain negative events and changes in the region and South Yemen by the overpowering policies of the "West" and its allies. ${ }^{40}$ However, two books by Halliday provided invaluable insights for this study: "The Middle East in International Relations: Power, Politics and Ideology" of 2005 and "Revolution and Foreign Policy: The case of South Yemen 1967-1987" of 1990. The

34 | This obviously has not changed since the early 2000s when Dahlgren decried the fact even for the most active discipline in Yemen, anthropology, that "anthropological Yemeni studies have in the last decades concentrated on the Northern Yemeni tribal society," Dahlgren, 2000, 1.

35 | Stookey, Robert W., South Yemen. A Marxist Republic in Arabia, Boulder, 1982.

36 | Kostiner, Joseph, The Struggle for South Yemen, New York, 1984.

37 | Lackner, Helen. P.D.R. Yemen. Outpost of Socialist Development in Arabia, London, 1985.

38 | Ismael, Tareq Y./Ismael, Jacqueline S., The People's Democratic Republic of Yemen. Politics, Economics and Society, Marxist Regimes Series, London, 1986.

39 | Cox, 2011, 1110.

40 | Halliday on the ongoing conflicts in Middle East: "the increasing pressure put upon [South Yemen] by Saudi Arabia, and indirectly, the USA. It was therefore a case of U.S.inspired 'destabilization' that in the end backfired," in: Halliday, 1979, 380. 
latter already anticipates Halliday's position as presented in “The Middle East in IR." His foreign policy analysis aims to include South Yemen's agency as a selfdirected actor on the one hand while upholding an "outside" view rather distanced from South Yemen's socio-political condition on the other. ${ }^{41}$

Noel Brehony's well-written story of the PDRY, ${ }^{42}$ initially published in 2011, made a decisive step to fill the gap in English literature on the formation of the NLF. It clearly is not an academic analysis in the strict sense and one may criticize Brehony's journalistic approach. However, the book benefits from Brehony's references to personal discussions and interviews with a significant share of the relevant actors. The narrative is based on the big names of English Yemen research, among them Dresch, Halliday, and well-known Marxist Robert Stookey, ${ }^{43}$ but also includes a high number of Arab original press releases, official party documents, and minutes. Brehony, former Chairman of the British-Yemeni society, successfully weaves together his interviewees' perspectives with the junctions of events, while clearly labelling the personal statements and attitudes as such. Some of his conclusions though should be handled with care. For example, Brehony comments on political and social reforms of the NLF/NF regime: “Though there were obvious flaws in the regime's economic policies, its social goals were both progressive and well-intentioned." ${ }^{\prime 4}$ The tendency to relativize the autocratic Marxist regime in Aden is probably explained by personal contacts and friendships, a circumstance to keep in mind when discussing Brehony's perspective.

The strength of the current research on Yemen clearly lies with the ongoing workshops and conferences and its tightly-woven academic community. Thus, there does not exist "one" monograph representing the most relevant findings, and even a long list of articles and papers wouldn't do justice to the thriving research of today. The following selection merely reflects the references of this analysis and does not aim to represent current research on Yemen. In 2009 Brian Whitaker, former Middle East editor of the Guardian, published "The birth of modern Yemen," which further closes the gap between Yemeni unification and current events. To connect the developments of the last decade with Yemen's divided history, such as the emergence of the "Southern Movement", the protests of the "Arab Upheavals" and the following transition process, and finally the reinvigoration of the Houthi movement, this analysis heavily relied on many of the contributors to the recently

41 | Halliday, 1990, 178-218.

42 | Brehony, Noel, Yemen Divided. The Story of a Failed State in South Arabia, London/ New York, 2013 (2011).

43 | Stookey, 1982.

44 | Brehony, 2013, 69. 
published anthology "Why Yemen matters: A Society in Transition"45 which offers up-to-date research and expertise on a wide range of topics. Among them are wellestablished authors like Marieke Brandt, Noel Brehony, Laurent Bonnefoy, Susanne Dahlgreen, Gerhard Lichenthäler and Lackner herself.

\section{Primary Sources: Between Archival and Personal Depths}

"If one looked for the concrete impact of the [MfS' work abroad on the secret services in the Global South], a look into the [relevant] countries would be most promising." ${ }^{\text {46 }}$ Ilko-Sascha Kowalczuck, ReSEarcher at the Stasi-Archive

The archival research for this project was guided by the analytical method of turning points and catalyst events determining phases of political development. ${ }^{47}$ The four phases suggested in this study bring together internal turning points of South Yemeni politics and turning points in Aden's bilateral relations with both Moscow and East Berlin. The reasons for the partial congruency of East German and Soviet engagement between 1970 and 1986 and for the discrepancy between East-Berlin's and Moscow's policy before and after are explained in the respective phase chapters. The most relevant dividing line with regard to the availability of sources can now be detected between the "Phase of Expansion", from 1970 to 1978 (Phase II), and the "Phase of Consolidation and Continuity", from 1978 to 1986 (Phase III): only one of the three included archives provides material on the topic for the time after 1980 that is comparable to the periods before: the Stasi Archive, or the BStU. ${ }^{48}$

The initial research was conducted at the Political Archive of the German Foreign Office $^{49}$ (PA AA). Here, Germany's 30-year blocking period for archival material applies in a very restrictive way. In addition to that, there is only limited access to certain files issued even before this period, due to security reasons and the protection of individual rights. As a consequence, the material of the PA AA mostly supported the analysis of the first two phases of East German foreign policy in South Yemen until about 1980. For the argument of these two phases,

45 | Lackner, Helen, (ed.) Why Yemen Matters. A Society in Transition, SOAS Middle East Issues, 2014.

46 | Kowalczuck, 2011, 260.

47 | On guidelines for archival research and the interpretation of historic sources: Budde/ Freist/Günther-Arndt, 2008, 159; Baumgart, 1977; Burkhardt, 2006.

48 | BStU - Bundesbeauftragte(r) für die Unterlagen des Staatssicherheitsdienstes der ehemaligen DDR.

49 | German: Politisches Archiv des Auswärtigen Amtes. 
the material of the Aden representation and embassy as well as the MfAA of the GDR have proven indispensable to the overall findings of the study.

The second major source of documents was a section of the German Federal Archive (SAPMO-BArch). ${ }^{50}$ Unfortunately, the working process of the Central Committee $(\mathrm{CC})^{51}$ did not file submissions in accordance with the actual decisionmakers at the top of the hierarchy, but with the inquiring office or section ${ }^{52}$ which clearly hampers focused research in the files of the SAPMO. As a consequence, and in combination with the sheer volume of documents available, research there requires significantly more time in the future to fully evaluate all sources relevant for the GDR's activities in South Yemen. The material of the BArch is included in this study mostly to close gaps in the findings obtained from the other archives included. The research focus for this project was on the SED party material, especially the work of the Central Committee and Politbüro of the SED, as well as documents of the ministries involved.

The GDR's activities in South Yemen were part of Moscow's wider strategy in the Middle East. A significant part of East German engagement was occupied with the security apparatus. The East German State Security (MfS), ${ }^{53}$ also known as the "Stasi", was highly active in Aden. As advisors to several South Yemeni ministers and policy-makers in various fields, the officers were highly involved in the installation of state institutions, policy generation, and even day-to-day politics. As a consequence, the focus of archival research of this study was on the files of the BStU. Since January 1992, these files have been open to the public, academia, and the media. They have proven to be quite a treasure trove on a wide range of topics. ${ }^{54}$ Unfortunately, the files produced by the Main Administration A (HV A), ${ }^{55}$ the MfS section occupied with international affairs, for the most part have been destroyed by the HV A itself. Between November 1989 and January of 1990, when the GDR's citizens occupied the MfS building, about 100 trucks are said to have left for a paper mill close by. ${ }^{56}$ The meagre remnants of the HV A files contending with the two Yemens do not offer much valuable information. ${ }^{57}$ On the

50 | German: Stiftung Archiv der Parteien und Massenorganisationen der DDR at the Bundesarchiv.

51 German: Zentral Komitee (ZK).

52 | Storckmann, 2012, 45.

53 | German: Ministerium für Staatssicherheit.

54 | Stasi-Records Act, first issued on December 29 1991, also see Version of 2012 of the Stasi-Records Act.

55 | German: Hauptverwaltung A.

56 | Müller-Enbergs, 1998, 17; Möller, 2004, 48.

57 | HV A files on the PDYR almost with no exemption (BStU MfS HV A Nr. 778) merely contain the annual report on political conditions in the country: e.g. BStU MfS HV A Nr. 40, $75,109,125,151,162,167,172,383,385,388,391$ and 394. 
other hand, the files of other sections involved in relations with South Yemen have been saved and oftentimes provided copies of HV A case files.

Studies and analyses on the Stasi in general and the HV A in particular mention their advisory activities in the Global South. In this context, the PDRY usually is either only mentioned in enumeration or not mentioned at all. ${ }^{58}$ Gieseke, for example, states that "at all times good relations" 59 had existed between the MfS and South Yemen. Documentation on the GDR's and especially the MfS's involvement in the establishment of South Yemen's state security apparatus is incomplete and the mostof the available files appear to have been destroyed with the files of the HV A. Fortunately, other Sections were involved in the process as well and the databases of HA II, III and especially HA X offer a broad overview of the cooperation between the MfS and the Yemeni "Committee for State Security" (KfS), which mostly allows us to corroborate the findings with a second source. These agreements and protocols describe the measures of cooperation and planned implementation in great detail. Other documentation is available, for example the files of the MfS's Section of Finances, and coded information can also be decoded by researching other files: The coding used for the "young nation states" by the HV A and its subunit HV A/III reappears in other Sections of the MfS as well. Financial, material, and personnel support for these "young nation states" were grouped under "Planteil III." ${ }^{160}$ All activities of delegations, advisory groups, finances or payments of solidarity in or for South Yemen were coded with a "C" $\mathrm{C} 11$ or "030." Also, one of the few comprehensive files on the PDRY of Section X not only provides a history of the development of the KfS, but also the full structure of the PDRY's Secret Service. ${ }^{63}$

The former Stasi documents have a downside which cannot be ignored in the process of research. Firstly, the Stasi Files are the result of the work of a former secret service and thus their content regularly concerns security interests of not only other states but also the Federal Republic of Germany, as well as individuals still active in public life. Secondly, the MfS was not a "secret service like any other", but also a political secret police without a clear separation of the two. Many of the results now conveniently accessible to the researcher have been acquired by betrayal, blackmailing, and sheer brute force. Consequently, for the sake of state

58 | For example Howell, 1994.

59 | Gieseke, in: Kaminski/Persak/Gieseke, 2009, 231.

60 | Zusammenstellung des MfS für Hilfeleistungen an junge Nationalstaaten 1978, December 15 1978, in: BStU MfS Abt. Finanzen Nr.1393, 149.

61 | "MR C“, in: Bericht über die finanzökonomische Anleitung in der Ministerratsgruppe der VDRJ in der Zeit vom 3.7. bis 5.7.1987, BStU MfS Abt. Finanzen Nr.85, 66.

62 | Vorschlag zur Verschlüsselung [suggestion for coding; handwritten note], 1980, in: BStU MfS BCD Nr.20802, 59.

63 | Strukturen des MfS der VDR Jemen; Zur Lage des MfS der VDR Jemen; Kadersituation des MfS der VDR Jemen, in: BStU MfS Abt. X Nr. 234, Part 1 of 2, 93-107. 
secrecy, but even more so for the individual dignity of the persons observed, the researcher not only has to be aware of these circumstances of the files' creation, but also has to consistently reconsider their genesis during the writing process.

\section{Interviews with Contemporary Witnesses}

A central methodological topic of this study is the proper inclusion of contemporary perspectives without overemphasizing these interpretations and losing touch with the fact of contemporary perceptions. Firstly, this analysis clearly has to overcome "outdated" policy papers and strategic analyses of the analyzed time period. Naturally, these do not necessarily provide reliable information on a country's policies or the international events this study is looking at. On the other hand, these analysis are invaluable to understanding the international perception of policies and events - what is assumed by political decision-makers may prove more powerful with regard to impact than actual facts. This study aims to strike the right balance between finding an appropriate analytical distance from these statements while providing them with sufficient room to speak for themselves. This is intended to be achieved by treating writings of the analyzed time period first and foremost as a primary sources on the respective topic.

The same approach applies for the However, in addition to the limitations of the personal perspective of contemporary writing, memories of course change over time. On top of that, the topic of the GDR's foreign policy turned out to be a highly sensitive topic for the political actors involved. The interviewer necessarily had to distance herself from the oftentimes very personal accounts of memory on the one hand, while showing the empathy necessary to interpret the given information on the other. What all interview partners had in common was a certain resentment toward the complete eradication of their profession as GDR diplomats. ${ }^{64}$ This attitude is understandable and inevitably has to be taken into consideration when using the results of the interviews for this analysis, as the procedure of the voluntary dissolution of the GDR and its inclusion into the Federal Republic seemed to have different effects on the potential and actual interview subjects. One of the interviewees, for example, summarized the attitude of the former political functionaries of the GDR toward their past:

"It's the same with our own people. The reflection of the circumstances is changing. Some fully block off certain topics, others opt for a 'soft line', trying to justify their political decisions afterwards. [...] The focus is on defense not reproduction [of policies and events]." 65

This observation already has to be considered relevant for the selection of partners, as not all contemporary witnesses able to offer information were also willing to do

64 | Pfeiffer, 1997.

65 | Interview with Hans Bauer June 202011. 
so. Furthermore it turned proved difficult to avoid the "mechanism of justification" described above. This was to be achieved by creating a positive and open interview atmosphere between interviewer and interviewed. To support this intention, the transcripts and notes which resulted from these meetings had been reviewed in a reciprocal exchange to assure the proper use of the perspective provided by the contemporary witnesses. These interviews are considered biographic primary sources, offering a very personal perspective. As part of the research for this study they serve two major purposes: Firstly, and most importantly, they illustrate or comment on certain policy decisions, developments, and events and thus help to interpret archival material. Secondly, and only in a few selected cases, they are used to support a line of argument in case archival material was contradictory. The latter of the two ways of processing the interviews is used carefully, taking into consideration the unsteady ground of personal accounts of history.

In the following, all interview partners who supported this research project with their personal account of East Germany's foreign policy activities are introduced in alphabetical order, while pointing out the relevance of their experiences for this study and summarizing the most important topics of the interviews. Due to the East German policy in the diplomatic sphere to train and assign their personnel with a regional focus, all of my interview partners from the MfAA had worked together at one point or the other in their careers, ${ }^{66}$ which significantly added to the worth of the interviews: by offering different perspectives on the same topic, they can be considered more than just the sum of their parts.

First of all, a written and published account on personal experiences in South Yemen can be introduced here, as the slim volume is approached in the same way as an interview - as a personal memory of events. Günther Scharfenberg, East German ambassador to the PDRY in the 1970s, published his memoirs and notes in 2012. Scharfenberg served as ambassador to Aden from September 1972 to May 1978. Before the posting, Scharfenberg had proven his abilities in foreign policy by substituting for the Head of Section Arab States of the MfAA, Karl-Heinz Lugenheim, from August 1970 to February 1971, and then for Wolfgang Bator in the Section International Relations of the CC in fall 1971. Thus, Scharfenberg's interpretations of foreign policy making in Aden regularly offer a perspective beyond South Yemen and tend to include the GDR's approach to the region, as well as details about the East German foreign policy apparatus.

Fritz Balke, considerably younger than the other interview partners, is the only interviewee who remained involved with actual German foreign policy making after reunification. Through contacts to West German foreign policy personnel, he was recruited as election observer 1996 in Palestine and 1997 in Yemen. In

66 | For example, Günther Scharfenberg (ambassador in Aden from 1972 to 1978) had shared an office with Freimut Seidel (ambassador to Aden from 1986 to 1989) in East Berlin, in: Scharfenberg, 2012, 14. 
the GDR, Balke had been Vice-Consul in North Yemen from early 1969 to the end of 1972. The Sana'a consulate, and later on the embassy, had depended on the communications and trade infrastructure of the comparably large embassy in Aden. Thus Balke visited the South on a frequent basis. After several other placements, Balke was assigned to East Germany's relations with both Yemens in the Section Near and Middle East of the MfAA in East Berlin. In the late 1980 s he returned to Aden twice, on the occasion of the YSP Conference in 1987 and accompanying the Head of the CC Section IV to renegotiate party relations between the SED and the YSP. Furthermore, he witnessed two meetings of Honecker with the PDRY's new President Al-Beidh after the "1986 crisis" in Moscow on the occasion of the CPSU Party Congress and the 7oth anniversary of the October Revolution in 1987. Balke's comments on the GDR's engagement in both Yemens are characterized by a very frank and open attitude, granting a glimpse of day-to-day friction in the political process and the existing variety of opinions among diplomatic personnel about East Germany's foreign policy making.

Due to regular publications and presentations, Wolfgang Bator is one of the most well-known former GDR foreign policy personnel today. In the GDR he pursed both a diplomatic and an academic career as a major expert on the Near and Middle East. He has been occupied with the region since he first left for Syria in 1958. He served as ambassador in Libya and Iran and was a member of the Section International Relations of the CC. ${ }^{67}$ In the early 1970 s he was nominated as the new ambassador to South Yemen, but withdrew himself for personal reasons. His interview focuses on the GDR's activities in the Near and Middle East and gives a personal account of the diplomatic service and day-to-day work in the East German embassies. As Bator explicitly takes a Marxist-Leninist stance and argues along its ideological lines, his comments on the relation between foreign policy and ideology support the interpretation of the discrepancy between ideological theory and political reality of this study.

According to the leftist newspaper "junge Welt", Hans Bauer is still working as an attorney in Berlin to "defend former citizens of the GDR against political prosecution and criminalization, [...] advocating for rehabilitation, justice and historic truth." ${ }^{68}$ Bauer had been a public prosecutor of the GDR and was recruited by the Stasi in 1982. Together with Volkbert Keßler, ${ }^{69}$ both of them high-level party functionaries (nomenclature) of the CC of the SED, he served for the HV A in the PDRY from 1982 to $1985 .{ }^{70}$ Due to his new position as an official Party-Secretary of the Department of

67 | German: Abteilung Internationale Verbindungen (IV).

68 | Rupp, Rainer, Interview with Hans Bauer, "Strafvollzug in der DDR zielte auf vollwertige Wiedereingliederung”, in: junge Welt, June 21 2012, 3.

69 | Brief HA XX Kienberg an HV A Stellvertreter, January 28 1982, in: BStU MfS AP Nr.68777-92, $27 f$.

70 | Vermerk über die Einstellung der inoffiziellen Zusammenarbeit mit dem GMS „Leonhardt“ Reg. Nr. XV3481/1982, October 11 1988, HAXX, in: BStU MfS AP Nr.36630-92. 
the Attorney General in South Yemen, Bauer was able to "entertain official contacts in political-operative cooperation [as well as] unofficial cooperation [with the MfS] which had been terminated" in fall $1988 .{ }^{71}$ During his years in Aden he emerged as a trusted advisor of the Attorney General of the PDRY.72 Even though Bauer's account on his actual work in the PDRY remains vague, his interview offers an interesting account on some details of his political and juridical work in Aden and the intensity of East German engagement in this field and thus helps to assess the impact of East German presence on South Yemeni internal development.

Werner Sittig had been the last serving ambassador in the PDYR. He and his family arrived in Aden in August 1989. Sittig witnessed the beginnings of Yemeni unification and was supposed to become the East German ambassador for unified Yemen in Sana'a. German reunification prevented that from happening. After his early return to East Berlin, he became Head of the Section Near and Middle East. He supported this study with a lengthy phone call about his experiences.

Heinz-Dieter Winter had joined the MfAA in 1960 in the Section Southeast Asia. He had started his diplomatic career in Laos, Vietnam and Cambodia, and advanced first to Head Deputy and then Head of the Section Near and Middle East until the late 1980 s. From 1986 until his resignation in 1990, he served as ViceMinister of Foreign Affairs and visited South Yemen on several occasions, the last time in 1990. From 1988 he had been assigned to the Section Near and Middle East. His interview is especially valuable regarding the assessment of structures and procedures of foreign policy making, the role of the Near and Middle East for East German foreign policy, and the final years of East German foreign policy. Last but not least, Winter provided the author with an inside view on the internal discussion on the ' 1986 crisis' in Aden and the GDR's resulting policy turn.

71 | Ibid. 48.

72 | Operative Einschätzung des GMS „Leonhardt“ - Vorg.-Nr.XV 3481/82, August 28 1986, HV A/III/AG/018, in: BStU MfS AGMS Nr.10208-88, 67. 


\title{
CHAPTER 3. Analytical Approach:
}

\author{
An Interdisciplinary Analysis of Foreign Policy
}

\author{
"What's past is prologue."1 \\ William Shakespeare, The Tempest, 1611
}

To understand the present without knowing the past may be compared to the attempt of crossing an ocean without seeing the sun: "[W]e need [history] to live and act, not to turn lazily away from life and action or even the whitewashing of a selfish life and times of cowardice and malice."2 This especially is the case when occupied with current history, which regularly encroaches upon current political developments as a major determinant and explanatory. About a century after Nietzsche, Halliday also advocates for the "need for history", though in less normative terms than Nietzsche, and emphasizes the benefit history brings to the analysis of international relations and foreign policy:

" $[\mathrm{H}]$ istory is necessary to explain why countries act as they do, and, equally, to provide the basis for analyzing how states, and their opponents, claim to use, select and falsify history to justify what they do." ${ }^{3}$

As a consequence, this analysis does not shy away from including "history" in the form of primary sources on East Germany's foreign policy or secondary sources of contemporaries to interpret this foreign policy in the context of its present, which itself has now become "history". While the analysis is based on a comprehensive political science approach, the important role of primary sources for this study led to continuous elaboration of this theoretical approach in the sense of deducing theory from the case study at hand. As a result, this study integrates methods and approaches of political science and history to prevent a mere presentation of

1 Antonio, The Tempest, Shakespeare, William, 1894 (1611), 31. Engraved on the National Archives Building, Washington. Görtemaker, 1999, 13.

2 | Nietzsche, 1937, 5.

3 | Halliday, 2006, 40. 
a theoretical account without any relevant connection to the actual analysis. Apart from historical methods, like the three-step process of "heurism, critique, and interpretation" for interpreting historic sources, ${ }^{4}$ the interdisciplinary openness resulted first and foremost in the identification of turning points and catalyst events of East German foreign policy engagement in South Yemen from which four phases of development were derived. ${ }^{5}$ These secondary methods substantively support the overall theoretical approach to foreign policy of this study as a "process".

The following chapter introduces the central analytical categories to connect them in a comprehensive theoretical approach. First of all, the term "foreign policy" is defined and operationalized as an analytical category with a focus on how foreign policy relates to its two major determinants, the national and the international. The analytical category "foreign policy" is connected with the macro-hypothesis of this study which considers East German engagement in South Yemen a "policy of socialist state- and nation-building" with a possible "neo-colonial" connotation. Finally, the relation of "foreign policy" to "state sovereignty" is explored to illuminate the normative-ethical dimension of the "limits of foreign policy". Here, the concept of "identity", and more specifically "national identity", plays a major role in explaining the impact or inefficacy of foreign policy on the "recipient of foreign policy" or host state.

\section{Foreign Policy: Where the Nation State Ends}

"The meaning of a complex expression can be derived unambiguously from the lexical meaning of its components, their grammatical meaning, and syntactical structure." 7

Compositional semantics ${ }^{8}$ suggests that, at least on the descriptive level of interpretation, any complex expression can be approached as lexically selfexplanatory based on its respective elements. According to this approach, the term "foreign policy" by itself may refer to either a "policy" that is considered "foreign" by the speaker, or a "policy" occupied with questions considered "foreign" by the speaker. With regard to the context in which the term "foreign policy" regularly is used, the latter relation between the two words is what determines its meaning: An expression to describe the "policy", the sum of a state's or other international actors' actions and non-actions, directed towards the "foreign" of this state or international

4 | Budde/Freist/Günther-Arndt, 2008, 159; Baumgart, 1977; Burkhardt, 2006.

5 | On Giddens" approach to history and change as "episodic", in: Joas, 2011, 427.

6 | Definition “Neo-Colonialism”, in: Stanton/Ramsamy/Seybolt/Elliott, 2012, 332-334 and Young, 2001.

7 | Löbner, 2002, 20.

8 | A sub-discipline of semantics: "Research of Meaning”, in: Lyons, 1995, 409. 
actor. Nonetheless, "foreign" is rather a vague term: "Foreign" as the opposite of "common", "native" or, "domestic"? "Foreign" for whom and in comparison to what? No more clarity can be found with regard to the French expression "politique étrangère", either, as its qualifying adjective only offers the same meaning. The German term "Außenpolitik" and the Arabic expression "al-siyasa al-harijiya" on the other hand offer easier access to the core meaning of the English term "foreign policy". Originally, the German and Arabic terms had been used for more or less defined territorial political entities which later on developed toward the nation state of the international state system as we know it today. Both "außen" and "al-harijiya" refer to the "external" as opposed to the "internal" of the respective actor.

Wilfried von Bredow clearly sticks to this basic meaning of the German term "Außenpolitik", when he defines foreign policy as

"the sum of all interactions of a state with other states or non-state actors outside its territorial borders. The state is represented by its government and claims [...and takes] ultimate responsibility for all external relevant actions of its citizens." 10

With his definition, von Bredow also points out the relevant actor in the international realm: the state. In doing so, he follows the realist approach to foreign policy.

"Contemporary scholarship has been for the most part content to see foreign policy explained as a state-centric phenomenon in which there is an internally mediated response to an externally induced situation of ideological, military, and economic threats." 11

As this quote by David Campbell suggests, both major streams of IR thought, realism and liberalism, derive their reflections on the international realm first and foremost from the actions and decisions of the state and its respective government. However, a significant change has evolved within the discipline, mostly due to substantial shifts in the international state system, but also within academia itself.

First of all, one of the most important characteristics of the realist point of view, has been challenged. According to realists such as Kenneth Waltz, foreign policy is formulated in the name of the state and presented as though it were the general will of the state. ${ }^{12}$ Hence, states always act as a unified actor, a "black box" to other states. Internal developments are of no relevance for Realists. This perspective has been

9 | Arabic: al-stāsa 'al-ḥāriğiya.

10 | Von Bredow, 2006, 38.

11 | Campbell, 1997, 36.

12 | Waltz, 1959, $178 f$. 
challenged repeatedly, from within the discipline but also by related disciplines. Anthony Giddens, for example, criticizes IR theory's tendency to obscure

"the fact that governments cannot be equated with states [...] and that policy decisions within governments usually emanate from highly contested arenas of social life." ${ }^{13}$

As a consequence, the "black box" approach has been revised in recent decades in mainstream IR theory. However, the most significant change to the Westphalian state system had already started during the time of the "founding fathers" of IR due to two phenomena: Domestic and international democratization. According to von Bredow, it is the state, represented by its government, which "claims [...] ultimate responsibility for all external relevant actions of its citizens". ${ }^{14}$ However, von Bredow argues, while the state remains responsible for its citizens' actions, in democracies any citizen or group of citizens can also become an external actor. Thus, the "inside" of the state becomes an immediate determinant of foreign policy. ${ }^{15}$

Furthermore, international institutions and organizations emerged while more treaties and trade agreements clustered around state interests, at least with regard to certain issues. The relation between "inside" and "outside" the state, the basis of the definition of foreign policy, is considered to have changed due to the growing importance of international and especially supra-national organizations. These entities form a new level between the national and international sphere. State actors have begun to hand over competencies ${ }^{16}$ and some of these organizations even have formulated foreign policy frameworks for their members. ${ }^{17}$ However, this development may not only be interpreted as the end of the nation state. Both Krasner and Giddens suggest that international organizations and state sovereignty rather have to be considered to mutually enhance one another. ${ }^{18}$

Nonetheless, the permeability, perhaps even dissolution of the boundary between "inside" and "outside" as described above may not be a new phenomenon after all, but rather the actual condition of the international system as it had been all along. Deconstructionist perspectives reject the role of foreign policy as a "connection" or "bridge" between a priori existing nation states and their anarchic international environment. Instead, this image is considered a mere assumption of the realist world view and as such does not have to be perceived as an eternal given, but instead may be questioned. An enlightening constructivist account of foreign

13 | Giddens, 1983, 289.

14 | Von Bredow, 2006, 38.

15 | Von Bredow, 2006, 44.

16 | Krasner, 1995, 120.

17 | E.g. the European Union (EU) or the North Atlantic Treaty Organization (NATO).

18 | Giddens, 1983; Krasner, 1995. 
policy in international relations is introduced by David Campbell. Campbell questions the established Realist perspective of foreign policy analysis on the international state system, though he does not dismiss it outright. While Campbell does not dispose of the state, he rejects the realist assumption of the state's unitary character and rather focuses on the emergence and construction of the national and international and the role of foreign policy in this process. He recognizes "foreign policy as the integral part of the discourses of danger that serve to discipline the state [and in doing so create its identity]. “19 These dangers from the "outside" are regularly based on the distinction between the "inside" and "outside" in terms of difference (the self/other dichotomy ${ }^{20}$ ) to generate identity and unity within the community on the "inside". For example, imperialism in general and Great Britain in particular had fostered a Yemeni identity of the "urban Adeni" by the Red Sea. What followed was a foreign policy that explicitly turned away from "Western imperialism" and towards "Anti-Imperialism" of the Eastern Bloc. This coincides with Campbell's conclusion that foreign policy does not create "bridges" between the national and the international, but rather boundaries between the two spheres, in the case of South Yemen a boundary against an "outside" of neighboring states and "Imperialist powers" perceived to be hostile.

This constructivist perspective as introduced by Campbell can be combined with the historic-sociological understanding of the international state system, which disputes the unitary character of states as well as the notion of the linear, or progressive emergence of states. ${ }^{21}$ In this perspective, the state is considered "an institution of coercion and appropriation which operates on two levels, the internal state-society dimension and the external state-state dimension," ${ }^{22}$ which generates and implements foreign policy. Clearly, this study does not consider the concept of the state disposable for the analysis of international relations or foreign policy, but rather aims to use the concept of the state to "assess the role of other formative factors such as economic ideas and social forces." ${ }^{23}$ This analysis concedes the constructed nature of the state, while embracing the historicsociological understanding of foreign policy generation between the internal and the external, the inside and the outside of the state. And even though states today are merely a certain kind of foreign policy actor among others in the globalizing world, they have emerged as the dominant actors in the realm of the international because states are the major implementers of foreign policy.

A constructivist approach to foreign policy enables the scholar to choose one reality among the various possible narratives, while urging the scholar to justify his or her choice by uncovering the construction of this version of "reality". To be

19 | Campbell, $1998,51$.

20 | Derrida, 1997 (1976).

21 | Giddens, 1983; Mann, 1993; Campbell, 1992, 40-43.

22 | Halliday, 2006, 37.

23 | Halliday, 2006, 71. 
able to grapple with this complex reality, simplifying models are needed. However, these may not be mistaken for a law-like explanatory of past or present social development and change: "There is no key opening the gates to the secrets of human and social development, none which could reduce these in a comprehensive scheme."24 Instead, the suggested schemes based on the preliminary thoughts on the state, as the main generator of foreign policy caught up between its inside and its outside, are considered a "sorting system" for the complex reality of current history, based on theoretical assumptions of so-called "medium-range".

With regard to foreign policy making, this analysis suggests a three-level-approach that modifies Waltz's "three images of international relations": The individual, the domestic, and the international. ${ }^{25}$ Waltz admits that "some combination of our three images, rather than any one of them, may be required for an accurate understanding of international relations, ${ }^{, 26}$ and warns that any emphasis on one of the three images "may distort one's interpretation of the others. ${ }^{27}$ However, in the end he does exactly that and considers the "system level" the major level of analysis and source of explanation. The tendency to over-emphasize one "image" of course is ever present in any analysis occupied with foreign policy that connects all three of the images. Thus, this study is just as prone to give one level too much weight in the analysis as any other study.

Based on the assumption that foreign policy is an answer to demands from both the state's "outside" and "inside", the following paragraphs understand foreign policy making as a process and strive to locate this process within the "three images". The modification of the "three images" considers the micro- and meso-levels/images to reside within the realm of the state as the major foreign policy actor. Also, one has to include the micro- and meso-level of the foreign policy actor, as well as the micro-and meso-level of the foreign policy host. The formulation of a state's or organization's foreign policy is located at the meso-level of foreign policy making. Foreign policy formulation is based on a state's goals and interests among the diplomatic and/or administrative functionaries, and, at least in liberal democracies, in consultation with the public. The boundary between the state and the international, the interface between "inside" and "outside", is defined by the macro-level of foreign policy making. The macro-level is where any foreign policy actor, be it a state, organization, company, or private person, is confronted with the demands of an "outside", the international. ${ }^{28}$ Thus, the state's scope of action is determined by demands from the "outside" and the "inside" at the so-

24 | Giddens, 1988 (1984), 300.

25 | On Waltz' concept of the "three images": Waltz, 1959, 14f and $238 \mathrm{f}$.

26 | Waltz, 1959, 14.

27 | Waltz, 1959, 160.

28 | Von Bredow, 2006, 44. 
called "inside-outside interface". ${ }^{29}$ The "inside-outside-interface" is characterized by other qualities than the international itself, as foreign policies between two states and the resulting bilateral relations regularly change the characteristics, i.e. the rules and institutions, of the international.

From this perspective we may finally be able to further specify the "foreign" in "foreign policy" according to the compositional semantics approach: Foreign in regard to what? At the core of its meaning the English term "foreign policy" only works in relation to the concept of the state, more precisely the nation state. The nation state formed itself as a political community based on a "self/other dichotomy" by referring to what the community had in common on the inside and defining what differentiated the community from the outside. "Foreign policy" is the policy of "us", the community, towards all the others "outside" our community. Thus, "foreign policy" has played a major role in forming the political communities we know as nation states, becoming monopolized by the nation state in the process.

How do these reflections further the analytical approach? First of all, the presumptions do not deny the central role of the state, but do not define "foreign policy" as a simple unitary product of state action, either. Rather, the preceding reflections emphasize the interdependent, fluent character of foreign policy, constantly challenged from the "inside" and "outside" of the state within the "inside-outside-interface" and thus less a condition, but rather an interactive process between numerous actors.

"A political system [state] tries to promote its fundamental objectives and values [...] while it is competing with other systems. This process is affected by social demands from within the system on the one hand, by demands from the [external] international system on the other. The result is a dynamic process of mutual impact and adaption on both the national and the international level." ${ }^{11}$

Helga Haftendorn, interdisciplinary foreign policy analyst

This study aims to work with a comprehensive theoretical approach, integrating methods of political science and history. Two of the pioneers of a possible interdisciplinary perspective in Germany have been Ernst-Otto Czempiel and Helga Haftendorn, who considered foreign policy a process, as opposed to an instantaneous snap-shot. Though the definition quoted above acknowledges the (pre-)existence of the state as a "political system", it also offers a differentiated view

29 | This approach is inspired by R.B.J. Walker's comprehensive account on International Relations and the role of the "inside/outside" notion. Walker 1990, 1992, and 2010.

30 | This approach brings together Gellner's, Hobsbawm's, and Ander's account on the emergence of the nation state: Anderson, 1983, 36; Gellner, 1983, 48; Hobsbawm, 1983, $1 \mathrm{ff}$.

31 | Haftendorn, 1989, 33. 
on the generation of foreign policy: Helga Haftendorn defines foreign policy as an "interactive process" ${ }^{32}$ The outstanding characteristic of a process is that it evolves over time as a reaction to internal and external influences - it changes. Thus, this approach sharpens the analytical eye for the most interesting and possibly most important "moments" of foreign policy - its "turning points", when continuity has to make room for change.

Like any other policy, foreign policy is an answer to demands from the environment of the state, which come from both "outside" and "inside". According to Czempiel, a state as a political system has to aspire to three major demands from within: Security from outside intervention, liberty and stability inside the system, and economic wellbeing of its society. He locates these three demands on the corners of a triangle. Their mutual relationship is what determines a state's foreign policy goals. ${ }^{33}$ These goals are regularly re-prioritized, usually through reconsidering the relationship between the three demands. Also, these priorities may contradict each other in a "priority conflict" ${ }^{\text {"4 }}$ which sometimes renders it impossible for a state to include all of its goals in its policy. Due to complex factors of influence "outside" the state and a high number of other actors pursuing their foreign policy goals, states are confronted with the fact that they cannot expect to always act according to their priorities, let alone achieve all of their goals. The ability to pursue and achieve self-declared foreign policy goals depends on the nature of a state's scope of action in the international realm on the one hand and the state's resources on the other. A state's resources may be classified as "hard facts", such as territory, population, natural resources, perceived and actual military power, training and education, and "soft facts", most importantly degrees of freedom, ideas, and innovation. Any retrenchment of resources or of the scope of action naturally leads to a limitation of possibilities for success of foreign policy. A possible reaction of a foreign policy actor to such limits could be either a change of strategy, or a change of mid-term or long-term goals.

The term "policy strategy" usually refers to planned action of a political actor. With regard to foreign policy, Krippendorf further defines it as the "combination of single elements of a state's foreign policy [generating a] relatively stable pattern of action." ${ }^{35}$ Based on these preliminary assumptions, a foreign policy strategy in this analysis is defined as a superordinate road map, formulated at the state or meso-level of foreign policy making by diplomatic and/or administrative foreign policy actors to promote a specific foreign policy goal, or a set of goals, by combining an indefinite number of concrete foreign policy tools in a planned and

32 | Haftendorn, 1989, 33. Weißbuch zur Sicherheit Deutschlands of 1994 and Weißbuch zur Sicherheitspolitik Deutschlands of 2006.

33 | Compare: Lehmkuhl, 2001, 29.

34 | Haftendorn, 1989, S.32.

35 | Krippendorf, Ekkehardt, 1973, in: Siebs, 1999, 25. 
purposeful manner. A foreign policy tool is defined as any foreign policy measure planned and formulated by diplomatic and/or administrative foreign policy actors. These tools are realized on the micro-level of foreign policy output, that is, by the performing actor in the host state with the purpose to attain a foreign policy goal.

\title{
2. How to Assess Foreign Policy: Tools and Criteria
}

\begin{abstract}
“Ultimately, foreign policy is a test of a nation's character. [...] [It] expresses the relationship we want with other nations. It must reflect our values and define our interests. The sacrifices we are willing to make in the pursuit of our foreign policy objectives also tell the rest of the world something about the courage of our convictions as a nation." 36
\end{abstract}

(Alexander M. Haig, U.S. Secretary of State 1981-1982)

\begin{abstract}
After defining foreign policy as a process and clarifying which foreign policy actor is considered to be at the center of this analysis, the methods of how to assess change within the process of foreign policy have to be discussed. With regard to the analysis itself, first of all the most relevant "fields" of the respective foreign policy are identified, i.e., the target of the policy's impact in combination with the tools used, followed by an evaluation of the "level" of this foreign policy. In his policy paper on the U.S. engagement in Yemen, Edward Prados, a researcher at the Center for Contemporary Arab Studies at Georgetown University, introduces a number of functional tools for foreign policy analysis, while explicitly referring to the role of the "intensity" of foreign policy. ${ }^{37}$ In the following section these concepts are reviewed critically and modified.
\end{abstract}

Prados' paper is one of the few current comprehensive studies published outside the military on the history of a Western country's relations with Yemen. From his perspective, foreign policy is not only defined as an "active" policy, but it also follows the traditional understanding of foreign policy as political action of one state towards another. Prados clearly distinguishes between the active, dominant role as opposed to a receiving, even submissive, inactive part. Throughout his argument he tries to go beyond mainstream U.S. foreign policy perspectives, but does not fully succeed: Prados' nationally colored perspective narrows his analytical view. Despite his critique of aggressive interventionism, he is not able to go beyond the demands of a policy paper and implicitly cleaves to realism's notion of the struggle for power for its own sake. In addition to that, Prados' "levels of engagement" as categories on the one hand unfortunately mix intensity and

36 | Haig, 1985, 71 and 75.

37 | Prados, Edward. The United States and Yemen: A Half Century of Engagement. Occasional Papers. Center for Contemporary Arab Studies, Georgetown University, 2005. 
intention of actions that aim to have an impact on the receiving side of foreign policy. On top of that he includes moral motivation - "good" or "bad" intentions in his analysis - so that it is difficult to distinguish motivations from other interests with regard to the intended outcome of "national interest" in the policy. On the other hand, Prados fully ignores the agency of the recipient, and thus overlooks the influence of the host state on a state's foreign policy.

Prados argues that any form of engagement in another state, even the most intensive one, can be free of concrete harmful intentions of the foreign policy actor. However, the actor always pursues a goal with his actions, a fact Prados' approach does not reckon with. A possible solution for this is to explicitly include the host state. For example, when comparing different cases of humanitarian intervention, Prados presumes a "good" intention of the foreign policy actor who offers military assistance for humanitarian purposes. However, "intention" in this case cannot be considered a reliable analytical category, as the only source available is the actor himself, who does not necessarily have to tell the truth. But ever since the first discussions on humanitarian intervention, consent of the host state is key to transform unlawful intervention into legal intervention. ${ }^{38}$ That said, a modified foreign policy approach of engagement that differentiates between "intensity" and "intention" may serve to analyze the actions and non-actions of the respective foreign policy actor and might be especially fruitful for evaluating the intensity of foreign policy activities during the different phases in a context of "developmental politics": In modifying Prados' approach, five levels of intensity are re-defined, referring not only to foreign policy as whole but also to different "fields of engagement".

Then, Prados introduces three levels of intensity of engagement: "influence", "involvement", and "intervention". Somewhat oversimplified, his approach turns a blind eye to many forms of political intent and action, especially at the margins of the spectrum of engagement. One may disagree that non-action does not qualify as foreign policy. However, the non-action or the delay of certain actions expected by the host state or the international community due to a state's history of foreign policy behavior can be just as impactful as explicit measures taken. To provide a more complete picture of levels of engagement, another level of engagement below "influence", labelled "interest", is added. This stage of engagement includes policies that observe another state's politics to determine whether and when an intensification of engagement might serve one's own ends better. "Influence" is defined as foreign policy engagement in the sense of reciprocation with basic diplomatic exchange. "Involvement" implies a functioning working relationship with the host state. Lastly, "intervention" includes any actions aimed at manipulating the internal affairs of the host state, but this need not

38 | On the legal and moral discussion on Humanitarian Intervention and its genesis: Welsh, 2005; Wheeler, 2000 and The Responsibility to Protect. Report of the International Commission on Intervention and State Sovereignty, December 2001. 
"be accompanied by the threat of hostile action," 39 as Prados claims. Bearing the major hypothesis of this study in mind, the spectrum of intensity of engagement does not stop at intervention. To illustrate this, the level of "imposition" is added as the highest possible intensity of foreign policy. "Imposition" is defined as the active control of parts of the host country's politics by the foreign policy actor and is regarded as the last stage before the de-facto inclusion of the host state into the territory of the foreign policy actor. The transition from one level of engagement to another is a gradual one. Accordingly, the transition from foreign policy "imposition" to "occupation" or "colonization" and thus intervention beyond the "limits of foreign policy" is also both gradual and possible.

\begin{abstract}
„[T]hose who study foreign policy must concern themselves with politics at all levels [...] it is in some profound sense a discipline with limitless boundaries: the discipline is imposed by the need to reorganize inquiry around the external behavior of nation-states [...] but insofar as its independent variables are concerned, the scope of the field is boundless." 40
\end{abstract}

(James Rosenau, Political Scientist, 1987)

With regard to understanding a country's foreign policy, its motives, goals, restraints and impact, there is no additional value in a mere enumeration of capitals visited, agreements signed or wars declared. This especially is the case for the approach of this study, as itexplicitly includes the host state of foreign policy. To be able to cope with the sheer amount of archival material, which is mostly occupied with exactly these "hard facts" of diplomacy, filtering tools that can focus the analysis towards its goal and thus generate new insights are needed. The first "sorting tools" have been introduced above, a method to identify change in foreign policy by considering the "fields of foreign policy" as well as the level of intensity of engagement, or the "levels of foreign policy". Change in the "fields" and the "intensity of engagement" can be observed on all three levels/spheres of foreign policy making.

Most of the time, change at the micro-level of foreign policy, i.e., the actual policy on the ground, is connected to a change at the meso- or even macro-level of foreign policy making, and thus entailing a change to the foreign policy actor's goals (meso-level) or a change to the scope of action within the framework of the international state system on the "inside/outside-interface" (macro-level). In other words, any foreign policy change on the ground may be an indicator of a more or less profound shift in a state's foreign policy orientation. The reasons for this kind of change, though, may not only be found within the state itself, but also within the host state. As with Soviet activities, the level of East Berlin's engagement depended on internal political developments in the extremely

39 | Prados, 2005, 4.

40 | Rosenau, 1987, 4. 
unstable milieu of South Yemeni politics. This circumstance already illustrates the necessity to include the receiving side of foreign policy, in this case the PDRY, as explanatory for foreign policy and its changes. As a consequence, the analysis of the GDR's foreign policy rests on a scheme of phases. In the case of South Yemen, it is less the stability of a certain phase which determines the room for foreign policy engagement, but rather the turning points and catalyst events, indicating a changing political situation in the country and the ability of the external actor to react. Thus, each chapter focuses on the turning point that initiates the phase as well as relevant catalyst events. To support and illustrate the argument, the most prominent events or political challenges within the "host state" in South Yemen are presented in more depth in each phase chapter to be able to characterize the GDR's foreign policy in South Yemen.

\section{Foreign Policy ends at the other State's Sovereignty}

To better analyze and interpret the GDR's engagement in South Yemen, however, this study does not settle for a phase analysis of the foreign policy itself. Here, the major hypothesis ties in with the approach introduced before: East German engagement is considered a "policy of socialist state- and nation-building" which had far reaching consequences. Apart from the very concrete goal of international diplomatic recognition, the GDR also pursued a highly normative, or rather ideological goal. In South Yemen, East Berlin sought to establish a socialist state in its own image. This hypothesis gives rise to normative-ethical and empirical questions. Firstly: When does a policy based on an ideological motivation exceed the "limits of foreign policy" and turn into imposition? Secondly: Is it possible for an external actor to promote state- and nation-building towards a state in one's own image and to induce social change in the host country? The following two subchapters are occupied with these questions and connect them with the GDR's "policy of socialist state- and nation-building".

The willingness of a state's representatives to engage with another state regularly means opting for "involvement and interaction as opposed to isolationism."41 This can imply that one state seeks to influence the behavior of another state in a certain way. ${ }^{42}$ In doing so, the influencing state can exceed the "limits of foreign policy". As indicated above, this study locates the "limits of foreign policy" where another state's "sovereignty" begins. This means that the infringement of a state's sovereignty is where the "limits of foreign policy" are exceeded. To be able to define this boundary though, the phenomenon of sovereignty in this context has to be analyzed and understood. The following subchapter explores the moments

41 | Haass/0'Sullivan, 2000, 18.

42 | Prados, 2005, 4. 
of friction in foreign policy and "sovereignty" and connects the results with the "policy of state- and nation-building" approach.

In the following, the concept of "sovereignty" is used in nominalist terms to include different meanings in different contexts. "Sovereignty" is regularly defined with a focus on either internal or external state sovereignty, the former being popular in philosophy and political theory, the latter in the field of international law. Questions about the "limits of foreign policy" tend to be occupied with the "external" side of sovereignty. To fully understand the Janus-faced nature of the concept, though, the "internal" side of sovereignty has to be understood as well. Internal sovereignty mostly refers to what Francis Harry Hinsley defined as the "final and absolute authority in the political community," where "no final and absolute authority exists elsewhere" ${ }^{\prime 4}$ in the respective territory. His definition rests on the essentialist understanding of sovereignty as it had been introduced by Jean Bodin and Thomas Hobbes in the $16^{\text {th }}$ and $17^{\text {th }}$ century, ${ }^{45}$ while he also included Max Weber's definition of the state as the agent that claims and owns the "monopoly of the legitimate use of [physical] violence within a certain territory."46 From this point of view, the monopoly of violence becomes a conditio sine qua non for the legitimacy and efficiency of the state, including its sovereignty as the final, absolute, and only authority within the given territory. Clearly, this definition has become constitutive of most conceptualizations of "internal sovereignty" in the tradition of Western thought, just as Georg Jellinek's defines the sovereign state in the international state system as a prerequisite for "external sovereignty".

Jellinek suggests three essential prerequisites for a state to qualify for external sovereignty: state territory, people, and authority. ${ }^{47}$ These three elements "are mutually dependent and thus their isolation is a mere hypothetical exercise as each of the three conditions the other two." ${ }^{48}$ Generally speaking, this approach considers "internal sovereignty" the basis for the justification of "external sovereignty". "External sovereignty" in legal terms is derived from the equality of sovereign states, that is, states claiming "internal sovereignty" for themselves in the international state system, as expressed, for example, in the non-intervention clause in Chapter 1 of the UN Charter. The origins of these principles can be traced back to continental Europe and the Treaty of Westphalia. ${ }^{49}$ Singed at the

43 | The argument follows Georg Jellinek, 1900; On "sovereignty" and "nominalism": Bartelson, in: Adler-Nissen/ Gammeltoft-Hansen, 2008.

44 | Hinsley, 1986 (1966), 26.

45 | For a discussion of Bodin's and Hobbes' understanding of “sovereignty": Schmitt, 1922, 33.

46 | Weber, 2004 (1919), $310 f$.

47 | German: "Staatsgebiet", "Staatsvolk" and "Staatsmacht".

48 | Jellinek, 1900, 393 and 426.

49 | The provisions of the Treaty are considered the condensation of the idea of sovereignty in Europe at the time, in: Schliesky, 2004, 87ff. 
end of the Thirty Years War, the Treaty is regularly considered a revolutionary step towards international regulations. The signatories accepted each other as equals representing a certain territory. This acceptance was based on the assumption of the other signatories' claim to unquestioned internal state sovereignty. The Treaty's provisions supposed to safeguard state sovereignty on the inside by preventing foreign interference from the outside and upholding state autonomy. ${ }^{50}$ In international law, this conceptualization gradually evolved towards today's concept of the nation state with its rights and duties as codified in the Charter of the United Nations.

According to the Charter of the UN of 1945, signatory states are obliged to observe the "sovereign equality of all its members." ${ }^{1}$ This principle is specified in the so-called "Friendly Relations Declaration" 52 of 1970 by including the provisions of Article 2(3) and (4): "sovereign equality" guarantees the rights inherent in full sovereignty to all member states including the inviolability of territorial integrity and political independence. ${ }^{53}$ Correspondingly, it demands the prohibition of any threat or use of force which is seen as jus cogens today. This principle is tightly linked with the principle of "non-intervention" of Article 2(7) which defines it as "the right of every sovereign state to conduct its affairs without outside interference." ${ }^{4}$ This right to "negative liberty" 55 is where the normative question of the "limits of foreign policy" come into play. According to the International Court of Justice

"a prohibited intervention must be one bearing on matters in which each State is permitted, by the principle of state sovereignty, to decide freely [...]. Intervention is wrongful when it uses, in regard to such choices, methods of coercion, particularly force, either in the direct form of military action or in the indirect form of support for subversive activities in another state." 56

Unfortunately, this narrow legal definition does not stretch to the normative question of the "limits of foreign policy" at hand, as its definition of "prohibited intervention" is solely focused on "methods of coercion", usually with the goal

$\mathbf{5 0}$ | On the role of state autonomy with regard to legal sovereignty: Krasner, 1995.

51 | Charter of the United Nations, Article 2 (4).

52 | Declaration on Principles of International Law Concerning Friendly Relations and Cooperation Among States in Accordance with the Charter of the United Nations, Appendix of GA/Res 2526 [XXV], UNYB, 1970.

53 | Declaration on Principles of International Law, 1970, Preamble.

54 | Case Concerning the Military and Paramilitary Activities in and against Nicaragua (Nicaragua v. United States of America), Separate Opinion of Judge Nagendra Singh President, 1986.

55 | Berlin, 2014 (2002), 244.

56 | Declaration on Principles of International Law, 1970, 202 to 209. 
to undermine the state and/or regime. ${ }^{57}$ The actual reason for this narrow understanding of 'intervention' is the prohibition of the use of force between states as one of the major principles of the UN Charter. ${ }^{58}$ As a consequence, acts of violence get prosecuted in praxis, even though the legal reading of the "nonintervention clause" includes all "methods of coercion". ${ }^{59}$ However, legal reality is no good reason to refrain from thinking outside the given framework of principles. The principles of "equal sovereignty" and "non-intervention" without doubt have been created with the intention to provide each member state with the right to settle its internal affairs by itself and to reject any assistance or interference from outside. ${ }^{60}$ As a consequence, this study claims that foreign policy can exceed its limits even before coercion and without force and that these actions already can be considered an infringement of sovereignty.

What does this mean for a state's sovereignty then? Generally, all states are considered to possess "equal sovereignty" in the international realm - at least with regard to legal provisions. The fact of "prohibited intervention" in the sense of "coercion" remaining unpunished in legal reality, however, leads to the conclusion that the concept of sovereignty can and has to be qualified, ${ }^{61}$ especially when going beyond the wording of legal provisions to discuss their actual output and thus the normative question of "sovereign equality". Despite nominal equality, states are not equal with regard to their resources and influence. As a consequence, a state's scope of action in the international realm depends on the "quality of its sovereignty", meaning the degree of the state's "autonomy". Haftendorn defines a state's autonomy as the ability to "enforce its values and goals despite competing values and goals of other systems (that is states), ${ }^{, 62}$ while relying only on its specific resources. Her definition recalls realism's "war of all against all" ${ }^{33}$ in the international system, where

57 | Without qualifying it as prohibited, Vincent defines intervention very similarly as an "activity undertaken by a state, a group of states or an international organization which interferes coercively in the domestic affairs of another state". According to Vincent, intervention furthermore "is a discrete event having a beginning and an end, and it is aimed at the authority structure of the target state." Vincent, 1974, 13.

58 | Excluding the right of self-defence of Article 51 which manifests in Article 2 (4) and is interpreted teleologically as well as historically as comprehensive and absolute. Together with the monopoly on the use of force of the Security Council this shall support the maintenance of "international peace and security". Charter of the United Nations, Preamble; Article 1, No. 1; Article 25.

59 | Vincent, 1974, paras. 202 to 209; Wheeler/Bellamy, in: Baylis/Smith, New York, 2001, 472.

60 | Apart from excesses like "crimes against humanity" or "genocide", in: Welsh, 2004.

61 | On the opposing arguments of nominalist and essentialist approaches to "sovereignty" and whether "sovereignty" may be qualified or not: Adler-Nissen/Gammeltoft-Hansen and Bartelson, in: Adler-Nissen/Gammeltoft-Hansen 2008.

62 | Haftendorn, 1989, 34.

63 | Hobbes, 1996 (1651), 258. 
every state is fighting for its own survival and leaves us with at least two weak points. Firstly, autonomy of a state is declared the ideal condition, as it is defined as the prerequisite to achieve one's foreign policy goals. Hence any strategy which does not rely on one's own resources cannot be taken into consideration when assessing its success or failure with regard to declared policy goals. As a result, this traditional definition of "autonomy" does not include the relationship between the states apart from competition, even though cooperation is one of the major determinants of the international state system today. Secondly, the use of the word "enforce" leads to the impression that values and goals can only be attained through foreign policy strategies with a high level of intensity. "Soft" tools like diplomacy, mediation or non-action are not included. However, Haftendorn somewhat revised her definition of autonomy about a decade later. Now "autonomy" is defined as the ability to "convince" other states "to respect [the state's] goals and values or accept these after certain adaptation.

A structural dependent system on the other hand is forced to continuous adaptation." ${ }^{64}$ By softening and differentiating her definition in this way, Haftendorn accounts for the fact that foreign policy offers a wide range of strategies and tools to achieve one's goals on the one hand, and that "autonomy" in international relations as an ability not only relies on "hard facts" but also "soft" and sometimes vague factors like prestige and reputation on the other. Thus, she clearly puts a new focus on the "degrees of autonomy", the capacity to act autonomously. While she equates a state's "autonomy"65 with the state's scope of action in the international realm in both versions of her approach, ${ }^{66}$ in 2001 this equation becomes more convincing, as the scope of action not only depends on the actions of other actors, but also on the "image" of the host state with these actors.

As a consequence, this study defines the quality of a state's external sovereignty by the "degree of its autonomy" that is staked out by a state's scope of action in the international sphere. The "limits of foreign policy" may be considered exceeded at the moment of infringement of a state's "external sovereignty" by the actions of another international actor. And while this infringement does not simply suspend a state's sovereignty, it may diminish its autonomy and thus impair the "quality" of its sovereignty. Reconsidering the argument that "internal sovereignty" proceeds "external sovereignty", "external sovereignty" in the sense of the degree of a state's autonomy can have an immediate impact on a state's "internal sovereignty", and thus may even endanger the very foundations of the state itself. By means of an argumentum e contrario, the forced curtailment of a state's autonomy may be considered an infringement of sovereignty with regard to its internal affairs and thus an excess of the "limits of foreign policy".

64 | Haftendorn, 2001, 13.

65 | German: Autonomiefähigkeit.

66 | Halliday appears to have a very similar understanding of state autonomy in international realtions. Halliday, 2006, 42. 
Reconnecting these conclusions with the conceptualization of foreign policy introduced above, the two highest levels of foreign policy intensity need to be reconsidered. "Intervention" may already aim to manipulate the "internal affairs or foreign policy activities," ${ }^{67}$ while "imposition" may include the active control of parts of the host country's politics. Without doubt, foreign policy at both levels of intensity, by whatever means, seeks to alter the conditions within the host country of foreign policy. All in all, this leads to the conclusion that both levels of intensity may give rise to the debate over whether measures taken by the foreign policy actor already are an infringement of the host country's sovereignty in itself. Judgment of these cases should be based on the major benchmark for a state's sovereignty: The state's right to "negative liberty" 68 and its ability to consent or renounce to measures taken. Unambiguously, foreign policy ends at the host state's sovereignty.

\subsection{On the Emergence of the Nation: Defining the 'Known' against the 'Foreign'}

After reflecting on the question about when foreign policy gives way to imposition, the puzzle about the "limits of foreign policy" offers another dimension to be explored. What can foreign policy actually achieve in the host country? Is an external power able to induce social change in the host country? To further think about these questions, a detour to the basic meaning(s) of 'foreign policy is deemed necessary. The question, 'foreign for whom and in comparison to what', so far has remained unanswered. The 'self/other-dichotomy', one of the major paradigms in Postcolonial Studies, might offer a satisfying approach to explain what is considered 'foreign' from a state's perspective. In his sweeping account on "Nations and Nationalism," "Ernest Gellner located the emergence of the "nation" within the process of transition from agrarian to industrial societies. What he is referring to is the transformation of Platonic "Gemeinschaft" (community) to Kantian "Gesellschaft" (society). ${ }^{70}$ This transition encompassed the dissolution of old structures which had given meaning to each individual's lives within small communities. Meaning had mostly been derived from kinship in a society where everyone was aware of his or her position and what this position entailed. During the transition to industrial societies, however, the "feeling of belonging" and security was questioned and the "well-walked paths" around people's villages were replaced by anonymous life in the city. In Gellner's account "culture" became the replacement for this "feeling of belonging". This culture could be acquired through education and literacy. In doing so, future members learned the "language" of the wider community - the nation - like an initiation ritual.

67 | Prados, 2005, 4.

68 | Berlin, 2014 (2002), 244.

69 | Gellner, Ernest, Nations and Nationalism, New York, 1983.

70 | Gellner, in: Periwal, 1995, 1-7. 
Based on Emile Durkheim's account of mechanical solidarity through mutual likeness that generated a "conscience collective"71 Gellner's conceptualization of the "nation" first of all is about what people and what a political community have in common: shared beliefs and attitudes that can operate as a unifying force.

Gellner's approach has been challenged butalso expanded by theorists following a critical or post-structural approach. ${ }^{72}$ His contemporary Benedict Anderson, for example, already focused on the "constructed", or in his words "imagined" character of the nation state. According to Anderson, "print capitalism" allowed the transformation from the concrete local community to what he describes as the abstract "Imagined Community," 73 the nation. For Anderson, the written word is the basis for national consciousness, which has to unify members of the future nation who never met and possibly will never meet. The state was able to include the various and oftentimes competing social groups and individuals through the idea of the nation as "the secular, historically clocked, imagined community," 74 a community that was able to overcome the spatial distance between its members through the "imagined feeling of belonging". Benedict's conceptualization of the "nation" had a major impact on the various accounts of the "nation state" that followed.

Mostly influenced by Jacques Derrida's deconstruction of Western history, ${ }^{75}$ post-positivist scholars examined the dichotomy of the "self" and the "other", of "inclusion" and "exclusion" to analyze the emergence of political communities. These accounts conceptualize the "nation" with a focus on the necessity of an "other" against which the members of a community define themselves. This constructivist stance also emphasizes the "nation" to be neither eternal nor stable. David Campbell, for example, defines the state as both real and discursive, and diagnoses a "permanent need of reproduction" in an ongoing "process of becoming." ${ }^{76}$ Campbell considers the nation state as created and recreated through the "discursive practice" of "othering", excluding non-members from the community. Taking into consideration both traditional and deconstructive approaches, one may conclude that collective identities ${ }^{77}$ such as the nation are permanently generated and regenerated by both sameness and difference and both can operate as the unifying force of groups - in this case, political groups.

71 | On Durkheim's notion of solidarity: Barnes, 1966, 163.

72 | This clearly has added to the epistemological shift of perspective within the debates centered on nationalism and ethnicity. Brubaker, 2009.

73 | Anderson, 1983, 6. However only in combination with mass reproduction and a certain degree of literacy can "print capitalism" have relevant impact.

74 | Anderson, 1983, 35.

75 | Derrida, 1997 (1976).

76 | Campbell, 1998, 12.

77 | A conceptualization of “collective identities", in: Eder/Giesen/Schmidtke/2003. 
Now the question remains: "Sameness" and "difference"; the "known" and the "foreign"; "us" versus "them"; with regard to what reference? This study locates the answer to these questions in the determinants of collective identities that are considered the basis for the formation of communities of any kind and may or may not be responsive to new ideas and values and thus social change.

\title{
3.2 Identity Formation, Social Change, and how they interrelate
}

Based on the questions "Who are you/we?", "Who do you think you are?", "Who do others think you are?", the "Handbook of Identity Theory and Research" describes identity as

\begin{abstract}
"the confluence of the person's self-chosen or ascribed commitments, personal characteristics, and beliefs about herself; roles and positions in relation to significant others; and her membership in social groups and categories [...]; as well as her identification with treasured material possessions and her sense of where she belongs in geographic space." ${ }^{78}$
\end{abstract}

To handle the concept of "identity" in the context of social groups and communities, this analysis includes the three ideal types of collective identity coding introduced by Eder et alia: Primordial, traditional and universalistic/ cultural. ${ }^{79}$ When collective identity is coded primordially, "the boundaries of identities such as gender, generation and kinship are reinforced[...] constituting difference by "structures of the world which are given and cannot be changed by voluntary action." While "primordial identities" rarely offer a choice of "opting in or out", "traditional identities" are generally open to new members, even though they "engender hierarchical distinctions between the bearers of traditions and new members." Furthermore, "traditional identities" are "constructed on the basis of familiarity with implicit rules of conduct, traditions and social routines." The "traditional type" places "temporal continuity" at the core of its identity and does not draw from an external reference, as opposed to the "primordial type" drawing from nature and the "universalistic type" drawing from the "divine", or transcendent logic. The "universalistic type" also allows new members to join, as the "boundaries between inside and outside can be crossed by communication, education and conversion."

It is the markers of a "collective identity" that determine the rules of "membership" for the respective community. The dimension of "membership" captures "external categorization" as well as "internal self-identification" and

78 | Schwartz/Luyckx/Vignoles(Ed.), Intrdocution: Toward an integrative View of Identity, 2011, 4.

79 | For the following approach and all related quotes: Eder et al., 2003, 25-34.

$\mathbf{8 0}$ | This conceptualization of "membership" is an adaptation of Brubaker's dimensions of nationalism. Brubaker, 2009, $26 \mathrm{ff}$. 
thus is considered the central category for self-definition of political movements by defining the group's boundaries. This "social closure" 81 generates loyalty and facilitates the mobilization of its members' support when facing an opponent of the group. To further complicate this "social closure", individual categories or groups of identification are not necessarily mutually exclusive; they can be multilayered. ${ }^{82}$ This is one of the preconditions enabling "collective identities" to encompass huge communities, even nation states: As a consequence, the "nation" may not only be considered a created "imagined community," ${ }^{13}$ but can serve as the identity of this community as a "collective identity" to integrate conflicting groups and overcome internal divides. For a "national identity" to evolve, this identity either has to be compatible with existing "collective identities" or foster social change by adapting to existing collective identities.

But how can the "nation", being an ideology, foster social change? Mann's approach on the "sources of social power" ${ }^{84}$ is considered here and modified. According to Mann, the structure of societies is determined by four sources of social power: The ideological, the economic, the military and the political. Mann refuses explanations for the organization of society which rely only on one of the four sources, as all four of them regularly cause social change. However, he points out that they do so in varying constellations and intensity. Mann considers the sources of social power "entwined", as "their interactions change one another's inner shapes as well as their outward trajectories. ${ }^{\prime 85}$ For social change to occur, the relation between the sources of social power has to shift, either by one or more sources intensifying or decaying. With his approach, Mann introduces an effective method to describe a society's condition as well how it changes over time. However, what Mann notoriously leaves unanswered is what actually "causes" the constellation of the sources of social power to change. Why do, for example, economic questions become more important or prominent in a society? Why does militarism recede in others? Without doubt, these questions cannot be answered while detached from the case and its special characteristics. But there is one hub in society upon which social change seems to be pivoting: Identity.

81| Brubaker, 2009, 27.

82 An individual can be a man, a doctor, a democrat, a Muslim and a Yemenī at the same time.

83 | Anderson, 1983, 36.

84 Mann introduced his approach in four volumes: Mann, Michael, The Sources of Social Power, Cambridge, 2012 (1993).

85 | The framing of this paper does not allow an in depth delineation on Mann's various subcategories and theoretical argument. Instead, the author contends with a rough outline to frame her theoretical approach towards the role of identity in society. Mann, 1993, 1-91. 
Repeatedly, Mann refers to 'identity' as a social category that is shaped by one or several of the four sources of power and depicts this phenomenon as "interstitial space" in the social fabric:

"The entwining classes and nation states produced emergent dilemmas for power actors to which clear solutions did not exist. [...] [T]he very identity of classes and nations was still fluid, influenced by ideologists. Interstitial space existed for ideologies to propose their solutions and influence social identities." ${ }^{" 86}$

However, this observation belies the decisive role of collective identities within the process of social change, as pointed out by the hypothesis introduced above. As an integral part of the actors involved, identities channel the sources of social power and connect them with the relevant actors. Thus, collective identities are not only shaped by the sources of social power but also allow or prevent the disruption of the constellation of these sources and thus social change. What Mann describes as "interstitial space" may be interpreted as the "degree of responsiveness" of collective identities to social change. The consequence of this theoretical argument is that social change can only be accommodated, if the identities of the relevant actors, decision-makers, and recipients of these decisions are receptive to what this change entails. So social change of (political) communities can only occur through the transformation of the community's "collective identity". Hence, the probability of social change hinges on two variables: Firstly, the "fit" between the old "collective identities" and the "new" identity offered, and secondly, the "degree" of the old identity's "ability" or "willingness" to accommodate change, interpreted as the "degree of responsiveness" to change. ${ }^{87}$

As pointed out above, collective identities are defined by what the group has in common and how the group differentiates itself from other groups. The shared characteristics of a group, the so-called "boundary markers" or "codes", define who is a part of the group and who is not. Reconnecting with the two statements of the hypothesis, social change can be accommodated only if identities are receptive to what this change includes. This mostly means that they have to be able to adapt by incorporating new characteristics, i.e. "codes", which are sufficiently similar to the new situation. If this fails, identities may lose their integrative function and, deprived from their essential core, fall apart. This may cause severe disturbances of social milieus, groups and individuals. What is more likely to happen to identities too rigid to adapt however, is that they fall back on their original "codes" and thus into their old shape. Being overwhelmed by or incompatible with the new situation, rigid identities might prevent social change in the end. Thus, this approach declares a certain "degree of responsiveness" of identities, meaning the ability to transform the codes of identity, a conditio sine qua non for any social

86 | Mann, 1993, 40.

87 | The author calls this the "responsiveness-of-collective-identities hypotheses" (RCIH). 
change. In the case of South Yemen, this means that success or failure of the profound social changes taking place in Aden and its hinterland highly depended on the compatibility of the respective identity codes with the new concepts and values, at first introduced by the revolutionary regime and later on by the external actors, the GDR and Soviet Union.

\section{The Major Hypothesis: The GDR's Foreign Policy as a Policy of State- and Nation-Building}

Based on the preliminary hypothesis of the "responsiveness of identities", the following section introduces the concept of state- and nation-building and its modification as a "policy of socialist state- and nation-building" as an attempt to actively promote or even force the change of "collective identities". Fanon concluded that the most difficult and also dangerous time for post-colonial states after independence was the less glorious phase when the "wind of revolution $\operatorname{los}[t]$ its velocity" 88 and national liberation had to be channeled into day-to-day politics. During the sensitive phase of development of the political community in South Yemen, the East German idea of nation- and especially state-building greatly influenced the creation of the South Yemeni state and upheld a certain relevance over time. This case study approaches the creation and establishment of South Yemen as a process of "nation building" actively pursued from the inside by the state's political leaders ${ }^{89}$ but also from the outside, by East Germany and its delegates on behalf of Moscow. In other words, the meta-level of the GDR's foreign policy making with regard to its goals somewhat coincided to a certain extent with the PDRY's internal policy-making and the South Yemeni regime's goals for their state. On first glance, one may conclude that a convergence occurred at the micro-level between the early NLF's policies and the output of the GDR's foreign policy, that is, its implementation. This concept allows to include both perspectives, the internal, Yemeni perspective, and the external, East German and Soviet perspective. A further assessment of the GDR's impact on this nationbuilding process in the PDRY might be a possible step beyond this study.

"Nation-building was a strategic and competitive enterprise, part of the Cold War competition between the United States and the Soviet Union," ${ }^{90}$ says Hippler of the role of the concept of nation-building during the bipolar conflict. As a Western concept of developmental politics of the 1950 os and 1960s, "nation-building" had been part of the U.S.' containment and even roll-back policy to "represent an alternative to the

88 | Fanon, 2004, 90.

89 | Already in 1990 Kostiner approaches the NLF/NF's policies in the 1960 s as a process of state-building, Kostiner, 1990, 11.

90 | Hippler, 2005, 5. 
victory of liberation movements and the 'revolution'." ${ }^{11}$ Based on "lessons learned" from Western state development, post-colonial states were supposed to follow, if not the same, at least a similar path of development. A political and economic system similar to the Western democratic model was the expected outcome. However, and regardless of different labelling, the general idea of nation-building was used by both sides of the Cold War to expand their spheres of influence. Just like the Western model of "democratization", the Soviet Union offered a comprehensive model for nation- and state-building: The "planned development of socialism,"92 based on the principles of Marxism-Leninism. In both cases, Western "democratization" and Eastern "development of socialism", nation-building was understood and used as a normative "political objective". ${ }^{93}$ This must be kept in mind when using the parameters of the concept as a tool to analyze, or in a sense to "deconstruct", the GDR's foreign policy activities in South Yemen. All in all, a meta-hypothesis on the character of the GDR's foreign policy in South Yemen and the possible motivation of the SED for the design and application of the "ideal type" of East Germany's foreign policy can be derived: The policy in South Yemen was aimed at duplicating the East German process of the "planned development of socialism".

In the following section, nation and state-building as a policy concept is introduced. To allow a more comprehensive understanding, certain characteristics of the modern state are addressed, though a full review of the concept of the state cannot be presented here. First of all, there is no proof that there even exists successful "nation-building" in the sense of active interference in social processes in a certain territory - whether by internal or external forces. One may settle for the possibility of "nation-growing" within a certain territory with the nation state as the ultimate outcome. While there cannot exist an ideal pathway to the nation and thus an ideal type of nation-building, various analysts have collected major preconditions which seem to be indispensable for successful "nation-growing" with a stable, integrative, and efficient nation state as an outcome. Tightly connected to these preconditions are certain social developments and occurrences that produce the assumption that it might be possible to actively promote these developments through the use of specific political tools and even the establishment of certain institutions. By bringing together these tools and institutions, a comprehensive policy approach was created, regularly referred to as "nation-building".

In the strictest sense of the word, the nation state may be described as a society that is formed into a political community by the idea of the nation and the

91 | The term somewhat went out of fashion in the 1970s academically and politically but celebrated a popular revival after the end of the Cold War, the dissolution of the Soviet Union, and the Kosovo War, in: Hippler, 2005, 5.

92 | German: Aufbau des Sozialismus. The concept is based on Stalin's "development of socialism in a country" under the condition of "capitalist encirclement", in: Gieseke, 2010, 21 and Schroeder, 1999, 119.

93 | Hippler, 2005, 6. 
form of the state. This suggests that the two terms "state building" and "nation building" are not identical, though closely related. "State building" focuses on state institutions and political actors, whereas the term "nation building" regularly includes a comprehensive perspective on the development of society as well as the "emergence of a [...] national identity." 94 The latter oftentimes is considered the over-arching concept of which state-building is merely one of several elements. This study follows Hippler's approach with the three major elements, or "preconditions", for "successful" state- and nation-building at the core of the concept. ${ }^{95}$ Hippler's "precondition triangle" consists of firstly, the communication and acceptance of an "integrative ideology", secondly the "integration of society" and lastly the establishment of a functional "state apparatus" in the sense of statebuilding.

The latter is the most obvious precondition for the nation-state and thus statebuilding. While the character and functions of the institutions forming a state may vary, state institutions necessarily have to encompass the triad of "powerpeople-territory' as introduced by Georg Jellinek ${ }^{96}$ and, following Max Weber, provide for the penetration of territory by the state, that is, by its administration

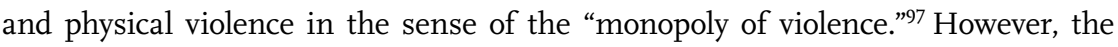
changes of the political system and society taking place during the emergence of a new state demand legitimacy for the pursued changes and the actors implementing them. On top of that, it has to tie in with a "higher purpose" to mobilize social support for this change. According to Hippler, "ideology" can serve as the integrative force promoting legitimacy for cause, measures, and end. As a consequence, the role of "ideology" may even be considered a prerequisite for the "integration of society" and transformation of the political system in general. In a nation state, social groups have to be connected to promote continuous exchange. However, these social groups must have both the will and ability to communicate with each other. While the latter has to be facilitated by communication infrastructure encompassing the whole territory of the emerging nation state, such as transportation, economy and mass media, the former is promoted by "feelings of sameness" 98 or at least shared interest, which is something "ideology" may achieve. The historio-sociological approach to the "nation state" explicitly encompasses values and ideologies, "not as the constitutive domain of politics, but rather as part

94 | Schneckener, 2003, 20.

95 | Hippler, 2005, 6-14.

96 | Weber, 2004 (1919), 310f; Jellinek, 1900, 393 and 426.

97 | On the origins of the "monopoly of violence", as introduced by Thomas Hobbes and Arthur Schopenhauer and Weber's account on the "monopoly of violence": The Monopoly of Force, in: Anter, 2014, 25-35.

98 | For the role of the "other" with regard to self-identification: Taylor, 1994, 47. 
of legitimation and coercion.,"99 Regardless of the nature of the "integrative ideology" evoked for the emergence of the state, its major task is to allow the various groups to identify themselves with this ideology and create a feeling of membership and belonging. ${ }^{100}$ This is how otherwise dissociated groups are unified. Should the superordinate national identity level be questioned or even missing, "a [nation] state will continue to be precarious. ${ }^{101}$ Within the nation state a major aspect of "ideology" is the idea of the "nation". But nationalism can be complemented, extended, or even replaced by other unifying ideological concepts, such as religion. In the case of South Yemen, the idea of the South Arabian nation ${ }^{102}$ in the 1960 s was intertwined with socialism. Later on, the Aden regime tried to fully replace this South Arabian nation with their version of socialism. For them, the 'nation state' was considered a mere transitional phase towards international world communism. ${ }^{103}$

The continuity and change of East Germany's "socialist policy of state- and nation-building" in South Yemen is described and interpreted with regard to the fields and levels of engagement in the context of the four phases. The fields of engagement are associated with the triangle of preconditions for "successful" nation-building as introduced by Hippler. ${ }^{104}$ The analysis shows that East German policy prompted all three dimensions of nation-building - always in relation to the current political situation in South Yemen and according to its political and financial abilities. The "ideological", however, is identified as the main driver of social change in the logic of "socialist state- and nation-building": MarxistLeninist ideology serves as the umbrella of state development to integrate state and society. It supports the concrete political approach as well as the motivation and justification for action. "Ideology" is considered the decisive tool for the decision-makers to exploit "identity" for the "mobilization of the masses" and to form a national identity that aligns with their respective political goals. To sum it all up, "socialist state- and nation-building" served as a "road map" for the GDR to promote the establishment of first a socialist and then a Marxist state.

99 | Halliday, 2006, 32; 37.

$\mathbf{1 0 0}$ | The conceptualization of "membership" is an adaption of Brubaker's dimensions of nationalism. Brubaker, 2009, $26 \mathrm{ff}$.

101 Hippler, 2005, 8.

102 | Dresch, 2000, 56; Holden, 1966, 25; Rogler, 2010.

103 | Ismael, 2005, 4f.

104 | Hippler, 2005, 6-14. 

SECTION B. ANALYSIS 



\section{PART I - The GDR as a Foreign Policy Actor}

The GDR's effort to achieve its foreign policy goals were subject to internal and external limitations similar to any other state in the international realm, despite an admittedly narrow scope of action. In particular, the GDR's relations to the Western powers and the Soviet Union's bloc policy characterized the limited nature of East Germany's autonomy. A self-directed foreign policy appears to have been almost impossible for the GDR. Nonetheless, East Berlin was able to find alternative ways within its "day-to-day politics" to promote its interests. ${ }^{1}$ As a consequence, the hypothesis that no true GDR foreign policy existed must be not only questioned but rejected. ${ }^{2}$ Whether these claims can be upheld is clarified in the conclusion of this study. The following five chapters provide the framework needed to embed the GDR's activities in South Yemen within the GDR's foreign policy in general and its activities in the Middle East in particular.

1 | For example during the first phase of the CSCE Process in Geneva and Helsinki in the early 1970s, in: Müller, in: DA 4/2010, 610.

2 | Gareis, for example, fully rejects the existence of an East German foreign policy in its own right, Gareis, 2006, 49. 



\title{
CHAPTER 4. Squeezed between Bonn and Moscow:
}

\author{
The GDR's Foreign Policy - An Overview
}

The following three chapters focus on the two major external determinants of any GDR policy: The activities and policies of the Soviet Union and the competitive relationship with the "other" Germany. While the former can be considered the GDR's early political and ideological midwife, and later on, its custodian, ${ }^{1}$ the latter remained a competitor and standard for comparison for Socialist Germany. The demands from within the national system itself are closely intertwined with these two external determinants and all three are considered mutually dependent. The most important watershed in the GDR's foreign policy were the years between 1969 and 1972. External pressures and new internal constellations had led to a policy change in West Germany and the "New Eastern Policy"2 of Bonn's coalition of social democrats and liberals. These changes finally made it possible to end the GDR's international isolation. ${ }^{3}$ When West Germany de facto recognized the GDR's statehood by signing the "Grundlagenvertrag" in $1971,{ }^{4}$ the GDR reached its long-sought goal of international recognition and was able to finally establish the foreign policy of a "normal" state in the international realm. ${ }^{5}$ In the following chapter, the GDR's foreign policy is analyzed based on the two phases before and after this turning point, starting with a brief outline of the development of the GDR's priorities in the international realm.

1 | See for example: Winzer, Otto, 1972, 3.

2 | German: Neue Ostpolitik.

3 | For a short overview on the "Neue Ostpolitik": Görtemarker, 2004, 530-563. To this day, the most extensive analysis of the topic remains Baring, 1982. Interpretations and comments on the formation of the "New Ostpolitik". Bender, 2008, 151; Görtemaker, 2004, 475; Hacke, 1988, 162; Haftendorn, 1989, 41; Haftendorn, 2001, 180; Hölscher, 2010.

4 | "Vertrag über die Grundlagen der Beziehungen der beiden deutschen Staaten" (Grundlagenvertrag) December 211972.

5 | Siebs, 1999, 11. 


\title{
1. Political Prologue: The Cards Are Shuffled Anew-Two German States and the Rules of the Cold War
}

\author{
"From Stettin in the Baltic to Trieste in the Adriatic, an iron curtain has \\ descended across the continent." ${ }^{\prime 6}$ \\ (Winston S. Churchill, Speech at Westminster College on March 5 1946)
}

At the Potsdam Conference in 1945, the obvious differences between the Western occupying forces and the Soviet Union could not be denied any longer. Reaching an agreement on a policy toward the "German Reich" appeared more and more improbable and already fundamentally different development paths within the two Germanys seemed likely ${ }^{7}$ - despite "almost identical industrial prerequisites." Only two years later Andrej Zhdanov, party secretary of the Communist Party in Moscow, announced what was to become the "Two Camp Theory", an event considered by some to be the beginning of the Cold War: ${ }^{9}$ Two irreconcilable world camps faced and confronted each other. ${ }^{10}$ Just one year later Zhdanov's scenario became reality when Nikita Khrushchev declared an ultimatum on Berlin's status as a free city and blocked traffic between the western zones and West Berlin. ${ }^{11}$ The Berlin Crisis and the Korean War accelerated the formation of the two "camps", or blocs. When in July 1955 the Conference of Foreign Ministers of the victorious powers finally failed as well, Khrushchev proclaimed his “Two States Doctrine”: Reunification could only occur on terms of both German states and would only be possible if the GDR-style socialism and its achievements remained. ${ }^{12}$

The founding of the two German states in $1949^{13}$ introduced an integration process for the two entities to join the respective economic and military systems of East and West, culminating in their memberships in the two major military alliances, the North Atlantic Treaty Organization (NATO) and the Warsaw Pact

6 | Churchill, The Sinews of Peace, March 51946.

7 | Bracher, Dietrich, in: Hacker, Jens, 1989, 41.

8 Schroeder, Klaus, 2006, 89f. On the changes of German economy during the war and the scope of economic destruction after the war in Central and Easter Europe: Applebaum, 2013, $10 \mathrm{ff}$.

9 | Applebaum, 2013, 219; Stöver, 2007, 74.

10 | Zhdanov, Andrej, September 1947, Zhdanov answers Harry S. Truman at the Conference of Communist Party of Europe, in: Lautemann/Schlenke (Ed.) 1980, $156 \mathrm{f}$.

11 | On the Berlin Crisis and Blockade and possible interpretations: Stöver, 2007, 89ff; Wettig, 1999, 145-152.

12 | Khrushchev, Nikita Sergeyevich, in: Schroeder, 1999, 132: Wentker, in: Hoffmann/ Schwartz/Wentker, 2003, 65.

13 | Judt, in: Judt (ed.), 1998, 493; Sywotteck, in: Pfeil, 2001, 51. 
(WP). ${ }^{14}$ When neither the Soviet quelling of the uprising in June $1953^{15}$ nor the erection of the Berlin Wall in 1961 changed the Western powers' strategy of restraint, it became clear that the West would not make any move to endanger the fragile balance in Europe. ${ }^{16}$ The Cuban Missile Crisis in 1962 signaled the climax of the East-West Conflict on the fringe of escalation. Scholars point to the attempts of superpowers and their allies to strive for an international détente in the wake of the crisis wake as the end of the first "hot" phase of the Cold War. ${ }^{17} \mathrm{Up}$ to this point, the management of international crises had been achieved through the "classic instruments of bilateral and multilateral diplomacy," ${ }^{18}$ though in the bloc conflict they had not yet been deployed comprehensively as preventive instruments. This process was about to change with the "Treaty Policy" of the late 1960 s. The treaties generated the feeling of a certain safety in the atmosphere of détente, ushering in the second phase of the Cold War, and last until the late 1970s. Both sides of the Cold War arranged themselves with the status quo and after the Berlin Wall had been become a fact, it was obvious that the division of Germany was not to be easily remedied. ${ }^{19}$ If control over Germany was only possible for a part of it, the Soviet Union preferred two German states instead of one. ${ }^{20}$

Thus the birth of the two German states also sounded the bell for four decades of separation in the heart of the two superpowers' confrontation. Haftendorn describes the German predicament as a "system of structural dependencies." Provisional occupation became permanent, as both superpowers hoped for more sustainable influence on Europe's "political order". Initially, American presence was meant to support the interests of Germany's neighbors, particularly France, by preventing Germany from re-establishing itself as a European power. With the Berlin Crisis and the beginning of the proxy war in Korea solidifying the Cold War in 1948-49, the Western occupation forces changed their major goals, with Washington shifting from "Containment" to its "Roll-back Policy" so as to not only prevent the Soviet Union from expanding its sphere of influence, but to repulse any Soviet presence. Meanwhile, the West organized itself according to the newly divided Germany. Germany's east and west had to fulfill their role as

14 | Foitzik, in: Hoffmann/Schwartz/Wentker, 2008; Haftendorn, 2001, 60.

15 | Schroeder, 1999, 83; Wettig, 1999, 256.

16 | Staadt, in: Schwartz (ed.), 2008, 160ff; Alisch, in: Schartz (ed.), 2008, 150.

17 | Most depictions of the Cold War follow the scheme of three roughly described phases and tend to subdivide these depending on their approach: Halliday, 2005; Steiniger, 2004; Stöver, 2007.

18 | Glaeßner, 1984, 239.

19 | Wentker, 2007, 316.

20 | Glaeßner, 1984, 239.

21 | Haftendorn, 2001, 11. 
bridgeheads at the "Iron Curtain"22 and soon became the major proxies for the Cold War in Europe.

The international power constellation at the time did not leave many alternatives for the two German states. During the early years of their existence the occupation forces controlled all areas of day-to-day life and granted only a little room for maneuvering at the national and especially the international levels. ${ }^{23}$ But even though both Germanys found themselves in similar positions in the late 1940s, their paths, predefined by their respective occupational forces, led them in very different directions of development. This is also true for their attempts to regain some autonomy in foreign policy. Despite the comparatively early establishment of foreign policy institutions in the young GDR, ${ }^{24}$ it remained highly dependent on foreign policy guidance by the Soviet Union and expanded its sovereignty solely "by grace of Moscow." 25 The institutions and competencies granted to West Germany, however, offered partial sovereignty to Bonn, including some measure of autonomy for its foreign-policy decisions. ${ }^{26}$

\title{
2. The GDR's Foreign Policy Priorities From the "Phase of ReCOGNition" tO the "High TIMES OF Diplomacy"
}

\author{
"Foreign Policy means something different for a defeated [...] Volk as the German \\ Volk is [right now] from what it means for a Volk as we have once been. As long \\ as we are still the object of other powers' politics we cannot implement social \\ policies, a proper national policy. Thus our [...] first and foremost intention must \\ be to [...] become a subject of politics in our own right again." ${ }^{27}$ \\ (Konrad Adenauer, Chancellor of the Federal Republic of Germany, 1952)
}

22 | Churchill, The Sinews of Peace, March 5 1946. The theatre term "iron curtain" had been used in politics before, e.g. by the German Reichskanzler Theobald von Bethmann Hollweg in 1916 ("Der gescheiterte Taktiker Bethmann Hollweg," sine anno) but is widely used as a metaphor for the division of the world during the Cold War.

23 | Wengst, in: Schwartz (ed.), 2008.

24 | The "Commission for Foreign Affairs" (German: Kommission für außenpolitische Fragen) and the "Ministry for Foreign Affairs" (German: Minsterium für Auswärtige Angelegenheiten), Scholtyseck, 2003, 6.

25 | Scholtyseck, 2003, 14.

26 | On the establishment of the FRG's Foreign Ministry in March 1951: Schöllgen, 2004, 29. On the expansion of Bonn's international room of maneuver: Begrenzte Souveränität, in: Bierling, 2005, 111-169; von Bredow, 1999, 89.

27 | Adenauer, Konrad. Speech for the CDU. Bonn, 28 March 1952. Bulletin 38/52. 
"The United Germany shall have accordingly full sovereignty over its internal and external affairs." 28

(Article 7(2) of the Treaty on the Final Settlement with Respect to Germany, 1990)

With the "unconditional surrender" by the German High Command of the socalled "Third Reich" ${ }^{29}$ on the $7^{\text {th }}$ of May $1945,{ }^{30}$ Germany forfeited its sovereign rights as an equal member of the international state community. In June 1945, the Allied Powers ${ }^{31}$ agreed that

"[t]here is no central Government or authority in Germany capable of accepting responsibility for the maintenance of order, the administration of the country and compliance with the requirements of the victorious Powers" 32

and thus claimed "supreme authority" over Germany. The founding of two separate German states just four years later did not do much to change this status and despite a successive expansion of the two Germanys' competencies, first with regard to their internal affairs, later on to the international realm, their sovereignty remained restricted. It was not until Germany's reunification in 1990 that the Allied Powers "terminate[d] their rights and responsibilities relating to Berlin and to Germany as a whole." ${ }^{3}$

When consulting sources from the West, conclusions about the GDR's foreign policy regularly paint the state as a "non-active actor", neither enjoying autonomy nor the incentive to achieve any goals in the international sphere. Hans-Dietrich Genscher, for example, labels the construction of the Berlin Wall as proof of the failure of the GDR's political system. According to him, East Berlin's policies did

28 | Treaty on the Final Settlement with Respect to Germany September 121990 in: Bundesgesetzblatt 1990 Part II. October 131990 (pub.), 1318-1329.

29 | On the origins and the controversies about the term "Third Reich" (German: "Drittes Reich"), in: Winkler,2000, $6 \mathrm{f}$.

30 | Act of Military Surrender, in: Treaties and Other International Agreements of the United States of America 1776-1949. Vol. 3. Multilateral 1931-1945. Bevans, Charles I. (ed.). Department of State Publication 8484. Washington, DC: Government Printing Office, 1969.

31 | The "Allied Powers" at this point include the governments of the United States of America, the Union of Soviet Socialist Republics and the United Kingdom, and the Provisional Government of the French Republic.

32 | Declaration Regarding the Defeat of Germany and the Assumption of Supreme Authority by Allied Powers. Introduction. 6 June 1945, in: Treaties and Other International Agreements of the United States of America 1776-1949. Vol. 3. Multilateral 19311945. Bevans, Charles I. (ed.). Department of State Publication 8484. Washington, DC: Government Printing Office, 1969.

33 | Article 7 (1), Treaty on the Final Settlement with Respect to Germany September 12 1990. In Bundesgesetzblatt 1990 Part II. October 131990 (pub.), 1318-1329. 
not go beyond maintaining grandfathering the GDR's status quo after that. ${ }^{34}$ Regardless of this judgment, the GDR did indeed declare and actively strive for policy goals during all phases of its existence, though any policy goal following the GDR's foreign policy priorities was in some way connected to either the Soviet Union or West Germany, the two decisive determinants of the GDR's scope of action. Recalling Czempiel's triangle of priorities, the foreign policy interests of the GDR have been interpreted based on the relation between the priorities "security/peace", "liberty/stability" and "economic welfare". For the analysis of Bonn's foreign policy, Helga Haftendorn added national unity to liberty/stability, ${ }^{35}$ as it had been a pivotal topic among East German foreign policy priorities. As such, "National unity" and how its interpretation changed over time must be considered as well when discussing the GDR's foreign policy interests.

"Security and peace" are not only the major goals of any state but may even be regarded a conditio sine qua non for the continuous existence of a state, comparable to food and shelter in Abraham Maslow's "Hierarchy of Needs." ${ }^{36}$ Without basic security from internal instability and external threats to its population, no state can uphold its existence in the long run. This ties in with Campbell's interpretation of foreign policy as the "discourse of danger" in that it is premised on the delineation of a state's inside and its outside. Throughout the GDR's history, the major priority for the SED regime remained "security" in its most fundamental sense: to secure the GDR's existence as a state, its territorial integrity, and thus the SED's claim to power. Accordingly, East German foreign policy was first and foremost focused on the "dangers" outside the GDR. Hence, the tight integration of the GDR into the Eastern Bloc was not only in Moscow's interest but also a primary foreign policy goal of the GDR. The major legal basis for this integration was the "Treaty of Friendship, Cooperation, and Mutual Assistance" (Warsaw Pact) of 1955 and the bilateral "Treaties of Friendship" of 1964 and $1975 .{ }^{37}$ The Treaty of 1964 sealed the GDR's integration as a state among others in the Eastern Bloc, though it did not explicitly affect "rights and obligations" agreed upon in "mutual [...] agreements including the Potsdam Agreement." ${ }^{38}$ Any other policy goal was subordinated to the SED's overarching interest to secure the GDR's existence while upholding the SED's political autocracy. With its aggressive public policy, the SED leadership successfully tied the GDR's survival to its own predominance. The VIII. Party Conference of the

34 | Interview of Hans-Dietrich Genscher (2015), Minister of Foreign Affairs in the FRG from 1974 to 1992, by Miriam Mueller on January 162009.

35 | Haftendorn, 1989, 32-49.

36 | See: Maslow's “Hierarchy of Needs," in: Maslow, 1954.

37 See: Extracts of the GDR's First Treaty of Friendship with the USSR of September 20 1955, in: Judt, 2008, 549.

38 | "Treaty of Friendship, Cooperation, and Mutual Assistance between the GDR and Soviet Union." June 12th 1964, Article 9, in: Kleines Politisches Wörterbuch, 1973, 894. 
SED in 1971 shows this focus on state survival: Each treaty mentioning territorial questions in Europe was supposed to acknowledge the territorial status quo and equated European security with "the security of its borders." ${ }^{39}$

In the GDR "national unity” was declared a primary foreign policy goal as early as October $1949^{40}$ and was closely connected to the GDR's existence as a state as well as its self-perception as the "better", anti-imperialist Germany until the mid-196os. This strive for national unity was abandoned with the recognition of the existence of two German states in $1971{ }^{41}$ In the "Grundlagenvertrag." the FRG was cautious not to endanger its foreign policy priority of reunification, ${ }^{42}$ as demanded for in the Grundgesetz. Bonn insisted on the continued existence of one German nation. This notion of "the continuity of a unified German nation." even after the de facto recognition of the GDR, was naturally considered an imminent threat to the GDR's existence as a separate sovereign state by the SED and thus part of the "discourse of danger" generating Eats German foreign policy. By "imagining" 43 an East German national community, that is, creating a separate identity of a "socialist nation" $" 44$ the SED aimed to reduce this threat against its national existence.

"Liberty" as a foreign policy priority for the GDR first of all is interpreted as external "autonomy" as well as freedom from external influence and thus may also be considered part of the foreign policy "discourse of danger". The FRG and its policies were perceived as an imminent threat to the GDR's existence. Thus, one of the major goals was the termination and prevention of any direct or indirect influence by West Germany on the GDR's internal affairs, i.e. to expand East Berlin's autonomy towards its Western sibling. With regard to the Soviet Union and the Eastern Bloc, "autonomy" was defined profoundly differently. Indeed, the SED never really hoped for the GDR's full sovereignty, in the sense of being able to act free from its creator's interference. As early as 1947, the SED leadership had publicly insisted to aspire to an "autonomous foreign policy orientation." ${ }^{45}$ And indeed, compared to its Western sibling, the GDR started with an advantage: While Bonn still had to wait to reclaim the ability to run its state's foreign affairs, East Berlin was granted a recognizable upgrade by Moscow in 1950. ${ }^{46}$ This "permit" included the ability to establish diplomatic relations and to give binding

39 | Honecker, 1980, 379.

40 | First foreign policy declaration by the government of the GDR on October 241949 by Georg Dertinger, Minister for Foreign Affairs of the GDR, in: ND, Vol.4, No.250, October 251949. 41 | BVerfGE 36,1, vom 31.Juli 1973, Grundlagenvertrag; Hacke, 1988, 288; Haftendorn, 2001, 200; Schroeder, 1999, 195.

42 | Preamble, Grundgesetz of the Federal Republic of Germany, May 231949.

43 | "Imagined Communities," in: Anderson, 1983.

44 | Howarth, 2001, 88.

45 | German: “eigenständige außenpolitische Orientierung." in: Scholtyseck, 2003, 5.

46 | Pieck, Wilhelm, “The Problems of German Foreign Policy” July 20 1950, in: Judt, 1998, 511. 
declarations ${ }^{47}$ However, despite this apparent freedom in the early years, the GDR usually had to receive Soviet approval for its actions and all in all was not able to deviate from the foreign policy path predefined by Moscow.

"Economic welfare" in East German foreign policy firstly balanced the SED's lack of legitimacy on the inside by appeasing the population through modest, but steady increases to their economic well-being. Secondly, the SED used economic policies to work toward international recognition as a state through foreign trade. ${ }^{48}$ "Foreign trade is the strongest weapon in the fight for recognition of the GDR,"49 summarizes Johannes König, East German ambassador to Moscow in 1956. Thus, "economic welfare" rather must be considered a foreign policy objective of medium range than a priority.

With its internal consolidation after the erection of the Berlin Wall, the sealing of the inner-German border and a positive economic trend, the GDR gained a certain self-confidence as a state. As a consequence, the SED aimed to loosen the tight corset of Moscow's "reign" by proving its loyalty to the Kremlin, but also by attaining "autonomy through status" within the framework of bloc discipline. Through economic progress and preemptive subservience to the Kremlin, the SED attempted to establish itself as a model state within the Eastern Bloc to expand liberty "on the outside." ${ }^{50}$ Liberty "on the inside," however, was no policy goal of the SED. The ruling party reduced political rights and liberties of the East German population to a minimum right from the start. To sum it up, this first priority throughout the GDR's history was to secure the GDR's existence. "Security" was closely linked to liberty in the sense of a limited autonomy and "economic welfare" as a means to an end. These priorities were expressed by closely bonding with Moscow, establishing the GDR as the political and economic "No. 2" within the Warsaw Pact, and attaining recognition as an equal German state in the international community of states. All these priorities, including the political survival of the GDR, intersected with the overall state objective: To establish first a socialist and then a Marxist German state and subsequently guarantee its survival.

47 | First foreign policy declaration by the government of the GDR on October 241949 by Georg Dertinger, Minister for Foreign Affairs of the GDR, in: Neues Deutschland, Vol.4, No.250, October 251949.

48 | Muth, 2001, 81 and Wippel, 1996, 4.

49 | König, Johannes, ambassador of the GDR in Moscow 1956, Meeting of the heads of missions, in: PA AA, MfAA, A 15470.

50 | Schweisfurth concedes the GDR a role as a trailblazer towards the "federation" of the Eastern Bloc. Schweisfurth, in: DA, September 1977, 940 and Judt, 1998, 499. 


\section{CHAPTER 5. Phase I: Between Internal Consolidation and International Recognition}

The following section contends with the GDR's policy in Phase I, from 1945-49 to 1971-72. The phase can be divided into two sub-phases, before and after 1955, when the GDR, at least officially, was granted more autonomy in its foreign affairs. The early years of the GDR have to be considered of little relevance with regard to its international presence, as the Soviet Union exerted full control over the GDR's foreign relations. However, to understand the social and political transformation from the former "German Reich" to the GDR and thus the socialist state- and nation-building process there, this period is briefly sketched out, with a focus on the role of the Soviet Union.

\section{The Soviet Union and the Warsaw Pact: In the Beginning THERE WAS MOSCOW}

In the beginning there was Moscow. Without doubt, this was just as true for foreign policy as for any other policy field in the East German state. After Stalin had given up his hopes for an expansion of its Soviet system over all occupied zones, the full and final integration of the new partial state in the Soviet Occupied Zone (SBZ) ${ }^{1}$ became Moscow's new primary objective, including the full control over the city of Berlin. Apart from numerous strategies toward the Western powers, Moscow applied extensive policies to ensure its control over the SBZ, and later on, the GDR. Wentker identifies three central policies: Direct military control, political and economic integration, and the policy of "Sovietization."

The policy of "Sovietization" can be subdivided into the "Sovietization" of society and of the "Sovietisation" political system, in which the latter was directed not only by Soviet functionaries but also by Germans on behalf of the Soviets: The new leadership in the SBZ had just returned from political exile in Moscow. These

1 I German: Sowjetisch Besetzte Zone.

2 | Wentker, 2007, 3; Applebaum, 2013, Introduction. 
so-called "Moscow cadres" of the Communist Party (KPD), ${ }^{3}$ a term introduced by Peter Erler, ${ }^{4}$ were formed by exiled communists who had fled persecution by the National Socialist (NS) regime in Germany during the 1930s. During their exile, the politically well-connected "Moscow group" successfully seized and kept their leadership role among the other German communist exiles. ${ }^{5}$ Back in Germany after the war, the "Moscow cadres" had to face competition from others who had also convincingly opposed the NS regime, but were much more popular among the population. In particular, the Social Democrats, the traditionally more moderate leftist adversary of the Communists, emerged as a serious problem for future Communist leadership. With Soviet support, however, the Communist cadres were finally able to overcome their minority position through the forced merger of the Communist Party of Germany and the Social Democratic Party, the SPD, in $1946 .^{6}$ The result of the merger was the Socialist Unity Party, a "new type of party" based on principles formulated by Stalin. It took several more years to eliminate or silence dissidents within the new Marxist-Leninist party, the SED: Blackmailing, threats and military trials subverted any opposition from not only the former Social Democrats, but also from within the Communist wing itself against the strict new leadership backed by Moscow.

The political system established with the founding of the GDR in October 1949 left room enough to accommodate a future transformation of the GDR towards the Soviet model. Furthermore, the loyal elites ensured that its accompanying values would be further entrenched into the political system and society of the GDR. The population of the SBZ did not have any choice when it came to embracing these new values transported by "Sovietisation." According to Schroeder, this imposition of Soviet values upon the East German population created the fatal gap between state and society with which the GDR would struggle throughout its existence. ${ }^{8}$ The radical measures implemented with this policy also removed from power the traditional elites. This was justified by the goal of "denazification", of which the disempowerment of former NS elites by the occupying force and the new regime was a side effect. The Soviet occupiers first of all aimed to prevent any former elites, including democratic actors connected to the Weimar Republic, from becoming a threat to the new functionary elites of the SED.

3 | Communist Party of Germany, German: Kommunistische Partei Deutschlands (KPD).

4 | Erler, in: Wilke (ed), 1998, 253.

5 | Schroeder, 1999, 9f; Wettig, 1999, 90. In the Soviet Union these German communists again suffered political purges, this time by Stalin's state apparatus. Those who survived only were able to do so through a sufficiently convincing political adaptation to the Soviet model.

6 | On the founding of the SED see: Malycha, 2009, 16ff; Wettig, 1999, 97-107.

7 | German: Sozialistische Einheitspartei Deutschlands (SED).

8 | Schroeder, 2006, 86. 
The long-term goal of "Sovietisation" and of the other early Soviet strategies was the integration of the new state into its sphere of control on the one hand and the successful development of "Socialism in one country" on the other. In 1924 Stalin had presented his argument for the possibility of the development of "Socialism in one country" as an intermediate step before worldwide socialism and communism. When in 1952 the "planned development of Socialism," program of the GDR, was announced, it clearly built on Stalin's approach and was developed according to Moscow's will. At the time, the existence of the SED and its claim to power fully depended on Soviet guarantees. Moscow had secured the SED's loyalty and gradually transferred responsibilities for the "development of socialism" to the new party's functionaries.

However, the GDR's population at the time did not submit to its new regime unconditionally. People had not yet internalized the new values of the policy system. In June 1953, Soviet tanks had to forcefully end a popular uprising which had spread all over the country. The economic shift towards heavy industry combined with a collectivization of agriculture and the halting of production of consumer goods had led to a supply shortfall in early 1953. When in May the SED raised the central production target, the first workers went on strike. Protests spread from Berlin all over the GDR and the SED felt that it was not able to keep the uprisings under control. This internal insecurities coincided with vagaries in the Soviet Union. Stalin died in March 1953 with no clear plan for succession. ${ }^{11}$ When Soviet tanks finally crushed ${ }^{12}$ the "popular uprising,"13 the SED's existential dependence on Soviet political and military support could no longer be denied. And while the SED regime felt assured that the Soviet Union was still willing and able to guarantee the survival of regime and state, the former "Moscow cadres" were fully aware how much their dictatorship depended on the "big brother" in Moscow.

To secure the SED's leadership of the GDR, the regime integrated the state politically and economically into the Eastern Bloc. The economy was integrated by implementing the Soviet economic system based on central planning, ${ }^{14}$ accompanied by an intensification of heavy industry that increased dependence

9 | Kapitel 6: Die Frage des Sozialismus in einem Lande, in: Stalin, 1946 (1924).

10 | German: planmäßiger Aufbau des Sozialismus. See: Schroeder, 2013, $110 \mathrm{ff}$.

11 | Wettig, 2011, 6, 62 and Wettig, 1999, 365.

12 | Order by the Military Commander of the Soviet Sector in Berlin, June 17th 1953, in: Judt, 1998, 512.

13 | German: Volksaufstand. While the SED regime kept talking about a workers' uprising initiated by infiltrated enemies of the GDR, current research argues that the 17 th of June had been nothing less than a nationwide uprising on the brink to revolution. See for example: Fricke/Steinbach/Tuchel, 2002, 322ff; Neubert, 2000, 80ff; Schroeder, 1999, 83.

14 | Ritter, in: Hoffmann/Schwartz/Wentker, 2008, 22f; Steiner, 2004. 
on imported raw materials from the Eastern Bloc and especially the Soviet Union. Foreign trade relations were artificially focused on the "socialist" world. The economic transplantation of this supposedly new German state into the Soviet satellite system was sealed when the GDR joined the Council for Mutual Economic Assistance of the Eastern Bloc (Comecon) in $1950 .{ }^{15}$ Political integration was promoted through the alliance of the militaries of the Eastern Bloc. In March 1954, after the Conference of Foreign Ministers of the victorious powers again failed to produce any results, the Soviet government announced the recognition of the GDR as a sovereign state. East Germany was now supposed to decide on its national and international affairs "on its own discretion."16 Meanwhile, Bonn had signed the "General Treaty"17 of the Western Allied Forces in May 1952, which came into effect in 1955. The treaty terminated the Occupation Statute and sealed Bonn's NATO membership. The corresponding step on the other side of the "Iron Curtain" was the GDR joining the Warsaw Pact. ${ }^{18}$ This move ultimately limited the GDR's sovereignty to a significantly larger extent than Bonn's NATO membership, as the Warsaw Pact did not include any provisions for the case of retirement. Article 7 of the Pact denied the signatories the ability to become a member of any other alliance. There did not exist any mechanism of arbitration within the Pact except for the "exclusive [Soviet] monopoly of interpretation"19 and decision. Thus, even after 1954, the "reserved rights" of Soviet Union with regard to the GDR's international affairs remained complex and muddled.

Nonetheless, the SED's fear that they would be "sold by Moscow"20 due to strategic considerations remained high - especially when the Soviet Union established diplomatic relations with the Federal Republic of Germany in $1955 .{ }^{21}$ The bilateral "Treaties of Friendship, Cooperation, and Mutual Assistance" can be considered the legal basis for the Soviet sphere of influence. And even though such a "Treaty of Friendship" in 1964 confirmed Soviet support of the SED regime, ${ }^{22}$ the regime still considered it necessary to overemphasize its loyalty toward its "big brother" via preemptive obedience. In 1968, a reformist movement led by the Czech regime and its figurehead, Alexander Dubček, First Secretary of the Communist Party of Czechoslovakia (ČSSR), had swept over the country. ${ }^{23}$ To force the ČSSR back in line, Moscow sent tanks to end the upheavals of the

15 | Hoffmann/Schwartz/Wentker, Einleitung, 2008, 11.

16 | Scholtyseck, 2003, 14.

17 | German: "Deutschlandvertrag."

18 | President of the GDR Otto Grothewohl signs the Warshaw Pact on May 151955 , Picture: Beitritt der DDR zum Warschauer Pakt, in: Quelle: BArch Va 75468.

19 | Grewe, Wilhelm, in: Hacker, 1989, 77.

20 | Fricke, 1997, in: Scholtyseck, 2003, 90.

21 | Görtemaker, 2004, 336.

22 | Bahr, 1991, 45; Kleines Politisches Wörterbuch, 1973, 893.

23 | Karner, 2008. 
"Prague Spring." The GDR proved itself a reliable "ally" and deployed troops of the national army, the "Nationale Volksarmee" (NVA), to the GDR-Czechoslovakian border. ${ }^{24}$ This intervention was a posteriori justified by the so-called "Brezhnev Doctrine," which de facto declared the limitation of sovereignty of Warsaw Pact members. ${ }^{25}$ Disagreements among researchers about Ulbricht possibly having a positive attitude toward the reform movement in Prague, while Honecker had already opted for a "hard line", may just be mentioned in passing as they are of little importance here: ${ }^{26}$ The SED regime clearly decided to stick closely to the Soviet path. The incident in Prague had triggered old fears within the SED leadership of national revolt and reminded them of their political dependence. ${ }^{27}$ From now on, a consistent fear of reformist movements in the neighboring countries of the Eastern Bloc that could undermine the SED's autocracy settled in the minds of the functionaries. The latent mutual interdependence between the internal political developments in the GDR and its relationship with the USSR became an unwritten law.

The GDR had proven its loyalty during the "Prague Spring" and began to establish itself as Moscow's international "junior partner." ${ }^{28}$ Also, within less than two decades, the GDR had been able to emerge as the second industrial power after Moscow and in the process developed a new self-confidence. ${ }^{29}$ In the words of Egon Bahr: “Being just a satellite probably isn't the most pleasant condition." ${ }^{30}$ On several occasions the GDR led by Walter Ulbricht ${ }^{31}$ seemed to have some voice in decisions concerning the GDR and even Berlin. An example of this new self-confidence is Ulbricht's active role during the Berlin Crisis of $1958,{ }^{32}$ as he urged the Kremlin to close the border. However, when this wish finally was granted in 1961 , it was as a political calculation and not as a reaction to Ulbricht's engagement. Emigration and brain drain after the revolt of 1953 threw into question the existence of the GDR, forcing Moscow to act. ${ }^{33}$ Nonetheless, and in spite of the GDR's obvious dependence on Moscow's protection and goodwill, Ulbricht demanded that the GDR be acknowledged as the model of a socialist industrialized nation and made it clear that he envisioned the GDR as

24 | Wentker, 2007, 269.

25 | Malycha/Winters, 2009, 184f; Wirsching, in: Wengst/Wentker, 2008, 366.

26 | Wentker, 2007, $267 f$.

27 | Schroeder, 1999, 98.

28 | Gasteyger, 1976, 38.

29 | Scholtyseck, 2003, 23.

30 | Interview with Egon Bahr February 3 2009, in: Müller, 2009.

31 | From 1950 to 1971 Walter Ulbricht was General Secretary of the Central Committee of the SED, and General Secretary of the SED, Müller-Enbergs/Wielgohs/Hoffmann (Hrsg.), 2000, 868f.

32 | Stöver, 2007, 129; Scholtyseck, 2003, 18; Lemke, 2000, in: Scholytseck, 2003, 95.

33 | Lemke, 1995, 277. 
a truly sovereign state - though remaining shoulder-to-shoulder with Moscow in the near future.

Obviously, Ulbricht not only overestimated the GDR's economic but also his own political capacities. His attitude led to "growing Soviet misgivings that the GDR's foreign policy might leave its predefined path." ${ }^{34}$ The Kremlin did not intend to take chances with its volatile "ally" Ulbricht. Moscow's primary interest was not to secure a GDR led by Ulbricht, but rather a socialist GDR led by cadres loyal to the Kremlin. ${ }^{35}$ The President of the United States summarized the GDR's importance to Moscow at the time: "When East Germany is lost, Poland is lost, and all of Eastern Europe is lost [to Khrushchev]." ${ }^{36}$ Consequently, the Soviet Union never intended to fully drop the reins on the GDR's national politics and never hesitated to emphasize its presence: "We [the SU] have our troops deployed with them [the GDR]. This is a good thing and we'll leave it at that" ${ }^{\prime 3}$. When in 1970 Ulbricht pointed out that "We are no Soviet state - only true cooperation!"38 his fate had already been decided. An internal putsch supported the Kremlin conspired to get rid of Ulbricht: On March 1971, thirteen members and candidates of the SED Politbüro sent a letter to its Soviet counterpart, the CPSU, stating that Ulbricht endangered unity on the international level. ${ }^{39}$ The USSR disposed of its insecure ally Ulbricht and replaced their former political locomotive with the younger and apparently more obedient Erich Honecker. ${ }^{40}$

\section{Bonn: A Permanent Benchmark? The GDR's Attempt to Promote Itself as the "Alternative Germany"}

Apart from the close ties to the Eastern Bloc, it was mainly the GDR's relationship with the "other Germany" that determined East Berlin's scope of action both outside and inside its borders. This was also true for the GDR's guarantor of existence, the Soviet Union and its Eastern Bloc: Due to the GDR's international isolation, its position within the Comecon and Warsaw Pact was vital for its survival. At any time East Berlin could have fallen victim to a change of plans in Soviet foreign policy and been sacrificed as a pawn in the Cold War game. This special role of the FRG for the GDR and its foreign policy is explored in the following sub-section.

34 | McAdams, 1993, in: Scholtyseck, 102.

35 | "The existence of the GDR is of interest for us, for all Socialist states." in: Brezhnev, Leonid on August 20th 1970, in: BArch, SAPMO DY 30 Büro Honecker Nr.441656, in: Judt, 2008, 516.

36 | Görtemaker, 2004, 364.

37 | Brezhnev, Leonid on August 20th 1970, in: BArch, SAPMO DY 30 Büro Honecker Nr.441656, in: Judt, 2008, 516.

38 | Ulbricht, 1970, in: Siebs, 1999, 113.

39 | Scholtyseck, 2003, 31.

40 | Schroeder/Staadt, 143f, in: Courtois, 2010. 
“West Germany was a giant. We, the GDR, were a dwarf. That's something our folks from time to time tended to forget - until the very end." ${ }^{\text {11 }}$

(Wolfgang Bator, member of Section IV of the CC of the SED, Ambassador of the GDR to Tripoli and Teheran)

As early as October 1949, the newly installed SED government had staked out the field of its aspirations for the GDR's foreign relations: ${ }^{42}$ It was the GDR's declared goal to prevent "German imperialism" from regaining strength by establishing peaceful relations with all other nations as the "German alternative" to the Federal Republic in the West. For the next two decades, the GDR had to navigate within this narrow scope of action in the international realm to become an equal member of the international community - at first by focusing on the neighboring states in the Warsaw Pact and then on the Global South. ${ }^{43}$

In one way or another, both German states claimed to be the legitimate representative of the German people. In September 1949, GDR Prime Minister Otto Grothewohl declared: “The Soviet Occupation Zone has to be considered the real Germany. Accordingly, [the founding of the GDR...] means the creation of a government for the whole of Germany." ${ }^{44}$ FRG chancellor Konrad Adenauer replied in even more concrete terms: "The Federal Republic of Germany remains the only legitimate representation of the German people until the day of German reunification." ${ }^{45}$ In the end, only the FRG was able to use this claim as political leverage. Based on the argument that the government in East Berlin had not been formed by free elections and thus did not have any political legitimacy, Bonn considered itself the only legitimate German government and offered citizenship to all Germans, East and West. As soon as Bonn had regained partial sovereignty, ${ }^{46}$ the narrative of the lack of political legitimacy of the "other Germany" was translated into the international realm. The so-called "Hallstein Doctrine"

41 | Interview with Wolfgang Bator May 272011.

42 | First foreign policy declaration by the government of the GDR on October 241949 by Georg Dertinger, Minister for Foreign Affairs of the GDR, in: Neues Deutschland, Vol.4, No.250, October 251949.

43 | In 1957 the GDR already had signed 71 international treaties, in: Muth, 2001, 38.

44 | Grothewohl, Otto, Governmental Declaration of September 8th 1949, in: SAPMO BArch NY 4036, No. 768, Pg.2, in: Judt, 1998, 493.

45 | "Die Bundesrepublik Deutschland ist [...] bis zur Erreichung der deutschen Einheit insgesamt die alleinige legitimierte staatliche Organisation des deutschen Volkes." Konrad Adenauer speaking on October 211949 at the Parliament in Bonn, in: Hacker, 1989, 46. The West "German people had acted on behalf of those Germans who were denied involvement," in: Präambel, Grundgesetz für die BRD (constitution) of May 231949.

46 | After the "German Treaty" of 1952 had come into force.

47 | The name is not fully correct as "Hallstein Doctrine" had been introduced Wilhelm Grewe. Görtemarker, 2004, 338. 
of 1955 became a stumbling block for the GDR's foreign policy until the 1970s. According to the doctrine, the FRG intended to terminate diplomatic relations with any state that established relations of this kind with the GDR. Naturally, at first no state was willing to risk its good relations with West Germany and its strong economy. Not even after the GDR's Eastern Bloc allies had recognized its statehood in 1949-50 did the list of East German diplomatic relations get much longer, as only Mongolia, Yugoslavia and Cuba did so. However, things gradually began to change in the mid-196os when the Hallstein Doctrine gradually lost its deterring effect on developing countries. Even countries in the "West" considered recognizing East Germany, mostly to improve relations with Moscow. ${ }^{48}$ This change is regularly attributed to the international atmosphere of détente after the Cuban Missile Crisis. However, this development was also rooted in various other dynamics, such as the growing self-confidence of the Global South, the emergence of the non-alignment movement, and the inner consolidation of the GDR after it had erected the de facto symbol of its continued existence, the Berlin Wall.

Whether the GDR's change of strategy to attain international recognition in 1959 was among these causes or a mere reaction to them is debatable: ${ }^{49}$ The East German strategy of "Recognition" moved somewhat outside "classic foreign policy." ${ }^{50}$ Instead of aiming at the final goal of full diplomatic recognition, including permanent embassies, the SED regime intended to achieve progress through more modest but persistent steps by either initiating contacts below the governmental level or pushing for the establishment of commercial agencies. The early achievements of this policy were put to the test six weeks before the first conference of the non-aligned countries in September 1961, when the "Politbüro" decided to become active with regard to diplomatic recognition. When considering the GDR's limited scope of action, this foreign policy maneuver has to be considered a success: The lion's share of leading non-aligned states, such as India, Indonesia, Ghana, and Egypt, referred to "two German states" in their speeches. But East German endeavors did not result in the expected outcome: Despite this promising development, Yugoslavia's proposal for joint recognition of the GDR by all non-aligned countries was rejected. Furthermore, this East German move in the end led to a significant setback. Bonn felt threatened by the near-recognition of the GDR by the leading non-aligned states. West Germany decided to intensify the Hallstein Doctrine and extended diplomatic consequences for any state recognizing the GDR by cutting loss of developmental assistance and aid. As soon as East Berlin's new strategy showed its first successes, Bonn again intensified its doctrine by making clear that the establishment of relations with the GDR on a consular level could lead to the reduction of financial aid by the Federal

48 | E.g. the GDR singed the Test Ban Treaty in 1963 - despite the FRG's misgivings.

49 | Engel/Schleicher, 1997, $183 \mathrm{f}$.

50 | Wippel, 1996, 12. 
Republic: "Depending on their intensity, any official contacts of third countries to Pankow [meaning East Berlin] will be answered with a reduction of our economic assistance." ${ }^{51}$ Despite these steps taken and their success with regard to preventing countries from fully recognizing the other Germany, the government of West Germany was not able to stop the Hallstein Doctrine from disintegrating afterwards. ${ }^{52}$ The GDR's government continued on its new path and created in 1963 a strategy to finally overcome the Hallstein Doctrine.

Due to a limited budged, the GDR had to concentrate its strategy on a small number of selected countries in the developing world. Among those initial countries were two of the nine states from the wider Middle East, Algeria and Egypt. In both countries, East Berlin hoped to be successful with its strategy, and also that the two would have an impact on other countries in the region. While this initial design had no specific focus on the Arab world, only a few years later it seemed obvious that the key to overcoming international isolation lay in the Arab countries: "There were General Consulates in several countries [in the Middle East] which merely needed an upgrade [to become an embassy], for example in Syria, in Egypt. In addition to that we had commercial agencies in most Arab countries." 53

On behalf of Willy Stoph, Head of the Council of Ministers, ${ }^{54}$ and drafted by the MfAA, the new "strategy of small steps" was complemented by a "resolution" in 1965 to support the African and Arab people in their struggles for liberation with "noncivilian materials." ${ }^{5}$ Thus the strategy officially acquired a regional focus. Bonn's response, more or less, was the "Peace Note" ${ }^{56}$ of 1966, which can be seen as West Germany's last attempt to save the Hallstein Doctrine and its policy of legitimate representation. Erwin Wickert, a diplomat with the foreign office and author of the "Peace Note," retrospectively phrased the motive for this diplomatic move as "the wish [...] to compound with the states of Eastern Europe." ${ }^{57}$ When the Federal Republic sent the note in 1966 to all states but the GDR, this meant nothing less than a threat to the GDR's position within the Eastern Bloc. In the case that the Eastern Bloc states would have accepted Bonn's offer to agree to renounce the use of force and establish

51 | Carstens, Karl. Runderlass, June 18 1964, in: AAPD 1964. Doc. 171. 688-690.

52 | Gerlach, 2006, 65ff.

53 | Interview with Fritz Balke May 23rd 2011.

54 | Head of the Council of Ministers: German: Ministerratsvorsitzender, in: MüllerEnbergs/Wielgohs/Hoffmann (Ed.), 2000, Stoph, Willy, $829 f$.

55 | Otto Winzer an Willy Stoph, May 28 1965, in: BArch, DC 20/13001, BI.28-33; Storckmann, 2012, 108.

56 | German: Friedensnote. Friedensnote der Bundesregierung, 7.3.1966; Abdruck in: Dokumente zur Deutschlandpolitik (DzD), 1966, hrsg. vom Bundesministerium für innerdeutsche Beziehungen, Reihe IV/Bd.12,1. 1981, 381-385.

57 | Blasius, 1995, 544. 
diplomatic relations, the GDR's international isolation would have been complete. ${ }^{58}$ The immediate political reaction by the states of the Eastern Bloc though was the so-called “Ulbricht Doctrine', a "Reversed Hallstein Doctrine”: Any move towards the offer of the "Peace Note" had to be preceded by Bonn's diplomatic recognition of the GDR as well as the acceptance of the Oder-Neisse Line. ${ }^{59}$ The "Ulbricht-Doctrine" was backed fulsomely by Poland, indicating some success for East Berlin's policy of integration in the Eastern Bloc through rapprochement towards its neighbours. Not surprisingly, the major driving force behind this countermeasure against the West German policy was no one less than the Soviet Union itself.

Under the protective wings of Moscow, the GDR had survived the first decade of its existence. The "Soviet hegemony with regard to questions of foreign policy," ${ }^{0}$ meaning the integration into the Soviet bloc system, was regularly reaffirmed by the SED leadership. ${ }^{61}$ Reconsidering the two major determinants of East Berlin's foreign affairs during the first phase of foreign policy, it becomes apparent that both of them significantly shaped the GDR's foreign policy inputs and outputs. On the one hand, Moscow clearly exercised an active role and thus can be considered a directive determinant. Bonn on the other hand, remained at most a mirror for comparison, as there did not exist immediate political contacts between the two German states beyond agreements of practical relevance like issues concerning West Berlin. ${ }^{62}$ Bonn's policy and actions, though highly influential on East Berlin's foreign policy decision-making, were only indirectly a reactive determinant.

\section{On the "Road to Recognition": The Turning Point of East German Foreign Policy}

Attaining full diplomatic recognition as an equal member of the international community was the most pressing issue of East Germany's foreign policy from the very beginning, as it would secure the GDR's survival as a state and thus of the SED regime. Naturally doing so would require overcoming West Germany's Hallstein Doctrine of 1955. Meanwhile, pressure on Bonn to change its diplomatic course towards the GDR was rising. Due to the thaw in Cold War relations during the late 1960 s, the FRG's allies at first urged Bonn to adjust and finally give up its

58 | Haftendorn, 2001, 156.

59 | Weidenfeld/Korte, 1999, 588.

60 | Klessmann, 1988, 431 and Judt, 2008, 500.

61 | Extracts of the GDR's First Treaty of Friendship with the USSR of September 201955 in: Judt, 2008, 549.

62 | Judt, 2008, 503f; Weidenfeld/Korte, 1999, 413. 
Doctrine. ${ }^{63}$ Furthermore, Bonn could not afford to endanger its relations with a rising number of developing states that decided to recognize the GDR.

In his personal notes, Egon Bahr, architect of the "New Eastern Policy"64 and a confidant of West German Chancellor Willy Brandt, analyzed the situation in July 1969:

"With the establishment of diplomatic relations in Cambodia, Iraq, Sudan, Syria, and South Yemen over the previous weeks [between April and June], the GDR successfully thwarted our policy of non-recognition." ${ }^{65}$

Even though Bahr relativizes the GDR's progress due to the "progressive" and "instable" nature of these countries, he recognizes how much the situation has changed: "[T]he GDR had been able to establish relations with non-Communist states for the very first time." Bahr warns of the possibility of the rest of the Arab world following these radical states to avoid being the last in line for the economic and political benefits offered by the Soviet Union in what he calls a "follow-up effect." According to Bahr, the strategy of "non-recognition" could be upheld no longer when the benefits of the strategy failed to outweigh the damage done "due to terminated or diminished presence in these countries." ${ }^{\text {The }}$ "Hallstein Doctrine" had finally lost its last teeth: When Cambodia recognized the GDR, ${ }^{67}$ Bonn did not terminate diplomatic relations, but merely froze them, ${ }^{68}$ while still upholding valid agreements. Bonn's reaction to Aden's establishment of diplomatic relations with the GDR was quite similar: While ongoing negotiations were interrupted, the West German ambassador stayed in Aden.

After earning initial recognition in 1969, East Berlin participated in the $\mathrm{CSCE}^{69}$ in Helsinki in 1975 as an equal member and thus an internationally recognized sovereign state. ${ }^{70}$ Striking a swift agreement with the GDR about the future of

63 | One of the transitional stages towards the dissolution of the Hallstein Doctrine was a modified version, also called Scheel Doctrine, that declared the regulation of the innerGerman dispute an injunction for the FDG's non-action in case of the recognition of the GDR by third countries. This version was prolonged at least for the NATO-states until both German states joined the UN in 1973. Conversation Bahr, Verner, and Winzer. in: Dok zur DP 1973 bis 1974, 2005, 713f.

64 | German: Neue Ostpolitik.

65 | Aufz. des Ministerialdirektors Bahr, July 1 1969, in: AzAP-BRD 1969 Vol.1, 751 .

66 | Ibid.

67 | On the role of Cambodia in the GDR's Policy of Recognition: Interview with HeinzDieter Winter on July 32012.

68 | Kupper, 1971, 82.

69 | Conference on Security and Cooperation in Europe.

70 | Müller, 2010. 
"inner-German relations," become inevitable for Bonn to prevent further international marginalization of the FRG. Based on the notion that "there existed an alternative to the elimination of communist regimes: to change them," 72 the socialist-liberal coalition adapted its policy towards the GDR and the Eastern Bloc according to its Western allies' policy of détente. In doing so, the new government in Bonn hoped to expand its scope of action toward its Western allies by a changing its policy towards "the East."73 Bonn's agreement with East Berlin, the "Grundlagenvertrag," was considered the core of a catalogue of treaties that redefined West Germany's relations with its Eastern neighbours as well as the Soviet Union. ${ }^{74}$ The treaty was based on "the existence of two German states in Germany." ${ }^{\text {" }}$ By including the support of the Allied powers, Willy Brandt was hoping to keep the door open for a unified Germany - regardless of the implicit and explicit recognition of the GDR as a state. For the same reason, however, West Germany refrained from a full diplomatic recognition: From Bonn's point of view, the relationship of the two German states would always be of a "special nature."76

The "Grundlagenvertrag" finally supplanted both the "Hallstein Doctrine" and its weak counterpart the "Ulbricht Doctrine." The GDR could finally hope to become a "fully respected partner" in the international sphere. Until the final years of this "Phase of Recognition" the GDR's foreign policy not only had highly depended on the Kremlin's guidance and affirmation, but also on the Soviet Union's active support as a foreign policy proxy for East Berlin whenever the GDR wasn't able to act itself. ${ }^{77}$ Apart from its "de facto recognition" by Bonn, the most important outcome of the "Grundlagenvertrag" for East Berlin was the installation of the "direct line" ${ }^{\text {" } 78}$ between the two Germanys. Until then any contact between the two had been directed by Moscow and "in accordance with [the Kremlin's own] interests." ${ }^{.79}$ From then on, the GDR at least was able to try to realize its own policies without depending on the Soviet's pre-acceptance of every East German move in the international realm.

71 According to the official policy of the FRG, the GDR was not considered a foreign state. This was expressed through the term "inner-German," whereas East Berlin consistently spoke of "German-German relations" to emphasize its position about "normal diplomatic relations" between the two German states. Winters, in: Weidenfeld/Korte, 1999, 442-453.

72 | Schulze, 1996, 256.

73 | Haftendorn, 1989, 41.

74 | Haftendorn, 2001, 200.

75 | Wentker, 2007, 320.

76 | "Beziehungen von besonderer Art." in: Gespräch des Min.pr. der DDR Stoph mit BK Willy Brandt, Erfurt 19.März 1970, in: Dok zur DP, 21. Okt. 1969 bis 31. Dez. 1970, Bd. 1 (2002), 405.

77 | Judt, 2008, 501.

78 | Wentker, 2007, 371ff and 413ff.

79 | Bahr, in: Die zweite gesamtdeutsche Demokratie, 2001, 192. 


\section{CHAPTER 6. Phase II: From No.2 in the Eastern Bloc to Just Another Isolation:}

The "Policy of Self-Assertion"

Even though East Berlin had achieved its major foreign policy goal of the "Policy of Recognition" in the 1970s, Bonn still maintained some reservations with regard to full diplomatic recognition of the GDR and East German citizenship. As a consequence, East Germany's international status and further establishment as an equal member of the international state community still remained the major focal point of East German international engagement. All in all, one may speak not of the end, but rather of a transformation and diversification of the "Policy of Recognition" into a "Policy of Self-Assertion" based on a variety of foreign policy strategies. This policy change could first be detected in the 1960 s, when the future Secretary-General of the SED, Erich Honecker, became considerably more active in foreign policy making, paving the way for his future political course.

Phase II of the GDR's foreign policy again can be characterized by two subphases which gradually merged into one another. After the GDR was established as an equal member of the international community of states, their "High Times of Diplomacy" would last for about a decade. Then, the internal weaknesses of the GDR, most prominently the SED's lack of political legitimacy amid a pressing economic crisis, became more and more apparent. Whereas foreign trade during the second sub-phase of the "Phase of Recognition" had been used to promote political ends, this relationship was somewhat reversed now and ideological principles had yielded to economic pragmatism. And due to the growing economic and political problems of the late 1970s, the GDR gradually expanded its foreign policy on trade relations outside the Eastern Bloc to delay East German economic decline. Decay caused by insufficient flexibility of both the political and the economic systems exponentially accelerated in the late 1980s: ${ }^{1}$ When Gorbachev initiated a policy change toward more transparency (Glasnost) and reform (Perestroika), ${ }^{2}$ the East

1 | Judt, 2008, 501.

2 | Courtois (Ed.), 2010, 83f; For a detailed account on the reforms: Kotz/Weir, 1997, 63-130. 
German regime was neither willing nor able to maintain its closeness to the guarantor of its existence and as such did not follow the Soviet Union on its new political and economic path.

In accordance with the first phase, the analysis of the second phase of the GDR's foreign policy focuses on the two major external determinants: The dominance of the Soviet Union and East Berlin's confrontation with the "other Germany." The "other Germany" had served as a consistently reactive determinant for the GDR's foreign policy during the "Phase of Recognition," whereas Moscow actively shaped East Berlin's foreign affairs as a directive determinant. This allocation profoundly changed after the establishment of official relations between the two German states. The mechanisms of consultation between the SED and CPSU (Communist Party of the Soviet Union) had become sufficiently routine after Moscow replaced Ulbricht with the less precarious and more loyal Honecker. Moscow settled for observing the GDR's activities and providing emphatic "advice" if needed, instead of outright intervention.

\section{Keeping the Distance from Bonn - Oscillating Between "RAPPROCHEMENT" AND "DISSOCIATION"3}

The second phase of the GDR's foreign policy is characterized by East Berlin's constant effort to balance its "rapprochement" with the "imperialist Germany," while keeping the distance necessary for justifying the GDR's existence as the "better Germany." In the early years of the "New Eastern Policy" and Bahr's notion of "change through rapprochement," the motives of West Germany's policy change towards East Berlin were not fully clear to the SED regime. Thus, Ulbricht's initial reaction was not only to keep his distance to Bonn, but even to increase it: "When Brandt implements a new 'Ostpolitik' now, we'll execute a new 'Westpolitik,' one they haven't seen before." As a reply to Brandt's "Unity of the Nation," Ulbricht created the "Two Nations Hypothesis," one of which was a "socialist and German nation state" in its own right, the "belated nation" in socialist terms. The new constitution of 1974 removed the last references to the

3| Scholtyseck, 2003, 30.

4 | Ibid., 33.

5 | Bahr, Egon, 1963, Akademische Akademie Tutzing, in: Haftendorn, 2001, 191.

6 | "Wenn Brandt eine neue 0stpolitik macht, dann machen wir eine neue Westpolitik, und zwar eine, die sich gewaschen hat." Ulbricht, Walter, 1969, in: Scholtyseck, 2003, 28.

7 | Hacker, 1987; Schroeder, 1999, 206.

8 | Helmut Plessner on the role of the "belated nation" ("verspätete Nation") and the emergence of Nation-Socialism in Germany, see: Bialas, 2010, 245ff. On the efforts to establish a separate "socialist German nation" and the "Two-Nations Hypothesis" in the GDR, see: Hacker, 1987; Schroeder, 1999, 206. 
former unified Germany. Considering the "Grundlagenvertrag" and the following "policy of two German nations," it is no wonder that the stagnation of the détente on the international level was mirrored on the inner-German level as well.

The GDR also attempted to distance themselves from Bonn by trying to make their economic model more attractive. Higher salaries and more availability of consumer goods were used to motivate workers, with the hope that this socialist version of "bread and circuses" " would increase productivity. While Ulbricht had always kept spending in line with revenues, Honecker significantly overstretched the GDR's economic abilities. From the late 1960s onward, the GDR's economic difficulties grew in number and severity while attempts to modernize the rigid system failed. When Ulbricht was replaced, hopes were high for political and economic change for the better. In reality, however, Honecker put an end to all "tentative attempts of reform." ${ }^{10}$ As a willing acolyte of the USSR, his economic policies also strictly followed the Kremlin's course. As early as 1972 Honecker removed the remnants of any independent entrepreneurship and in doing so shut down the "last resorts of the bourgeois milieu." At the time, Honecker had already realized the gravity of the looming economic crisis: "We might as well declare bankruptcy."12 Regardless, the Secretary-General decided to keep these problems from the population and instead of austerity plans, he introduced extensive social policies.

In June 1971, Honecker announced "unity of economic and social policy"13 to improve social benefits and the standard of living. The shortage of consumer goods was to be eased by short-term imports and mostly Western loans instead of long-term investments. At the time this "socialism of consumption"14 seemed to aim at nothing more than the appeasement of the population and to subsist in the shadow of the economic "wonderland" in West Germany. Social benefits were tied not to economic performance, but rather to the "SED's will to survive."15 In combination with successes in the international sphere, these policies were supposed to mollify East Germany's population and uphold the reign of the SED. However, the effort only accelerated the recession. The economic problems of the 1970 s erupted as a full-blown crisis in the early 1980s, significantly affecting the GDR's activities in the developing world.

Honecker's social offensive was in large part financed by political loans from Bonn. Thus the improvement in the GDR's relations with its Western sibling

9 | Schroeder, 1999, 199.

10 | Schroeder, 2006, 89.

11 | Neubert, 1997, 204.

12 | “An sich müssen wir Pleite anmelden.” Erich Honecker, 1975, in: Wentker, 393.

13 | German: Einheit von Wirtschafts- und Sozialpolitik.

14 | German: Konsumsozialismus, in: Siebs, 1999, 112.

15 | “Überlebenswille der SED-Führung." Wentker, 2007, 393. 
was mostly motivated by economic considerations, ${ }^{16}$ bringing about other severe political problems: While conceding as little as possible to Brandt's demands for "humanitarian relief" for the divided German population, ${ }^{17}$ Honecker tried to draw as much know-how and technology to the GDR as possible so that East Germany remained "No. 2" in the Eastern Bloc. Nonetheless, the "humanitarian relief" promoted more exchange of good, people and especially ideas, between the two Germanys. As a result, the GDR's population became less and less convinced by negative news coverage of the "imperialistic West" and the efforts to control coverage by Western media on the GDR proved insufficient. ${ }^{18}$ These developments led to more citizens questioning the SED's legitimacy and its political system, further undermining the party's absolute claim of primacy. Also, the GDR's economic dependency on West Germany became a never-ending source of conflict between East Berlin and Moscow: The Kremlin seemed to sense the imminent dangers posed by inter-German arrangements to the viability of the East German state. ${ }^{19}$

At the beginning of political exchange between the two Germanys, the GDR's dilemma had become clear: The "unsolved conflict between claims of ideology and political reality," ${ }^{20}$ as Ludz describes it. At first, international détente demanded "rapprochement" to the unloved sibling state; later on it was economic need demanding it. However, any relaxation of relations between the blocs and thus between the GDR and FRG somewhat questioned the GDR's justification for existence. The GDR's “rapprochement” regularly had to be accompanied by national "dissociation" based on the rules of "class struggle" 21 to ensure the GDR's ideological legitimation as the "democratic," that is, socialist alternative. Regardless of the superficial reconciliation between East and West, the GDR's foremost interest remained its "external and internal consolidation,"22 rather than further political "fraternization" with its sibling. In addition to that internal development had gained importance compared to Soviet influence and West German attraction during Honecker's "reign," as political and economic problems intensified and again endangered the GDR's existence from within. After the

16 | One of the most spectacular incidents was the so-called "Billion Deal" of 1983 between the Bavarian Prime Minister Franz Josef Strauß and the Head of Commercial Coordination (KoKo) Alexander Schalck-Golodkowski. Strauß granted two loans to the economical ailing GDR in exchange for the dismounting of the GDR's border protection system, including its automatic guns and other concessions in visa issues and prisoners' ransoms, in: Scholtyseck, 2003, 41.

17 | German: menschliche Erleichterungen.

18 | Trampe, in: Judt, 1998, 311.

19 | Scholtyseck, 2003, 41.

20 | Ludz, 1977, 300.

21 | ibid., 299.

22 | Scholtyseck, 2003, 32. 
"wave of diplomatic recognition" of the early 1970s, international acceptance and respect for Honecker as an esteemed statesman was more important for internal than for external policies. ${ }^{23}$ Honecker's public appearances more often than not were intended to brush over the accumulating internal political, economic and social problems. The "discourse of danger" of foreign policy in the GDR had shifted from the external to the internal sphere.

\section{Growing Distance from "Brother Moscow": "Steadfast FRIENDSHIP" IN DANGER?}

"Without us there is no GDR," ${ }^{4}$ clarified Leonid Illich Brezhnev, reminding Erich Honecker of his loyalties towards the Soviet Union. In the GDR's constitution of 1974 , the alliance with the Soviet Union was declared "irrevocable." 25 Internally, the GDR was continuously kept on a very short political "leash." However, the USSR apparently had other plans for "Socialist Germany" with regard to its position in the international community. At least outside the Eastern Bloc, it appeared to be in the Kremlin's interest to generate the image of a sovereign GDR. During any negotiations concerned with questions of sovereignty of the young state, Moscow stressed the GDR's autonomy and demanded to draw into consideration East Berlin's position. During the negotiations of a treaty package called the "Ostverträge" (Eastern Treaties) in the early 1970s, Hermann Axen, ${ }^{26}$ at the time chairman of the Committee for Foreign Affairs of the GDR, even considered the GDR as the Soviet Union's "main consulting partner." ${ }^{27}$ With regard to the topic such a characterization might even be true, but Moscow did neither need nor desire to consult any of its satellite states. However, the "big brother" withdrew more and more from the GDR's day-to-day politics, first from the internal, then from the external sphere. ${ }^{28}$ Gradually, and within the predetermined scope of action, the GDR used its new leeway to establish itself as a "junior partner" 29 to the Soviet Union internationally and within the Warsaw Pact.

Without doubt, the SED functionaries were well aware of the dubious character of its "limited sovereignty": Soviet "consultant" were to remain in the GDR

23 | Wentker, 2007, 372.

24 | Scholtyseck, 2003, 30.

25 | Constitution of the GDR of 1968, Version October 7 1974, Art.6(2).

26 | From the late 1960s onward, Hermann Axen was considered the "architect" of the GDR's foreign policy. In 1970 he became a member of the Politbüro, in 1971 chairman of the committee for foreign affairs of the Volkskammer. in: Müller-Enbergs/Wielgohs/ Hoffmann (Ed.), 2000, 34.

27 | Axen, 1996, 356.

28 | Wentker, 2007, 367.

29 | Gasteyger, 1976, 38. 
throughout its existence. ${ }^{30}$ They were supported by a wide network of undercover informants which guaranteed the leadership in Moscow to be informed of any political developments within the country. This arrangement was an open secret and political functionaries would act in anticipatory obedience and refuse to deviate too far from the field of political maneuver Moscow had staked out for them. To that effect, the "exchange of dictators" ${ }^{31}$ from Ulbricht to Honecker in 1971 meant more than a simple change of the figurehead. Honecker's inauguration was not only an act by Moscow's grace but a well-planned stroke which moved the GDR closer to the Kremlin again. ${ }^{32}$ Another revision of the constitution bore witness to this development: The GDR was to pursue a foreign policy of "socialism and peace, for international understanding and security" based on the "Leninist policy of peaceful co-existence" ${ }^{33}$ and the "irrevocable" ${ }^{34}$ alliance with the Socialist Soviet Republics was lifted to constitutional rank.

This political bond was not meant for eternity. Its demise, however, in the end was caused by quite other reasons than the Kremlin might have feared. The disintegration of relations between East Berlin and Moscow can be traced back as far as the 1970 s and was tightly interwoven with the GDR's economic ties with West Germany. When the Kremlin found out about the extent of East German financial dependency, Honecker avoided the open confrontation with Brezhnev and sent Axen on his behalf. ${ }^{35}$ The disagreement over East Germany's policy towards its capitalist counterpart was never really addressed and remedied and thus kept smoldering below the shining surface of Soviet-East German relations. Meanwhile, the GDR had to witness an improvement of Soviet-West German relations and old fears of being "sold" as a political pawn sacrificed by the "big brother" were just as present as ever before.

The first harbinger of estrangement between East Berlin and Moscow was Brezhnev's surprisingly moderate reaction to political unrest and opposition in Poland in 1980. The SED regime readily declared the reformist movement a "counter-revolutionary" danger - clearly the "shock of 1953" had never lost its sting. But the Polish "aberration" from the path of Soviet bloc discipline did not result in the merciless military intervention by the Soviet Army East Berlin had been hoping for. ${ }^{36}$ Apparently, political and economic pressures prevented a Soviet

30 | On the early activities of the Soviet secret services and their interconnectedness with the East German secret service see: Kowalczuck, 2013, 30-46 and 53.

31 | Schroeder, 2006, 89.

32 | Wentker, 2007, 363.

33 | Constitution of the GDR of October 7 1974, Art. 6; Hänisch, in: Hahn/Hänisch/Busse/ Lingner, 1974, 207.

34 | Constitution of the GDR of October 7 1974, Art. 6 I.

35 | Scholtysek, 2003, 33f.

36 | Ibid., 37. 
reaction similar to the earlier "counter-revolutionary" incidences in the GDR, Hungary or the ČSSR. Times indeed had changed when Moscow opted against the possible political damage and loss of prestige caused by a military enforcement of the Brezhnev Doctrine.

\section{The Double-Edged Sword of International Recognition AND THE END OF THE GDR}

The early years of this second phase of the GDR's foreign policy can be considered the "High Times of Diplomacy." The GDR became significantly more active and the analyst might recognize long-term foreign policy strategies. Due to a lack of alternatives, East Berlin's foreign policy efforts after the "wave of recognition" in general displayed a noticeable focus on mediation and multilateral support. ${ }^{37}$ With the blessing of the Soviet Union, ${ }^{38}$ the GDR became considerably more active within the framework of international organizations and conferences like the suborganizations of the United Nations ${ }^{39}$ or the CSCE Process. The latter turned out to be a double-edged sword for the SED regime, though. By signing the Final Act of Helsinki in 1975 Honecker himself had confirmed a comprehensive guarantee of human rights. ${ }^{40}$ The Conference in Helsinki in the end provided the "legitimate reasoning for the people in the Eastern Bloc and especially the GDR which could not simply be put aside by the ruling party." ${ }^{\text {,4 }}$ The gap between political promises and social reality was made clear.

In the European context the two major fields for the GDR's foreign policy goals were the CSCE process and the Mutual Balanced Force Reduction (MBFR) negotiations, but not for long. Just as many contemporaries had predicted, the "European Peace Process" and its conferences somewhat stagnated in the late 1970s. After the Soviet invasion of Afghanistan, the new "ice age" in the Cold War also froze any movement in the European power constellations. The functionaries of the SED had to realize that the GDR, even though it was now an equal member of the international community, still was subject to the rules of the bloc and that it remained a small state with little to no leverage on the playing field of Europe. This realization without doubt further intensified the GDR's engagement towards the countries of the Global South: ${ }^{42}$ First the Arab states, then Africa, and finally, in the late $198 \mathrm{os}$, Asia. Outside Europe, the GDR more than ever aimed to make its

37 | Muth, 2001, 23.

38 | Scholtyseck, 2003, 35.

39 | Both German states obtained a full UN membership in 1973.

40 | Final Act of the Conference on Security and Co-operation in Europe (CSCE).

41 | Müller, 2010.

42 | Scholtyseck, 2003, 36. 
mark as the "better Germany," free of a colonial past. In the meantime, the Soviet Union, the major determinant of East German foreign policy, was well on its way to political transformation.

\title{
3.1 "Limits" May Change: The Transformation of the Major Determinant of East German Foreign Policy
}

\author{
"Perestroika - the process of change in our country - started from above. It \\ could not have been otherwise in an authoritarian state." ${ }^{43}$ \\ (Mikhail Gorbachev, former General-Secretary of the CPSU)
}

After Brezhnev passed away in late 1982, the transitional phase with two secretary generals of the Communist Party, Yuri Vladimirovich Andropov Konstantin Ustinowich Czhernenko, revealed the first structural problems of the huge political "Empire" Moscow had built. ${ }^{44}$ Despite several attempts to reform the Bolshevik system, the Soviet Union never actually touched its central principle of organization, the "Communist Party Dictatorship," including the "omnipresent surveillance and social penetration" ${ }^{\text {n5 }}$ to uphold political control of society. Interestingly, this politically self-controlling system, which was exceptionally resistant to change, carried the seeds for its own destruction within: "The centralized, autarchic, dictatorial institutions of the Soviet system [also] dictated that the source of change had to originate from within and at the top." ${ }^{\text {"6 }}$ The hierarchic structure focused on a single, ultimate decision-maker who could move beyond the control of its system of origin: the Secretary-General of the CPSU.

The new and noticeably younger Secretary-General of the Communist Party, Mikhail Gorbachev, aimed to tackle the country's problems by introducing a strategy of "radical reform ${ }^{\text {"47 }}$ that he officially announced at the XXVIIth party meeting in February 1986. With the initial support of the "hard liner" and without immediately challenging the existing structures, Gorbachev aimed to change the system incrementally. The first priority was to change its actors. Gorbachev simply replaced the majority of his opponents. ${ }^{48}$ Clearly, his reform endeavors did not rest on pluralist inclusion of interests, but rather upheld the "Leninist tradition [of] centralized political power. ${ }^{49}$ Nonetheless, this new path included a comprehensive new foreign policy that was confirmed at the Comecon meeting in November 1986. This new approach firstly aimed to stop Moscow's confrontation

43 | Gorbatchev, 1996, 76.

44 | Scholtyseck, 2003, 42.

45 | McFaul, 2001, 36; On the "Political Structure of the Soviet Sys.": Kotz/Weir, 1997, 23-33.

46 | McFaul, 2001, 39.

47 | Hewett quoting Gorbachev, in: Kotz/Weir, 1997, FN 80, 55; Scholtyseck, 2003, 43.

48 | Adelman/Palmieri, 1989, 233.

49 | McFaul, 2011, 57. 
with the West, secondly to create a feeling of security for the other international actors with regard to the Soviet Union, and thirdly to reduce spending on security and developmental aid. ${ }^{50}$ Most importantly, the new policy meant nothing less than the official termination of the Brezhnev Doctrine. This "Wind of Change," 51 as the international atmosphere of the time was summed up by the West German band The Scorpions, was bound to have an extremely high impact on the Socialist alliance.

This is where real trouble started for the SED-led GDR. Already in the 1970s, Honecker was hoping to be able to visit the FRG as the official Head of State of the GDR. East Germany considered this high-ranking visit a significant step to full diplomatic recognition by the "other Germany." But the Kremlin at the time rejected outright the endeavor and even the official agreement on a visit in April 1983, which had been a success for East German diplomacy, did little to impress the Soviet Union. At the very last minute the SED regime had to cancel the trip. This attitude in Moscow was not about to change before the profound shift in Soviet leadership under Gorbachev. When in 1987 Honecker finally visited Bonn, East Berlin considered it a decisive step for the GDR toward full sovereignty and diplomatic recognition. However, it instead may be considered the very last moment of "diplomatic glory" for a decaying state and an aging party elite that was neither willing nor able to react to Moscow's policy change or the shifts within the bipolar international system.

The ongoing disagreements between Moscow and East Berlin over how the latter should frame its relations to the "other Germany" were now complemented by more severe discrepancies. Moscow's policy change and the new scope of action it granted to the members of the Warsaw Pact questioned basic ideological and political foundations of the Eastern Bloc, which had been part of Moscow's "guarantee of existence" for the GDR and thus an integral part of the SED's "Policy of Survival." The USSR immediately translated "Glasnost" and "Perestroika" to the international sphere and opened up new doorways for the members of the Warsaw Pact and the ideological allies of the Global South. In a short time, the internal and external room for these regimes' maneuvering extended significantly. For the GDR, however, this policy change barred the path that the "SED state" had followed for over four decades, while the SED regime was not able to make use of this newfound freedom. In an often-quoted interview in 1987 with the West German magazine "STERN," Kurt Hager, member of the Politbüro and assigned with questions on ideology, summarized East Germany's position towards Moscow's reform policies in the most pointed way: "Would you [...] put up new wallpaper just

50 | Kanet, in: Greiner/Müller/Weber, 2010, 57. On the effect of Gorbatchev's policy change on the "international community states," esp. the "West": Adelman/Palmieri, 1989, 242.

51 | The Scorpions, Album "Crazy World," Lyrics "Wind of Change" in English and Russian; Also see: Zum Mauerfall, in: Spiegel Online, October 271999. 
because your neighbor decided to do so? “52 The GDR's political system, its policies and functionaries were not flexible enough to leave this dead end and find an alternative. ${ }^{53}$ Gieseke even speaks of an emerging "schism" between Moscow and East Berlin at the time. Mielke had prevented a meeting between functionaries of the KGB and MfS in April 1989, as he was "worried about the negative impact of the Soviet reformative spirit." 54 In retrospect, one may conclude that the GDR had been a child of the Cold War. Hence, the only thing left to do for Honecker and his generation was to cling to the old ideology of bloc confrontation in their foreign policy. Even though the "Big Brother" in Moscow had proclaimed a new style of fashion, Honecker kept faith with "socialism in the colors of the GDR."

\subsection{Why the Dissolution of its "Foreign Policy Limits" meant the End of the GDR}

Inspired by changes in nearby countries, most prominently in Hungary and the ČSSR, the summer 1989 witnessed an increase in refugees who tried to flee the GDR via West German embassies in the neighboring countries. The lack of legitimacy inside the GDR had built up and erupted in enormous demonstrations in the GDR's bigger cities: In the month of October hundreds of thousands took to the streets, from Leipzig to Berlin. The SED regime's "discourse of danger" had manifested. However, the people and the regime alike could not yet be sure about the true intentions and extent of Moscow's "new" course of policy towards the members of the Warsaw Pact - especially not with regard to the value of an SED-led GDR for the Kremlin. In the end the Soviet Union's troops did nothing to intervene and nothing to save the SED regime. In late October of 1989, the SED Politbüro decided to dethrone Honecker to save a socialist GDR, the "Primacy of the Party," and thus their own neck. But the change to the new leader, Egon Krenz, came too late to make any difference, ${ }^{56}$ as this was also the moment when "the full truth about the condition of the GDR's economy came to light." ${ }^{57}$ Overstrained and still inflexible, the new regime stumbled into both drastic and uncoordinated action. Triggered by a double entendre in a public interview by Günter Schabowski, the "wall" in Berlin had to yield to the will of the people. ${ }^{58}$ After almost three

52 Kein Tapetenwechsel: Kurt Hager beantwortete Fragen der Illustrierten Stern, in: Stern, April 91987.

53 | Muth, 2001, 9 and 22.

54 | Gieseke, in: Kaminski/Persak/Gieseke, 2009, 203.

55 Honecker, Erich, Report of the Politbüro to the VII. Conference of the Central Committee, in: Neues Deutschland, December 21988.

$\mathbf{5 6}$ | On the downfall of Honecker see for example Malycha/Winters, 2009, 333-339, Schroeder, 1998, 300f.

57 | Schroeder, 1998, 308.

58 | Scholtyseck, 2003, 48; Schroeder/Staadt, in: Courtois, 2010, 138. 
decades of detention in their own country, the people in the GDR regained their full freedom of movement.

The GDR had broken. It was a period of fundamental changes in East German society, and also for the political system. Consequently, these changes also disrupted the centralized process of foreign policy making profoundly. HeinzDieter Winter, at the time Vice-Minister of Foreign Affairs, remembers: "There were almost no internal orders and directives anymore. I had to find my own line of argument." ${ }^{59}$ The ambassadors mostly had to act on their own accord. While the MfAA and its embassies at first tried to continue their regular work under the new circumstances, the first and final free elections in East Germany in March 1990 sealed the GDR's fate. The only task left to the foreign policy apparatus was to administer its dissolution and find new assignments for the former personnel. ${ }^{60}$ The newly granted scope of action in the international realm could neither be filled nor used by the decaying regime. While the international realm demanded more flexible foreign policy reactions, the GDR's old one-party system could not afford this flexibility internally. The time was up for any gradual reforms.

The people of the GDR had been calling for free elections for a long time, and finally won them in March 1990. This election presented the choice between a supposedly reformed separate socialist GDR or German reunification under Article 23 of the "Grundgesetz" of the FRG. The outcome did not leave any doubt: Despite all its endeavors between bribery and coercion, the SED-led GDR had not been able to "integrate" its own population. The majority voted against gradual reforms along a "Third Path" and for the end of the GDR. They voted for a unified Germany under the umbrella of the "Grundgesetz." In the end "the democratically elected government under [...] Lothar de Maizère (CDU) became a kind of executive organ for the liquidation of the GDR." ${ }^{61}$

Just as Moscow's active role in determining the GDR's foreign policy at the time had diminished, Bonn's role had increased. At first Bonn took the place as the major determinant of the GDR's foreign policy and expanded its impact up to the point that the GDR's "foreign policy initiative was incrementally taken over by Bonn" during the " $2+4$ negotiations." ${ }^{12}$ At the same time, the end of the GDR was somewhat the harbinger to the last throes of East Germany's other foreign policy determinant, its "guarantor of existence." "Glasnost" and "Perestroika" had come too late to save the sclerotic political giant that was the Soviet Union:

59 | Interview with Heinz-Dieter Winter July 32012.

60 | Phone interview with Werner Sittig May 72014.

61 Scholtyseck, 2003, 51.

62 | Scholtyseck, 2003, 50; The "2+4 negotiations" resulted in the Treaty on the final settlement with respect to Germany of September 12 1990; PA AA MULT 781. 
"Once Gorbachev opened up the agenda of change [...], the dynamics of simultaneous political and economic change had a logic of their own that eventually could not be controlled by Gorbachev." ${ }^{63}$

Apart from the fading ideological glue, massive economic problems and the waning of the existential fear of the Warsaw Pact members coincided with a "period of interpenetration" ${ }^{4}$ by ideas and "Weltanschauungen" which challenged the ideological pillars of the Soviet system. The Marxist promise of "salvation on earth" 65 had not been fulfilled. Today, current discourse names an "imperial overstretch" ${ }^{\prime 66}$ of Soviet power in the Global South as one of the many reasons for the Soviet Union's dissolution, calling it a "Failed Empire." ${ }^{67}$ In addition to that, another decisive aspect should not be overlooked. The Cold War had been a war after all, an "inter-systemic war," ${ }^{68}$ as Halliday puts it. And the Soviet system, at least economically, had lost this war. Meanwhile, the SED regime had kept on walking its well-trodden path of Real Socialism and thus had to walk its very own road to perdition all by itself - the GDR's last and only policy decision outside the Soviet-approved room for maneuver.

63 | McFaul, 2001, 60.

64 | Shearman, in: Shearman, 1995, 18.

65 | Löwenthal, Messianism, Nihilism and the Future, in: Schmeitzner (Ed.), 2009, 462.

66 | The "Imperial Overstretch Hypotheses" is regularly connected to Edward Gibbon's monograph "Decline and Fall of the Roman Empire" published in six volumes between 1776 and 1789. Gibbon argues that the collapse of Rome had actually been caused by the exhaustion of its military and economic ability which in turn led to the decay of its comprehensive citizenship. Gibbon, Edward, in: Womersley, 1994.

67 | Zubok, 2007, 227.

68 | Halliday, 1993. 


\title{
CHAPTER 7. The "Three Spheres of Foreign Policy Making":
}

\author{
Party, State, and Society
}

"Of course that is the downside of a centralized state like this. When the boss says: "This is how you do it," then this is how you do it." 1

InterVIEW With Wolfgang Bator on the 27th of May 2011

To understand East German engagement in South Yemen, we have to understand the mechanisms and details of East German foreign policy. What institutions, bodies, or persons formulated, interpreted, and implemented the policy? Who was supposed to execute this policy within East-Berlin's tight scope of action? Compared to Western democracies, the internal structures of the GDR did not only pose a very different background for foreign policy making, they also played quite a different role for foreign policy formulation itself. The political system excluded any significant participation in the state's external affairs that was beyond the control of the party apparatus. Companies, cultural societies, youth groups, the media - the SED selected any actor who was about to move outside the allied states of the Eastern Bloc with great care. The party instructed them to adhere to the Party's foreign policy directives and monitored them closely for compliance. ${ }^{2}$ To be able to analyze and interpret the generation of East German foreign policy in South Yemen, this chapter first sketches the determinants of the political system of the GDR. Then, the Soviet Union's policy towards East Germany in the first decade after WWII ${ }^{3}$ and the "planned development of socialism" ${ }^{4}$ are introduced in more detail. Second, the chapter gives a short account on foreign policy actors in

1 | Interview with Wolfgang Bator, May 272011.

2 | A major task of the HV A of the MfS was to monitor GDR citizens working or studying abroad and to find out about their possible plans for escape, in: Kowalczuck, 2013, 252.

3 | The major policies draw on Wentker's findings and modify his analysis, Wentker, 2007, 3. On Soviet policies towards Eastern Europe also see: Applebaum, 2013, Introduction.

4 | Schroeder, 1999, 119ff; Schroeder, 2013, 110ff. 
the GDR, as well as the decision-making process at the national level. Finally, this chapter introduces the relevant actors for the case study of South Yemen. Based on these findings, this chapter develops and presents the "Three Spheres Approach," a general conceptualization of East German foreign-policy-making.

\section{ON the Political System of the GDR and its Social Reality}

"As Marxists we should know: When we form a government, we will never give it up again, neither because of an election, nor because of any other procedure." 5

(Gerhart Eisler, Chief of the Department for Information)

In democracies not only is the reciprocal relationship between the national and international level decisive for foreign policy generation - so too are the demands from within the national system. For example, Robert D. Putnam's theoretical approach of the "two-level game" is fully based on the fact that interest groups at the national level are able to put significant pressure on their government to influence the country's foreign policy and its strategies according to their preferences. ${ }^{6} \mathrm{On}$ the international level, governments aim to consolidate their internal power and reelection within the national system: "First of all we have to make sure that we keep our majority at home." 7 Furthermore, foreign policy decision-making in democracies is complicated by both the separation of powers as well as attempts to represent "the will of the people" in policy. A concrete example is the ratification of an agreement or treaty. For this step, state policy cannot simply be "run" by the government, as von Bredow points out. ${ }^{8}$ A functioning democracy regularly demands a positive vote in parliament at the national level as a prerequisite for the ratification of international agreements, such as in the U.S.A. or the Federal Republic of Germany. ${ }^{9}$ In conclusion, pressures from within the system may determine a state's scope of action to a similar extent as external factors do.

Unfortunately, the convincing model of the "two-level game" and the resulting conclusions turn out to be useless when looking at the one-party system of the GDR. The central principle of organization, "democratic centralism," ${ }^{10}$ created a political system based on the absence of democratic control by and political participation of the governed. In Ursula Lehmkuhl's reply to Czempiel's argument

5 | Eisler, Gerhart, quoted in: Suckut, 1991, 160f. Gerhart Eisler had been a major functionary during the founding years of the GDR, in: Müller-Enbergs/Wielgohs/Hoffman (Ed.), 2001, $180 f$.

6 | Putnam, 1989, 433ff.

7 | Stoltenberg, 1986, in: Putnam, 1989, 437.

8 | Von Bredow, 2006, 38.

9 | Brugger, 2001, 36f und Maurer, 2003, 443f.

10 | The first Party Congress of the SED in January 1949, Avantgardeanspruch und innerparteiliche Diktatur Januar 1949, in: Judt, 1998, $46 f$. 
about the limitations of foreign policy originating at the national level, she notes that in "dictatorial-authoritarian systems"11 the state and its official agents remain the only relevant actors in the international realm. She puts forward the socialist dictatorships in Europe in the 1970 s as explicit examples. According to Lehmkuhl, the leading elites in socialist regimes not only directed the state's foreign policy without any interference from within, but also restricted, controlled, and guided any international exchange below the level of government to uphold their monopoly of power. What Lehmkuhl does not take into consideration, though, is the growing dependence of the dictatorial government, in this case the SED regime, on foreign policy outcomes. In the GDR, economic and political success in the international realm over time had come to compensate for the regime's lack of legitimacy and a tool to appease the population. Therefore, foreign policy making in the East German socialist dictatorship was not fully decoupled from society, but indeed was one of the few policy fields in which the regime intended to satisfy its population's demands.

As a consequence, the following sub-chapter aims to serve two purposes: First, it clarifies the role of internal conditions and developments of the GDR's political system $^{12}$ in forming foreign policy and introduces a general conceptualization of East German foreign-policy-making, the formulation of the "Three Spheres." Second, the sub-chapter summarizes the major features of the "planned development of socialism," which was the "road map" for the SED's policy of state-building in 1952. In Chapter 10, "Methodological Prelude: Between Bonn and Moscow," these features are connected to Hippler's approach to state- and nation-building. This connection serves as the method of analysis for the concept of socialist nation- and state-building to interpret concrete East German foreign policy in South Yemen.

\section{1 "It only has to look Democratic": The "D" in GDR}

Reconsidering the initial quote in this chapter by Eisler, it reminds of the often-quoted statement by Ulbricht, "It only has to look democratic while we keep everything in our hands. ${ }^{13}$ Even though the authenticity of the latter quote is sometimes questioned, it still aptly summarizes the SED's approach to the GDR and its nation- and statebuilding process. As Schroeder's comprehensive analysis of the political system of the GDR and its history concisely suggests in its title "Der SED-Staat,"14 the state and its institutions were incorporated into the party apparatus and not the other way around.

11 | Lehmkuhl, 2001, 29.

12 | Internal developments of polity and politics, Van Waarden, in: Schubert/Bandelow, 2004, $257 f$.

13 | Ulbricht, Walter, May 1945, in: Leonhard, Wolfgang, 1961, 365. Leonhard, as a former member of the "Ulbricht Group" and the "Moscow cadres," quotes Ulbricht from his memory.

14 | Schroeder, 1999 (2013). 
Accordingly, Storckmann pinpoints that academic discourse in Germany today is beyond the question whether the GDR was ruled by the SED, but rather occupied with the "how" of party rule. ${ }^{15}$ As such, the following sub-chapter is occupied with Real Socialism, the East German interpretation of Marxism-Leninism, and how this interpretation directly affected the GDR's political system.

\subsection{Marxism-Leninism, Its Claim to Truth, and the Promise of "Salvation on Earth"16}

Despite the "democratic" in the middle of the country's name, its leading party never had the intention to establish a Western-style democracy, instead choosing to found a "dictatorship of the proletariat." 17 The principle is not only in accordance with the theoretical approach of Marxism-Leninism, but also based on the role model of the Soviet system. This study does not allow for a thorough discussion of the ideological differences between Marx and Engels' writings and Lenin's ${ }^{18}$ interpretation of them, nor an examination of the gap between Lenin's theory and his praxis after $1921 .{ }^{19}$ Nonetheless, the major differences at the very least have to be named to be able to interpret the discrepancy between the GDR's constitutional ideals and East German political reality.

According to Marx and Engels' approach of "historical materialism," it was inevitable that the capitalist system would exhaust itself at one point. Then, the "dictatorship of the proletariat" would overcome the condition of the worker's exploitation to finally realize worldwide communism. ${ }^{20}$ However, both authors repeatedly warned their contemporaries that not any outcome of history could be "deducted from a general theory," as "history [was] a consequence of the interaction of many factors that must always be empirically analyzed in their specific situations." ${ }^{21}$ Current Marxist theorists such as John F. Sitton often use sections of Marx and Engels' writings to emphasize the differences between their writings and Lenin's and Stalin's interpretations ${ }^{22}$ led to the totalitarian reality of

15 | Storckmann, 2012, 55.

16 | Löwenthal, Messianism, Nihilism and the Future, in: Schmeitzner (Ed.), 2009, 462.

17 | The Dictatorship of the Proletariat [in Russia], in: Courtois (Ed.), 2007, Courtois, 1917 bis 1922, Die Oktoberrevolution, 63.

18 | Born in 1870 as Vladimir llyich Ulyanov, he later on was known as Vladimir llyich Lenin. Read, 2005.

19 | Lenin abolished any possibility of political opposition after the Kronstädter Uprising of March 1921. Löwenthal considers this a turning point at which Lenin leaves behind his own theoretical principles. Löwenthal, Jenseits des Stalinismus, in: Schmeitzner (Ed.), 2009, 395.

20 | Baudouin, Jean, Marxismus, in: Courtois, 2007, 568; Kowalczuck, 2013, 25.

21 | On this interpretation of Marx and Engels' "Historical Materialism," see: Sitton, 2010, 24.

22 | Josif Wissaryonowich Zhugashwili. 
Real Socialism in the Soviet Union and the GDR. These modern Marxists contrast with Richard Löwenthal, who does not attempt to "save Marxism" by emphasizing the differences between Marx's writings and Real Socialism. Rather, Löwenthal addresses Marx's writings as a theoretical starting point that caused MarxismLeninism's landslide development toward a "totalitarian ideology."23

The academic debate over "totalitarianism" is a crucial one in the social sciences. As such, a comprehensive discussion of the topic simply exceeds the scope of this study. Thus, neither the history, nor the theoretical debate on "totalitarianism" will be discussed here; ${ }^{24}$ Rather, the argument contents itself with the referral to Löwenthal's enlightening insights on the transformation of Marx's writings through Lenin and the consequences that this transformation entailed. According to Löwenthal, it was Lenin's approach that transformed Marx's

\begin{abstract}
"abstract [...] myth of the inevitable victory of the proletariat that would bring about the classless society [into an] unconditional identification of the hope of secular salvation, not with the victory of a class, [...] but with the power of a specific organized group and its leader." 25
\end{abstract}

Despite the ideology's explicit secularism, Löwenthal considers Marxism-Leninism a political religion, as it "promise[s] salvation on earth," and "the millennial rule of the saints." What Löwenthal also touches here is the difference between Lenin's theory and political praxis. According to Lenin, "the end justifies the means" for the higher, quasi-transcendent goal of a better world. The ultimate goal of worldwide communism could only be reached by the realization of Lenin's version of a vanguard party under his leadership. Any opposition to this leadership was considered an obstacle to the ultimate goal, as Löwenthal lucidly comments: "An abstract paradise may justify crimes - but only a concrete Messiah can authorize and order them." In Real Socialism, it was the vanguard parties and their leaders who stepped forward to fill the role of this Messiah.

While Lenin relocated the driving force of revolutionary change from the whole of society to a Soviet-style vanguard party, ${ }^{26}$ his contemporary, Stalin, modified the idea of worldwide revolution and its role in achieving worldwide communism.

23 | This study cannot offer a full discussion of Totalitarianism. According to Löwenthal, one of the core elements of a totalitarian ideology and system is the: "institutional possibility of terror", in: Löwenthal, Die totalitäre Diktatur, in: Schmeitzner (Ed.), 2009, 552. The quotes of the following paragraph can all be found in Löwenthal, Die totalitäre Diktatur, in: Schmeitzner (Ed.), 2009.

24 | On the "Totalitarianism" debate in Germany: Süß, 1999, 16-27.

25 | Löwenthal, Messianism, Nihilism and the Future, in: Schmeitzner (Ed.), 2009, 462. For the following quotes in this paragraph also see: Löwenthal, in: Schmeitzner (Ed.), 2009, 462-464.

26 | Read, 2005, 66. 
Stalin's notion of "socialism in one country"27 considers the establishment of Socialist regimes in nation-states an intermediate step before worldwide socialism and communism can be achieved. The concept is considered a law-like principle, laying the foundations of "scientific socialism," 28 which "declares history an object of exact science." ${ }^{29}$ Stalin's argument follows a progressive logic of development with world communism being the inevitable outcome of history. This encompassed the necessity to "give back all functions of the state to society" 30 and thus included the inevitable withering away of the nation-state in the end, at least in theory. According to Löwenthal, Lenin had moved away from his own aspirations rather grotesquely and his successor "only carried Leninism to its logical conclusion," 31 just as one may interpret the German version of Marxism-Leninism a “logical conclusion” of Lenin's ideas and writings in combination with Soviet instructions to the SED regime.

\title{
1.3 The Two Conditional Determinants of the GDR's Political System: "Democratic Centralism" and the "Primacy of the Party"
}

\begin{abstract}
"Political power was exercised by two parallel bureaucracies in the Soviet Union, those of the state and the Communist Party. On paper, the party had a democratic structure, [...] [b]ut in reality, power flowed from top to bottom, not from bottom to top. The general secretary was the dominant figure in the system, and the political bureau, chaired by the general secretary, was the most important organ for policy formulation [...] The central committee had a full-time executive staff known as the "secretariat," which served as the executive arm of the politburo. [...]

[I]ndividual party members merely carried out the policies decided at the top." ${ }^{32}$
\end{abstract}

(Kotz and Weir on the Political Structure of the Soviet System)

According to Lenin, it was the elitist vanguard party that had to lead the revolution and transformation of society toward communism. From this notion, two mutually dependent principles emerged as the major determinants of the Soviet political system: "Democratic centralism"33 and the "primacy of the party." Though neither of the two principles was explicitly included in the first East

27 | Kapitel 6: Die Frage des Sozialismus in einem Lande, in: Stalin, 1946 (1924).

28 | German: Wissenschaftlicher Sozialismus. The concept is opposed to "critical-utopian socialism" of Saint-Simon and Fourier, in: Dilas-Rocherieux, Yolène, Sozialismus: Courtois (ed.), 2010, 688 .

29 | Dilas-Rocherieux, Yolène, Sozialismus, in: Courtois (ed.), 2010, 688.

30 | Schroeder, 2013, 520.

31 | Löwenthal, Die totalitäre Diktatur, in: Schmeitzner (Ed.), 2009.

32 | Kotz/Weir, 1997, $23 f$.

33 | The first Party Congress of the SED in January 1949, Avantgardeanspruch und innerparteiliche Ditatur Januar 1949, in: Judt, 1997, $46 f$.

34 | Schroeder, 1999, 421. 
German Constitution of 1949, they served as the political compass during the early years of East German "state- and nation-building" and later on grew into a specific German form.

"Germany is an indivisible, democratic Republic." ${ }^{35}$

(Article 1, Constitution of the GDR 1949)

Without doubt, the constitution and the constitutional reality of the GDR could not have been further apart. Officially, the Volkskammer was declared the "highest organ in the Republic." ${ }^{36}$ However, neither the Soviet occupiers nor the SED ever wanted Parliament to wield actual political power. All in all, with some minor exemptions, the East Germany political system followed the Soviet model:

\footnotetext{
"The organization of political institutions within the Soviet Union concentrated special powers of agency among a select group of decision-makers. In contrast to pluralist regimes, the Soviet political system did not allow for alternate centers of political power either within or outside the state." ${ }^{37}$
}

Just as in the Soviet Union, internal and external decision-making in East Germany was centralized in the party by what Jessen called the "secret constitution of the GDR." ${ }^{38}$ As a consequence, the political system did not include regulated control by the governed based on free elections, nor did it provide for any other control outside the SED party apparatus. In addition to that, loyalty of party cadres was secured by a tightly controlled cadre selection process. The political elite relied on its own structures and recruited personnel and functionaries independently from the rest of society. This apparatus was tightly intertwined with the state and its institutions, including party equivalents to state institutions at all levels. Within this system, the party was supposed to overrule any state actions and decisions. ${ }^{39}$ The "primacy of the party" 40 was the fundamental determinant of the political system, as Fürnberg's song so succinctly summarizes: "The Party is always right." ${ }^{\text {11 }}$ This notion also includes the universal truth claim of "the party," which

35 | Constitution of the GDR. October 7 1949, Art. 1.

36 | Constitution of the GDR. October 7 1949, Art. 51-70.

37 | McFaul, 2002, 34.

38 | German: heimliche Verfassung der DDR; Jessen, in: Judt, 1998, S.77f; Richtlinien über die Fertigstellung von Regierungsvorlagen zur Entscheidung durch die zuständigen Organe des Parteivorstands sowie über die Kontrolle der Durchführung dieser Entscheidungen, Anlage Nr. 5 zum Protokoll Nr.57 der Sitzung des Kleine Sekretariats [des Politbüros] am 17.0ktober 1949, in: SAMPO-BArch DY 30/J IV 2/3/57.

39 | The so-called "Kompetenzkompetenz", Schroeder, 1999, 388.

40 | Schroeder, 1999, 421.

41 | “Das Lied der Partei” by Louis Fürnberg, 1950. in: Judt, 1997, 47; See: Giordano, 1961. 
pertained to the provision and interpretation of ideological principles. ${ }^{42}$ This claim, originally introduced in the Party statute of the SED, ${ }^{43}$ was finally raised to constitutional rank in 1968 when the "leadership of the working class and its Marxist-Leninist party" 44 acquired priority over any other constitutional norm.

The idea of absolute party leadership was based on the principle of "democratic centralism." ${ }^{45}$ Schroder describes this principle of political organization as the "strict party hierarchy" wherein "lower levels were subordinated to higher levels of organization. [Thus] all fields were subject to the highest level of leadership." ${ }^{46}$ The official interpretation of socialist publications stresses that the principle was based on "collective leadership," the socialist interpretation of democratic participation. The consequences implied by this, however, were "absolute party discipline; minority's subjugation under the majority; unconditional commitment to the higher organ's decisions for the lower organs and their members." ${ }^{47}$ Hence, every political decision on any level, including questions of cadre selection, had to be approved by each higher authority, while every state entity had to answer to its administrative equivalent within the SED.

Apart from the praxis of personal unions among higher party posts and state functions, party and state were connected by two major state organs, the "Ministerrat" and the "Staatsrat," both pro forma elected by the "Volkskammer." While the former brought together the ministries, secretaries of state and highranking administrative officials, the latter was formed after Wilhelm Pieck's death as the "collective representation of the state." 48 Together they acted as the communicative and administrative interface between state and party.

The principle of "democratic centralism" also extended to the party apparatus. In theory, the highest organ within the party structures was the Party Congress, an assembly of all party members. In between Congresses, the Central Committee, ${ }^{49}$ a body of well-served and loyal Party members, was supposed to lead. In reality, however, the Party Congress acclaimed what had been decided by the CC, and later on by its smaller version, the "Politbüro." ${ }^{50}$ In the final decade, decisions were further concentrated within the Politbüro's Secretariat, the "small Politbüro.”

42 | Muth, 2001, 10.

43 | Stellung des Bereichs Kommerzielle Koordinierung im Partei- und Staatsgefüge der DDR, in: Deutscher Bundestag, 1994, 103.

44 | Article 47 II, Constitution of the GDR of 1974.

45 The first Party Congress of the SED in January 1949, Avantgardeanspruch und innerparteiliche Ditatur Januar 1949, in: Judt, 1997, $46 f$.

46 | Schroeder, 1999, 389.

47 | German: “Demokratischer Zentralismus“, in: KI. polit. Wörterbuch, 1973, 148-150.

48 | Diedrich/Ehlert/Wenzke (ed), 1998, 10.

49 | German: Zentral Kommittee (ZK).

50 | Schroeder, 1999, 398. 
"We don't demand negative proof of non-culpability [with regard to NationalSocialism], [or] neutrality, we demand positive proof of participation." 51 Thus, the Party was also organized hierarchically, with obedience and loyalty emerging as the most important merits of the party members. As a consequence, party loyalty became the prominent prerequisite for professional success. In these early years it became apparent that the political system marginalized the GDR's constitutional organs, including the government. ${ }^{52}$ This was accompanied by a power concentration in the hands of the SED, its leader, the secretary-general, and his secretariat. This was especially true for the field of foreign policy. In addition to that, the SED system of nomenclature cadre recruitment ensured loyalty and conformity to the political course of the party. ${ }^{53}$

\section{4 "Homogenization of Society" and the Creation of the "Socialist Human"}

The ultimate goal of social policies under both Soviet occupation and SED governance was the reconstruction of German society as a socialist, and thus homogenized, society. In the late 1940s, the Kremlin had launched intensive and comprehensive "Sovietization" in the Soviet Occupied Zone (SOZ, SBZ), a forced transformation of society as a whole. This also meant that "the Soviet Union did import certain key elements of the Soviet system into every nation occupied by the Red Army, from the very beginning. ${ }^{54}$ The narrow timeframe of implementation did not allow for voluntary or gradual adoption of the transported values ${ }^{55}$ and can be considered a first example in GDR history where social change became a matter of official declaration: "Social stratification changed profoundly during the existence of the GDR, while the ultimate goal of a classless society was never achieved." ${ }^{56}$ Political forces outside the SED were either channeled into a bloc party system or swallowed by newly founded mass organizations. ${ }^{57}$ Likewise, the Catholic and Protestant churches had been disempowered and marginalized early on as well. ${ }^{58}$

To eliminate any possibility of control by the governed and thus fully secure the "primacy of the party," the SED had to eliminate civil society and the agency

51 | Tagung der Oberbürgermeister, Landräte und leitender Mitarbeiter der Regierung, 2-4 April 1949, in: BArch, SAPMO, NY 4277/4, Blatt 147, Quoted in: Kowalczuck, 2013, 23. 52 | The organs of the President, the Council of Ministers and the State Council, which were founded in the 1960s, degenerated rapidly and ended up as mere executive institutions, in: Muth, 2001, 10.

53 | Schroeder, 1999, 407.

54 | Applebaum, 2013, Introduction.

55 | Schroeder, 2006, 86.

56 | Segert/Zierke, in: Judt 1998, 169.

57 | Schroeder, 1999, 101-104.

58 | Goerner/Kubina, 1995. 
of its actors. As a consequence the only other independent source of social power disappeared, allowing the party to monopolize any communication between the political system and society. To perfect regulation of the political system and its exchange with society, public opinion was deliberately steered by a partycontrolled media. Former editor-in-chief of the "Nachrichten des DDR Funks," the radio broadcasting organization of the GDR, summarizes:

\begin{abstract}
"Information policy was an important, at certain times the most important sinew of the leadership and apparatus of the SED. In short, the monopoly worked like this: There was reality, and there was truth about this reality communicated by the Party." 59
\end{abstract}

In the field of international relations, the East German public almost fully depended on party-directed information on happenings outside their state's borders. The intense control disrupted the connection between society and the rulers' politics and eliminated any basis for assessment of the SED's politics. In accordance with Lenin's notion of "socialist journalism," the media in the GDR was to impart ideology to the "masses" by supporting "collective propaganda" and "agitation." In the GDR, this was especially the case for international coverage, even more so after international recognition. While the primary goal of "Auslandsinformation" 61 before the 1970 s had been the promotion of recognition, ${ }^{62}$ its major task afterward was to disrupt and fend off Western ideological influences. ${ }^{63}$ Growing economic difficulties increased the need for reports of political success and distraction through state media. One of the most effective party instruments to form both the public space and the media, even was of constitutional rank: "Boycotting demagoguery" ${ }^{64}$ was introduced under Article 6 of the GDR's constitution of 1949 as a criminal offense. In its vagueness, this article opened the door for excessive punishment of any unwanted oppositional behavior. As a consequence of full media control and concentration of political and social forces in mass organizations, there neither existed free public space nor any civil society to speak of. The centralization of the economic system had

59 | Klein, in: Spielhagen, 1993, 84.

60 Lenin, in: Function of socialist journalism, Excerpt in: Wörterbuch der sozialistischen Journalistik, Berlin-Ost, 1984, in: Judt, 1998, 354f.

61 English: international information or propaganda. Until now there only exist very few studies on this tool of the GDR's foreign policy. Brünner, 2011, 14.

62 | Protokoll Nr.8/63 der Sitzung des Politbüros, March 27 1983, Annex 5, in: BArch SAPM0, DY 30/JIV 2/2 A 953, 1.

63 | Brünner, 2011, 29.

64 | "Boykotthetze", in: Article 6(2), Constitution of the GDR of 1949, October 71974. 
enforced the socialization of all larger companies. ${ }^{65}$ Thus, all social and nonstate organizations of economic importance were either embedded in or at least associated with the party in one way or the other. ${ }^{66}$

However, "homogenization of society" went beyond the public space. According to Marxist-Leninist ideology, the creation of the socialist society was only possible by creating the "new human." This "new human" first and foremost was defined as part of the "collective" and free of egoism. ${ }^{67}$ Accordingly, youth in the GDR always played a highly political role in the "planned development of socialism" to ensure the next generation's ideological loyalty and engagement. This goal was pursued by forming and "educating the socialist personality"68 early on in children's lives. The GDR's pedagogy drew extensively from Anton Semyonovich Makarenko's writings. Based on the idea of the mutability of human nature, Makarenko elaborated on the creation of the "new human" and the logic of "collective education." His pedagogical approach aimed at minimizing individualism for the sake of solidarity in the collective community. According to Makarenko, the ideal type of the "socialist human" had be reeducated through a "homogenized socialization process" to form the ideal of the "homo sovieticus" 69 in the end.

The SED's education policy fully embraced Makarenko's concept: Socialist education in the GDR meant that "the individual was transferred from one collective to the other throughout his life." ${ }^{\text {70 }}$ Applebaum quotes Otto Grothewohl in this context, calling the youngest children the "cleanest and best human material" for the GDR's Socialist future. About eighty per cent of East German infants and toddlers spent their days at the "Kinderkrippe" while ninety-five percent of children under six learned about socialist virtues in kindergarten. ${ }^{72}$ Furthermore, the obligatory forms of social organization were complemented by "facultative" organizations, such as the Freie Deutsche Jugend (FDJ) founded in 1946 and its preparatory organization, the Ernst-Thälmann Pioneers. ${ }^{73}$ Not surprisingly, these "facultative" organizations ostracized all those who refused to join and celebrated the "good socialists." Finally, the youth received vocational training in the "Betrieb,"

65 | On the requisition of some property categories in Germany, October 30th 1945, excerpt of military order by the Soviet Military Administration, in: Judt, 1998, 183.

66 | On the reorganization of political society and its actors see: Schroeder, 1999, 416 and $532 f$.

67 | Segert/Zierke, in: Judt (ed.), 1998, 171.

68 | Segert/Zierke, in: Judt (ed.), 1998, 177.

69 | Alexander Zinoview, quoted in: Applebaum, 2013, 300.

70 | Schroeder, 2013, 738.

71 | Otto Grotewohl in: Partei und Jugend: Dokumente marxistischer-leninistischer Jugendpolitik, East-Berlin, 1986, quoted in: Applebaum, 2013, 301.

72 | Numbers in Anweiler, 1989, in: Schroeder, 2013, 746.

73 | Segert/Zierke, in: Judt (ed.), 1998, 177. 
the socialized enterprises idealizing collective production. The idealized idea was that the "new human" was integrated in collective communities from the cradle to the grave. Even the social nucleus of the small family was included in this logic. The families were supposed to dissolve into other social collectives, mostly by reducing the time families spent together.

\subsection{Conclusion: A Substitute for Legitimacy? The GDR's Carrot-and- Stick-Policy}

After "Nazi Germany," many functionaries and the population alike at first had hoped for a "better Germany" in this young, socialist state. ${ }^{74}$ However, the harsh realities of the GDR were hard to reconcile with the high hopes of the early founding years: Economic hardships, suppression of opposition, political cleansings, and the forced "homogenization of society" quickly disillusioned early idealists. Elections were considered a mere formality without any effect on political conditions. After the national uprising of 1953 against SED rule was quelled violently by Soviet tanks, the number of refugees trying to flee westwards reached an all-time high. ${ }^{75}$ The GDR's citizens simply decided that there was no other way than a "walking ballot"76 to turn their backs on East Germany. The SED's reaction was to make "fleeing the Republic" a criminal offense. ${ }^{77}$ And even after the wall was built in Berlin and the inner-German border further fortified after 1961, thereby significantly reducing the numbers of registered refugees, the Ministry of State Security successively expanded their personnel and their operational activities. ${ }^{78}$ To prevent the GDR's citizens from leaving the country and starting their new lives as citizens of the Federal Republic, state control intensified in an unprecedented way. These repressive measures are one of the most impressive examples for the citizens' lack of identification with their state.

Over the decades, the SED-regime developed and applied two major strategies to counter its lack of legitimacy in the eyes of its citizenry. The first major strategy was the oppression of resistance and opposition. The intensity of this strategy

74 | See, for example, the memories of the GDR author Christa Wolf on the hopes for the creation of a "new society" after the defeat of German fascism, June 1987, in: Judt, 1998, 59 f.

75 | Compared to East-West migration, the numbers migrating from the FRG to the GDR were relatively low. Including the last year before the founding of the two German states, only about 600.000 people moved from West to East, in: Wunschik, 2013.

76 | German: Abstimmung mit den Füßen; Müller-Marein, 1961.

77 | After 1957 the attempt to leave the GDR without state permission, the "unlawful border-crossing" under $\S 213$ Abs. 2 StGB of the DDR, usually led to a prison sentence, Stöver, 2007, 237.

78 | From 1961 to 1968 the MfS personnel increased by more than fifty per cent, in: Schroeder, 1999, 436. 
decreased somewhat after the closing of the inner-German border and the erection of the Berlin Wall. Then the strategy transformed into a policy to create fear among the population by assumed or real surveillance carried out by a specialized security apparatus. The second major strategy was the appeasement of the population. Socialist welfare promises and grants fed into this strategy, as well as notions of the "socialist nation" that were intended to create a feeling of community and belonging. Just like sports and culture, foreign policy achievements served as an integrative factor to legitimize this nation and its policies to distract the population from its internal strife.

In conclusion, "foreign policy" in the GDR not only highly depended on the two major structuring determinants, the Soviet Union and the "other Germany," but also must be considered a too used to appease society and achieve internal national consolidation..$^{79}$ Being part of the political system, foreign policy served as a tool to secure the SED's position; it was a "maid of politics. ${ }^{80}$ Hence, one has to disagree with Lehmkuhl's conclusions about the restricting influence of national politics on the scope of action in foreign policy. She contends: "the more authoritarian the rule on the inside, the higher the 'autonomy' of the state from internal determinants on the outside." In theory, this would result in an extremely high level of autonomy for the GDR in the international system. However, even without including the restrictions posed by the international determinants, such autonomy never existed.

The combination of the principles of "democratic centralism" and the "primacy of the party" transformed the SED's retention of power into a moral and legal sine qua non for the GDR's survival as a socialist state. Hence, and in spite of the obvious separation and apparent independence of governors from the governed, there existed a profound flaw of insecurity in the power relationship that ostensibly was so fully dominated by the SED. Any questioning of the SED and its cadres had to be avoided at any cost. From the very beginning, the SED had to struggle with a lack of legitimacy - not only with respect to the FRG, but towards its own population as well. This assumption agrees with Gidden's "dialectic of control/ leadership." Giddens denies the existence of situations of absolute powerlessness, as long as one option to act remains: "[S]ubordinates and the ones subjugated to power regularly may claim a considerable scope of action, as the rulers depend on the cooperation of the ruled." ${ }^{81}$ In the GDR, the existence and thus the autonomy of the state did depend on the affirmative behavior of its citizens. Apart from fear and collaboration, the SED regime's power and thus the existence of the

79 | Ludz, 1971, in: Scholtyseck, 2003, 54. Even though many of his conclusions must be reviewed critically today, Peter Christian Ludz contributed to research on the GDR and its political and social realities in the 1970s in an extraordinary way.

80 | Scholtyseck, 2003, 53; Siebs, 1999, $19 \mathrm{ff}$.

81 | Joas, 2011, $416 f$. 
state itself depended on acquiescence, or at least apathy, of the population. As a consequence, this acquiescence was ensured by the population's awareness of Moscow's guarantee of existence for the SED regime. The crushing of the June uprising in 1953 made that clear in no uncertain terms.

\title{
2. Ideological Principles and Foreign Policy in "Socialist Germany"
}

\begin{abstract}
"International relations, like all politics, is also most vividly interpreted, as much as anything, through what people think and believe. [...] [H]erein lies the international importance, and impact of ideologies - sets of belief about how the past shapes the present, [...] how the world works, and, equally important, about how it should [sic!] work." 82
\end{abstract}

(Fred Halliday, 2005)

First, foreign policy in the GDR had been ideologically embroidered and geared toward the "planned development of socialism." Second, due to the GDR's role in the Cold War, East Berlin's foreign policy had to clearly position the GDR within the Bloc confrontation to secure its existence as the "German alternative." And third, any element of foreign policy had to be firmly based on the ideological principles of Marxism-Leninism. According to Lenin, Marxism-Leninism ${ }^{83}$ was based on three "inseparable elements:" ${ }^{44}$ Dialectic and historical materialism, the political economy of capitalism and socialism, and scientific socialism. According to Marx's approach of "historical materialism," ${ }^{85}$ socialism is considered the transitional phase between capitalism and communism. This approach was adopted by Lenin who then predicted that the socialist phase would follow the seizure of power by the proletariat. ${ }^{86}$

Lenin expected that not all countries would aspire to this ideal nor struggle to make it a reality. His successors in the Soviet Union thus concluded that the world would be divided into two camps until the ultimate goal of a communist world society was achieved: The camp of the "imperialistic-anti-democratic West" and the camp of the "anti-imperialistic-democratic East." ${ }^{87}$ At first, this camp division was

82 | Halliday, 2005, $195 f$.

83 | Official interpretations and recommendations with regard to Marxism-Leninism were centralized exclusively at the Institute for Marxism-Leninism at the central committee of the SED“ (German: “Institut für Marxismus-Leninismus bei Zentralkomitee der SED“). Sindermann, 1980.

84 | Schroeder, 2013, 716.

85 | Baudouin, Jean, Marxismus, in: Courtois, 2007, 568; Kowalczuck, 2013, 25.

86 | Dilas-Rocherieux, Yolène, Sozialismus, in: Courtois (ed.), 2010, 688.

87 | Zhdanov, Andrej, answering Stalin's and Truman's “declarations of war” on Sept 221947. 
interpreted as a violent struggle. The resolutions of the XX Party Congress of the Communist Party of the Soviet Union (CPSU) in 1956, however, modified this to the more pragmatic approach of "peaceful co-existence." It was meant to regulate the relations between socialist and capitalist states based on "mutual respect for each other's sovereignty, territorial integrity and non-intervention in internal affairs," but also included "a specific form of class struggle [...] on the international level" 88 that focused on economic and social development. Derived from this highly ideological view of the international system, the GDR developed its own interpretation of Marxist-Leninist principles as the basis of its foreign policy.

"Socialist Foreign Policy [rests] on the nature of class of a Socialist state, which is shaped by the character of the ruling working class and its revolutionary fighting party. The Communist and the working parties of the Socialist countries analyze every stage of development of international relations based on a fruitful application of the theory of Marxism-Leninism." 89

(“The Little Political Dictionary," East Berlin, 1973)

“The Little Political Dictionary," a widely read reference book in East Germany and today a priceless source of the GDR's ideological orientation on many topics of social life, lists the following "general laws" for the "development of socialist society." These "laws" are especially relevant for the field of foreign policy, as they form the basis of the socialist interpretation of international relations:

“[1] To erase national oppression and establish equality and brotherly friendship between the peoples; [2] to promote political and economic approximation of the countries of the community of Socialist states; [3] to uphold solidary of our working class with the working class in other countries."

The concept of "proletarian internationalism" ${ }^{91}$ was considered the most important principle of the GDR's foreign policy towards the Global South and was included in the GDR's constitution of 1968 under the term "socialist internationalism."92 The concept is based on Marx and Engels' idea of "internationalism" as introduced in the "Communist Manifesto": Capitalist nations have to rely on a working-class proletariat for their development. These proletarians "know no country," but share "common interests." 93 And due to capitalism diminishing the role of national

88 | Kleines Politisches Wörterbuch, 1973, 87.

89 | Außenpolitik (English: foreign policy), in: Kleines politisches Wörterbuch, 1973, 86f.

90 | Außenpolitik, in: Kleines politisches Wörterbuch, 1973, 86f.

91 | Sozialismus und Kommunismus (English: Socialism and Communism), in: Kleines politisches Wörterbuch, 1973, 761.

92 | Article 6 of the Constitution of the GDR of 1968.

93 | Marx, in: Gilbert, 1978. 
borders, proletarians all over the world would be able to connect and unify. As neoMarxist Alan Gilbert points out, there are no further specifications to be found in the "Communist Manifesto" on how this unification is to evolve, so he draws from other writings by Marx: ${ }^{94}$ The actual unifying force for the "international proletariat" is a common enemy threatening the very existence of the workers, thus generating a "want for solidarity." 95 To promote the spread of socialist societies, "internationalism" is supposed to forge an alliance "with the national liberation movement to support peoples and states fighting against colonialism and its aftermath." This support is summarized under the label of "international anti-imperialistic solidarity" 96 and includes any other "support of countries of the socialist world system who fell victim to imperialistic aggression."

The concepts of "international socialism" and "international anti-imperialistic solidarity" were integrated into the Soviet Union's strategy towards the countries of the Global South and copied by the GDR - though the GDR took them considerably more seriously than the other states of the Warsaw Pact: East Berlin was struggling for its survival and hoped to broaden its international maneuvering room under Moscow's wings. Ingrid Muth distinguishes between ideologically-inspired longterm strategies and goals and pragmatic mid- and short-term policies..$^{98} \mathrm{~A}$ former diplomatic functionary herself, her conclusions strongly resemble the conclusions of other former diplomatic personnel: Many of those who had been part of the GDR's state apparatus are still convinced of the ideological orientation of the GDR and share the opinion that its ideology merely failed due to its neglect of socialist ideals.

According to Muth, the elite first of all rigidly followed ideologically-defined long-term interests that led to severe discrepancies and even "mistakes" in the end. However, Muth's assessment has to be reviewed critically. Even though a significant number of functionaries and bureaucrats of lower rank in the diplomatic field were quite convinced of the truth and success of these ideological foreign policy concepts, ${ }^{99}$ actors higher up in the hierarchy followed a more realistic approach. Whenever ideological principles were contradicted by the rational reasoning of the state, the SED leadership would adjust ideology to political realities rather than the other way around. In conclusion, ideology very rarely was an actual limitation on the GDR's scope of action and it may and must be doubted that the SED's political

94 | Alan Gilbert refers to Marx's critique of German Social Democracy's Gotha Program, in: Gilbert, 1978, 348ff.

95 | Marx, Karl, Critique of German Social Democracy's Gotha Program, in: Gilbert, 1978, 349.

96 | German: antiimperialistische Solidarität.

97 | Außenpolitik, in: Kleines politisches Wörterbuch, 1973, 86f.

98 | Muth, 2001, 50.

99 | As the interviews with Wolfgang Bator, Heinz-Dieter Winter, Fritz Balke and Hans Bauer have shown. 
elites felt more obliged to this socialist idealism than to rational "raison d"état." Ideology merely remained the basis of foreign policy theory, a theory that had to yield to the demands of political praxis.

\section{Foreign Policy Actors, their Competencies and the Decision-Making Process: The "Three Spheres APPROACH"}

Foreign policy has been defined as an "interactive process," ${ }^{100}$ evolving over time due to influences both inside and outside of the state. Among the major internal factors of influence are the actors who develop foreign policy as a reaction to internal and external circumstances. Thus, the GDR's foreign policy making is described by situating the most relevant actors within the structures of the political system. With regard to responsibilities of foreign policy making, the former foreign policy personnel Muth identifies three hierarchical levels, equivalent to the overall structure of socialist society in the GDR: first, the "party apparatus," second, the "state apparatus," and finally, the homogenized "political actors of society." All in all, this is just another way to look at the concept of political power of MarxistLeninist vanguard parties known as "democratic centralism." Nonetheless, Muth's approach can further elucidate the discrepancy between the "written" political system and its political reality. In the following, Muth's approach is introduced and modified.

First of all, notional inconsistencies and weaknesses in Muth's approach have to be pinpointed. Muth introduces the term "foreign policy apparatus"101 for her threelevel approach. Unfortunately, she does not use the term consistently. Most of the time, the term in her work refers to all foreign policy actors, ${ }^{102}$ but Muth sometimes narrows down its meaning to the actors of level two and three to contrast them with level one, the party apparatus. ${ }^{103}$ To generate more conceptual coherency, this study opts to consistently use the term "foreign policy apparatus" for all actors - party, state or society - occupied with foreign policy in the GDR. This use of the term firstly emphasizes the close connection between the three levels and secondly accounts for a significant weakness of Muth's approach: The party level, though superordinate to levels two and three, always had to rely on the legwork of state and society actors. This undeniable dependency of the party apparatus - regardless of the party's overpowering dominance in foreign-policy-making and the overlapping of functions are not captured by the concept of hierarchical

$100 \mid$ Haftendorn, 1989, 33.

101 | Muth, 2001, 54f.

102 | For example Muth, 2001, 57.

103 | Muth, 2001, 249. 
levels. As a consequence, this study replaces the term "level" with "sphere," while the numeration indicates the actors' position in the process: The first sphere, the party apparatus, directs the second sphere, the state apparatus, and the third sphere, the homogenized political actors of society. The term "sphere" offers both meanings necessary for a convincing conceptualization of East German foreign policy making: It expresses the close connection between the three kinds of actors and the party's dependence on the unconditional loyalty of state and society actors.

\subsection{On the Director of Foreign Policy and Its Executive: Interweaving Power between the Spheres of Party and State}

\section{East German Foreign Policy and its Ministry}

Foreign policy defined as any state policy beyond the state's borders usually is conducted by designated state actors, typically a state's foreign ministry, its minister and the head of state. In the GDR's political system, however, the spheres of party and state were closely intertwined to ensure full control of the party over all political decisions and decision-making processes. This also applied to the field of foreign policy. Thus, the majority of analysts of East German foreign policy tend to describe the MfAA as a mere executive organ of Politbüro directives. Opposing this interpretation, former MfAA personnel Wolfgang Bator gives his personal perspective on the GDR's foreign policy making of the early 1960 s and thereafter. According to Bator, foreign policy directives usually were based on the work of the MfAA, processed by the Volkskammer and its commissions, and then decided by the Politbüro. This account of the process of GDR foreign policy making as primarily "bottom-up" and only secondarily "top-down" undeniably idealizes East German foreign-policy making. The political system's mode of operation first of all was based on "top-down" administrative processes. ${ }^{104}$ But to simply label the MfAA a mere executive organ oversimplifies the working procedures of the ministry and its interconnections with the corridors of power in the Politbüro.

All in all, both perspectives encourage the right questions about the foreign policy network and the distribution of responsibilities. While Bator's perspective may help to understand the self-perception of foreign policy personnel, a perspective farther removed from the individual actors reveals that the GDR's state apparatus first of all was tailored to suit the SED's needs. Just as in the Soviet Union, ${ }^{105}$ the ultimate decision-making responsibility lay with the party, regardless of the sources of information on the topic, and thus with its most powerful organ, the Politbüro, and later on the Secretary-General of the SED, Erich Honecker. Bator admits:

104 | Möller, 2004, 56f.

105 | Shearman, in: Shearman, 1995, 14; Malcom, in: Shearman, 1995, 23-26. 
"Ultimately, the Politbüro decided on the final version and this directive was binding for everybody. [...] And before this decision [was] made [...] not much happened." ${ }^{106}$

The MfAA was merely meant to be "handyman and advisor"107 to the SED's socialist foreign policy, just as any other state organ was supposed to serve the party policies.

Nonetheless, the field of foreign policy has to be considered a special case among the SED's policies: The external inputs and outputs of foreign policy in the end laid beyond the SED's - and even the Soviet Union's - sphere of control, especially after the international recognition of the GDR in the early 1970s. In addition to that, foreign policy making in the GDR depended on the influence of individuals. Thus, foreign policy making was more flexible than forms of policy-making. Furthermore, the MfAA's role in the process varied considerably over time and space due to the personalities of the respective minister, the head of section in the MfAA, and the ambassadors, as well as their relation with the secretary-general. Even though the MfAA clearly acted on behalf of the SED and its Politbüro, the ideal of full party control over the GDR's foreign policy could not always be achieved in practice.

By law, the MfAA was subordinate to the "Ministerrat" (Council of Ministers) ${ }^{108}$ and the parliament, the "Volkskammer." While the "Ministerrat" indeed instructed the MfAA as an executive organ implementing party decisions, ${ }^{109}$ the "Volkskammer" was irrelevant in the decision-making process. Article 112 of the GDR's constitution of 1949 leaves "the exclusive law-making responsibility with regard to foreign relations " ${ }^{\text {"110 }}$ to the "republic," meaning the state organs and, most prominently among them, the GDR's legislative body. However, constitutional reality never granted the "Volkskammer" any room for actual policy-making. "Democratic centralism" in principle declared the "Volkskammer" a mere organ of acclamation for the decisions of the party apparatus, the Central Committee and the Politbüro, ${ }^{111}$ while the "Ministerrat" served as an implementing organ for these decisions.

106 | "Important decisions always demanded for a Politbüro resolution," in: Interview with Wolfgang Bator May 272011 and Interview with Heinz-Dieter Winter July 32012.

107 | Storckmann, 2012, 137; Wentker, 2007, 382-387.

108 | Verordnung über das Statut des Ministeriums für Auswärtige Angelegenheiten vom 14.Dezember 1959, in: Gesetzblatt der DDR, Part I, No.18, March 23 1960, $160 f f$.

109 | Schaubild Partei und Staat, in: Schroeder, 2011, $38 \mathrm{f}$.

110 | Constitution of the GDR, 7th of October 1949. This formulation cannot be found in the version of 1968 anymore, but is expressed implicitly.

111 | This was secured by the SED's majority of votes within the parliament, Neubert, 2000, 880; Weidenfeld/Korte (ed.), 1999, 181. 
Personal relationships between ministers with high-ranking party positions, however, positioned the "Ministerrat" at an important juncture between party and state. From here, foreign policy tasks were delegated to the ministries. Until Honecker's "reform of leadership" in 1976, the central figure of this juncture was Willy Stoph, a member of the "inner circle" of power from the very beginning. Stoph, a former KPD intelligence agent, had become a member of the Politbüro in 1953 and served as Minister of Interior and Defense in the 1950s, until he succeeded Otto Grothewohl as Head of "Ministerrat" in $1964 \cdot{ }^{112}$ In 1976 , Stoph was finally sidelined when Honecker claimed the position as Head of "Ministerrat" for himself. Instead he was "promoted" to Head of "Staatsrat" and thus was banished to second-tier representation. ${ }^{113}$

In the early years of the GDR, the Soviet occupying forces established a "Commission for Foreign Affairs"114 in East Berlin and then the "Ministry for Foreign Affairs" only shortly thereafter. In comparison to the FRG, which was not able to resume work in its foreign office until March $1951,{ }^{115}$ this was an early move by the Kremlin toward granting supposedly more autonomy to the GDR in the international realm. Nonetheless, these early years of the MfAA were characterized by close guidance and supervision of the Soviet Control Commission (SCC) while foreign policy was made in the office of Secretary-General Walter Ulbricht. ${ }^{116}$ As a result, foreign policy personnel for a long time lacked the ability or will to act without concrete orders. ${ }^{117}$

\section{The Role of the Central Committee in the Process of Foreign Policy Making}

The GDR's foreign policy in the beginning was formulated among the members of the Central Committee as the "most important body for decision-making and coordination"118 and its "Abteilung Internationale Verbindungen des ZK," the "Section of International Relations" (CC Section IV). The section, headed by its

112 | Müller-Enbergs/Wielgohs/Hoffmann (Ed.), 2000, Stoph, Willy, 829f. Pieck's and Grothewohl's deaths in 1960 and 1964 profoundly changed the major foreign-policy constellation, the triumvirate of "Grothewohl - Pieck - Ulbricht," which had dominated the early years of East German foreign policy making.

113 | Schaubild Partei und Staat, in: Schroeder, 2011, 38.

114 | "Kommission für außenpolitische Fragen“, Scholtyseck, 2003, 6.

115 | Schöllgen, 2004, 29.

116 | Muth, 2001, 75 and Lemke, in: Pfeil, 2001, 71.

117 | First Foreign Minister Georg Dertinger decries the situation in 1951: "Due to habit, there prevails an understandable but fundamentally wrong attitude: the good friends of the SCC will straighten it out. If there is something to do, they'll tell you to! This is a fundamentally wrong attitude. [Now] [W]e have to rack our own brains!". Dertinger, stenographisches Protokoll der Tagung der Chefs der Missionen der DDR, 3.Tag, March 9 1951, in: PA AA, MfAA, A 15465.

118 | Meyer, 1991, in: Scholtyseck, 2003, 70. 
long-lasting Secretary Hermann Axen, claimed responsibility for foreign policy making ${ }^{119}$ though it mostly focused on countries where strong party ties already existed. ${ }^{120}$ Indeed, it was ZK Section IV, not the MfAA, that commissioned country analyses and policy papers. It also had the final say about suggestions from the embassies. ${ }^{121}$ After the death of its section head, Paul Markowski, the section's influence started to wane. ${ }^{122}$ Until their fatal accident in Libya, Paul Markowski ${ }^{123}$ and Werner Lamberz, ${ }^{124}$ were considered the central figures of foreign policy making in the Global South. According to Möller, it was the duo who took over the political aspects of agreements, while Alexander Schalck-Golodkowsi of the Ministry of Foreign Trade was responsible for the economic. ${ }^{125}$ After Markowski's and Lamberz' death, Schlack-Golodkowski began to fill the emerging power vacuum on the economic side, while Honecker did so on the political side. The secretary-general's interest in the field was clearly growing. None of Markowski's successors as Head of CC Section IV were able to reclaim his power and influence. ${ }^{126}$

Apart from the MfAA, other state organs claimed significant responsibilities in the field of foreign relations early on: The Ministry of Foreign Trade ${ }^{127}$ and InnerGerman Trade, the Ministry of Culture, and even the Ministry of Education. The ministries were under the authority of different sections of the CC, leading to an unexpected side effect of the system of "democratic centralism": Efficient policy communication between the ministries and the SED leadership, and in turn a ministry's impact on policy-making, depended on whether the CC secretary responsible for the ministry or section occupied with foreign policy was a member of the Politbüro, the "inner circle" of power. ${ }^{128}$ The same applies for the "rule that each Secretary of the Politbüro was responsible for [one or several countries of focus]." ${ }^{129}$ In addition, the fragmentation of responsibilities among the state

119 | BStU MfS HA II 28713, 263.

120 | Interview with Heinz-Dieter Winter on July 32012.

121 | Einschätzung der Ergebnisse der bisherigen DDR-Regierungsberatertätigkeit mit Schlußfolgerungen für das weitere Vorgehen auf diesem Gebiet in der VDRJ, June 27 1972, in: PA AA MfAA C 156276.

122 | Paul Markowski, Müller-Enbergs/Wielgohs/Hoffman (Ed.), 2001, $553 \mathrm{f}$.

123 | Ibid., 553f.

124 | Lamberz had been a member of the Politbüro since 1971, in: Scharfenberg, 2012, 59.

125 | Möller, 2004, 326.

126 | Egon Winkelmann succeeded Markowski, who was followed by Günter Sieber in 1981. Winkelmann kept the post until 1989.

127 | German: Ministerium für Außenhandel (MAH). The Ministry was responsible for "planning, implementation, and control of the entire foreign trade," including the preparation and completion of bi- and multilateral agreements, in: Möller, 2004, 59.

128 | Muth, 2001, 56, 61 and 63.

129 | Scharfenberg, 2012, 52. 
organs naturally led to unhealthy competition for attention of the "inner circle" of the CC and the Politbüro. ${ }^{130}$

\section{Civil Society Actors without Civil Society?}

“There existed no organizations 'on the side,' like, for example, NGOs."131

(Wolfgang Bator, former East German diplomat)

In the GDR, the majority of state and society actors in the field of foreign policy, ${ }^{132}$ such as the Ministry for Foreign Affairs, the Agency of Service for Representation Abroad, ${ }^{133}$ the League of the United Nations, ${ }^{134}$ and the Committee of Solidarity, were subordinate to the CC International Relations Section. The "Foreign Information" Section oversaw the League of International Friendship, ${ }^{135}$ as well as any media activities outside the $\mathrm{GDR}^{136}$ or media reports on foreign affairs for the GDR public, including the major publishing house. The described dominance of the party over the state's foreign policy actors becomes more tangible with the following example of publication policy: In preparation for Honecker's official visit to Ethiopia and South Yemen in 1979, the party tightly controlled the number of texts written, and features produced:

"The media in the GDR will receive orientation about amplified coverage about both countries and the bilateral relations in preparation of the visits and for the journalistic work about the visits themselves by the Section Agitation. [...] For the purpose of their support, the media will receive written materials [...]."137

130 | Muth, 2001, 73; Storckmann, 2012, 78; Wentker, 2007, 53.

131 | Interview with Wolfgang Bator May 272011.

132 | Organization refers to Muth's work based on Wagner, Matthias, Ab morgen bist du Direktor. Das System der Nomenklaturkader in der DDR, Berlin, 1998, 138-210, in: Muth, 2001, Annex VI "Overview subordination of state and society institutions of the foreign policy apparatus to the Party apparatus,“ $249 \mathrm{f}$.

133 | German: Dienstleitungsamt für Auslandsvertretungen der DDR.

134 | Founded in 1954.

135 | German: Liga der Völkerfreundschaft.

136 | Like Radio Berlin International, the foreign affairs agency PANORAMA and the publication house "Zeit im Bild," which published material on the GDR used abroad, and finally DEWAG (Deutsche Werbe- und Anzeigegesellschaft; English: German Society of Promotion and Advertisement), which coordinated promotion and organization of trade shows and exhibitions.

137 | Brief Oskar Fischer an Joachim Herrmann, Mitglied des Politbüros und Sekretär des ZK der SED, 1979, in: PA AA MfAA C 4959, 23. 
Thus, no actor, not even the MfAA itself nor its embassies, had the authority to decide on materials to be distributed abroad. The decision on publications, and more often than not their content as well, lay with the "Foreign Information" Section. ${ }^{138}$

Nonetheless, mass organizations and other society actors such as the "Societies of Friendship" played a significant role abroad, especially before the "wave of recognition" in the 1970s. They not only have to be considered the predecessors of, but for quite some time even the GDR's substitute for official diplomatic state relations. Of course, the party leadership did everything to secure control over these makeshift actors of foreign policy as well. While the work of these societies and mass organizations in the respective countries was coordinated and controlled by the embassies, ${ }^{139}$ the SED created a central organ to control their work within the GDR. Founded in 1952, the "Society for Cultural Relations" was supposed to coordinate all these societies, each of which had to work closely with the state and thus the party organs. ${ }^{140}$ Until the late 1950 , these societies were open for engagement from the public sphere, but then the members were added in accordance to a quota as defined by the SED. The Society's work in the GDR and abroad, including publications, was of course financed by the state. In 1961 it was succeeded by the "League for International Friendship," which immediately focused on the formation of "committees of recognition." 141 Hence, these societies played a significant role in East-Berlin's foreign policy for the next decade until the GDR was finally recognized internationally and able to establish "regular diplomatic relations" with a majority of states itself. As a consequence, the relevance of the "Societies of Friendship" and its equivalents decreased, as did the importance of the "Foreign Information" Section.

\section{The Centralization of Responsibility in the Field of Foreign Policy}

As in other policy fields, responsibility for the field of foreign policy was over time withdrawn from constitutional state organs. The influence of the party was growing, mostly at the expense of the MfAA's responsibilities. This process was clearly in the interest of the members of the Politbüro ${ }^{142}$ and can be reconstructed by looking at the succession of personnel at the top of the Ministry for Foreign

138 | Muth, 2001, 67.

139 | Interview with Wolfgang Bator May 272011.

140 | Muth, 2001, 89.

141 | Muth, 2001, 93f.

142 | Compare the loss of the MfAA's responsibilities from 1959 to 1970 , which is even documented in the official Statutes of the MfAA, "Verordnung über das Statut des MfAA" of December 141959 and of February 18 1970; See also: The Department of the Head Deputy of the International Relations Section at the Central Committee of the SED, Training of Party Secretaries of diplomatic representations from August 11 to 18 1967, in: BArch, SAPMO, DY 30/IV A 2/20/1141, quoted in: Muth, 2001, 56. 
Affairs. Until the mid-196os, the most influential post in the MfAA was not the minister, but the state secretary. The reason for this was that the first two ministers were both members of bourgeois bloc parties that had been selected to appease the "integrated" political actors. From the very beginning, the post of state secretary was occupied by a loyal party member. ${ }^{143}$ The secretary's role changed in 1965 when Otto Winzer became minister. At least in the field of foreign policy, the centralization process of political responsibilities and decision-making was quite complete.

Winzer died in 1975 and was succeeded by Oskar Fischer, the second and last SED foreign minister. ${ }^{144}$ Fischer showed more initiative than his predecessor and aimed to regain certain responsibilities for the MfAA by tightly integrating the ministry into the party structure. In Fischer's view, the ministry was supposed to work like a section of the Central Committee ${ }^{145}$ and thus he aimed to centralize it even further. Fischer, the former leader of the youth organization "Freie Demokratische Jugend" (FDJ), "obviously had been trained within the MfAA to be qualified for his future position as minister."146 In his analysis, Möller even considers Fischer's appointment a consequence of Honecker's inauguration. Heinz-Dieter Winter, a high-ranking East German diplomat and GDR viceminister of foreign affairs from 1986 to 1990 , remembers the close relationship between Honecker and Fischer, who used this contact to skip the regular processes of decision-making: "Sometimes even Axen was excluded." Winter considers it likely that there existed a range of issues in foreign affairs that no MfAA personnel other than the Minister knew about, such as certain weapons exports. ${ }^{147}$ All in all, Fischer's style of leadership furthered the integration of the MfAA in the "primacy of the party" system instead of expanding its scope of action.

Both the ministry and its minister remained more reactive than proactive with regard to foreign policy making, their domain more a supportive than a directive one. This arangement is also due to the fact that Honecker aimed to concentrate all foreign policy authority in his own hands. As a consequence, the development of this Honecker-centred foreign policy often reduced the highly-centralized political system to absurdity. Honecker's final authority in all matters of the international,

143 | Wentker, 2007, 44.

144 | During the last months of the GDR's existence, Markus Meckel took over the MfAA in Lothar de Maizière's cabinet before de Maizière himself became foreign minister. Scholtyseck, 2003, 51.

145 | Muth, 2001, 71.

146 | Grunert, 1995, in: Möller, 2004, 57; After he had taken office, Honecker had rewarded his "fellow conspirators" by including them in the Politbüro, along with a high number of Honecker's loyal followers and comrades from the FDJ, among them Egon Krenz and the new minister of foreign affairs, in: Hertle/Stephan(ed.), 2012 (1997), 29.

147 | Interview with Heinz-Dieter Winter July 32012. 
for example, sometimes allowed ambassadors to cut through red tape and address the secretary-general directly instead of consulting the MfAA first:

"When we were lucky, we [the MfAA] received a copy. We had our opinion on the ambassador's suggestions. But this opinion was of no more importance. Honecker had decided as he saw fit." ${ }^{148}$

Storckmann even claims that "Erich Honecker already had been pulling all the strings of security policy during [the late years of] Ulbricht's reign." ${ }^{149}$ According to Storckmann, the ministries of Defense, Interior and State Security had reported to Honecker, not Ulbricht. ${ }^{150}$ There is no shortage of indications that this early power shift toward Honecker began well before Ulbricht's departure.

Thus, the centralization process in the field of foreign policy did not stop at the party level but rather expanded into the party apparatus itself. Over time, the ZK of the SED lost authority to the smaller, elitist circle of the Politbüro, while the government ministries only could claim some influence if the minister was also a member of this party organ. In addition, the gradual shift of power toward the secretary-general accelerated after Honecker's inauguration. Wilhelm Pieck's and Otto Grothewohl's deaths in 1960 and 1964 , respectively, had ended the major foreign policy power constellation of "Grothewohl - Pieck - Ulbricht." And while Ulbricht had always held on tightly to the strings of foreign policy direction, he nonetheless had been aware that "his rule depended not only on Soviet support, but also on the loyalty of the leading party institutions and its apparatus. ${ }^{\text {“151 Honecker, }}$ on the other hand, gradually extended his sphere of influence into the parallel system of party and state. From there, he created a separate apparatus of decisionmaking comprised of loyal henchmen. In 1976, Honecker took over the position as head of the Staatsrat as well, the organ of international representation, deciding on matters of national defense. ${ }^{152}$ Current academic discourse considers Honecker as the major director of East German foreign policy from the early 1980 os on. ${ }^{153}$

Nonetheless, these assessments remain generalizations about a policy field that has to be considered the most complex, with regard to responsibilities and influence, in the GDR's short history. Oftentimes, the position of the secretarygeneral of the SED has been likened to the leader of the CPSU, omnipotent and omniscient. And indeed the decision-making processes in the GDR shifted the

148 | Ibid.

149 | Storckmann, 2012, $71 f$.

150 | Storckmann mainly refers to interviews with former NVA personnel, but also presents several examples to support his claim. Storckmann, 2012, 73f.

151 | Wentker, 2007, 371. Also see Storckmann on Honecker's "collective style of leadership," in: Storckmann, 2012, 71.

152 | Diedrich /Ehlert/Wenzke, Rüdiger (ed), 1998, 10.

153 | Scholtyseck 2003, 70; Siebs, 1999, 61-63; Storckmann, 2012, 70; Wentker, 2007, 372. 
position of the secretary-general, if it had ever been, far away from a "primus inter pares." ${ }^{154}$ Nonetheless, to simply conclude that Honecker had "nearly unlimited"155 influence does not do justice to the complex reality of the GDR's day-to-day politics. ${ }^{156}$ One must recognize the existing limits of human capacity, not only due to Moscow's watchful eye, but also to an inherent competition between the various organs included in the process of foreign-policy making. Honecker's ubiquitous signature of "Einverstanden E.H." or "Einverstanden Erich Honecker"157 may not simply be considered automatic proof of the secretary-general's omniscience, as the signature does not automatically mean Honecker had the time or interest to read all of the document in question. Even though one may assume that the majority of functionaries acted in anticipatory obedience, ${ }^{158}$ this clearly does not exclude other actors reaching beyond or even working against Honecker's ideas of foreign policy.

\section{The "Inner Circle" of Power and the Role of the "Ministries in Arms" in Foreign Policy Making}

Despite the increased concentration of foreign policy decision-making in the hands of the secretary-general, the "inner circle" of policy-making included both the party and the state level throughout the GDR's history. According to Wentker, the formal processes of decision-making in the higher state and party organs assured the consent of the central functionaries and thus their loyalty, which was indispensable for the regime's survival. ${ }^{159}$ This "inner circle" regularly included the leading figures of the security apparatus. An indication as to who was in this "inner circle" can be found in the context of who was present when high-ranking military and political officials visited from allied countries. During South Yemeni Minister of Defense Muti'a's visit in May 1972, he met with not only Walter Ulbricht, Willy Stoph, and his deputy Weiß, but also Minister of Defense Heinz Hoffmann, Minister of Interior Colonel-General Dickel, and Minister of State Security Erich Mielke. ${ }^{160}$ Apart from Weiß all of them dealt with issues of security and the "ministries in arms."

While the "soft" ministries, such as the Ministry of Culture or the Ministry of Education, were subordinate to a section of the CC, the "ministries of power" or "ministries in arms" regularly moved beyond this system of control. "The ministries of power" - the Ministry of Defense, the Ministry of Interior, and the

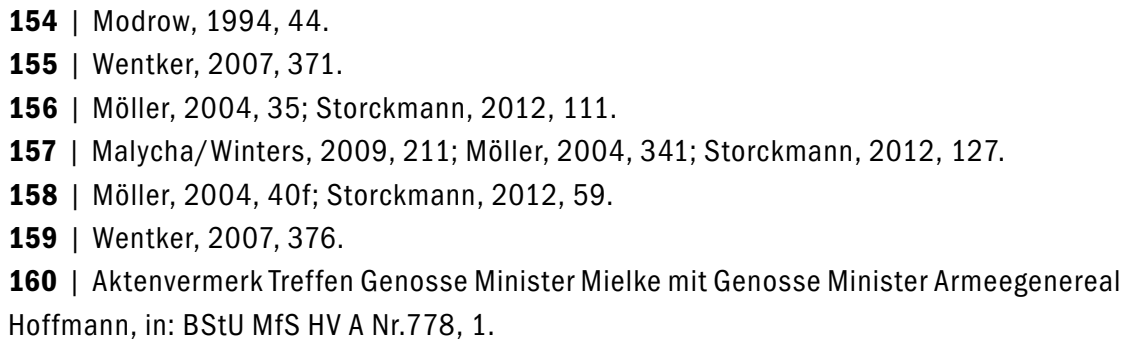


Ministry of State Security (MfS) - were all linked directly to the Politbüro and this "inner circle" of power clustered around the secretary-general. This arrangement intensified after Ulbricht was succeeded by Honecker, as he had been working closely with the MfS and its Minister Mielke during the 1960 s. But when he became secretary-general, Honecker finally was able to initiate, formulate, and implement international policies of the security apparatus himself. ${ }^{161}$ The three ministries listed above were in constant exchange with their Soviet overseers, though the development of this subordinated relationship developed differently for each of the three ministries. While the MfS and the Ministry of Interior successfully emancipated their day-to-day business from Soviet supervision in the late 1960 , the Ministry of Defense never was able to claim a comparable autonomy. The Ministry of Defense de jure led the Nationale Volksarmee (NVA), but de facto all relevant decisions were made by the Politbüro, which received its orders concerning the military from Moscow. Nonetheless, longtime Minister Heinz Hoffmann was well-established within the GDR system. Thus, he was able to realize at least some of his policies based on his personal position. ${ }^{162}$ However, the NVA and its ministry were far more integrated into the hierarchy of the Warsaw Pact and thus into the Soviet sphere of control than any other ministry. The NVA's policy in the developing world is an excellent example for the character of the relationship between the Ministry of Defense and the Soviet-led Warsaw Pact: In early 1972, Minister of Defense Heinz Hoffmann asked for permission to answer requests by states of the developing world to support their military training. In July 1972 this request was granted ${ }^{163}$ and the GDR began to expand its military engagement. In conclusion, the activities of the NVA abroad in general and the Near and Middle East in particular contribute to an analysis of the wider Soviet strategy rather than to one of the GDR's foreign policy, motives, and goals. However, military issues as a focal point of collaboration cannot be ignored when analyzing East German engagement in the Global South.

\section{The Reciprocal Relationship between Leading Figures in East German Foreign Policy Making and Their Institutions}

As indicated above, some individuals were able to move beyond both the centralized structures of foreign policy making and the strict party-state parallelism. The reasons for exemptions like these usually can be found in a combination of personalities and connections to the "inner circle," but sometimes also in the responsibilities of the organ or institution itself. Oftentimes, this included

161 | Möller, 2004, 37.

162 | Before Hoffmann took office as minister of defense in 1958 he had served within the HV A of the MfS, as head of the Kasernierte Volkspolizei (KVP), the GDR's police and as vice-minister of interior, East Germany's police, in: Diedrich/Ehlert/Wenzke (ed), 1998, 261, 267, 356, and 644.

163 | Engelhardt, 1993, in: Möller, 2004, 30. 
personal unions of a high-ranking state post and a seat in the ZK or even the Politbüro. This was a popular method to assure the functioning of "democratic centralism" in the sense of party-state parallelism. The following subsection introduces three major figures in East German foreign policy making who moved somewhat outside the regular hierarchy of authority, but have to be considered highly influential: Hermann Axen, Gerhard Weiß, and Günther Mittag.

Axen, oftentimes considered the "architect of the GDR's foreign policy,"164 was the secretary of the CC responsible for Section IV starting in 1966. He remained a central figure in the field of East German foreign policy until he was forced to leave his post during the Peaceful Revolution of 1989. In 1979 he became head of CC "International Information" Section ${ }^{165}$ With regard to final decisionmaking, Axen's political power was quite limited ${ }^{166}$ and only was included in the "inner circle" of actual policy-makers when the powerful wished so. However, Axen's impact on East German foreign policy making as a close confidant of Ulbricht may not be underestimated: One of the major tasks of his Section IV was to coordinate relations with the communist parties of the Eastern Bloc and thus with the CPSU. ${ }^{167}$ Accordingly, Axen always was well informed about the current state of affairs between East Berlin and Moscow. Also, the theoretical analysis and policy papers produced by Axen rooted Honecker's foreign policy in socialist ideology. Axen had been close to Ulbricht and joined the Politbüro in 1970 where "international relations" became his field of expertise, but was able to hold onto most of his competencies under Honecker as well. Most importantly for this analysis, Axen became member of the Koko late in his career in 1981 and remained, more or less, a major consultant on the Middle East for Honecker until the late 1980 s. $^{168}$

In the field of foreign policy, one example for a mere coordinator working wellbeyond his position is Gerhard Weiß. He had been vice-chairman of the Ministerrat from 1965 to his death in 1986 and advanced as a member of the Foreign Policy Commission of the CC in 1971. ${ }^{169}$ From 1958 to 1970, he was Vice-President of the "German Arab Society" 170 and acted as a coordinator for military exports and "non-

164 | Müller-Enbergs/Wielgohs/Hoffman (Ed.), 2001; Axen, Hermann, 34.

165 | German: Abteilung Auslandsinformation. This section was the successor of the Section Agitation which at first had been part of the Section International Relations. in: Muth, 2001, 65; In the late 1980s Axen even was Head of the ZK Section of International Economy, in: Modrow, 1994, 34.

166 | Storckman, 2012, 78ff.

167 | Möller, 2004, 38.

168 | On the demise of Axen's position see: Uschner, Manfred, in: Storckmann, 2012, 79.

169 | Müller-Enbergs/Wielgohs/Hoffmann (Ed.), 2000, Weiß, Gerhard, 901.

170 | On the GDR's Societies of Friendship (Freundschaftsgesellschaften), see: Golz, 2003. 
civilian solidarity support" in the 1960 s and 1970 s. ${ }^{111}$ From 1969 onward, Weiß had a working group at his disposal, formed by high representatives of the MfAA, MfNV and MAW: ${ }^{172}$ Wolfgang Kiesewetter, from $1963-1971$ a vice-minister of the MfAA, ${ }^{173}$ Werner Fleißner, from 1964 to 1985 a vice-minister of the MfNV ${ }^{174}$ and MAW Secretary of State Hans Albrecht. ${ }^{175}$ Between 1965 and 1977, foreign policy procedures regularly included a proposal for support by the minister of foreign affairs or his deputy to Stoph, his deputy Weiß, Minister of Foreign Trade Horst Sölle, and the Chair of the Planning Commission Gerhard Schürer. Confirmation clearly depended on Weiß. An example for this process are the letters on the establishment of a Generalconsulat in Aden in August $1968 .{ }^{176}$ However, under Honecker, Weiß was "eliminated" from the coordination process in 1977 and in the course of political centralization, his former responsibilities were moved to the MfNV. ${ }^{177}$

Based on the power shift towards the position of secretary-general under Honecker, another important figure in the realm of the GDR's foreign policy was on the rise: The "No. 2" in foreign affairs in the 1980s, Günter Mittag. For Storckmann, Mittag is one of the most prominent examples of an individual actor who extended his sphere of influence considerably beyond his nominal function. ${ }^{178}$ Positioned at the interface between foreign policy, foreign economy, and secret service, Mittag found himself at the interface of foreign policy power in the GDR. In the late 1970s, Mittag took over the presidency of two foreign policy commissions, the AG "BRD-Westberlin" and, more importantly for the Middle East, the "Commission for Coordination of Non-civil Activities in the Countries of Asia, Africa, and the Arab world. ${ }^{179}$ The commission was meant to coordinate all contacts and activities concerning the "developing countries" in Africa and Asia. Later on it was simply called "Mittag Commission,"180 an undeniable indicator for Mittag's role. The commission was closely connected with the "Kommerzielle Koordinierung" (Koko), a special unit with the explicit task of acquiring foreign currency for the internationally weak economy of the SED regime.

171 | Storckmann, 2012, $121 \mathrm{ff}$.

172 | BArch, DC 20/16653, Also see: Storckmann, 2012, 125.

173 | Müller-Enbergs/Wielgohs/Hoffmann (Ed.), 2000, Kiesewetter, Wolfgang, 423.

174 | Ibid., Fleißner, Werner, 215.

175 | Ibid., Albrecht, Hans, 19.

176 | Briefe Winzer an Stoph, Weiß, Sölle, Schürer, August 1968, in: PA AA MfAA C 1219/71.

177 | Storckmann, 2012, 127.

178 | Storckmann, 2012, 89; Wentker, 2007, 378.

179 | Translation of name shortened by author. German: "Kommission zur Koordinierung der ökonomischen, kulturellen, wissenschaftlich-technischen Beziehungen und der Tätigkeit im nichtzivilen Bereich der Länder Asiens, Afrikas und des arabischen Raumes“, Protokoll Politbüro Nr.49/77, 12 December 1977, Annex 13, BI. 156, in: SAPMO BArch, DY30 J IV 2/2 1705.

180 | See, for example, Möller, 2004, 40. 
Mittag's role with regard to Koko is more evidence of his special position within the foreign policy making process. Founded in 1966, the Koko's task was to “acquire forex 'outside the plan' [through arms trade or trafficking], as well as products banned by Western embargo." ${ }^{181}$ The Koko is regularly mentioned in context of military relations and exports, its major function being exchange transactions to increase foreign currency reserves. ${ }^{182}$ It relied on several dummy companies, like the IMES (Internationale Messtechnik) $\mathrm{GmbH}$ founded in 1981 or the "Ingenieur-Technischer Außenhandel” (ITA). On behalf of but officially without knowledge of the SED, these dummy companies struck the deals in the field of military trade with political friends and enemies alike, including terrorist groups. ${ }^{183}$ The decision-making process and responsibilities of the Koko were quite complex: While Honecker himself was responsible for inner-German affairs, Erich Mielke decided on security issues, and Mittag on questions related to the economy. ${ }^{184}$ Furthermore, and despite its official affiliation with the Ministry of Foreign Trade, the Koko was directly subordinate to the Secretariat of the CC and Mittag. Under Schalck-Golodkowski's leadership, the unit itself acquired functions and responsibilities similar to those of a section of the CC. ${ }^{185}$ The working processes related to the Koko had to be connected to and coordinated with the party. At first this was mostly achieved by Mittag himself, later on also by Schalck-Golodkowski. The Koko's mode of operation was deeply entrenched with the work processes of the MfS and especially the HVA, at times even observed and directed by the MfS, again highlighting its importance and the level of secrecy applied to it. ${ }^{186}$ All in all, the Koko is an excellent example for the SED-leadership's tendency to obscure certain foreign policy decisions by creating additional organs not only beyond the state but also beyond the party apparatus. The case of Koko furthermore illustrates how the GDR's foreign policy over time more or less was used as a tool of East Germany's security, military, and economic policies. Just like any other policy field, foreign policy was subordinate to pragmatic goals when deemed necessary by the "inner circle."

181 | Gieseke, in: Kaminski/Persak/Gieseke, 2009, 236.

182 | Möller, 2004, 61.

183 | Aktivitäten von Unternehmen des Bereiches KoKo zur Devisenerwirtschaftung, in: Dt. BT (ed.), 1994, 170-250; On arms tarde with Iraq-Iran and terrorist groups in particular see: ibid., 191ff and 204; The Koko was actve until the very last year of the GDR, 1989-90. Bericht über die ADR nach Nord- und Südjemen, Arbeitsgruppe BKK, January 30 1989, in: BStU MfS BKK Nr.95 Teil 1 von 2, 30-36; Storckmann, 2012, 90.

184 | Buthmann, 2004, 5.

185 | Deutscher Bundestag (ed.), 1994, 103.

186 | In 1983 the independent working group "Bereich Kommerzielle Koordinierung (AG $B K K$ )" took over the surveillance and guidance of the Koko from the HA XVIII/7.BefehI Nr.14/83 des Ministers für Staatssicherheit, September 1 1983, in: Dt. BT (ed.), 1994, 107 and 115. Buthmann, 2004, 5; Gieseke, in: Kaminski/Persak/Gieseke, 2009, 236f; Möller, 2004, 61. 


\subsection{The Foggy Fringes of the Political System: The Ministry of State Security and the HVA in the International Sphere}

In the parallel structures of party-state hierarchy, the MfS clearly occupied a special position and ranked at the highest level of decision-making. ${ }^{187}$ However, the MfS never operated outside the structure of the GDR's political system and "democratic centralism," and always remained subordinate to the party. The following section introduces the structure and responsibilities of the Ministry of State Security to offer information on responsibilities and changes in structure and personnel. This extensive approach allows to both evaluate and understand the comprehensive archival material of the MfS as well as to interpret the MfS' role in the GDR's foreign policy in South Yemen.

\section{Between Secret Service and Secret Police: The Origins and Functions of the Stasi}

"The major function of the MfS [or Stasi] is [...] to guarantee state security of the GDR against attacks by all internal and external enemies [of the state]." ${ }^{188}$

(Dictionary of State Security, 1985)

The Stasi relied on two major principles that had been significant elements of the Soviet secret police as a "new type" of service: The "enemy" of one's state was not first of all defined by competition for resources or power, but based on ideological bogeymen. In doing so, the distinction between internal and external enemies ${ }^{189}$ gradually vanished and "preventive" action could be justified even before actual crimes under GDR law had been committed. ${ }^{190}$ Thus, the Stasi was both a secret police and a secret service, ${ }^{191}$ not only spying on "external" but also "internal" enemies. Of these, the ministry found plenty among its own citizens, not only because of real opposition against the SED regime, but also because of the ministry's self-perception: Kowalczuk considers the early Stasi personnel a paranoid group "surrounded by overactive enemies." ${ }^{192}$

When in 1950 the Department of Defense of the Political Economy ${ }^{193}$ was extracted from the Ministry of Interior and reformed as an independent ministry, this step neither draw much attention by the public, nor drew international recognition as

187 | Schaubild Partei und Staat, in: Schroeder, 2011, 38.

188 | Das Wörterbuch der Staatsicherheit, 2001, 164.

189 | Kowalczuk, 2013, $27 \mathrm{f}$.

190 | Schroeder, 1999, 437.

191 | Engelmann (et al.), 2011, 11; Kowalczuk, 2013, 13 and 249.

192 | Kowalczuk, 2013, 24.

193 | German: "Hauptverwaltung zum Schutze der Volkswirtschaft." 
a significant change of the political system. ${ }^{194}$ However, the new Ministry of State Security ${ }^{195}$ (MfS) was meant to play a significant role in the establishment and maintenance of the SED dictatorship. The super-ministry cast a conspiratorial net to gather any information, regardless of importance or political relevance. Furthermore, the MfS incrementally extended its responsibilities within the system.

The notorious Stasi did not settle for mere observation of "hostile-negative forces" 196 from within. Rather, it aimed to subvert and destroy these "forces," that is, groups and individuals, through conspiratorial operations. ${ }^{197}$ The activities of the Ministry included recruiting, bribing, or threatening friends and family of the suspect, known in Stasi jargon as the "target." Violence and murder - even though not common practices - were part of the ministry's aresenal. ${ }^{198}$ After all, its political mandate as "shield and sword of the party"199 granted it universal access to every part of society. Nonetheless, the GDR's secret service was never quite the omnipotent center of power as the picture painted by the media might suggest:

"Officially, the Ministry of State Security had been a state institution. In fact it had been founded as a party organ of the SED and as such by the Soviet occupational forces and its Communist Party." 200

Institutionally, the Stasi was positioned under direct control of the secretarygeneral of the SED and to a certain extent the Politbüro as well. ${ }^{201}$ Hence, the MfS was fully embedded in the political system of the SED and - at least in theory - subsumed under the principle of "democratic centralism." As part of the GDR's foreign policy as directed by the Politbüro, the MfS always hovered under the watchful eye of Soviet supervision. ${ }^{202}$ Like the German police of the SOZ, the installation of the MfS itself had been prepared and accompanied by Soviet institutions, notably the People's Commission for Internal Affairs and the

194 | Engelmann (et al.), 2011, 213; Kowalczuck, 2013, 21.

195 | German: Ministerium für Staatssicherheit (MfS).

196 | German: feindlich-negative Kräfte.

197 | Deutscher Bundestag (ed.), 1994; 107; Schroeder, 1999, 445.

198 | On the MfS' “mode of operation" and work procedures also see: Dt. BT (ed.), 1994, 107; Gieseke, in: Kaminski/Persak/Gieseke, 2009, 245-255; Schroeder, 2013, 576-579. 199 | Das Ministerium für Staatssicherheit als Herrschaftsinstrument der SED. Kontinuität und Wandel, Protokoll der 23. Sitzung der Enquete-Kommission, "Aufarbeitung der Geschichte und Folgen der SED-Diktatur in Deutschland“, 15. Januar 1993, in: Materialien der Enquete-Kommission, Vol. VIII; Schroeder, 1999, 430.

200 | Kowalczuk, 2013, 54.

201 | Gieseke, in: Kaminski/Persak/Gieseke, 2009, $200 f$.

202 | Hilger, in: Kaminski/Persak/Gieseke, 2009, 99. 
People's Commission for State Security of the USSR, ${ }^{203}$ renamed "KGB" in $1954 .{ }^{204}$ For example, every work unit was supported by their own "instructor" from the Soviet Union. ${ }^{205}$ As a consequence, the structures of the security services, organs of the SOZ and later on the GDR, were modelled on Soviet institutions, just as East Berlin aimed to do in South Yemen about two decades later.

Development on Soviet terms was guaranteed by the fact that the majority of early functionaries of the GDR's secret service had been trained and educated in Moscow. All of them, in one way or the other, had proven their loyalty to the Soviet ideology and system. ${ }^{206}$ The Stasi's longtime Minister Erich Mielke, who had fled to the USSR in 1931 to be trained as a military-political lecturer at the Lenin School, is one of the most renowned examples. ${ }^{207}$ Throughout the 1950 s, Soviet counselors obtained not only the position to observe, but also the authority to control the processes and decisions of the GDR's secret service. ${ }^{208}$ The early activities of Soviet security organs may be considered an indicator of the role of the GDR in Moscow's security strategy for Central Europe. "After all, the KGB built up the SOC/GDR as their own line of defense against [secret] services of the West"209 and as a home base for Soviet espionage. And despite a tenacious shift from full supervision to guided cooperation between Stalin's death in March 1953 and $1958,{ }^{210}$ the Stasi remained tightly connected with and depended on Soviet guidance throughout the GDR's existence. ${ }^{211}$

203 | NKVD - Narodnyjkomissariat vnutrennich del; German: Volkskommissariat des Innern, in: Werth, in: Kaminski/Persak/Gieseke, 2009, 38. In February 1941 the KVD was divided into NKGB and NKVD. NKGB - Narodnyi komissariat gosudarstvennoj bezopasnosti, in: Werth, in: Kaminski/Persak/Gieseke, 2009, 38; From 1946 both NKVD and NKGB were considered ministries: MVD and MGB. For further information on the restructuring of NKGB and KGB see: Hilger, 2009, in: Kaminski/Persak/Gieseke, 2009, 44ff; Engelmann (et al.), 2011, Soviet Secret Service, 275. On the influence of the KGB see: Borchert, 2006, 42; Kowalczuk, 2013, 43-45; Schroeder, 1999, 431.

204 | From 1954 to 1978 Komitet gossudarstwennoi besopasnosti pri Sowjete Ministrow SSSR; German: Komitee für Staatssicherheit beim Ministerrat der UdSSR. The KGB in Berlin-Karlshorst, Wentker, 2007, 367.

205 | Gieseke, in: Kaminski/Persak/Gieseke, 2009, 200.

206 | Kowalczuk, 2013, 46ff and 67.

207 | From 1952 to 1957 Erich Mielke had been Vice-Minister of State Security and then succeeded Ernst Wollweber as Minister of State Security. He remained in office until December 1989, in: Müller-Enbergs (et al), 2000, $579 f$.

208 | Engelmann (et al.), 2011, Soviet Counselors, 56.

209 | Hilger, in: Kaminski/Persak/Gieseke, 2009, 100.

210 | Hilger, 105 and Gieseke, 200, in: Kaminski/Persak/Gieseke, 2009.

211 | Borchert, 2006; Engelmann (et al.), 2011, Soviet Secret Service, 275-279; Schroeder, 1999, 433f. 


\section{Espionage or Politics? The Activities of the MfS Abroad}

The Stasi's task of preserving "peace and security" within the GDR became even more pressing after the international recognition of the GDR due to the perceived and actual influence of "Western ideology and thought." Gieseke even considers the MfS the "decisive guarantor of inner stability under the condition of détente" inside and outside the GDR. ${ }^{212}$ The major actor for the Stasi's work beyond the GDR's borders was the HV A, ${ }^{213}$ the former Hauptabteilung XV. ${ }^{214}$ To this day, researchers haven't been able to fully analyze and reconstruct the duties and working-processes of this section, as the lion's share of its files were either destroyed or manipulated before they could be secured and reviewed after $1990 .{ }^{215}$ Nonetheless, some significant progress has been made in this respect due to ongoing archival research in Germany. This research allows for a rough description of the work of the HV A, its subsections, and estimate numbers of personnel.

\section{Role and competencies of the HV A}

Even more than in other fields, the Stasi's activities outside the GDR were controlled and later on guided by the Soviet Union. Despite a certain air of elitism held by the HV A and its employees, it had always been an integral part of the Stasi. As such the HV A received direct orders from the minister of state security who himself had to rely on the advice of the KGB. ${ }^{216}$ Just as with the leadership of the MfS itself, the HV A had been under the reign of one single functionary almost throughout the whole existence of the GDR: Markus Wolf. At the age of eleven Wolf had immigrated to the Soviet Union. When he returned in 1945, he came equipped with the "fitting pedigree" for the future East German state. Wolf advanced as the head of HA XV as early as $1953^{217}$ and became head of the reformed Section "HV A" in 1956 until he resigned due to private reasons in $1986 .{ }^{218}$

212 | Gieseke, 2001, 84.

213 | English: Main Administration A. "A" in HV A does not stand for "Aufklärung” (English: reconnaissance). The name is modelled on the No.1 Administration Section of Espionage of the KGB (komitet gosudarstvennoy bezopasnosti), the Soviet Committee for State Security, in: Müller-Enbergs, 2011, 21 and 41; The former Major Department XV (Hauptabteilung XV) was renamed to HV A in 1956, Engelmann (et al.), 2011, 131 and $142 \mathrm{f}$.

214 | The Hauptabteilung XV was restructured as the HV A in 1956. Its major field of activity was West Germany, Gieseke, in: Kaminski/Persak/Gieseke, 2009, 208.

215 | Müller-Enbergs, 2011, 43.

216 | Schroeder, 1999, 447; Müller-Enbergs, 2011, 41.

217 | In 1953 HA XV was formed out of the "Institute for Economic Research" (German: Institut für Wirtschaftswissenschaftliche Forschung), founded in 1951, Müller-Enbergs, 2011, $20 f$.

218 | Müller-Enbergs (Ed.), 2000, Markus Wolf (Mischa), 935f; Wolf, 1997, 437. 
Within the MfS, the HV had been assigned had a special role. ${ }^{219}$ Nonetheless, it applied just the same methods as the other MfS Sections and was tightly connected with them. ${ }^{220}$ Organized in a strictly hierarchical way, the MfS was subdivided in Hauptabteilungen (HAs) that were under direct control of the minister or one of his deputies. The guidelines of responsibilities for the HAs followed either thematic or operational considerations. ${ }^{221}$ In this context, MfS Minister Mielke's style of leadership is regularly described as patriarchal if not despotic. For this reason, Möller ascribes the efficiency and success of the ministry's work rather to the independent nature of the ministry's highly specialized subunits ${ }^{222}$ than to its inflexible leader. This probably was the case for the sections occupied with the ministry's activities abroad, especially the HV A, as they relied not only on their own employees, but on a wide network of "unofficial employees," their agents and spies, as well.

Like all sections of the MfS, the HV A was not only assigned to observe, but to act - reactively and preemptively. In the case of the HV A, this meant inside and outside the GDR, towards its own citizens as well as the citizens of the "partner countries." Officially, the sections' work was based on two "pillars:" First, the work of the legal residencies, that is, official representations abroad, and second, the cooperation with the "partner countries." Former special officers (OibEs) ${ }^{223}$ never ceased to emphasize that these two were always supposed to be separate, while downplaying the special role of illegal residencies and illegal intelligence. ${ }^{224}$ However, residential work and cooperation with the "partner countries," meaning their secret services, always tended to blend together, as in Aden. Furthermore, both legal and illegal residencies were integrated into the GDR's trade missions, other international representations, and later on embassies abroad, all of which were usually led by OibEs. This was made possible through the Politbüro directive

219 | In 1958-59, the HV A was reorganized and subdivided into eight sections and "Object 9," the separate school for HV A cadres. Also, the head of the HV A was one of several deputies of the minister of state security, which also illustrates the prominent role of the HV A within the ministry. Müller-Enbergs, 2011, 41.

220 | Like the other sections, the HV A relied on the Officers on Special Mission (OibE), IME (IM-experts), GSMs and a network of IMs abroad. IME: Unofficial Employees on Special Mission, German: Inoffizielle Mitarbeiter im besonderen Einsatz; GSM; Societal Employees for Security. German: Gesellschaftliche Mitarbeiter für Sicherheit.

221 | English: Main Sections.

222 | Möller, 2004, 42.

223 | Officers on Special Mission, German: Offiziere im besonderen Einsatz. These MfS officers could rely on a second identity and usually acted from an important political, social or cultural position, e.g., as security personnel of GDR representations abroad, in: Engelmann et al., 2011, 226f;

224 | Bernd Fischer and Rudolf Nitsche, in: Fischer, 2009, 20; Nitsche, 1994, 51. "illegal residencies": German: illegale Residenturen. 
of February 1957 that aimed to create "a type of IM immediately depending on the MfS."225 Oftentimes these IMs worked undercover, mostly as delegates or representatives of other ministries both abroad and in the GDR. Thus, and especially before "international recognition," illegal residencies and intelligence were at the center of East German foreign policy.

Among the different subsections of the HV A, subsection HV A III must be considered the most relevant for this analysis, as one of its major tasks was to coordinate support for those countries of the Global South that were classified as countries of "socialist orientation." In the following, its structure and leadership are introduced. Until 1971, the subsection HV A III was led by Horst Jänicke, who travelled to Aden frequently. ${ }^{226}$ His next post was deputy head of the HV A, which illustrates the importance of subsection III within the HV A. Jänicke's successor in subsection HVA III, Werner Prosetzky, was followed by Horst Machts in 1983 and lastly Dietmar Bauer in $1989 .{ }^{227} \mathrm{HV}$ A III/B coordinated the lion's share of activities in the Middle East in general and gathered and analyzed general information. Unit $\mathrm{HV} \mathrm{A/B/4}$, the former unit $\mathrm{HV} \mathrm{A}$ III/7, focused on Algeria, Kuwait, Libya, the two Yemens and the PLO. ${ }^{228}$ Head of unit HV A III/7 was Herbert Fechner, of unit HV A/B/4 Klaus Guhlmann. For the whole unit, Müller-Enbergs registers seven operative employees and $15 \mathrm{IMs} / \mathrm{KPs}$ from abroad and counts 140 process files. ${ }^{229}$ During the 1970s, Oberstleutnant Fiedler, head of a working group on the "young nation states," regularly appears as addressee of reports, information, or financial statements in the $\mathrm{HV}$ A III/7. ${ }^{230}$

225 | Müller-Enbergs, 2011, 96.

226 | Scharfenberg, 2012, 36 and 38.

227 | Müller-Enbergs, 2011, 73.

228 | Müller-Enbergs, 2011, 42 and 80.

229 | Müller-Enbergs, 2011, 85.

230 | Hilfeleistungen gegenüber jungen Nationalstaaten auf nichtzivilem Gebiet. Übersicht über Ausgaben [...] von 1967 bis 1976, Brief Oberst Henning Abt. Finanzen an HV A/III, 26.April 1977, in: BStU MfS Abt. Finanzen Nr. 1393, 151-161 (166 including notes); Brief Stellvertreter HV A an MfS Abt.Finanzen Oberst Hennig, November 30 1977, in: BStU MfS Abt. Finanzen Nr.1419, 163. 


\section{Other Stasi Sections and their role abroad}

Apart from the HV A, other sections of the Stasi active abroad or involved with international issues were HA I, HA II, HA XX, and HA XXII. HA I was assigned to observe the activities of the Ministry of National Defense and its subordinate organs including the NVA itself. ${ }^{231} \mathrm{HA}$ II was occupied with counter-intelligence and, in addition to the special officers of the HV A (OibEs), its employees were deployed in the embassies for just this purpose. ${ }^{232} \mathrm{HAXX}$ focused on the prevention and termination of "political-ideological diversion" 233 and "political underground activities," ${ }^{34}$ both inside and outside the GDR. The "struggle against ideological enemies," that is espionage and surveillance towards the West, demanded close cooperation between HV A, HA II and HA XX. ${ }^{235}$ After Honecker succeeded Ulbricht in 1971, HA II almost quadrupled its personnel, to "penetrate and control the recently established diplomatic representations of Western states." Furthermore, the newly established international diplomatic representations of the GDR were infiltrated as well. It was the assigned task of the HV A employees to watch GDR citizens and prevent possible defections or treason. ${ }^{237}$ The internal exchange of information, espionage and counter-intelligence within the Stasi naturally eased the path to involvement of the HA II and HA XX in the Global South, as will be seen in the analysis of the MfS' activities in South Yemen.

Finally, Special Section XXII was involved in all countries connected to international terrorist groups. Due to the public's interest in the subject, the files of Section XXII are likely the most quoted in the media, though the files only offer restricted information with regard to actual operations abroad. In 1975 the section was founded as a "counter-terrorism unit," though it also verifiably excelled in supporting international terrorist organizations and cooperated with the Koko. ${ }^{238}$ Terrorist groups in the Near and Middle East were observed and "handled" in XXII's subsection No.8. This subsection also coordinated the infiltration of these groups with IMs, among them the Abu-Nidal and the Carlos Group, both of which had close ties to the South Yemeni regime. ${ }^{239}$ The recruitment of international

231 | Engelmann et al., 2011, $120 f$.

232 | Möller, 2004, 42.

233 | German: politisch-ideologische Diversion (PID), Suckut, 2001, 303; Auerbach et al., 2008, 151.

234 | German: politische Untergrundtätigkeit (PUT), Suckut, 2001, 17; Auerbach et al., 2008, 150.

235 | Auerbach et al., 2008, 157.

236 | Gieseke, in: Kaminski/Persak/Gieseke, 2009, 229.

237 | Kowalczuk, 2013, 252.

238 | Deutscher Bundestag (ed.), 1994, 207; Gieseke, in: Kaminski/Persak/Gieseke, 2009, 235; Möller, 2004, 44.

239 | Möller, 2004, 45. 
IMs was combined with the education and training of members of these terrorist groups, coordinated by Section XXII and implemented by Section AGM/S. ${ }^{240}$

\section{Three phases of the Stasi's "foreign policy"}

Müller-Enbergs defines three phases marked by turning points for the HV A's activities: The erection of the wall in 1961 and the enforcement of the "Grundlagenvertrag" in $1972 .{ }^{241}$ In the following, the three phases of HV A activities are interpreted with regard to the GDR's foreign policy towards the Global South, among them the states of "socialist orientation" and especially South Yemen. While the HV A had mostly focused on the newly formed FRG before 1961, the scope of operations in the Global South was broadened significantly thereafter, including the profile of the special officers (OibEs) and the work of the responsible subsection, HV A III. ${ }^{242}$ As a consequence, the Ministry gradually expanded its influence abroad at the expense of the regular diplomatic personnel of the GDR until the "wave of recognition" in the early 1970s. Until then, the HV A had had to fully rely on illegal residencies, that is, disguised operative bases abroad. However, due to the lack of diplomatic relations and thus representations, this had also meant a "monopoly of information" (Müller-Enbergs) for the HV A in the international realm at the time.

Consequently, this had to change after the establishment of official diplomatic relations and embassies. Afterward, the number of legal residencies grew and the HV A's work became more integrated into the GDR's “official” foreign policy endeavors: The GDR had successively expanded its cooperation with developing countries of "socialist orientation" and in doing so promoted a "state-building policy" with a focus on security organs and the educational system of recipient countries, the most prominent of which were South Yemen, Ethiopia, ${ }^{243}$ and Nicaragua. It was mostly the special officers (OibEs) who were highly involved in the installation of secret services modelled on the GDR's system in the "partner countries," including the training of personnel and the preparation and the delegation of so-called advisory groups. ${ }^{244}$ Furthermore, East German embassies now served as the ideal coverage for short-term visits of Stasi personnel. In early

240 | AGM/S: Arbeitsgruppe des Ministers; English: Working group of the minister. AGM/S was also occupied with acts of sabotage abroad. It later on was renamed Section XXIII, in: Möller, 2004, 45 and 47. On the recruitment process see for example: Operative Einschätzung des GMS “Leonhardt“-Vorg.-Nr.XV 3481/82, August 28 1986, in: BStU MfS AGMS Nr.1020-88, 66-68. On training courses see for example: Konzeption für die Durchführung eines Sonderlehrganges zur Ausbildung von Mitarbeiter des MfS VDR Jemen, Section X to Section XXIII May 4 1988, in: BStU MfS Abt. X Nr. 234, Part 1 of 2, $125 f$.

241 | Müller-Enbergs, 2011, 22.

242 | Müller-Enbergs, 2011, 42.

243 | Borchert, 2006, 201 und 241; Dagne, 2006.

244 | German: Beratergruppen; In this, the HV A worked closely with the GDR's Army, the NVA (German: Nationale Volksarmee), Kowalczuck, 2011, 259; Müller-Enbergs, 2011, 73. 
1984, for example, four high-ranking Stasi employees, of the HV A Section N, and two delegates from HA III, visited Aden to check on the condition of the GDRfinanced surveillance base "Netzwerk 3," with the two HA III delegates travelling under cover as MfAA diplomats. ${ }^{245}$

\subsection{Responsibilities for and in the PDRY: East Berlin and the Diplomatic Mission in Aden}

According to Wolfgang Bator, former GDR ambassador, each embassy, regardless of its size, had a section or at least one diplomat each responsible for political affairs, foreign trade, and culture. All of them officially answered to the ambassador. ${ }^{246}$ The East German embassies on the ground mostly fulfilled an executive and coordinating function, directed by the MfAA in Berlin. ${ }^{247}$ Apart from the minister of foreign affairs, one of his deputies in Berlin was assigned to coordinate and decide on the relations with the countries of the Near and Middle East. After 1972, this was Klaus Willerding, ${ }^{248}$ and after 1988 Heinz-Dieter Winter. ${ }^{249}$ Sometimes this deputy was head of the respective regional section.

\section{The "Arab States/Near and Middle East" Regional Section}

South Yemen was part of the "Non-European Countries No.3: Arab States" regional section, which was renamed "Arab States Section" and then "Near and Middle East Section" in the 1970s. Head of this section in the late 1960 s was Kiesewetter and after him Siegfried Kämpf. ${ }^{250}$ He was followed by Karl-Heinz Lugenheim who officially

245 | Konzeption für die Durchführung einer Dienstreise im Rahmen der Aktion “Netzwerk 3“, in: BStU MfS HA III Nr.8, 212-215. In South Yemen, this part of the GDR's nation- and statebuilding policy was coordinated by $\mathrm{HAX}$ which first of all regulated relations of the MfS with security organs of countries of the Eastern Bloc but also other close allies like South Yemen and thus worked closely with the HV A. Möller, 2004, 42. See for example a comprehensive file on South Yemen, BStU MfS Abt.X Nr.324 Teil 1 von 2; Korrespondenz Oberst Kempe (Abt.X) und Oberst Machts (HV A), Zusammenarbeit mit den Sicherheitsorganen der VDRJ, February/March 1989, in: BStU MfS Abt.X Nr.324 Teil 1 von 2, 23-25.

246 | E.g. the "culture section," coordinated and directed the activities of East German actors from the social sphere, esp. the "Societies of Friendship". Int. with Wolfgang Bator May 272011. 247 | The major sources for the succession of personnel are archival material and Muth, who relies on Radde, Jürgen, Der Diplomatische Dienst der DDR. Namen und Daten, Köln, 1977, in: Muth, 2001, Annex XVII "Overview of the Heads of Country sections from the 1960s to 1972-73 and Annex XIX "Overview of personnel of diplomatic missions of the GDR from 1949 to $1975,279-295$.

248 | Brief Scharfenberg an Rost, December 20 1973, in: PA AA MfAA C 1555/76, $116 f$.

249 | E-Mail Heinz Dieter-Winter, May 262014.

250 | Brief von Winzer an W. Stoph und Prof. K. Hager, June 12 1969, Berlin, in: PA AA MfAA C 1219/71, sine pagina. Kämpf followed in 1970. 
remained head of the section from 1970-1977. ${ }^{251}$ In between, Günther Scharfenberg substituted for Lugenheim for about half a year until Günter Mauersberger took over in July 1972. ${ }^{252}$ In 1977 Wolfgang Konschel became the new section head, followed by Wolfang Schüßler from 1978 to 1985 . Heinz-Dieter Winter took over until 1986 and was succeeded by the last head of section, Reiner Neumann, who served until 1990. Another important link between the foreign policy headquarters in East Berlin and the respective embassies in the 1970s was the official appointment of a Politbüro secretary to one or several countries as his "countries of focus" to improve political relations and personal contacts. "The relations of the PDYR [for example] were assigned to Gerhard Grünberg" ${ }^{253}$ who appears regularly as the coordinator of meetings with high-ranking Yemeni delegations in East Berlin. ${ }^{254}$

\section{East German Ambassadors to Aden}

With regard to the number of diplomats and employees, the embassy in Aden was one of the biggest East German embassies in the Global South. All in all, six ambassadors were sent to Aden: Karl Wildau, who had been general consul in Aden since 1968, served as ambassador from July 1969 to 1972 . He was likely well acquainted with Honecker, as he married Honecker's daughter Erika. ${ }^{255}$ Wildau was dismissed from his post after South Yemen complained about the disclosure of secret information by the minister of justice to Soviet and East German officials. ${ }^{256}$ Wildau was succeeded by Günther Scharfenberg who remained in office until 1978 and thus was the longest-serving ambassador to the PDRY. Scharfenberg was replaced by Ernst-Peter Rabenhorst who remained on his post until 1981. Rabenhorst had been a member of the CC "International Relations" Section and had recommended himself for the post during a visit to the PDRY while consulting on foreign policy regarding the establishment of relations with Washington and Bonn in $1974 \cdot{ }^{257}$ Rabenhorst was succeeded by Reiner Neumann who had to leave the country due to the "January 1986" massacre. The next ambassador to Aden,

251 | Beschlußvorlage [sic!] zur Konzeption Entwicklung der politischen, ökonomischen und kulturellen Beziehungen zur VDRJ 1968, in: PA AA MfAA C 1219/71; E-Mail Heinz Dieter-Winter, May 262014.

252 | Scharfenberg, 2012, 17.

253 | Grünberg, member of the Politbüro since 1966 and mostly occupied with question of agriculture, was assigned to entertain relations with the PDRY at the highest party level. Scharfenberg, 2012, 52.

254 | Stenografische Niederschrift der Beratung mit der Delegation der NLF Südjemen am 2.11.1970 im Hause des ZKs, in: BArch, SAPMO/DY 30/11407, 5-71.

255 | Erika Wildau, in: Der Spiegel, No.49, 1988,

256 | SAPMO BArch, DY 30/IV B/2/20/285; Scharfenberg, 2012, 33.

257 | Scharfenberg, 2012, 48; A few years later Rabenhorst even published an article on the PDRY's progressive development in the SED magazine on theory and praxis of scientific socialism "Einheit” (Unity). See: Rabenhorst, 1977. 
Freimut Seidel, then gradually aimed to revive relations. Though East GermanSouth Yemeni relations did not recover fully until 1990, they were very well on their way after March 1989. Seidel left the country in 1989 and Werner Sittig took over in August. Sittig witnessed the beginnings of Yemeni unification and initially was supposed to establish the GDR embassy of a unified Yemen in Sana'a. However, he wasn't able to put his experiences to use anymore. Sittig was only to serve until 1990 and was the very last ambassador of the GDR sent to Aden. With unification on the horizon, Sittig was called back to East Berlin to take over as Head of the MfAA Near- and Middle East Section ${ }^{258}$ under the last two ministers of foreign affairs in East Germany, Markus Meckel, from April to August 1990 and Lothar de Maizière, for the final three months of the existence of the GDR.

\section{Inside the Embassies: Cadre Selection and Responsibilities}

Future embassy staff and their families had to meet a certain "standard" of Party loyalty. This was especially true for the ambassador and his family for two major reasons: The ambassador firstly was considered responsible for the East German "collective" in his country of service. The "Aden collective" was comprised of more than 240 GDR citizens. ${ }^{259}$ But secondly, the ambassador was afforded much mobility and had to act independently but in accordance with the SED regime in countries of the developing world. As a consequence, ambassadors were tested and screened thoroughly with regard to their party loyalty. Werner Sittig, for example, reports of that each ambassador had to attend the SED party school for one year. ${ }^{260}$ An everyday example for the self-controlling nature of the system is the reaction of the HV A resident's wife to the arrival of the Scharfenberg couple in Aden. Repeatedly she reminded Scharfenberg's wife, Meike, of the fact that she was not an SED member which was a rare condition for the wife of an East German ambassador. ${ }^{261}$ This exception probably occurred due to extraordinary circumstances. The Scharfenbergs had met merely a year before Günter Scharfenberg was called upon as ambassador. ${ }^{262}$ Furthermore, he was only the second choice, after Wolfgang Bator, to serve in Aden. Nonetheless, the post demanded a high level of experience in both the state and party apparatus, and in the middle of the "wave of recognition," there was an extreme shortage of able and loyal foreign policy cadres. Thus, it must have been enough for the Politbüro at the time that “there didn't seem to exist any doubts about Meike's political reliability and attitude," ${ }^{263}$ whereas this clearly didn't stop the MfS personnel from commenting on the situation.

258 | Notes on telephone interview with Werner Sittig, May 82014.

259 | Scharfenberg, 2012, 88.

260 | Notes on telephone interview with Werner Sittig, May 82014.

261 | Scharfenberg, 2012, 25.

262 | Scharfenberg, 2012, 13; 16.

263 | Scharfenberg, 2012, 16. 
Officially, it was the ambassador who had the highest authority over GDR citizens abroad. In reality though, this authority depended on the character of each ambassador and his relationship with the MfS residents. Scharfenberg reports about a conflict of "positions" between himself and the visiting political cadres:

"But regardless of the political cadre's position at the headquarters [in East Berlin], abroad, the ambassador was the designated representative of "party and government.'"264

However, the ambassador's authority by no means was a given that any ambassador could rely on. According to the principle of "democratic centralism," the ambassador was regarded a representative of the government, i.e., the state sphere, and thus subordinate to any high-ranking party representatives. Apart from Scharfenberg, several former ambassadors report of conflicts due to an unclear assignment of responsibilities with visiting cadres, especially Stasi delegates. Heinz-Dieter Winter remembers: "The Resident and his people had their own rooms. I visited the embassy in Aden in 1990. The ambassador had no access to these rooms," 265 At the time, the Stasi's work obviously was beyond the ambassador's sphere of control.

Not only did the ambassador's family have to prove they were "in line" with SED politics. Indeed, every other GDR citizen had to display his or her loyalty to the regime. This was ensured by the expansion of the system of control from the GDR to its "partner countries." Aden was no exceptional case in this regard and not only official HV A officers, but also several East German and Yemeni IMs were on duty at the embassies until the very last days of East German foreign policy, usually without knowledge of the ambassador himself. ${ }^{266}$ According to former special officer (OibE) Rudolf Nitsche, the special officers of the Stasi within the MfAA were meant to merely provide "counter-surveillance" for the MfAA and its representatives abroad, while working "just like any other" international secret service. But even though Rudolf Nitsche emphasizes that neither the HV A in general, nor the special officers in particular were intended to "spy upon employees of the MfAA [in the GDR and abroad]," ${ }^{267}$ Nitsche's own history tells a different story. Under the code name "Winter," he was appointed deputy of a GDR trade mission in the Arab world in 1966 - without the knowledge of the head of the mission. Nitsche writes about these years:

264 | Scharfenberg, 2012, 34.

265 | Interview with Heinz-Dieter Winter, July 32012.

266 | Abschrift einer IM-Information der HA VII, Abt.1, February 28 1990, in: BStU MfS HA VII 7054, 51-53. In the PDRY, MfS-officers remained active until the official disbandment of the Ministry, announced in January 1990 by Hans Modrow. Gieseke, in: Kaminski/ Persak/Gieseke, 2009, 209.

267 | Nitsche, 1994, 51. 
"One should be aware that only the best and most conscious citizens of the GDR were appointed to posts in the capitalist [countries]. I expected to join a small, steadfast socialist collective of convinced and collegial Genossen. I was badly mistaken."268

Among others, Nitsche was on duty to improve what he viewed to be scandalous circumstances by intensifying control of the MfAA functionaries even before they were sent abroad, such as through Nitsche's "operation" in the MfAA to form the "Internal Information" Section. ${ }^{269}$ Regardless of a certain autonomy for the East German embassies and their employees, the watchful eye of the SED regime was omnipresent. The Stasi observed and reported about life and work of the diplomatic personnel at home and abroad to be able to react to internal disloyalties, but also preemptively to prevent possible "treason" or attempts to flee the GDR.

\section{Summary: Competencies and Influences oVer Time}

This chapter aimed to embed the actors involved in East German foreign policy making into the reality of the GDR's political system to be able to interpret the GDR's activities in South Yemen as typical or atypical for East German foreign policy making. While concrete implications of the relations between the actors are illuminated in Chapter 8 on the dominant foreign policy strategies in the Arab world, this chapter sketched the complex system of the GDR's foreign policy making process in general to assess the role and position of the Aden embassy and its policy within the system. This chapter pointed out two actors which moved outside the rigid hierarchical system that was East German foreign policy, though both were an integral part of it: The major external determinant of foreign policy, the Soviet Union, and the Stasi and its officers.

\section{Moving beyond the SED System of Foreign Policy: The Stasi and Moscow}

After two decades of access to a huge corpus of documents, research and academic discourse on the structures, decision- and policy-making process of the Stasi, research has moved from its infancy to adolescence, ${ }^{270}$ but a big share of material still awaits academic attention and thus oftentimes conclusions remain speculative at best. The MfS was able to gradually expand its own sphere of action within the political system of the GDR. The Stasi was able to create a certain aura of omniscience, elitism, and influence within East German society and successfully combined this policy with an atmosphere of mutual suspicion, insecurity, and

268 | Nitsche, 1994, 55.

269 | English: Internal Information Section; Nitsche, 1994, 40. Later on after the "wave of recognition" the "Schutz und Sicherheit" Section was formed, simply called "Section S" in this context.

270 | Schroeder, 2013, 558; See also: Engelmann (et al.), 2011; Gieseke, 2011; 
even fear among the foreign policy personnel to use the "wrong" that is, non-party conform, political statements and engagement in public. Abroad, this created extraordinary power for a ministry which otherwise was subordinate to the party like any other state institution.

The work of the GDR's secret service in the Global South, and particularly in the Arab world, played a decisive role in the GDR's activity during the establishment of a communist state system. This was especially the case in efforts to support the socialist state- and nation-building of the Aden regime. All in all, the MfS and the adjunctive section HV A both served the same purpose as the MfAA: "[T] o stabilize the GDR-system, [and] secure the rule of the SED"271 by increasing East German prestige abroad and improving the political and economic outputs of GDR foreign policy. The concrete case of South Yemen gives an excellent example of this involvement, as will be shown in the analytical chapters on the GDR's policy in the country.

Apart from the foreign policy headquarters in Berlin, it was not only the Stasi that had a close eye on East Germany's embassies. "[C]lose contacts between the GDR's diplomats abroad and the Soviet representatives had to be emphasized."272 To this day, the mechanisms and processes of Soviet control over the GDR's foreign policy remain insufficiently analyzed. Nonetheless, it may be concluded that the Soviet urge and "need for control" 273 of the SED regime seemed to decrease over time. After 1955 there merely remained the Soviet embassy to direct East-Berlin's politics, at least officially. Nonetheless, Moscow made sure to create its very own power base in East Germany by establishing their organizational system and thus securing a certain structural power for themselves: Similarities between the Soviet and the East-German security services KGB and Stasi were numerous, among them a hierarchic system modelled on military ranks. ${ }^{274}$ This emphasizes the special role of the Stasi within the system and may explain its employees' self-perception as a distinctive political elite. In addition to that, the Soviet Union ensured control of East German activities abroad, based on the close cooperation between KGB and MfS, but also between Soviet and East German diplomats in the respective countries, such as South Yemen.

\section{Foreign Policy Responsibilities in the GDR: Three Phases of Development}

As indicated above, the reality of power distribution among state and party organs did not correspond with the constitutional political system. Constitutional genesis rather has to be considered a belated confirmation of actual circumstances, as the constitutions of 1968 and 1974 merely adapted constitutional law to political

271 | Müller-Enbergs, 2011, 20.

272 | Scharfenberg, 2012, 62.

273 | Wentker, 2007, 29.

274 | Kowalczuk, 2013, 48. 
realities. Distribution of responsibility within the GDR depended on two factors: First, the efficiency of the complex relation between party and state and second, the personality and the power network of foreign policy functionaries. Based on these two factors, three phases of development of foreign policy responsibilities can be identified that coincide with Müller-Enbergs' three phases of the Stasi's activities abroad, but also agree with the major phase of East German foreign policy introduced in chapters 5 and 6: The first "Phase of Collective Improvisation" from the founding of the GDR to 1961 , the second "Phase of Consolidation and Professionalization" until international recognition in 1971-72, and the third and last "Phase of Established Administration" until 1989 during which the state, its political system and the ruling elite were able to act from an established position.

Understandably, the transition from the "Phase of Consolidation and Professionalization" to the "Phase of Established Administration" is the most relevant period for collecting information on the development of power distribution within the foreign policy apparatus. The expansion of the GDR's activities in the international sphere in the 1960 s, mostly in the Global South, had led to a "certain [...] professionalization" ${ }^{275}$ of the foreign policy apparatus, while selection processes and training made sure that foreign policy personnel were among the most loyal to the party, its policies, and political survival. ${ }^{276}$ Muth mentions the common slogan according to which the MfAA personnel first of all were "workers for the party before they were diplomats." 277 Hence, Wolfang Bator's memories as a long-time, high-ranking foreign policy functionary cannot be too surprising. His impression of a more influential role of the MfAA on the GDR's foreign policy without doubt belittles the fact that the CC and Politbüro not only decided on the final version of foreign policy directives, but also whether the draft handed in by the MfAA was to be discussed at all. In addition to that, the majority of the MfAA personnel were integrated into the party at a considerably high level, ensuring that they were less likely to suggest policies outside the general "party line," as they had internalized what was expected from them. ${ }^{278}$ Furthermore, these personal unions of party posts and other functions oftentimes created shortcuts in the "chain of command," and policy-making sometimes became an almost impossible task without consent of the highest party levels.

275 | Wentker, 2007, 191.

276 | As early as March 1949, diplomatic personnel was trained at the Institut für Internationale Beziehungen (IBB), the Institute for International Relations, in PotsdamBabelsberg, in: Crome, 2009, 9.

277 | Muth, 2001, 73.

278 | On the process of "internalization" in the sense of creating "habits of order and obedience" as part of what Foucualt described as "subjectification" see: Foucault, 1995 (1975), 242. 
All in all, the actual accomplishment of the MfAA may not be found in proactive policy-making, but rather has to be sought in the reduction of friction losses within the spider web of responsibilities and involvement between party, state, and "society actors": Within the second and third sphere, responsibilities were highly fragmented, and the MfAA was able to acquire the role as coordinating "mediator" 279 between state and society actors. During and right after the "wave of diplomatic recognition" of the early 1970s, the MfAA personnel had high hopes for the extension of its authority, but these hopes were not to be fulfilled. Only occasionally did the room for actual "policy-making" expand, as in the case of the GDR's embassy in Aden:

“After consultations [...] with Genosse Dr. Weiß in August [1973] and delegation Heydel in Aden in fall 1973, we aimed to process relations with the PDRY through the embassy as a matter of principle."

However Scharfenberg does not end here, but continues: "insofar as there do not exist immediate contacts between central state institutions of the GDR and partners of the PDRY." ${ }^{280}$ Thus, the question of responsibility with regard to decision-making always had an easy answer: Regardless of the contacts of the GDR state apparatus with the respective county, it was always the party apparatus and its "inner circle" that decided on matters of importance. ${ }^{281}$ Despite a certain influence with policy suggestions in emergency situations, the MfAA rarely left the policy path staked out by the leaders of the SED. The MfAA rather remained an active executive "subordinate regulator." 282 The one-party system combined with nomenclatural recruitment concentrated the decision-making process of all policy fields in a very small circle of decision-makers. ${ }^{283}$ Furthermore, the alreadycentralized political system over time condensed power distribution among the SED's leading functionaries even more, so that in the 1980 s, individuals' opinions and interpretations, most prominently those of the secretary-general, became highly influential. On the one hand, this allowed for quicker and more flexible responses than before, but also led to rash actions without the necessary comprehensive consideration, as will be illuminated with the analysis of East Berlin's foreign policy engagement in Aden.

279 | Muth, 2001, 67.

280 | Brief Scharfenberg an Willerding, Aden, March 20 1974, in: PA AA MfAA C 1555/76, 4f.

281 | Schmitt's definition of the "exception" as "a danger to the existence of the state" reveals his wish for the securing of the state's existence, Schmitt, 2005 (1922), 6.

282 | Scholtyseck, 2003, 71; Wentker, 2007, 382.

283 | Principles of nomenclature in the Ministry for Foreign Affairs, June 18 1964, in: PA AA, MfAA, LS-A 29, in: Muth, 2001, 268. 
SECTION B. ANALYSIS

\section{PART II - The GDR in Yemen}





\title{
CHAPTER 8. The GDR and the "Arab World":
}

\author{
A Small State's “Fill-In Policy"
}

Until now, no in-depth analyses of East German activities in the Middle East nor any brief overviews on the four full decades of East German engagement in the region have been published. This is mostly due to the lack of case studies on East German foreign policy in the Middle East from the 1970s onwards, but also to significant gaps in research on the GDR's foreign policy in general. The following chapter cannot be considered this long-awaited overview, as it is merely conceptualized to support the analysis of the GDR's engagement in the People's Democratic Republic of Yemen. Any interpretation of the GDR's activities in the Global South must remain piecemeal, as there is no way to "accurately assess the nature and volume" of East German aid. It was not before the mid-1980s that the GDR was urged by the UN and World Bank to publish systematized numbers, ${ }^{1}$ and even these cannot be considered fully reliable: Foreign aid remained a tool of a foreign policy, serving political and ideological ends. Thus, any interpretations with regard to the actual volume of spending have to content themselves with a short- to medium-range explanation. In addition to that, there did not exist a central agency to coordinate the GDR's policy towards the Global South: Though the Politbüro decided on the formation of a "Commission for the Developing Countries" in $1977,{ }^{2}$ this decision was not enforced to any effect before German reunification.

Despite this pessimistic outlook, this chapter intends to offer a foothold and orientation on East German engagement in the Middle East for future research. Based on the Soviet interests in the Middle East during the Cold War, the following chapter firstly sketches the GDR's activities in the region and how it had to navigate within this rather narrow scope of action. Secondly, this brief

1 | Howell, 1994, 307.

2 | German: Kommission für Entwicklungsländer, "to coordinate the economic, cultural, scientific-technical and non-civilian activities in the countries of Asia, Africa and the Arab world," in: Beschluß des Politbüros, Protokoll Nr. 49/77, December 20 1977, in: BArch, SAPMO, DY JI 2/2 1705; also see: Döring, 1999, 44ff; Howell, 1994, 313. 
outline introduces the East German engagement in the Middle East before and after international recognition and thirdly concludes with the three dominant strategies that structured East German activities in the Middle East.

\section{The Middle East between Washington and Moscow: Pawn or Player?}

"The Soviets were responsible for the whole world and left small bites to their agencies in East Berlin, Sofia, Bucharest, Warsaw, and Prague." ${ }^{3}$

The GDR's activities in the Middle East had mostly been shaped by Moscow's interests in the region. The following subsection places the Middle East within the wider framework of the Cold War to sketch the relationship between the international and the regional. Then, the political development and processes in the region are summarized briefly along major events, most of which were conflicts, in the wider Middle East to identify Soviet interests and strategies in the Cold War.

Halliday diagnoses a "reciprocal relationship" during the Cold War between the international and the regional levels, the system and the sub-system, and the globe and the Middle East. He also considers the Cold War both a "global, formative context" and a system of "strategic control," reaching out to steer regional actors as well. ${ }^{5}$ The relationship between the international level and the regional level had changed significantly after the "high colonial epoch" between 1918 and 1945 and was now characterized by more interaction between "global and regional forces." Halliday's approach clearly ascribes more agency to the regional actors of the Middle East, going well beyond the image of the region as produced by the narrative of the superpower conflict. ${ }^{6}$ Halliday diagnoses a considerably more active role of regional actors. Thus, one may imply an overall change of character of foreign policy of the global towards the regional powers in the Middle East with the onset of the Cold War. With regard to the levels of engagement, "imposition" of external actors, i.e., colonial powers, was replaced by the two superpowers oscillating between "intervention" and "involvement" to "influence" due to the growing agency of regional actors who were not only willing, but also able to pursue their own interests.

This change in relationship was demonstrated during the Suez Crisis of 1956 when Egypt unilaterally nationalized the Suez Canal. The former global and

3 | Kowalczuck, 2013, 251.

4 | Halliday, 2005, 98.

5 | Ibid., 127.

6 With this approach, Halliday opposes Westad, who emphasizes the agency of the two superpowers, Westad, 2005, $272 \mathrm{ff}$. 
colonial powers, the United Kingdom and France, supported an Israeli initiative to prevent what they considered Egypt's seizure of the canal and in doing so once more demanded a major power position in the region. In the end, the United States prevented this military move. Still, from then on the Middle East and its regional powers were both pawns and active players in the global conflict: While the region cannot be considered the major venue of the bloc confrontation, it was still "vital to [the superpowers"] security."7 This was especially true for an extremely sensitive field of foreign policy and economy: For both superpowers and their allies, the Middle East emerged as the primary recipient of their arms trade among the countries of the Global South.

\subsection{Heading for New Shores: Moscow's Early Engagement in the Middle East}

Compared with the United States, the Soviet Union had a noticeably higher interest in the events and power distribution in the region, even though it "had no direct interest in Middle Eastern oil" at the time. Rather, the relevance of the region to the USSR was of a more immediate nature: the Greater Middle East directly bordered its territory and sphere of influence. ${ }^{9}$ Apart from the countries of the Middle East in its immediate vicinity, the Horn of Africa and Bab Al-Mandab were of utmost geostrategic importance for the Kremlin. Not only as a possible naval base between Africa, Europe, and Asia, but also as part of the shipping route between the European West, the Black Sea, and the Asian East on the Sea of Okhotsk that surrounded the vast territory that was the Soviet Union.

Until the so-called "détente period" of the Cold War in the early 1970s, Moscow officially pursued a foreign policy based on ideological assumptions, conclusions and goals that were formulated as ideological principles. The major school of Marxist-Leninist thought in the field of International Relations was the concept of historical materialism. The concept predicts the deterministic expansion of communism and its culmination in world communism. When the hope for Europe as a possible field of Communist expansion was extinguished with the Berlin Crisis of $1948-49,{ }^{10}$ the Soviet Union began to search for new sinecures to actively support the expansion of their worldview in competition with the "imperialist West." To support the "developing world" in its transition to socialism and finally communism, the countries of the Eastern Bloc applied the principle

7 | Halliday, 2005, 124.

8 | Ibid., 98.

9 | In the Middle East, the Soviet Union bordered Afghanistan, Iran and Turkey from east to west. Political and ethnic organization of the USSR before 1990, in: Putzger, 2001, 190. 10 | The United States and their allies had clearly expressed that they would not give up their sphere of influence in Central Europe during the Berlin Crisis as evidenced by the spectacular support of West Berlin with essential supplies by air in 1948/49. Wettig, 1999, 147. 
of "international" or "anti-imperialist solidarity" to their foreign policy. Marx and Engel's writings do not offer much guidance on the topic. Lenin, however, did:

\begin{abstract}
"The Communist International has to formulate and argue for the principle that the backward countries can achieve the Soviet order and [...] communism without going through the capitalist stage - with the support of the proletariat of the most progressed countries."11
\end{abstract}

In retrospect, the comprehensive ideological approach and the Soviet Union's foreign policy were in constant reciprocal exchange and thus mutually dependent. As a consequence, ideology considerably influenced Soviet strategy in the Near and Middle East - though it never determined it exclusively. On the one hand, Moscow carefully selected its closest allies among the most loyal socialist countries of the developing world and focused its attention on the countries of "socialist orientation." The concept "was elaborated as a developmental model based on the Soviet system."12 On the other hand, however, and with regard to mid-term considerations, Soviet policy towards the Middle East also has to be considered "Realpolitik": whenever it was deemed politically or economical beneficial, the Kremlin did not hesitate to side with conservative and even reactionary regimes. ${ }^{13}$

Halliday distinguishes between four periods of the Cold War in the Middle East that can be used to illustrate the changes in Soviet engagement in the region over time. ${ }^{14}$ During the first phase from 1946 to 1955 , the Soviet Union focused its efforts on the "non-Arab" north of region, Turkey and Iran, while it "possessed neither the will nor the capacity to challenge the [W]est in the Arab world itself." 15 This changed profoundly during the second phase from 1955 to 1974 . While the United Kingdom successively lost ground in the Middle East, the Kremlin expanded its sphere of influence. In the early years of the Cold War, Washington considered the Soviet Union's new interest in the Middle East less motivated by "economic need or lack of oil resources, but part of a drive to communize the world." assessment was not far off from the truth at the time, as the official policy change from Andrei Zhdanov's “two camps theory” to Nikita Khrushchev's doctrine of "peaceful coexistence" in 1961 indicates. ${ }^{17}$ This perceived threat was answered by Washington with the so-called "Eisenhower Doctrine" of 1957, which aimed "to

11 | Lenin, Werke, Vol.31, 1959 (1966), 232.

12 | Shearman, in: Shearman, 1995, 16.

13 | Katz, 1986, 8.

14 | Halliday, 2005, 99.

15 | Halliday, 2005, 99.

16 | Choueri, 2000, 191.

17 | Khrushchev, Nikita S., On Peaceful Coexistence, Moscow, 1961. Kanet, in: Greiner/ Müller, Weber (ed.), 2010, FN 5, 47. 
deter the aggression of 'international communism' and ensure 'the continued independence' of the free nations of the Middle East"18 through economic and military assistance. Obviously, Washington included the Middle East into the wider frame work of Cold War rivalry - and for the states of the Middle East, it was clear that from then on they no longer could avoid taking sides in the conflict.

After some maneuvering, Moscow finally sought strategic alliances with the "progressive"19 regimes in the region who pledged themselves to some sort of Arab nationalism. The losses in French and British prestige and influence in the Middle East following the Suez Crisis and the Six-Day War not only helped Moscow's attempt to establish itself as the dominant external actor in the Middle East but also allowed the Kremlin to profile itself as the alternative to "Western imperialism" and a "major ally of a number of radical Arab nationalist regimes" 20 such as Egypt, Iraq, Syria, Libya, and South Yemen - against the "imperialist imposition" of the West, but also in opposition to the conservative forces of the region. This policy pattern was readily picked up by Moscow's student, the GDR: The Kremlin's policy explicitly aimed to include coordinated action of the Warsaw Pact states under Soviet supervision. ${ }^{21}$

During this period, Soviet engagement intensified from "influence" to "involvement" and "intervention," as evidenced by, for example, Moscow's support of Egypt's involvement in the Yemeni Civil War in $1962-63 .{ }^{22}$ A year before this engagement, Nasser had introduced an Egyptian version of socialism. ${ }^{23}$ This "Arab socialism" paired George Antonius' notion of "Arab nationalism"24 with a vague socialist concept based on political instruments. Here Rome Spechler identifies a distinctive phase of Soviet policy toward Egypt and the Middle East over the period between the two Arab-Israeli Wars of 1967 and $1973:{ }^{25}$ During the expansion of their influence from 1955 onward, the USSR further intensified its involvement while emphasizing its claim to political and especially military control over the Arab states. Beginning in the mid-196os, developmental aid was advanced as a popular tool on both sides of the Cold War rivalry to expand their

18 | Choueri, 2000, 191.

19 | Choueri, 2000, 192.

20 | Halliday, 2005, 99.

21 | Storckmann rightly decries a lack of sound archival findings on the coordination between Moscow and its political orbit of Warsaw Pact states due to lack of access to the relevant archives in Moscow: Storckmann, 2012, 38. Nevertheless, archival documents of the GDR allow some insights to the processes and thus permit generalized conclusions to a certain extent.

22 | Ferris, 2008.

23 | Arabic: al-ishtirākTyah al-'arabTyah; English: Arab Socialism, see: Hanna/Gardner, 1966, $77 \mathrm{f}$.

24 | Antonius, (1938) 2000.

25 | Rome Spechler, in: Marantz/Steinberg, 1985, $134 \mathrm{f}$. 
respective sphere of influence. On the Soviet side this approach culminated when Leonid Brezhnev announced the approaching victory of the socialist world system over the dominant capitalist system in the 1970s. ${ }^{26}$ Part of this strategy was the explicit inclusion of the most able states of the Eastern Bloc to support the Soviet Union's publicized developmental policy in the Global South, most prominently the Poland, GDR, and the ČSSR.

\title{
1.2 Maneuvering as an Established Actor: Moscow's Consolidation and Expansion in the Region
}

\author{
"The Soviet Union is now firmly established in the Middle East, and is \\ undoubtedly there to stay." 27
}

(The International Institute for Strategic Studies, 1969)

\begin{abstract}
After the initial years of establishing the Soviet Union in the Middle East, Moscow's strategy toward the region may be summarized as a Janus-faced approach. The support for the revolutionary nationalist movements in the region, foremost those with socialist leanings, remained their first priority. Cooperation with "reactionary" actors nonetheless was always an option out of pragmatic considerations. Nasser's defeat in the Six-Day War against Israel and his death three years later paved the way for a policy change in Cairo toward Moscow under its new leader, Muhammad Anwar al-Sadat. In July 1972, al-Sadat demanded the withdrawal of Soviet advisors due to Moscow's refusal to provide more sophisticated weapons in the Arab war against Israel. ${ }^{28}$ In the light of the changes in the superpower relationship toward détente, Moscow clearly intended to restrain any violence against Israel. ${ }^{29} \mathrm{Al}$ Sadat declared October 31 of the same year the "target date" to remedy this lack of military support, otherwise the renewal of the Treaty of Friendship and thus the Soviet use of Egyptian port facilities would be at stake. ${ }^{30}$ However, in April 1973 alSadat announced: “The Russians are providing us with everything that's possible for them to supply. And I am now quite satisfied." ${ }^{31}$ When Egypt finally attacked Israel on Yom Kippur in 1973, Washington considered the Soviet involvement an infringement of the détente. ${ }^{32}$
\end{abstract}

26 | Hakhnazarov, Georgij, 1974, in: Kanet, in: Greiner/Müller, Weber (ed.), 2010, FN 5, 46 and 51.

27 | Hunter, 1969, in: The International Institute for Strategic Studies (ed.), 127.

28 | Halliday, 2005, 119.

29 | Rome Spechler, in: Marantz/Steinberg, 1985, 135.

30 | Ibid. 142.

31 | A saber rattles in Cairo, Interview by Arnaud de Borchgrave with Anwar al-Sadat, in: Newsweek April 91973.

32 | Quandt, 1973. 
A final judgment on Moscow's intentions is neither possible nor necessary here. What has to be pointed out is the delicate political dilemma of the Soviet leadership: While Moscow had agreed to significant steps toward a détente with Washington, it still had to prevent military deployment close to its borders and uphold alliances with the Arab world. ${ }^{33}$ As mentioned above, Moscow's attitude of restraint before 1973 may be considered the logical consequence of Moscow's détente policy, and Moscow's policy change a result of political pressure by Cairo. On the other hand, Soviet maneuvering might also be the outcome of a tactical move of Cairo and Moscow. Either this is not the case, or Cairo was able to attain the upper hand in the Soviet-Egyptian relationship in the end. Undeniably, Egypt, the dominant regional power, left the Soviet side and turned toward Washington and the West in the mid-1970s. This policy change in Cairo culminated in the Camp David Agreement of 1979, which was followed by the establishment of diplomatic relations between Israel and Egypt in February 1982. ${ }^{34}$ Al-Sadat had recognized Israel as a state and thus - from the perspective of the rest of Arab world - had accepted Israel's existence, its policies, and given up the Palestinian cause. Egypt was isolated among the Arab states.

Moscow was quick to stigmatize its former ally by the Nile as a henchman of imperialism and develop a full-fledged argument in accordance with MarxistLeninist ideology. This position was integrated into the GDR's official reading of politics in the Middle East. The GDR's Institute of International Relations fully agreed with Moscow on the fact that Egypt "in fact had turned away from the Arab Front [and...] "had broken with the commitments of the Arab League. [...The Camp David agreement] had weakened the anti-imperialist alliance and opposed cooperation with the Soviet Union." ${ }^{35}$ Socialist commentators are quick to interpret the participation of the United Sates in the process of approximation between Egypt and Israel, as well as Washington's investment in the Middle East conflict in general, as solely motivated by self-interest. This stance is vividly summarized by the term "separate policy." 36 The quoted East German analysis directly links all violent conflicts in the region with this "separate policy," as it "had destroyed Arab unity," 37 e.g. the Lebanon War of 1982, and emphasizes the condemnation of this policy by the Communist and Workers' parties of Bulgaria, the ČSSR, Hungary, Poland, the USSR, and the GDR on November 25 in 1978.

This example illustrates how Soviet policies and activities regularly engaged a number of other Eastern Bloc states, most prominently the ČSSR, Hungary, Poland, and the GDR. As involvement in the Middle East increased, competition between

33 | Halliday reminds us of the connection between the Kremlin's fear of a U.S. American missile deployment in Turkey and the deployment of Soviet missiles in Cuba, Halliday, 2005, 125.

34 | Peace Treaty Egypt and Israel 1979, in: Jaeger/Tophoven (Ed.) 2011, 182f; Hourani, 2003, 504.

35 | Hänisch et al, 1982, 35.

36 | Ibid., 38.

37 | Ibid., 38. 
the states increased as well, for their prestige in the host country, their position among the other states of the Warsaw Pact, and above all, Soviet benevolence. Interestingly, the GDR pleaded for an improvement of the competitive situation in early $1978 .^{38}$ Regardless, it had become clear to Moscow that a coordinated strategy was needed to avoid further "friction losses" within its own ranks. In December 1978, the Committee of the Ministers of Defense of the Warsaw Pact ${ }^{39}$ put forward a draft on coordinated engagement with regard to military support according to "proletarian internationalism." About one year later, during the $12^{\text {th }}$ meeting of the Ministers of Defense, the states of the Warsaw Pact finally agreed on the basic principles of coordination for military relations with the Global South. ${ }^{40}$ During that time the vice-minister of defense of the USSR listed the focal countries of the Global South: Ethiopia, Vietnam, Angola, Afghanistan, Syria, Iraq, Libya, Algeria, and South Yemen. These efforts clearly not only reached the mentioned Arab states, but also had a certain impact on their willingness to cooperate: Only two years earlier, the leading parties of four of the enumerated states together with the Palestine Liberation Organization had announced a political merger as the "National Front" in the Tripoli Declaration of December $1977 .^{41}$

"Of the eighteen Arab states only one [...] was a full supporter of the Soviet Union, embracing the theory of 'scientific socialism' and modelling itself on the Soviet pattern of political and economic development." ${ }^{42}$

(Fred Halliday, a Marxist scholar of Middle Eastern Studies)

Why and how did one of the least significant countries in the Arab world become Moscow's closest ally in the region? One may say that in the end there simply did not exist any better options for the Kremlin. During the Ethiopian-Somali War, South Yemen served as a military shipping center, but also offered active support in the fighting. In the process, Moscow understandably lost Somalia's political trust and its naval base in Somali Berbera accordingly. The radical regime in Aden successfully replaced Cairo and Berbera as Moscow's new unofficial military

38 | NVA-General Theodor Hoffmann to Minister of Defense of the USSR Dmitri Fjodorowitsch Ustinov, February 21 1978, in: BArch, AZN 30552, BI. 14f, quoted in: Storckmann, 2012, 170. Hoffmann had been trained in the USSR and advanced to Minster of Defense of the GDR in 1989, Müller-Enbergs/Wielghos/Hoffmann (Ed.), 2000, 369.

39 | Protokoll 11. Sitzung Komitee der Verteidigungsminister TS des Warschauer Vertrages vom 4 bis 7.12 1978, Ost-Berlin, in: BArch DVW 1/71035, 318-357.

40 | Protokoll 12. Sitzung Komitee der Verteidigungsminister TS des Warschauer Vertrages vom 2 bis 6.12 1979, Warschau, in: BArch DVW 1/71036, sine pagina.

41 The Tripoli Declaration, 2 to 5 December 1977, in: Letter dated 5 December 1977 from the Permanent representative of the Libyan Arab Jamahiriya to the United Nations addresses to the Secretary-General, Annex, A/32/411, 6 December 1977, I; Halliday, 1990, 155.

42 | lbid., 126. 
stronghold in the region. ${ }^{43}$ This cooperation did surprise some observes of the time, but its roots stretched back some time.

The Kremlin's interest in the Red Sea had surfaced as early as the late 1960s. Unofficial support for the PFLOAG, ${ }^{44}$ a revolutionary group of the Arab Peninsula, started in 1968 and became official in $1971 .^{45}$ The PFLOAG was closely allied with Aden and aimed to overthrow the conservative rulers of the area, first and foremost those of its country of origin, Oman. The support of PFLOAG is a revelatory example for the long-term nature of Moscow's regional strategy in the Middle East. ${ }^{46}$ Soviet engagement was never direct and remained mediated, usually carried out by two levels of middlemen: On one level there were its closer allies, like the GDR. These allies implemented Moscow's policy as messengers to the second level of middlemen, in this case the PDRY. ${ }^{47}$ The second level then executed the mediated policy, which meant direct support of PFLOAG through training and equipment. The use of political henchmen was part of a "low-key strategy," used whenever Moscow wanted to be able to deny its active involvement. ${ }^{48}$ Soviet restraint in the mid1970 s is especially noticeable after relations with Cairo had started to taper off. Due to the evolving détente, Moscow acted carefully with regard to any support for revolutionary movements in the region, even with regard to the PLO and its liberation case against Israel.

The third phase of the Cold War in the Middle East, from 1974 to 1985 , saw the peak of Soviet influence in the region, as well as its subsequent decline of power. Despite the loss of its major ally in Cairo, Moscow went to great lengths to remain among the major regional powers by fostering old alliances and forging new ones. Meanwhile, Soviet interests switched from long-term involvement to "more immediate benefits. ${ }^{\prime 4}$ In the early 1980 s, Moscow could rely on the Ba'athist regimes in Syria and Iraq, both located near Soviet territy. Libya replaced Egypt as a

43 | Halliday, 1990, 204f.

44 | Popular Front for the Liberation of the Arab Gulf (PFLOAG).

45 | Halliday, 1990, 184.

46 I In the mid-1960s the Dhofar Liberation Front located at the Oman-South Yemeni border, changed its name to PFLO, Popular Front for the Liberation of Oman and again in 1968 to PFLOAG, Popular Front for the Liberation of the Arab Gulf. Chubin, Adelphi Paper No.157, 1980, in: The International Institute for Strategic Studies (Ed.), 301.

47 | The GDR Afro-Asiatic Committee of Solidarity was active in developing relations to the PFLOAG throughout the 1970s, in: Bericht über den Besuch des Ministers für Auswärtige Angelegenheiten der VDRJ, Mohammed Saleh Aulaqi in der DDR in der Zeit vom 1. bis 5.Februar 1972, PA AA MfAA C 156276, 61; Brehony, 2013, 77 and 81.

48 | Chubin, Adelphi Paper No.157, 1980, in: The International Institute for Strategic Studies (Ed.), 302.

49 | Yodfat, 1983, 115. 
close ally by the Mediterranean Sea and in Ethiopia and South Yemen the Kremlin had positioned itself around the Horn of Africa. Nonetheless, the high times of Soviet prestige and presence in the Middle East were coming to an end. Moscow's allies in the region, though loyal and determinate, for the bigger part were among the poorest, politically weakest, and most isolated in the region. Meanwhile, the Soviet Union began to face the first severe economic difficulties of its own, forcing Moscow to cut its developmental spending and focus on economically more beneficial investments. ${ }^{50}$ This withdrawal in engagement was officially explained by a policy change toward the Global South, but also toward the states of the Warsaw Pact. As a kind of "empowering policy," the Kremlin under Mikhail Gorbachev gradually sought to create a perception that it was loosening its grip on its dependent allies. This policy change was meant to firstly ease the economic and political burden created by its ideologically motivated policy and secondly to assure the U.S. and the West of Moscow's willingness for détente.

Half a decade earlier, Moscow had become involved in a conflict on its very own doorstep and paid a high price in trust and prestige among the Arab states. In Afghanistan, the Soviet Union had intervened on behalf of the radical regime. Shortly thereafter, the Iraq-Iran war broke out and complicated matters for the next decade, as Moscow was not able to openly support Iraq. In Afghanistan, the Kremlin was ensnared in a vicious war it could not win - a "bleeding wound" 51 for the Soviet Union in the Middle East - while internationally it faced an unsolvable dilemma, as Westad summarizes:

\begin{abstract}
“From early 1986 onwards, there was considerable tension between Gorbachev's basically Marxist understanding of Third World events on the one hand, and his wish for détente with the United States on the other. [...] The Americans wanted to see the Soviets begin to give in [with regard to Third World expansionism] before other bilateral issues could be solved." 52
\end{abstract}

When in 1988 the Soviet Union finally withdrew from Afghanistan, it was not only considered a defeat of Soviet Third World engagement at the time, but in retrospect can be considered the end of the Cold War in the region. ${ }^{53}$

Despite some preludes after the founding of the state of Israel in 1948, it was not until the Suez Crisis and the Six-Day War that the Cold War fully encompassed the Middle East and with it its major conflict, the Arab-Israeli dispute. Hence, when reconsidering Halliday's four phases, one may conclude that the region was quite important for the Cold War and vice-versa during the second and third phase, between the Suez Crisis and the decrease of Soviet involvement in the mid-

50 | Kanet, in: Greiner/Müller/Weber, 2010, 56 and 59.

51 | Gorbachev, XXVII CPSU Congress 1986, in: Westad, 2005, 371.

52 | Westad, 2005, 371.

53 | Kanet, in: Greiner/Müller/Weber, 2010, 58. 
eighties. ${ }^{54}$ During that time, the Soviet Union presented itself as a major, and at times as the dominant external actor in the region. While its activities were clearly motivated by geopolitical considerations of national security, the Kremlin included the states of the Middle East into its wider ideology as "national democratic" states or countries with a "socialist orientation" under the label of "anti-imperialist solidarity." Throughout its engagement in the region, the Kremlin aimed to distinguish itself as the guarantor of "security and sovereignty of all states of [the Middle East]," ${ }^{55}$ while condemning the United States' strategies as power- and interest-driven. And while Lenin's writings were regularly used to explain and justify this ideological approach to the Cold War in general and the Middle East in particular, Soviet statements accordingly were used as claims of truth by East German functionaries and analysts alike. ${ }^{56}$

Moscow's official reading of politics in the Middle East dominated the GDR's foreign policy approach throughout East Germany's existence as a separate state. Not surprisingly, the Kremlin's high times of engagement in the region from the 1970 s to the early 1980 s coincide with the GDR's most active phase in the Middle East. In the following section, the GDR's foreign policy activities in the Arab world, and sometimes in other countries of the wider Middle East, will be sketched, oscillating between the two major determinants of East Berlin's foreign policy, Moscow and Bonn. Based on the assumption that indeed there existed an East Germany "policy" toward these countries that deserves the label, decisive policyturns are pointed out, while sketching the emergence of new fields of engagement to support the above statement of a coherence between Soviet and East German levels of engagement in the region.

\section{The GDR's "Policy of Recognition" translated to the Middle EAst}

The GDR's room for maneuvering in the Middle East was sharply staked out by characteristics and actions of the Federal German Republic. However, the region turned out to be politically rather welcoming for East Berlin. In combination with the increase of political agency on the side of the Arab states as described by Halliday, ${ }^{57}$ this resulted in what Das Gupta considers the East and West German "race for the Third World's favor" ${ }^{58}$ in the Arab world. Bonn could not be as close to the Arab world as it might have wished and left certain gaps or at least room

54 | Halliday even states that as early as 1980 the bloc confrontation was supplanted by a regional contention, the Iraq-Iran-War, as the dominant conflict. Halliday, 2005, 100.

55 | XXVI. Party Congress of the CPSU 1981, in: Hänisch et al, 1982, 46.

56 | Lenin, Vol.22. 1959 (1960), 265 quoted in Hänisch et al, 1982, 44.

57 | Halliday, 2005, 98.

58 | Das Gupta, in: Wengst/Wentker, 2008, 132. 
for political maneuvering in the "Arab world" - more than in other regions in the world. The restraint on West German policy that created these gaps for East Berlin was the German-Israeli relationship: While Bonn's policy in the Middle East always had to balance between the Arab countries and the Jewish state, East Berlin's relations with Tel Aviv were non-existent until the mid-1980s. ${ }^{59}$ West Germany had accepted the responsibility as the "Third Reich's" successor in title which meant that it had also acquiesced to the moral, political, and financial obligations toward the Jewish people. In addition to that, the FRG's relationship with Israel became one of the major indicators of West Germany's metamorphosis in shedding National Socialism and militarism once and for all. As a consequence, any rapprochement to the Arab-Palestinian cause of Bonn conflicted with Israel's interests, endangered West German-Israeli relations, and with it, West Germany's reconciliation with its past. ${ }^{60}$

The GDR benefited directly from this West German dilemma: The SED leadership severed its connections to the past and introduced a foreign policy of "Marxist connotation." The SED leadership explicitly dissociated itself from Germany's recent history, including any responsibility for the atrocities of the National Socialist regime. This policy decision of East Berlin was justified by differentiating between the Jewish people and the State of Israel. Based on this presumption, East Germany denied all responsibilities for Israel as a state. Thus, the GDR simply rejected compensation payments demanded by Israel for suffered injustice until its very last months of existence. ${ }^{61}$ Ideologically, the separation between the people and state of Israel also allowed the GDR to brand Israel as part of the "imperialistic-antidemocratic West" ${ }^{\text {"62 }}$ and thus an adversary to peace and the self-determination of the Palestinian people. This policy move with regard to Israel was to become one of the few relevant political "advantages" of the GDR in the international sphere over the Federal Republic. Without the inherited responsibility for the political actions of "Nazi Germany," the German twin excluded the Holocaust from its anti-fascist interpretation of history. ${ }^{63}$

59 | On East and West German relations with Israel see: Meining, 2002, 269; Timm, 1997a, $25 f$.

60 | This was not about to change before the first tentative steps of the Arab-Israeli peace process of the early 1990s.

61 | First concrete steps had not been instated before spring 1989. Brief des DDRAußenministers, Oskar Fischer, an Ministerpräsident Hans Modrow über die Aufnahme diplomatischer Beziehungen zu Israel vom 15.Februar 1990, BArch/D04, Nr. 1549 and Ministerratsbeschluß über die Aufnahme diplomatischer Beziehungen der DDR zu Israel am 13.Juni 1990, BArch, DC 20, I/3-1991, in: Timm, 1997b, 587; 590 and Trigor, Yehoshua, Untenable position for the DDR, in: Jerusalem Post, May 7th, 1991; First talks had been held as early as 1974, in: Meining, 2002, 381.

62 | Zhdanov, Andrej, September 221947.

63 | Hartewig, in: Zuckermann, 2022, 56. 


\title{
2.1 East Berlin Turns from Tel Aviv and toward the Arab world
}

When the GDR officially turned away from Tel Aviv ${ }^{64}$ in 1956 , its new foreign policy approach clearly followed Soviet logic:

\begin{abstract}
"The struggle of the Arab people against imperialism and Israeli aggression is an integral part of the struggle between the forces of freedom and socialism on the one hand and international imperialism on the other. In this strategically important region, rich in oil, the growing national liberation movement and social progress cause the hatred of imperialists and oil monopolies. They conspire against this movement, unleash wars, and launch aggressive attacks. ${ }^{65}$
\end{abstract}

As a consequence, all the target countries of the GDR's early policies were led by strong leftist liberation movements. These were considered promising candidates for "socialist development" and either had already acquired or were striving for a leading role in the region. Clearly, East Berlin was hoping for international recognition in the Arab world. Even before the GDR gained formal international sovereignty in 1955, East Berlin had initiated first contact with Egypt, its major partner country in the Arab world until the early 1970s: By 1953 the GDR had already established a trade mission in Cairo. ${ }^{66}$ Two years later, the first visits by an East German minister to countries outside the Eastern Bloc were to India and Egypt. ${ }^{67}$ In 1958 Egypt was the first country to receive financial aid from the SED regime and in 1961 the GDR was the seventh-largest donor state to Cairo, though Western Germany ranked third. ${ }^{68}$ During these years, trade and cultural agreements were conducted with Egypt and Syria, followed by trade agreements with Lebanon and Sudan. After the downfall of the monarchy in Baghdad in 1958, Iraq became another focal country. Accordingly, it comes as no surprise that the "German-Arab Society" became the first East German Society of Friendship in $1958 .{ }^{69}$ These early contacts in the Arab world and East Berlin's reputation of advocating for "liberation movements" were combined to put forth an international image of the GDR as a "peace state." This image probably motivated several of these movements to turn to East Berlin for support, i.e., military equipment. After an early phase of aloofness to these requests, EastBerlin decided to get involved. The actual reasons for this policy change have not

64 | In December 1955 East Berlin rejected Tel Aviv's aide-mémoire that asked for redress, Meining, 2002, 257f; Also see: Timm, 1997, 25; 34f.

65 | Int. Beratung der Kommunistischen und Arbeiterparteien, Moskau, 1969, in: Kleines Politisches Wörterbuch, 1973, 561-565.

66 | Dok zur AP der DDR I, 1954, $505 f$.

67 | Dok zur AP der DDR Republik V, 1958, 279.

68 | Wippel, 1996, 17.

69 | Wentker, 2007, 55. 
yet been brought to light. Nonetheless, Moscow ordered the SED to act. ${ }^{70}$ In 1965 , the Ministerratsvorsitzende Willy Stoph assigned Foreign Minister Otto Winzer to draft a "fundamental resolution" on the support of the African and Arab peoples in their struggle of liberation with "non-civilian materials":

\begin{abstract}
“Any achievement of these peoples' struggle of liberation will have a positive effect on the anti-imperialist attitude of other African an Arab states. By supporting these liberation movements, the GDR will improve its position with the progressive forces in Africa and the Arab world and thus promote the rollback of Western imperialist influence. ${ }^{71}$
\end{abstract}

The Politbüro quickly followed suit. ${ }^{72}$ With this, the NVA, the Volkspolizei, ${ }^{73}$ and the MfS were ordered to sift through their stocks to find equipment to be sent to the GDR's "partner countries." Coordination, transport, and delivery were put in the hands of the MfAA and the MfS. Even though this directive appears to be quite specific, Storckmann rightly considers it an "indicatory decision,"74 which profoundly shaped the character of the GDR's engagement in the Global South. Furthermore he verifies the interdependence between military exports and the GDR's "policy of recognition" in the 1960 s. ${ }^{75}$ Accordingly, other decisions on military engagement followed, like military training and visits by military delegations. ${ }^{76}$

\title{
2.2 The Role of Anti-Semitism in the GDR's Middle East Policy
}

The Soviet position toward Israel had been muddled from the very beginning:

\footnotetext{
"Moscow had hoped to extend its influence on the young state of Israel, but was disappointed when Israel emerged as a democratic country modelled on the West: [In the early 1950s] Soviet foreign policy was turning away from Israel and more and more toward supporting and exploiting Arab nationalist movements."77
}

70 | Storckmann, 2012, 109.

71 | Otto Winzer and Willy Stoph, May 28 1965, in: BArch, DC 20/13001, BI.28-33. Also see: Storckmann, 2012, 108.

72 | Politbürositzung January 10 1967, Annex 5, in: BArch SAPMO, DY 30/J IV 2/2/1093.

73 | English: The People's Police.

74 | Storckmann, 2012, 109.

75 | Based on his analysis of documents and minutes of the Ministry of Defense and Gerhard Weiß, Storckmann, 2012, $123 \mathrm{ff}$.

76 | Storckmann names the exchange of military delegations in the early to mid-70s, such as the exchange of delegations with Syria, Iraq and Egypt in 1971, Storckmann, 2012, 113.

77 | Thomson, Gerald E., 1967, in: Ostow, 1990, 54. 
Arab anti-Zionism was a dependable link between the Arab world and the states of the Warsaw Pact. "Chauvinist Zionism," 78 Judaism, and the Jewish state were identified as and used to form a homogeneous opponent of the "just cause" of the PLO and the "Arab struggle."79 The SED was able to use this pivotal conflict in the region for its own ends. Regularly, East Berlin's struggle for existence against "imperialist Germany" was equated to the Palestinian fight for self-determination. This "policy of fraternization" against the "Washington-Bonn-Tel Aviv axis"80 included straightforward anti-Semitism ${ }^{81}$ and turned out to be an extremely fruitful and sustainable strategy for the GDR in the Arab world.

Over several years, the obvious focus on Israel by West Germany escalated to the severance of diplomatic relations by the majority of Arab states: When the actual extent of a West German-Israeli arms trade came to light in 1964, the new chancellor Erhard's prestige in the Arab world was substantially damaged. Naturally, East German representatives did everything possible to claim this diplomatic vacuum for themselves. In the same year, Egypt's invitation for Walter Ulbricht to visit Cairo as a Head of State was a spectacular example for an apparent ascendancy of the GDR in the international realm. ${ }^{82}$ For the GDR's population, the ostentatious reception of Walter Ulbricht "of course was a highlight. It was an official state visit with all the bells and whistles, " 83 remembers Fritz Balke, ViceConsul in Yemen's north from in 1969.

However, one has to consider Cairo's explicit fraternization with East Berlin a warning for Bonn rather than an actual commitment to the GDR: As a reaction to Ulbricht's visit, West Germany established diplomatic relations with Israel in May 1965 while ten Arab states terminated their diplomatic relations with Bonn in return. ${ }^{84}$ From East Berlin's point of view this should have been the straw to break the camel's back and ought to have led to the GDR's international recognition. But Nasser remained hesitant toward the establishment of diplomatic relations. Nonetheless, East Berlin's hopes for a final breakthrough and the "en

78 | Timm, 1997a, 24.

79 | Timm, 1997b, 395ff.

80 | The Egyptian newspaper al-ğumhurīya on Bonn's credit for Israel in September 1969, in: Neues Deutschland vom 2.0ktober 1969, S.7.

81 | Eckard, Gabriele, The GDR and Anti-Semitism?: A Comparison of Jan Koplowitz' Novel Bohemia, mein Schicksal (1979) and Horst Seemann's Film Hotel Polan und seine Gäste (1981), in: Shofar: 2008, 86.

82 | Blasius, 1998.

83 | Interview with Fritz Balke on May 232011.

84 | Compare Ludwig Erhard's speech on Germany's Near East Policy at the German Parliament on February 17 1965. Excerpt in: Auswärtiges Amt (ed.), 1989, 165; Also see: Gerlach, 2006, 48. 
bloc recognition by the Arab countries" ${ }^{85}$ remained high, but it took another five years of diplomatic "courtship" 86 by the GDR's diplomats in Egypt and Syria before the Arab states finally gave in. Until then, East Berlin could do nothing more than to live with the status of relations with these two leading states as it was. As a consequence, the GDR had begun to direct its efforts to the less powerful but possibly more receptive actors of the region - such as the two Yemens - and continued its incremental "policy of recognition" with new enthusiasm.

\section{The GDR and the Middle East dURing the "High Times of DIPLOMACY"}

Against East German hopes, the "wave of recognition" did not simply sweep over the Arab world: "Most of the Arab states [North Yemen among them] did not establish diplomatic relations before the 'Grundlagenvertrag' was signed in 1971." 87 However, in May 1969 the "breakthrough in international diplomatic arena" 88 finally was within reach. The radio channel "Free Europe," financed by the U.S. Congress, speculated about the visit of Iraq's foreign minister to the Soviet Union and East Germany in March: "[S]teps for the deepening of cooperation in political, economic and cultural fields" 89 might have been taken there. Kuztnetzov's discussion with PDRY President al-Sha'abi in June 1969 completes the picture: ${ }^{90}$ Even though Bonn had offered significant financial aid to Baghdad to prevent Iraq from recognizing East Germany, Moscow apparently was willing to offer at least as much.

Without doubt, the Kremlin's political and financial insistence played the major role in the last mile toward East Germany's recognition. In May 1969

“Foreign Minister Gromyko supposedly expressed that any further arms delivery by the Soviet Union [to Egypt] depended on the establishment of diplomatic relations with the GDR." 91

85 | Ibid., 330.

86 | Reinhardt, 1969, 331.

87 | Interview with Fritz Balke on May 232011.

88 | Miller, 1969.

89 | Gould, 1950.

90 | Vermerk über ein Gespräch des Genossen Kiesewetter mit dem sowjetischen Gesandten, Genosse K.P. Kusnezow, June 11 1969, in: PA AA MfAA C 1223/71, 67-71.

91 | Helwig, 1969, 894 and Instructions for the Soviet ambassador in Cairo, May 16th 1969, in: BArch SAPMO, DY 30/3524, 108-111, quoted in: Wentker, 2007, 285. 
In June, the SED was informed that "[T] he Soviet representation to the UN is working toward the diplomatic recognition of the GDR in collaboration with missions of other countries." 92 This included the PDRY, which continued to advocate for the GDR's membership to the UN. Thus, the Arab world indeed played its role to increase pressure on West Germany's "Hallstein Doctrine." A prime example is the case of South Yemen, as Chapter 10 of this book describes in greater detail.

After the "wave of diplomatic recognition," which had been building up since 1969 and reached full force after the signing of the "Grundlagenvertrag," the GDR's foreign policy did change in a profound way, transforming from its "policy of recognition" to a "policy of self-assertion." Accordingly, East Germany's policy toward the Middle East also was rather "continued by other means" than a radical breach. East Berlin explicitly built on its first decade of foreign policy making by keeping and even expanding its ideological focus. In 1974 the SED included the "support for anti-imperialistic struggle" around the world as introduced by its new constitution. ${ }^{93}$ The principle of "anti-imperialist solidarity" as a policy directive became centrally coordinated by a new commission of the Politbüro three years later. ${ }^{94}$ On the occasion of the XIth and also final Party Congress of the SED, Honecker explicitly included the continuation of the GDR's active support policy of "International Solidarity" toward the "liberated states" of Africa, Asia, and Latin America in their "struggle for peace and social progress" but also toward those people who were still in the middle of this "struggle." 95 This move toward central coordination of "anti-imperialist solidarity," and thus a comprehensive developmental strategy in the late 1980 s, not surprisingly coincides with Sovietled coordination for military relations of the Eastern Bloc with the Global South. ${ }^{96}$

From then on, East Berlin's foreign policy expanded and transformed significantly. The GDR's political coming of age followed its internal consolidation after the closure of the border in 1961 and coincided with a period of economic growth. This

92 | Vermerk über ein Gespräch des Genossen Kiesewetter mit dem sowjetischen Gesandten, Genosse K.P. Kusnezow, June 11 1969, in: PA AA MfAA C 1223/71, 67-71.

93 | Constitution of the GDR of 1968, Version October 7 1974, Art.23.

94 | Scholtyseck, 2003, 36.

95 | Bericht des ZK der SED an den XI. Parteitag der SED, April 17 1986, 41ff, in: Protokoll der Verhandlungen des XI: Parteitags im Palast der Republik in Berlin 17. bis 21. April 1986, Berlin (Ost), 1986; Protokoll Nr.23/87 der Sitzung des Politbüros, June 9 1987, BArch, SAPMO, DY 30/J IV 2/2/2224; Ordnung für die Koordinierung und Abrechnung der Hilfeleistungen der DDR gegenüber Entwicklungsländern, in ökonomischer Hinsicht weniger entwickelten sozialistischen Ländern, Beschlüsse des Sekretariats, Oktober 1988, in: BArch, SAPM0, DY 34/13551.

96 | Protokoll 12. Sitzung Komitee der Verteidigungsminister des Warschauer Vertrages vom 2 bis 6.12 1979, Warschau, in: BArch DVW 1/71036, sine pagina. 
translated into a new self-confidence, both within the Eastern Bloc and toward the international community of states. East Berlin became more active as part of Moscow's international strategies and policy making but also aimed to fill its new room for political maneuvering with own initiatives. Having its own case in mind, East Germany tried to emphasize the "right to self-determination" internationally and support movements and states following this principle. For example the GDR had been one of the first states of the Eastern Bloc to contact and establish diplomatic relations with the Palestine Liberation Organization (PLO) in $1969 .{ }^{97}$ Not only among the states of the Warsaw Pact did East Berlin position itself as Moscow's "junior partner." 98 The states of the Global South, first and foremost in Africa and the Middle East, also began to perceive the GDR as a confidant of the powerful Soviet Union. ${ }^{99}$

After international recognition, several of the countries of "socialist orientation" received a strategic "upgrade" by the GDR. These countries were supposed to follow a "socialist path of development" 100 and in the Arab world they accounted for about ninety per cent of East German trade with the region. ${ }^{101}$ However, most of the countries of "socialist orientation" were located in sub-Saharan Africa and thus the GDR's foreign policy focus moved away from its former major partners in the Middle East to provide more substantial support to Ethiopia, Ghana and Sudan. ${ }^{102}$ After the sixth conference of non-aligned countries in Havana in 1979, the GDR began to strive for "Treaties of Friendship" with states following a "socialist path of development"103 - a form of bilateral bond which had been reserved for the socialist states of the Eastern Bloc.

However, East German international recognition coincided with new challenges for the small country emerging from its relationship with the Soviet Union. Significant changes to the GDR's external economic determinants were caused by Moscow's inability to uphold the GDR's oil supply coupled with mounting difficulties of the GDR's economy. ${ }^{104}$ Both trends significantly affected East Germany's activities in the Middle East with regard to oil imports and arms exports to acquire foreign currency. And while the former can be considered a success, the latter cannot. To secure its energy supply, East Berlin had to develop new strategies, among them canvassing for alternative oil suppliers. Hence, it was a stringent foreign policy incentive to improve relations with oil exporting countries - most importantly the

97 | Maeke, 2012; Wippel, 1996, 29.

98 | Bock, in: Bock/Muth/Schwiesau, 2004, 235; Muth, 2000, 27.

99 | Bücking, 101.

100 | Wippel, 1996, 28.

101 | Wippel, 1996, 32.

102 | See for example: Schleicher/Schleicher, 1993.

103 | The East German Treaties of Friendship followed the Soviet model, for example East-Berlin's Treaty with Aden in 1979, in: Jemen (Demokratischer), Völkerrechtliche Vereinbarungen der DDR, 1987, 140-1.

104 | Wippel, 1996, 30. 
OPEC states. ${ }^{105}$ In the early 1980 s East Berlin tried to increase its foreign currency reserve without being detected by Moscow through the international trade company IMES. It worked in the greatest secrecy and in doing so was able to ignore East German foreign policy principles. Former Vice-Foreign Minister Winter comments: "I've always considered it problematic that questions of arms deals mostly were kept secret and lacked sufficient control. ${ }^{106}$ Regardless of this secrecy, a high number of IMES' business transactions simply turned out to be inefficient with a higher cost than revenue. ${ }^{107}$ All in all, the extremely pressing need for foreign currency and oil during the 1980 s created a "double standard" in East German international behavior. More often than not, pragmatic considerations overruled ideological principles, a characteristic which similar to Soviet "realpolitik" in the region. Also, this "double standard" challenged one of the major foreign policy strategies of the GDR in the Near and Middle East, the "strategy of the honest broker."

\title{
4. Means to an end: The GDR's Foreign Policy Strategies in the Arab Wortd
}

\begin{abstract}
"The imperialist countries aim to subvert and push back both the progressive development of some Arabic states and the anti-imperialist attitude and nonalignment-policy of most members of the Arab League. They exploit the discord among the Arab states and do not refrain from political, economic, and military coercion." 108
\end{abstract}

(The GDR's Little Political Dictionary on the Arab League)

For the most part, even analysts who acknowledge the existence of legitimate East German foreign policy refuse to speak of coherent East German policies or even strategies. Wippel argues that "[f]oreign relations never exceeded single strategies, as they were not merged into a long-term, coherent Near East and trade policy."109 Siebs, on the other hand, considers East German developmental policy a "provisional arrangement."110 According to him, the GDR's decision-makers tended toward spontaneous actions, especially after gaining international recognition, while they often ignored the official foreign policy decisions and concepts. In addition to that, there never existed a dedicated administrative unit, or budget for development policy, let alone a separate ministry. Nevertheless, Siebs' judgment concedes the existence of such a policy, albeit a provisional one. And indeed, the GDR did opt for

105 | Wippel, 1996, 30 and 32.

106 | Interview with Heinz-Dieter Winter July 32013.

107 | Buthmann, 2004, 22.

108 | Kleines politisches Wörterbuch, 1973, 499.

109 | Wippel, 1996, 6f.

110 | Siebs, 1999, 100. 
a comprehensive developmental strategy in its final decade. Part of this development was due to international pressure by the World Bank and the United Nations to present reliable data on developmental aid and technical assistance, but it also had become a pressing issue due to East Germany's economic problems.

In 1977 the Politbüro decided on the formation of a "Commission for the Developing Countries." 111 A decade later, this commission provided the Politbüro with a draft on the "results and efficiency of the scientific-technical cooperation of the GDR with the developing countries" and in October 1988 Gerhard Schürer, Head of the Planning Commission, presented a paper which aimed to incorporate developmental engagement into the GDR's foreign policy and trade policy. ${ }^{112}$ During the "last year of the GDR," its development policy also was a topic at the grassroots roundtable on democratization held in February 1990. This also included the emergence of the first truly non-governmental organizations in the field, the "Society for Solidarity in Development Cooperation" and the "Society for Development Policy." However, neither the concepts of the late SED nor the ideas of the newly emerging civil society actors were put into practice - time was running out for the SED regime, but also for the GDR itself. In October 1990, Bonn's Ministry for Economic Cooperation (BMZ) incorporated the GDR's aid program. "[F]rom then on, only those projects were to be continued which conformed to the development principles of the former West Germany." 113 East German foreign policy had missed its "window of opportunity" to develop and enforce a full-fledged policy toward the Global South by a hair's breadth.

However, and even though East Berlin did not implement a coherent foreign policy concept for the "developing countries" or the Middle East, ${ }^{114}$ dominant policy strategies toward the Middle East can be identified in retrospect. A big part

111 | German: Kommission für Entwicklungsländer, "to coordinate the economic, cultural, scientific-technical and non-civilian activities in the countries of Asia, Africa and the Arab world," in: Beschluß des Politbüros, Protokoll Nr. 49/77, December 20 1977, in: BArch, SAPMO, DY JI 2/2 1705; also see: Döring, 1999, 44ff.

112 | Bericht des ZK der SED an den XI. Parteitag der SED, April 17 1986, 41ff, in: Protokoll der Verhandlungen des XI. Parteitags im Palast der Republik in Berlin 17. Bis 21. April 1986, Berlin (Ost), 1986; Protokoll Nr.23/87 der Sitzung des Politbüros, June 9 1987, BArch, SAPM0, DY 30/J IV 2/2/2224; Ordnung für die Koordinierung und Abrechnung der Hilfeleistungen der DDR gegenüber Entwicklungsländern, in ökonomischer Hinsicht weniger entwickelten sozialistischen Ländern, Beschlüsse des Sekretariats, Oktober 1988, in: BArch, SAPMO, DY 34/13551.

113 | Howell, 1994, 320.

114 | The proposal to formulate a comprehensive concept among the members of the "Mittag Commission" had been declined in 1978, due to the lack of concepts for the individual countries. Möller, 2004, 40. 
of these were born of necessity to live and work with the strong competitor West Germany: Bonn's successful moves to keep the GDR in international isolation forced East German foreign policy personnel and SED functionaries alike to become creative with regard to their foreign policy strategies. Muth, for example, considers the GDR's activities in Africa "active, at times [even] innovative." ${ }^{\text {"15 }}$ The following subsection identifies three pivotal East German strategies toward the developing world and the Middle East.

\subsection{Toward Recognition: A "Strategy of Focus and Low-Profile"}

From $1959-63^{116}$ the GDR established a strategy to attain international recognition, labelled here as a "strategy of focus and low-profile." 117 The Hallstein Doctrine was meant to be overcome through modest but persistent steps, especially by the "third sphere" of the foreign policy apparatus, i.e., society and its mass organizations, while the GDR's resources had to be concentrated on a small number of selected countries. By working below official diplomatic channels, especially in countries of little interest for Bonn, East Germany aimed to initiate relations through personal connections and social groups. The most important vehicle for this strategy were the "progressive" and communist parties.

This strategy was especially relevant for the GDR's focal countries in the Arab world. ${ }^{118}$ Major actors, apart from parties and trade unions, were the Societies of Friendship, the Committees of Solidarity and, especially in North Africa, the Free German Youth (FDJ). ${ }^{119}$ On the ground these actors were supposed to be coordinated by the MfAA and the embassies. ${ }^{120}$ The GDR's foreign policy strategy in the Middle East and all over the "developing world" was complemented by propaganda dispensed by SED officials and its media whenever East Germany was present at international sports competitions, academic conferences, or economic exhibitions. ${ }^{121}$ Thus, any international activity in the international realm was considered political, as it could be used in the "struggle for recognition." On various occasions, such as sports events or business conferences and exhibitions, ${ }^{122}$ first

115 | Muth refers to Ulf Engel's and Hans-Georg Schleicher's monograph on the GDR's foreign policy in Africa of 1997, in: Muth, 2001, 27.

116 | Engel/Schleicher, 1997, 183f; See also Ch 8. The GDR and the "Arab World": A Small State's "Fill-In Policy."

117 | Von Bredow had described the GDR's performance during the negotiations of the CSCE-process as a "Iow-profile" strategy, Von Bredow, in: Equete-Kommission, Band VIII, 1999, 954.

118 | Wippel, 1996, 4.

119 | Interview with Heinz-Dieter Winter July 32012.

120 | Muth, 2001, 67.

121 | Bericht des ZK der SED an den V. Parteitag der SED, July 1958, in: Judt, 1998, 503.

122 | Judt, 1998, 503f. 
contact was supposed to be established through low-level relations between civil society organizations such as the "Societies of Friendship."

Previously, the "Societies of Friendship" had been centralized and connected to the one-party system as a "transmission" between party and society. From there it was only a small step to establish party relations between the SED and Marxist, socialist, or at least left-wing associations in the host country. Ideally, the "partner state" was already led by such a party or the respective party at least was aspiring to take over leadership. "Historic determinism" envisaged that these parties in the long run were to transform their society and political system toward first socialism and then communism. This policy of "one-party expansion" naturally was in accordance with the approach of Sovietization led by a vanguard party.

One of the two major determinants of East Berlin's foreign policy, Bonn's "claim of exclusive representation," forced East Berlin to establish and develop its international contacts below the governmental level and thus was an important trigger for the emergence of the GDR's "low-profile strategy." Combined with EastBerlin's limited economic resources, the strategy was complemented by a focus on certain selected countries to finally overcome the international limits of the GDR's foreign policy created by West Germany. As soon as diplomatic relations were established, the GDR was able to simply build on its "low-profile strategy" by connecting the "second" and "third sphere" relations between the parties and society actors with the "first sphere," the state and its government, through official bilateral agreements, such as agreements on scientific-technical cooperation or the "Kulturarbeitspläne."123

\subsection{Improving the Well-tried Concept of Focus: Ideological Reasoning and the Countries of "Socialist Orientation"}

East Berlin was somehow able to make a virtue out of necessity. Its "strategy of focus and low-profile" was further developed throughout the 1960 , especially with regard to concentrating foreign policy on a few select countries. The concept of "anti-imperialist solidarity" had been used as a moral coating for the GDR's policy toward former colonies and "developing countries" early on and included the support for the liberation movements in the Global South. ${ }^{124}$ Based on this logic of mutual solidarity between socialist countries, the SED expanded the strategy based on the Soviet concept of the countries of "socialist orientation." 125 These countries became prioritized due to their "ideological orientation," or rather the likelihood of their becoming a socialist state.

123 | Examples of this are South Yemen and Algeria. Interview with Heinz-Dieter Winter July 32012.

124 | Kowlaczuck, 2011, 262.

125 | Shearman, in: Shearman, 1995, 16. 
In the beginning, the SED did not offer its diplomatic personnel a specific definition for this category: "There was a huge discussion over the years about this term 'states with a socialist orientation.' Hermann Axen all of a sudden declared: 'These are the ones, these aren't."'126 The categorization of "developing countries" and thus also countries of "socialist orientation" had evolved over the years and after some time was defined officially. For example in the "Foreign Policy Dictionary" of $1980^{127}$ the countries of the world were categorized as follows: First, countries that had opted for a "capitalist path of development." These were of lower priority, as the GDR usually had not much to offer where Western states were involved. Second, countries where the struggle between left-wing or Marxist groups and "reactionary powers," that is "bourgeois," "capitalist," or powers of Western democratic orientation, had not yet been decided. And third, countries of "international importance," those following a path of "socialist orientation." For sure, this categorization of non-socialist "developing countries" partly was motivated by pragmatic considerations: The distribution of the very limited resources to promote the GDR's international recognition needed some kind of justification beyond economic interest.

Without doubt the countries of "socialist orientation" enjoyed the highest foreign policy priority among the "developing countries." ${ }^{128}$ In 1969 these were Algeria, Egypt, Iraq, Libya, the PDRY, Somalia, Sudan, and Syria. All of them also ranked high in foreign trade volume - except for the extremely poor states of Somalia and the PDRY. These two are not even mentioned in the East German Yearbook of Statistics. ${ }^{129}$ In the most comprehensive overview of East German foreign trade with the Middle East available, neither of the two is to be found among the first thirteen trading partners either. ${ }^{130}$ Nonetheless, Somalia and the PDRY verifiably received the same preferential treatment as the other focal countries of the Middle East and Africa inclined toward "socialist orientation." They were contrasted with those "developing countries" governed by a "national bourgeoisie" that were considered to be following some kind of capitalist path. Everyone else was grouped into the in-between states where "weak class structures" had not yet been able to induce socialist development. ${ }^{131}$ Two cases hovered somewhere between this last category and the countries of "socialist orientation" without being labelled as

126 | Interview with Wolfgang Bator, May 272011.

127 | Wörterbuch der Außenpolitik und des Völkerrechts, 1980, $153 \mathrm{f}$.

128 | Kanet, in: Greiner/Müller/Weber (ed.), 2010, 50.

129 | German: Statistisches Jahrbuch der DDR 1973 and 1979, Staatliche Zentralverwaltung für Statistik (ed.), Staatsverlag der DDR, Berlin (East), 1973 and 1979.

130 | The thirteen top-ranking destinations of East German trade with the "Middle East" between 1949-1989 are: Egypt, Algeria, Iraq, Kuwait, Lebanon, Morocco, Sudan, Syria, Tunisia, Iran, Turkey, and Afghanistan, in: Wippel, 1996, 44-46.

131 | Categorization of non-socialist "developing countries" in: Wippel, 1996, $19 f$. 
such. The PLO and Ethiopia both enjoyed a special status. The former on the one hand was not a state but gradually became more of an official partner, especially after it was granted status by the United Nations in 1974. The latter, on the other hand, clearly replaced Somalia as the closest partner not only of Moscow, but also of East Berlin, in the Horn of Africa after the Soviet pullout from Berbera in the late 1970 .

Most interestingly, among all these countries, South Yemen not only was grouped with the high-priority category of countries of "socialist orientation," it also topped the list of "solidarity spending." This kind of developmental aid at times was up to a half, of overall East German "developmental aid." 132 This clearly shows Yemen's significance in East German development policy. Between 1966 and 1984, the GDR spent about 248 million GDR marks on "international solidarity," 133 of which South Yemen received the biggest share with 94 million, followed by Vietnam with 48 million, Tanzania with 22 million and the PLO with 8 million. ${ }^{134}$ This categorization of the "developing countries" clearly had an impact on the shape of the GDR's foreign relations that should not be underestimated. Based on fundamental ideological principles of Marxism-Leninism, it turned into an inflexible dogma that could not be questioned ${ }^{135}$ - even after it had proven to be of little to no use with regard to possible success or failure of the GDR's foreign policy activities. In many cases the categorization led to East German investments beyond any political benefit for the GDR, with South Yemen being one of the most prominent examples.

\subsection{The Strategy of the Honest Broker}

"As opposed to the anti-Arab policy of the West German Republic's government which is supporting British colonial terror in Aden morally and materially, the GDR sides firmly with the people of Aden fighting for their right of self-determination." ${ }^{136}$

(MfAA official on April 8th 1967)

From the very beginning, the two Germanys had been proxy states of their allied superpowers and thus competitors. Bonn's integration into the capitalist Western hemisphere and affiliation with "imperialism" made it possible for the GDR to successfully promote its propaganda of the "German alternative" among

132 | For example Howell, 1994, 313.

133 | Each GDR citizen had to give 25 marks for solidarity purposes a month, in: Interview with Wolfgang Bator May 272011.

134 | Möller, 2004, 43. As Möller rightly remarks, Ethiopia paradoxically is missing in this list. Möller is referring to Monika Tanzscher's findings. Tantzscher, in: Timmermann (Ed.), 1996, 614.

135 | See for example Muth, 2001, 40.

136 | Public decl. by MfAA official on April 8 1967, DOK zur AP der DDR XV/2, 1970, $1026 f$. 
the post-colonial states. East Berlin skillfully marketed the GDR as a "better state" through its cultural and educational foreign policy and aimed to create a positive image among the public of its "partner countries." ${ }^{137}$ The other aim of this "public relations campaign" was to discredit the "other Germany." East Berlin emphasized Bonn's negative reputation to exploit disagreements between the Arab states for its own ends. This attitude can be found regularly in its party organ "Neues Deutschland." In 1969, the Algerian news agency APS commented on the changes of the Hallstein Doctrine: "Bonn's institutions appear to disregard the sovereignty of the countries of the Third World."138 Hence, at least some Arab countries considered the Hallstein Doctrine to have marginalized their very own sovereignty by dictating their preferred diplomatic behavior to the Arab world. This attitude of course came in handy for East Germany's campaign against West Germany.

Using the slogans of "anti-imperialist solidarity" once again, East-Berlin aimed to present itself as the more humane version of Germany to the states of the Global South and used this notion to justify its existence. When the GDR gradually accepted German separation, it began to focus on the principle of "peaceful coexistence" that locates the "struggle" of the two opposite political and social systems not with the military but rather in the field of economic and social development. The socialist scholar Werner Hänisch paints Europe as the "main battlefield for peace and international security [where] the confrontation of the two political systems"139 could be felt the most. He conventionalizes the "BRD" (FGR) as a symbol for the "aggressive policies of world imperialism" led by the United States of America. The GDR, on the other hand, in his view is indispensable for any solution of Europe's problems of security and cooperation, a "better Germany" that promotes "progress and peace."140 Hänisch's position does nothing more than summarize the regime's position on the matter.

Foreign trade also tied in with this "strategy of the honest broker." The GDR did not separate its foreign trade and development policy mostly because development policy was often used either for economic or political ends or both. ${ }^{141}$ This was the case in the Arab world, where the GDR's trade policy followed the "pattern of traditional North-South Trade": Finished products were exported, especially technical equipment and machinery, while raw materials were imported. ${ }^{142}$ Though East German products were mostly not able to compete in terms of

137 | Das Gupta, in: Wengst/Wentker 2008, 119.

138 | “Interesse für DDR wächst ständig,“ in: Neues Deutschland, Oktober 2 1969, 7.

139 | Hänisch, in: Hahn/Hänisch/Busse/Lingner, 1974, $209 f$.

140 | Hahn/Hänisch/Busse/Lingner, 1974, 44f.

141 | Wippel, 1996, 5.

142 | Wippel, 1996, 15. 
quality with products from other industrialized countries, and in particular West Germany, they were often priced competitively.

Foreign trade with "developing countries" was embedded in the wider framework of development. Developmental policies of the time usually meant a strategy based on investments, credits and technical assistance that were tied to conditions that benefited the donor nation. Despite the often fair conditions for the host states, ${ }^{143}$ the GDR used the concept of "tied credit" and "tied aid" just like any Western nation. Usually, this meant that the receiving country had to spend aid and credits on GDR machinery and expertise. Wippel suggests that credits were supposed to be repaid with profits obtained from these economic improvements financed by GDR capital. ${ }^{144}$ Nonetheless, the exchange of investment and finished products for raw materials largely characterized the GDR trade policy in the Global South in general and the Middle East in particular.

All in all, the GDR was able to offer a foreign trade policy which at times appeared to be more beneficial and thus attractive for the economies of postcolonial states: East Berlin was one of the few emerging industrialized nations advocating for the establishment of the "most-favored-nation clause," 145 while it also offered to barter in international trade arrangements significantly longer than other industrialized states. ${ }^{146}$ Where possible, "traditional North-South trade" evolved toward cooperation, for example in industrial production. East German foreign trade policy was complemented by "economic and scientific-technical cooperation," such as by providing tools meant firstly to enable the host countries to use and repair GDR machines and thus be able to sell them, and secondly to strengthen bilateral relations and generate trust. However, East Germany did not abstain from measures that exploited the recipient, either. Its policy toward the "Global South" by and large was not far off from Western liberal trade policies that the GDR condemned as "imperialist" and "neo-colonialist."

143 | Winter mentions governmental loans to Syria with only about $2.5 \%$ to $3 \%$ interest and a maturity of up to twelve years, Interview with Heinz-Dieter Winter July 32013.

144 | Wippel, 1996, 32f.

145 | The "Most-favored Nation Clause" guarantees that any trade advantage granted by one state to another has to be granted to any other state as well. The clause, for example, is valid among the GATT-states today. Socialist International Economic Policy aimed at the implementation of this clause for all of the WTO. Woll, 1990, 609ff.

146 | This traditional foreign trade approach is based on the direct exchange of goods and served the import-demanding economy of the GDR extremely well. Interview with Wolfgang Bator May 272011.

147 | Scholtysek, 2003, 36. 


\section{Conclusion: The GDR in the Midde East: A Showcase of East German Foreign Policy Strategies}

Interestingly, the East German policy change at the turning point of "recognition" is not only visible in the GDR's Middle East policy. The region itself is an excellent case study in which one can reconstruct a policy change that coincided with the replacement of Ulbricht by Honecker. The "strategy of focus and low-profile" had defined the intermediate goal to establish consular and general consular relations as the last step before full recognition. Even though in the early 1960 s there were only two countries from the wider Middle East fulfilling this requirement Algeria and Egypt - only a few years later it was obvious to the SED regime that the key to overcoming international isolation lay in the Arab countries.

\footnotetext{
"There were general consulates in several countries already which merely needed an upgrade [to become an embassy], for example in Syria, in Egypt. In addition to that we had commercial agencies in most Arab countries." ${ }^{148}$
}

The Middle East turned out to be one of the few fields where East Berlin was able to actively implement a foreign policy - not in spite of but due to the restrictive impacts of the Soviet Union and the Federal Republic. From the early 1960 s to the late 1970s, the two German states switched the main venue of their conflict to the developing world, that is, first and foremost the Arab states. ${ }^{149}$ While East Berlin passively stepped in wherever Moscow ordered it to, the GDR reacted proactively to West German restraints and gaps in international activities. Thus, the GDR's policy in the Middle East can be characterized as a "fill-in policy" between Bonn and Moscow based on the three major strategies of "focus and low-profile," "socialist orientation," and the "strategy of the honest broker."

Moscow's control of the GDR's internal and external affairs remained constant over this first phase of East Berlin's foreign policy. However, the GDR was granted a semi-sovereign status after 1955 and under Ulbricht's leadership seemed to have some voice in decisions concerning its "SED state" 150 and even Berlin. Ulbricht's policy toward Moscow can be characterized as active, though this did not lead to a self-directed foreign policy. Rather he tried to "incorporate the GDR's interests into the Soviet Union's policy."151 On behalf

148 | Interview with Fritz Balke May 23rd 2011.

149 | See Chapter 3. Analytical Approach: An Interdisciplinary Analysis of Foreign Policy on the "levels of engagement" and Muth, 2001, 31.

150 | Schroeder, 1999.

151 | Bonwetsch/Filitow, 2000, in: Scholtyseck, 2003, 96. 
of the Kremlin, ${ }^{152}$ the GDR had presented itself as the "peaceful" alternative to West Germany in the developing world. Its lack of diplomatic ties and international prestige made it appear to be an "honest broker" for the young nation-states in Africa, Asia and the Arab world. In addition to that, the GDR was able to distance itself from German history and heritage, while claiming the traditionally positive relations between Germany and the Arab world for itself. As opposed to Bonn, East Berlin saw no necessity to take into consideration interests or sensitivities of Israel, while it could rely on traditionally good relations between Germany and the Arab states. ${ }^{153}$ Thus, despite regular direct competition with the well-heeled FRG, the GDR was able to establish intensive relations with a number of "developing countries." 154 And even though it did not have comparable financial means at its disposal, Eastern Germany as a rising industrial nation during certain periods was able to offer attractive developmental aid through trade, technical support, educated personnel, and even certain monetary concessions.

Until the early 1980s, the Arab countries remained the major destination of foreign diplomacy and trade for East Berlin. Despite the extension of its foreign trade, the GDR's global economic involvement had intensified only modestly. Developmentally motivated trade and aid remained rather insignificant in comparison to other donor nations. ${ }^{155}$ Nonetheless, former short- and mid-term foreign trade arrangements grew into long-term foreign trade relations based on trade and aid agreements and East Berlin acquired more diverse trading partners. ${ }^{156}$ Even though many countries in the Middle East sympathized with the GDR, the decline of its status in the region was predestined. In the 1970s, East German foreign policy in the "developing countries" began to show its first cracks. After the specious prosperity during the last 1960 , major economic problems surfaced. East Berlin was often unable to fulfill its foreign policy promises. Technical projects in particular suffered from parts shortages in the GDR. Bator, for example, mentions "permanent difficulties" with deliveries "from home" to the flour mills in Libya. ${ }^{157}$ Similar problems were reported from South

152 | Compare relations to Egypt: "Abschluss eines Abkommens über den Handelsund Zahlungsverkehr mit Ägypten," March 7 1953, in: Dokumente zur Außenpolitik der Regierung der Deutschen Demokratischen Republik, 505.

153 | Compare Signing of German-Yemeni Communiqué, in: Dok zur AP der DDR III, 1956, 696.

154 | By 1979, not even a decade after the wave of recognition, East Berlin had signed over 50 governmental agreements with “developing countries," in: Möller, 2004, 43.

155 | Wippel, 1996, 5.

156 | Wippel, 1996, 30.

157 | Interview with Wolfgang Bator May 272011. 
Yemen. ${ }^{158}$ Furthermore, Scharfenberg reports on the planned sale of a cold-storage warehouse for potatoes in the mid-1970s. In the end a Danish company won the bid. It simply offered better conditions. ${ }^{159}$ As a result, East Germany simply was not able to compete with other economic actors for reasons that had nothing to do with its political standing and prestige. The scope of trade and aid it could offer clearly had its limits and the GDR remained a rather insignificant partner in foreign trade for the Arab states. Thus East-Berlin only remained attractive for those countries which lacked alternatives, such as South Yemen, which had been marginalized by its fellow Arab states.

158 | A motor from the oil mill had to be used to substitute the broken engine of the flour mill. Scharfenberg, 2012, 45.

159 | Scharfenberg, 2012, 45. 



\title{
CHAPTER 9. Forging a National Identity in Yemen's South:
}

Social Change between Foreign Interference and a Fragmented Nation

\begin{abstract}
"[Only about] a hundred years ago, the divisions of Arabia were expressed in loosely defined geographical terms - al-Sham, 'the North,' al-Yaman, 'the South,' [...] and in terms of ancestral origin. A particular region might have developed a cohesive cultural identity, as Yemen did early on, but there were no fixed borders. 'Territory equaled sphere of influence'; boundaries were as mobile as people." ${ }^{1}$

Tim Mackintosh-Smith, British Author living in Sana’a, Yemen
\end{abstract}

\section{ON the Relevance of Identities for this Study}

This chapter grapples with a regularly ignored aspect of foreign policy - the "receiving" side of the external actors' efforts, the host state. The analysis of South Yemen's society at this pivotal political turning-point of Yemen's modern history aims to overcome the tendency of similar case studies that often degrade the "host country" to a static structural element or passive "pawn" of the international "game." Only by taking into account the specifics of the "receiving side of foreign policy" and by including the "host" into the analysis as an autonomous actor, is assessment of the impact by internal and external influences on these societies, actors, actions and ideas possible. In turn, only then can the "limits of foreign policy" in theory and praxis be explored and understood comprehensively.

The political analysis of this chapter focuses on the struggle for independence in South Yemen in the late 1950 s and early 1960s - a time when new external actors expressed their interest in the British Crown Colony, most prominently the GDR and the Soviet Union. The radical National Liberation Front's main goal was

1 | Mackintosh-Smith, 2007 (1997), 30. 
consolidate the socio-politico preconditions needed to seize power and establish their idea of a Marxist state in accordance with the concept of socialist state- and nation-building. How and why did a revolutionary Arab regime adopt MarxismLeninism as their state ideology, even though there did not exist any other Marxist state in the region? The answer to this question is first detected in the emergence of a new political identity in South Yemen's urban center Aden, a highly dynamic social environment, and second in the changes of identities among the rural population of the "tribal space" in South Yemen. The following depiction of Yemeni society at the beginning of the GDR's involvement in the country is based on an approach to identities defined in terms of "spheres of influence" and "ancestral origin" ${ }^{2}$ and focuses on the overlapping, sometimes conflicting, sometimes mutually enhancing identities and how they stifled or enhanced social change by supporting or resisting internal and external forces. Thus, instead of merely describing the society "on the other end" of the GDR's international activities, the analysis interprets the findings in the light of the correlation between the "responsiveness of identities" and social change, as introduced in Chapter 3's "Analytical Approach."

To use "identity" as an analytical category in International Relations has become quite common over the last two decades and has even been integrated into a recent analysis of Yemen itself. Unfortunately, this analysis by Stephen W. Day "Regionalism and Rebellion in Yemen" approaches "identity" on the national level similarly to how Samuel Huntington applied the concept to the international level. ${ }^{3}$ For Day, "identity" is something static, resilient to internally or externally induced change. Based on his hypothesis of "Yemeni Regionalism," Day defines regional divisions as the decisive determinants of people's (political) identity ${ }^{4}$ in Yemen, as they are "far more significant than the relatively superficial northsouth boundary drawn by the British and Ottoman empires in the early 1900 ." This approach has to be rejected as oversimplified. ${ }^{6}$ First, even though Day rightly denies the north-south divide to be the major source of identification, the divide remains one of the most relevant sources of positive and negative political and social identification to this day. As Brehony has clarified in his narrative of the PDRY's history, before unification, the leaders of both Yemens always considered the North and the South as shatrayn, as two halves of one country that were supposed to unite one day.? Today, two decades later, only time will tell

2 | Mackintosh-Smith, 2007 (1997), 30. On the role of "origin" (Arabic: așl) with regard to tribal identities, also see: Dahlgren, 2000, 6.

3 | Huntington, 1993; 1996. For a critical account on Huntington's conceptualization of identity see: Salter, 2002.

4 | Lapid/Kratochwil (ed.), 1996.

5 | Day, 2013, 7.

6 | On the oversimplified nature of Stephen W. Day's approach see: Petouris, 2013.

7 | Brehony, 2013, Introduction. 
whether the recently re-emerged distinct southern identity can be reconciled with what some southerners today consider "northern occupation," integrated in a unified Yemeni identity. Thus, the "north-south divide" clearly has to be considered equally relevant as other codes of Yemeni identification. As shown in the sub-chapter "Identity, Nation-Building and Social Change" of this study, identities may not be perceived as unchanging constants that feed from only one source. Even artificially created social divides, like census categories or borderlines, may develop a meaning of their own, due to people adapting their to the reality of day-to-day circumstances, as shown by many studies concerned with "identity politics." 9 Thus, regional ties are an important determinant, but neither the only nor the decisive factor for a people's political identification. All in all, Day's understanding of "identity" simply appears to be to too rigid to include the multi-layered character of Yemeni loyalties.

The following chapter first offers an overview of the historic external influences relevant to modern Yemen's history and depicts the modern Yemeni nation-state as a consequence of both external intervention and internal Yemeni strife. Second, Yemeni tribal identities are contrasted with the emerging urban identity in the city of Aden, while illuminating the role of British presence during the change. Collective identities are characterized along three ideal types of collective identity coding as introduced by Eder et alia: "primordial, traditional and universalistic/ cultural." ${ }^{10}$ With regard to this approach, the major focus rests on the ambiguity between the overlapping "primordial-traditional" identity coding of the tribes on the one hand, and "universalistic/cultural" coding of an evolving urban population on the other. This division is identified as one of the major reasons for the emergence of a distinct identity of "the urban Adeni" in South Yemen as opposed to Yemeni tribal-regional identities. Accordingly, it is expected to produce an effective framework for interpreting the emergence of the only Marxist state in Arabia. The chapter lastly explores the impact of two supposedly contradictory ideological concepts, Arab nationalism and socialism, on the decisive political actors in South Yemen and how these concepts finally merged into, or rather were consumed by, Marxism-Leninism and its most fervent advocate in the Arab world, the National Liberation Front and future Yemeni Socialist Party.

8 | Dresch, 2000, 150.

9 | Nobles, in: Eisenberg/Kymlicka, 2011, 31-51.

10 | Eder et al., 2003, 25-34. 


\section{From Tribal lands to a Divided Yemen: A History of FOREIGN INTERFERENCE}

Before its unification in the early 1990s, Yemen had never been a "nation-state" in the modern sense. However, and as opposed to much of the Arab world, the concept of the "state" is not new or alien to Yemen, neither today nor in its ancient past. ${ }^{11}$ Landmarks such as the Marib Dam, which was built about 2500 years ago by the Sabateans, have served as sources of identification for

\footnotetext{
"those Arabs who trace their ancestry back beyond the time when nationalities were invented, to Qahtan, son of the Prophet Hud, great-great-grandson of Sam and progenitor of all southern tribes." 12
}

The political separation of Yemen's traditionally tribal society between 1962-63 and 1990-94, however, appended a new, artificial source of identification for Yemenis, induced by external interference in the region. The following section connects the geostrategic characteristics of modern Yemen to the motivations of the two powers that dominated the region in the past and, more or less, created this divide in Yemen: the Ottoman and the British empires. South Yemen's geographic position was the major reason that determined Ottoman and British interest and among the priority interests of the Soviet Union as well. Thus, this chapter begins with the "geopolitical" relevance of South Yemen and its "geographic identity."

\subsection{The Shared History of "Geopolitics" and International Relations}

Even though the term "geopolitics" has been radically redefined and reframed since the end of the Cold War, the idea that geographic factors determine power distribution in international relations remains a focal point in international politics. Introduced by Rudolf Kjellén in 1899, the term "geopolitics" swiftly became a trendy concept in international politics at the time. During and after WWI, "geopolitics" was established as the basic pattern of foreign policy strategy in theory and praxis, as it was regarded as one of the most comprehensive approaches to explain power politics. In its most radical interpretation, it was used to justify dominance and subjugation of peoples in the Global South by colonial powers and later emerged as a decisive analytical tool of foreign policy analysts under the German National Socialist regime. As a consequence, Atkinson and Dodds speak of a "shameful category"13 in the field of geography. Nonetheless, the interrelation of human geography and politics cannot be denied outright: A nation-state's endowment with regard to its geographic position, natural resources

11 | Ayubi, 1995, 4.

12 | Mackintosh-Smith, 2007 (1997), 30.

13 | Atkinson/Dodds, 2002, 1. 
and level of education does determine its scope of action in the international realm to a significant extent. The division between "hard" and "soft facts" of a country's availability of resources remains part of any analysis of foreign policy today, even without the explicit label of "geostrategic" factors. After the end of the Cold War, constructivists finally began to critically reframe a concept they regarded as overly static. Following Ó Tuathail, this study agrees that geopolitics "cannot be abstracted from the textuality of its use,"14 and thus includes geopolitical factors only in relation to their historical context and political relevance, interpreting them as a tool of foreign policy representations and justifications.

\subsection{Yemen's Geostrategic Relevance: Past and Present}

Throughout history very different external actors have shown an interest in the remote place that is Yemen. Over the past decade, the unified state has gained a reputation as a "safe harbor" for terrorism: Al-Qaeda seized the opportunity of increasing internal turmoil in the country and chose to establish a new foothold for itself in the Middle East. When the Saudi and Yemeni branches of al-Qaeda ${ }^{15}$ merged to form "al-Qaeda in the Arabian Peninsula" (AQAP) in 2009, ${ }^{16}$ public opinion and the media tended to interpret the rise of the terrorist network in light of Osama bin Laden's family ties to Wadī Hadramaut. ${ }^{17}$ Despite the symbolic meaning, the expansion of Al-Qaeda rather is in large part due to Yemen's geostrategic determinants. Al-Shishanī, a researcher of the "Emirates Center for Strategic Studies and Research" points out the worth of Yemen for al-Qaeda in $2007^{18}$ by referring to Syrian Abu Musa'ab al-Surī" s ${ }^{19}$ book, "The Responsibility of Yemenī People toward Muslim Holy Shrines and Wealth" of 1999. Apart from rugged, mountainous terrain, as well the seemingly infinte plains and deserts combined with weak infrastructure, for al-Surī the rebellious and martial spirit of the Yemeni people as well as their poverty is what distinguishes Yemen as "a

14 | Toal (Ó Tuathail) 1996, 65.

15 | Transcription: al-Qā'eda; English: The Basis.

16 | Masters/Laub, 2013.

17 | Arabic: Wadī Ḩaḍramaut. Bin Laden's father Muhammad bin Awad bin Laden was born in "Wadi Douan in the Hadhramawt [sic!]" and moved to Saudi Arabia in the 1950s, in: Bin Ladin [sic!] family and Usama bin Laden, in: Burrowes, 2010, 56.

18 | Al-Shishani, $17^{\text {th }}$ of January 2013, in: The Emirates Center for Strategic Studies and Research.

19 | Abu Musa'ab al-Surī' writes under the pseudonym of Omar Abdul Hakeem. Al-Surī was released from Syrian prison in February 2012. He is known to be one of the main advocates of "leaderless jihad" that demands the formation of cells without linking up with al-Qaeda's global network. He currently is considered one of the most influential ideologists of alQaeda and other jihadist movements, see: Flade, in: Die Welt, 14th of February 2013; On al-Surî's background also see: Said, 2015, 35-44. 
strong natural bastion for the people of Arab Peninsula, if not for the whole of Middle East." ${ }^{20}$ A fellow-traveller of bin Laden since the 1980 s, al-Suri currently is considered one of the most influential ideologues of the network. The impact of his comments on Yemen's potential as a long-term base of operation for al-Qaeda must not be underestimated.

While the "soft facts" of Yemen's geostrategic position play an equally important role for al-Qaeda today as the "hard facts," earlier power actors were almost exclusively interested in Yemen's geographic position between Europe, Africa, and Asia. Both before and after the dawn of aviation, the southern tip of the Arab Peninsula provred to be a key economic and military outpost due to its strategic location near the Bab al-Mandab, the gate to the Red Sea on the western coast of the former YAR. In addition, it boasted, in a perfect location, a natural port in the south - Aden. ${ }^{21}$ Once called the "eye of Yemen" ${ }^{\text {"22 }}$ and to this day the major urban center in the south, Aden presents itself as "a magnificent natural fortress:" The town center is nestled within the crest of an inactive volcano, almost fully surrounded by a semi-circle of mountain slope and rock-face which gave the downtown its name, "Crater." From the ocean, the entry to the port is guarded by a second volcanic peninsula, home of "Little Aden," and the rocky Sirah Island, ${ }^{24}$ almost blocking the settlement from view when approached by sea.

The eye of the Ottoman Turks eventually fell on the green and humid coastline south of the holy sites of Mecca and Medina ${ }^{25}$ from which coffee, the "black gold" of the highlands, was shipped to Europe. After landing in Moch by the Red Sea in $1526,{ }^{26}$ the Ottomans were able to fight their way east until the Yemeni imam's son halted their expansion at the mountain stronghold Thula. From that point on, the northern Yemeni highlands remained a continuous nuisance for the Ottoman Empire. The costs of upholding Ottoman rule near the Yemeni tribes almost exceeded the benefits of access. Nonetheless, Yemen's produce and its coastline appeared to be too valuable for the Ottomans to give up - even after the

20 | Al-Shishani, January 17 2013, in: The Emirates Center for Strategic Studies and Research.

21 Shaharam, Adelphi Paper No.157, 1980, in: The Int. Institute for Strategic Studies (Ed.), 301; Linde, 1987, 1.

22 | Burrowes, 2010, 10.

23 | Gavin, 1975, 2.

24 Aden, Aden Colony and the Port of Aden, in: Burrowes, 2010, 10.

25 | Ottoman expansion to the holy sites of Islam under Selim I, in: Houarani, 2003, 283f; Karpat, 2000, 241ff; Peri, 2001, 45.

26 | Masters, Bruce, "Yemen and the Ottoman Empire," in: Ágoston/Masters, 2009, in: Modern World History Online. 
British decided to secure the port of Aden for the Crown and thus limit Ottoman expansion to the south. ${ }^{27}$

\begin{abstract}
"My British colleague asked me why Aden was important for the GDR. According to him, there was not much to gain apart from stones. I answered with yet another question: What had Great Britain hoped to gain there for over 130 years [of their occupation]?"

(Günther Scharfenberg, East German ambassador to the PDRY from 1972 to 1978)
\end{abstract}

The English East India Company was the first to set foot on future British soil, long before any troops were to arrive. In 1609 the Company landed in Ottoman $\mathrm{Mocha}^{28}$ and about two centuries later, London officially expressed its interest in the Crater and the surrounding hinterland: "As early as 1825 the British ConsulGeneral [...] had begun warning Muhammad Ali Pasha ${ }^{29}$ against interfering with Aden." 30 Gavin, who published one of the most detailed works on the British presence in southern Arabia prior to 1959, suggests that the Ottoman expansion to the Bab al-Mandab probably had not been of great concern to the British, "[b]ut the establishment of a first-rate power so near to India as Aden" ${ }^{31}$ would have posed a major threat to British trade routes. Furthermore, a refueling station between Suez and Bombay at the time was desperately needed and thus British economic interests coincided with regional power politics. In January 1839, "[t]he British flag was hoisted and Aden became the first colonial acquisition of Queen Victoria's reign." 32 The British had arrived at the Bab al-Mandab.

The expansion of the Ottoman sphere of influence in the northern part of Yemen in 1872 was followed by an agreement with the British on separate spheres of influence that was set at the "Anglo-Ottoman line" of 1904, the future demarcation between North and South Yemen. ${ }^{33}$ Clearly, the Crown had no interest in the allowing the Ottomans, the other major foreign power in the region, too establish themselves too close to Aden - not least due to the opening of the Suez Canal in 1869 . However,

27 | Kuehn, 2011, 9; 46.

28 In 1728 the Sultan of Lahj separated his territory including Aden from Zaidi influence in the north, and about a century later the British East India Company was able to establish intense economic relations. Blumi, FN 8, in: Al-Rasheed/Vitalis, 2004, 115; Faroughy, 1947, 50; Mackintosh-Smith, 2007 (1997), 31; Willis: in: Al-Rasheed, 2004, 121.

29 | Muhammad Alī Pasha had been Wāli (Governor) and self-declared Khedive (Eng. Viceroy) of Egypt and is considered the "founding father" of modern Egypt. See: Fahmy, 2000 (1998), esp.179 and Dresch, 2000, 9.

30 | Gavin, 1975, 26.

31 | Ibid., 26.

32 | Ibid., 1.

33 | Burrowes, 2010, 275; Ismail/Ismail, 1986, 11; Koszinowski, Thomas, Jemen, in: Nohlen/Nuscheler (ed.), 2003, 366f; Mackintosh-Smith, 2007 (1997), 31. 
London did not have to worry about the Ottoman Empire's influence in the region for long. The Ottoman reign in Yemen never fully penetrated the country to begin with ${ }^{34}$ and early in the $20^{\text {th }}$ century the Ottoman Empire gradually disintegrated due to power struggles within. Muhammad Ali Pasha and his successors in Egypt ascended from a mere nuisance to serious competition for the central power of the Ottoman Turks. Over time Egypt gained relative autonomy from Ottoman central rule and in combination with secessionist movements motivated by ethnic, religious, and political differences between rulers and ruled all over the Ottoman territory, the Ottoman Empire gradually fell apart.

In the Empire's weakest hour, Zaidi Imam Yahia gained independence for his Mutawakilite Kingdom of Yemen ${ }^{35}$ and in doing so, definitively laid down the boundaries between north and south in 1934. The Zaidi teachings legitimized Yahia's reign based on his ancestry to the Prophet Muhammad ${ }^{36}$ and depictions of him as "the embodiment of Prophetic authority by means of erudition and symbolic acts centering on prayer, generosity, and the banishment of evil." ${ }^{37}$ As a consequence, Yahia, the religious leader of one of the oldest Shiite dynasties, was able to fight the foreign invaders with the support of the legend of the rightful ruler defending against illegitimate occupation. ${ }^{38}$ To secure the status quo, Yahia then followed a path of extreme conservatism. The King's authoritarian style of leadership left little room for any social change in his realm. Over the decades Yahia had thoroughly prepared his son Ahmad as his successor ${ }^{39}$ - even though Zaidi rule traditionally had not been legitimized through direct lineage, but through the combination of political merit and noble ancestry from the family of the Prophet.

After Yahia was assassinated in old age, people hoped for a leader more open to the outside world. Ahmad, however, followed his father's well-trodden paths: the father had tried to seal off his realm from outside influences while simultaneously upholding a Schaukelpolitik between Washington and Moscow. The son followed the same strategy. After Ahmad had renewed the trade agreement of 1928 with the Kremlin in $1955^{40}$, the Yemeni Kingdom received substantial financial aid and

34 | Faroughy, 1947, 51; Ismail/Ismail, 1986, 11.

35 | Arabic: zayIdI; Imām al-Hādt Yahiā 'ibn al-Husein; al-mamlaka al-mutawwakiltya al-yamanīya.

36 | Arabic: Muḥammad.

37 | Vom Bruck, 2005, 1.

38 | For more details about the back and forth between the Ottomans the British, and the various rulers between the coast and mountain area during WWI and after see: Dresch, 2010, 11 and 28

39 | Arabic: Aḥmad. Dresch, 2000, 44.

40 | Braun, 1981, 35. 
probed possible relations with the GDR ${ }^{41}$ After a short intermezzo as a member of Egyptian Nasser's United Arab Republic (UAR), Ahmad feared he would be overpowered by Cairo's new strength and again put out feelers to the "West." ${ }^{\text {"2 }}$ In doing so, the Kingdom managed to maintain the necessary distance from both sides of the Cold War while keeping the social changes in Aden at bay. In the meantime, Ahmad tentatively initiated minor structural reforms to soothe public opinion while upholding the country's isolation. But he clearly underestimated the political changes taking place in the region and their impact on the Yemeni people. Baby steps seemed to accelerate political events by adding to the pressure within the tight limits of Ahmad's control. Numerous murder attempts demonstrate the widespread dissatisfaction with his reign and monarchy.

When Imam Ahmad finally died of natural causes in September 1962, his son al-Badr was not able to prevent the "Free Officers" under Abdallah al-Sallāl from seizing power through a military "coup d'état." The short-lived imam fled the scene and mobilized supporters of the Zaidi lineage. What followed were five years of civil war between republicans and royalists backed by Nasser's Egypt and the Saudi kingdom until Cairo's defeat in the Six-Day War of 1967 forced Egypt to agree to a mutual withdrawal. Naturally, the years of ongoing war in the north had a significant impact on developments in the south: In fall 1963 , violent resistance against British occupation erupted and in the end forced a British pullout four years later.

\section{Determining a Yemeni identity in the South}

In their introductory chapter on South Yemen's social structure, Ismail and Ismail emphasize its complexity and the diversity of its origins and rulers in a land that had always attracted external interest, but upheld its isolation due to the "rugged nature" of both the terrain and its people. However, the two authors also identify "a common denominator running through the complex social history of South Yemen [...] - the network of kinship, clan ties and social identity known as tribalism. ${ }^{343}$ The following chapter aims to identify the major characteristics of

41 | Besuch des Kronprinzen des Königreichs Jemen 1956 in 0st-Berlin, in: Kronprinz des Königreichs Jemen, Emir Seif el-Islam Mohammed el-Badr, vom 25. Juni bis 2. Juli 1956 in Berlin, in: DzAP der Reg der DDR III, 1956, 687; Besuch des Ministers für Post-, Telegrafenund Telefonwesen des Königreiches Jemen, Qadi Abdulla Ben Ahmed el Hagri, 1961, in: Chronik, in: DzAP der Reg der DDR IX, 1962, 452.

42 | Hare (Kairo) an State Department, 19.3.1959: FRUS 1958-1960, XII, Nr. 368, in: Berggötz, 1998, 311.

43 | Ismail/Ismail, 1986, 5. The authors describe three social strata: the tribal units, the "religious sheikhs and town-dwelling tribesmen," and the "masakin," the poor. Ismail/ Ismail, 1986, 7f. 
this "common denominator" while keeping in mind the problematic nature of the term "tribalism." 44

\subsection{On the Significance of Tribalism in a "Modernizing" Society}

The gradual separation between north and south that began in the mid-19th century $^{45}$ and culminated in the founding of two separate states in the 1960s did little to separate the tribes ${ }^{46}$ and tribal federations from their political affiliations. Nor did it affect the tribes' status as sources of identity. Even during the late years of President Saleh's presidency in unified Yemen, the Yemeni media coded national identity in tribal terms with state officials wearing traditional tribal dress or embroidering their political campaigns with their tribal affiliations. Today, tribal identity tends to blur and mix under urban influences such as TV programs, lifestyles, and the latest fashions. Nevertheless, the use of tribal esthetic markers ${ }^{47}$ has intensified in towns and cities even by those who were not formerly defined as tribal. ${ }^{48}$ Notwithstanding today's conflicts between the competing political groups, they seem to agree on the ideal of a self-determined Yemeni state, while tribal identity serves as the main point of reference in creating contextual cohesion. Before the founding of the two nation-states, approximately ninety percent of the Yemeni population were considered tribal and with some exceptions most urban Yemenis still cherish their tribal affiliations. However, this inclusion of supposedly "traditional" markers and values into more modern ways of living by no means has to be an irreconcilable contradiction. This study rejects a conceptualization of "tradition" and "modernity" not as opposites or a dichotomy to be found in their pure form, but rather understands them as "complementarities." "Tradition" and "modernity" are perceived as sources of identification that feed a continuous and "intense struggle between various ideas of modern and tradition." Thus, a diversity of many "moderns" and "traditions" in society is imaginable, just as Dahlgren describes Aden in the early 1990 s as a "fusion of traditional and modern." 49

44 | On the emergence of a "modern Yemeni identity" also see: Weeden, 2004, in: AlRasheed/Vitalis, 2004, 275.

45 | For a brief introduction to the division of the country between the Ottoman Empire in the North and Great Britain in the South see: Dresch, 2000, 11.

46 | Arabic: qabā'il.

47 | Also compare Adra, 2012, 66.

48 | Adra, 2010, 55.

49 | Dahlgren, 2000, 2. Dahlgren refers to Eickelman and Piscatori's argument of 1996 that "a sharp division between tradition and modern oversimplifies a complex process of interaction in a society where religion and tradition coexist with economic development and elements of modern culture." 
Tribal identities somewhat "miraculously" survived military nationalism in the north and social nationalism in the south. They are currently experiencing a political revival in the insecure milieu of the post-Saleh era. Ayubi clearly agrees with Gellner:

\begin{abstract}
"The importance of studying tribalism in Arabia and the Gulf is not only warranted by the significant demographic and economic weight nomads [and sedentary tribes] still represent in some of these countries, but because of its at once surviving, but changing, social and political significance." 50
\end{abstract}

Ayubi rejects the anthropologic depiction of tribes as "isolated" units, sealed off from modernization and thus from social change by external impact and introduces two counter-arguments: First, Arab tribes rely on strong social interconnectedness due to the wider "socio-economic activities [...] of the surrounding social space." Second, "tribalism as a 'state of mind,' as a set of values, and as a pattern of social organisation" may of course be influenced by modernization, but can have an impact on "new and presumably 'modern' structures" in return. ${ }^{51}$ Ayubi's arguments support the "responsiveness-of-collective-identities hypothesis" introduced in Chapter 3 of this book. He depicts tribal identities as mutable under external influences, while claiming a meaningful social impact of their own. The following section discusses the "boundaries," "codes," and values constructing qabyalah, the conceptualization of tribal identity in Yemen, and how British colonial rule became the decisive source for identity change in the country's modern south.

\title{
3.2 Politics and Qabyalah: The Tribe as a Political Unit
}

"[T]ribes may or may not be cultural units, [...[ they certainly are political ones." ${ }^{52}$

Any definition of the tribe as a social entity, be it among anthropologists, historians or sociologists, is sure to be challenged. ${ }^{53}$ As the category of the "tribe" has been used for a wide range of social entities in place and time, this disagreement won't be solved in the near future. Nonetheless, the term offers classification of the basis of social structures in Yemen like no other, especially in relation to "modern state formation" there. This analysis understands a tribe first and foremost as a "social unit" and a "pattern of social organization" ${ }^{44}$ complemented by a political and

50 | Ayubi, 1995 (2006), 124.

51 | Ibid., 125.

52 | Ibid., 125.

53 | Tapper, 1990, 50; Lewis, 2014, 15.

54 | Ayubi, 1995. (2006), 125. 
a military dimension. ${ }^{55}$ For the tribes in South Yemen a territorial reference is added, as the regions have become closely connected with certain families.

However, the tribe as a social entity in Yemen goes beyond this basic approach. Yemeni tribal identifications are embedded in complexhistorically grown dependencies and as the dominant form of social organization, the "tribe" encompasses all spheres of social life. All over Yemen tribal customary law regulated - and still regulates rights and obligations of the tribe as well as their relation to the city dwellers. ${ }^{56}$ Without doubt there do exist profound differences of certain customs and rules between the Yemeni tribes, most of all between those of the north and those of the south. But as Ayubi points out, "tribalism" can be regarded "as a 'state of mind', as a set of values, and as a pattern of social organization" 57 that suggests the hypothesis that - despite change over place and time - major identity markers that the various Yemeni tribal identities had and have in common do exist. ${ }^{58}$

Today's rules of political conduct in Yemen remain strongly influenced by “tribal ways." 59 For the most part, tribal identities have mostly been shaped positively, as the coding relied on what a certain tribe had in common as a community. These shared codes also constructed tribal identity negatively by forming the boundaries against the neighbouring tribes. To operationalize tribal identities in Yemen, this analysis follows Eder's three ideal types of collective identity coding. ${ }^{60}$ First and foremost, Yemeni tribal identity is coded "primordially": A tribe dates back its lineage to one or several shared ancestors. In the case of the tribes and clans in the south of Yemen, this ancestor is Qahtan, ${ }^{61}$ who is regarded as the ancestor of the southern Arabs or oftentimes referred to as the "true Arabs." ${ }^{2}$ The concept of the "true Arabs" serves as a unifying construct for "southern Arabia" to this day. The Qahtanis ${ }^{63}$ traditionally reject religious or ethnic supremacy of the Hashimis, ${ }^{64}$ who are part of the Adnani tribe, which can be found in the north and a few towns in the south. However, the distinct tribes in the south cannot be considered closed social or religious classes. Intermarriage between tribes has always been allowed.

55 | Adra, 2010, 86

56 | Arabic: 'urf and adah, see for example: Dahlgren, 2000, 6; Lewis, 2014, 21.

57 | Ayubi, 1995. (2006), 125.

58 | Al-Dawsari, 2013.

$\mathbf{5 9} \mid$ For a current analysis on the relationship between state and Yemeni tribes, see: Lewis, 2014.

$60 \mid$ This analysis will elaborate on the different characteristics of the typology in more depth.

61 | Arabic: Qahtān.

62 | As opposed to Adnan who is believed to have fathered many of the tribes in the north. The Adnani tribe is regarded as the origin of the Quraǐš, the tribe of the Prophet Muhammad to whom the ZayTdTs trace their ancestry, in: Stookey, 1982, 3. Also See: Ismail/Ismail, 1986, 7f; Manea, 2010, 4.

63 | Arabic: Qaḥtānīs

64 | Arabic: Hašīmīs. 
There clearly is more to tribal membership than just kinship: the abstract "blood relationships" ${ }^{15}$ of the tribe are regularly confirmed and contextualized by concrete "local traditions and civic practices" $"$ that allow them to take over political roles.

The south today is still dominated by tribal confederations relying on the fertility of tribal land, most of them peasants who boast an ancient history of agricultural civilization. Private land ownership regularly was and is restricted to cultivated land: "pasture land is shared by residents of a village, and water for domestic use is accessible to all." ${ }^{67}$ Tribal territory is the basis for the tribes' social status ${ }^{68}$ in accordance with the Arab proverb "Your land is your honor." ${ }^{69}$ The status of the southern tribes traditionally was defined in contrast to the city dwellers, the religious elite, merchants, and craftsmen. This status rested on their two prominent abilities derived from the territorial character of these tribes: farming and warfare.

For these tribes, warfare and agriculture depend on each other. Every large stretch of cultivated land is well-fortified with guard towers, and tribe members have a responsibility for not only the lot but all tribal land. ${ }^{70}$ Warfare is still considered a part of daily life in Yemen. There is no generation that did not experience war on a larger scale, not to mention the countless local feuds that can be dated back decades, sometimes centuries, erupting in some regions as street fighting or spontaneous shootings on a regular basis. Nonetheless, these occurrences bring to light the most decisive feature of tribal identity: personal and tribal honor. Tribal customary law, which refers to pre-Islamic practice, traditionally obliges the tribes to protect the urban population of those cities within their domain as well as the connecting pathways. ${ }^{71}$ This obligation has survived to this day, as shown during the upheavals in 2011-12. ${ }^{72}$

"The notions of a single place called "al-Yaman" and of one Yemeni people are old ones. [...] In addition, Yemenis have a sense of a shared history and are inclined to define themselves in terms of a vaguely recollected past greatness. [...] At the same time, most Yemenis equate being Yemeni with being Muslim.

65 | Eder et al., 2003, 36.

66 | Eder et al., 2003, 36.

67 | Adra, 2010, 71.

68 | Whereas water rights regularly define the actual property rights over land, in: Lichtenthäler, 2000, 144ff.

69 | Arabic: ārḍaka ¿arḍak.

70 | Dresch, 1993, 334.

71 | Oftentimes cities were declared "designated sanctuaries (hijrahs) where violence was prohibited. Tribes still tend to avoid warfare within dwellings, in: Adra, 2010, 85; Also See: Ismail/Ismail, 1986, 5.

72 | Al-Dawsari on the role of “Tribal Governance," in: Al-Dawsari, 2012; Lewis, 2014, 4. 
The Islamic nature of Yemen and Yemenis is implicit and is assumed to be in the nature of things." 73

(Robert D. Burrowes, Historical Dictionary of Yemen)

Despite the differentiation between tribes and tribal federations, all tribes north and south share a mutual feeling of being Yemeni. As Burrows rightly summarizes: "The notions of a single place called 'al-Yaman' and of one Yemeni people are old ones." ${ }^{74}$ Historic references and cultural commonalities are connected by belief and language. In terms of Eder's categories of identity coding, the belief system of Islam adds a "universalistic" dimension to Yemeni identity, shifting the ultimate source of identity to the transcendent realm. Overlapping with what can be considered the "traditional coding" of identity, the religious practices of Islam are shared by all tribes and, at least in the south, these are not crossed by sectariaan divides. ${ }^{75}$ In addition to that, the tribal and local dialects are very close to classic Qur'anic Arabic and thus Yemeni tribes share an understanding of "high Arabic," the basis for written standard Arabic. ${ }^{76}$ In conclusion, common ancestry, tribal structures, and the similarity of customs and codes have provided the often competing Yemeni tribes of both north and south with a shared social framework, a "lowest common denominator" valid all over Yemen until modern times.

\title{
3.3 Defining against the "British Other": Who is "the Urban Adeni"?
}

\author{
"A visitor to Aden in that period [of the 1950s] had the impression that Aden was \\ an alien city in Arab country." 77
}

After depicting the tribe as the central reference of identity formation in both Yemens, the following section takes a closer look at the impact of British colonial interference on the socio-politico milieu in Aden and its hinterland, especially the Western Aden Protectorate. The major focus is on the evolution of a specific urban identity in Aden that is considered a decisive prerequisite for the independence movement against colonial occupation and thus for the emergence of an Arab version of Marxism in South Yemen.

The British Crown settled for a strategy to maximize political influence outside the city of Aden at a minimum cost by using what they considered to be the existing power structures and binding the majority of sultans to advisory

73 | National identity, traditional, in: Burrowes, 2010, 254.

74 | Burrowes, 2010, 254; Also see. Lewis, 2014, 32.

75 | As opposed to the political north, Yemen's south does not suffer from sectarian divisions as the prevailing majority considers itself scha'âfī Sunnī, Manea, 2010, 4.

76 | Stookey, 1982, 3.

77 | Muheirez, Abdallah Ahmad, 1985, in: Dahlgren, 2000, 8. 
treaties. ${ }^{78}$ This approach at the time appeared to be the most practical to secure the port of Aden from the threat posed by often uncooperative tribes from the hinterland. As a consequence, the intensity of British rule decreased in accordance with growing distance from the city that led to a socio-political dissolution between Aden and the hinterland, including a "buffer" or "transitional zone" surrounding it. ${ }^{79}$ Current research even suggests two distinct strategies of British colonial rule toward the port of Aden and its "hinterland," defining spaces as "city" and "tribe," to ensure the safety of Aden's port and its trade routes over land and sea. ${ }^{80}$ According to Willis, the British had defined a "tribal space" in Aden's hinterland. There, the occupational policy was to exert a type of indirect rule by preserving "traditional, social, and political forms." In contrast to this policy, Aden society was to be recreated as a "colonial civil society" based on a strong "commercial class." 81

Regardless of British intent, British rule in any case had established the preconditions for the emergence of a distinct identity of "the urban Adeni" in a metropolitan society alien to the Yemeni context. Even though still connected to the hinterland by tribal and economic ties, the "Protectorate of Aden" introduced a new way of life in a place that its contemporaries considered "the most politically sophisticated territory in Arabia." ${ }^{22}$ Aden emerged as a cosmopolitan island which had grown beyond its socio-politico surroundings. Based on Benedict Anderson's concept of "official nationalism," the following section shows how British occupation policy actually facilitated the emergence of this distinct identity with some national connotations among the population of Aden.

\section{On the Way to a True Cosmopolitan: The Creation of an Adeni Public}

The Crown Colony at the Gulf of Aden had been intended to emerge as the main shipping center of the British-Indian trade route, a "new Singapore," 83 and at that time was considered geopolitically invaluable in connecting the continents of Europe, Africa, and Asia. ${ }^{84}$ With the Suez Canal still open, the decades before and after World War II caused an economic and societal boom in Aden. ${ }^{85}$ From 1931 to

78 | Arabic: șulțān; Before colonization "the power of the sultan was [...] contingent upon support given him by the tribes and townspeople" and had to rely on the power of sheikhs who themselves were "subject to some degree of scrutiny by those who selected them." in: Ismail/Ismail, 1986, 9f; Also see: Willis, in: Al-Rasheed, 2004, 122.

79 | Manea, 2010, 5.

80 | Willis, in: Al-Rasheed, 2004, 120.

81 | Willis, in: Al-Rasheed, 2004, $121 \mathrm{f}$.

82 | Holden, 1966, 25.

83 | Willis, in: Al-Rasheed, 2004, 120.

84 | Gavin, 1975, $22 \mathrm{ff}$.

85 | Brehony, 2011, 5. 
1946 the city population increased by more than seventy percent ${ }^{86}$ and employment opportunities drew workers from the whole country and even Yemen's neighbors. ${ }^{87}$ Aden lived through the establishment of the Western capitalist system based on industrialized production in less than two decades. This included the detachment of the city from the traditional Yemeni social system of dependency between the rural tribes and the "townsfolk." During this rapid transformation, Aden's industrializing society saw the formation of classes with a growing crowd of wageworkers. ${ }^{88}$ This political incubation was supplemented by the founding of several newspapers, political clubs, and blue-collar unions: in 1956 twenty-five of these unions organized in the Aden Trade Union Congress (ATUC). ${ }^{89}$ Without doubt, these were the beginnings of a modern public in the city of Aden.

"Official nationalism" encompasses the effort to merge the "nation" with the dynastic power into a congruent whole - a venture which Anderson debunks as the attempt of the colonial power to conceal the discrepancy between the evolving national consciousness of the ruled and the dissonant nationality of the rulers. While all characteristics of "official nationalism" described by Anderson emerged within British colonial rule in Aden, ${ }^{90}$ one of them has to be considered the most decisive in terms of creating the Adeni society and catalyzing the emergence of a distinct "Adeni identity": compulsory standardized education based on the model of British public schools:

"An educational system was set up based on the public-school ethos with ArabIslamic overlay.[...]The British brought boys from Sayyid and other influential families into a milieu where free thought was encouraged." ${ }^{91}$

Paradoxically, it was British education that created several of the preconditions for the identity of the "urban Adenis" and thus for the future revolutionaries to emerge: Access to political writings, room to discuss new ideas, and sufficient literacy to publish them. In addition to that, British rule established a modern economy that offered jobs for qualified workers and employers, thereby providing for another space of political engagement. In Anderson's words economy and education

86 | Dresch, 2000, 58.

87 | Dresch, 2000, 71ff; Stookey, 1978, 31-57.

88 | Slaughter, 1985, 24.

89 | Ismail/Ismail, 1986, 23. On the political clubs see: ibid, 15.

90 | Anderson points out five characteristics of "official nationalism": state education, propaganda, rewriting history, militarism and affirmation of the dynasty, in: Anderson: 1983, 101.

91 | Mackintosh-Smith, 1997, 164. 
"constituted simultaneously a colonial community and an upper class. [This class was] economically subjected and exploited, but [was] essential to the stability of the empire." ${ }^{\prime 2}$

Willis builds on and reformulates Gidden's interpretation with regard to the Aden case: According to Willis, the British had actively sought to transform "the social and political and social identities of the colonized with the constitution of society and economy as objects of rule, and more specifically, urban commercial society." ${ }^{\prime 3}$ The "urban Adenis" were mobilized by the hope of transforming from political subjects, in this case second-class subjects to the Crown, to equal citizens of an independent state in which the rulers and the ruled belonged to the same nation. $^{94}$

\section{Defining the "Urban Adeni": Why the Former Yemeni "Ruling Class" Joined Forces with the Poor}

The question remains how and why the better-educated and all in all better-off Sayyid sons came to join the poor and multi-ethnic wage-workers and unemployed for the same cause. At that time, "discontents of the very poor and complaints of the more privileged coincided only in anti-colonial rhetoric." ${ }^{25}$ While the "privileged" were involved in riots caused by English opposition to employing Egyptian and thus Arabic teachers in 1958, the reasons for the workers' "discontent" were of a very different nature, as they suffered from unemployment and hunger. What united these quite different worlds was an anti-colonial "resentment"96 that in Gellner's words regularly stems from the fact that "the rulers of the political unit belong to a nation other than that of the majority of the ruled."97 This "resentment" was caused by the shared experience of objectification through British policies. In addition to that, unlike in India, the British never transferred any power to the new and educated indigenous class the Empire had created among the colonized population of Aden. Until 1937, the British exercised Aden's official business from Bombay and the Bombay Presidency. ${ }^{98}$ As a consequence, the overpowering presence of Indian and thus alien culture appeared to "dominate the country." 99 All this diminished, or maybe veiled, the differences which might have otherwise surfaced between the "educated" and the "working class" Adeni.

92 | Anderson, 1983, 58.

93 | Willis, in: Al-Rasheed, 2004.

94 | Gellner, 1983, 1.

95 | Dresch, 2000, 85.

96 | Fanon, 2004, 89.

97 | Gellner, 1983, 1.

98 | Under its executive, the Governor General of India in Delhi; Blumi, in: Al-Rasheed/ Vitalis, 2004, 122; Burrowes, 2010, 73.

99 | Muheirez, Abdallah Ahmed, 1985, in: Dahlgren 2000, 6. 
All in all, the general character of British colonial rule helped to the Yemenis and Arabs in Aden overcome their differences by shifting the focus on the even bigger differences between the Arab "Adenis" and the foreigners. This further unity was further forged through policy tools, like the British census, that defined the distinction between rulers and ruled in the multi-ethnic society. In Aden, census categorization constructed individual and group identities "directly through its activities of counting and classifying," but also "indirectly through the vigorous responses provoked among those counted and classified." ${ }^{100}$ The categories of "Arab," "European," "Indian," and "Jewish"101 created a coherent Arab identity, distinct from the identities of the minorities. These minorities were associated with British rule and embodied the "other" against which Adenis defined themselves. About two-thirds of Aden's population were of Arabic decent, but not even half of them were "Adeni-born": British records simply did not distinguish between Adenis, Yemeni Arabs and Arabs of other origin. ${ }^{102}$ Even though the Arab population would not forget its national origins at first, this categorization allowed all of the urban population in Aden to identify with the city, no matter where they came from. In the colony, the Empire ruled through European and Indian clerks and officials. This practice exposed "the imperium as a protracted, almost metaphysical obligation to rule subordinate, inferiors, or less advanced peoples." ${ }^{103}$ While Indian clerks and tradespeople governed the "Adenis" through administration and employment, these administrative and political acts created the category of the "Adeni" and with it the identity of the "urban Adeni."

However, the British census categorizations did not only unify the Arab melting-pot of Aden and add to the construction of the urban Adeni identity. They also furthered the establishment of Arab nationalism as the notion that allowed the Adenis to identify as cosmopolitan and Arabic, while still maintaining their religious identification. "The urban Adeni" could have been a religious blue-collar worker, one of the first teachers of Yemeni origin teaching in Arabic and English, or an atheist intellectual who brought home new ideas from his studies in Cairo or Damascus. And even though Aden's society and economic system fostered the emergence of class, it did not seem to matter much at the time, as every "Arab" shared the same relationship to the occupying power. The collective identity of the urban Adenis was coded "primordially" by a shared feeling of "Arabness" based on origin, promoted by the "universalistic" code of Arab nationalism and framed by a vague, but powerful nationalist idea of being "Yemeni." Both dimensions formed the boundary toward the "other" represented by British occupation. Simultaneously, "the urban Adeni" adapted new practices established by the British, such as the daily walk to the workplace, reading the newspaper or listening

100 | Berman, in: Eisenberg/Kymlicka, 2011, 54

101 Aden Population 1839 to 1955, Appendix B, in Gavin, 1975, 445.

102 | Gavin, 1975, 445.

103 | Said, 1993, 10. 
to the radio, and attending political meetings. These practices can be considered the fragile beginning of a shared tradition among "the urban Adenis.”

\subsection{A "Tribal Identity" under British Rule?}

"[The Western Aden Protectorate] was a mosaic of principalities governed by
emirs, sultans, sheikhs, each jealous of his nominal sovereignty, and peopled by
tribes so resistant to outside influence that even the most doctrinaire of London
theoreticians could not seriously contemplate direct rule by British officials."

The intensity of British rule decreased the further away one was from Aden. While this very modest form of British rule beyond Aden had served the Empire's interest for a long time, it became clear that London would not consider giving up its strategic and economic pivot between Europe and India any time soon. Thus, as a reaction to the fear of losing authority over the port of Aden, the Crown transformed its indirect rule to a proper Crown Colony in 1937, in part due to the unrest in India and the resulting increased importance of Aden to the British economy. ${ }^{105}$ However, Yemeni resistance became more and more pressing. Thus, the Crown devoted significant resources to a campaign in the 1950 s to ensure the support of the more powerful sheikhs in their Protectorates and to unify South Yemen as the Federation of South Arabia (FSA).

\section{Final Throes of British Occupation: The Failure of the Federation of South Arabia}

Based on the initiative of the Governor of Aden Sir Tom Hickinbotham, the Empire's last attempt to unify the South under its rule was the "Federation of South Arabia." ${ }^{106}$ Hickinbotham had developed the idea of a unified "south Arabia" as the nationalist counterpart to pan-Yemeni nationalism. His successor, Sir William Luce, continued this policy and created the Federation of Arab Emirates of the South (FAAS) by unifying six major players. In combination with "Britain's only claim to presence in the area defensible before world opinion [...], her treaties with the twenty-five relatively major ruling houses," 107 the next governor, Sir Charles H. Johnson, aimed to finally merge the FAAS and the Western Aden Protectorate into the Federation of South Arabia (FSA). However, this foray, which tried to mobilize tribal support by relying on what the British considered to be tribal hierarchies, turned out to be a disaster. In the end, former south Yemeni allies turned their backs on the Crown and denied it their signature. ${ }^{108}$ Despite several

104 | Stookey, 1982, 51.

105 | Ismail/Ismail, 1986, 13.

106 | Sir Tom Hickinbotham, Aden Governor from 1951 to 1956. Burrowes, 2010, 74.

107 | Stookey, 1982, 51.

108 | Kopp, 2005, 158. 
other participating leaders, the Federation never came into force. Two days after the British had gathered all their signatures, Imam Ahmad, ruler of the north, died in his sleep and in so doing freed the way for the Yemen Arab Republic (YAR).

While the country had expected Aden to be the first "liberated place" in Yemen and thus the birthplace of Yemeni unity, the establishment of a republic in the north came as a surprise. The fire of violent resistance in Aden was fed with new inspiration, and started to smolder within the tribes far away from the city as well. Obviously, the Empire's officials had mistaken the lordly demeanor of the sheikhs as the ruling power of absolute monarchs. But apart from some exceptions for imams, ${ }^{109}$ the tribes traditionally relied on the quality of their leadership with regard to "qabyalah," the shared values of tribal identity in Yemen. Unfortunately for the British policy, not all members of the tribes seemed to agree with the decision of their sheikhs to collaborate with the British. Clearly, the British administration had no ideas to offer the "rifle-carrying tribesmen" that could compete with Cairo's resounding appeals to Arab brotherhood and denunciations of colonialism." 110 It came as a big surprise for the British when, pressured by their tribesmen, many of the leaders broke their alliance with the colonial power.

\section{British Perceptions of the "Yemeni Character"}

One may speculate about the British (male) perspective on Yemeni political behavior by piecing together some attitudes and opinions of the time. Hamilton, a British officer who served in the Crown Colony before and during the Second World War, suggested that tribal political life followed very different rules than the British had assumed. Hamilton noted a difference from the Western tradition of hierarchical rule: ${ }^{111}$ "Yemeni tribesmen didn't seem to understand the word 'rule.' They were in fact shy of ruling." ${ }^{112}$ With this statement, though expressed in colonial language, Hamilton might not to be too far off from characterizing Yemeni societal organization. According to the tribal ideal, tribal customary law is based on egalitarian principles. Honor and tribal virtues are considered universal for every member of the tribes and thus neither wealth nor power of the individual or the tribe should have any implications for the validity or application of tribal law. ${ }^{113}$ The power of tribal leaders is supposed to rely on the quality of their leadership, while the relation to the clan members is comparable to the concept "primus inter pares." 114 Tribal self-definition crystallizes around the ideal of the tribesman as a

109 | In this case polit. authority is hierarchical and derived from a relig. leader, an Imām. 110 | Gavin, 1975, 333.

111 | On the origins of “Feudalism," see: Onuf, 2013 (1989), 216; Spruyt, 1996 (1994), $36 \mathrm{ff}$. 112 | For a more thorough assessment of Hamilton's and other British officals' views on Yemen of the time, see: Dresch, 2000, 37f, Willis, FN 57, in: Al-Rasheed/Vitalis, 2004, 148. 113 | In general, this also applies to women. However, female honor and virtue are upheld by their male relatives, as women don't enjoy autonomy as a political person within the tribe.

114 | English: "First among equals." 
"man of his word," courageous, generous, independent, and dutiful with respect to kinship and his wards. Thus, not violence and coercion, but rather persuasion through argumentation, reparations, and intercession are considered the desirable and honorable solutions for social conflict. This interdependence of tribal honor, virtue, and the traditional customary rules is summarized by the Arabic term "qabyalah." Regardless of the actual realization of these virtues in social life, the Yemeni approach to the distribution of political power was alien to the processes of generating and perpetuating Western political hierarchies.

\section{The Impact of Modernization on Traditional Tribal Lifestyle}

In the late 19th century, much of the so-called Middle East had entered the "modern world [while the] centralization of imperial administrations and military modernization went hand in hand." ${ }^{" 15}$ Whereas the larger part of the Arab world embraced "modernization," the impact on Yemeni tribes, even from the bigger Yemeni cities themselves, had been minimal. As a consequence, the "ways of modernity" reached the remote tribes much later than more populated parts of Yemen. When the tribes finally had to deal with "modernization," they regularly refused any involvement beyond what their traditional lifestyle could easily incorporate. This can be explained by tribal identities' extremely low degree of "responsiveness," as described above. The ideas promoting individualism, but also bureaucratic authority, simply did not resonate well with tribal identity.

Tribal lifestyle blocked the British from accessing the social tribal sphere. If there was any at all, contact with the British colonial power was kept highly official and restricted to the political realm. Cooperation with the colonial power was one option among others for the tribes, typically reserved for when political necessity demanded it and it would not transform into long-term arrangements with the occupying power. Even though the tribes "lacked the conveniences associated with industrial society, they maintained a pride in their own heritage and civilization that contrasted radically with the attitude of colonized peoples. Not well-informed about modern industrial and technological capabilities, rural Yemenis had very little reason to question the validity of their own civilization that once controlled the coffee trade, commerce in silk and spices from Asia, and the legendary incense route." ${ }^{116}$ Not surprisingly, the tribes usually considered themselves as an equal, if not superior partner to the British. The tribal leaders and fighters outside Aden and its closer hinterland had no reason to consider themselves inferior and it can be doubted whether they actually felt oppressed by the British presence before British air strikes reached their homes.

Not all of the tribes had regular exposure to the British and even fewer considered them a dominating colonial power. But eventually contact with modernization

115 | Choueiri, 2002, 650.

116 | Adra, 2010, 65. On Yemeni consciousness of its pre-Islamic history also see: Dahlgren, 2000, . 
did have an impact, as soon as some notions were translated into a language more fitting to the social context. Technical advancement remedied the gap in knowledge on the "modern ways." Radio broadcasts from Cairo, and after 1962 also from Sana'a, delivered colonial occupation as well as the solution to "a mass audience among the poor and the remote"117 in the Yemeni hinterland. The radio broadcasts coincided with the British expansion of infrastructure. By building roads and rail tracks, the British often disrupted the supplementary incomes of many tribes from "levying tolls or transporting goods by camel."118 All of a sudden, the southern tribes suffered from hardships that they could link directly to the British presence.

Arab nationalism, in conjunction with Nasser's Arab version of socialism, ${ }^{119}$ translated "Western" ideas like the nation and the state into concepts closer to Arab social development. ${ }^{120}$ The ideas of Arab nationalism assumed a strong national identification within the Arab countries based on "distinct ethnic rights and histories"121 shared by all Arab people. It formulated "anti-colonial" notions and - in its extremist guise - called for violent resistance against domination. Thus Arab nationalism both raised awareness of the foreign power, but also offered a framework for the southern tribes to comprehend their negative experiences with the colonial power. Arab socialism as a political concept, on the other hand, not only explicitly included religion but derived its constitutive political values from Islam. As a consequence, nationalism was transformed into something more attractive for people whose identity was strongly connected to their ethnic history and Islam. Thus it can be coded "universalistic" and "traditional." Both the construct of Arab nationalism and the moderate ideas of Arab socialism resonated well with the tribal codes of independence, autonomy, and warfare. Even among tribes hostile to each other could now express a common history and culture with their neighbors. Thus, the British Empire paradoxically served as a unifying force: without disturbing the coherence of "qabyalah" among the tribes in the process, the British served as the invading, foreign power that promoted the construction of a Yemeni nation.

117 | Gavin, 1975, 333.

118 | Gavin, 1975, 334.

119 | Arabic: al-ishtirākTyah al-'arabiyah. For further exploration on the mingled ideologies of Arab nationalism and socialism see subchapter 4 "Ideological Blueprints" of this study. 120 | Hanna/Gardner, 1966, $77 f$.

121 | Kayali, Hasan, in: Choueiri, 2002, 653. 


\section{Ideological Templates: Political Influences from the Middle EAst and Europe}

"It was not until after the Second World War that an ideology arose that was capable of binding together and organizing South Yemeni opposition to colonial rule: Arab nationalism."122

This study considers the creation and establishment of South Yemen as an independent state a process of "nation- and state-building" that was actively pursued from the inside by South Yemen's political leaders, but also from the outside, by East Germany and its delegates on behalf of Moscow. Based on the findings of the preceding subchapter, "Determining a Yemeni Identity in the South," the following section focuses on the milieu of the political epicenter Aden during the last two decades before independence. What are the reasons that the ideology of Marxism-Leninism finally prevailed against competing ideological concepts available and promoted at the time?

Two major concepts are identified as the dominant sources of inspiration and direction for the political actors in South Yemen: Arab nationalism and socialism/ Marxism. While the former originated in the region of the wider Middle East itself, the latter was a concept alien to the region. Though the two concepts commingled all over the Arab world, they emerged in very different shapes, by including various local nationalisms. How was it possible for two locally distinct and, content-wise, very different ideologies to coexist and even mix? What actor or actors made this connection in South Yemen? To understand the role of ideology in South Yemen's early years of nation-building, and thus to be able to assess the impact of external ideological involvement by the GDR and Soviet Union on this process, the origins of the NLF/NF's vague, mixed, and multi-layered ideological presumptions need a thorough exploration.

\section{1 "Awake, 0 Arabs, and Arise!:"123 "Arab Nationalism" as yet another Ideological Golem" ${ }^{124}$}

The origins of a specific Arab nationalism can be traced back to the Ottoman Empire. Universal demands for a unified Arab independence had not yet been made and opposition to Ottoman rule had not yet envisioned a post-Ottoman order. With the "Arab Revolt" against British rule and Jewish settlement in Palestine in 1920, the first notions of the Arab nation mutated gradually into an

122 | Ismail/Ismail, 1986, 13.

123 | Al-YazijT, Ibrahim, 1868. Even though the poem was not being printed at that time it became one of the most powerful slogans of the self-declared movements of Arab nationalism, Kramer, 1996, 2ff and 19.

124 | On the creature in Jewish mythology, see: Schwarz, 2004, 280. 
overarching concept and party that degenerated into what Mann considers the "perversion" of the idea of the nation: a legitimization for "aggressive action against other nations." 125 What followed was the "anti-imperialistic" phase of Arab nationalism. "Imperialism" was defined as the aftermath of colonialism and as "a form of indirect domination" which supposedly "serv[ed] no other purpose but to perpetuate the underdevelopment of newly independent states."126

However, the shared attitude of "anti-imperialism" among the Arab states only lasted until they lost the war against the new Israeli state in 1948. After this defeat, it became more and more difficult to blame "imperialism" alone for the discord within the Arab world. Nonetheless, some advocates of Arab nationalism tried to reform the concept by incorporating socialist ideas. The anti-imperialist perspective of Arab nationalism and the political attitudes it generated among the urban population have to be considered one of Marxism-Leninism's advantages in establishing itself as a political alternative. Arab nationalism grew into something revolutionary and somewhat international in a Marxist sense. ${ }^{127}$ In the following section, Arab nationalism is defined in such a way to distinguish its transformation toward Arab versions of socialism in Egypt and the Yemeni version of MarxismLeninism, and also to emphasize its role in "preparing the ground" for MarxismLeninism to eventually prevail in the traditional society of South Yemen.

\section{Arabia - The Impossible Nation?}

"No European nationalism has claimed a potential constituency as large, as far flung, or as fragmented." 128 This observation gets to the heart of analytical difficulties when approaching the notion of Arab nationalism, but also hints at the reasons for the concept's durability. The demise of Arab nationalism has been proclaimed again and again in academia, ${ }^{129}$ and with a few exceptions, the concept vanished from the academic agenda about two decades ago. ${ }^{130}$ Nonetheless, it has persistently resurfaced from time to time in references to the Arab world as a political entity. During the Arab uprisings of 2011, analysts were surprised of its absence from slogans, while the uprisings themselves nonetheless had Arab connotations. ${ }^{131}$ More importantly, its core ideas have been kept alive in movements like Arab socialism/Nasserism, Ba'athism, and even Islamic fundamentalism. ${ }^{132}$ With Anderson's conception of the nation in mind, ${ }^{133}$ this relevance becomes

125 | Mann, in: Periwal, 1995, 44.

126 | Choueiri, 2000, 196.

127 | Kramer, 1993, $184 f$.

128 | Kramer, 1993, 173.

129 | Wilson, in: Khalidi (et al.), 1991, 204.

130 | Choueri, 2009 and 2000; Kramer, 1996a and 1996b; Tibi, 1997; Wien, 2011.

131 | Al-Azm, 2011; Temlali, 2011.

132 | Kramer, 1996b.

133 | Anderson, 1983, 6. 
evident. According to Anderson's approach, nations have to be imagined as a "community," as "sovereign," and as "limited," with other nations lying outside these boundaries. The latter prerequisite is closely linked to "membership": Who is part of the nation, and who is not? Answering this question with regard to the "Arab nation" turns out to be an almost impossible task: Cultural, religious and even communicative characteristics of the Arab nation overlap and dissolve within societies one might at first identify as Arab. This is mainly due to two historic phenomena: First, the spread of Islam from the Muslim sanctuaries of Mecca and Medina in the late the 7 th century had in fact been a military conquest. ${ }^{134}$ Supported by the migration of Arab people to the conquered regions and their mixing with local populations, the conquest included vast territories in North and West Africa as well as Asia, spanning from Andalucía in the West to Pakistan in the East. ${ }^{135}$ Second, large parts of this former Arab realm had fallen under foreign rule at one time or the other, both Muslim and Christian. The dynasty of the Turco-Mongolian ruler Timor in the $14^{\text {th }}$ century, the Ottomans a century later, and finally European colonial rule ${ }^{136}$ had brought their people to the conquered territories, but also displaced the local populations by force and attracted the conquered population to their own home lands. Hence, Arab nationalism can be described by Anderson's "imagined community" in the literal sense of the word. Its "community" could not rely on a homogenous constituency and thus had to explicitly create, that is to imagine, its boundaries. Only after inventing and constructing this community, did it become possible to formulate the demands for Arab "sovereignty," meaning external sovereignty delineating against outside interference.

Mostly due to the heterogeneity of its members, the "[v]ariations of Arab nationalism multiplied"137 right after the notion was created: the results of the concept's impact on the different regions and countries of the Arab world differed widely. Hence, generalizations are difficult to make and usually oversimplified. Thus, the following analysis offers a means to substantiate "Arab nationalism" as a collective identity constructed based on the dimension of "membership." "Membership" is created on the inside by "internal self-identification," including a shared history, geography, and values, but also from the outside by "categorization" of an external agent. Colonial rule is considered the adversary on both the in- and outside against which the Arab community defined itself. The analysis relies on several major theorems of three authors: Anderson's concept of "official nationalism,"

134 | Hourani, 2003, 44-50.

135 | Map 1: The rise of Islam and the Arab conquests, in: Lockman, 2010, xiv and Hourani, 2003, 60f, $128 f$.

136 | Halm/Haarmann, 2004.

137 | Kramer, 1993, 173.

138 | Anderson, 1983, 101. 
notion of "resistance,"139 and lastly Gellner's basic definition of nationalism as political congruence. ${ }^{140}$

\section{Occupation and Colonialism as Midwives of Arabian Identity}

The Ottoman Empire had been damaged severely by its Christian subjects' demands for self-determination and finally independence. ${ }^{141}$ The Ottomans struggled hard to prevent its Arab subjects from following suit. One of the major turning points was Sultan Abdulhamid II's attempt to cast a new Ottoman identity during the last third of the 19th century. ${ }^{142}$ Following the integrative state reforms of his predecessors, ${ }^{143}$ Abdulhamid's efforts significantly intensified in scope and penetration. Anderson's concept of "official nationalism" 144 offers an explanation for the correlation between the Sultan's policy and the rise of Arab nationalism: The major integrative factor among the Turkish and the Arab population had always been the shared belief of Islam. Thus Abdulhamid utilized the notion of "pan-Islamism" for his own ends to affirm the identity of his dynasty and the nation. He invented a "political imagery of the Sultanate and the Caliphate, turning his personage in the process into a holy symbol of Islamic power and Ottoman invincibility."145 Not much later, he complemented this notion by introducing Turkish as the official language of state at the expense of Arabic and other languages "to give the polyglot Empire more of the character of a European nation-state." ${ }^{146}$ Before, the Empire had relied heavily on Arabic as its second lingua franca in administration as well as standardized primary education. ${ }^{147}$

Both of Abdulhamid's policy measures triggered attempts to save the "Arab heritage" within the Ottoman Empire and to renew cultural Arab consciousness. The movement radiated from an "Arab literary revival" in Beirut at its center to Egypt, Greater Syria and Tunisia. ${ }^{148}$ "Cultural Arabism"149 became the intellectual home for the Arab-speaking elite of the Empire's administration and military, but soon turned against the Empire's structures that had promoted and accommodated this cultural identity: While the Ottoman army had played a highly integrative role among the various groups within the Empire for centuries, it could not withstand the separate nationalisms seeping into its ranks. Apart from unveiled competition

139 | Said, 1993, xii.

140 | Gellner, 1983, 1.

141 | Kramer, 1993, 175 and Choueiri, 2000, 60f.

142 | Arabic: “Abdulhamīd II, short Abdulhamid. Deringil, Selim, 1998, in: Choueiri, 2002, 651.

143 | For Ottoman reformist policies of the early 18th century see Choueiri, 2000, $62 \mathrm{f}$.

144 | Anderson, 1983, $101 \mathrm{f}$.

145 | Deringil, Selim, 1998, in: Choueiri, 2002, 651.

146 | Kramer, 1993, 176.

147 | Anderson, 1983, $101 f$.

148 | Kramer, 1993, 175.

149 | Choueiri, 2000, 66. 
between Christians and Muslims within the state apparatus, "grievances of those [Arabs] passed over"150 during replacement periods for administrative positions furthered general dissatisfaction. Then, the final decades of the Empire saw an "Arab Revolt" against Ottoman rule, led by a local potentate of Mecca: Sharif Husayn. ${ }^{151}$

Initially, "cultural Arabism" created an "Arab community" under the "political umbrella" 152 of the Ottoman Empire. But the change in Ottoman policies turned out to be a catalyst for the simmering discord within the state institutions, creating a new awareness of Arab identity in contrast to the "Ottoman Other."153 Naturally, the dynastic realms, when confronted by the "decline of automatic legitimacy"154 derived from divinity, felt increasingly threatened by the emerging national consciousness of its subjects. This is what Anderson considers the crucial moment of "official nationalism." As a pre-emptive strike, the dynasties tried to "rewrite history" and establish their own "top-down" version of nationalism as a substitute for the popular "bottom-up" nationalisms $\mathrm{s}^{155}$ that endangered their rule. But despite the propagandistic efforts of the Ottoman Sultan and his entourage, their occupation policy did not grow into a viable nationalism with the Sultan at its center. Rather, it facilitated the emergence of an Arab national identity among the population. "[W]hile the Ottoman Empire lasted, [...] Arabism did not develop into full-fledged nationalism." ${ }^{156}$ Kramer reasons that the image of the "Arab nation," the ultimate goal of this nationalism, at the time was merely a belief of the supporters of the "Arab revolt." To forge it into a mass ideology, it would have needed another theoretical basis, lending the "Arab nation" a legitimacy that could transcend people's mundane existence. The solution was to abandon the French notion of the nation, which considered it a voluntary contract. Instead, the "Arab nation" was interpreted as a "sleeping-Beauty," a destined community, "bound by the mystery of language and lore"157 that mingled with the growing militarism in the Empire.

\section{George Antonius: Father of Arab Nationalism?}

The transformation of Arab nationalism from a specific phenomenon within the Ottoman realm to a universalistic notion valid for all Arabs is associated with

150 | Kramer, 1993, 175.

151 | Husayn, however, was less motivated by Arab emancipation than by his "dynastic ambitions," such as a significant expansion of his sphere of influence. Kramer, 1993, 176.

152 | Choueiri, 2000, 66.

153 | For the role of the "other" with regard to self-identification also see: Taylor, 1994, 47.

154 | Anderson, 1983, 19.

155 | Mann, 1995, $46 f$.

156 | Kramer, 1993, 177.

157 | Kramer, 1993, 181. 
one particular author. Born into a Christian Orthodox family in Lebanon, George Antonius, a Cambridge graduate, served in the British Mandate of Palestine. ${ }^{158}$ The fact that he "adopt[ed] a secular form of Arab nationalism, rather than PanIslamism"159 is usually explained by his liberal Western education. However, his concerns were initially purely political. His monograph “The Arab Awakening” of ${ }_{193} 8^{160}$ criticized the British policy in Palestine mostly in political terms.

"[T]he British government, seeking to retain its empire, declined to acknowledge openly, or act upon, his findings." ${ }^{161}$ But Antonius was not very popular among other Arab patriots either, who criticized his "affinity with the West and loyalty to Great Britain." 162 Regardless, his work became one of the most influential translations of the Western conceptualization of nationalism in the Arab world. As Hobsbawm has pointed out for "traditions" in general, there had to exist some connection between the nation and the social structures preceding it to make its claim of being "pre-historic" plausible. Nationalism "sometimes takes pre-existing cultures and turns them into nations, sometimes invents them, and often obliterates pre-existing cultures," 163 as Gellner summarizes. By borrowing from what had been there before, the new nation appeared more familiar to its new members.

This is exactly what Antonius did. He dated the first call for Arab selfdetermination back to the publication of Ibrahim Al-Yaziji's ode in 1868: "Awake, O Arabs, and arise!" and declared the following developments up to his own time as the "awakening" of the Arab nation. In so doing, he successfully connected the person of Al-Yaziji and other political authors and poets of the previous centuries with himself and the current political situation. Al-Yaziji's poem already implies that there had existed a collective of the "Arabs" which could be addressed by it. Antonius sketches the Arab nation as a "sleeping beauty" that had to be awakened. Thus he successfully built his narrative of the Arab people on the "style by which one is defined by the nation, which in turn derives its authority from a supposedly unbroken tradition." ${ }^{164}$ Antonius successfully created what Said called the "guiding imagination" 165 for the independence movements promoted by Arab scholars, a

158 | Antonius to Walter Rogers on 28 May 1937, New York, in: Kramer, 1996, 112.

159 | Silsby, 1986, 81.

160 | Antonius, (1938), 2000.

161 | Great Britain, Minutes of Cabinet Meeting, 23 February, R.0., F.0. 371/23226, in: Silsby, 1986, 94.

162 | Silsby, 1986, 81.

163 | Gellner, 1983, $48 f$.

164 | Said, 1993, xxv.

165 | Said, 1993, 212. 
"cultural Arabism"166 based on a common language and the (re-)construction of a shared heritage.

Nationalism in the Arab world not only relied on revived Arab literature, but also on an even more significant element of the Arab culture. Even though Antonius' thoughts had been explicitly secular, his concepts were flexible enough to transcend the religious divide. The shared codes and customs of Islam were transferred from the "pre-existing"167 to the new culture of nationalism. Arab nationalism in the beginning first and foremost had been a political concept that had emerged as a "critique of the state of the Ottoman Empire." 168 And even though Antonius' secular notion of "Arab nationalism" was detached from Islamic thought, it did not question or diminish religion. Thus it was able to integrate Islam as a unifying factor and source of legitimacy. As a consequence, the role of religion in the formation of Arab nationalism has to be considered supportive in some cases and restrictive in others. ${ }^{169}$ When the main identity markers offered by this new nation resonated with people's collective identities, they were incorporated into the identity of the Arab nation.

\subsection{Arab Nationalism absorbs Soviet and Maoist Thought: A South Arabian Version of Marxism-Leninism}

\section{Nasser's Socialism: The Link between Arab Nationalism and Marxism?}

Political setbacks and military debacles deprived Arab nationalism of its velocity as a universal ideology. Nonetheless, Arab nationalism as an idea evolved and was able to survive by mingling with other ideologies, notably socialism and MarxismLeninism. The most prominent and likely most influential case of reshaping Arab nationalism through socialism was Nasser's construct of Arab socialism. ${ }^{170}$ Increasing commercial, political, and cultural interconnectedness of governments and governed all over the world brought the ideas of "the Bolshevik revolution" and the "American notions of the right of self-determination" to the Near and Middle East where they fed indigenous national movements. As Said puts it, "a new global

166 | Choueiri, 2000, 66.

167 | Gellner, 1983, 48f.

168 | Kramer, 1993, 174.

169 | "Arab Nationalism" has to be distinguished from conservative "Pan-Islamism." The ultimate objective of the latter in the early 19th century was the "realization of the Islamic ideal, the unity of the world in Islam, the central direction under a leader (Imam) of the world community," or in other words the global expansion of the Muslim Umma (English: the global community of all Muslims) and its transformation into a political entity based on religious legitimacy, a global theocracy. As Lee rightly points out, "the basic concept [of Pan-Islamism] from which thought and action sprang was religious rather than racial or national." Lee, 1942, 279; Also see: Burrowes, 2000, 171.

170 | Arabic: Ğamāl 'Abd al-Nașīr and al-ishtirākīyah al-'arabīyah. Hanna/Gardner, 1966, 77f. 
consciousness connect[ed] all the various local arenas of anti-imperial contest." ${ }^{171}$ Nasser's Arab socialism “turned Arab nationalism [sic!] into an ideology based on a radical programme,"172 as written in his National Charter of 1962.

The Charter declared socialism the "inevitable result of a new revolutionary age of social change” realized by "popular progressive forces." It painted Arab unity as the long-term goal preconditioned by socialism. It also named the adversaries of the Arab world in unmistakably leftist fashion: imperialism and local reactionaries. Nasser's concept was able to trigger the feelings of "Arabism" which had hatched from "anti-Turkish opposition" and had been simmering all over the region since the first upheavals against Ottoman rule. Arab socialism explicitly included religion and derived its constitutive political values from Islam. It had transformed the Arab nationalism into something more attractive for people whose identity was mostly coded "universalistic" but still strongly connected to religion. And while the Middle East soon saw a considerable decline of Arab Socialism, the aftermath of both concepts, Arab nationalism and socialism, thrived in radicalized milieus of second-wave decolonizing countries.

So what is the link between these concepts and the future YSP-regime? A "mood of nationalism [was] sweeping the Arab world."173 But in Yemen this mood not only took root in the two major cities of Aden and Sana'a. The idea of the Yemeni nation was beginning to spread all over the country, and by the 1950 s these ideas had found a foothold even in the mountainous northwest of South Yemen. ${ }^{174}$ The major impact of "revolutionary writing" can be dated back to several copies of "The Nature of Oppression" by al-Qawakibi. ${ }^{175}$ In 1944 they were smuggled into Sana'a and passed on to the south. Tribal affiliations of returning intellectuals who "trans-coded" the writings to their kinsmen skirted official channels, ignoring regulations and borders. The social structure of tribal Yemen, mostly considered a stumbling block for change, facilitated the distribution of ideas like no other. In the tribal hinterland, Yemen's major threshold to social change, illiteracy, was bypassed by the new medium of radio broadcast ${ }^{176}$ and the strong family ties of intellectuals.

Countless political movements began to form across the country, most of them inspired by Nasser's Arab socialism. Nasserism already used socialist
171 | Said, 1993, xxiv.
172 | Choueri, 2000, 193.
173 | Brehony, 2011, 30.
174 | Kostiner, 1990, 16.
175 | Arabic: Al-QawakTbT ; Pridham, 1984, 245 and Dresch, 2000, 45.
176 | Gavin, 1975, 333; Ismail/Ismail, 1986, 15. On the role of communication, technology, and transport in community formation in Michael Mann's and Anthony Gidden's approach also see: Joas, 2011, 422. 
ideals as a possible "ideological core of nationalism and its true identity"177 for the newly independent states. According to Choueiri, this included "a socialist plan of [economic and political] reconstruction and regeneration"178 in each country, meaning a socialist plan of nation- and thus state-building. In the long run, all socialist Arab countries were to unite as one Arab nation under Egyptian leadership. Based on a network of personal and tribal allegiances, ${ }^{179}$ all movements in Yemen were either connected to Sana'a or the city of Aden, the future center of the South Yemeni liberation movement. Several of the early leading figures of the NLF, like Muhammad Saleh Yafa'I, had committed themselves to this version of Arab socialism. ${ }^{180}$ Among the many sympathizers was the forerunner of the future South Yemeni regime, the highly active Aden branch of the Movement of Arab Nationalists. ${ }^{181}$

\title{
South Yemen and the Movement of Arab Nationalists (MAN)
}

Founded in Beirut by Palestinian students under George Habash's leadership ${ }^{182}$ in the early 1950s, the MAN's first cell was established in Aden at the end of the decade. Burrowes comments on the importance of these early years for the future South Yemeni regime:

\begin{abstract}
"The fact that the regime in the PDRY was the only one in the Arab world that could trace its ideological roots directly to the old [MAN], as well as to the Marxism-Leninism of the PFLP, helps explain the special relationship and sense of kinship that existed between [Habash] and the leaders of the YSP in the PDRY through the 1980s." 183
\end{abstract}

Over the coming years, both Habash's Popular Front for the Liberation of Palestine (PFLP) and the NLF, formerly South Yemeni MAN, not only oriented itself toward but kept drawing from the development of Nasserism. It also cultivated an extreme approach to "revenge" against the "usurpation of Palestine by Zionism." 184 Nasser had included the ideas of Arab nationalism and Arab unity in his political

177 | Choueri, 2000, 193.

178 | Choueri, 2000, 193.

179 | Dresch, 2000, 55ff; Halliday, in: Jankowski/Gershoni 1997, 32.

180 | Yafa'i had been South Yemen's Minister of Interior from June 1969 onwards. After a half-year-long visit in Cairo he returned as a self-declared "Nasserist." Einschätzung über Mohammed Saleh Yafai, Minister des Innern der Volkrepublik Südjemen, in: BStU MfS Abt.X Nr.234 Teil 1 von 2, 331.

181 | Also: Arab Nationalist Movement; Arabic: Ḥarakat al-Qawmiyyīn al-'Arab.

182 | Arabic: Jürj Habash. Later on Habash became Secretary-General of the Popular Front for the Liberation of Palestine (PLFP), Also see: Mattar, 2004, 961.

183 | Burrowes, 2010, 33f.

184 | Choueri, 2000, 205. 
ideology to appeal to everyone identifying as "Arab." Hence, the failure of political experiments in the name of Arab nationalism, namely the United Arab Republic, ${ }^{185}$ and especially Nasser's defeat in the Six-Day War, deprived Nasserism of its universalist appeal and left the Arab world disillusioned. Clearly, Nasser's star was on the wane: Just like many other movements inspired by Nasser, the MAN turned away from his approach, ${ }^{186}$ gradually radicalized and disaggregated into Marxist cells, among them the notorious terrorist group of Wadī Haddad. ${ }^{187}$ And while the majority of the MAN's branches sank into insignificance, the Yemeni MAN not only survived, but reinvented itself as a revolutionary movement. In 1963, the South Yemeni MAN had reformed itself as a merger of six groups under the new name National Liberation Front (NLF). The members of the NLF preferred "Guerrilla warfare, as developed in North Vietnam and Cuba"188 over Nasserist reform and thus adopted violence as a major tool to achieve their agenda. In the very same year, the NLF launched the Radfan Rebellion, the decisive spark toward revolutionary struggle against the British. The NLF and its successor, the Yemeni Socialist Party (YSP), would evoke images of these "heroic" years of struggle for political purposes on a regular basis.

\section{Ideology and the Singularity of the South Yemeni Case}

In his comprehensive overview "The Communist Movement in the Arab World," Ismael explores "the Communists' inability to adapt Marxist-Leninist ideology to Arab societies and to traditional Arab cultural norms and traditions. ${ }^{189}$ How was it possible for the NLF to overcome this apparent threshold of "traditional Arab cultural norms," when no other regime in the Arab world had been willing and able to do so? The next section takes a closer look at Ismael's arguments. Both concepts, Arab nationalism and Marxism-Leninism, in the long-run aimed to overcome national boundaries, while the revolutionaries of the liberation movements instead aspired to establish a nation-state:

"As fervent Yemeni nationalists, though, few of these young men were captive to the pan-Arabism of these ideologies. Instead, most of them were drawn to these ideologies by their goals of national strength and development, and by the strong state to achieve those goals. In short, they were statist ideologies,

185 | Founded in 1958 under Egyptian Leadership, its other members, Syria and Yemen, left the Union in 1961. Choueri, 2000, 193.

186 | Kostiner, for example, refers to the Beirut-based MAN groups that adopted Marxism in the mid-1960s, Kostiner, 1990, 17; Also see: Burrowes, 2010, 251; Dresch, 2000, 67; Mackintosh-Smith, 1997, 165.

187 | Mackintosh-Smith, 1997, 165; Linde, 1987, 3.

188 | Kostiner, 1990, 17.

189 | This quote relates to the 1920s. Ismael, 2005, 2. 
and most of the young Yemenis became statists." ${ }^{190}$ Thus, any ideology able to capture the support of the majority of young politicized Yemeni men at the time had to include the idea of a nation-state based on the image of "one Yemeni homeland." ${ }^{\prime 191}$

How was the nation brought back into ideologies that had emphasized the international as the ultimate goal of their struggle, then? While Arab nationalism had already tried and failed to move beyond the stage of the nation-state, ${ }^{192}$ Marxism-Leninism offered a feasible solution for this dilemma based on Lenin's writings and his theory of imperialism: The nation-state was redefined as the transitional stage on the way to "Internationalism" and declared the installation of an elitist national vanguard party was to lead the masses to acquire first socialism and then Marxism as the sine qua non for this transition. This vanguard party was supposed to induce the establishment of a socialist state as a remedy to "imperialism as the final stage of capitalism." Here, Lenin introduced the notion of "neo-colonialism," which included the idea of continued domination even "after a colonial nation had attained independence." 193 This notion of "neo-colonialism," and its implicit critique of imperialism, is what the otherwise contradictory projects of Arab nationalism and Marxism-Leninism had in common: The opposition to external and hostile forces. As a consequence, postcolonial liberation movements who full-heartedly had embraced the notion of "Arab nationalism" were now able to shift their allegiance to the MarxistLeninist idea of "anti-imperialism.”

In his argument Ismael also lists the lack of "objective conditions of industrialization"194 in the Arab world as a reason for the minimal penetration of Marxist-Leninist notions there. This clearly was not the case for industrialized Aden in the 1940s and 1950s, thriving as it was on the mechanisms of capitalism. However, the creation of modern public space that accompanied the emergence of capitalism in Aden has to be considered the pivotal factor in connecting ideology to reality. It was the possibility to discuss the new reality of modern, industrialized life under capitalism that opened Adeni society for Marxist critiques of capitalism. In addition to that, British policy indirectly facilitated the spread of these notions

190 | Burrowes, 2005, 171.

191 | Halliday, 2002 (1990), 99-139.

192 " "On February 1 1958, the unification of Syria and Egypt was heralded as the first step in the revival of the Arab nation. Less than four years later the union was torn asunder." in: Palmer, 1966, 50. Also see: Seale, 1961.

193 | Ismael, 2005, 4f. Also see: On the notion of "neo-colonialism"; also see: Chapter 17. Moscow, East Berlin and the "Hawks of Hadramaut."

194 | Ismael, 2005, 2. 
in written form. Anderson considers the combination of the capitalist system with the technology of print the main catalyst for the development of nations.

According to Anderson, "print-capitalism" facilitates the transformation from a local community to what he describes as the abstract "imagined community," 195 the nation. For Anderson, the written word is the basis for national consciousness, which has to unify members of the future nation who have never met and possibly will never meet. Only in combination with mass reproduction and a certain degree of literacy can it have any impact. In Aden all these conditions came together. Both literacy and "print-capitalism" were rendered possible by the British. Their schooling system granted the Adenis access to alternative ways of political organization and enabled them to share their opinions. Not surprisingly, it was a newspaper that initially reformulated "south Arabia" "as culturally a single entity," the Yemen. ${ }^{196}$

Apart from the prevalence of a vanguard party, other reasons for the emergence of the only Marxist state in Arabia can be found in the mutual enhancement of and reconciliation between the diverse ideological convictions of these leaders: Arab nationalism, socialism and Marxism-Leninism. In conclusion, three unique features of the Yemeni case relevant to this ideological merger can be detected. First, the South Yemeni emerged from the industrialized, cosmopolitan island of Aden, created by the colonial approach of the British that led to a distinct identity of "the urban Adeni." The milieu of the "urban Adeni" appeared to be significantly more receptive to the Marxist critique of capitalism and imperialism than other urban centers of the Arab world, as both phenomena were part of the daily lives of the Adeni population and not just abstract ideas. Second, the forerunner of the revolutionary Yemeni party NLF, the MAN, considered itself first and foremost an academic elite - one of many possible reasons that its most radical members turned toward Lenin's idea of the vanguard as "leader of the masses." Third, change in what the British had defined as "tribal space" had begun. Far away in time and place from the urban center of Aden, the notion of "Arab nationalism" had considerable impact on peoples' thinking there. This notion drew on the preexisting image of the "Yemeni homeland" stemming from pre-Islamic times. ${ }^{197}$ This effect transformed into the modern idea of the "Yemeni nation" as one of the "finest Arab societies." The internalization of nationalist notions has to be considered a necessary condition for the tribes' interest in the developments in the "city space" of Aden and furthermore prepared the ground for the reconnection of the "cosmopolitan island" with the South Yemeni hinterland in the joint "struggle for independence" that was to follow.

195 | Anderson, 1983, 6.

196 | Dresch, 2000, 56.

197 | Dahlgren, 2000, 6. 


\title{
5. Synthetic Politics in Yemen's South: A Marxist State FROM SCRATCH
}

\begin{abstract}
"The early leaders of the NLF planned not simply to bring about the withdrawal of the British presence, but to break down the entire tribal structure of the protectorates, destroy the Sultan system on which the South Arabian Federation was being constructed and create a classless, disciplined society out of the ashes. [...] What they lacked in sophistication they made up for in ruthlessness and willingness to fight long, hard and if necessary dirty." 198
\end{abstract}

The liberation movement in South Yemen was highly fragmented. Countless groups would fight together one day and against each other on the next. In the late 1950 os, two groups had taken the lead as the two major political movements, ${ }^{199}$ the Front for the Liberation of Occupied South Yemen (FLOSY) and the successor to the Aden MAN, the National Liberation Front (NLF). Outside Yemen, FLOSY had been considered the most influential and organized of the various movements - not only by the British, but also by Egypt and the Soviet Union. Not even by November 1967 had Moscow decided which fraction to support, FLOSY or NLF, and was holding back its support until the "winner" emerged. ${ }^{200}$

How and why did this most extremist group among the South Yemeni prevail in the internal struggle for political leadership and establish itself in one of the most traditional societies of the Arab world? Scholars of Yemen's modern history present structural as well as descriptive approaches to this puzzle. While they agree on a complex set of reasons for the NLF's successful seizure of power, the scholars apply different focuses in their analyses. Whereas Brehony emphasizes the failure of the British to modernize Aden's hinterland and the NLF's close ties to the tribes there, ${ }^{201}$ Gavin describes the military victories of the NLF against both the British and the FLOSY in minute detail. ${ }^{202}$ Dresch focuses on the loss of power of the local sheikhs. ${ }^{203}$ According to him, this was the main reason that

198 | Muqbil, A.S., Uktubar, in: Brehoni, 2011, 20.

199 | Even though the NLF was only established in 1963, earlier, more radical generations had been active within other associations years before. Gavin, 1975, 345.

200 | Notes of GDR's diplomat Seidel on consultation with Soviet Foreign Ministry embassy counsellor Serjogin, in: PAAA MfAA C 1224/71, 18; Egypt and the Egyptians, in: Burrowes, 2010, 109; Gespräch von Freimut Seidel am 15.November 1967 mit Rat in der Abteilung Naher Osten des MID (Außenministerium der Russischen Föderation), Serjogin Aufzeichnungen von Freimut Seidel, Konsul am Generalkonsulat der DDR in Kairo 1966/67, Ende der 1980er Jahre Botschafter der DDR im Südjemen.

201 | Brehony, 2011, 30.

202 | Gavin, 1975, 345-351.

203 | Dresch, 2000, 108ff. 
the NLF was able to link "country and city" by infiltrating all relevant political and tribal groups. Stookey complements these observations with the "enormous appeal of the principle of armed action [...] among the masses." 204 The following analysis includes all of these explanatory factors, but centers them on the role of identity with regard to social change, an area that has been widely neglected by all authors. ${ }^{205}$

\subsection{The NLF between the Escalation of Violence and Ideological Restraint}

The two dominant groups of the South Yemeni "liberation struggle," FLOSY and NLF, used very different strategies to realize their own political vision for a future South Yemeni state. On the one hand, FLOSY and its intellectual leaders seemed willing to make concessions with regard to the British Empire's withdrawal and thus could focus on their fight against the NLF. The NLF on the other hand refused to cooperate with the colonial power and decided to fight not only the more moderate FLOSY, but any other competitor suspected of "collaboration" with the occupying force. Clearly, the NLF seemed to have opted for the less promising path: Strictly following their policy of "zero tolerance" on their way to power, the NLF and its leaders more or less eliminated their competitors for political leadership by force within only a few years. Among the most powerful social groups were the trade unions. Even though some of their leaders politically prevailed, their organization did not survive the NLF's crusade: The most powerful union, the Aden Trade Union Congress (ATUC), was accused of being "an agent of the British." 206 Finally, ATUC literally was decapitated when NLF fighter and chief ideologue Abd Al-Fattah Ismail killed the ATUC leader in February 1966. Ali Husayn al-Qadi had been the major integrative figure between the working unions, Ba'athist and nationalist circles and his death erased any influence these groups might have had. ${ }^{207}$ In the same year, NLF and FLOSY were pushed by Cairo to merge. But due to their huge ideological and political differences, the NLF quickly left the joint venture and its new leader Abdullah al-Asnag behind, opting instead to fight them in the hills of the countryside and the streets of Aden. ${ }^{208}$

However, the NLF had never been a homogeneous movement, either. In the late 1960 s the NLF was dominated by two major camps and it hadn't been decided yet which political direction would prevail within movement. Until 1965, the leader of

204 | Stookey, 1982, 62.

205 | When mentioned, this determinant is merely described in vague terms of "grown structures" or “mentalities," see for example: Braun, 1981, 46.

206 | Dresch, 2000, 99.

207 | Dresch, 2000, 110.

208 | Burrowes, 2010, 132. 
the more pragmatic wing, Qahtan al-Sha'abi, had been the movement's politically experienced father-figure who boasted a strong tribal background and pretty much shaped the public face of the NLF. He was opposed by a smaller group of utopian Marxists inspired by their main ideologue Abd al-Fattah Ismail. ${ }^{209}$ As a consequence, any statement made by an NLF functionary at the time had to meet the lowest common denominator of the two fractions. Thus, the radical approach displayed in the NLF's writings was not what dominated the NLF's public image during the crucial years of power struggle. Instead, the movement relied heavily on nationalist and anti-colonial rhetoric which appealed to a significantly larger constituency. Marxist rhetoric was reduced to moderate clichés congruent with general notions of Arab Socialism of the time. Especially within the tribal realm, the NLF's activities were undertaken with little to no communist influence and generally avoided interfering with tribal social structures. ${ }^{210}$ It seems unlikely that the NLF consciously opted for a pragmatic strategy with regard to their true political intentions so that they could appeal to a broader audience. Rather political restraint has to be regarded as a side effect of the small proportion of intellectuals within the NLF and the necessity to include the opposing factions within the movement. Nonetheless, this pragmatic restraint allowed for tribal and moderate forces to join the NLF's fight.

From the very beginning it had been the explicit goal of the extreme fraction within the NLF to "transform [...] existing social relations"211 by abolishing all preexisting social structures and replacing them with a new, classless society. Thus, it may be assumed that illiteracy of the tribes accidentally had helped the NLF: Their radical documents were not accessible to most of their tribal supporters. Calls for a united Yemen that was free from British rule were widely accepted by tribal Yemen - the abolishment of society as it had existed for centuries certainly was not. Indeed, the reason for the NLF's prevalence may be found in their ability to include quite solid and thus low-responsive tribal identities. For this, in the following section three major reasons are identified: Ideological restraint in the early years, the appeal of the NLF's violence to the tribes, and tribal affiliations among the NLF's leading figures.

\subsection{Tribal Affiliations: On Yemeni Pride and Independent Thinking}

"The poor region of high, jagged mountain peaks and deep, steep-sided, rockstrewn ravines in South Yemen is where the [NLF] translated tribal dissidence into the start of its guerrilla war against Great Britain in October 1963." ${ }^{212}$

209 | Arabic: “Abd Al-Fattah Ismā”tl.

210 | Halliday, in: Braun, 1981, 44.

211 | NLF statement in Mukallā, in: Dresch, 2000, 120.

212 | Burrowes, 2010, 301. 
Mainly due to the first closure of the Suez Canal in 1956-57 and its resulting economic hardships, the late 1950 were characterized by upheaval and general political unrest in Aden and the hinterland. This is where resistance finally turned into violence. In October 1963 fighting broke out in the mountains of Radfan north of Aden against the local emir who was invested in and backed by the British. To this day, October 141963 is commemorated as the "Day of Independence." 213 However, as Dresch rightly notes, the "Rebellion of Radfan" may neither easily be interpreted as a "class struggle," nor as a fight against "colonialism." The eruption of violence of 1963 and the following years was the result of crisscrossing political, economic, and also personal motivations of groups and individuals. However, while "fighting in the countryside [...] could be taken for tribalism [by the British], events in Aden could not." ${ }^{214}$ When fighting reached Aden and grew into an urban guerilla-war, the city became the focal point at which the simmering discontent of decades flowed into a political revolution - a revolution driven by a diffuse Adeni/ Yemeni identity with the common goal of national independence.

Arab nationalism and socialism had taken root among the workers and actors from the "provincial lower middle-class" emerged as their political leaders who tried to channel the city's movement into the hinterland. But while no "translation" was necessary for the workers of Aden, modern ideas only took root among the tribes after being trans-coded by Arab nationalism and a moderate Arab socialism. And while print had brought the new concepts to the urban Adeni intellectuals, it was not before radio broadcast reached the tribal lands that a modern national consciousness began to emerge. The new technology did not rely on written but spoken standardized Arabic which was comparably close to the Arabic spoken by the Yemeni tribes. It was radio that linked the illiterate majority of the Yemeni population, including the tribes, with the cosmopolitan, intellectual leaders of the independence movement in Aden ${ }^{215}$ - by making the Yemeni people "aware of one's self" 216 as belonging to the same people. This was the common ground necessary to establish the shared national consciousness of a Yemeni identity and to bridge the very different identities of the two different worlds in the "city" and the "tribal space."

\section{Of Tribal Pride and Independence: Why Follow Marxist Leaders?}

Yemen's tribal identity had turned out to be rather insusceptible to external influence at the time, while also refusing to internalize the "picture of their own inferiority" as the dominance and "misrecognition" 217 of British colonial rule had suggested. Tribal communities are among the strongest forms of political

213 | Dresch, 2000, 96; Also see: Radfan and the Radfan Rebellion, in: Burrowes, 2000, 301ff.

214 | Dresch, 2000, 99.

215 | Gavin, 1975, 333.

216 | Said, 1993, 214.

217 | Taylor, 1994, 25. 
organization with regard to identification while characterized by a low "degree of responsiveness" to change. Maybe tribal identities in Yemen can even be considered immune to what Fanon describes as "resentment" ${ }^{218}$ caused by colonial oppression. As Adra convincingly observes, Yemenis

\begin{abstract}
"maintained a pride in their own heritage and civilization that contrasted radically with the attitudes of colonized peoples. Not well informed about modern industrial and technological capabilities, rural Yemenis had very little reason to question the validity of their own civilization." ${ }^{219}$
\end{abstract}

Nonetheless, British presence had intensified, especially after World War I, with the aim of securing Aden's trade routes over land and thus had given up its policy of "non-intervention" in the hinterland. The new ideas of Arab and Yemeni empowerment were communicated at a time when the British occupation started to be perceived as a potential threat to tribal lifestyle. Thus, while anti-colonial notions with socialist accents inspired the Adenis, nationalism united the tribes. The NLF profited from both the impact of Arab nationalism on tribal identities and the awakening resistance against the colonial power.

During the "revolutionary years," the NLF's ideology as a mobilizing force for political support had focused on the evolving national consciousness of the people to "integrate society" while keeping any extremist rhetoric out of the public eye. Yemeni society probably was ignorant of the looming ramifications of a future NLF regime. The NLF's reluctance to any compromise with regard to the British pullout distracted attention away from their extremist political stance. Prone to violence but at the same time victorious, the NLF enjoyed tribal acknowledgment and respect due to their regional ties:

\begin{abstract}
"The term "regionalism" means that a given regime, however ideologically uniform and institutionally centralized, nevertheless operates according to primordial, regional-tribal inclinations that govern both its main political groups and their leaders. [...] [I]t was a combination of regional perceptions mingled with outlooks they developed on the job that shaped the revolutionary concepts of Aden's leaders." 220
\end{abstract}

With this, Kostiner nicely sums up the revolutionary leader's political identity in the NLF as an unlikely combination of Marxism-Leninist ideology and tribal regionalism. Tribal support and acceptance for the NLF's version of Yemeni identity were carried by its nationalist aspect, which resonated well with some of

218 | Fanon, 2004, 89.

219 | Adra, 2010, 65.

220 | Kostiner, 1990, 14 and 16. 
the core markers of tribal identity: Independence from foreign interference and the shared values of qabyalah.

\subsection{Conclusion: How the Radical NLF and Its Ideology Prevailed}

Without doubt the British Federation's proposal of January 1954 finally "marked the turning of the tide in the Aden Protectorate"221 for the British colonial presence. However, this also became the turning point in the power struggle within the independence movement. The international esteem of FLOSY caused many observers to overlook the standing and power position of the NLF. FLOSY had recruited mostly from the new "provincial middle-class" with their leaders being drawn from what has been described as the highly educated "urban Adeni." In contrast to this, only a few of the NLF's leaders "had received a higher education."222 As a result, FLOSY's supporters within the city exceeded the NLF's followers by far. But what constituted FLOSY's source of strength around the "Crater"223 turned out to be their major weakness in the hinterland and beyond. FLOSY "and its associates lacked both the NLF's organization outside Aden and its ability to mount military and terrorist attacks." 224 And while FLOSY missed the opportunity to connect with the tribes, the NLF's leaders enjoyed strong tribal affiliations.

In the end, FLOSY was neither able to benefit from the mobilizing effects of resistance nor the shared national consciousness. Their moderate approach to violence did nothing to improve their relationship with the tribes, who regularly preferred a quick and violent policy toward the British. Favoured by the international players and the occupational power itself, FLOSY lost standing and credibility among the radicalized masses in the city in the end. The NLF on the other hand successfully adopted the opposite strategy by rejecting any compromises with regard to the British pull-out. As soon as the British forces had withdrawn in the summer of 1967 , the NLF overthrew those it considered to be "enemies" of the revolution, the supposedly "co-opted" sultans, sheikhs, and FLOSY. ${ }^{225}$ To the surprise of many at the time, the NLF was more than a lose assembly of fierce fighters: It was well-organized internally and able to draw from a widely interconnected network of supporters all over the Arab world who only revealed themselves during the independence negotiations with the British.

$221 \mid$ Kostiner, 1990, 333.

222 | However, some of its later leading figures, among them Abd al-Fattah Ismail and Ali Nasir Mohammed, were well-educated. Brehony, 2011, 31.

223 | What is Aden downtown today used to be the main commercial area of the city. It is located in the crater of a dead volcano. See: Aden, Aden Colony and the Port of Aden, Burrowes, 2000, 10ff.

224 | Brehony, 2011, 20 and 25.

225 | Brehony, 2011, 27. 
All in all British presence had had a decisive impact on national Yemeni identity both in negative as well as in positive terms. The negative impact refers to the creation of boundaries against the British as "the other," while the positive focuses on the establishment of new identity markers provided by British occupation policy. And while the British dual policy toward the "city" and the "tribal space" had affected the respective identities in very different ways, it had fostered the unification of an otherwise highly fragmented Yemeni society. Facing a common external threat, the tribal glorification of warfare in Yemen was used and politicized by political groups in a way that can be described by Said's concept of "resistance." 226 As the shared reaction to dominance among people identifying themselves with the same "nation," "resistance" became the unifying factor of otherwise fragmented and even competing revolutionary factions in Aden. Thus, and paradoxically, without British colonial rule there would not have been any identities in Yemen receptive to the rather intellectually extremist ideas promoted by the NLF.

At first, British colonial policy had prevented the emergence of a "national consciousness or a national opposition to the colonial rule," 227 as it fully controlled access to the city and even attempted to use existing conflicts and competition between sultans and hinterland sheikhs for its own ends. The British Crown had not reckoned with any significant resistance to their policy, as the British had won the allegiance of what they considered the major tribal rulers. The British had realized "Arab nationalism to be the most effective instrument of wrestling the eastern Arab world from Ottoman control." ${ }^{228}$ When they tried to use this powerful notion for their own ends in Yemen's south, Yemeni nationalism had already begun to engulf all of Yemeni territory under British control. Afterward, the Empire was not able to adapt its strategy and had to consider Aden a lost cause.

When British occupation was nearing its end, Yemenis began to incorporate traditional images of al-Yaman, its ancient pre-Islamic history, and also its role in the Arab world after the expansion of Islam, with new conceptualizations of the modern nation. As Said points out, the shared feeling of belonging to a "nation" usually is caused by the wish "to see the community's history whole, coherently, integrally." 229 Regularly this includes a strong ideology that gives the community new meaning. Thus, it seems reasonable that the political group that appeared most likely to provide Yemeni society with an ideology capable of transporting this meaning while simultaneously being compatible with existing identity markers of the majority would be the most likely to succeed. Eder acknowledges the "steering

226 | Said, 1993, xii.

227 | Ismail/Ismail, 1986, $13 \mathrm{f}$.

228 | Choueiri, 2002, 654.

229 | Said, 1993, 215. 
effect," ${ }^{230}$ that is, the speeches and actions of political leaders, might have helped the construction of collective identities. With regard to the masses in Aden on the one hand and the very different audience in the tribal areas on the other, this suggests the ability of the NLF's political leaders to "translate" their vision of a Yemeni nation-state in a way that responded to the identities of both, the "urban Adeni" and the tribal fighters envisioning a Yemeni nation-state. However, it must be assumed that this was only possible due to the lack of clear communication of the NLF's true intentions: The radical left of the NLF intended to create not only a new state and nation but also a brand new society, a vision of their very own interpretation of a Marxist state. 


\title{
CHAPTER 10. Methodological Prelude:
}

Connecting the Case Study, the Foreign Policy Phase Analysis, and the State- and Nation-Building Approach

During the early 1950s, neither North nor South Yemen played a significant role in West German foreign policy. While Aden was little more than a port occupied by British forces, the North remained an unimportant player even on the regional level. The reasons why Bonn nevertheless engaged in the north of Yemen while East Germany became as the major partner of the South Yemeni regime are sketched out in this chapter. Accordingly, the two major analytical methods of this case study, foreign policy phase analysis and the dimensions of state-building, are introduced and related to the case itself.

\section{Two Germanys, Two Yemens and the Cold War: How East Berlin "Lost" the North and "Won" the South}

With regard to West German interests in North Yemen, Berggötz rightly summarizes:

\begin{abstract}
"Taking into consideration the relevant criteria [of foreign policy], [North] Yemen without doubt ranked at the very bottom of potential partners for the Federal Republic in the Near East [...]: Politically and socially even more backwards than Saudi Arabia, just as poor as Jordan, and located at a peripheral strategic position, it presented itself susceptible to offers from the Eastern Bloc - There did not exist many reasons to be interested in the country."
\end{abstract}

Nevertheless, the FRG engaged relatively early with the Yemeni Kingdom. By 1960 Bonn had already opened an office in its capital Sana'a. ${ }^{2}$ In the context of West Germany's limited resources and its major foreign policy goal at the time - to

1 | Berggötz, 1998, 309f.

2 | Arabic: San’āa, in: Festschrift, 1999, 4. 
vindicate itself among the international community of states - this move seemed to be nothing short of odd. However, another foreign policy priority was at stake here. The East German state, regarded by Bonn as a non-state and unlawful competitor to the claim to the German nation, had opened a trade mission with consular rights there only four years prior. This was considered a threat to Bonn's claim of exclusively representing the German people.

When reconsidering East Berlin's foreign policy focus in the first two decades of its existence, the establishment of this trade mission in a traditional, supposedly "feudal" monarchy, must be considered just as unusual. The GDR's focal countries of the time usually were potential "socialist" allies that boasted an active "liberation movement.” In Sana'a this clearly was not the case. For East Berlin's early interest in North Yemen, other reasons existed: First, Arab nationalism and Nasserism had found their way to the isolated North of Yemen during the 1950s and there were plenty of personal ties between Cairo and the MAN. Clearly, East Berlin nourished the hope that Yemen would follow the revolutionaries in Egypt, Syria, and Iraq. Second, and maybe more importantly, North Yemen did not appear to be a top priority for West German foreign policy in the Middle East in the 1950s reason enough for East Berlin to seize the opportunity.

\subsection{Yemen: Place of Interest for the Superpowers?}

Bonn's sudden interest in the Yemeni Kingdom came as quite a surprise for East Berlin. But Bonn's engagement in a place of such minor political and economic potential cannot simply be interpreted as a counter-policy to the East German presence. The answer can instead be found in the wider framework of the Cold War and its major players. South Yemen had started to slip from British grip, while Washington hadn't fully established itself in the region yet. Accordingly, Moscow tentatively initiated the expansion of its influence in the Middle East.

In 1955, Imam Yahya renewed Yemen's Trade Agreement with Moscow $^{3}$ and received considerable aid in return. Correspondingly, the GDR initiated its first contacts when the Crown Prince visited East Berlin in the following year ${ }^{4}$ and opened a commercial agency in Taiz. ${ }^{5}$ The Soviet Union was dedicated to including Yemen's north within its sphere of influence. Washington and London

3 | The trade agreement between the two states had first been signed in 1928. Braun, $1981,35$.

4 | Besuch des Kronprinzen des Königreichs Jemen 1956 in Ost-Berlin, in: Kronprinz des Königreichs Jemen, Emir Seif el-Islam Moahmmed el-Badr, vom 25. Juni bis 2. Juli 1956 in Berlin, in: DzAPR-DDR III, 1956, 687 und Besuch des Ministers für Post-, Telegrafenund Telefonwesen des Königreiches Jemen, Qadi Abdulla Ben Ahmend el Hagri, 1961, in: DzAPR-DDR IX, 1962, 452.

5 | Berggötz, 1998, 312. 
considered it was high time to act to secure the possible new ally for the West, as the American representative at the time remarked:

"[The] increasing Soviet infiltration in Yemen induced the British and U.S. American government to advice the Federal Government [of Germany] on the establishment of a representation in Yemen. The intention was an improvement of the Western position [in the region]. “6

The political putsch of 1962, inspired by Egypt's “Free Officers Movement," endangered these hopes for a Western foothold in the north, as well as for Bonn's Hallstein Doctrine. How much West Germany feared for the recognition of the GDR by this new Yemeni Republic is demonstrated by Bonn's rather hasty move to recognize the Yemen Arab Republic as the first country from the Western sphere. ${ }^{7}$

\subsection{Sana'a's Seesaw Policy in the Cold War}

The newly founded Arab Republic of Yemen followed Cairo's seesaw policy towards East and West, remaining an unstable ally for both sides until the end of the Cold War. ${ }^{8}$ The downfall of the pro-Egypt regime of Abdallah al-Sallal in $1967^{9}$ did not change the ambiguous nature of the YAR in the bipolar conflict. However, it became clear that the north would neither become the close ally Moscow had hoped for, nor would it further the GDR's international diplomatic recognition in the region:

"North Yemen, working closely with Egypt under President Sallal, had been a hot candidate for recognition, even more so when diplomatic relations were established with South Yemen in spring of 1969. Literally every day, we expected North Yemen to follow. In July 1969 the relations to the Federal Republic were reestablished. That was rather an unexpected blow." ${ }^{10}$

Indeed the YAR's move was unexpected, as this strategic decision of Sana'a threatened to isolate the country in the region. A majority of "progressive" Arab states had been boycotting West Germany's political rapprochement with and support of Israel since the so-called "Near East Crisis" in West German-Arab

6 | "Errichtung einer ständigen Vertretung im Jemen," Aufzeichnungen Voigt (316) April 211958 and Gesprächsprotokoll von Scherpenberg/Trimble (Amerikanischer Gesandter), February 28 1958, in: PA AA, Abt. 7, Bd. 1058b, quoted in: Berggötz, 1998, 312.

7 | Berggötz, 1998, 313.

8 | On Egypt's seesaw policy: Blasius, 1998, 748f.

9 | Al-Sallal Regime and Era, Burrowes, 2010, 334

10 | Interview with Fritz Balke May 232011. 
relations of $1965 .{ }^{11}$ As such it was the YAR that "broke the boycott imposed on West Germany by the Arab states." 12

Regardless of the danger of Sana'a's isolation in the region, Bonn's economic support seemed worthwhile to Sana'a. Burrowes comments: "For years thereafter, West Germany was the biggest and perhaps most successful donor of aid to the YAR." As a consequence, the YAR declined the Eastern Bloc's advances and abstained from any further rapprochement with the GDR. When in October 1969 the YAR weakly spoke of "amicable relations with the GDR,"13 East Berlin and Moscow had "lost" the YAR as the closest ally in the region. The GDR reacted accordingly: Balke vividly remembers the "period of neglect" by East Berlin toward North Yemen and the East German representation in Sana'a that followed - especially in comparison with East German engagement in Aden. ${ }^{14}$

\subsection{Where the GDR's Foreign Policy Thrived: The Benefits of West German Absence and Soviet Long-Term Commitment in South Yemen}

“The Federal Republic [of Germany] didn't play any role there [in South Yemen], not even for us."

Hans Bauer, East German HV A Resident to Aden

While North Yemen turned out to be a "lost cause" for East Germany's "Policy of Recognition," South Yemen was quite a different matter. At first Bonn pursued the same strategy as they did in North Yemen. Immediately after South Yemen declared independence, FRG President Heinrich Lübke sent a telegram to recognize the young state and its government - almost 24 hours before the East German telegram arrived, very much to Ulbricht's displeasure. ${ }^{15}$ After the first GDR delegation visited South Yemen in June $1968,{ }^{16}$ the South Yemeni Minister of Agriculture returned the favor by visiting East Berlin July. ${ }^{17}$ Bonn reacted

11 | During the so-called "Near East Crisis" of West German Middle East policy, many Arab countries determined diplomatic relations to Bonn, in: Blasius, 1998; Nahostkrise. Schlußbilanz [sic!], in: Zeit, March 19 1965. YAR's President Al-Iryani even tried to justify his move as "unharmful to the Palestinian cause," in: Süddeutsche Zeitung, No.147, June 201969.

12 | Germany, in: Burrowes, 2010, 138.

13 | Süddeutsche Zeitung July 221969.

14 | Interview with Fritz Balke May 232011.

15 | Informationstelegr. Wildau to the MfAA, Oct 30 1968, in: PA AA C 1125/71, 118-120.

16 | Vermerk über ein Gespräch des Ministers für Auswärtige Angelegenheiten, Genossen Otto Winzer, mit dem Minister für Landwirtschaft und Bodenreform der VRDJ, Ahmed Saleh As-Shari [sic!], June 25 968, in: PA AA MfAA C 1223/71, 21.

17 | Programm für den Besuch S.E. MfL der VDRJ Herrn Achmed Salem Ashair [sic!] am 12. Und 13. Juli 1968 in Berlin, in: PA AA MfAA C 753/73, 14-16. 
swiftly. According to South Yemeni President Qahtan Muhammad al-Shaabi, ${ }^{18}$ "West German offers for financial aid exceeded everything any other party had offered so far."19 On August 30 1968, the West German Foreign office signed an agreement with South Yemen's secretary of state for Ministry of Agriculture to "send three agricultural experts" and the pledge of ten million German marks in financial aid. ${ }^{20}$ Just as well, East German recognition was high on Moscow's political agenda at the time and Soviet support contributed greatly to the first diplomatic recognitions of the GDR, among them the radical South Yemeni regime.

Even though Aden was neither internationally nor regionally important enough to have a big impact on widespread international recognition of the GDR or the establishment of diplomatic relations, South Yemen was to play its part in further diminishing the deterring effect of the Hallstein Doctrine, which had started to deteriorate in the preceding years: ${ }^{21}$ "Federal Minister Brandt reports on the diplomatic recognition of the 'GDR' by the general command of South Yemen on June $30^{\text {th }}$. He suggested to close the [West] German embassy at once and to withdraw the diplomatic personnel. [According to him] there did not exist any [West] German interests warranting protection in South Yemen. The mutual economic relations were insignificant. [...] The Federal Chancellor [Kurt-Georg Kiesinger] agreed to this approach while emphasizing that this decision was no precedent for other severe cases of 'recognition' by other Arab states. More severe cases would cause more severe actions taken."22

Despite of Chancellor Kiesinger having declared that Bonn's behavior towards Aden could not be considered a precedent for West Germany's policy towards Arab states recognizing the GDR in general, it was only two more years until the "Grundlagenvertrag" between the two Germanys was signed and Bonn recognized the GDR as a de-facto state.

The moment Aden officially established relations with East Berlin, Bonn immediately suspended theirs with the potentially Marxist regime by the Red $\mathrm{Sea}^{23}$ and did not reestablish diplomatic relations with Aden until September

18 | Arabic: Qaḥtān Muḥammad al-Sha’ābi (short: Qahtan).

19 | Vermerk über ein Gespräch des Genossen Kiesewetter mit dem sowjetischen gesandten, genosse K.P. Kusnezow, June 11 1969, in: PA AA MfAA 1223/71, 64.

20 | Bulletin des Presse- und Informationsamtes der Bundesregierung, Nr. 112, September 7 1968, in: PA AA MfAA C 753/73, 13.

21 | Gerlach, 2006, 65ff.

22 | Kabinettsprotokolle der Bundesregierung, Vol. 22, 1969, 172. Kabinettssitzung am Mittwoch dem 2.Juli 1969, außerordentlicher Tagesordnungspunkt [B].

23 | Lamm/Kupper, 1976, 59. 
1974. ${ }^{24}$ Nonetheless, a considerable volume of trade between Bonn and Aden developed, especially in comparison to the official trade with the GDR. ${ }^{25}$ However, these allowances have to be considered an arrangement with merely practical benefits for South Yemen. West German involvement and influence in the PDRY remained almost non-existent. ${ }^{26}$ Bonn's lack of activity had opened up a new venue for East German foreign policy free of Bonn's usual diplomatic presence. Here, in the comparatively diplomatic no man's land of this young and minor player, East Berlin found an opportunity for active involvement and seized it.

\subsection{Soviet Interests in South Yemen and its Impact on East German Engagement}

All in all, West Germany has to be considered an indirect determinant of the GDR's foreign policy towards the PDRY, as it still shaped the GDR's general foreign policy. Thus, the Soviet Union remains the only direct determinant of East German engagement in South Yemen. Due to the lack of access to the relevant archival material, Soviet policy in the Middle East in general and in South Yemen in particular can only be assessed based on Soviet actions. Halliday's suggestion to consider these actions as a "response to, and rivalry with" 27 the U.S. policy in the region may serve as a first guideline. This approach has already been taken into consideration in the short account of Soviet engagement in the Middle East in Chapter 8. From the very beginning, the Soviet Union had a watchful eye on nascent state by the Red Sea, though the full extent of Soviet long-term engagement did not become clear before the mid-1970s. The mid-term benefits of the Soviet-Yemeni relationship for Moscow serve as an indicator for the Kremlin's actual interest in South Yemen:

"[The] USSR has gained access to the fine natural harbor of Aden near the straits of Bab el-Mandeb [sic!] and overlooking the Red Sea [and] she has secured a base for operations in the Arabian Peninsula and the Horn of Africa." ${ }^{28}$

Clearly, the poor, unstable, and politically isolated South Yemen first and foremost was of geostrategic interest for the USSR.

24 | Kabinettsprotokolle der Bundesregierung, 172. Kabinettssitzung am Mittwoch dem 2.Juli 1969, Tagesordnungspunkt [B] und 50. Kabinettssitzung, am Mittwoch dem 13. Februar 1974, Tagesordnungspunkt [C].

25 | Regardless of the suspension of relations, Halliday estimates about three times the volume for the period 1969-1977, Halliday, 1990, 76.

26 | Interview with Fritz Balke on May 232011.

27 | Halliday, 1990, 180.

28 | Chubin, Adelphi Paper No.157, 1980, in: The International Institute for Strategic Studies (Ed.), 301. 
Analysts of the early 1980 s diagnose the PDRY being "almost totally dependent on the USSR" due to Aden's extremist internal politics, as well as its foreign policy towards its neighbors and Israel. ${ }^{29}$ Regardless of the value of this assessment, the impression the Soviet-Yemeni relationship made on the international stage was that of a tightly-woven alliance based on shared ideological principles. And even though it may be doubted that Aden fully embraced Marxist-Leninist ideology, the fundamental ideas served as a binding force, initiating and then intensifying the bilateral relationship between the USSR and the PDRY through a shared "feeling of sameness" which served as a common source of identification. Moreover, the shared dissociation from a common hostile "other," the "imperialist West," unified the two very different actors in a common cause. And last but not least, what also helped to overcome these differences, was the role of a smaller version of the USSR in size, population, and also actions: The GDR.

\section{Phases of the GDR's involvement in South Yemen: Internal Developments Determine External Foreign Policy Engagement}

The following analysis of the GDR's involvement in South Yemen roughly follows the same policy phases as those of Soviet involvement. This is not a coincidence. While foreign policy engagement of Moscow and East Berlin during the early years of the PDRY differed widely, the "Corrective Move" of 1969 changed that quickly. For the next two decades, East German and Soviet policies cannot be analyzed separately, as they were directed by Moscow to complement one another, and must be considered accordingly. As a consequence, this study suggests congruent phases of foreign policy engagement for both the GDR and the USSR, even though their levels and fields of engagement do differ on first glance.

Halliday, the most distinguished analyst of Soviet-South Yemeni relations, suggests the four presidencies as a basis to describe the changes in Soviet foreign policy towards Aden. ${ }^{30}$ Clearly, the presidencies do not simply represent political power distribution in the country. But they do give an initial idea of the political changes and "reshuffles" taking place. In conclusion, the four phases this study suggests follow internal turning points of South Yemeni politics, ${ }^{31}$ which also

29 | Ibid., 301.

30 | Halliday, 1990, 189.

31 | Burrowes suggests five major periods by counting Ismail's presidency from 1978 to 1980 as a phase of its own. in: Burrowes, 2010, 278f. Nonetheless, four phases appear to provide a more fitting analytical framework. First and most importantly, the replacement of Ismail by Ali Nasir had no significant impact with regard to East German or even Soviet foreign policy. Secondly, Ismail's exile in 1980 has to be considered one of the most 
qualify as turning points in Aden's relations to Moscow and East Berlin. However, it is not the Presidencies, but catalyst events that define these phases:

Phase I: The Phase of Sampling, 1963-67 to 1970;

Phase II: The Phase of Establishment and Expansion, 1970 to 1978 ;

Phase III: The Phase of Continuity and Consolidation, 1978 to 1986;

and Phase IV: The Phase of Neglect, 1986 to 1990.

The phases end with German and Yemeni unification, both of which coincided with the dissolution of the USSR. As this classification suggests, phases II and III are characterized by a continuous intensification of the GDR's level of engagement, but also a diversification of fields of engagement. The reasons for this are explored by pointing to several events that might have reversed approximation between the GDR and Aden, but in the end promoted and strengthened relations instead. These may not be considered turning-points but rather catalysts which provide the division between the two phases.

\section{Factionism, Alliances, and Executions as Political Means: The Unstable Milieu of South Yemeni Politics}

The following introduction to the developments in South Yemen serves as a rough framework for the characterization of foreign policy phases. The complex power constellations and shifts in South Yemen will be explored in greater depth as part of the phase analysis chapters on East Berlin's foreign policy in Aden.

The struggle for independence and the early formative years of South Yemen's existence are characterized by internal power struggles that remain difficult for both insiders and outside observers to properly comprehend. Nevertheless, the founding of the South Yemeni state was realized by revolutionaries in the truest sense of the word. Beyond Aden and its vicinity, the British had refrained from significant occupation, meaning only modest transport and communications infrastructure existed. The "hinterland" appeared detached from the political developments around Aden. And while the Yemeni rulers enjoyed no actual authority over all of South Yemen's territory, lack of recognition and influence was mutual. Apart from the tribal ties of some of the NF revolutionaries that might have had a certain impact, the "hinterland" did not have much say in the future of its country. After the NLF's victory against FLOSY and the British, disputes and plots erupted in the "Glorious Corrective Move" of 1969. The "Corrective Move" must be considered the turning point that determined South Yemen's future as a Socialist state. While veteran leader Qahtan had hesitated to shut

significant causes for the eruption of violence in 1986 but was merely a minor internal turning point in comparison to the other three identified in 1969-70, 1978, and 1986. 
the door on the West, his successor was more determined with regard to his position toward the two adversaries of the Cold War and their proxies. In June 1969, President Qahtan, a moderate, was replaced by Salim Rubayyi $\mathrm{Ali}^{32}$ and in July, Salmin's new regime, now called the People's Democratic Republic of Yemen, ${ }^{33}$ recognized the GDR and established diplomatic relations.

During Salmin's presidency, Moscow and East Berlin intensified their engagement, though Salmin acted hesitantly with regard to Moscow's wishes for the formation of a vanguard party and its support of the Ethiopian rebels. NF chief ideologue Abd al-Fattah Ismail, ${ }^{34}$ however, showed his colors early on. Ismail, secretary-general of the NF, travelled to Moscow and East Berlin on a regular basis. ${ }^{35}$ Salmin at the time "was concentrating power too much in his own hands for the comfort of [Ismail, Ali Antar, and Ali Nasir Muhammad]." ${ }^{36}$ After an affair over a political contract-killing and mounting criticism, Salmin was forced to resign. His apparent reaction to this was the launching of a rocket attack on the CC meeting room and the residencies of Ismail and Ali Nasir Muhammad. ${ }^{37}$ Salmin and two of his closest supporters were sentenced to death.

Salmin's demise cleared the road for two long-term "friends" of Moscow: After Salimin's presidency from 1970 to 1978 a six-month interlude of Ali Nasir followed. Then, Ismail, a long-time ally of Moscow and East Berlin, took over the presidency from 1978 until 1980. During Ismail's short "reign," the NF reformed as a Leninist vanguard party, the Yemeni Socialist Party, in 1978, an event that served as the major catalyst during this period and culminated in the signing of Treaties of Friendship with Moscow and East Berlin. Thus, despite Ismail's deposition and exile in 1980, the high times of Soviet- and East German-South Yemeni relations of the late 1970 s continued and remained at this level of intensity until the turning point of the 1986 crisis. In the bloody massacre of January 1986 , Ali Nasir Muhammad and his closest allies organized a "preemptive" strike against Ali Nasir's political opponents, among them Ismail, recently returned from his exile in Moscow.

With this attack against the majority of established political actors in Aden, the Aden's relationships with Moscow and East Berlin were disrupted profoundly. Both connections had lived off personal relationships between Yemenis, Soviets and East Germans. A noticeable policy change followed. On first glace there was

32 | Arabic: Sālim Rubiłã ‘Alī. (short: Salmin)

33 | Arabic: Jumhūrīyat Al-Yaman Al-Dīmuqrāț̦īya Al-Sha'abīya. (short: PDRY)

34 | Arabic: 'Abd al-Fattaḥ Ismā”īl. (short: Ismail)

35 | Ismail's first official visit as secretary-general of the NF was in July-August 1972, while he had travelled to the GDR before. Volksdemokratische Republik Jemen, zur Entwicklung des Landes, 1973, in: BStU MfS Allg. S. Nr.332/73, 8.

36 | Dresch, 2000, 147.

37 | Arabic: 'Alī Nāșīr Muḥammad al-Ḥassanī. (short: Ali Nasir) 
not much to gain in Aden anymore for either East Berlin or Moscow after the Soviet Union's loyal allies were removed from power. However, after several days of uncertainty, Moscow surprisingly introduced a strategy to stabilize the new leadership, and with it, the country. This strategy aimed at renewing Soviet-Yemeni relations. While the Kremlin had sided quickly with the new regime in Aden, Honecker decided otherwise for the GDR. Engagement was almost terminated fully and it took several years until East Berlin followed Moscow's lead in actively approaching the new Aden regime and restoring relations to their old strength.

\section{The Major Hypothesis: The GDR's Foreign Policy as a Policy of Socialist State- and Nation-Building}

The brief overview on the extremely unstable milieu of South Yemeni politics above suggests that the level of East Berlin's engagement highly depended on the internal political developments in the PDRY. This already illustrates the necessity to include the receiving side of foreign policy as an independent variable that explains foreign policy and its changes. As indicated above, the analysis of East Berlin's engagement in South Yemen rests on a chronological scheme of phases that is focused on the turning points and catalyst events. These represent the change of the political situation in the country and the possibilities for or limitations on external actors' ability to react. Each chapter focuses on the turning point that begins the phase as well as relevant catalyst events. To support and illustrate the argument, the most prominent events and political challenges are analyzed in more depth to be able to characterize the GDR's foreign policy in South Yemen.

Each phase takes into consideration East-Berlin's fields and levels of engagement and connects them with the major meta-hypothesis of this study: After diplomatic relations between East Berlin and Aden were established, the SED developed a new comprehensive bilateral policy towards South Yemen that was pursued with other close allies, such as Ethiopia. On behalf of Moscow and at the request of the South Yemeni regime, the GDR's foreign policy emerged as a "Policy of State- and NationBuilding." 38 This hypothesis is concerned with the intention of East Germany's foreign policy in Aden: East Berlin aimed to duplicate the East German process of the "planned development of socialism." ${ }^{39}$ Clearly, this goal brings to mind the Soviet Union's policy towards Europe, when Moscow had "import[ed] certain key elements of the Soviet system into every nation occupied by the Red Army" after the end of the Second World War. ${ }^{40}$

38 | Also see subchapter "Foreign Policy: Where the Nation State Ends" in Chapter 3, "Analytical Approach: An Interdisciplinary Analysis of Foreign Policy" of this study.

39 | German: planmäßiger Aufbau des Sozialismus. Schroeder, 2013, $110 \mathrm{ff}$.

40 | Applebaum, 2013, Introduction. 
The following subsection summarizes the most important features of the "development of socialism" as introduced in Chapter 7 of this study. ${ }^{41}$ These are related to Hippler's approach of the three preconditions needed for "successful" state- and nation-building ${ }^{42}$ to create an analytical framework for the GDR's approach in South Yemen. Following Hippler's precondition triangle for "successful state- and nation-building," East German policy measures are grouped according to first, the emergence of a functional state apparatus, second, the "integration of society," and third, the communication and acceptance of an "integrative ideology."

\subsection{Integrative Ideology}

The "planned development of socialism" approach relies on the integrating force of ideology. As such it is based on Lenin's three "inseparable elements" ${ }^{3}$ of MarxismLeninism: ${ }^{44}$ dialectic and historic materialism, political economy of capitalism and socialism, and scientific socialism. From the very beginning, Marxist-Leninist ideology served as the umbrella to integrate state and society. The ideology offered theoretical reasoning for concrete political approach and measures, as well as the motivation and justification for action. The two major ideological notions of the approach were mutually dependent: The creation of a vanguard party and its establishment at the center of the political system was based on the principle of "democratic centralism," which included a strict hierarchy of authority. To acquire a "socialist, centralist unitary state according to the Soviet example, ${ }^{45}$ the two other dimensions of state- and nationbuilding, the establishment of administrative and state structures and the "integration of society" had to intertwine closely with these two central notions.

\subsection{A Socialist State Apparatus}

The efficient and functional socialist state apparatus in the GDR was built through the enforcement of the principle of "democratic centralism." The SED was created not only as the leading party of the state, but also as the ultimate decision-maker in the sense of the "primacy of the party." 46 "Democratic centralism" suspended the separation of powers of the constitution and resulted in parallel structures of party and state with the party overruling the state organs. This was ensured by careful cadre selection, but

41 | Also see: Chapter 7 "The 'Three Spheres of Foreign Policy Making': Party, State, and Society"; Subchapter 1. On the Political System of the GDR and its Social Reality.

42 | Hippler, 2005, 6-14.

43 | Schroeder, 2013, 716.

44 | Official interpretations and recommendations with regard to Marxism-Leninism were centralized at the Institute for Marxism-Leninism at the central committee of the SED“ (Ger.: Inst. für Marxismus-Leninismus beim der SED). See also: Sindermann, 1980.

45 | Schroeder, 2013, 120.

46 | Schroeder, 1998, 421. 
also by the watchful eye of the security apparatus, which also only answered to the Politbüro as the highest Party organ. ${ }^{47}$ The party directed the state organs towards the overall objective of socialist state-building. This centralization of the political and the economic systems ensured full Party control. The first preparatory steps towards this centralization, however, had already been conducted before the founding of the state in the SOZ. This included economic planning and the socialization of all means of production: Production sites, machines, and land. In 1952, the "planned development of socialism" was declared the explicit policy goal and agriculture was gradually collectivized. ${ }^{48}$ In July of the same year, the "Länderreform" was implemented and federalism was abolished once more on German soil, at least in the East. This reform dissolved the provinces, connected them to the capital city in a centralist manner, and reorganized the state parallel to the new SED party structures.

\subsection{Homogenization Instead of Integration of Society}

Internal and external security organs were to play an indispensable role in the process of socialist state- and nation-building in the GDR and have to be considered the "backbone" of the policy. The military, the police, and the secret service, all traditional state organs, only answered to the SED Politbüro. However, the GDR's security apparatus not only supervised the establishment and prevalence of a state apparatus loyal to the party, but also ensured the loyalty of its population. The security organs, first and foremost the MfS, controlled the implementation of the socialist ideals that were fundamental to the process of homogenization of the future socialist society. The NVA, on the other hand, executed the SED's strategy of consolidation by controlling the borders of the GDR - officially to defend the GDR against outside intruders, but in reality to prevent its citizens from leaving the country and enforce the de facto suspension of the freedom of movement. ${ }^{49}$ This socialist approach to society may be considered an extreme and absolute interpretation of the "integration of society" of nation- and state-building.

The socialist integration of society was intended to be achieved by a centralization of political and social life on the one hand, and a homogenization of society on the other. Centralization of political and social life again was spearheaded by the creation of a vanguard party claiming the monopoly of power over public life and opinion. Thus, the party not only decided on the determinants of public life, but also on how this public life was perceived and interpreted. The strongest indicator for this is the expansion of full control of East German media and culture in general. After the

47 | The judiciary, for example, was watched closely by the MfS. Engelmann et al. 2011, 170-173; Schroeder, 2013, 123.

48 | Schroeder, 2013, 127.

49 | On the suspension of the freedom of movement and the possible effects on the population, see: Blickle, 2003, 214. 
goal of German reunification was given up and the German nation replaced by its socialist version, German culture was redefined as "socialist culture." 50

Homogenization of society was based on a twofold approach: through group integration and by actually changing the individual's personality. Political and social factionalism was supposed to be molded into bloc parties and mass organizations controlled by the party. Other influential social actors were either destroyed or integrated. A prominent example of this was the policy of suppression and neutralization over the decades towards the churches and Christian belief. ${ }^{51}$ On the level of the individual, the long-term goal was the creation of the "new human" which defined itself first and foremost as part of the "collective" and "free of egoism." 52 The "socialist personality" 53 was to be formed at all ages, but the central focus of "reeducation" were children and young people, who played a highly political role in ensuring the next generation's ideological loyalty and engagement. This approach was implemented by a comprehensive education policy.

The theoretical notion of the "planned development of socialism," as it was enforced in the GDR, included various policy tools and measures and is considered to have been used as a "road map" by the Soviet occupiers and its SED henchmen to establish first a socialist and then a Marxist state. The following phase analysis of the GDR's activities in South Yemen connects the characteristics of the East German "development of socialism," that is, the East German experiences of the 1950s and 1960 s with regard to this model of state-building, to the GDR's foreign policy of socialist state- and nation-building by in Yemen from the struggle for independence during the 1960 s to the demise of both states about thirty years later.

50 | Honecker, 1980, 391.

51 | Neubert, in: Judt (ed.), 1998.

52 | Segert/Zierke, in: Judt (ed.), 1998, 171.

53 | Ibid., 177. 



\section{FOREIGN POLICY PHASE ANALYSIS:}

\section{THE GDR's ENGAGEMENT IN SOUTH YEMEN}

The following chapters analyze East Berlin's engagement in South Yemen according to a chronological scheme of phases that is focused on the turning points and catalyst events of the GDR's policy. The analysis of each phase begins with a short account of the major turning point that is considered to be the beginning of the phase, setting in motion internal South Yemeni socio-political changes. Next, Soviet interests and policies during the phase are sketched briefly to allow for an assessment of Moscow's major fields of engagement and, more importantly, Moscow's level of engagement. This short account of Soviet engagement is followed by the analysis of the GDR's foreign policy in South Yemen itself. The analysis draws extensively from the introductory outline of Moscow's policy and South Yemen's internal political developments, as they are considered the major determinants of the GDR's activities on the ground. 



\section{CHAPTER 11. Phase I: The Phase of Sampling and Creation}

The GDR in Yemen from 1963 to 1970: A Constitutional Draft and the Road to Recognition

As early as its first Party Congress in June 1965, the NLF expressed its intent to create not only a new state but also a new nation based on the ideology of Marxism and Leninism: ${ }^{1}$ The Yemeni actors clearly had their own vision of a Marxist state in South Yemen. The following chapter first explores the NLF/NF's early steps on South Yemen's radical political path toward becoming a Marxist state in Arabia and how the GDR gradually became more and more involved in the process. Soviet intentions and its hesitancy towards the new regime in Aden are used to highlight the individuality of East Berlin's engagement during this phase.

\section{The Revolutionary Phoenix from Aden's Ashes: Opting fOR a SOCialist State}

"[B]adu with long curly black hair wearing indigo tunics, peasants with
multicolored füțahs wrapped around their waists [...] students in shirt-sleeves,
soldiers in khaki, surge around the avenues and public squares, which are
heavily decorated with posters and huge banners [denouncing ...] 'reaction'
and 'imperialism.'"2

(Rouleau's travels in Yemen, published 1967 in Le Monde)

Another closure of the Suez Canal in June 1967 exacerbated the already tense economic situation in South Yemen and left the fledgling South Yemeni leadership with vast economic challenges. The rapid British pull-out significantly added

1 Reference to the first Congress, in: Stenografische Niederschrift der Beratung mit der Delegation der NLF Südjemen am 2.11.1970 im Hause des ZKs, in: BArch SAPMO/DY 30/11407, 11.

2 | Rouleau, in: Le Monde Diplomatique, December 1967. 
to the economic and political pressures, as this also meant the withdrawal of British and Indian civil servants, military and security personnel, businessmen, and British money. ${ }^{3}$ Despite their support for the NLF during their fight against FLOSY, the loyalties of the Yemeni military forces trained under British rule were uncertain, and the ranks of the NLF were anything but unified. Also, the NLF was far from being in control of the whole territory of their state and only few of the NLF's leaders "had received any higher education and none had experience in government." ${ }^{\text {"4 }}$ Seeking firm rules and guidance for the establishment of the independent South Yemen seems a logical reaction, and this guidance was offered by the ideological role-models of the partisan struggle for independence. Among the conglomeration of ideologies discussed, Marxism-Leninism soon prevailed as the major doctrine. ${ }^{5}$

\subsection{NLF Factions - Qahtan's "Right" and a Fragmented "Left"}

Part of this tentative orientation toward socialist state- and nation-building was that the NLF openly prevented the formation of any new political organizations, while the staff of the NLF's General Command, now renamed National Front (NF), swiftly formed a one-party government. However, differences between various factions of the progenitor organizations of the NLF/NF still persisted. After its official formation in 1963 , it took more than 15 years until the movement had eliminated all shades and varieties of leftist attitudes.In the beginning, the major figurehead neither had the same approach to everyday politics nor did they put the same emphasis on ideology. While the whole movement was formed by leftist extremists of one kind or the other, the most important divide in the early 1960 s runs between a more moderate "right" under Qahtan's leadership and the highly fragmented "left," boasting figureheads like Ali Salem Al-Beidh, ${ }^{6}$ who had also come close to erecting a Maoist regime in Hadramawt.

The "left" was extremely fragmented as well. Two major groups can be identified that would determine South Yemen's destiny after 1970: "ideologues" and "pragmatists." The "ideologues," on the one hand, were mostly Marxists of some sort who rallied around the NLF's chief ideologue Ismail. They focused on the establishment of a Soviet-style vanguard party and entertained close ties to the communist People's Democratic Union (PDU) and their leader, Abdallah Abd al-Razzaq Badheeb. ${ }^{7}$ Badheeb had been among the founding members of the first

3 | The British withdrawal cut the number of ships using Aden by about $75 \%$. The GNP dropped by at least $15 \%$ in 1968 and again in 1969, while unemployment drove up to 200,000 people out of the city. Brehony, 2013, 31; Also see: Burrowes, 2010, 278.

4 | Brehony, 2013, 31.

5 | Ismail/Ismail, 1986, 26; 37.

6 | Arabic: ‘Alī Sālim Al-Bīọ ; Also Al-Baydh, Al-Bid, Ali Salim, in: Burrowes, 2010, 53.

7 | Burrowes, 2010, 47; Kostiner, 1990, 19; Naumkin, 2004, $290 f$. 
communist group in South Yemen in 1953, which he later reshaped as the PDU in 1961. ${ }^{8}$ The unlikely alliance between PDU and NLF may not be considered a given, as the PDU rejected violence as a means to an end. But the PDU's intellectual approach was not too far off from some of the ideas of the leftist "ideologues" of the NLF, and when the moderate Qahtan was dethroned in 1969, the previously suppressed communist party PDU joined the corridors of power. As a symbol of unity between the nationalist and violent NLF and the communists, the Higher School for Scientific Socialism of the 1970s was renamed after Badheeb, the "godfather of Yemeni communism." The left's "pragmatists" were a loose coalition that broke several times. Among them were Ali Nasir, Salmin, and the commander during the guerilla war against FLOSY in Aden, Ali Ahmad Nasir Antar (Ali Antar). ${ }^{9}$ Apart from these two major groups, the left consisted of neoTrotskyists and a motley assembly of tribal-affiliates siding with them out of opposition to Qahtan.

\subsection{Unique Yemeni Leadership: Civilian Backgrounds of Revolutionary Leaders}

Despite these ideological discrepancies, the leaders united under their first president and father-figure, Qahtan. These initial leaders were held in high esteem throughout South Yemen's short history and were to determine South Yemen's destiny from its birth to its demise. ${ }^{10}$ This small circle of "revolutionary leaders" is critical to South Yemeni politics: To create a unified and efficient military, a loyal instrument for the new party-leadership, the "Liberation Army of the National Liberation Front was merged [...] with the units inherited from the British colonial power to form [the] People's Defense Forces [PDF]." ${ }^{11}$ However, the key members of the new leadership, though all of them veterans of the struggle for independence, were no army men: ${ }^{12}$

8 | Scheider, 1989, 259.

9 | Arabic: 'Alī Aḥmad Nāșir 'Antar; Also see: Encyclopedia of Yemen (Arabic), Vol.3, 2003, 2119. 10 | In the following no transliteration given: Muhammad Ali Haytham, Minister of Interior, Saif al-Dhalal, Minister of Foreign Affairs, Faysal al-Sha'bi, Minister for Economy, Trade and Planning, Ali Salim al-Beidh, Minister of Defense, Mahmud Abdullah Ushaysh, Minister of Finance, Abd al-Fattah Ismail, Minister for Culture, National Guidance and Yemeni Unity. Only the latter three could be considered members of the "left" of the NF.

11 | Burrowes, 2010, 36f.

12 | President-to-be Ali Nasir, for example, had been an elementary teacher previous to his career as a revolutionary leader. Informationsmappe für den Besuch des Generalsekretärs des Zentralkomittees der Jemenitisch Sozialistischen Partei [...] Ali Nasser Mohammed, November 1984, in: BStU MfS HA II Nr. 28712, 179. 
"Ruling parties in the radical Arab states were generally dominated either by the military in uniform or, more often, by former senior military officers now appearing as civilians, the situation in the PDRY was an exception. From the beginning, civilians had full control over the military." ${ }^{13}$

Even though Yodfat's final remark in this quote has to be differentiated, as "full control over the military" was never guaranteed, this is one of the decisive differences between South Yemen and other young independent states in the Arab world - a major factor which eased the way for socialist state- and nation-building along the lines of the East German model.

\subsection{Planned Social Transformation: Marxism-Leninism as a New "Religion"?}

During the years of fighting, it had been the explicit goal of the NLF's left to "transform [...] existing social relations"14 by abolishing all pre-existing social structures, namely regional ties and tribal affiliations, and replace them with the vague idea of a new, classless society imbued with socialism. And they were serious.

"[T]he northern sayyids studied the Book of God, while the books of Marx and Lenin became the major reference for the Socialist Politbüro. Chief Politbüro exegete was Abdulfattah Ismai'l [sic!], an expert on Socialist doctrine who was known, wryly, as al-Faqih (literally, the scholar of holy writ)." ${ }^{15}$

Marxism-Leninism and its transcendent aspiration advanced as a religious substitute for many followers of the NLF. Less than a fortnight after independence on 17 December 1967, all sultans were declared to lose land and title. The first laws on agrarian reform followed soon thereafter. ${ }^{16}$ Furthermore, the PRSY regime abolished the traditional names of the provinces - Aden, Lahej, Abyan, Shabwa, Hadhramawt and Mahra. Just as it had happened with the GDR's "Länder," the South Yemeni provinces were now labelled with numbers - the First to Sixth Governorates. ${ }^{17}$ Tribal names and even the traditional Yemeni dagger, the "jambiyya," were banned. In January 1968, the NF declared tribal conflict

13 | Yodfat, 1983, 7.

14 | NLF statement in Mukallā, in: Dresch, 2002, 120.

15 | Mackintosh-Smith, 1997, 165.

16 | Informationsmappe für den Besuch des Generalsekretärs des Zentralkomitees der JSP [...] Ali Nasser Mohammed, November 1984, in: BStU MfS HA II Nr. 28712, 139.

17 | Burrowes, 2010, 141; Sharabi, Al-Thaura journalist, PDRY, in: PA AA, MfAA, C 122571, 110-123; Informationsmappe für den Besuch des Generalsekretärs des ZK der JSP [...] Ali Nasser Mohammed, November 1984, in: BStU MfS HA II Nr. 28712, 135. 
regulation and ruling invalid. On top of that, they decided on the suspension of tribal disputes, and tried to enforce this decision. ${ }^{18}$

However, the NF's policies cannot be taken as unanimously supported as they appeared. Many of the measures taken were promoted by the "left" and connived by the "right" under Qahtan, who would regularly opt for a more practical path. During the fourth NF Congress, held just east of Aden in March 1968, ${ }^{19}$ the inner cracks of NF leadership started to show. The "left" presented a kind of charter, the "National Democratic Liberation," that was strongly influenced by the extremist Nayif Hawatma. ${ }^{20}$ After intense debates, the adapted and officially adopted document was a compromise between the "left" and "right," including the core leftist demands, while leaving unanswered "how the principles would be implemented." ${ }^{21}$ The most important point both wings agreed on was the transformation of the NF to a vanguard party, based on the principles of scientific socialism. This decision implicated most of the other fundamental provisions to change the state's internal and external modes of action: First, the NF was supposed to merge with other revolutionary parties in the country, mainly al-Tali'a, the South Yemeni branch of the Ba'ath Party, and Badheeb's PDU, to establish a oneparty system based on "democratic centralism." This move clearly opted against Qahtan's moderate but single-handed leadership, as he had officially prohibited any political activity outside the NLF. ${ }^{22}$ Second, the economic system was to be transformed into a socialist economy based on production and public planning. These two goals flanked the "integration," or in socialist terms "homogenization," of society. Third, and with regard to external implications, the NF was to pursue a foreign policy oriented towards the Eastern Bloc and its allies to "draw[...] on their experiences." ${ }^{23}$ This commitment to international socialism also included the support of the "revolutionary" forces in the north of Yemen as well as the liberation movements in the region.

Compromise aside, the charter nonetheless remained a document proclaiming radical social transformation. Thus, the disputes revolving around the political

18 | Dresch, 2000, 121.

19 | Ibid., 121.

20 | Arabic: Nāîf Ḥūātma; Movement of Arab Nationalists activist who worked with George Habbash, leader of the PFLP. Also see: Nayif Hawatma, in: Mattar, 2004; Even though the document was not fully approved of at the time, Hawatmah nonetheless played a significant role in radicalizing and thus unifying the left between 1967 and 1969. He remained a close ally of the YSP even after his secession from the PFLP with the more radical wing, the future "Democratic Front for the Liberation of Palestine." Brehony, 2013, 37f; Palestine and the Palestine Question, in: Burrowes, 2010, 276.

21 | Brehony, 2013, 38.

22 | Scheider, 1989, 260.

23 | Information über die Lage in der Volksrepublik Südjemen, 1969. in: BStU HV A Nr.151, 170. 
orientation appear to have been over minor political differences only. But by this time, an undeniable rift emerged, originating in personal backgrounds and their attitude toward ideology. Qahtan always had aimed for a more pragmatic approach. For example, he promoted the expansion of the British system of administration over the whole territory, "taking over the ministries, armed forces, and police [...] and using them," ${ }^{24}$ instead of establishing a new, more centralized system. Not able to enforce his more moderate course, he felt rather cornered by the provisions of the charter. To prevent a looming military coup, Qahtan removed the two most radical of his ministers, Ismail and Minister of Defense al-Beidh, as the latter had intended to transform the army into a branch of the party. ${ }^{25}$ But it was too late to secure Qahtan's political survival. While he had fostered a more and more autocratic style of politics and relied on his "elder" status ${ }^{26}$ among the young revolutionaries, the "left," led by Salmin as chairman of a five-member presidential council, finally replaced him as president after the "June 22 Corrective Move"27 in 1969. Four days later Ismail was back - as the secretary-general of the National Front. This also once and for all settled another topic at the center of discussions between Qahtan's right and the new left: South Yemen's positioning between the fronts of the Cold War in general and towards the new East German ally in particular. A publication on South Yemen by the GDR's state publishing house emphasizes: “The decision of the PDRY's government to establish diplomatic relations with the GDR on June $30^{\text {th }} 1969$ had been one of the first foreign policy decisions of the new regime." 28 South Yemen's political bed for the next two decades was made.

\section{Soviet Engagement in South Yemen: When Aden Shed its Geostrategic Invisibility Cloak}

Not much can be said with regard to Moscow's early contact with the NLF: "It is not clear how far direct links between [USSR and China] and the Front existed before independence." ${ }^{29}$ But without doubt, divided Yemen did not come into focus as a major country of interest among the Arab states for Moscow before the mid-196os. Even after the declaration of independence, Moscow did not get engaged right away: the USSR waited two full days before it recognized the new regime in Aden on December 21967 . Nonetheless, it set up its embassy in less than a month and diplomatic representation assured continuous exchange. At the time, the Kremlin was occupied with other actors, primarily Egypt, the emerging regional power,

24 | Brehony, 2013, 36.

25 | Ibid., 35.

26 In the 1950s Qahtan used to be an agricultural officer of the British administration.

27 | For a brief summary of the "resurrection" of the Left see: Brehony, 2013, 42-46.

28 | Gambke et al., 1974, $131 \mathrm{f}$.

29 | Halliday, 1990, 178. 
in the region due to the war of June 1967 . Soviet political restraint in this context mostly arose from the unpredictable appearance of the new revolutionary regime and its unpredictable behavior towards its neighbors. But due to Aden's longing for security from British imposition, the new regime was looking for a powerful guardian. Hence, al-Beidh's early visit in February 1968 to Moscow comes as no surprise - at least from the Yemeni point of view.

The strategic importance of the otherwise insignificant country obviously helped to diminish Soviet reservations. "[L]ocated at the junction of important military, strategic and commercial lines of communications, the military base in Aden had a special significance for British imperialism." ${ }^{30}$ As a consequence and in spite of a certain political distrust toward the young radical regime, Moscow started to engage in the fishing industry and simultaneously began to use the Port of Aden and the waters in its vicinity to station its ships as early as $1968 .{ }^{31}$ In August 1968 , the first military agreement was signed, followed by several agreements on trade, economic and technical assistance, culture and science, and support for the PRSY's fishery in February 1969. ${ }^{32}$ Moscow's political and financial restraint toward the NF regime continuously decreased after the "Glorious Corrective Move" of $1969:^{33}$ South Yemen finally opted for some kind of socialist development. In addition to that, relations between Aden and Bonn, as well as Washington, were terminated, opening up considerable room for the USSR and its allies. In 1970, a visit paid by PDSY President Salmin to the USSR resulted in Moscow's agreement to train South Yemeni personnel in Moscow and start a technical mission to further improve South Yemen's fishing industry. In April 1970, on occasion of Lenin's $100^{\text {th }}$ birthday, Ismail visited Moscow and two months later he officially confirmed extensive future support in party cadre training by the USSR and the GDR. ${ }^{34}$ Aden had shed its political invincibility cloak and became a potential political ally for Moscow in the region.

30 | Pozdnyakov, E., Narodnaya Respublika Yuzhnogo lemena, 1968, in: Cigar, 1985, 776.

31 | Cigar, 1985, 776; Halliday, 1990, 203.

32 | Vermerk über ein Gespräch des Genossen Kiesewetter mit dem sowjetischen Gesandten, Genosse K.P. Kusnezow, February 1969, sine diem, in: PA AA, MfAA, C 1223/71, 30-34; Cigar, 1985, 776.

33 | Brehony, 2013, Chapter 3, 31-49 and 81.

34 | From 1972 political training was institutionalized at the College of Socialist Sciences in Aden, Halliday, 1990, 183. 


\section{The Phase of Sampling: From First Contact to Socialist Nation- ANd State-Building}

Phase I of East German engagement in South Yemen is an example of the GDR's efforts to pursue a foreign policy in its own right. In late 1967 , shortly before independence, external actors in East and West alike expected the revolutionary group FLOSY led by Abdallah al-Asnaj to become the future leading force in South Yemen, while its competitor, the more radical NLF, was almost ignored. Even Moscow was quite uncertain about which of the two to support. ${ }^{35}$ The GDR, on the other hand, had entertained contacts with a wide range of different actors from South Yemen as early as 1961. East German functionaries had invited Yemeni media multiplicators to East Berlin ${ }^{36}$ and even met with one of ATUC's leaders, Muhsin Ahmad Alaini, ${ }^{37}$ in late 1961 to offer the opportunity for two delegates to study at East Germany's universities. ${ }^{38}$

\subsection{Kindred Spirits: East Berlin as Aden's Companion of the First Hour}

"I consider the proclamation of the People's Republic of Southern Yemen to be yet another important step in the successful struggle of the peoples against imperialism, colonialism and neo-colonialism." ${ }^{39}$

(Letter Ulbricht to al-Shaabi, December 1 1967)

In July 1966, FLOSY leader al-Asnaj visited East Berlin. ${ }^{40}$ However, later that year the SED took hints about FLOSY being "bourgeois-conservative" seriously and East Berlin opted for a double-track policy towards the two major emerging political

35 | Gespräch von Freimut Seidel am 15. November 1967 mit Rat in der Abteilung Naher Osten des MID (Außenministerium der Russischen Föderation), Serjogin Aufzeichnungen von Freimut Seidel, Konsul am Generalkonsulat der DDR in Kairo 1966/67, in: PA AA, MfAA, 1224/71, 16-19.

36 | Einladung des Herausgebers und Chefredakteurs der Tageszeitung Al-Tariq Mohammed Nasser 1963 und 1966 nach Berlin, in: C 1126/71, 113; Vorbereitung der Einladung AI-Asnags in die DDR im Juni 1965, in: PA AA, MfAA, 1226/71, 131f; Kontakte der DDR-Institutionen ab 1965, PA AA, MfAA, 1224/71, 138f; Besuch einer FLOSY Delegation in der DDR 1966, in: PA AA, MfAA, 1224/71, 137. In 1966 Al-Asnag was affirmed to receive military equipment for FLOSY in Hodeidah. See: Gespräch Eggebrecht mit Al-Asnag am 4.Juni 1966 in Kairo, in: PA AA, MfAA, 1224/71, $135 f$.

37 | Arabic: Muhssin Abmad al-'`Ainī.

38 | Aktenvermerk über eine Gespräch mit Herrn Alaini, Vertreter der Aden-TUC im Allarabischen Gewerkschaftsbund (ICATU) am 4.Dezember 1961 in den Räumen des Büros des Bevollmächtigten der DDR in der VAR, in: PA AA, MfAA, C 1224/71, 145-147.

39 | Ulbricht, Walter, in: PA AA, MfAA C 744/73, 51.

40 | Kostiner, 1984, 136. 
groups in Aden. Accordingly, GDR representatives held exploratory meetings with both groups in October 1967 , FLOSY and NLF. ${ }^{41}$ When it was the NLF that prevailed after the British pullout, this was quite a surprise for external observers. However, the GDR's diversified strategy gave them the advantage of personal contacts with the radical NLF. Despite its early and positive contacts with FLOSY, East Berlin was able to build on these contacts, especially with Ismail. Now, after several years during which East Berlin had followed its recognition policy in both Yemens, there was a new window of opportunity, as well as fresh perspectives on matters in South Yemen. ${ }^{42}$ Profiling itself as the advocate of the postcolonial world - as opposed to the "imperialist FRG" the new regime in Aden. In November the same year, SED dispatched Klaus Gloede with the authority to "recognize South Arabia and to establish diplomatic relations with [the young South Yemeni] state. ${ }^{44}$ This move was supported by East Germany's hope for a swift recognition of the GDR in return.

In the end, East Berlin had to wait for another two years for this hope to be fulfilled. Until then, the GDR focused on its low-profile strategy as part of the GDR's policy of recognition. For this major component of East Germany's Middle East policy, relations between Berlin's and Aden's trade unions are an impressive example. In February 1965 , a delegation of the Aden Trade Union Congress had its first meeting with the executive committee of the FDGB, the East German mass organization of trade unions. ${ }^{45}$ When in 1969 official relations between the newly founded Yemeni federation of trade unions and the FDGB were established ${ }^{46}$ this clearly was due to the SED regime's early contacts with the leaders of the trade unions in Aden. The early engagement of the GDR in the country had built up trust and personal relationships and is one of the major explanations for the swift succession of political steps that followed the establishment of diplomatic relations between the two countries in 1969 .

41 Unterredung in der Residenz der DDR mit Funktionären der NLF am 21. Oktober 1967, in: PA AA, MfAA, 1224/71, 88-94.

42 | On the GDR's focus in South Yemen at the time see: Bericht Wildaus über ein Gespräch des Ministers für Auswärtige Angelegenheiten der DDR Genosse Otto Winzer mit der ersten Delegation der VRSJ in der DDR in: PA AA, MfAA, C 1223/71, $23 \mathrm{ff}$.

43 | Public declaration by MfAA official on April 8 1967, DOK zur AP der DDR XV/2, 1970, $1026 \mathrm{f}$.

44 | Direktive für die Dienstreise des Genossen Gloede vom 21. November 1967, PA AA, MfAA, C 1226/71, 96-98.

45 | Aktennotiz über den Besuch der Delegation des Aden Trades Union Congress beim Bundesvorstand des FDGB, vom 24. Februar bis 1. März 1965, in: PA AA, MfAA C 1226/71, 125-129.

46 | Gambke et al., 1974, 111. 


\subsection{The GDR's Policy of Recognition in South Yemen: The "Strategy of Focus and Low Profile"}

Despite East Berlin's early contact with North Yemen, the GDR in the early 1960 s rather had concentrated its efforts on the two major actors in the region, Egypt and Syria. After Ulbricht's invitation on Nasser's behalf in 1965, the GDR had to cope with the disappointed hope of recognition by its main and powerful partner in Cairo. It was East Berlin's early and positive relations with the radical regime in Aden below the governmental level which pushed the GDR's policy of recognition in the Arab world in a new direction. From 1963, personal and institutional contacts had been developed consistently and successfully and provided the perfect environment for East Berlin's “low-profile strategy.”

Driven by the hope of swift diplomatic recognition, the GDR tried to accommodate Aden's wishes as far as possible. Just one day after the declaration of South Yemeni independence in late 1967, East Berlin agreed to offer training for South Yemeni political cadres in the GDR. ${ }^{47}$ Half a year later, a South Yemeni delegation stayed for an extended visit in Berlin to intensify cooperation. The GDR's state and party officials discussed the economic possibilities of developmental support for "structurally and politically interesting objects" and delegate Clausnitzer suggested to subsidize communications and electricity. ${ }^{48}$ On this occasion Otto Winzer, minister of foreign affairs, reacted to the PRSY's demand for "advisors on state and administrative affairs" and promised to send an advisory group as soon as possible. ${ }^{49}$ Two months later, the Ministerrat was assigned to review the conditions for a loan comparable to those that had been given to Tanzania, Zanzibar, and the YAR. ${ }^{50}$ The amount of US\$3 million granted by the GDR in 1968 appears rather modest. ${ }^{51}$ But added to the costs and the effect of advisory support, East Berlin clearly intended to go the extra mile in supporting the new regime in South Yemen.

In February 1968, Qahtan and his regime still appeased Soviet inquiries about a possible recognition of the GDR by delaying it until an agreement of "all progressive and Arab countries" 52 was reached. In the end, the NF regime offered

47 | Kiesewetter an Gießmann, in: PA AA C 1226/71, 89f; Zusage Gießmanns am 1.Dezember 1967, PA AA C 1226/71, 88.

48 | MAW Brief von Clausnitzer, Ministerium für Außenwirtschaft, Direktionsbereich Übersee, in: PA AA, MfAA, C 121971, 61.

49 | Brief Winzer an Minister für Landwirtschaft und Bodenreform Ahmed Saleh al-Shair, June 1968, in: PA AA, MfAA, C 1226/71, 37.

50 | Brief Zscherpe an Winzer, August 21 1968, in: PA AA, MfAA, C 1219/71, sine pagina.

51 | Beschlußvorlage [sic!] zur Konzeption Entwicklung der politischen, ökonomischen und kulturellen Beziehungen zur VDRJ 1968, in: PA AA, MfAA, C 1219/71, 42.

52 | Vermerk über ein Gespräch des Genossen Kiesewetter mit dem sowjetischen Gesandten, Genosse K.P. Kusnezow, February 1969, sine diem, in: PA AA, MfAA, C 1223/71, 33. 
a consular agreement between Aden and East Berlin. ${ }^{53}$ Consul Wildau, as well as SED functionaries who met with actors from South Yemen, considered West Germany's presence and policies one of the major reasons for Aden's caution: "[T]he West German Embassy does everything to keep up sole representation [in Aden] and to limit [our] room for maneuver." ${ }^{4}$ They were not too far off from reality.

The GDR's position in South Yemen by no means was secured. In October 1968 , consul Wildau reported back from Aden:

"The GDR is well-known and liked by the masses due to its consequential support of the Arab peoples, especially in Aden with its strong working class. [...] Simple people asked when the GDR would open a diplomatic representation and expressed that the West German Consulate, which already had existed under British occupation, had to be closed. Officially though there have been no statements made with regard to the 'German Question' [...]. In the same month, A.F. Ismail acknowledged the GDR's attitude towards South Yemen in a personal meeting with correspondents of Radio DDR and the ADN." ${ }^{55}$

During a delegation visit in June earlier that year, however, South Yemen's minister of agriculture had summarized the PRSY's position:

"Concerning the credit, we are aware that the GDR cannot offer money, but might help with consumer goods. [...] We highly appreciate the GDR's position towards the Arab countries. And we took this into consideration, by visiting the GDR and not West Germany. We hope that [...] these steps take will be appreciated [by the GDR]." 56

Aden clearly was gambling on profiting from the inner-German dispute. In December 1968, the GDR's Karl Wildau and Wolfgang Hunger joined an official trip for the political missions in Aden - along with the Soviet ambassador, the charge d'affairs of the United States, and British, French and Indian representatives. ${ }^{57}$ East German diplomatic equality with the other states of the

53 | VDRJ, zur Entwicklung des Landes, 1973, in: BStU MfS Allg. S. Nr.332/73, 9.

54 | Brief Wildau an Kämpf January 23 1969, in: PA AA C 1125/71, 63-65.

55 | Informationstelegramm Wildau to the MfAA October 30 1968, in: PA AA, MfAA, C 1125/71, 118-120.

56 | Vermerk über ein Gespräch des Ministers für Auswärtige Angelegenheiten, genossen Otto Winzer mit dem Minister für Landwirtschaft und Bodenreform der VRSJ, Ahmed Saleh As-Shair [sic!], June 25 1968, in: PA AA, MfAA, C 1223/71, 27.

57 | Bericht ueber eine Reise der Genossen Karl Wildau und Wolfgang Unger auf Einladung des MfAA in die 5.Provinz der VSRY, Aden, December 4 1968, in: PA AA, MfAA, C 122571, 69. 
international community seemed to be within reach - at least in South Yemen. In March 1969, an agreement over a long-term credit was finally signed and East Berlin added a donation of medical supplies and equipment to express its goodwill. ${ }^{58}$ After the diplomatic recognition by Cambodia, Iraq, Sudan, and Syria, all occurring between April $30^{\text {th }}$ and June $6^{\text {th }}$, ${ }^{9}$ Aden was meant to follow suit. In early June 1969 , Soviet representative Kusnetzov ${ }^{60}$ informed Kiesewetter about a discussion with PRSY President Qahtan, who openly told Kusnetzov about the support offered by West Germany "exceeding everything South Yemen had been offered so far.” According to Kusnetzov:

\begin{abstract}
"West Germany is putting pressure on the Afro-Asian states to prevent a chain reaction of normalization of relations with the GDR. Bonn especially is using economic measures, promises high credits, increases technical assistance, etc. and special emissaries are foremost sent to those countries considered 'weak links in the chain.' [But] if extensive help were suggested [by Moscow and EastBerlin] the question of recognition [of the GDR] was decided." ${ }^{11}$
\end{abstract}

Kusnetzov recommended an immediate visit by a GDR delegation to Aden to hamper talks between Bonn and South Yemen. Only days later, the first official high-ranking political delegation from East Berlin arrived at the Red Sea.

After the "Corrective Move" of 1969, one of the first official actions taken by the new regime was the recognition of the GDR, an explicit expression of the political attitude of the new leadership. On July 22' the first East German ambassador was accredited in Aden, the first South Yemeni ambassador to the GDR arrived in East Berlin in August $1970 .{ }^{62}$ Bonn reacted swiftly and froze its relations and its financial aid accordingly. ${ }^{63}$ East Germany aimed to substitute these losses for Aden at once. Only a few days after the recognition, a governmental delegation from East Berlin travelled to Aden to sign a first mutual communiqué, the agreement on the establishment of relations as well as a protocol on future economic and cultural cooperation. ${ }^{64}$ In September 1969, more solidarity donations, medical devices, medication and other material support arrived. ${ }^{65}$ Other agreements followed,

58 | Quartalsbericht l/69 der Vertretung Aden, in: PA AA, MfAA, C 744/73, 24.

59 | Aufzeichnung des Ministerialdirektors Bahr, July 1 1969, in: AzAP-BRD 1969 Vol.1, 751f.

60 | The Source does not specify whether this was Vice-Minister of Foreign Affairs Wasilij Wasiljewitch Kusnezow or not.

61 | Vermerk über ein Gespräch des Genossen Kiesewetter mit dem sowjetischen Gesandten, Genosse K.P. Kusnezow, June 11 1969, in: PA AA, MfAA, C 1223/71, 64-71.

62 | Gambke et al., 1974, 132.

63 | Wippel, 1996, 22; Halliday, 1990, 76.

64 | Quartalsbericht III/69, Volksrepublik Südjemen, Abt. Arabische Staaten, sine anno, in: PA AA, MfAA, C 744/73, 23.

65 | lbid., 22. 
such as the agreements on air and maritime traffic, which were somewhat more beneficial for the GDR. ${ }^{66}$

Right after Aden recognized the GDR and Sana'a had reestablished its relations with Bonn, the role of North Yemen in East German foreign policy significantly declined, while the PDRY's star was on the rise. As a consequence, the Aden embassy became the major East German representation in the region. The GDR's personnel in the YAR travelled frequently between the two Yemeni capitals, as the embassy in the YAR fully depended on Aden's communication network and for consumer goods and supplies for the GDR's citizens. ${ }^{67}$

\title{
3.3 Writing a Marxist State in Southern Arabia: East-German Experts and the First Constitution of Independent Aden
}

\author{
"Based on Scientific Socialism, [the National Front] leads the political \\ activities of the masses and the mass organizations, to further the society's \\ non-capitalist path." ${ }^{68}$
}

(Constitution of the PDRY, November 30 1970)

\begin{abstract}
"The German Democratic Republic is a Socialist state based on the German nation. [The GDR] is the political organization of urban and rural workers who jointly realize Socialism led by the working class and its Marxist-Leninist Party. "69
\end{abstract}

(Article 1, Constitution of the GDR, April 6 1968)

In 1971 even West German academic discourse recognized the close kinship between the PDRY's new constitution of 1970 and the GDR's major political document in its 1968 version. And indeed the 1968 Constitution of East Germany may be considered the long-term model for South Yemen's constitutional genesis. From April to June 1970, the GDR initiated what was to become its major tool of foreign policy in South Yemen: To support the NF with the "drafting of a

66 | Quartalsbericht IV/69, Volksrepublik Südjemen, Abt. Arabische Staaten, January 20 1970, in: PA AA, MfAA, C 744/73.

67 | Interview with Fritz Balke on May 232011.

68 | German original: [A]uf der Basis des wissenschaftlichen Sozialismus [führt die Nationale Front] die politischen Aktivitäten unter den Massen und innerhalb der Massenorganisationen [...], um die Gesellschaft auf dem nichtkapitalistische Weg [...] voranzubringen, in: Gambke/Jacob/Mätzig, 1974, 98.

69 | German original: "Die Deutsche Demokratische Republik ist ein sozialistischer Staat deutscher Nation. Sie ist die politische Organisation der Werktätigen in Stadt und Land, die gemeinsam unter Führung der Arbeiterklasse und ihrer marxistisch-leninistischen Partei den Sozialismus verwirklichen." Art. 1, Verfassung der DDR vom 6. April 1968. 
new Constitution of the PRSY and the organization of the state and juridical apparatus,"70 the SED delegated their first advisory group to South Yemen. ${ }^{71}$

The East German constitution undeniably had been South Yemen's blueprint in many different ways. ${ }^{72}$ While the constitutions resemble each other in structure, content and language, the inclusion of the Leninist principle of the "democratic centralism ${ }^{\text {"73 }}$ has to be considered the most relevant similarity - both politically and ideologically. The new constitution of 1970 was intended to promote "the transition from a capitalist and pre-capitalist structure to a Socialist structure of society."74 This indicated that the GDR's advisors didn't consider it possible to simply adopt the GDR's political system wholesale at the time. Rather, South Yemen had to create certain prerequisites to further the state's development toward becoming a socialist state. From the advisor's ideological point of view, socialist state-building indicated the first steps to "restructure" society and, most importantly, it required the formation of a vanguard party to foster these social changes.

Much like its East German equivalent, the PDRY's constitution on first glance heralded democratic values and institutions. The document included an extensive catalogue of political and social rights and entitlements. A number of today's researchers and political advocates of the former South Yemeni state regularly quote significant improvements in this respect, ${ }^{75}$ especially in comparison to the initial years of "travail" after the declaration of independence. At that time dissidents were imprisoned, executed, or simply disappeared without due process. ${ }^{76}$ Even Brehony, the British author, politician, and certainly not a Marxist, stresses the regime's positive intentions and achievements with regard to people's rights.

70 | Quartalsbericht II/70, Abteilung Arabische Staaten (Quarterly Report II/70, Section Arab States), in: PA AA, MfAA, C 744/73, Jahres- und Quartalsberichte der AV in Südjemen 1966-1970, $16 \mathrm{f}$.

71 | Oswald Unger was part of the delegation. In 1971 he summarized the East German contribution to the new Constitution of South Yemen: Unger, Oswald, Die Verfassung für die national-demokratische Entwicklungsetappe der VDRJ, in: Staat und Recht, Nr.20, 2/1971, 1162.

72 | Even single provisions like the "obligation to work," Art.35 of the Constitution of the PDYR of 30 November 1967, in: Hachicho, 1976, 97.

73 | Comp. Art.47, Constitution of the GDR, April 6 1968; Art.11 Constitution of the GDR, November 30 1967, in: Hachicho, 1976, 99.

74 | Hachicho, 1976, 94.

75 | Brehony, 2013, 55 and 63; Interview with Hans Bauer June 202011.

76 | Security Services, in: Burrowes, 2010, 346. 
"The constitution was a comprehensive document guaranteeing citizens a wide range of rights and entitlements, though it took some years before the regime was in a position to implement many of them."77

However, Brehony and others often neglect the regime's political intentions, the wider political framework, and constitutional reality. In any case these optimistic praises of the achievement of socialism in South Yemen not only have to be modified, but questioned, as they simply do not reflect social reality. To acquire a more complete perspective, several aspects have to be taken into consideration: First, almost any form of self-governance would have provided a certain improvement of political rights in comparison to the conditions during colonial occupation in Aden. Second, South Yemen never approached the living and education standards of its industrialized model states in the Eastern Bloc, especially those of the GDR. Improvements of living conditions were achieved, but these were modest and limited to the urban areas. Lastly, one has to reconsider the standard of comparison: Political freedoms in the Eastern Bloc.

The states under Soviet influence fall far short of the Western approaches to political liberty or juridical security. While social rights with an economic dimension on the one hand mostly could not be achieved due to economic inability in Yemen, the guarantee of political rights on the other hand was always subordinate to possible “progress” toward communism under Marxist-Leninist ideology. Citizens' rights could be overruled by the decisions of the vanguard party at any time. From the outset, the political system introduced by the constitution, including the provided civil rights, were designed to accommodate the establishment and advancement of this party. Based on the principle of "democratic centralism," 78 the party was supposed to lead the masses toward a "non-capitalist state" and later on to socialism based on party structures not just paralleling but also overruling state structures. Thus, today's praises of "democratization" in former South Yemen made by former YSP and SED functionaries, as well as by the current secessionist movement, rather glorify a political past as it never existed. These statements simply have to be handled with caution, as more often than not they remain within the logic of socialist state- and nation-building ideology.

Unger, the leader of the GDR's advisory delegation, described the political system of South Yemen as "democratic": "The political fundamental of power exertion by the working people are the Peoples' Councils which are formed through free, general, equal and immediate elections." ${ }^{79}$ Even though Yemenis in 1970 gave the preference to the term "democratic" over "socialist," in constitutional

77 | Brehony, 2013, 55.

78 | The first Party Congress of the SED in January 1949, Avantgardeanspruch und innerparteiliche Diktatur Januar 1949, in: Judt, 1998, $46 \mathrm{f}$.

79 | Unger, 1971, 1170. 
reality the meaning of the two terms did not differ. According to Unger, the leader of the GDR delegation, elections for this Supreme People's Council (SPC) were scheduled for October $311971 .{ }^{80}$ However, the first SPC simply was appointed. "[T] he first elections for the 111-member [SPC] were not held until 1978." 81

On paper, the SPC was the PDRY's legislative body, and it also elected members of the Presidential Council and the Council of Ministers. ${ }^{82}$ In reality though, the SPC was constructed as a mere acclamation organ right from the start, wielding no political power, just like the East German Volkskammer. While the Council of Ministers as the executive and administrative organ also pretty much mirrored the role of its East German equivalent, in Aden it was the Presidential Council that decided on all central questions and policies. These were then confirmed by the SPC and implemented by the Council of Ministers. To improve the inclusion of the country's periphery in the system, the SPC was complemented by Local People's Councils. These LPCs

\begin{abstract}
"were to be elected for two-and-a-half year terms to manage [...] affairs on the local level under the supervision of the central government and in cooperation with the mass organizations and the state farms." 83
\end{abstract}

Clearly, the LPCs did less to empower the periphery and more to control it and achieve centralization. This political structure was designed to transform into a political system led by a socialist vanguard party, just as it had taken place in the GDR. Party structures of the NF at the time already offered a connection between party and state that was gradually expanded in practice until the 1978 constitution came into effect. The new version repeated: "The organization of the state power and its administration are subject to the principle of democratic centralization" ${ }^{\prime 4}$ and from 1978 the YSP officially was at the center of all political decision-making:

"The Yemeni Socialist Party, armed with the Scientific Socialism theory, is the leader and guide of the society and the state. It shall define the general horizon for the development of the society and the line of the state's internal and external policy." 85

80 | Unger, 1971, 1173.

$\mathbf{8 1}$ | Elections, PDRY, in: Burrowes, 2010, 110.

82 | Der Staatsaufbau der VDRJ entsprechend der Verfassung vom 30. November 1970, in: Gambke et al, 1974, 102.

83 | Burrowes, 2010, 226.

84 | Constitution of the PDRY of October 31st 1978, published by the Foreign Ministry of the PDRY, 14 October Corporation Aden, 1981.

85 | German Translation: "Bewaffnet mit der Theorie des Wissenschaftlichen Sozialismus ist die Jemenitische Sozialistische Partei Führer der Gesellschaft und des Staates. [...Sie] führt den Kampf des Volkes und seiner Massenorganisationen an, [...] um schließlich den 
The GDR's advisors intended to take into consideration the cultural and social characteristics of South Yemen. ${ }^{86}$ But the resulting constitution indeed rather mirrored the ideological ideal, not the possible need of South Yemen for a political system including the existing social structures. South Yemen's constitution was nothing less than a copy of the East German constitution of $1968:{ }^{87}$ the basic principles of political organization and of Marxist-Leninist ideology were merely complemented by few specific cultural characteristics of South Yemen. Even the attempts to justify radical political measures by referring to religious sources of legitimacy and the inclusion of Islam as the official religion in Art. $46^{88}$ by the NF was less attributable to the leader's preference for cultural specifics, and more to East German advice: "East German [...] leaders had advised the NF to harness Islam for its cause. [...] Islam could be adapted to the regime's ideology in what was called 'liberation theology.'" 89

\section{Conclusion: East Berlin's New Ally by the Red Sea}

Even though the regime in Aden and its insignificant state appear rather powerless with regard to the acceleration of the GDR's international diplomatic recognition, East Berlin considered it another small, but no less important step in their "LowProfile Policy" towards recognition. Aden emerged as the most fervent advocate for the acceptance of the GDR as a full-fledged member of the United Nations General Assembly. ${ }^{90}$ After the initial years of insecurity, East Germany had secured the loyalty of an ally not shy of forceful words and saber-rattling on the Red Sea.

Moscow's policy during the first three years of South Yemen's existence is characterized by oscillation between restraint and open support. Similar to other external powers like the British, ${ }^{91}$ the Kremlin was not sure whether the regime would be able to stay in power. This first phase of Soviet engagement was characterized by a low level of intensity and solely focused on fields of engagement

Aufbau des Sozialismus zu erreichen." Art.2, Constitution of the PDRY of October 31st 1978, published by the Foreign Ministry of the PDRY, 14 October Corporation Aden, 1981. 86 | The GDR advisors initiated interviews and discussions with Yemenis to become acquainted with Yemeni society, in: Hachicho, 1976, 98.

87 | Schwarzenbach, 1971, 1157.

88 | For example the drafting of a new Family Law in 1976 was justified by "research[...] in the old books of hadith," in: Dahlgren, 2000, 7; Constitution of the PDRY of 31 October 1978, published by the Foreign Ministry of the PDYR, 14 October Corporation Aden, 1981.

89 | Abd al-Fattah Ismail at the 1972 Party Congress, in: Brehony, 2013, $70 \mathrm{f}$.

90 | Quartalsbericht IV/69, Volksrepublik Südjemen, Abt. Arabische Staaten, January 20 1970, in: PA AA, MfAA, C 744/73, 20; Südjemen fordert UN-Mitgliedschaft der DDR, Neues Deutschland, October 1969, 7.

91 | The British ambassador to the PRSY in January 1970, quoted in: Brehony, 2013, 48. 
that were first and foremost beneficial for the Kremlin and its immediate interests: Securing another safe haven to station its naval forces in the region. Engagement was exclusively related to military and ideological matters, while involvement in civil matters of state was almost non-existent. Nonetheless, 1969 must be considered the turning point for Soviet-South Yemeni relations. Aden openly committed itself to a socialist path of development and Moscow opted for an active course of support, as will be shown in Phase II.

While Moscow's engagement during the first years of South Yemeni existence as a state can be considered minimal, the GDR had engaged more actively right from the beginning. This is an impressive example of East Berlin's attempts to implement a foreign policy of its own within the narrow scope of action between Soviet and West German interests. First of all, this first phase of East German involvement is characterized by a high number of unknown factors for the SED regime and thus resulted in a hesitant stance towards the new and radical regime in South Yemen. One of these unknowns was Aden's attitude toward the West in general, and the German question in particular. At this time it was not clear where Aden would position itself and whether it would be possible for East Berlin to become active in South Yemen at all. But even though Phase I of East German engagement provided a political environment of high insecurity, South Yemen is an excellent case example for the GDR's policy of recognition and the major strategies of the GDR's policy in the Middle East at the time, "low-profile" and the "honest broker" strategies. Furthermore, a major East German foreign policy tool used widely in the Global South was established during this phase, which also became crucial for GDR-PDRY relations during the 1970 s and early 1980 s: Political engagement through "advisory groups."

This tool played a big part in easing the way from first contact to socialist nation- and state-building during the Phase of Sampling. Involvement was expanded steadily. But regardless of this new cooperation on the state level, the third sphere of GDR's foreign policy making also continued to play its part in further intensifying East Berlin's presence in Aden, closely supervised by the SED. Right after the recognition by the PDRY, the GDR's foreign media service, the ADN, argued for a swift establishment of a media center for the region, as the recognition by North Yemen

"was only a matter of time and thus international coverage had to be concentrated in one hand. According to the MfAA the establishment of ADN offices in Aden and Khartoum were imperative to be prepared for the expected recognition of the GDR [in the region]." 92

92 | Mittwoch, Korrespondentenbüro/Ausland an Direktion Genosse Wieland, Berlin, July 9 1969, in: BArch 900/537, sine pagina. 
Even though this appeal by the ADN was not granted right away, it paved the way for the first GDR media presence in Aden: a local journalist supported by an East German official. ${ }^{93}$

This is a clear indicator of East Germany's intent to stay and get involved in the day-to-day politics of this young state by the Red Sea. East Germany's early engagement in Aden initially had been motivated by the possibility of a swift establishment of diplomatic relations, and thus lacked a comprehensive foreign policy approach. But the political measures taken by East Berlin to further the goal of recognition soon developed a dynamic of its own. During this period, East Berlin acquired the first samples for a possible future cooperation. East German willingness to offer support coincided with the new Yemeni regime's commitment to a radical transformation of Yemeni society: The traditional administrative structures were dissolved, the sultans expropriated and land newly distributed. In addition to that, the NF prevented the formation of new political organizations. The Charter of 1968 assured East Berlin that Aden was leaning towards a socialist path, including the introduction of a socialist economy and a political system based on the principle of "democratic centralism." When East Germany assisted the drafting of a new South Yemeni constitution, it became involved with the whole process of state- and nation-building that was to follow. Based on the principle of "democratic centralism," the constitution laid the foundations for the parallel structures of party and state that were common among states patterned on the Soviet system.

East German fields of engagement, even in this first phase of foreign policy activity, were considerably diverse. East Berlin's intensity of engagement clearly suggests that the GDR wanted more than a mere "diplomatic exchange," as the SED regime did everything to prepare a "close working relationship" and to lift its presence in Aden from foreign policy "influence" to "involvement." First advances had been made in the fields of legal affairs and the cooperation of mass organizations. With its activities during the drafting of the constitution, East Germany already arrived at the brink of "intervention." While the recognition of South Yemen as a state in its own right by East Berlin marks the beginning of East Germany's first phase of engagement in Yemen, the publication of South Yemen's first constitution has to be considered both the culmination of relations between East Berlin and Aden until then and the decisive catalyst with regard to the GDR's future foreign policy approach: Its policy of socialist state- and nation-building.

93 | Redaktion für Auslandssendungen an Korr-Büro Ausland, HA Kader/Bildung, Betr. ADN-Mitarbeiterin in der Volksrepublik Südjemen, August 21 1970; Der außerordentliche und bevollmächtigte Botschafter der DDR in der Volksrepublik Südjemen Wildau an Generaldirektor des Allgemeinen Deutschen Nachrichtendienstes Genossin Deba Wieland, March 9 1970, in: BArch DC 900/410, sine pagina. 



\section{CHAPTER 12. Phase II:}

The Phase of Establishment and Expansion 1969 to 1978 Incorporating Marxism-Leninism into a Tribal Society

In 1969-70, the radical Aden regime appeared as one of the most promising partners for East Germany in the Middle East. The turning point of the "Corrective Move" in June 1969, the launching of the new constitution in late 1970, and the fifth Party Congress in 1972 initiated a phase in South Yemen that built toward the formation of a Soviet-style vanguard party. However, the actual realization was not a guaranteed outcome and thus Soviet and East German engagement first and foremost supported advocates for the Marxist-Leninist cause among the leadership in Aden.

\section{Internal Developments: The First Steps toward a Socialist State}

"C'est cette pâte humaine que le gouvernement révolutionnaire est en train de travailler pour construire le socialisme. Un million et demi d'hommes qui tirent leurs revenus de la terre, de la mer... et du désert, et vivent à la limite du dénuement le plus absolu.» ${ }^{1}$

\subsection{Setting the Stage for a Yemeni Vanguard Party}

South Yemenis and international socialists shared their enthusiasm over the intentions of the "revolutionary government" to "develop socialism" out of the "human clay" of South Yemen. Brehony clearly sympathizes with the positive attitude of those years. He considers the "Glorious Corrective Move" of June 22 1969 the "most decisive event in the early history of independent South Yemen,"

1 | Deffarge and Troeller, 1971, 6.

2 | Translation of "pâte humaine," in: Deffarge and Troeller, 1971, 6. 
as it "marked the emergence of the PRSY as a truly revolutionary state." 3 The new power constellation propelled the implementation of the leftists' charter of "National Democratic Liberation," whereas the majority of its provisions was included in the new constitution released on November 301970 . Henceforth, the People's Republic of South Yemen was known as the People's Democratic Republic of Yemen.

After South Yemen's new constitution was launched in 1970, the early decision to expand the British administrative system all over the country served as a solid base of state-building with regard to the consolidation of the PDRY's state territory. ${ }^{4}$ With regard to the socialist nature of this state- and nation-building policy, the process was intended to be mostly driven by ideological means and justifications:

"The NF leaders turned to the provinces to [...] foster the revolutionary spirit that they thought was essential to get through the period of state-building and the hardships that were necessary." 5

The "leaders" of these initial moves were influenced by theoretical anti-colonial writings like the works of Frantz Fanon. ${ }^{6}$ But when it came to the more concrete activity of creating state institutions, the NF relied on strategies used by communist regimes of the Eastern Bloc. Mass organizations were intended to mobilize the "masses" for the cause of the NF and to communicate the party's policies and ideology to the people. The army was completely restructured based on a "revolutionary concept," meaning subordinate to the party: The Popular Defence Forces (PDF) were meant to be "a shield in protecting the country internally and externally."7 By establishing a socialist economy, the NF regime hoped for a swift transition: From its own condition of "underdevelopment" to a level of welfare similar to the GDR's. The YSP regime deliberately replaced Fanon's emancipatory approach of anti-colonialism with Marxist-Leninist ideology. In doing so, the regime not only denied the Yemeni "masses" the ability to emancipate themselves, but ascribed this right and ability to a political vanguard - itself.

The "Corrective Move" had set the political course for the years until the demise of South Yemen and guided the political leadership until the coup of 1986. Salmin had become chairman of the five-member Presidential Council, which also included chief ideologue Ismail and the military man Ali Antar. ${ }^{8}$ The Council

3 | Brehony, 2013, 45.

4 | On the role of administration in the state-building process see: Giddens, 1983.

5 | Brehony, 2013, 59.

6 | Fanon would warn of the difficulties waiting for the newly independent states after "wind of revolution los[t] its velocity," in: Fanon, 2004, 90.

7 | Naumkin, Red Wolves of Yemen, 323; Brehony, 2013, 62.

8 | Brehony, 2013, 45; Lackner, 1985, 64; Burrowes, 2010, 160. 
was reduced to three shortly thereafter, and in the following year Ali Nasir forced his way into the council: The three major figures of political life in South Yemen, Salmin, Ismail, and Ali Nasir, had risen to power. The fifth NF Congress followed suit in spring 1972.9 Its closing document spelled out the central provisions of the constitution, the commitment to "scientific socialism," "democratic centralism," "collective leadership," and to the "struggle against imperialism, Zionism and reaction." ${ }^{\circ}$ The NF was renamed National Front Political Organization (NFPO) and a future merger with the Ba'ath and the PDU was in the air. The former General Command was replaced by a Central Committee, the Executive Committee was transformed into a Politbüro. The Congress decided to form a secretariat subdivided into bureaus occupied with all relevant areas of internal and external policy. Gradually, the Politbüro replaced the Presidential Council as the center of political power in South Yemen. In 1972 the two institutions were comprised of almost the same figureheads. ${ }^{11}$ Clearly, the redesigning of the NF/ NFPO as a Soviet-style vanguard party was under way.

\subsection{Internal Frictions: Between "Individual" and "Collective" Leadership}

The "Corrective Move" of 1969 had set the agenda for foreign policy as well toward Moscow and the Eastern Bloc, though the intensity of this relationship hadn't fully been settled yet. The following eight years were characterized by a political tug-of-war between two factions defined by their ideological orientation and their attitude toward Moscow. Salmin's faction opted to uphold reservations toward the Eastern Bloc to maintain more maneuvering room on the global scene. Also, Salmin favored his very own interpretation of Maoism. This included a revolutionary approach that was to be initiated at the lowest social level. According to Salmin, leadership was supposed to respond to the action of the masses rather than the other way around. The creation of a vanguard party simply contradicted his political belief in the "autonomy and power of the masses." Still, it may be doubted that these ideological deliberations were the only reason for him opposing further empowerment of the NF, as this is what the conversion to a vanguard party in fact meant at this point. In practice, Salmin's style of politics clearly favored him as an individual political leader.

As a consequence, Salmin emerged as the immediate opponent of Moscowfriendly Ismail. Ismail's main goal was the erection of a "truly" socialist state led by a Marxist-Leninist vanguard party. Accordingly, he criticized Salmin on any possible occasion:

9 | Burrowes, 2010, 256.

10 | Articles 1-4 of the new by-laws of the party, in: Ismail/Ismail, 1986, 36.

11 Salmin, Ismail, Ali Nasir, Ali Saleh Ubad Muqbil (Muqbil), Saleh Musleh, al-Beidh and Muhammad Saleh Muti'a. 
"No individual, whatever his qualities of leadership, his genius or feeling for the masses, can ever be a substitute for the collective [...]. Everything done by the individual ends with the individual." 12

This quote by Ismail from the late 1970 not only reveals his rejection of Salmin and his style of leadership, but also the reason why Ismail was popular among the younger revolutionaries and intellectuals but less so among the Yemeni population. Ismail's admiration for the Soviet system did not leave room for Salmin's individual charismatic leadership, despite the prominence and popularity of this traditional concept in traditional Yemeni society. However, the concept of "collective leadership" does not necessarily mean a more democratic way ruling. According to Löwenthal, the concept as it was introduced in Moscow after Stalin's reign did not change anything about the distribution of power in the state. Rather, "collective leadership" in the Soviet Union meant the inclusion of advisors in the secretary-general's decision-making process, the "transition from despotic reign of arbitrariness to [...] a relatively enlightened absolutism."13 Ismail, however, had the tendency to take official statements and writings literally and seemed to believe in the concept of "collective leadership" himself.

The internal struggles around Salmin finally erupted in the "June 1978 Crisis." In September 1977, the NF, rebranded the Unified Political Organization of the National Front (UNFPO) at the Congress of Unification in $1975,{ }^{14}$ finally overruled Salmin's wishes and voted for the creation of a vanguard party in the second half of $1978 . .^{15}$ Despite the UNFPO's resolution, Salmin openly and aggressively tried to prevent realization of the project. His adversaries rallied behind Ismail and Ali Nasir. Regional politics came into play. Relations between North and South Yemen had been tense throughout the 1970s and fighting had repeatedly occurred on the border. In the middle of promising negotiations between the North Yemeni state and the northern branch of the al-Ahmar tribal confederation, President Ibrahim Muhammad al-Hamdi supposedly was killed on orders from Ahamad Husayn al-Ghashmi. ${ }^{16}$ As a reaction Al-Ghashmi, the new president of the north, was killed by a PDRY emissary, probably on behalf of Salmin. ${ }^{17}$ In retrospect, these events of 1977 have to be considered if not the cause then the opportunity for Salmin's downfall. From within the party, Salmin already had been challenged

12 | Embassy of the Peoples' Democratic Republic of Yemen in London. Present and Future, in: Brehony, 2013, 89.

13 | Löwenthal, Jenseits des Stalinismus, in: Schmeitzner (Ed.), 2009, 396.

14 | Burrowes, 2010, 256; Lackner, 1985, 70-73.

15 I Informationsmappe für den Besuch des Generalsekretärs des Zentralkomitees der JSP [...] Ali Nasser Mohammed, November 1984, in: BStU MfS HA II Nr. 28712, 140.

16 | Burrowes, 2010, 141 and 154; Burrowes, Yemen Arab Republic, in: Chelkowski/ Pranger (Ed.), 1988, 236.

17 | Yodfat, 1983, 53. 
due to his reluctance toward Moscow: He had refused to support Ethiopia by sending troops in January 1978. At the time, external forces seemed to agree that Salmin was "against the relations with the socialist countries and formed separate [foreign] relations, not through the Foreign Ministry" ${ }^{18}$ which produced a popular conspiracy theory circulating until today. According to this interpretation of events, either the extreme left of the NLF ${ }^{19}$ or even the Soviet Union in cooperation with East Germany had staged al-Ghashmi's assassination to get rid of Salmin. ${ }^{20}$ Regardless of these recriminations, the active engagement of Salmin's opponents working toward his disempowerment cannot be denied, nor can his death be denied as being convenient for Moscow and East-Berlin. Still, Soviet involvement in the matter remains speculative.

To fulfill Moscow's wishes, Ismail had ignored Salmin's decision to refuse South Yemeni participation in Ethiopia and over the next six months he took other steps to weaken Salmin. The Politbüro simply seized the opportunity to force Salmin out of office, officially to prevent an escalation of North-South Yemeni relations. After an attempted coup to save his position, Salmin was arrested and executed. ${ }^{21}$ During Salmin's "reign" the regime and political system had been consolidated and profound social and economic changes had been introduced. Justifiably, Lackner considers Salmin "the most important figure of the first decade of independence." ${ }^{22}$ When Ali Nasir took over Salmin's post, he got a short but impressive taste of power: The competition and conflict between the veteran leaders that awaited him in retrospect appears predetermined. After an interim presidency of only six months, Ismail, the chief ideologue, succeeded Ali Nasir as president - right on time for the Founding Congress of the Yemeni Socialist Party in October of the same year.

18 | Mutia, Muhammad Saleh (member of the NLF's Politbüro and of the Presidential Council, as well as foreign minister at the time), in: Beirut weekly "al-Houriya," July 24 1978, in: Ein-Gil, 1981 (2004).

19 | Ein-Gil, 1981 (2004), sine pagina.

20 | Brehony, 2013, 99.

21 | Dresch, 2000, 147.

22 | Lackner, 1985, 78. 


\title{
2. Soviet Interests and Fields of Engagement: From SUSPicion to "Best Friends Forever"
}

\author{
"Yemen was of great geostrategic importance for the Soviet Union. Thus, I \\ assume that [the USSR] told our people: Do something there. And that's how \\ the whole policy in Yemen came about." 23
}

After the "Corrective Move" of 1969, Moscow gradually gave up its reservations toward the Aden regime, bilaterally and internationally. In the same year, the Kremlin started its "long-term" involvement and henceforth, bilateral relations continuously intensified. In October 1971, Ali Nasir praised Soviet support and the "firm friendship" of South Yemen with the "socialist camp" as a major factor in South Yemen's transformation. ${ }^{24}$ East German ambassador Scharfenberg reports on Ali Nasir's "almost religious esteem toward the advisors from socialist countries."25 The decisions of the NF's Fifth Congress of 1972 led away from marginal extremist currents within the former liberation movement, such as Maoism, that had contradicted MarxistLeninist ideology. In addition to that, the distance between Aden and Peking seemed to grow and to a certain degree assured Moscow of Aden's future course.

The restructuring of the NF toward a vanguard party was under way, while East German functionaries served as appreciated and established advisors among the highest ranks of state and administration. In a communiqué from November 1972, the Soviet Union openly sided with the National Front and its "progressive" policies $^{26}$ and a mere two years later the Kremlin declared "unfailing support" during South Yemen's transformation process ${ }^{27}$ - as long as this process evolved along socialist "progressive" lines. But even though the NF regularly exchanged delegations with the CPSU, SED, and other Communist parties of the Eastern Bloc, some of the NF's policies were considered extremist by both Moscow and East Berlin. Especially with regard to South Yemen's foreign policy, Soviet and East-German advisors aimed to "generate a more realistic perspective among the leaders of the PRSY." ${ }^{28}$

\subsection{Engagement in Aden and Soviet Strategy in the Middle East}

Internationally, Moscow's engagement in Aden has to be considered part of the USSR's wider strategy in the Middle East in general and in the Horn of Africa in particular, combining geostrategic and ideological considerations. The strategy

23 | Interview with Wolfgang Bator on May 272011.

24 Ali Nasser Mohammed, in: Halliday, 1990, 187.

25 | Scharfenberg, 2012, 24.

26 | Halliday, 1990, 187.

27 | Ibid. 188.

28 | Brief Lugenheim an Scharfenberg, April 29 1973, in: PA AA, MfAA, C 1555/76, 3. 
included ongoing exchange with and support of other potential allies in South Yemen's vicinity to prevent a "strategy of encirclement" by Washington. ${ }^{29}$ To the Kremlin's displeasure, its strategic allies in the region one by one turned away and were lost to "Moscow's cause". What followed was a phase of Soviet reorientation in the region. It was accompanied by the reopening of the Suez Canal in 1975 and the British withdrawal from the Middle East. ${ }^{30}$ London's departure left some political space to be filled by external powers. The few years before the increase of U.S. involvement after 1979 were the high times of Soviet influence in the Middle East.

The two cases of "lost Soviet allies" most relevant for Soviet-South Yemeni relations were Egypt and Somalia. Both had required much financial and political maintenance and their loss as a close political partner freed considerable resources for Moscow. Shortly after the Kremlin had given up its military base in Egypt, Chief of the Soviet Navy Admiral Gorshkov paid his first visit to Aden in 1974. He came back only a few years later after Somali leader Muhammad Siad Barré had forced the Soviet naval pullout from Somalia and turned to the United States in 1977..$^{31}$ Obviously, a new safe and reliable Soviet naval base in the region was needed. Intensive engagement by the USSR, GDR, and Cuba in Ethiopia, ${ }^{32}$ the People's Republic of Congo, Angola, and Mozambique, was now complemented by the establishment of a new foothold at the Bab al-Mandab in Aden. As a consequence, the PDRY became Moscow's major ally at this strategically important position: During the Somali-Ethiopian war, South Yemen served as Moscow's main shipping center for arms, men, and equipment headed for Addis Abeba. Understandably, Somalia "broke up" with the Soviet Union: it declared the termination of their mutual Treaty of Friendship on November 13 1977.33 Soviet advisors and personnel were expelled and the main Soviet naval base in the region was gone for good. The relocation of the base from Somalia's port of Berbera to Aden coincided with the consolidation of Moscow's position in Ethiopia. ${ }^{34}$ The Kremlin invested significant sums in Aden's port by expanding the former British facilities.

On May 23 1978, a new agreement on military cooperation between Moscow and Aden was reached and Ali Antar, minister of defense of the PDRY, travelled to East Berlin to meet General Heinz Hoffman and then to Moscow to meet the Soviet

29 | Storckmann, 2012, 309.

30 | Cigar, 1985, 776.

31 | Halliday, 1990, 194.

32 | See Storckmann's detailed account on Soviet engagement and the role of the GDR in Ethiopia and on the Horn of Africa, Storckmann, 2012, 304-312.

33 | Yodfat, 1983, 46.

34 | Treaty of Friendship signed in January 1979, Halliday, 1990, 193 and Chubin, 1980, in: The International Institute for Strategic Studies (Ed.), 303. 
Minister of Defense Dmitri Ustinov.35 On August 19, "a unit of Soviet warships [arrived] on an official friendly visit to the port of Aden" 36 and three months later "Soviet combat aircraft" 37 were positioned on South Yemeni territory. From now on South Yemen served as a training ground for maneuvers, as well as for naval and amphibious landing exercises. There is no evidence that Moscow ever entertained an official military base in South Yemen in the strict sense of a territory granting extraterritorial privileges to the Soviets. However, Moscow had a fully-equipped naval, air, and artillery base at its disposal without the political burden of calling it such.

\subsection{Object of Political Speculations and Military Debate: The Island of Socotra}

This opens an extremely interesting chapter of Soviet geostrategic engagement in the region: The island of Socotra. The secluded tropical island in the Arabian Sea guards the Gulf of Aden and has long been part of Yemeni territory. International geostrategic interest in the island at the time was high..$^{8}$ In combination with the natural harbor of Aden, the island is positioned to provide swift naval reaction to any incidents in the region as well as a quick and safe retreat to Aden. Contemporary witnesses like Vladimir Agafinov, a Soviet military interpreter and orientalist, insist that the island of Socotra has never been used as an unofficial naval, air force, or rocket base by the Soviet Union and that Moscow had used it as a major military bluff for Western Secret Services. ${ }^{39}$ But even though the island had not much to offer in terms of a port or even a moorage, Moscow indeed had started to use the waters around Socotra to anchor its ships around 1970, if not earlier. ${ }^{\circ}$ Hence, the transfer of the Soviet moorage from Berbera, Somalia to the port of Aden in 1977 seems an elusive move. With the moorage came a tracker station, a tactical missile warehouse, a big fuel storage and accommodation facilities for about one thousand people. Thus, it is more than likely that the late 1970 s indeed witnessed the installation of "mooring buoys off the island of Socotra"41 that would counter Agafinov's statements.

\subsection{Moscow Commits: Domestic Politics and New Party Ties}

Regardless of the extent of military facilities on Socotra, a stable and loyal South Yemen was of highest priority for Soviet strategy in the Horn of Africa after 1977. The

35 | ADN, June 2 1978, in: Yodfat, 1983.

36 | FBIS, USSR, July 11 1978, F3 and San Diego Union, December 1 1978, both quoted in: Yodfat, 1983, 55.

37 | Ibid., in: Yodfat, 1983, 55; Cigar, 1985, 781.

38 | On the strategic relevance of Socotra at the time see: Elie, 2006, $151 \mathrm{ff}$.

39 | Agafinov visited Socotra several times (1976 -1980), Agafinov, 2008; Elie, 2006, 152.

40 | Yodfat, 1983, 6; 110; Agafinov, 2008.

41 | Halliday, 1990, 203. 
increased Soviet presence had a significant impact on the internal developments that mostly served Ismail and his faction, $4^{2}$ and thus the NF's emergence as a communist vanguard party in 1978. In this regard, the change of leadership from Salmin to Ali Nasser and Ismail was not to the disadvantage of Moscow and East Berlin. Moscow denied any "Arab and Western media reports of Soviet, Cuban, and East German involvement." 43 Nonetheless, Halliday hints at a certain Soviet involvement during the internal crisis of June 1978.44 This not only appears possible but also highly plausible with regard to Moscow's previous naval activities in the area. Furthermore, Scharfenberg reports of a meeting with the secretary-general of the Communist Party of Lebanon, Nicolas Chaoui, in June 1977, who shared Ismail's position on the matter of the formation of a vanguard with Scharfenberg:

"The socialist states had to acknowledge [the fact that any Western support for the PDRY would be terminated as soon as the UNFPO was reformed as a vanguard party]. Ismail explained to [Chaoui] that the formation of a vanguard party depended on the Soviet Union." ${ }^{\text {55 }}$

However, the Soviet Union clearly had no interest in an escalation of violence within or outside its new Socialist model state, such as between the two Yemens, as this most certainly would have led to further involvement of other powers in the region where Moscow preferred to be left alone. Without doubt, both new presidents, Ali Nasir and Ismail, were more convenient allies for the Kremlin than Salmin had ever been and Soviet-South Yemeni relations intensified accordingly: Shortly before the NF completed its metamorphosis into a Soviet-type vanguard party in 1978, official party ties were established between the CPSU and the future YSP. ${ }^{6}$

As a consequence of the PDRY's engagement in Ethiopia, Aden was finally granted a dear wish that its leadership had expressed in 1973:47 The PDRY was invited as an observer to the Comecon annual meeting in Moscow in June 1979. ${ }^{48}$ In that year, the Soviet-Yemeni relations clearly reached a new level: Only three months after the meeting, Soviet Premier Alexei Kosygin visited Aden, and in October Ismail once more met Brezhnev in Moscow. Apart from a renewal of economic and technical assistance and an agreement on future collaboration on the party level between the YSP and the CPSU, Moscow and Aden signed the

42 | Yodfat, 1983, 51 and 52.

43 | Ibid., 53.

44 | Halliday, 1990, 191.

45 | Scharfenberg, 2012, 50.

46 | Yodfat, 2011 (1983), 56.

47 | Brief Scharfenberg an Willerding, July 25 1973, in: PA AA, MfAA, C 1555/76, 52.

48 | At this point, Mongolia, Cuba, and Vietnam already were full members of the Comecon, while the PDRY shared an observer status with Angola, Afghanistan, Laos, Mozambique, and Ethiopia, in: Halliday, 1990, 192. 
first "Treaty of Friendship and Cooperation." 49 The treaty was followed by similar agreements with the GDR and ČSSR in November. Yodfat, one of the few academic commentators on the treaty, hints at the possible similarity of the treaty's Article 2 with what became known as the "Brezhnev Doctrine": The signatories agreed that they would aim "for the safeguarding and further development of the socioeconomic gains of their peoples." ${ }^{\circ}$ Yodfat's comment however, appears exaggerated and manipulated by the atmosphere of the Cold War. Though comparable to the bilateral agreements forming the Warsaw Pact, all Soviet treaties with states from the "Global South" excluded any guarantees of mutual assistance in case of attack.

Nonetheless, the Treaties of Friendship outside the Comecon had a significant symbolic political meaning. The signatory states declared their close relationship with the Eastern Bloc and committed themselves to a common foreign policy position. Furthermore, Halliday notes several characteristics of this specific Treaty that, according to him, were "noticeable." "W1 While Article 1 of the treaty assured Aden of the "unbreakable friendship of the two countries," Article 5 emphasized that military cooperation would continue to strengthen Aden's defense capacity to secure Moscow's new naval "base" in the region. In addition to that, the treaty raised rumors about "secret clauses". Again, these may be speculations. But at the time, these theoretical considerations created suspicion among other regional actors and the USSR's adversaries, which in turn could have led to very concrete and real political consequences. On top of that, Moscow did not do much to deny the rumors: By October 1979, when about two brigades of Soviet troops were airlifted from southern Russia to the PDRY and Ethiopia, ${ }^{52}$ the Kremlin's claim to its new strategic base was more or less common knowledge.

All in all, the "Treaties of Friendship" were part of the wider framework of Moscow's new policy of commitment that included noticeable endeavors of its closest allies. For instance, official relations between the East German and South Yemeni army were established as complementary support for the intensive Soviet and Cuban engagement in the military. ${ }^{33}$ Secondly, the "Treaties" were the preliminary stage

49 Mongolia, Cuba, and Vietnam enjoyed treaties including mutual assistance. Treaties comparable to the South Yemen Treaty of Friendship had been signed with Egypt and India in 1971, followed by Treaties with Iraq, Somalia, Angola, Mozambique, and Afghanistan. Earlier in 1979, Moscow had signed a similar Treaty in Ethiopia and in the following year with Syria. See: Halliday, 1990, 193. On the Soviet bilateral Treaties of Friendship also see Chapter 4. Squeezed between Bonn and Moscow: The GDR's Foreign Policy - An Overview. 50 | Treaty of Friendship and Cooperation between the USSR and the People's Democratic Republic of Yemen, October 25 1979, in: Pravda, September 26 1979; Also see: Yodfat, 1983, 109.

51 | Halliday, 1990, 194.

52 | Ibid. 195.

53 | Scharfenberg, 2012, 86. 
for possible further integration into the Soviet sphere of influence. Lastly, the "Treaties" were of high symbolic value for the PDRY, which had further isolated itself in the region. After the establishment of a Soviet-style vanguard party, they were a keystone of South Yemen's long-term alignment with the Eastern Bloc.

\title{
3. The Phase of Expansion: The GDR as the Director of "Civilian Matters" of Socialist Nation- and State- Building in South Arabia
}

\author{
"It was assumed that after [...] independence the PRSY would mostly need \\ political-ideological help and advice on fundamental questions about the \\ economy and the state apparatus." 54 \\ (Embassy of the GDR in Aden on the activities of East German advisors, 1972)
}

After the hesitant attitude of the 1960s, Moscow began to explicitly back East Germany's interest and engagement in South Yemen and finally even directed East Berlin with regard to the extent of the SED's duties in the PDRY. For Ethiopia, Dagne mentions the division of labor between Moscow and East Berlin with regard to the security apparatus. ${ }^{55}$ According to him, the USSR focused on military support in Ethiopia, while the GDR was occupied with the field of internal security.

For the PDRY, this concept was also applied, and even expanded: While HeinzDieter Winter considers a "division of labor" between the civil and the military sphere in South Yemen at least a possibility, Fritz Balke emphasizes the exclusive Soviet engagement in the field of the military. Hans Bauer's interpretation of East German presence even relies on the fact that an agreement between Moscow and East Berlin on a "division of labor" had existed. According to him, the GDR was responsible for the "inner stability" of the country, ${ }^{56}$ while the Soviet Union, alongside with Cuba, contributed the "military" part.57 When Moscow opted for Aden as its new unofficial base in the region, East Germany was then included in

54 | Einschätzung der Ergebnisse der bisherigen DDR-Regierungsberatertätigkeit mit Schlußfolgerungen für das weitere Vorgehen auf diesem Gebiet in der VDRJ, June 27 1972, in: PA AA, MfAA, C 156276, 33.

55 | Dagne, 2006, 35.

56 | Interview with Fritz Balke on May 23 2011; Interview with Hans Bauer on June 20 2011; Interview with Heinz-Dieter Winter July 32013 ; “With regard to the military, the PDRY for the biggest part was supported by the Soviet Union." in: Scharfenberg, 2012, 86.

57 | "In [South] Yemen, with the assistance of a small number of specialists, we helped to organize the militia". Rodriguez, Carlos Rafael, Conference of Deputy Chairman of the State Council of Cuba, Carlos Rafael Rodriguez with U.S. Secretary of State Alexander Haig, in Mexico, 23 November 1981, "Year of the 20th Anniversary of Victory at Playa Giron," in: Russian \& East German Documents on the Horn of Africa, 1977-78, Cold War 
the military sphere,,$^{8}$ probably due to East Berlin's good standing among the Yemeni leadership and the mounting material demands of the regime. As a consequence, East Berlin emerged as the director of "civilian" matters of state-building, which was inseparably mixed with matters of ideology and the integration of society when applying the concept of socialist state- and nation-building.

\subsection{Bilateral Rapprochement and the Major Tool of East Germany's State-Building Policy: The GDR's Policy of Consultancy}

“The GDR supported [South Yemen] in various central fields, mostly by sharing its experiences during the period of the establishment of an anti-fascistdemocratic order." 59

(Results of the GDR's governmental advisor groups in South Yemen, 1972)

Actors from all three spheres of East German foreign policy making shared with each other their experiences during the decisive years of South Yemeni stateand nation-building. Apart from security issues, the whole process was mostly coordinated by the embassy, from 1972 to 1978 under its ambassador, Günther Scharfenberg. However, bilateral rapprochement following the establishment of diplomatic relations was mostly driven by the SED party and its organs: ${ }^{\circ \circ}$ Exchange of delegations on all levels became a major tool in East Berlin's policy, whereas each high-ranking delegation was accompanied by at least one party official. The first visit at the party level was even performed before the new constitution was launched, in early November 1970 under Ismail's leadership. Ismail returned to East Berlin one and a half years later, and the Yemenis received the East German party delegation in February 1974. On the East German side all three meetings were coordinated by Gerhard Grünberg. ${ }^{61}$ Shortly thereafter, delegation visits attained a new level of importance. In September 1976. Willi Stoph visited Aden

International History Project Bulletin Issues 9-10, 210; Also see: Cuba, in: Burrowes, 2010, 83; Scharfenberg, 2012, 65.

58 | A protocol for the support of the PDRY's military by the GDR was signed in June 1978, in: Scharfenberg, 2012, 86.

59 | Einschätzung der Ergebnisse der bisherigen DDR-Regierungsberatertätigkeit mit Schlußfolgerungen für das weitere Vorgehen auf diesem Gebiet in der VDRJ, June 271972 , in: PA AA, MfAA, C 156276, 39.

60 | Stenografische Niederschrift der Beratung mit der Delegation der NLF Südjemen am 2.11.1970 im Hause des ZKs, in: BArch SAPMO/DY 30/11407, 5-71. Informationsmappe für den Besuch des Generalsekretärs des ZK der JSP [...] Ali Nasser Mohammed, November 1984, in: BStU MfS HA II Nr. 28712, 167.

61 | Grünberg, member of the Politbüro since 1966 and mostly occupied with question of agriculture, was assigned to entertain relations with the PDRY at the highest Party level. Scharfenberg, 2012, 52. 
as a high-ranking representative. ${ }^{62}$ In June 1977 , a "Party and governmental delegation" under Werner Lamberz renewed the party agreement between the UNFPO and the SED until $1979 .{ }^{63}$

In the heyday, there were more than 2,000 East German experts delegated to the PDRY. ${ }^{6}$ By that time, East Germany appears to have had a full-fledged statebuilding policy in mind. By sending the constitutional advisory group, the GDR had signaled its full support for the establishment of a functional socialist state apparatus. Apart from juridical advice, the economy was at the forefront of GDR consultancy. While the advisory group may be considered the first foreign policy tool used in East Germany's support of socialist state- and nation-building, the first agreement represents its immediate follow-up: The Agreement of ScientificTechnical Cooperation ${ }^{65}$ (WTZ). The WTZ Agreement sent some thirty advisors to Aden. The majority of these delegates were assigned as governmental advisors in all fields relevant for state-building, while another five other advisors were sent under the Kulturarbeitsplan, the "Cultural Working Plan" of 1970-71. ${ }^{66}$ These five were supported by 20 more experts, among them three teachers.The GDR's engagement under the provisions of the "Working Plan" was initiated in October 1969 and was transformed into a long-term mission in $1971 .{ }^{67}$ Active involvement during those early years was demonstrated in the fields of economy and finance, agriculture, youth, education, communication, and the media: In 1972. East German advisors introduced the basic principles of planning and socialist economy, directing the first steps toward agrarian reform and socialization, including the formation of agrarian collectives and agricultural mass organization. ${ }^{68}$ This

62 | Stoph visited Aden just one month before Honecker took over his post as Staatsratsvorsitzender and thus international representative of the GDR. Scharfenberg, 2012, 56.

63 | Communiqué on the occasion of a visit by an NFPO delegation in East-Berlin in February 1974, Agreement on the cooperation between the SED and the UNFPO, June 13 1977, in: Jemen (Demokratischer), Völkerrechtliche Vereinbarungen der DDR; 1987, 140; 140-1; Scharfenberg, 2012, 59.

64 | Panecke, Volker, Vorwort, in: Scharfenberg, 2012, 7.

65 | German: Wissenschaftlich-technische Zusammenarbeit (WTZ). Wissenschaftlichtechnische Zusammenarbeit zwischen der DDR und der VDRJ und wissenschaftlichtechnische Hilfeleistung der DDR gegenüber der VDRJ in Form des Einsatzes von DDRBeratern in zentralen Staatsorganen und im Bereich der Wirtschaft der VDRJ 1971-1974 [Abschlussbericht], in: PA AA, MfAA, C 156276, 1-32.

66 | The Kulturarbeitsplan for a period of one to two years was renewed regularly. The next followed in February 1973, in: Scharfenberg, 2012, 47.

67 | Ibid., 33.

68 | Ibid., 38-41. 
"Policy of Consultancy" was translated into the first economic five-year plan in South Yemen in April $1974 .{ }^{69}$

Another important area of consultation was the field of foreign policy. According to Scharfenberg, Aden itself had requested support, and in September 1974, a joint delegation of the CC International Relations Section and the MfAA visited the PDRY. $7^{\circ}$ The topics discussed reveal the potential explosiveness of this advisory mission: The possible establishment of relations between the PDRY, the USA, and the FRG were to be reconsidered. These consultations have to be considered one of the few occasions when East Germany was able to distinguish itself as a proactive actor in international relations: East Berlin claimed agency for a matter concerned with the "other Germany" in the West. The consultations resulted in the reestablishment of relations between Aden and Bonn on September 161974 . The FRG's representative, Alexander Mühlen, arrived soon thereafter. ${ }^{11}$ In May 1976, East German foreign policy consultancy was institutionalized by ViceMinister of Foreign Affairs Klaus Willerding. ${ }^{2}$

\section{The MR Groups: An Open Secret of Stasi Presence in Aden}

Bauer concedes: "For sure it was no secret that any advisory mission [abroad] was a political mission." 73 The most notorious advisory groups in this respect were and are the so-called "MR Groups." ${ }^{4}$ Not without reason, Scharfenberg considers these groups "the most important pillar of political consultancy,"75 as they were delegated by the GDR's Ministry of the Interior and Ministry of State Security. Most of them were sent to Aden to support the state-building process in the PDRY. The members of these groups who could rely on expertise in their assigned field were either sent directly by the MfS, or joined the ranks of the Secret Service right before their mission abroad. Comprised of several experts and an executive of the group, the MR Groups officially were placed as advisors at the highest governmental levels and regularly consulted with several of the PDRY's ministers. ${ }^{76}$ Thus, only the most loyal cadres were selected to serve as these kind of consultants, as they advised Yemeni personnel up to the rank of the PDRY's government and thus party officials. According to Hans Bauer, the former GDR resident in Aden, the

69 | Informationsmappe für den Besuch des Generalsekretärs des Zentralkomitees der JSP [...] Ali Nasser Mohammed, November 1984, in: BStU MfS HA II Nr. 28712, 140.

70 Among the delegation was Peter Rabenhorst, at the time member of the ZK International Relations Section. Scharfenberg, 2012, 48.

71 | Botschafter Held, Sanaa, an das Auswärtige Amt, June 3 1976, in: AzAP der BRD, 1976, Vol.1, 1. Januar bis 30. Juni, FN 1 and 2, 807; Scharfenberg, 2012, 69.

72 | Scharfenberg, 2012, 49.

73 | Interview with Hans Bauer June 202011.

74 | Abbreviation for German Ministerratsgruppe. English: Groups of the Council of Ministers.

75 | Scharfenberg, 2012, 34.

76 | Ibid., 38. 
MR Groups worked closely with both the "partner country" and the "embassy" on the ground, though contemporary witnesses report of regular conflicts over responsibilities between the ambassador and MfS delegates. Scharfenberg, for example, remembers the independent modus operandi of the MR Group at his arrival in 1972 and how he tried to clarify questions of responsibilities in Aden. ${ }^{77}$ According to him, the head of the MR Group in Aden consulted with him on a weekly basis, and with the heads of the other advisory groups on a monthly basis or according to need.

The conflict of jurisdiction between the embassy and consultants is a telling example for the conflicts inherent in the GDR's political system, especially the competition between party and state institutions. While there usually was not much room for discussion for the state institutions within the borders of the GDR, this was a very different matter abroad. Even though the MfS was "sword and shield of the Party," and, according to the principle of "democratic centralism," ranked above state institutions in the hierarchy, it was the East German embassies that entertained personal contacts and were able to accumulate insider knowledge about the country. This was even more the case in a remote state like South Yemen, where only few political actors spoke anything but Arabic.

\subsection{Integration of Society: Training, (Re-)Education and the Formation of a New Public}

As part of its "low-profile" strategy, East Germany had sought contacts below the governmental level among the "mass organizations" early on, mostly to promote the establishment of diplomatic relations. After relations between the GDR and South Yemen were established, the major goal was to direct the process of "the integration of society" of socialist state-building, that is, the homogenization and centralization of mass organizations..$^{8}$ Lenin had described "integration of society" through political and social mass organizations, including the media. According to him, they were to serve as a "Transmissionsriemen," a transmission belt, translating Marxist-Leninist ideology and party policies to society.

Apart from the first treaties initiated by the party at the state level, a significant number of other actors became active in South Yemen. Especially at the level of foreign policy making, all actors outside the state and Party apparatus had been highly active in the PDRY in the early years of East German-South Yemeni relations. The central concept for the establishment of relations between mass organizations was the concept of "solidarity."

77 | Ibid., 2012, 36.

78 | Ismail/Ismail, 1986, 56. 


\section{"Realizing the National-Democratic Development": ${ }^{79}$ Integration of the Media}

The two major fields of East German economic engagement in the Third World had been the infrastructure of telecommunications and print industry ${ }^{8 \circ}-$ and not without reason. Similar to the centralized direction and control of East German media, South Yemeni media was embedded in the PDRY's political system. East German media actors had become active early on to support the GDR's state- and nation-building assistance, foremost for the "integration of society." In the late 1960 s the SED's international media service $\mathrm{ADN}^{81}$ had relied on a local journalist, but finally established its office in Aden under leadership of Deba Wienand. This was based on a cooperation agreement between the ADN and the Aden News Agency (ANA) which included free exchange of content as well as six free college placements in Berlin and Prague. ${ }^{82}$ Also, ANA received a loaned radio unit under the obligation to broadcast the Arab programs of the ADN. Without doubt, the GDR aimed to have Yemeni media in its grip.

On July 28 1971, a governmental agreement on postal and communication services was signed. ${ }^{83}$ Only a few months later, Scharfenberg reports on a meeting of the NF's Politbüro, CC, and the media on the "intensification of the politicalideological impact of mass media." ${ }^{34}$ This confirms the official report on the work of East German governmental advisors in 1972: "Advisors [on communication focused on] the efficient realization of the national-democratic development through mass media." ${ }^{85}$ Shortly thereafter a commission on ideology at the CC was founded with its main function being "the enforcement and coordination of ideological work in the country [...] while especially focusing on mass media." ${ }^{86}$ The political process of media integration was sealed by an agreement on

79 | Einschätzung der Ergebnisse der bisherigen DDR-Regierungsberatertätigkeit mit Schlußfolgerungen für das weitere Vorgehen auf diesem Gebiet in der VDRJ, June 271972 , in: PA AA, MfAA, C 156276, 43.

$\mathbf{8 0} \mid$ A printing house from Leipzig was active in Aden, in: Interview with Hans Bauer June 202011.

81 | Allgemeiner Deutscher Nachrichtendienst; English: General German News Service.

82 | Vertrag zwischen dem Allg. Deutschen Nachrichtendienst, der Nachrichtenagentur der DDR, und der Aden News Agency, der Nachrichtenagentur der Volksrepublik Südjemen, über Zusammenarbeit auf dem Gebiet des Nachrichtenwesens, in: BArch DC 900/920.

83 | Regierungsabkommen über Post- und Fernmeldewesen, July 28 1971, in: Jemen (Demokratischer), Völkerrechtliche Vereinbarungen der DDR, 1987, 139.

84 Informationen zu einigen inneren und äußeren Problemen der VDRJ, Aden, February 6 1973, in: PA AA, MfAA, C 1555/76, 100.

85 | Einschätzung der Ergebnisse der bisherigen DDR-Regierungsberatertätigkeit mit Schlußfolgerungen für das weitere Vorgehen auf diesem Gebiet in der VDRJ, June 271972 , in: PA AA, MfAA, C 156276, 43.

86 | Gambke et al., 1974, 106. 
cooperation between a newly created television committee in South Yemen with its East German counterpart in June $1972 .{ }^{87}$

Another important reason for the GDR's interest in South Yemen's media was its intention to control the image of East Germany abroad. During Honecker's official visit to South Yemen in 1979, GDR media was instructed by the Agitation Section to provide South Yemeni media with features about the GDR and publications written and designed for the region. ${ }^{88}$ East German journalists and advisors in the field remained active in South Yemen throughout the GDR's existence, while their role as the "Transmissionsriemen" of Marxist-Leninist ideology and East German interests toward the South Yemeni people never changed. All of the media actors had to abide by "party and state discipline" 89 - just like any other East German actor abroad.

\section{Organizing the Masses: Unifying and Controlling Workers, Women, and Youth}

Cooperation with mass organizations was performed quite extensively, whereas the GDR got quickly involved with the workers union, women's union, and the youth organization. The General Union of Yemeni Women, for example, had been founded in February 1968 and in 1971 the society's leader, Aida Yafa'i, visited the GDR. $9^{\circ}$ Relations between the workers and trade unions and the FDGB had been established as early as 1961. Immediately following independence, the self-directed ATUC was replaced by the General Union of Workers, which was modelled on socialist mass organizations. Relations between the FDGB and this new centralized federation were made official in $1969.9^{11}$ While the Yemeni trade unions once had been one of the major revolutionary driving forces, the organizations had lost their influence and credibility during the revolutionary fighting while the NLF actively homogenized what was left of the trade unions: "The Soviet and East German advisors [...] did everything to eradicate [the trade unions'] independence and to create an organization supportive of the regime

87 | Vereinbarung über die Zusammenarbeit zwischen dem Staatlichen Komitee für Fernsehen beim Ministerrat der DDR und dem Fernsehen der VDRJ, June 2 1972, in: Jemen (Demokratischer), Völkerrechtliche Vereinbarungen der DDR, 1987, 140.

88 | Vorschläge für auslandsinformatorische Maßnahmen anlässlich des Besuchs einer hochrangigen Delegation der DDR im Sozialistischen Äthiopien und in der VDRJ vom 11. Oktober 1979 der Abteilung Auslandsinformation, in: PA AA, MfAA, C 4959, 1-6.

89 | Report on a journalist's dismissal after the events of the "1986 crisis" in Aden. Stellungnahme zum politischen Fehlverhalten des Genossen [geschwärzt], March 17 1986, Verband der Journalisten der DDR, in: BStU MfS HA XX Nr.13169, $179 f$.

90 | Dahlgren, 1998; Halliday, 1974, 241; Ismail/Ismail, 1986, 59f; Scheider, 1989, 263. 91 | Aktenvermerk über eine Gespräch mit Herrn Alaini, Vertreter der Aden-TUC im Allarabischen Gewerkschaftsbund (ICATU) am 4.Dezember 1961 in den Räumen des Büros des Bevollmächtigten der DDR in der VAR, in: PA AA, MfAA, C 1224/71, 145-147; Gambke et al., 1974, 111; Ismail/Ismail, 1986, $57 \mathrm{f}$. 
according to the real-socialist model." ${ }^{2}$ In May 1971, and following East German advice, ${ }^{93}$ the independent leadership of the trade unions was terminated by force, and in early 1972 an Institute for Trade Union Studies led by Soviet and East German lecturers was established.

But workers and women were only of secondary interest for the GDR, as the former represented merely a marginal part of the population and the latter remained politically insignificant. 94 To change South Yemen's society in the long run, it was the youth who had to be converted to Marxist-Leninist ideology and the directed toward a socialist political system.

"In many ways, Asheed is the most important mass organization in the PDRY. Part of the reason for this is purely demographic: approximately one-quarter of South Yemen's young population are between the ages of 16 and 28. [...] Above and beyond this, however, the YSP has found the youth of the country most open to ideas of social reform and change." ${ }^{95}$

From the first days of diplomatic relations until the end of the GDR, the East German youth organization FDJ ${ }^{6}{ }^{6}$ was actively involved in South Yemen, ${ }^{97}$ first and foremost with a brigade of about 25 delegates "training young Yemeni cadres in technical vocations" 98 in the present-day governorate of Abyan. The first agreements between the FDJ and Asheed were signed in November 1971 in East Berlin 99 and cooperation was expanded significantly over the following years. Further activities of the group were coordinated by a member of the Stasi-based MR Group, Manfred Weigandt. Weigandt was assigned to be the advisor for state media, but was also closely involved in the preparation of the Xth World Festival of

92 | Scheider, 1989, 262.

93 | Unger, DDR-Erfahrungen gefragt, in: Horizont 23/71, 1971, 28-29.

94 | Dahlgren, 1998.

95 | Ismail/Ismail, 1986, 59.

96 | FDJ - Freie Deutsche Jugend; English: Free German Youth.

97 | The "FDJ Friendship Brigades" were organized by the "Solidary Committee," and thus any aid provided by the FDJ was also part of so-called "solidarity spending". in: Howell, 1994, 313.

98 | See: Zusammenarbeit mit Jugend- und Studentenorganisationen in der VDRJ 19691990, in: BArch DY 24/22196, 21884, 22197, 21886, and 22198; Informationsmappe für den Besuch des Generalsekretärs des ZK der JSP [...] Ali Nasser Mohammed, November 1984, in: BStU MfS HA II Nr. 28712, 176; Interview with Hans Bauer June 20 2011; Scharfenberg, 2012, 44.

99 | See: Vereinbarungen und Kommuniques zur Zusammenarbeit des Zentralrates der FDJ mit den Zentralkomitees von Jugendorganisationen der VDR Jemen, in: BArch SAPMO/DY 24/21884 Vol.2; Interview with Faruq Mustafa, member of the CC of the Democratic Youth Organization of Yemen, in: Neues Deutschland, November 301972. 
Youth and Students. ${ }^{100}$ In January 1973, the PDRY established a National Festival Committee (NFC) to prepare for the World Festival. The GDR's "Red Woodstock" still has to be considered part of East Berlin's long-term "policy of recognition" and the event clearly followed the "strategy of the honest broker" toward the Global South, as the Festival's slogan indicates: The GDR was to incorporate "antiimperialist solidarity, peace, and friendship." ${ }^{102}$ The supposedly "better Germany" propagated a relationship with the Global South based on "equality." 103

East Berlin clearly hoped to direct as much of the process as possible: "Comments by the GDR embassy toward the Festival Committee were in principle included in [the preparatory] plans." ${ }^{104}$ Among the activities during the preparation were joint events of the South Yemeni Youth and the Soviet and East German embassies. Most importantly, the Committee induced the founding of the NF youth group in this context in February 1973, ${ }^{105}$ the Yemeni Union of Democratic Youth (YUDY). The YUDY established relations with the FDJ right away and also organized itself among the South Yemeni students in the GDR. Particularly with the Yemeni youth, the YSP and SED appeared to have cooperated successfully: In the early 1980 s, contemporaries considered YUDY the "best organized, most dynamic and progressive mass organization in the PDRY [...], being recognized in the party constitution as the YSP's main reserve and assistant." ${ }^{106}$ In conclusion, despite the considerable impact of trade unions, it was the youth, and relations between the youth organizations in particular, that opened the door for East German engagement.

\section{(Re-)Educating South Yemeni Society}

Apart from mass organizations, the major avenue for GDR engagement to further the "integration of society" in the socialist sense was the field of education. In March 1976, a delegation of the Academy of Pedagogy of the GDR travelled to Aden $^{107}$ and a protocol on scientific-technical cooperation was signed in September 1976. This was followed by an agreement on the mutual recognition of academic degrees and transcripts in April 1979, paving the way for the intensification of

100 | Scharfenberg, 2012, 39.

101 | Comp. Blog - The GDR Objectified. The Red Woodstock: 10th World festival of Youth and Students East Berlin, no author.

102 | VDRJ, zur Entwicklung des Landes, 1973, in: BStU MfS Allg. S. Nr.332/73, 16.

103 | Howell, 1994, 306.

104 | Volksdemokratische Republik Jemen, zur Entwicklung des Landes, 1973, in: BStU MfS Allg. S. Nr.332/73, 12.

105 I Informationen zu einigen inneren und äußeren Problemen der VDRJ, Aden, February 6 1973, in: PA AA, MfAA, C 1555/76, 101.

106 | Ismail/Ismail, 1986, 59.

107 | Grünberg, 2012, 52. 
future exchange. ${ }^{108}$ To be able to influence education in the new state, however, a different strategy was needed.

For the SED leadership, "integration of society" meant the "homogenization of society" and they thus aimed at applying strategies in South Yemen similar to those used in the GDR. Schools, technical training centers, and even Aden University, which had opened in 1975, were designed as centers of ideological multiplication and propaganda. The East German "collective" of authors who wrote a highly ideological state publication on South Yemen summarizes the GDR's role in this process and emphasizes the importance of the "measures to ideologically stabilize" ${ }^{\prime 109}$ the central party in Aden. Also, they minutely describe all the steps taken by East Germany to support this process, most prominently the establishment of a College of Political Sciences in Aden in 1971. ${ }^{110}$ Teachers of Marxism-Leninism and scientific socialism were delegated by the "CPSU, the SED and other Communist parties" ${ }^{\prime \prime 1}$ to teach about their vision for South Yemen.

The ideological education at the College of Aden was complemented by programs abroad. In December 1973, the NF itself had asked for the extension of the "program of NF-leading functionaries in the GDR which was readily granted. ${ }^{112}$ In 1971 , the South Yemeni minister of economy and industry ${ }^{13}$ himself trained there and later on aimed for the inclusion of economics and finances in the program. Furthermore, a high number of other high-ranking South Yemeni party functionaries were educated in Moscow and East Berlin, while vacation packages were granted regularly to the most important cadres and their families. ${ }^{114}$ The GDR clearly presented itself as the "shop window of socialism, ${ }^{115}$ selling their concept of socialist state- and nation-building to the South Yemenis.

However, neither cadre training "on the job" nor at the party school can be considered the central focus of East German engagement in the field: "Youth education is

108 | Abkommen über die gegenseitige Anerkennung von akademischen Graden und Zeugnissen der Bildung, April 18 1979, in: Jemen (Demokratischer), Völkerrechtliche Vereinbarungen der DDR, 1987, 140-1.

109 | Gambke et al., 1974, 104.

110 | German: Hochschule für politische Wissenschaften.

111 | Gambke et al., 1974, 105; 112. The first lecturer groups consisted of three instructors on ideology and two translators, in: Scharfenberg, 2012, 41.

112 | Scharfenberg himself openly advocated for it. Brief Scharfenberg an Rost, December 20 1973, in: PA AA, MfAA, C 1555/76, $116 f$.

113 | No transliteration given: Abd Al-Azziz Abd al-Walli (al-Walli).

114 | Interview with Fritz Balke on May 232011.

115 | German: Schaufenster des Sozialismus. For the Soviet union East Germany served as their "shop window of Socialism" toward the West, in: Wentker, 2007, 6. 
political education ${ }^{{ }^{116}}$ was the slogan for East German engagement in this policy field. In the GDR, youth had always played a highly political role for the "planned development of socialism" to ensure the next generation's ideological loyalty and engagement. This goal was pursued by "educating the socialist personality." ${ }^{17}$ The creation of the "new human" regularly was considered the most effective during childhood and adolescence. By organizing courses for South Yemeni teachers, the teaching philosophy was transferred to the PDRY, while the "Soviet experiences" served as the East German and thus South Yemeni role model."18

The GDR's multifaceted strategy to transfer the East German educational approach to South Yemen unfolded continuously over the 1970s. Not only did it aim at determining the pedagogical approach and ideological basis for schooling, pre-schooling, and vocational training of youth, but also at directing the concrete implementation of the new system by educating disseminators and teachers in South Yemen and socialist countries by creating teaching materials and supervising the process. The placement of two advisors to the Ministry of Education and the Ministry of Sports and Youth was greeted enthusiastically in the GDR's evaluation report from 1972. ${ }^{119}$ According to this report, the East German advisor had significantly influenced the new law on education and contributed to all central documents on education, including the curricula for all schools and the creation of a separate ministry unit occupied with political-ideological strategies in education. ${ }^{20}$ Throughout the 1970s, East German lecturers and instructors taught the fundamental principles of the GDR school system under labels like: "Principles of socialist School [education] policy in the GDR," "Selected Problems of the Development of Marxist-Leninist Pedagogy," and "Theory and Praxis of Collective Education in the GDR."121 These presentations and workshops

116 | Direktive für die Reise einer Delegation des Ministeriums für Volksbildung in VDR Jemen [March 1 to April 24 1977], in: PA AA, MfAA, C 1874, 49-51.

117 | Segert/Zierke, in: Judt (ed.), 1998, 177.

118 | Direktive für die Reise einer Delegation des Ministeriums für Volksbildung in VDR Jemen [March 1 to April 24 1977], in: PA AA, MfAA, C 1874, 49-51.

119 | Einschätzung der Ergebnisse der bisherigen DDR-Regierungsberatertätigkeit mit Schlußfolgerungen fürdas weitere Vorgehen auf diesem Gebiet in der VDRJ, June 27 1972, in: PA AA, MfAA, C 156276, 43.

120 | These early advisors had been assigned under the Kulturarbeitsplan 1970-71, which was regularly renewed, in: Brief Bollmann (Botschaft Aden) an Sittig, October 31 1971, in: PA AA, MfAA, C 1874, 141. Also see: Einschätzung der Ergebnisse der bisherigen DDRRegierungsberatertätigkeit mit Schlußfolgerungen für das weitere Vorgehen auf diesem Gebiet in der VDRJ, June 27 1972, in: PA AA, MfAA, C 156276, 43.

121 | Anlage: Themen der Vorträge von Prof. Dr. Wilms und Teilnehmerkreis, in: PA AA, MfAA, C 1874, 40-42. 
were designed for to be replicated in South Yemeni education. ${ }^{122}$ In 1975, the First Pedagogic Congress of the PDRY had decided on the establishment of eight-grade comprehensive schools following the GDR model. East German curricula were introduced ${ }^{123}$ and in 1977 the last cohort sixth graders from the former English school system was to be examined.

Until then no standardized procedure of teacher training had existed in South Yemen. As such, "a high number of qualification courses [for multiplicators] was the solution at the time." ${ }^{124}$ New books and materials for the new system were to be formulated by the recently founded Pedagogic Center supported by East German, Soviet, and UNESCO experts. ${ }^{125}$ But teacher training first of all meant ideological training. After several visits by Marxist-Leninist lecturers, a permanent lecturer was delegated in 1977 to educate multiplicators of the Ministry of Education. ${ }^{126}$ He was supported by at least two more GDR experts on education in late 1978.127 Finally, East Germany's engagement in the field of education was complemented by the establishment of a permanent German lectorate in Aden in $1978 .{ }^{128}$ Instructions from December 1978 continued the line of action of the years prior: The delegation was supposed to “impart the GDP's experiences on political-ideological education in science classes" and to explain "what knowledge, perceptions, abilities, and convictions their students are supposed to acquire in biology, chemistry in physics." ${ }^{129}$

A report on the work of the GDR's experts in 1978 highlights the actual level of intensity of East German engagement in the education sector by formulating concrete objectives for the following years: Gathering information on the training of teachers at all levels, identifying possible obstacles for the PDRY Ministry of

122 | Bericht über eine Dienstreise in die VDRJ vom 22.3. bis 3.4.1977 by Scheidig, in: PA AA, MfAA, C 1874, 60-74.

123 | Bericht über eine Dienstreise in die VDRJ vom 22.3. bis 3.4.1977 by Scheidig, in: PA AA, MfAA, C 1874, 60; Karuse, 2009, 206.

124 | Bericht über eine Dienstreise in die VDRJ vom 22.3. bis 3.4.1977 by Scheidig, in: PA AA, MfAA, C 1874, 61.

125 | All East German educational advisors worked closely with Soviet advisors in the late 1970s, in: Bericht über eine Dienstreise in die VDRJ vom 22.3. bis 3.4.1977 by Scheidig, in: PA AA, MfAA, C 1874, 65; Also see: Delegational visit by Vice-President of the GDR's Academy of Pedagogic Sciences Günter Wilms in Macrh 1976, in: Scharfenberg, 2012, 52; Bericht über eine Dienstreise in die VDRJ vom 22.3. bis 3.4.1977 by Scheidig, in: PA AA, MfAA, C 1874, 60.

126 | Bericht über eine Dienstreise in die VDRJ vom 22.3. bis 3.4.1977 by Scheidig, in: PA AA, MfAA, C 1874, 87.

127 | Brief Bollmann an Sittig, December 4 1978, in: PA AA, MfAA, C 1874, 143.

128 | Protokoll über die Einrichtung eines Deutschlektorats in Aden, April 1978, in: Jemen (Demokratischer), Völkerrechtliche Vereinbarungen der DDR, 1987, 140-1.

129 | Brief Bollmann an Sittig, December 4 1978, in: PA AA, MfAA, C 1874, 143. 
Education to the implementation of the eight-grade comprehensive school, and "orientation toward fields of the GDR system of education where concrete help and support can be offered as a communication of experiences." ${ }^{130}$ East German efforts in the schooling system were complemented by the work of an East German advisor who accompanied the establishment of a kindergarten system in the early 1980 s. ${ }^{131}$

The high priority of education in East Germany's policy of socialist stateand nation-building for example is expressed by a visit paid in 1982 by Margot Honecker, the minister of education and wife of the secretary-general. ${ }^{132}$ Meanwhile, the PDRY minister of education, Hassan al-Salami (al-Salami), ${ }^{133}$ at the time was pursuing his East German doctorate in education as a distance learner. ${ }^{34}$ Two years after Margot Honecker's trip to Aden, al-Salami travelled to Berlin for a return visit and attended the GDR's $35^{\text {th }}$ Anniversary. His personal friendship with the Honecker couple ${ }^{135}$ turned out to be a decisive factor for the evolution of the character of East German-Yemeni relations.

\title{
3.3 The Backbone of Socialist State-Building: The Internal and External Security Apparatus ${ }^{136}$
}

\begin{abstract}
"It was extremely difficult [...] to build up a security apparatus in South Yemen. Our decision was guided by the world strategic position of Aden. And very different from the majority of the countries of the Near East, [in Aden] we were welcomed with open arms." ${ }^{137}$
\end{abstract}

(Markus Wolf, Head of the HV A of the MfS)

130 | Vorgaben für die Berichterstattung zum Studien- bzw. Schuljahresabschluß [sic!] 1977/78 der Kader des Ministeriums für Volksbildung der DDR in der VDR Jemen (Anlage), 1978, sine diem, in: PA AA, MfAA, C 1874.

131 | Brief Bollmann der HA IV Abt.II and Kopp, October 17 1977, in: PA AA, MfAA, C 1874, 94; October 14th, daily South Yemeni newspaper, June 41982.

132 | Informationsmappe für den Besuch des Generalsekretärs des Zentralkomitees der JSP [...] Ali Nasser Mohammed, November 1984, in: BStU MfS HA II Nr. 28712, 170.

133 | Arabic: Ḥassan AI-Salāmī.

134 | Bericht über eine Dienstreise in die VDRJ vom 22.3. bis 3.4.1977 by Scheidig, in: PA AA, MfAA, C 1874, 72.

135 | Interview with Fritz Balke on May 232011.

136 | For an introduction to archival material on military and MfS' activites in South Yemen see: Ch 2. On Archival Research, Technicalities, and the State of Research, 1. State of Research: The Selection of Secondary Sources for an Interdisciplinary Undertaking.

137 | Wolf, 1997, 376. 
"The citizen in South Yemen lived under police surveillance all day, from the moment he left the house to his return. [...]"138

(South Yemeni contemporary witness, 1993)

According to Arab diplomatic observers of the time, "the survival of the current regime of the PDRY highly depends on the behavior of the police and the military." ${ }^{39}$ Thus, the new regime focused on the reform of the military, the police, and the establishment of a security apparatus right away, aided by extensive support from the Eastern Bloc. While the Soviet Union and Cuba provided for the "hard facts" of the security apparatus, that is, military equipment and training, East Berlin held back with material deliveries and rather covered the "civil" side of security by promoting the connection between the party and security apparatus, the state, and society.

The Kremlin acknowledged the new regime's need for military efficiency and support early on and ushered the reform of South Yemen's army, the Popular Defence Forces (PDF), to finally wrestle the military forces from the "tribal" grip and bring them under the NF's control. While the army system more and more resembled the Soviet model, Cuba actively trained new military personnel. From 1972 to 1978 , the total numbers in the country were raised from 14,000 to 24,000 trained soldiers. The GDR's contribution in material has to be considered modest, and in firepower even insignificant. This followed the idea of a "division of labor" between Moscow and the GDR, between the military and the civil side of statebuilding. However, as part of the establishment of a state security apparatus and the equipping of its armed forces, mutual visits of high-ranking military personnel and a certain volume of equipment deliveries by the GDR at times played a highly symbolic part in the Soviet and East German policy of communist state-building.

In May 1972, the PDRY's Minister of the the Interior Mutia ${ }^{140}$ visited East Berlin and met with the GDR's inner circle of the security apparatus. ${ }^{141}$ Even though the Ministry of the Interior and the MfS agreed that they were neither willing nor able to "satisfy [all of] Minister Mutia's wishes," GDR Minister of Defense Hoffmann was asked to decide whether to supply the PDRY with air defense, land mines and ammunition for "weapons already delivered to the PDRY."142 The first delivery of fire arms, ammunition, vehicles, as well as related equipment

138 | Al-Adhal, Husayn Sulayman, 1993, 408, in: Dresch, 2000, 146.

139 | Information über die Lage in der Volksrepublik Südjemen, September 4 1969, in: BStU HV A Nr.151, 175.

140 | Muhammad Saleh Yafi Muti'a.

141 | Aktenvermerk Treffen Genosse Minister Mielke mit Genosse Minister Armeegenereal Hoffmann, in: BStU MfS HV A Nr.778, 1-2.

142 | In detail, the delivery included about 100 GAZ-69 (light Soviet army trucks), 1800 $9 \mathrm{~mm}$ pistols, 150 7,62 mm MG RPK and 1000 AK-47 as well as sixteen 14,5 mm FlaLafetten (anti-air gun carriage); exact designations: LMG 7,62mm; SMG 7,62 mm, FlaMG 
was ordered in July 1971. This shipment had been decided on behalf of Moscow as part of a significant Soviet delivery. ${ }^{143}$ This indicates that Moscow had been showing at least some interest in South Yemen significantly earlier than 1977. This first relevant arms delivery in 1972 by East Germany included light Soviet army trucks, 1,800 pistols, 150 machine guns for air defense, 1,000 AK-47 rifles, and 16 anti-air gun carriages. ${ }^{144}$ The majority of this kind of arms export in the sense of “military aid" was provided by the GDR's Ministry of the Interior and the Ministry of State Security. An MfS IM, positioned in the Ministry of the Interior in the GDR, reports about 57 Valuta Marks worth of arms supply in the period between 1970 and October 1979. According to IM “Dieter Gerlach," South Yemen received the biggest share of arms by the Ministry of the Interior among all other recipient states. He lists 719 heavy weapons, 26,730 handguns, and about 9०,0०० grenades ${ }^{145}$ sent to the PDRY until 1980.

\section{The GDR's Military Contributions: Worth More Than Just Its Numbers}

Even though East Berlin's involvement in the security sector provided only some training and deliveries of mostly basic and sometimes outdated equipment, there was more to these efforts than their sheer numbers. First, they have to be interpreted in the context of Moscow's military and state-building policy in South Yemen and second, as part of the GDR's wider strategy toward South Yemen's security, including legal affairs, jurisdiction, and the establishment of both a regular and a secret police. The first major steps in state-building for security matters were made in legal affairs. In 1971, GDR Minister of Justice Kurt Wünsche invited his South Yemeni colleague ${ }^{146}$ and the two states agreed on long-term judicial cooperation, including a Treaty on Juridical Assistance that remained in force throughout the GDR's existence. ${ }^{147}$ Furthermore, Aden itself had asked East Berlin for support with the establishment of its police force, including training and equipment. ${ }^{14^{8}}$ As part of the establishment for the Committee of State Security of the PDRY (KfS), East Berlin organized and implemented the education and preparatory training of the KfS personnel. Thus all in all, East German material support for the PDRY has to be considered a political

14,5 mm, Pak 57, RPG 7, no quantity, in: Aktenvermerk Treffen Genosse Minister Mielke mit Genosse Minister Armeegenereal Hoffmann, in: BStU MfS HV A Nr.778, 2.

143 | Lieferungen von Waffen und Ausrüstungen in die Demokratisch Volksrepublik Jemen, in: BStU MfS Sekretariat des Ministers 668, 6.

144 | Ibid., 7.

145 | IM “Dieter Gerlach," in: BStU MfS HA VII 5012, 4ff.

146 | Brief Geibel an Süß, Februrary 23 1971, in: MfAA C 3858, 1.

147 | Bericht über den Aufenthalt der Studiendelegation des Ministeriums der Justiz in der VDR Jemen in der Zeit vom 14.-25.2.1988 [sic!], February 26 1988, in: BStU MfS Abt.X Nr.234, Teil 1 von 2, 195; Treaty on Juridical Assistance April 1st 1971, in: BStU MfS HA IX Nr. 13694.

148 | Brief Winzer an Dickel, December 1968, sine diem, Beziehungen zur Polizei und innerer Organe der Volksrepublik Südjemen, PA AA, MfAA, C 76073, $15 \mathrm{ff}$. 
symbol of respect toward the South Yemen security apparatus and to build up trust and personal friendships. As a consequence, the military deliveries described above have to be interpreted within the context of East Berlin's wider strategy on the civilian side of state-building with its focus on the establishment of comprehensive security apparatus stretching into society, similar to the GDR.

\section{Cooperation between the Stasi and Its South Yemeni Counterpart}

Interestingly, the Stasi had become involved even before the South Yemeni constitution was launched. The first agreement between the East German MfS and its South Yemeni counterpart $\mathrm{KfS}^{149}$ was already signed on November 6 $1970,5^{15}$ whereas the first MfS officer had been active in South Yemen starting in February 1970.151 These early contacts had been initiated by South Yemen and its minister of the Interior Mohammad Saleh Yafa'i. The first meeting between him and high-ranking officials of the GDR's security apparatus, including Mielke himself, had taken place in late 1969 in Berlin. ${ }^{152}$ The first shipment of technical equipment for telecommunication for the KfS was delivered in $1974 .{ }^{153}$

Relations between the two interior ministries developed in parallel to the relations between the two security services, including a significant number of advisors and regular mutual visits of delegations. ${ }^{154}$ This kind of "state-building synergy" probably saved a considerable amount of money and personnel. Nonetheless, the whole process of establishing a security apparatus, including its armed forces, demanded a significant quantity of equipment and financial aid. Reliable numbers for the money spent on "deliveries" for this sector during the building phase from 1971 to 1977 are available. Putting these numbers in relation to the GDR's overall spending on financial, material, and personnel support for "young nation states" between the years of 1967 and 1976 clearly shows East German preferences: While the full spending of this decade adds up to about 105 million East German Marks,

149 | The Section Revolutionary Security Service. German: Revolutionärer Sicherheitsdienst (RSD), Zur Lage des MfS der VDR Jemen, in: BStU MfS Abt. X Nr. 234, Part 1 of 2, 96.

150 | "To develop and deepen the cooperation established with the agreement of November 6 1970," in: Vereinbarung über die Zusammenarbeit zwischen dem MfS der DDR und dem Komitee für Staatssicherheit der VDRJ, November 25 1980, in: BStU MfS Abt. X 1789, 1.

$151 \mid Z u$ den Beziehungen des MfS der VDRJ mit dem MfS der DDR und mit Sicherheitsorganen anderer Länder, in: BStU MfS Abt. X Nr. 234, Part 1 of 2, 102.

152 | Ibid., $329 f$.

153 | Maßnahmen zur solidarischen Unterstützung der Sicherheitsorgane der VDR Jemen, May 2 1988, in: BStU Sekretariat Schwanitz 24, 5.

154 | Zur Lage des MfS der VDR Jemen; Kadersituation des MfS der VDR Jemen in: BStU MfS Abt. X Nr. 234, Part 1 of 2, 104. 
including about six million Valuta Marks, ${ }^{155}$ the GDR's MfS used more than half of this amount for South Yemen. ${ }^{156} 1971-72$ were the years of highest MfS spending in Aden of the period under review. ${ }^{157}$ Of this, the two biggest spending categories, with almost half of the amount spent on were vehicles, arms and ammunition. Another quarter was spent on communications technology. East Germany mostly delivered equipment for special forces from their BCD Section, ${ }^{158}$ the Armament and Chemical Service Section. Between 1971-1977, the deliveries from this section equaled nearly six million VM, 159 and another eight million VM were planned for the period from 1977 to 1980 , demonstrating that the material engagement was kept up even beyond the early years of the establishment of the South Yemeni KfS.

In 1972 the Revolutionary Security Service Section was formed in the KfS and Muhammad Said Abdallah Muhsin (Muhsin) ${ }^{160}$ became its minister. He served in this post until 1979 and thus was able to accompany and direct the whole establishment process of South Yemen's Secret Service. Mushin, a close acquaintance of Ismail throughout his career, greeted the material support by the MfS and worked closely with East German State Security and its advisors. During Muhsin's reign, the PDRY's security apparatus was expanded successively and gradually entered into the civilian sphere.

An example for Muhsin's policies that mirrored East German measures was a new law banning any unauthorized contact with foreigners. In 1975, this law was mostly directed at Western diplomats. In a letter from Sana'a, West German ambassador Günter Held reports on behalf of the West German charge d'affaires in Aden, Alexander Mühlen, about the "restrictions of individual liberties in the PDRY":

“a) Directed by the GDR, the omnipresent KfS 'interviews' every local who has been seen sitting at the table with foreigners. b) Local visitors of foreign representations only have access on the grounds of an official pass issued by the Foreign Ministry [...]; this is also the case for the local domestic workers. Thus unofficially employed workers had to be replaced by governmentally accredited ones. c) This policy is

155 | "The foreign exchange component of the GDR's aid was calculated in 'Valuta Marks.' One VM corresponded to the amount of GDR Marks that would be needed to obtain one unit of convertible currency through the export of GDR goods," in: Howell, 1994, FN 7, 307. 156 | Hilfeleistungen gegenüber jungen Nationalstaaten auf nichtzivilem Gebiet. Übersicht über Ausgaben [...] von 1967 bis 1976, Abt. Finanzen an HV A/III, 26.April 1977, in: BStU MfS Abt. Finanzen Nr. 1393, 152 and 164. This high percentage is reached despite rather modest spending on the PDRY between 1967 and 1970.

157 | Ibid., 166.

158 | BCD - Abteilung Bewaffnung und Chemischer Dienst.

159 | Wertmäßige Übersicht über Lieferungen in die VDR Jemen 1971-1977, Berlin, November 2 1977, in: BStU MfS BCD Nr.2854, 134.

160 | Arabic: Muḥammad Sayyd 'Abdallāh Muḥsin. 
expressed in the new Penal Code of the PDRY. It dedicates one full chapter of its Special Section ${ }^{161}$ (Art. 110-120, 126) to contacts with foreigners. It introduces 'private contact with foreigners (Art.113),' sharing of economic information with foreigners (Art.115), and the acceptance of tips from foreigners as criminal offences with a minimum penalty of one year imprisonment, being extended to up to five years, if espionage or treason cannot be proven (Art.120)."162

Clearly, the intention behind these laws was to eliminate the political opposition by prosecuting as many of them as possible on the grounds of "espionage" and "treason." The law was complemented by more concrete measures like a wall around the embassies and the diplomatic quarter ${ }^{16_{3}}$ which also aimed to isolate Westerners from the population. ${ }^{164}$

But the South Yemeni KfS did not settle for mere observance and the exertion of control. Muhsin's years as minister of the KfS even "earned him the title of 'the butcher' and references to arbitrary imprisonments and executions by the PDRY's Secret Service usually refer to his period of service."165 In the late 1970s, the Aden regime agreed to end Muhsin's excesses for the time being and he was removed from office on the occasion of Salmin's downfall. ${ }^{166}$ During Salmin's presidency, one of the main venues of power struggles within the leadership was located at the intersection of state security and the military, more precisely around the person of Muhsin himself. Brehony claims that before Muhsin was sacked he was responsible for the execution of about 250 of Salmin's followers, all of them military officers, but without due process or the CC's knowledge. In the end Muhsin, a confidant of Ismail, was held responsible and forced to resign.

After Muhsin was removed, his extreme legislation was revised and actual terror of the security apparatus in South Yemen somewhat decreased. However, this did neither decelerate the expansion of the apparatus nor reduce its power. The heyday of Aden's Secret Service as a secret police were yet to come: Over the 1970s, both the Ministry of State Security and the Ministry of the interior had steadily increased their influence and power, not least due to East Berlin's intensive advice and assistance during the process of their creation.

161 | German: Besonderer Teil; The PDRY's Penal Code followed the East (and also West) German model of dividing the Penal Code in a General and a Special Section.

162 | Botschafter Held, Sanaa, an das Auswärtige Amt, June 3 1976, in: AzAP der BRD, 1976, Vol.1, 1.Januar bis 30.Juni, FN 3, 807.

163 | In the beginning, the wall even affected the East German embassy, though this was quickly remedied, in: Botschafter Held, Sanaa, an das Auswärtige Amt, June 3 1976, in: AzAP der BRD, 1976, Vol.1, 1.Januar bis 30.Juni, 807; Scharfenberg, 2012.

164 | Kutschera, 1982, 22; Brehony, 2013, 63.

165 | Security Services, in: Burrowes, 2010, 346; also see: Ismail/Ismail, 1986, 67.

166 | Ismail/Ismail, 1985, $67 \mathrm{f}$. 


\section{Conclusion: South Yemen as the Model Case of a Possible East German Foreign Policy}

The second phase of Soviet engagement was characterized by an increasing level of intensity, while the focus on the two major fields of engagement, the military and ideology, was upheld. Clearly, it was not only the beginning, but also the "high times" of Soviet-South Yemeni relations. In less than a decade, the USSR had become the most important political, economic, and ideological ally for the isolated PDRY. But Aden also could claim a value for Moscow beyond its political importance, such as the unofficial military and naval base on the Horn of Africa. "Neither the Soviets nor the South Yemenis gave much publicity to [their] military cooperation, but they loudly played up the economic and technical [assistance]." 167 While the former type of cooperation clearly aimed to support the Moscow-friendly regime - both to keep it in place and forge it into yet another Soviet ally - the latter served no other purpose. Support for the fishing industry, maintenance and expansion of the naval facilities, and education with an ideological focus: During the 1970s, Moscow's intentions did not have much to do with South Yemen's needs.

In tune with both Moscow's awakening interest in South Yemen as a potential military partner in the region and with Aden's clear commitment to MarxismLeninism, the second phase of East German engagement has to be considered the most comprehensive with regard to the extent of socialist state- and nationbuilding. The fifth NF Party Congress of 1972 interpreted the new constitution in a way that assured East Berlin of the Aden's willingness to go all the way in becoming socialist state and, from the GDR's point of view, go beyond the lipservice of many other Arab regimes evoking socialist rhetoric. Even a future merger of the few remaining political organizations with the NF, now called UNFPO, was a possibility. The Aden regime seemed to fully agree with the East German interpretation of the "integration of society" as "homogenization" and the GDR offered its advice and expertise on how to bring Aden's diverse media landscape under tight party control. With East German help, the control of the press and public opinion was ensured by the network of South Yemen's Ministry for State Security, growing denser and denser throughout the 1970s.

All in all, the numbers of advisors and experts remained constant over several years ${ }^{168}$ and even increased later in the decade after the founding of the YSP. Therefore, Phase II is characterized by a continuous intensification of the GDR's level of engagement, but also a diversification of fields of engagement. An extraordinary example of this is the field of foreign policy. Though not a field of engagement directly associated

167 | Yodfat, 1983, 112.

168 | Einschätzung der Ergebnisse der bisherigen DDR-Regierungsberatertätigkeit mit Schlußfolgerungen für das weitere Vorgehen auf diesem Gebiet in der VDRJ, June 27 1972, in: PA AA, MfAA, C 156276, 46. 
with the concept of state- and nation-building, which on first glance is focused on change within a country's borders, foreign policy is an important field at least in socialist state- and nation-building. Marxist-Leninist ideology, as propagated by Andrei Zhdanov's "Two-Camp Theory,"169 is based on a dual weltbild of capitalist/ imperialist and socialist/anti-imperialist states. As a consequence of the Cold War and its Marxist-Leninist interpretation, a state's political stance in international relations serves two purposes with regard to its internal process of state- and nationbuilding. First, the identity of the state's population in the sense of a national identity may be forged as the righteous socialist "self" against the malicious "capitalist" or "reactionary" "other". Second, a feeling of belonging is created among the state's population as members of a bigger community, the community of socialist states. The founding of the YSP and the regime's commitment to the Soviet Bloc had sealed the PDRY's isolation in the region and the Arab world, depriving South Yemen of other options in the international sphere. Thus, asking for East German foreign policy guidance shows South Yemeni desire for security and its wish to be accepted in the Socialist community of states. For the GDR, however, granting this wish has to be considered an important building block of socialist state- and nation-building in Yemen.

The GDR's high level of engagement during this time in almost every social and political field was promoted by two dynamics that seemed to oppose each other, but rather were mutually dependent. On the one hand, the PDRY had clearly turned to the socialist camp. West Germany had withdrawn from South Yemen and Moscow signaled not only its approval of East German activities, but even developed some interest of its own in the location. ${ }^{170}$ On the other hand, new state and non-state actors perceived as "imperialist" by the socialist camp became involved in South Yemeni affairs, including United Nations advisors and experts from Western countries, as well as representatives from the International Monetary Fund. East Berlin ascertained: "[O]ur advisors and their thoughts and ideas have to prevail [against Western orientations]." ${ }^{171}$ This motivation of fending off "imperialist advancements" tied in neatly with East Berlin's strategy of the "honest broker" and clearly goaded East German engagement in socialist stateand nation-building.

An impressive number of East German actors were engaged in South Yemen early on: The embassy; the party and its mass organizations like the East German

169 | Zhdanov, Andrei, party secretary of the CPSU, in September 1947, Zhdanov answers Harry S. Truman at the Conference of Communist Party of Europe, Speech in: Lautemann/ Schlenke (Ed.) 1980, $156 \mathrm{f}$.

170 | Letter Scharfenberg and Grünheid, Ministry of Planning, January 1 1974, in: PA AA, MfAA, 166276, 79.

171 | Einschätzung der Ergebnisse der bisherigen DDR-Regierungsberatertätigkeit mit Schlußfolgerungen für das weitere Vorgehen auf diesem Gebiet in der VDRJ, June 271972 , in: PA AA, MfAA, C 156276, 38. 
Trade Union (FDGB) and the youth organization FDJ; advisor groups and experts; and the members of the East German-Arab Society of Friendship and the PDRYGDR Society of Friendship, who officially connected in $1974 .{ }^{172}$ Throughout the 1970 , the actors in South Yemen demanded even more qualified cadres and experts for advice on nation- and state-building. Most of these requests were granted to as far an extent as possible. ${ }^{173}$ This also exemplifies the supposedly high priority of the GDR's involvement. All of them were part of a highly diversified structure of control, directed from East Berlin, coordinated by the embassy in Aden and watched closely by Stasi officers and IMs. Considering that the Soviet KfS did not add any material support and training until 1974, ${ }^{174}$ the East German MfS undeniably performed pioneer work. With the benefit of hindsight, this second phase of East German engagement may be considered the heart and heydays of East German socialist state- and nation-building, as it enhanced the Aden regime's endeavors and culminated in the founding of the South Yemeni vanguard party, the Yemeni Socialist Party (YSP), in 1978.

172 | Scharfenberg, 2012, 42.

173 | Einschätzung der Ergebnisse der bisherigen DDR-Regierungsberatertätigkeit mit Schlußfolgerungen für das weitere Vorgehen auf diesem Gebiet in der VDRJ, June 27 1972; WTZ-Protokoll 74/75 by HA FTZ Entwicklungsländer HA-Leiter Sachse, November 6 1974, in: PA AA, MfAA, C 156276.

174 | Zur Lage des MfS der VDR Jemen, Kadersituation des MfS der VDR Jemen, in: BStU MfS Abt. X Nr. 234, Part 1 of 2, 96. 



\section{Interlude. South Yemen:}

\section{A "Rough State" in the Region and in the World}

During the Cold War, the Horn of Africa was of much geostrategic interest and relevance. This importance was closely connected to free sailing through the Bab al-Mandab and the question of access to Aden port for both superpowers, but also regional actors. Extreme poverty, regular news about terrorist training and erupting violence, as well as the ideological saber-rattling of Arabia's one and only Marxist state all fostered more attention for South Yemen than its political relevance might have justified. In the 1970s the PDRY forged an alliance across the Red Sea with the other two radical regimes in Africa: Ethiopia and Libya. Clearly, the fledgling South Yemen emerged as a constant factor contributing to the political insecurity in the region and was, due to Soviet military support, a military threat to its neighbors. The following interlude chapter aims to clarify Aden's position in the region and illuminate the state's course in Cold War reality to support the reasoning on Moscow's and East Germany's interests. The PDRY's policy and role in the region can be divided into three subject areas: The PDRY and its neighbors, its geostrategic position on the Horn of Africa, and the regime's extremist tendencies.

\section{Aden: Actor and Pawn in the Cold War Game}

The regime's radical path isolated the new state in the region right from the start, and the provisions of the Fourth Congress of the NF did not do much to improve that. At least at the party level, Aden was able to bond with other "progressive" regimes in the region, but even these regimes criticized South Yemen for its closeness to Moscow and East Berlin, condemning Aden and its policies as a betrayal of Islam and Arabism. ${ }^{1}$ Naturally, the conservative monarchies of the gulf considered the PRSY/PDRY an imminent threat to their rule and their

1 | Wildau und Serauky zur Reise der VDRJ Delegation in arabische Länder 1972, in: PA AA MfAA C 1555/76, 176. 
state's stability. Saudi Arabia, bordering South Yemen in the east, and Egypt, the aspiring regional power, had supported the disempowered sultans and their ally, FLOSY, from early on. After their hopes for a moderate regime had been dashed, Riyadh as well as Cairo tried to find common ground with Aden, in one way or the other. Speculations about newly found oil in the border region between Saudi Arabia, North Yemen, and South Yemen ${ }^{2}$ offered simple reasons for distrust and fueled conspiracy theories. As a consequence, this perceived external threat served to unify the divided ranks of the NF.

\subsection{Brotherly Love and Hate: North and South Yemen at War}

When the Aden regime eliminated the qualifier "South" in the name of its republic in 1970, this not only referred to Yemeni unity, but undeniably expressed the regime's political claim to all of Yemen. ${ }^{3}$ The tensions between North and South had continuously been building up for quite some time and the final outbreak of violence was no surprise. The border war between the two Yemens in 1972, however, was merely a short one. The peace agreement reached between al-Aini, foreign minister of the YAR, and Aden's Ali Nasir in Cairo even formulated Yemeni unification as a common goal ${ }^{4}$ - though it turned out to be one of long-term character. It took more than two decades before actual peace between North and South was achieved. In the meantime, the "Cairo Agreements on Unification" of 1972 were followed by new fighting along the border in 1979, while "the PDRY-supported National Democratic Front (NDF) rebellion in the borderlands of the YAR"s kept conflict between North and South quite alive well into the 1980 s.

Saudi Arabia's support for the YAR in these conflicts and Moscow's role in these regional disputes illustrate the regional relevance of the conflict. While the Kremlin displayed political restraint when fighting erupted between Saudi Arabia and the PDRY in 1969, it still blamed Saudi Arabia for "fanning all kinds of discord between the [YAR] and the [PDRY]" in $1972 .{ }^{6}$ In doing so, Moscow positioned itself against Riyadh as well as Washington in the region. Due to its realistic perspective on South Yemen's capabilities, Moscow clearly had no interest in a unified Yemen in this period, as long as an expansion of the South Yemeni system to the North was not guaranteed. Rather, the Kremlin had a smaller but stable and loyal Marxist-Leninist regime for South Yemen in mind. This clearly

2 Information über die politisch-militärische Lage der VDRJ (VDRJ), 1972, in: BStU MfS HV A 388, 278.

3 | Brehony, 2013, 55; Burrowes, 2010, 263; Unger, 1971, 1172.

4 | Burrowes, 2010, 67.

$5 \mid$ Borders and border disputes, wars and agreements, in: Burrowes, 2010, 59.

6 | Izvestia, August 1972, in: Halliday, 1990, 185. 
did not correspond with South Yemen's interests at the time. Aden aimed for a fast unification under its Marxist leadership. Scharfenberg, the GDR ambassador, considered this a possibility. After the peace negotiations in Cairo and Tripoli between the YAR and the PDRY under Soviet leadership, he reports to Berlin about "national enthusiasm" among the public and party officials and perceptions that "Yemen unity could be swiftly achieved." In retrospect this was not about to happen too quickly.

The creation of South Yemen's vanguard party in 1978 also led to the official inclusion of the socialists in the YAR. "The YSP is convinced that nothing but a broad-based popular movement backed by all popular forces can achieve unity for the Yemeni homeland." 8 This meant nothing less than an immediate attack on the northern leadership. Furthermore, the YSP never made it a secret that it intended to expand its version of Marxism-Leninism to the north. 9 Understandably, this led to increased distrust of the newly installed regime in Sana'a under the leadership of young Ali Abdallah Saleh. Fighting between the two Yemens erupted once more shortly thereafter and it was not until another civil war in the early 1990 s that the two Yemens finally unified.

\subsection{Regional Ties, New Friendships, and Rivalries of the 1970s}

Meanwhile, Moscow was still hoping to improve relations with Saudi Arabia in the mid-1970 and Aden's saber-rattling became more of a nuisance than a help for Soviet interests in the region. The Kremlin urged Aden to improve the situation and Salmin's pragmatic policies eased the way to the establishment of relations between the PDRY and Saudi Arabia. ${ }^{10}$ But other events overruled these considerations. Fighting erupted between Somalia and Ethiopia and caused significant turmoil in the region. Aden became renowned as a political meeting point of the regional powers involved and the allies of the Eastern Bloc. ${ }^{11}$ Cuban leader Fidel Castro pointedly describes the Soviet dilemma to Honecker: "If the Socialist countries help Ethiopia, they will lose Somali Siad Barré's friendship. If they don't, the Ethiopian revolution will founder." ${ }^{12}$ In February 1977, after several failed mediation attempts between Somalia and Ethiopia moderated by South

7 | Brief Scharfenberg an Scholz, December 5 1972, in: PA AA MfAA C 1556/6.

8 | Lackner, 1985, 85.

9 | Abd al-Fattah Ismail, in: Grünberg, 2012, $60 f$.

10 | Yodfat, 1983, 51.

11 | Additions to February 21977 Report by Third African Department, Soviet Foreign Ministry, on “Somalia's Territorial Disagreements with Ethiopia and the Position of the USSR," apparently in late May-early June 1977, 63, in: Russian \& East German Documents on the Horn of Africa, 1977-78, in: Cold War International History Project Bulletin Issues 9-10.

12 | Castro, Fidel, in: Abebe, 1996, 43. 
Yemen, Cuba, and the GDR,,$^{13}$ Mengistu Haile Mariam seized power and Moscow took the opportunity to side with Addis Abeba against Riyadh-backed Mogadishu. Werner Lamberz, “SED Politbüro member and Erich Honecker's troubleshooter for Africa," 14 and thus a confidant of Soviet diplomats, had been visiting Addis Abeba at the time and readily ensured Mengistu of the support of the Eastern Bloc. Half a year later, the Soviet ambassador to Ethiopia, A.P. Ratanov, reported to Moscow:

"On September 10, together with the heads of the diplomatic missions of Bulgaria, Hungary, the GDR, PDRY, Poland, Czechoslovakia, Romania, [North Korea], Cuba, and Yugoslavia, I was invited to visit Mengistu Haile Mariam.[...] There, I was informed about] the discovery [...] of an imperialist plot against the Ethiopian revolution [by] the USA (the initiator of the plot), Sudan, Saudi Arabia, Egypt, Kenya, and Somalia." ${ }^{15}$

As this report summarizes, alliances in the confrontation were clear and characterized the tendencies of political and military cooperation of the time: In the dispute, the USSR demanded South Yemeni loyalty and support, despite the danger of isolating Aden once more. Against Salmin's wishes, Ismail opened up Aden's port for shipping arms and Cuban troops to support Ethiopia. As a consequence of the dispute, Moscow lost Berbera, its naval base in Somalia, and Aden its fragile relationship with Riyadh. Instead, Aden became Moscow's unofficial substitute for lost Berbera.

Ethiopia's move to the extreme left and the PDRY's support during Addis Abeba's conflict with Somalia made the two radical regimes natural allies in the region, especially as both were very close not only to Moscow, but also to its junior partner the GDR. In 1981, the new friendship culminated in the Tripartite Agreement among Ethiopia, Libya, and the PDRY. ${ }^{16}$ The new coalitions forged during the confrontation in the Horn were quite unsettling for the Western powers and the conservative neighboring states. ${ }^{17}$ Hitherto, the USSR was considered not

13 | Third African Department, Soviet Foreign Ministry, Information Report on SomaliEthiopian Territorial Disputes, February 2 1977, 53 and Soviet Foreign Ministry and CPSU CC International Department, Background Report on the Somali-Ethiopian Conflict, 3 April 1978, 92-94, both in: Russian \& East German Documents on the Horn of Africa, 1977-78, Cold War International History Project Bulletin Issues 9-10.

14 | Ostermann, 1996, 48.

15 Soviet Ambassador to Ethiopia A.P. Ratanov, Memorandum of Meeting with Mengistu, 10 September 1977, 78f, in: Russian \& East German Documents on the Horn of Africa, 1977-78, Cold War International History Project Bulletin Issues 9-10; On the GDR's involvement in the peace talks see: Dagne, 2006, 18.

16 | Burrowes, 2010, 121.

17 | Moskauer Strafexpedition am Horn von Afrika, in: Der Spiegel, No. 7, 1978. 
only a major player in the region, but also able to control access to the Red Sea and thus the Suez Canal. Saudi Arabia, Kuwait, and the United Arab Emirates jointly offered assistance and support to the "people of South Yemen" in return for "good behavior," that is, restraint with regard to PFLOAG and general political moderation. ${ }^{18}$ This policy also aimed to curb Soviet influence in the PDRY: In a meeting with the West German Chancellor Helmut Schmidt, the Saudi Arabian Crown Prince Fahd declared Saudi Arabia's intention to offer an "alternative" to the people of South Yemen. The destabilized situation in South Yemen

\begin{abstract}
"may serve to improve the Soviet position in the country. South Yemen disposes of weapons like tanks and planes it does not need for its defense, that's the danger. The country's army doesn't have the opportunity or ability to use these weapons. Thus one has to ask what they are there for. This military power indeed can only be used against countries like Somalia, Sudan or the Gulf states." ${ }^{19}$
\end{abstract}

Aden repeatedly labelled Riyadh's policy as hostile and in June 1972 Salmin explicitly announced that the PDRY would work toward the "extinction of the regime [in Riyadh] and the establishment of a republic." ${ }^{2 \circ}$ This attitude toward Saudi Arabia was not about to change before Ali Nasir established himself as unchallenged leader in 1980. The PDRY's military forces, however, clearly were no match for Riadh, and comments by contemporary analysts and today's historians alike consider Soviet military support for the PDRY rather "unimpressive." ${ }^{21}$ However, the PDRY's dedication to its military forces was not to be denied: A standing army of about 27,500 regulars was entertained by one of the poorest countries in the world with a population of about three million people. Due to Soviet and Cuban training and Soviet arms deliveries, the PDRY's army noticeably exceeded the equipment, training, and discipline of its immediate neighbours, the YAR and Oman. ${ }^{22}$ In addition to that, the new leader Ismail gradually drifted away from Salmin's moderate pragmatism and back to the PDRY's policy of "revolution export" to the north and east. ${ }^{23}$ Saud's open worry about the extent of military equipment in the PDRY and possible “unrest” in its near vicinity, as well as Washington's decision to substantially engage in the Yemen Arab Republic during the second Yemeni War in $1979,{ }^{24}$ clearly show that the PDRY was perceived as a serious threat in the

18 | Chubin, 1980, in: The International Institute for Strategic Studies (Ed.), 303.

19 | Dialogue of Crown Prince of Saudi Arabia Fahd with Chancellor Helmut Schmidt on April 27 1981, in: AzAP-BRD 1981, FN 18, 652.

20 | Der Generalsekretär Robaya Ali, June 22 1971, in: PA AA MfAA C 1555/76, 169.

21 | Chubin, 1980, in: The International Institute for Strategic Studies (Ed.), 303.

22 | Burrowes, 2010, 39; Halliday, 1990, $202 f$.

23 | Katz, 1986, 8.

24 I In February 1979, the USA finally gave in to persistent Saudi requests and agreed to $\$ 1.4$ bllion aid including military equipment. Chubin, 1980, FN 93, in: The International 
region. Thus, even though the total amount of Soviet military support in South Yemen had been decisively smaller than in Iraq or Syria, its political impact has to be considered significantly higher. This was due to geostrategic reasons, but also to the fact that South Yemen was perceived as an unpredictable actor in in the region, thus capable of producing much instability. Aden's close ties to Moscow and the YSP's open striving for a leadership role among the communist parties in the Arab world, as well as the PDRY's habit to harbor terrorists, certainly did not improve South Yemen's reputation either. ${ }^{25}$

\section{Between Conspiracy Theories and Security Policy: East Berlin, Aden and International Terrorism}

The results of the archival work undertaken within the research for this study undeniably point at a certain exchange between East Germany and South Yemen on international terrorism and possible cooperation in the field. Thus, the topic cannot be left out when analyzing the GDR's foreign policy in the PDRY. However, due to a research gap compounded by a lack of sources for verification, current publications hover between spy novels and conspiracy theories. As a consequence, this chapter is not grouped under one of the analytical phases and rather presented as an excursus.

The 1970 also have to be considered the high times of South Yemen's support for what the PDRY called "national liberation movements". While some of the supported groups and individuals pursued the goal of liberation, many of them not only agreed with Aden that they had "a right to struggle by "all means," they also acted on this principle. South Yemen "became a center for revolutionaries, opposition forces and rebels," ${ }^{26}$ some of them straightforward terrorist groups. In Aden and its hinterland, movements such as the PFLOAG in Oman, ${ }^{27}$ the Eritrean Liberation Front (ELF), Naif Hawatmah's Popular Democratic Front for the Liberation of Palestine (PDFLP), and George Habash's Popular Front for the Liberation of Palestine (PFLP), set up their offices, training centers, and meeting points. During the 1970s, the PDRY became notorious as a training ground and safe haven for terrorists.

Institute for Strategic Studies (Ed.), 322; Halliday mentions about “ $\$ 400$ million worth of US arms to the YAR" as well as the development of naval forces in the gulf to deter South Yemeni forces, in: Halliday, 1990, 192; Also see: Burrowes, 2010, 39.

25 | Informationsmappe für den Besuch des Generalsekretärs des Zentralkomitees der JSP [...] Ali Nasser Mohammed, November 1984, in: BStU MfS HA II Nr. 28712, 153.

26 | Yodfat, 1983, 49.

27 | Arab National Movement; Border and Border Disputes, wars, and Agreements, in: Burrowes, 2010, 33 and 59. 
Even though the South Yemeni leaders always denied these activities, clues and events are just too pressing to deny the PDRY's engagement with and support for international terrorist groups and individuals. The MfS reports: "In context of [...] reconnaissance of terrorist groups and forces, it was concluded repeatedly that the PDRY serves as a country of transit and residence [...]." ${ }^{28}$ International terrorist Ilich Ramirez Sanchez, also known as "Carlos the Jackal," boasted two South Yemeni passports, one of them a diplomatic document. His girlfriend "Lilly" also used a PDRY passport. ${ }^{29} \mathrm{He}$ and his groups received extensive consular support by South Yemeni embassies worldwide and were able to use the PDRY as a training and home base. ${ }^{\circ}$

Some MfS documents suggest that Carlos aimed to extend his status there,by acquiring a "Party over Governmental decision" on the cooperation with his group. ${ }^{31}$ Speculations about institutionalized cooperation between Carlos' group and the PDYR may find at least some support in the MfS files as well: "The unofficial source informed [us] that President Ali Nasser is not responsible for the Ministry of State Security anymore. Thus, the contacts for the Carlos group have changed as well." ${ }^{22}$ Another document of the South Yemeni KfS may be considered more resilient. There, the KfS is asking for the MfS' advice with regard to the handling of Carlos and his supporters:

"1. May the group around Carlos be trained in the PDRY? (The import of weapons to the PDRY will be possible) 2. May the PDRY be used as a base for the group? 3. Is there agreement [of the MfS] with regard to a possible issuance of passports for the members of the group by the PDRY?"33

28 | The report names a South Yemeni liaison officer of the KfS as source. Konzeption für ein Gespräch mit dem Vorsitzenden des MfS der VDR Jemen zur Fragen des Terrorismus, November 12 1980, in: BStU MfS HA XXII Nr.20004, 51.

29 | Bericht "Carlos", January 10 1980, in: BStU MfS HA XXII Nr.11, 239; 252; Gesprächskonzeption über die am 16.8. - 17.8.1979 durchzuführende Beratung mit Vertretern der ČSSR-Sicherheitsorgane in der ČSSR-Hauptstadt - Prag, August 14 1979, BStU MfS HA XXII Nr.20004, 11

30 | Bericht "Carlos", January 10 1980, in: BStU MfS HA XXII Nr.11, 239; Report on Carlos“ future moves, dated probably before 1981, in: BStU MfS HA XXII Nr.17191, 53.

31 | Report on Carlos' future moves, dated probably before 1981, in: BStU MfS HA XXII Nr.17191, 53.

32 | Information über die Zusammenarbeit der "Carlos"-Gruppierung mit der VDRJ, in: BStU MfS HA XXII Nr.17191, remnant, sine anno, sine pagina.

33 | Vermerk Telegramm aus Aden vom 20.8.1979 an Neiber, Roscher, HV A/III, August 20 1979, in: BStU MfS HA XXII Nr.20004, $7 f$. 
This document, which is dated before the two South Yemeni passports were issued for Carlos, ${ }^{34}$ suggests that the East German MfS usually knew about South Yemen's contacts in this regard and maybe even had a say in the PDRY's decisions. However, political cooperation with international terrorist groups had not been too profitable for the PDRY, neither politically nor economically. In the end, and despite several years of close cooperation between the PDYR and Carlos the Jackal, "relations [somewhat] cooled down" in 1981. In accordance with the quoted "top secret" MfS report, Carlos had begun moving arms and equipment from Aden to Syria due to the remote position of the country.35 In addition to the GDR's knowledge of South Yemen's contacts with terrorist groups, East Berlin undeniably followed its own interests in this regard. According to Kowalczuck, the GDR's MfS "not only entertained contacts to the PLO, but also to Arab terrorist groups. Hundreds of these fighters [...] had been trained by officers of the MfS. ${ }^{36}$ Carlos and his closest partners were able to move freely between several states of the Eastern Bloc and certain "safe harbor states" like the PDRY:

“[Carlos] left Bagdad in January 1979 because of fear of reprisal and has been residing mostly in the Socialist countries GDR, Hungary, Bulgaria and the ČSSR. Exemptions are short visits to the PDRY, Libya, Lebanon and Syria." ${ }^{37}$

The "Carlos" Group or "Organization of International Revolutionaries,"38 as the group members called themselves, officially supported national liberation movements against "Imperialism, Fascism, Zionism, Racism, and Colonialism." 39 Major allies in this fight were the socialist countries, as an MfS report of 1980 suggests: "Out of strategic considerations friendly relations are to be established and maintained [with the Carlos Group]."40 Despite the GDR's refusal to offer full support to the Group as a "safe harbor state," the report mentions that "visa for entry and transit to the GDR" had been issued and that the leading figures of the group received accommodation." ${ }^{41}$ Carlos and his supporters repeatedly visited East Berlin between 1979 and 1982 as a "guest of the embassy of South Yemen." ${ }^{42}$ There they received substantive support by Arab and East German citizens in the GDR,

34 | Bericht über die Tätigkeit terroristischer Organisationen, unter besonderer Beachtung der "Organisation Internationale Revolutionäre," die vom bekannten Terroristen "CARLOS“ geleitet wird, Februar 10 1981, BStU MfS HA XXII Nr.20004, 42.

35 | lbid., 39.

36 | Kowalczuck, 2011, 262.

37 | Bericht "Carlos", January 10 1980, in: BStU MfS HA XXII Nr.11, 231 .

38 | Ibid., 234.

39 | Bericht "Carlos", January 10 1980,

40 | Ibid., 235.

41 | Ibid., 237.

42 | Wolf, 1997, 383. 
including long-term accommodation. ${ }^{43}$ Also according to the report, the "Carlos Group" had declared that it was willing to "execute operations on behalf or in the interest of Socialist states against imperialist targets and individuals." 44 During a certain period, the GDR verifiably provided home and shelter for the Carlos Group in Central Europe. There they were able to meet with other international terrorists as well as representatives of secret services, such as during Carlos' visit to the GDR in July $1979 .{ }^{45}$

However, the affiliation of the GDR with terrorist individuals like "Carlos" backfired soon enough, as can be seen in a document summarizing the "dangers and security threats resulting from the [activities] of the 'Carlos Group' for the Socialist countries."46 Despite the group's assurance not to interfere with internal and external Socialist politics, neither the MfS nor other secret services of the Eastern Bloc trusted these promises. ${ }^{47}$ And while the political acceptance of the Carlos Group in the GDR was upheld during the $1980 \mathrm{~s},{ }^{48}$ the MfS watched the group's movements closely. By helping him to reestablish his relations with Iraq and arranging a meeting with a member of the Iraqi Secret Service, ${ }^{49}$ the MfS clearly hoped to finally getting rid of Carlos.

East German support for Carlos had been especially delicate with regard to relations to Western Germany. The 1970s in West Germany sometimes are referred to as the "German Fall," "Deutscher Herbst". . $^{\circ}$ This was the heyday of a West German terrorist group, the Rote Armee Fraktion (RAF), and its affiliates who entertained contacts with other terrorist groups worldwide, especially in the Arab world, and profited from their experience and training, among them the PLO, the "Abu Nidal Group," and the "Carlos Group"..$^{1}$ In the end, cooperation with Carlos all in all must have become considerably less advantageous for the GDR.

43 | Bericht "Carlos", January 10 1980, in: BStU MfS HA XXII Nr.11, 268.

44 | Ibid., 238.

45 | Ibid., 244; Bericht "Carlos", Februar 10 1981, BStU MfS HA XXII Nr.20004, 32.

46 |Bericht "Carlos", January 10 1980, in: BStU MfS HA XXII Nr.11, 231; $271 \mathrm{ff}$.

47 | Ibid., 232; 246; Bericht "Carlos", March 10 1980, in: BStU MfS HA XXII Nr.20004; Bericht "Carlos", Februar 10 1981, BStU MfS HA XXII Nr.20004, 28-40.

48 | Bericht "Carlos", January 10 1980, in: BStU MfS HA XXII Nr.11, 274.

49 | Ibid., in: BStu MfS HA XXII Nr.11, 247; Bericht "Carlos", March 10 1980, in: BStU MfS HA XXII Nr.20004, 1-6.

50 | On the controversies about this term see: Jesse, in: Jesse, 2007, 15.

51 | Wunschik, 2007, $25 f$. 



\section{CHAPTER 13. Phase III: The Phase of Continuity and Consolidation}

The GDR in Yemen from 1978 to 1986: German Guidance and

Yemeni Emancipation

The second phase of East German foreign policy in the 1970 s established the GDR as a reliable supporter of the state- and nation-building process in Aden. Internal developments in the PDRY during the 1970s culminated in one particular event: The founding of the YSP and installation of Ismail as its secretary-general concluded the development of the former revolutionary movement NLF to a Marxist-Leninist vanguard party. The founding Congress of the YSP has to be regarded as the final catalyst for the intensification of South Yemeni relations with the Eastern Bloc in general and East Germany in particular, as engagement between the states reached a new level in the early 1980 s. The following chapter captures the major contributions of the GDR to the state-building process in South Arabia with a focus on the partycentered political system, economic aid, the media, and the security apparatus.

\section{Aden hovering between the Peak and Abyss of its Political and Economic Development}

\subsection{The Left Prevails and then falls Apart: The New Vanguard between "Individualism" and "Collective Leadership"}

"The Yemeni Socialist Party is the vanguard of the Yemeni working-class [...]."

(Party Program of the YSP, 1978)

The internal struggles between Salmin's followers and his opposition finally erupted in a political and military crisis in June 1978. The establishment of a Soviet-style vanguard party and thus the long-term alignment of the PDRY with the Eastern Bloc had by no means been an unchallenged development. After

1 | JSP - Avantgarde des jemenitischen Volkes. Auszüge aus dem Programm der JSP (I) und (II), in: horizont No.50/51 1978, in: BStU MfS HA II Nr.27368, 4-11. 
Salmin's execution and Ali Nasir's six-month presidency, Ismail, the party's chief ideologue, succeeded him as president to direct the "Founding Congress of the Yemeni Socialist Party" from 11-13 October, 1978, in Aden. ${ }^{2}$ All in all, the event may be considered an act of consolidation of the "former left" and the keystone of the implementation of "democratic centralism"s as the fundamental principle of the political system. Ismail opened the Congress with a speech clearly declaring the YSP a Marxist-Leninist vanguard party with close ties to Moscow. ${ }^{4}$

However, this clear commitment came at a cost to Aden. Scharfenberg quotes Nicolas Chaoui, former leader of the Lebanese Communist Party, on the matter:

"Abdel Fattah Ismail explained to him, Chaoui that it would depend on the [financial and political support of the Soviet Union and its Socialist brother states], whether the vanguard party was to be founded or not." ${ }^{5}$

Explicit South Yemeni demands for compensation for actual and perceived loss due to the opting for the "progressive path" emerged as an important argument within Aden's policy towards the Eastern Bloc and remained a central feature until the very end of the PDRY's existence.

From 1978 onward, Ismail, Ali Nasir and Minister of State Security Muhsin advanced as the state's leading figures. Now the former "left" was firmly established as the leading faction. But the political differences within the regime already began to show and a new rift emerged between idealistic Ismail and pragmatic Ali Nasir, who only reluctantly had left his presidency to Ismail. First, Ali Nasir was by far more popular with the Yemeni youth. Compared to Ismail, Ali Nasir regularly is described as an appealing public speaker:

"His speeches contrast sharply with those of Ismail and Salmin. They are expressed in simple and direct language, and discuss how policies should be applied, rather than ideas and ideology" ${ }^{6}$.

However, during the locking of horns which followed, it was tribal ties that decided the outcome. Ever since South Yemen's declaration of independence, political mobilization, and thus power, gradually had shifted from Aden and Aden Colony to its hinterland. In 1979, Ali Nasir "made moves [...] to win over

2 | The creation of the YSP included a merger of the NF, or NFPO as it was called at the time, and the other leftist forces in the country, namely the PDU and the Ba'athists, Gambke et al., 1974, 103; Ismail/Ismail, 1986, 37.

3 | JSP - Avantgarde des jemenitischen Volkes. Auszüge aus dem Programm der JSP (I) und (II), in: horizont No.50/51 1978, in: BStU MfS HA II Nr.27368, 10.

4 | Grünberg, 2012, 60. On the party structures of the YSP see: Ismail/Ismail, 1986, 38ff.

5 | In: Scharfenberg, 2012, 50.

6 | Brehony, 2013, 122. 
Salmin's remaining supporters,"7 while he could rely on wide support from his home region Abyan. Even the powerful Governor of Abyan, Muhammad Ali Ahmad, was counted among his supporters. Ismail had migrated from Yemen's north and had never been able to establish a home base and constituency in the south. Coinciding with intensifying social pressure due to economic hardships, the struggle soon was decided. Ismail's opponents blamed the economic problems and political isolation on Ismail's overly theoretical approach to politics. Support for him gradually deteriorated. On the occasion of an extraordinary Party Congress in April 1980, later on named the "Second Congress of the YSP," Ismail finally was forced to resign. He was sent off to exile in Moscow and Ali Nasir took over: As president, prime minister and secretary general of the YSP. ${ }^{8}$

Even though Ali Nasir did not much to change the existing state structures, he "operated them differently [than Ismail]." 9 Under his presidency, the idea of "collective leadership" faded into the background. While Ali Nasir made his mark as a charismatic leading figure, he seemed to aim at disempowering the former revolutionaries in the leadership by drawing from Salmin's former supporters. ${ }^{10}$ MfS documents describe the Second YSP Congress of 1980 as a generational change in the YSP in general and the Central Committee in particular. According to this document, the new leadership mostly relied on younger cadres "educated in the USSR and other [socialist] countries [...], some of them [even had] received profound Marxist-Leninist instructions." ${ }^{11}$ Of the "old guard" only Ali Nasir and Ali Ahmad Nasir al-Antar (Ali Antar) ${ }^{12}$ remained in the YSP's inner circle.

In the meantime, the rift that had appeared within the YSP between the pragmatic Ali Nasir and the ideologue Ismail progressed regardless of Ismail's absence, even though he had received unexpected support from al-Beidh and Ali Antar. Although the latter had played a significant part in Ismail's removal from his posts in 1980, he sided with Ali Nasir's opponents, and thus with his former adversary Ismail, soon after. As a consequence, Ali Antar, at the time minister of defense as well, had to leave the country in 1981 and was suspended soon thereafter. From then on, he had to content himself with a minor post. Finally al-Beidh, firmly rooted in and supported by his home base Hadhramawt ${ }^{13}$ and Ali Antar's constituency in Lahj, began to form a new alliance in 1982. Copying the criticism against Salmin, al-Beidh and Ali Antar both demanded Ali Nasir to yield some of his powers. According to them, Nasir was ignoring the principles of

7 | Ibid., 110.

8 | Burrowes, 2010, 27f; Dresch, 2000, 151.

9 | Brehony, 2013, 122.

10 | Halliday, 2002, 46.

11 | Informationsmappe für den Besuch des Generalsekretärs des ZK der JSP [...] Ali Nasser Mohammed, November 1984, in: BStU MfS HA II Nr. 28712, 149.

12 | Arabic: `Alī Aḥmad Nāșir `Antar.

13 | Arabic: Ḥadramawt. 
"democratic centralism" and "collective leadership." In addition to that, one may speculate that Muhsin, former minister of state security, kept contact with Ismail in Moscow from his post as South Yemeni ambassador in Budapest, so that the Kremlin might have had a hand in the rehabilitation of Ismail's standing. ${ }^{14}$ In the end, the chief ideologue of the YSP was allowed to return. However, conflict was far from over. Disagreement and competition between the factions kept smoldering, until a fierce, full-fledged civil war erupted in January 1986.

\subsection{Economy and Public Welfare in the mid-1980s: South Yemen's Golden Years or Struggle for Survival?}

Even before the "1986 crisis," South Yemen's economy was weak, with the PDRY ranking among the poorest countries in the world. Living conditions nonetheless had somewhat improved in the early 1980.s.5 National GDP and household consumption expenditures both had risen steadily, the latter from about \$55 Million in 1972 to almost \$300 Million in $1982 .{ }^{16}$ At least in Aden, these years usually are remembered as a time of political stability and general public welfare by Yemenis and foreigners alike who were living in the Yemeni capital. In his short account of the South Yemeni state of development, Lewis summarizes: "During the 1970s, national industrial production rose fivefold as a result of the opening of factories." ${ }^{17}$ The majority of industrialization was subsidized with money from the Eastern Bloc. But economic growth was not about to last.

Soon enough the PDRY arrived at its limits of expansion. The factories again drew immigrant workers and by the end of the decade, population and industrial growth had exceeded the capacity of South Yemeni infrastructure. Concentrated in the two most developed areas, Aden and Mukhalla, ${ }^{18}$ average industrial productivity and efficiency for South Yemen remained low. This was not about to change easily due to a lack of natural resources, inadequate infrastructure, ${ }^{19} \mathrm{a}$ low level of education, and poor quality of equipment. Despite a modest growth of industrial production, agriculture remained the main economic sector with the

14 | Brehony, 2013, 131f; Also see below.

15 | On economic reforms and central planning in the PDRY see: Lackner, 1985, 149-169.

16 | UN Data, Former Democratic Yemen.

17 | Fivefold in comparison to production right after the British had left which equaled almost zero [comment: author], in: Lewis, 1987, 362.

18 | Lewis gives estimates of the urban population of South Yemen's biggest cities in 1987: Aden (350,000), Mukhalla (50,000), Seiyun (22,000), Tarim (21,000), in: Lewis, 1987, 362. 19 | The 1st governorate (Aden), the southern parts of the $2 \mathrm{nd}$, 3rd and 4th governorate and parts of the 5 th governorate were connected with main roads, and a paved road connected Aden and Sana'a. The Aden airport offered direct flights to Moscow, Addis Abeba, Kuwait, Beirut, Jeddah, Bombay (Mumbai) and Sana'a. 
Soviet-financed fishery providing the biggest share of exports. ${ }^{2 \circ}$ More than half of the total of about 350,000 to 400,000 South Yemeni adults worked in fishery and agriculture. ${ }^{21}$ Especially after a disastrous flood in 1982 that caused damage of more than $\$ 1$ billion, ${ }^{22}$ agricultural production could not keep up with population growth, creating the most pressing problem for the South Yemeni economy: To feed its own population, massive imports were needed. ${ }^{23}$

East German reports offer quite a detailed picture of the condition of infrastructure, housing and the economy in general, ${ }^{24}$ even though they also impose a Socialist perspective on the reader. According to East German analysts, South Yemeni society in the mid-1980 was still far from fulfilling socialist ideals, especially with regard to Marxist-Leninist requirements for the emergence of a revolutionary proletariat. Right after the declaration of independence, the Adeni working class "numbered only a few thousand." ${ }^{25}$ About fifteen years later, the situation had not changed much. By including state employees, the YSP considered about 150,000 people "working class." The SED, however, appeared to have been more strict with its socialist approach and merely counted a modest 35,000 to 40,000 as "wageworking proletariat." ${ }^{26}$

Unfortunately, East German reports judge the fundamental changes enforced by the NF/YSP in terms of the East German understanding of "planned development of socialism," ${ }^{27}$ while the actual economic outcome and efficiency remain secondary. An example of this is the extremely positive view of the increasing socialization of industry, while the disastrous "economic and financial situation" is described as merely "strained." ${ }^{28}$ This must be considered a massive understatement. Despite some economic progress, South Yemen's economy in

20 | About 40 per cent, in: Informationsmappe für den Besuch des Generalsekretärs des ZK der JSP [...] Ali Nasser Mohammed, November 1984, in: BStU MfS HA II Nr. 28712, 162. 21 Informationsmappe für den Besuch des Generalsekretärs des ZK der JSP [...] Ali Nasser Mohammed, November 1984, in: BStU MfS HA II Nr. 28712, 160.

22 | Burrowes, 2010, 258; Lewis, 1987, 362.

23 | Informationsmappe für den Besuch des Generalsekretärs des ZK der JSP [...] Ali Nasser Mohammed, November 1984, in: BStU MfS HA II Nr. 28712, 161.

24 | Ibid., 136.

25 | Na'ana, Hamida, The Homeland, Garnet, Reading, 1988, in: Dresch, 2000, 120.

26 | In addition to the apparent lack of "workers" in the sense of the word, the biggest part of the work force was not to be found in the country anyway. Just like today, a considerable part of Yemeni employees at the time, about 250,000, worked abroad, sending home the PDRY's lion's share of foreign currency and somewhat keeping alive the economy.

27 | Schroeder, 1999, 119ff; Schroeder, 2013, 110ff.

28 | Informationsmappe für den Besuch des Generalsekretärs des ZK der JSP [...] Ali Nasser Mohammed, November 1984, in: BStU MfS HA II Nr. 28712, 159. 
the early 1980 s was built on the unsteady ground of a debt of $\$ 1.2$ billion. ${ }^{29}$ State survival depended on further financial credits, the two biggest lenders being Moscow with about a quarter of the funding and the World Bank with about a tenth. On top of that, the ever prevailing hope to find oil to save the economy was not to be fulfilled before $1986.3^{\circ}$ The discoveries simply happened too late to buffer the humanitarian and economic catastrophes of the "1986 January crisis" and severe flooding that occurred afterwards..$^{31}$

\section{Aden: A Soviet "First-Priority Goal" in the Arab World}

"[Soviet assistance should be reserved only for] our most important, justified and first-priority goals. It [...] should go first of all to the state with the explicit and consistent socialist orientation. I have in mind such states as the People's Republic of Yemen, Ethiopia, Angola, Afghanistan and some others." ${ }^{32}$

(Leonid Brezhnev, November 1978)

During the 1970s, the South Yemeni leadership repeatedly stressed that the aid and assistance they received were insufficient. The leadership made it known that their future steps towards the Eastern Bloc highly depended on a possible improvement of their situation..$^{33}$ By 1976, the PDRY had not received any assistance from the ČSSR yet, while Poland and Hungary had merely sent delegations under a UN mandate. ${ }^{34}$ But despite Aden's complaints, not much happened until the YSP was formed. Salmin's execution finally freed the way for the establishment of the Marxist-Leninist vanguard party, boosting South Yemen's relations with the Eastern Bloc in general and Moscow and East Berlin in particular. Without doubt, the creation of the YSP was a Soviet interest, and Soviet advisors and functionaries had done their share to express this wish. 35

With the installation of a rather dependent and thus loyal vanguard party at the center of South Yemen's political system, the inherently unpredictable PDRY transformed into a somewhat more reliable ally for Moscow. The Kremlin clearly

29 | National debt of 1980, in: Informationsmappe für den Besuch des Generalsekretärs des ZK der JSP [...] Ali Nasser Mohammed, November 1984, in: BStU MfS HA II Nr. 28712, 165.

30 | Burrowes, 2010, 280.

31 | Ibid., 258.

32 | Brezhnev, Leonid, November 22 1978, Opening the session of the Political Advisory Committee of the Warsaw Treaty Organization, The Intervention in Afghanistan and the fall of Détente - A Chronology, in: The Carter-Brezhnev-Project, The National Security Archive. 33 I Information über einige innen- und außenpolitische Entwicklungstendenzen in der VDR Jemen, September 14 1976, in: BStU MfS HV A Nr. 125, 22.

34 | Ibid. 22.

35 | Cigar, 1985, 780. 
signaled its wish to keep the YSP regime in power by backing it with a more efficient and loyal military. Soviet military aid doubled between 1978-79 to about \$250 million, ${ }^{36}$ while the first "young officers educated in [Bulgaria, Cuba, GDR the ČSSR and Romania] were about to report for duty." 37 By the mid-1980s, South Yemeni military had shed its British skin and reformed "along Soviet lines," including close party ties and Soviet control by integration of party officials. ${ }^{38}$

\begin{abstract}
"All military forces [of the PDRY] are equipped with modern, mostly Soviet, engineering. The comprehensive deliveries of arms by the Soviet Union are either granted on the basis of long-term credits or without any financial payment in return. The USSR provides the lion's share of the political, material, and financial support of the PDRY's armed forces." 39
\end{abstract}

An estimate of about 1,000 Soviet advisors in the state and party apparatus were supported by another 500 Cuban experts who trained South Yemeni militia and police, while East Germany's delegates from the defense, interior and security ministries were active in the establishment of the security and judicial apparatus.

\title{
2.1 Intention to Stay: Stable Relations Between Moscow and Aden
}

Before his death, one of the last international visits Brezhnev made was his trip to Aden in May 1982. It was followed by a communiqué in September that praised the PDRY's advancement on "the road of socialist orientation."40 Regardless of Moscow's policy change toward the YAR and possible Yemeni unity, the signed communique clearly illustrates the stability of USSR-PDRY relations during this period, demarcated by the signing of the Treaty of Friendship and the crisis of 1986. In this phase, bilateral relations were consolidated and the Soviets intended to stay: In early 1985, the USSR officially established a "link [from South Yemen] to the Soviet Intersputnik satellite communications network," ${ }^{41}$ which meant installing a direct hotline between Aden and Moscow. In context of the HV A project "Netzwerk 3," the installation of an East German radio surveillance base starting in 1983 , this engagement has to be interpreted as a long-term commitment

36 | Brehony, 2013, 115.

37 | Informationsmappe für den Besuch des Generalsekretärs des ZK der JSP [...] Ali Nasser Mohammed, November 1984, in: BStU MfS HA II Nr. 28712, 166.

38 | Cigar, 1985, 778.

39 | Informationsmappe für den Besuch des Generalsekretärs des ZK der JSP [...] Ali Nasser Mohammed, November 1984, in: BStU MfS HA II Nr. 28712, 166.

40 | Halliday, 1990, 197.

41 | Dienstreisebericht der HA III, 15 February 1984 (Aktion “Netzwerk 3“), in: BStU MfS HA III 8873. At the time US $\$ 1$ and 1 Rubel were of about the same worth in the world economy. 
to South Yemen. Also, Soviet financial and economic commitments increased significantly. In 1984, the GDR reported about a secret increase of Soviet aid to the PDRY "of another 2 billion rubles." 42 This quote suggests that there had been a comparable amount of aid prior to this second secret loan. Soviet support for the YSP regime in this phase clearly was clearly much more than the official loan in 1985 of about 384 million rubles. ${ }^{43}$

The secret loan clearly fits the shift of Soviet economic policy towards Aden: The Kremlin had begun to include South Yemeni economy in its Comecon plans. ${ }^{44}$ As a reaction, the YSP officially opted to decrease imports from "imperialist countries." 45 The actual decline of Aden's non-socialist foreign trade from 70 percent to about 56 percent in $1983^{46}$ underlines the mutual agreement between the USSR and the PDRY to draw Aden closer to the Eastern Bloc economically. So far, the support of South Yemen merely served geostrategic purposes. But Moscow and East Berlin both were hoping for more concrete economic benefits from their engagement. "Encouraging signs near Shabwah,"47 as well as rumors about an actual oil find by Italy, ${ }^{48}$ were cause for new hope for more concrete benefits for the Eastern Bloc from its engagement in South Yemen. Supported by the GDR and ČSSR, Soviet companies increased their efforts in their search for oil, a line of action that was to be continued even after Moscow's change of leadership to Gorbachev. 49

\subsection{Why the Kremlin let go of Its Ally Ismail: Moscow's Support for Ali Nasir}

In 1980, the Soviet Union at first apparently attempted to save its ally, Ismail, who had just received the Soviet Order of Friendship among Peoples the year before..$^{\circ}$ But soon enough it became obvious that Ismail lacked the necessary support for leadership among his own peers. As a consequence, the Kremlin accepted Ismail's removal from office and Moscow explicitly supported Ali Nasir's leadership. When taking a closer look at Moscow's interests at the time, this move does follow a certain logic. Ali Nasir was not unknown to the USSR and he was fully aware of the importance of a healthy South Yemeni-Soviet relationship for the PDRY. Furthermore, this change

42 | Ibid.

43 | Cigar, 1985, 778.

44 | Ibid., 778.

45 | Information über die Entwicklung in der VDR Jemen, in: BStU MfS HV A 81, August 1978, Part I of I, Nr. 35/78, $110 \mathrm{ff}$.

46 | Cigar, 1985, 778.

47 | Dresch, 2000, 161.

48 | Informationsmappe für den Besuch des Generalsekretärs des ZK der JSP [...] Ali Nasser Mohammed, November 1984, in: BStU MfS HA II Nr. 28712, 163.

49 | Brehony, 2013, 145.

50 | Ibid. 120. 
at the top of the YSP might even have been of a certain political convenience for the Kremlin. After the Camp David Accords, power in the region again was shifting towards Washington and its allies. Moscow needed to improve its relations with its former enemies. During this phase, the USSR performed a noticeable policy change in the region, including its first advances towards Saudi Arabia, something Ismail never supported. Furthermore, Moscow sent the first significant arms supplies to Sana'a, and Ali Abdallah Saleh, who was close to Ali Nasir, visited Moscow.

Apart from Moscow's overtures to Saudi Arabia and the Kremlin's hope for a more "progressive" leadership in the YAR, the additional major cause for this policy change might be found in the current socio-political condition of the PDRY: After a decade of consolidation, the Kremlin considered South Yemen's political system politically stabilized, that is, ruled by a vanguard party of Marxist-Leninist orientation..$^{1}$ Ali Nasir must have appeared as the more predictable alternative to the extremist Ismail: Ali Nasir advocated for moderation towards the neighboring states and with regard to the Palestinian case. This clearly was in Moscow's interest. However, Ali Nasir did not appear to be a Marxist at heart, unlike Ismail. In 1983, Moscow even had to remind Ali Nasir to focus on "the consolidation of [the YSP"s] ideological, political, and organizational unity." ${ }^{2}$ Nonetheless, the Kremlin was sure of Ali Nasir's loyalty and he was not expected to depart from the course of the Marxist-Leninist state.

According to an internal document of the GDR's Ministry of Defense, the PDRY's foreign policy under Ali Nasir's leadership in the early 1980s followed three major premises:53 First, the promotion of close cooperation with Ethiopia; second, the normalization of relations with the YAR, as opposed to Ismail who repeatedly had been preaching the expansion of the YSP to the north;54 and third, the improvement of relations with Saudi Arabia. Clearly, Ali Nasir's approach coincided with Moscow's endeavors to keep close ties to Addis Abeba and to win the Saleh regime from Washington for the Eastern Bloc. Furthermore, the PDRY under Ismail's leadership had been far from negotiating, let alone cooperating, with Riyadh or Sana;a. To sum it up, all three of these goals fit in neatly with Moscow's wider strategy for the Horn of Africa after Mengistu's violent coup of 1977.55 Thus, the change of leadership from Ismail to Ali Nasir has to be considered at least convenient for both Moscow and East Berlin alike - at least

51 | After two Northern leaders were killed in 1977 and 1978, the comparably unknown Major Alī Abdallah Sāleḥ had stepped forward to take over presidency. Dresch, 2000, 143 and 147. Saleh remained president even after unification until he was forced to resign in the course of the so-called Arab Uprisings in early 2012.

52 | Pravda, November 14 1983, in: Cigar, 1985, 789.

53 | Angaben zur Außen- und Militärpolitik sowie zur Entwicklung der Streitkräfte der VDR Jemen, January 17 1981, in: BStU MfS ZAIG Nr.5905, 1-6.

54 | Scharfenberg, 2012, 61.

55 | Westad, 2005, 271. 
when it happened in 1980. In an MfS document from 1984, the vote for Ismail's resignation is considered "the correction of the adventurous course by the [...] the YSP in 1979. ${ }^{.56}$

\section{Consolidation and Continuity of East German State- BuILding: How the GDR's Foreign Policy Tied IN WITH the YSP'S APPROACH}

\subsection{The Founding of the YSP: The Keystone of Socialist Nation- and State-Building?}

"The visit of the Party and state delegation under leadership of SecretaryGeneral Erich Honecker to the PDRY [in November 1979] and the signing of the Treaty of Friendship and Cooperation preluded a new stage of bilateral relations. [...] The close cooperation between the SED and the YSP is taking center stage in the process. ${ }^{.57}$

In the formation process of the Soviet-style vanguard party, Aden relied heavily on the support of its closest allies, the USSR and GDR. In 1976, PDRY Foreign Minister Mohammed Saleh Mutia ${ }^{8}{ }^{8}$ attended the SED's IX. Party Congress in East Berlin,59 and East German advisors accompanied the preparations for the founding congress of the YSP.

"The German Democratic Republic is a Socialist state based on the German nation. She is the political organization of urban and rural workers who jointly realize Socialism led by the working class and its Marxist-Leninist Party."

(Article 1, Constitution of the GDR, April 6th 1968)

"The YSP, armed with the theory of Scientific Socialism, is the leader and guide of society and the state. [...The Party] leads the struggle of the people and their mass organizations to [...] finally realize Socialism." 60

(Article 2, Constitution of the PDRY, October 31st 1978)

56 | Informationsmappe für den Besuch des Generalsekretärs des ZK der JSP [...] Ali Nasser Mohammed, November 1984, in: BStU MfS HA II Nr. 28712, 142.

57 | Ibid.175.

58 | Arabic: Muḥammad Saleḥ Mutiła.

59 | Informationsmappe für den Besuch des Generalsekretärs des ZK der JSP [...] Ali Nasser Mohammed, November 1984, in: BStU MfS HA II Nr. 28712, 168.

60 | German Translation: "Bewaffnet mit der Theorie des Wissenschaftlichen Sozialismus ist die Jemenitische Sozialistische Partei Führer der Gesellschaft und des Staates. [...Sie] führt den Kampf des Volkes und seiner Massenorganisationen an, [...] um schließlich den 
These two excerpts present the mid- and long-term impact of South Yemen's cooperation with East Germany on the development of the PDRY's political system. With the founding of the YSP, the existing constitution was amended in a fashion undeniably reminiscent of East Germany's constitutional genesis between 1949 and 1968. The YSP's party program of the same year stated:

"[The YSP] is considered the logic conclusion of the [NF]. [...] Fundamental economic, social and political changes [...] created the prerequisites to transform the political vanguard represented by the [NF] into a new type of party." ${ }^{11}$

From then on, the South Yemeni vanguard party officially claimed to be the highest authority in a centralized state in South Yemeni territory. ${ }^{62}$ Without doubt, the GDR's influence on the PDRY's constitution and legal system is not restricted to the first drafts and early years, as it is also relevant to the further constitutional and legal genesis. Throughout the 1970s, state structures had gradually been remolded into East German-style party-state parallelism. Similar to the GDR's Constitution of 1968, the "primacy of the party"63 was elevated to the highest organizational state principle. The following elections were "fixed," as "people voted for candidates from approved lists"64 comparable to the GDR. Thus, the "elected" Yemeni Parliament, the SPC, was kept under the tight control of the Politbüro, similar to the "Volkskammer" of the GDR. The institution of the presidium elected by the SPC remained, while all members in personal union also were members of the YSP Central Committee. At the intersection between party and state in South Yemen, a "Council of Ministers" could be found just as in the GDR. ${ }^{65}$ In addition to that, the YSP pledged to carefully select cadre members "on the basis of the working class ideology." 66 Moscow and East Berlin actively supported this process through their intense involvement in the field of education: Throughout the schools' existence, East Germans taught at the "Abdallah Badheeb School for Scientific Socialism" as well as at Aden's police academy. ${ }^{67}$

Aufbau des Sozialismus zu erreichen." Art. 2, Constitution of the PDRY of October 31 1978, pub. by the Foreign Ministry of the PDRY, 14 October Corporation Aden, 1981.

61 | JSP - Avantgarde des jemenitischen Volkes. Auszüge aus dem Programm der JSP (I) und (II), in: horizont No.50/51 1978, in: BStU MfS HA II Nr.27368, 6 f.

62 | On the interconnection of state and Party after launching the constitution see: Ismail/ Ismail, 1986, 42-55.

63 | Schroeder, 1999, 421; Schroeder, 2013, 483-486.

64 | Brehony, 2013, 108.

65 | Ismail/Ismail, 1986, $52 \mathrm{f}$.

66 | JSP - Avantgarde des jemenitischen Volkes. Auszüge aus dem Programm der JSP (I) und (II), in: horizont No.50/51 1978, in: BStU MfS HA II Nr.27368, 7.

67 | Cigar, 1985, 778. 
Due to close cooperation of Soviet and East German advisors, but also due to the GDR's function as a role model, the newborn vanguard party explicitly continued and even intensified its close ties with the Eastern Bloc: Based on the "principle of Proletarian Internationalism," ${ }^{68}$ the YSP declared the "continuous strengthening of the alliances with the Socialist state community under Soviet leadership" ${ }^{69}$ one of its priority goals and the East Germans readily worked towards this objective. The first party communiqué after the establishment of diplomatic relations between the SED and the UNFPO was followed by another agreement in June 1977, which preceded the "YSP Founding Congress" that further expanded cooperation..$^{\circ}$ This line was continued with a more comprehensive agreement in 1981.

"[The] cooperation agreement [of $1981^{71}$ ] between the SED and the YSP for the period of 1982 to 1987 now [in 1984] already has contributed significantly by imparting experiences." 72

Before the "1986 crisis," the SED clearly planned for a long-term commitment in the PDRY that even exceeded involvement of the Soviet CPSU.73

\subsection{Pushing Development: The Impact of the Founding of the YSP on Socialist State-Building}

The GDR's efforts to promote the establishment of a socialist state in South Yemen corresponded well with the YSP's intentions. The party program of the YSP was even more explicit than the new constitution with regard to the Party's plans of the "development of Socialism" as a long-term goal. According to this document, society had to change as a whole to achieve socialism. The leadership of the vanguard party was to promote a "change of the relation of classes within society" to ensure "the dictatorship of the proletariat." led by the YSP were to contribute to the process by "organizing and educating

68 | JSP - Avantgarde des jemenitischen Volkes. Auszüge aus dem Programm der JSP (I) und (II), in: horizont No.50/51 1978, in: BStU MfS HA II Nr.27368, 8.

69 | Ibid. 4 ; 8.

70 | Communiqué on the occasion of a visit by an NFPO delegation in East Berlin in February 1974, Agreement on the cooperation between the SED and the UNFPO, June 13 1977, in: Jemen (Demokratischer), Völkerrechtliche Vereinbarungen der DDR; 1987, 140; 140-1.

71 I Informationsmappe für den Besuch des Generalsekretärs des ZK der JSP [...] Ali Nasser Mohammed, November 1984, in: BStU MfS HA II Nr. 28712, 178.

72 | Ibid., 176.

73 | Interview with Fritz Balke on May 232011.

74 | JSP - Avantgarde des jemenitischen Volkes. Auszüge aus dem Programm der JSP (I) und (II), in: horizont No.50/51 1978, in: BStU MfS HA II Nr.27368, 5. 
the masses as well as developing their class consciousness and strengthen the connection between Party and people."75 This formulation unmistakably reminds one of Lenin's approach to society: "Integration of society" in the new Yemen also meant "homogenization of society." The language of the new party program now resembled less the predecessor's mixture of vague revolutionary thoughts and Marxist phrases and more the East German ideological jargon of the time.

During the 1970s, the USSR supported East Berlin's activities in the "civil sphere" not only with personnel but also with technical equipment. This was especially the case for communications and the media, realms in which East Berlin had been active since the late 1960 s. The Soviet construction of a station for receiving satellite signals in South Yemen enabled Moscow and East Berlin to directly broadcast to Aden. This complemented the East German news agency ADN's deal with Aden News Agency (ANA) in 1970 in which ANA had agreed to broadcast East German features. East Berlin clearly had expected that this policy would pay off and further increase influence on the national South Yemeni media. Another agreement on the cooperation of the journalist federations of both countries for the period between 1983 and 1987 was signed in September $1983 .{ }^{76}$ East German influence without doubt showed itself more and more in political practice and legislation. The program of the YSP of 1978 is just one of many indicators here:

"The Party especially focuses on the development of mass media - press, radio and TV broadcasting - as it is considered an effective political and ideological weapon to fulfill the tasks of the national-democratic revolution and to education the working masses." ${ }^{77}$

At the end of the decade, the once flourishing media landscape of British-occupied Aden also had to yield to the YSP's drive for socialist one-party rule and its full control of the public.

The GDR's promotion of ties between actors of the "society sphere" was continued, not only with regard to the media, but in all fields of engagement. Cultural, economic, industrial, and technical cooperation were all renewed or expanded..$^{8}$

75 | Ibid., 5.

76 | Vereinbarung über die Zusammenarbeit zwischen den Journalistenverbänden der DDR und der VDR Jemen für die Jahre 1983 bis 1987, September 5 1983, in: Jemen (Demokratischer), Völkerrechtliche Vereinbarungen der DDR, 1987, 140-3.

77 | JSP - Avantgarde des jemenitischen Volkes. Auszüge aus dem Programm der JSP (I) und (II), in: horizont No.50/51 1978, in: BStU MfS HA II Nr.27368, 6.

78 | Unterzeichnung eines Abkommens über kulturelle und wissenschaftlich-technische Zusammenarbeit, April 7 1981; Unterzeichnung eines Abkommens über wirtschaftliche, industrielle und technische Zusammenarbeit sowie über ein Abkommen auf dem Gebiet 
The "Agreement on Health Cooperation" of 1982 even preceded the Soviet-South Yemeni equivalent of 1987 . One of the major fields of engagement remained the education sector, in which East German influence even increased: an overwhelming majority of 217 of the 258 PDRY citizens residing in the GDR in 1979 were students. ${ }^{79}$ Apart from the presence of education advisors at all levels of South Yemeni politics, the opportunities for Yemeni students to come to East Germany steadily increased during the 1980s, especially after the official "Agreement on Student Exchange" was signed in December $1983 .{ }^{80}$ Stipends usually included flights and accommodation. ${ }^{8}$ South Yemeni youth delegations regularly visited the GDR and were complemented by engagement in the mentioned policy fields. In January 1982, for example, an FDJ delegation visited Aden to celebrate the first Anniversary of the "Days of Friendship" between East German and South Yemeni youth, a visit which was returned by the South Yemeni youth organization Asheed in March $1983 .{ }^{82}$

Other indications of the intensification of engagement after the founding of the YSP are financial aid, investments, and trade: Despite East Germany's own financial problems, the SED remained rather generous with its credit conditions. The third and fourth governmental credits loaned to the Aden regime in 1978 and 1980 were accompanied by a consumption credit for the period of 1979 to 1983.83 Furthermore, the repayments of the first three governmental credits of 1969 , 1974, and 1978 were "deferred at the PDRY's request." ${ }^{4}$ However, trade relations intensified as well. East Germany benefited immediately from Aden's decision to increase its trade volume with the Eastern Bloc at the expense of trade with the "imperialist states." "GDR export to the PDRY rose from 4,8 illion VM in 1974, to an estimate of 10,3 Million in 1980 and about 24 Million VM in 1983." 5

Finally, a brief look at the development of the major East German strategy in socialist state- and nation-building during this phase is necessary. The work of the advisor groups had been continued throughout the 1970s and in some fields

des Gesundheitswesens, in: Jemen (Demokratischer), Völkerrechtliche Vereinbarungen der DDR, 1987, 140-3f.

79 | Sofortinformation AG Ausländer an HA II, February 26 1979, in: BStU MfS HA II Nr. $27850,46$.

80 | Vereinbarung über ein Abkommen über den Studentenaustausch zwischen den beiden Staaten, December 7 1983, in: Jemen (Demokratischer), Völkerrechtliche Vereinbarungen der DDR, 1987, 140-3.

81 | Planvorschlag 1986 und Plankorrektur 1985, Ministerrat der DDR an MfS Leiter der Abteilung Finanzen, July 18 1985, in: BStU MfS Abt. Finanzen Nr.3492, 45.

82 I Informationsmappe für den Besuch des Generalsekretärs des ZK der JSP [...] Ali Nasser Mohammed, November 1984, in: BStU MfS HA II Nr. 28712, $170 f$.

83 | Ibid., 177.

84 | Ibid., 178.

85 | Ibid., 178. 
even expanded after the establishment of the YSP. One example of this is the legal apparatus. While the GDR had been highly active in consulting on constitutional law since 1969, East Berlin decided to become involved in the more concrete design of the PDRY's legal system later on. The PDRY's attorney general had visited the GDR in 1980 and asked for consultancy support from East Berlin. His request was granted two years later. Hans Bauer was delegated as an official Party-Secretary of the Department of the Attorney General in 1982. ${ }^{86}$ According to Bauer, the PDRY had expressed their preference to follow the model of East Germany as the socialist "Musterländle," the model state: "The Yemenis were interested in the GDR because it was comparable. The Governorates were similar to our 'Bezirke,' the Districts to our Counties. Not all could be converted, but a lot was similar." ${ }^{7}$ All in all, Bauer considers East German engagement in this sector alone of the most decisive external factors of significant impact on the juridical system of the PDRY.

\subsection{A Beneficial Investment? Scope and Intensity of East-German Cooperation with the South Yemeni Military and Security Apparatus}

"Apparently there existed important cooperation in the field of security in South Yemen, though I didn't have any information about this in my area of responsibility in the Ministry." 88

Heinz-Dieter Winter, GDR Vice-Minister of Foreign Affairs, 1986-1990

After the merger of all relevant political groups and parties and the Founding Congress of the YSP, the GDR's policy of socialist state- and nation-building transformed smoothly from "establishment" to "consolidation and continuity" with regard to all three dimensions of state- and nation-building. Just as in the 1970s, Moscow left the civil sectors and security apparatus as part of Socialist nation-building to East Germany. In Addition to that, East German engagement now was expanded to the military sphere to support the USSR policy. ${ }^{89}$ During the "Phase of Continuity and Consolidation," engagement usually was either continued on the same level of intensity or even increased. This was especially the case for the support of the security apparatus and military cooperation, which was coordinated in great secrecy.

86 | Vermerk über die Einstellung der inoffiziellen Zusammenarbeit mit dem GMS “Leonhardt“ Reg. Nr. XV 3481/1982, October 11 1988, in: BStU MfS AP Nr.36630-92.

87 | Interview with Hans Bauer June 20 2011. On the GDR's “model character" for the developing countries, also see: Howell, 1994, 328.

88 | Interview with Heinz-Dieter Winter July 32012.

89 | Möller, 2004, 54. 


\section{Contributions to the PDRY's Military as Part of Moscow's Strategic Policy}

The involvement of the NVA in the PDRY remained quite modest, though this was rather owed to the NVA's insignificant contribution of military equipment in the developing world in combination with Soviet dominance in the field. In 1972, Minister of Defense Heinz Hoffmann acquired the permission to train military personnel in the developing countries by the Warsaw Pact leadership, ${ }^{9 \circ}$ but it was not before 1978 that the first military protocol was signed between the two countries..$^{91}$ Throughout its existence, the SED had been extremely secretive about its military cooperation with the states of the Third World: While the party organ "Neues Deutschland" regularly and freely reported about any protocol signed with states outside the Eastern Bloc, agreements on military or security issues regularly were left out. ${ }^{92}$

Thus, it was not until the end of the 1970s that the intensity of engagement became internationally public and thus relevant in international relations: the West German weekly magazine "Der Spiegel," for example, reported about East German support for revolutionary and potentially aggressive regimes of the Third World. In 1980, a feature warned of a looming revolution in North Yemen, the former "bastion of the West between Saudi Arabia and leftist South Yemen," exported from Aden. ${ }^{33}$ Rumors about Soviet and East German engagement usually exceeded the actual presence and cooperation by far and thus increased insecurities for any neighboring state siding with the other player in the Cold War.

However, East German engagement in the military and security apparatus indeed was expanded in scope and intensity and could not be kept a secret any longer.94 Despite the comparably late start of official military training in South Yemen, the PDRY ranks second only to Vietnam in numbers of officers trained by the GDR between 1973 and 1989. ${ }^{95}$ Furthermore, the GDR's Ministry of the Interior repeatedly granted "emergency" demands. But this was not restricted to provisioning South Yemeni troops or civilians: ${ }^{96}$ The GDR's Ministry of the Interior quickly and non-bureaucratically processed the demand for 4,000 grenades for the recoilless gun $\mathrm{B}-10 .{ }^{97}$ On the one hand this big share of a small contribution to

90 | Engelhardt, 1993, in: Möller, 2004, 30.

91 | Scharfenberg, 2012, 86.

92 See: Jemen (Demokratischer), Völkerrechtliche Vereinbarungen der DDR, Mostly based on publications of "Neues Deutschland," 1987.

93 | Feuer der Revolution nicht zu löschen, in: Der Spiegel, No.10, 1980.

94 | For example sixty South Yemeni officers at the Offiziershochschule Otto Winzer in the GDR were granted a course of three years, see: Abkommen zwischen der Regierung der DDR und der Regierung der VDRJ über die Ausbildung von Militärkadern der Streitkräfte der VDRJ in der DDR vom 11.6.1981, in: BArch, DVW 1/54328.

95 | Möller, 2004, 54.

96 | Vermerk über Hilfsleistungen, July 18 1978, in: BStU MfS AGM Nr.430, 1.

97 | Letter to Dickel, July 12 1978, in: BStU MfS AGM Nr.430, 63. 
the military in the developing partner countries may be interpreted as part of the GDR's interest in maintaining good relations with the PDRY. On the other hand, it has to be considered an indication of the integration of the GDR into Moscow's policy toward South Yemen.

\section{Cooperation between Two Secret Services - The GDR's Major Field of Action in the PDRY}

Archival material on the Stasi's engagement in Aden during the 1980 os is rich and plentiful, as divisions other than the HV A became involved during that period. Relations especially between the two security services undeniably were close and East Berlin went to great lengths to strengthen the South Yemeni version of itself. The Stasi supplied the PDRY's KfS with the equipment and training needed and tried to fulfill their partners' wishes as much as possible..$^{8}$ After the first agreement between the GDR's Stasi and the PDRY's KfS, signed in November 1970, a new agreement was signed in November 198099 that included and spelled out the provisions of the two protocols of November 1979 between the two organs in greater detail. ${ }^{100}$ They affirmed the modus operandi and significantly intensified cooperation. New protocols were to be signed in November each year and secret information exchanged in quarterly intervals. ${ }^{101}$ The agreement of 1980 included a five-year period for which it would remain in force unless new regulations deemed otherwise. ${ }^{102}$ Similar to other policy fields, the GDR offered training for KfS cadres in the GDR, but also pledged material supplies. All in all, these added up to 8 million East German Marks, including arms worth 3.6 million and an additional 2.6 million to upgrade the surveillance network. An additional 1,800 firearms were sent as a "gift" to the KfS in May $1980 .{ }^{103}$ These did not include any costs

98 In the protocol of 1979, the KfS for example asked for another 5,000 machine guns and 500 pistols. Protokoll über die vorgesehenen Maßnahmen der Zusammenarbeit zwischen dem MfS der DDR und dem KfS der VDRJ im Jahre 1980, November 17 1979, Article 15, in: BStU MfS Abt. X Nr. 1767.

99 | "to develop and deepen the cooperation established with the agreement of November 6 1970," in: Vereinbarung über die Zusammenarbeit zwischen dem MfS der DDR und dem KfS der VDRJ, November 25 1980, in: BStU MfS Abt. X 1789, 1.

100 | Protokoll zwischen dem MfS der DDR und dem KfS der VDRJ vom November 17 1979, in: BStU MfS Abt X Nr.1763; Protokoll über die vorgesehenen Maßnahmen der Zusammenarbeit zwischen dem MfS der DDR und dem KfS der VDRJ im Jahre 1980, November 17 1979, in: BStU MfS Abt. X Nr. 1767.

101 | Vereinbarung über die Zusammenarbeit zwischen dem MfS der DDR und dem KfS der VDRJ, November 25 1980, Article 13, in: BStU MfS Abt. X 1789.

102 | Ibid.

103 | Oberst Fiedler HV A III an MfS Abt.X Geberalmajor Damm, May 13 1980, in: BStU MfS Abt.X Nr.234 Teil 1 von 2, 392. 
for personnel and training. ${ }^{104}$ The Stasi even coordinated the construction of the KfS building and sent seven permanent Stasi advisors to the KfS who were to be positioned in the operational service of the KfS, the Defense Forces, the KfS cadre school, bodyguard services, and surveillance. ${ }^{105}$

Based on coded notes of Section BCD, the PDRY at times ranked the highest among all partners with regard to internal security support. File BCD No. 2802 includes an overview of the main material deliveries by the HV A to Third World countries in 1980. Equipment worth 6.85 million VM was delivered to the top three countries in terms of spending: “-030-" (South Yemen), "-020-" (Mozambique), and "-120-" (PLO). The share spent on South Yemen totals about 5 million. ${ }^{106}$ Though 1980 had been the year of highest solidarity spending in the history of the HV A, ${ }^{107}$ the share spent on the PDRY nonetheless is by far the greatest, which was also the case for most of the years of this period: During the three years between 1980-82, about 6.3 million of the total 15.8 million of equipment and arms deliveries by the HV A to the closest political allies was sent to Aden. Apart from arms, guns, and ammunition, the GDR supposedly delivered chemical warfare substances as well. ${ }^{108}$ All in all, deliveries worth about 6 million GDR Marks were sent by the BCD alone within only two years. Taking everything into consideration, it may be assumed that actual spending of the MfS in South Yemen probably even exceeded the numbers provided in the available files.

\section{The Stasi's Most Ambitious Project in Aden: The Rise and Fall of "Network 3"}

However, East German support was not given without very concrete political and economic motives. While the biggest share of money spent on the KfS was for training and special forces equipment, the Stasi established a surveillance outpost by the Red Sea that fully depended on East German instruction and money as part of the Warsaw Pact surveillance network. Under the code name "Netzwerk 3," or "Network 3," the project was coordinated jointly by the Section HA III

104 | Protokoll über die vorgesehenen Maßnahmen der Zusammenarbeit zwischen dem MfS der DDR und dem KfS der VDRJ im Jahre 1980, November 17 1979, Annex 1, in: BStU MfS Abt. X Nr. 1767.

105 Protokoll über die vorgesehenen Maßnahmen der Zusammenarbeit zwischen dem MfS der DDR und dem KfS der VDRJ im Jahre 1980, November 17 1979, in: BStU MfS Abt. X Nr. 1767, Article 6.

106 | Lieferungen 1980: Gesamt [handwritten], 1980, in: BStU MfS BCD Nr.20802, 73.

107 | For example in 1981, only about 0.75 million of the full 5.2 million Valuta Marks were spent on the PDRY and in 1982 only about 0.5 million of a total 3.1 million Valuta Marks. Also see: Sendungen 1965-1982, in: BStU MfS BCD Nr.20802, 93.

108 | Even though there is no detailed listing about the concrete amounts, a coding list for the different kinds and amounts of these substances can be found in file BCD 2854. Ziffern-Code, GVS MfS 031-944/76, 1976, BStU MfS BCD Nr.2854, 114-116. 
and the H VA. ${ }^{\circ 9}$ Gieseke describes the HA III as a "cross-section unit" ${ }^{110}$ that analyzed radio traffic inside the GDR and also between the territory of the GDR and West Germany. In addition to that, HA III had been active abroad. The project "Network 3" clearly was part of Moscow's wider surveillance strategy in the region rather than just an East German initiative. ${ }^{111}$ The station at this geostrategically decisive position between Africa and Asia at the time was the only one outside East Germany's vicinity ${ }^{112}$ and the expansion of East German radar activities was ordered by the Soviet Ministry of State Security itself. The establishment of a military radio station in South Yemen was intended to "skim [the enemy's] secret communication [by the HA III] which is only possible in this area." ${ }^{113}$ With regard to the exchange of information, very concise instructions can be found:

"Both sides exchange information on a regular basis on the following topics: [...] The politics of the U.S.A., France, Great Britain and the FRG and their allies [...] aiming to disturb cooperation between the Soviet Union and the Socialist states with [the countries of the Middle East and the Horn of Africa]," including the activities of their secret services. ${ }^{114}$

The two cooperation protocols of 1979 pledged a "half stationary radio station" 115 to Aden, worth more than 1 million East German Marks. With these protocols, East Germany handed over any "demand for certain information" to the fS and vice versa, while the KfS guaranteed to supply the GDR with information

109 | Schmidt, 2010, 245.

110 | "Querschnitsseinheit," Gieseke, in: Kaminski/Persak/Gieseke, 2009, 220.

111 | Schmidt, 2010, 20f; Schreiben Horst Männchen Abt. III an den 1. Stellvertreter des Ministers, Generalleutnant Bruno Beater, Meldung zur Aktion "Netzwerk 3," November 3 1978, in: BStU, MfS, HA III 680, 29.

112 Apart from the station in the PDRY, the GDR entertained three stations in the ČSSR, four in the FRG, two in Austria and one in Belgium. in: Schmidt, 2010, 21. Station "Windrose" in Ethiopia and "Netzwerk 4" in Mozambique followed in 1979 and 1980. Schmidt, 2010, 106; Schreiben Horst Männchen an Stellvertreter des Ministers, Bruno Beater: Konzeption zum Aufbau einer Funkabwehr in Äthiopien und Jemen (VDRJ), February 23 1978; BStU, MfS, HA III 11787, 312-314; Stellvertreter Operativ: Konzeption zur Vorbereitung und Durchführung der Aktion "Netzwerk 4 " in der Abt. III in Zusammenarbeit mit der HV A, March 31 1980, in: BStU, MfS, HA III 11787, 371-389.

113 | "Abschöpfung der Nachrichtenverbindungen [des Gegners durch die HA III des MfS, Anm. Autorin], die nur in diesem territorialen Raum möglich sind“; On the establishment of Netzwerk III“: Neiber an Mielke, April 25 1984, in: HA III 11099, 121.

114 | Protokoll über Maßnahmen der Zusammenarbeit zwischen dem MfS der DDR und dem KfS der VDRJ für das Jahr 1983, in: BStU MfS Abt.X Nr. 1811, 2.

115 | Protokoll zwischen dem MfS der DDR und dem KfS der VDRJ vom November 17 1979, in: BStU MfS Abt X Nr.1763, Article 1. 
relevant for "the specific interests of the MfS" ${ }_{116}$ and mutual reports in quarterly periods. ${ }^{17}$ Furthermore, East Germany and South Yemen agreed to jointly "create the foundations to process [sic!] the agency of the Bundesnachrichtendienst [West German secret service] on the territories of the YAR and the PDRY."118 To train and support the KfS personnel responsible for the station, the MfS guaranteed to send not only a support delegation, but also a "long-term" expert in 1980. This permanent advisor, together with loyal IMs among the South Yemeni KfS, made sure that no relevant information was withheld from the Stasi. ${ }^{19}$

\section{Conclusion: East-German Engagement swings from Enthusiasm to Disillusion}

Apart from its unique geostrategic position, the PDRY proved to be also of political use for the USSR, as long as it moved within its given room of maneuver to accommodate Soviet foreign policy goals. When the former NLF finally merged with the remaining other political organizations in the country to form an actual "Yemeni vanguard party," the Soviet Union as well as the GDR could hope for possible long-term cooperation in their interest. As the YSP vanguard was modelled on the CPSU, and even though the result widely differed from the efficiency of Soviet party discipline, the "Treaties of Friendship" with Moscow and its most important henchmen in the Soviet Bloc, the GDR, ${ }^{120}$ left no doubt that Moscow intended to closely connect with the YSP: On Soviet accord, Erich Honecker had travelled to Aden to personally sign the "Treaty of Friendship." ${ }^{121}$ Internal documents also support this assumption: One of the most politically remarkable features of the protocols and agreements signed between the MfS and the KfS for example, is the inclusion of the PDRY in the sphere of the states of the Eastern Bloc, as opposed to the "imperialist forces," simply presupposing a congruence of interests between

116 | lbid., Article 2 and 3.

117 | Protokoll über die vorgesehenen Maßnahmen der Zusammenarbeit zwischen dem MfS der DDR und dem KfS der VDRJ im Jahre 1980, November 17 1979, in: BStU MfS Abt. X Nr. 1767, Article 3.

118 | Protokoll über Maßnahmen der Zusammenarbeit zwischen dem MfS der DDR und dem KfS der VDRJ für das Jahr 1983, in: BStU MfS Abt.X Nr. 1811, 3.

119 | E.g. Brief an HA I Kommando Landstreitkräfte Unterabteilung Stab, November 28 1984, in: BStU MfS HA I 13551, 26; Protokoll über die vorgesehenen Maßnahmen der Zusammenarbeit zwischen dem MfS der DDR und dem KfS der VDRJ im Jahre 1980, November 17 1979, in: BStU MfS Abt. X Nr. 1767, Article 6.

120 | Vertrag über Freundschaft und Zusammenarbeit zwischen der Deutschen Demokratischen Republik und der VDRJ, November 17 1979, in: Jemen (Demokratischer), Völkerrechtliche Vereinbarungen der DDR, 1987, 140-1.

121 | Scharfenberg, 2012, 93. 
South Yemen, the Soviet Union, and East Germany. Another strong indication is the presence of several Soviet long-term advisors to the president of the PDRY, especially during Ali Nasir Mohammed's tenure. ${ }^{122}$

Still, both historical and current commentary on Soviet involvement in the PDRY regularly emphasizes Moscow's modest economic and financial support in Aden: Economic assistance between 1967 and 1980 added up to only around $\$ 152$ million. ${ }^{123}$ However, analysts tend to overlook the fact that Soviet aid grew continuously after the installation of Moscow's new naval base and the signing of the Treaty of Friendship in $1979^{124}$ and of course do not take into consideration several secret loans granted to the PDRY. Nonetheless, the growth of support cannot camouflage its purpose. Throughout the 1970s, Soviet engagement focused first and foremost on military development tied to ideological training, mostly delivered by Cuban and East German experts. The long-term objective was the stabilization of the most loyal country and regime in the region.

Soviet engagement during the third phase of East German foreign policy in the PDRY was characterized by a continuously high level of intensity, while the two major fields of engagement, the military and ideology, were complemented by technical assistance. The GDR, however, upheld its engagement in various policy fields. This especially was the case in the crucial civil fields of law, economics, education, and the media, where the Yemeni side repeatedly asked for more assistance. In addition to that, the intensity of East German engagement, especially toward the security apparatus, continuously increased until the "1986 crisis." Investments by the Stasi in the establishment of the Marxist-Leninist regime in South Yemen reached an all-time high of 10.6 million East German Marks in 1978, almost two-thirds of the full East German spending on "young nation states" of internal security's "Planteil III," ${ }^{25}$ which included the Stasi's spending on the ten closest partners in cooperation with secret services. Furthermore, the GDR finally became involved in the training of military personnel. The former annual routine of high-ranking delegation exchanges noticeably changed its pace after 1979, with an average of six mutual visits at the state and party level every

122 | Interview with Hans Bauer June 202011.

123 | Halliday, 1990, 199.

124 | Aid increased by about a third from 1976 to 1978 and tripled until 1983: Soviet gross aid disbarments by recipients (\$m.)1976 - 1983; PDRY absolute numbers in \$ million 1976: 6,6; 1978: 8,8; 1983, 21.

125 | The PDRY tops a list of ten countries: PDRY, Mozambique, Ethiopia, Tanzania, Libya, Somalia, Syria, Bissau, Angola and Cape Verde, in: Zusammenstellung des MfS für Hilfeleistungen an junge Nationalstaaten 1978, December 15 1978, in: BStU MfS Abt. Finanzen Nr.1393, 149. 
year. ${ }^{126}$ The dominance of the party sphere in bilateral relations is undeniable, as the term "party and state delegation" ${ }^{127}$ suggests. Also, after the founding of the YSP, each and every delegation visiting from both sides was accompanied by a high-ranking party member. ${ }^{128}$ This routine was upheld until the "1986 crisis" and supported by the installation of a "Joint Yemeni-German Commission" that held its first meeting in May 1980 in Berlin and congregated annually to discuss political matters of mutual interest. ${ }^{29}$

But regardless of this increased engagement from both the USSR and the GDR, discontent with the actual results of their engagement was growing in the early 1980 s. The hopes to find oil had not been fulfilled. Evaluation of its performance indicated that South Yemen's secret service was still inefficient and not producing any valuable information. The same was the case for other state institutions. According to Hans Bauer, a trusted advisor to the attorney general of the PDRY from 1982 to 1985 , not all ministries were working efficiently. ${ }^{130}$ Despite the establishment of the YSP as the central power organ, the decisive step towards the realization of "democratic centralism," socialist state- and nation-building was still far from being realized. As a consequence, East Germany seemed to concentrate more on ensuring a beneficial outcome for itself at the end of Phase III than it had during the intense years of state- and nation-building of the 1970s. While ideology and "anti-imperialist" solidarity had been the major focus of East Germany during that decade of optimism, its interest appeared to have shifted more toward military engagement now. And in case Moscow and East Berlin had hoped for a fully controllable socialist homunculus by the Red Sea, these hopes were not fulfilled, either. Aden over time appeared to develop a mind of its own about the character and degree of external involvement in South Yemen. At the end of Phase III, the external powers' policy goal of a stable, loyal socialist ally more and more receded into the distance until the events of 1986 finally challenged the regime's survival and thus the future of Eastern Bloc involvement in the country.

126 | Six mutual delegation visits at the state and party level/sphere in 1980, five in 1981 and another six in 1982. Informationsmappe für den Besuch des Generalsekretärs des ZK der JSP [...] Ali Nasser Mohammed, November 1984, in: BStU MfS HA II Nr. 28712, 167-174.

127 | Informationsmappe für den Besuch des Generalsekretärs des ZK der JSP [...] Ali Nasser Mohammed, November 1984, in: BStU MfS HA II Nr. 28712, 168.

128 | Interview with Wolfgang Bator May 272011.

129 | Informationsmappe für den Besuch des Generalsekretärs des ZK der JSP [...] Ali Nasser Mohammed, November 1984, in: BStU MfS HA II Nr. 28712, 169.

130 | Operative Einschätzung des GMS “Leonhardt“ - Vorg.-Nr.XV 3481/82, August 28 1986, HV A/III/AG/018, in: BStU MfS AGMS Nr. 10208-88, 67; Interview with Hans Bauer June 202011. 


\title{
CHAPTER 14. Phase IV: The Phase of Neglect - The GDR in Yemen from 1986 to 1990:
}

\author{
The "Ice Age" of Relations and the End of Socialist State-Building
}

"For both the GDR's policy and the PDRY, there seemed to exist only one direction - towards steady success." 1

GDR EMBASSY COUNSELOR IN ADEN IN 1988 COMMENTING IN 2012

The former Yemeni comrades in arms against British colonialism were at war with each other. The conflict left Ismail dead and Ali Nasir in exile. The events of the "January crisis" fundamentally disturbed East German trust in Aden, the YSP, and the unquestioned success of socialist state- and nation-building. Even though relations somewhat recovered over the years that followed, they never regenerated fully before the GDR joined the Federal Republic of Germany in the West: the coup of January 1986 not only has to be considered another turning point of South Yemeni-East German relations, but marks the beginning of the end of the first and only Marxist state in Arabia.

1 | Panecke, Volker, Vorwort, in: Scharfenberg, 2012, 6. 


\section{Internal Developments: The Last Throes of a Wounded And Dying State}

\subsection{The "January Crisis" of 1986: "When Do You People Stop Killing Each Other?"2}

"Monday, January 13th 1986 - [...] I feel that hard times are lying ahead. In the late afternoon there are shootings [...] in all quarters of the city. [...] I live about two $\mathrm{km}$ from the airport. LMGs, tanks and A.A. guns are shelling the airport. Following my intuition, I'm leaping from one corner of the apartment to the other and believe it to be the safest. [...]

Tuesday, January 14th 1986 - I believe that now you cannot speak of a putsch or a putsch attempt anymore. A cruel, hard, and bestial civil war has erupted. The airport is attacked with heavy guns. [...] There is a hell of a noise all around me. [...] Tanks are rolling through the streets. There is fighting the whole day.[...]

Wednesday January 15th 1986 - [...] Now all hell broke loose. The biggest ammunition storehouse of the PDRY exploded a mere two and a half kilometers away from my apartment. [...] The people in [the quarter] Khormaskar ${ }^{3}$ panicked and fled in our direction, away from the blaze. Children, women, the old ones, and pregnant women were trampled down. [... $]^{\prime 4}$

(East German ideological advisor and IMK ${ }^{5}$ Dufft on his experiences during the 1986 crisis in Aden)

On January 13 1986, Ali Nasir Mohammed launched a "preemptive strike” against internal rivals, as he himself would justify it later on. In the fighting that followed, an estimated 10,000 people died. ${ }^{6}$ Apart from a few military advisors, the PDRY's allies and other foreign countries present in Aden evacuated their citizens immediately. The Soviet Union, the United Nations and a remarkably active PLO worked out a short ceasefire and started evacuating children and women aboard

2 | Castro, Fidel, about the "1986 crisis" in Aden on occasion of the 27th Congress of the Soviet Communist Party, in: Halliday, 2002, 45.

3 | A suburb of the old city closest to the "Crater" near the intl. airport. Burrowes, 2010, 11.

4 | Informationsbericht über die Lage in der VDRJ, January 25 1986, in: BStU MfS ZAIG Nr.6725, $239 f$.

5 | IMK - Inoffizieller Mitarbeiter zur Sicherung der Konspiration und des Verbindungswesens. English: Unofficial employee to uphold conspirative communication and exchange, in: Engelmann et al., 2011, 162.

6 | The number was mostly cited by Western media at the time. Estimates today reach up to 25,000 victims, in: Kifner, 1986a and 1986b. 
Soviet, French, and British ships on the January 17.7 The majority of foreign citizens had to wait another four days until they could board the last evacuation ship, the East German Müggelsee. ${ }^{8}$ Surprisingly, the "1986 crisis" had initiated close cooperation between ideological adversaries. The British ship Britannia evacuated East Germans, while the GDR's Müggelsee saved three West Germans a few days later. Not even the state of emergency did much to change internal GDR policies. According to a report of events, the East German embassy even held on to their citizens' passports in the middle of fighting on the January 21, and in the end, half of the East German builders and engineers were evacuated without their legal documents. ${ }^{9}$

In the first days after the coup, national and international media repeatedly contradicted themselves, as circumstances proved to be extremely confusing. A few months after the incident, Katz summarizes: "Reports claiming that the leaders of each side had been killed alternated in quick succession with reports stating the leaders of each to be alive and victorious." ${ }^{\prime \prime}$ Ali Nasir had realized that he politically wouldn't survive the dawning reelection on the three major posts he was holding at that time. He convinced others that a putsch against him was being prepared by his adversaries. Thus, he decided to prevent his downfall by setting up a trap on the occasion of a planned meeting, ${ }^{11}$ which the majority of academics today interpret as a "preemptive strike" to prevent Ali Nasir's looming dethronement. ${ }^{12}$ In the course of events, four key members of the Politbüro were assassinated, ${ }^{13}$ among them longtime Minister of Defense Ali Antar. ${ }^{14}$ The only high-ranking member of the meeting who in the end was able to escape was al-Beidh, as Ismail was killed in the fighting and thus joined the victims of the "preemptive counter-coup" a few days later.

7 | Telegramm Krauße, Aden an König, Sieber, Bunkert, Winter, Jaunary 17 1986, in: in: BStU MfS ZAIG Nr.6725, 159; Informationsbericht über die Lage in der VDRJ, January 25 1986, in: BStU MfS ZAIG Nr.6725, 242.

8 | The ship also picked up an East German construction team and several West German and Filipino citizens at Aden. On January 23, and thirty miles away from Aden, the last GDR citizens came aboard the Müggelsee: the FDJ Brigade. Bericht über die Ereignisse auf der Auslandsbaustelle "Bridges Reconstruction in Aden“ im Januar 1986, January 29 1986, in: BStU MfS ZAIG Nr.6725, 247.

9 | Bericht über die Ereignisse auf der Auslandsbaustelle "Bridges Reconstruction in Aden“ im Januar 1986, January 29 1986, in: BStU MfS ZAIG Nr.6725, 245-250.

10 | Katz, 1986, 7.

11 | Yahia, Hassan Anis, in: Information über die Entwicklung in der VDRJ und internationale Reaktionen, Februar 1986, BStU MfS HV A Nr. 40, Part 1 of 2, 179.

12 | Burrowes, Robert D., Ali Nasir Muhammad al-Hasani [1939-], in: Mattar (Ed.), $2004,143$.

13 | Day, 2012, 73.

14 | Freedman, Rabinovich/Shaked, 1988, 35. 
And fighting there was. Over the course of one week, violent clashes erupted all over Aden and its vicinity, usually fought with heavy weapons: A.A. guns, tanks and RPGs. Armed forces were quickly rallied for a counter-attack against Ali Nasir Mohammed and his allies. These troops had been readied as early as late December and gradually moved closer to Aden. ${ }^{15}$ Regardless of the official reasons for these military preparations, the maneuver came in quite handy for the "new left" that had been attacked by Ali Nasir in the Politbüro meeting. To Ali Nasir's allies' surprise, the army did not fully support him then, as the middle-ranking officers were still loyal to former the ministers of defense and state security, Ali Antar and Muhsin. Ali Nasir's troops were scattered and had to withdraw to the north, while the naval forces fled to Ethiopia. At the time, Ali Nasir "had no options at his disposal to reclaim his leadership position without external support." 16 The two former leaders of the PDRY, Ali Nasir and Ismail, had left the political stage of the PDRY for good.

A final conclusion on the actual circumstances and events of the "1986 crisis" still must leave important questions unanswered due to contradictory reports, murky alliances, and the complex network of personal loyalties in the circle of leadership at the time. Tensions had been building up ever since Ismail's return from Moscow in May the year before. Supported by Ali Antar and Saleh Musleh Qasim, ${ }^{17}$ the minister of defense at the time, this "new left" demanded that Ali Nasir share his power and even intensify cooperation with the Eastern Bloc. In early 1986, Ali Nasir's power was disintegrating. ${ }^{18}$ An MfS report on the events refers to a statement of Hassan al-Salami, ${ }^{19}$ who claims that "he had been warned of an imminent putsch on January $13^{\text {th }} 1986$ against Ali Nasir Mohammed by a member of the Politbüro." ${ }^{20}$ Regardless of several reports like this, the MfS draws a profoundly different conclusion on the situation:

"The fact that the cadres of leadership killed on January $13^{\text {th }} 1986$ exclusively have to be considered opponents of Ali Nasser [sic!] Mohammed, suggests that Nasir's opponents were unprepared for a move like this." ${ }^{21}$

15 | Brehony, 2013, 155; Halliday, 2002, 45.

16 Information über die Entwicklung in der VDRJ und internationale Reaktionen, Februar 1986, BStU MfS HV A Nr. 40, Part 1 of 2, 184.

17 | Arabic: Saleh Musleh Qasim

18 | Informationsbericht über die Lage in der VDRJ, January 25 1986, in: BStU MfS ZAIG Nr.6725, $238 f$.

19 | This clearly marks him as a follower of Ali Nasir Mohammed. Arabic: Ḥassan Al-Salāmĩ. 20 Information über die Entwicklung in der VDRJ und internationale Reaktionen, Februar 1986, BStU MfS HV A Nr. 40, Part 1 of 2, 179.

21 I Information über die Entwicklung in der VDRJ und internationale Reaktionen, Februar 1986, BStU MfS HV A Nr. 40, Part 1 of 2, 180. 
While the "new left" around Ismail and Ali Antar obviously had expected Ali Nasir's resistance against reelection, they clearly were not prepared for being slaughtered during this exact meeting. Corresponding with the overwhelming majority of personal accounts by South Yemenis and foreigners who had witnessed the events, the conclusion of the MfS report appears to be the most plausible.

\subsection{Reconstruction and Deterioration: The New Leadership and the Final Years of the Only Marxist State in Arabia}

What followed the final battle of the "comrades in arms of the first hour" in January 1986 were the last throes of a wounded and dying state. On the January 24 , the remaining members of the CC of the YSP gathered to decide on a new leadership. ${ }^{22}$ A new government was formed, based on the new generation of leaders who had been educated abroad or within the PDRY's post-dependence system of party education. There were not many possible choices. About "three quarters of the [CC] of the YSP were gone," ${ }^{23}$ either dead, in northern exile, or awaiting their trial in prison. The security forces were significantly decimated. For example, the whole leadership of the police in the Third and Fourth Governorate had fled to the YAR. ${ }^{24}$ Over the following weeks, only few of the cadres of the YSP could reclaim pivotal posts in the state apparatus: ${ }^{25}$ The technocrat and former minister of fisheries Yassin Said $\mathrm{Nu}$ 'man $^{26}$ became the new prime minister. Said Saleh Salem, ${ }^{27}$ who had been a minor actor among the revolutionaries and a generally politically modest man, became minister of state security, ${ }^{28}$ and Abd Rabbuh Mansur Hadi (Hadi) was appointed new deputy chief of staff. Almost

22 | Zur Lage in der VDRJ - Stand vom 24.1.1986, January 25 1986, in: BStU MfS ZAIG Nr.6744, 45-50.

23 | Brehony, 2013, 157.

24 | Bericht Besuch des IM “Klaus Winter," 1989, in: MfS HA VII 7054, 54-58. According to former OibE Rudolf Nitsche his code-name had been "Winter." Taking into consideration Nitsche's service in a GDR mission in an Arab country in 1966, it seems likely that the author of the information provided by IM "Klaus Winter" had been Rudolf Nitsche himself, in: Nitsche, 1994. On the role of the HV A also see Ch 7. The "Three Spheres of Foreign Policy Making": Party, State, and Society, 3. Foreign Policy Actors, Competencies and the Decision-Making Process.

25 | Al-Beidh, al-Attas, al-Dhali, Salem Saleh Mohammad and Saleh Munasir al-Siyeli, in: Information über die Entwicklung in der VDRJ und internationale Reaktionen, Februar 1986, BStU MfS HV A Nr. 40, Part 1 of 2, 181.

26 | Burrowes, 2010, 264.

27 | Arabic: Sa"īd Saleḥ Sālem.

28 | Mitglieder der Delegation, in: BStU MfS Abt.X Nr. 234 Teil 1 von 2, $85 f$. 
thirty years later, Hadi was to step into the international spotlight as unified Yemen's new leader in $2012 .{ }^{29}$

In the two years after the coup, al-Beidh was able to somehow integrate the heterogeneous new leadership, but he was not able to emerge as the dominant leading figure. In summer 1987, he aimed at disposing of the majority of the new leading figures, some of whom he considered incapable, others he simply considered a danger to his leadership role in party and state..$^{\circ}$ In a meeting with the Soviet ambassador, al-Beidh suggested dismissing a majority of his ministers, among them al-Dhali. Several members of the PDRY's Politbüro were less than happy "with al-Beidh's [...] style of leadership." ${ }^{31}$ MfS reports repeatedly suggest that they were not alone in this. The Kremlin clearly disapproved of abrupt political moves like this, as well as al-Beidh's plan and decisions in general. ${ }^{2}$ However, none of the changes in leadership personnel prepared by al-Beidh were realized. The relevant individuals expressed their refusal during the CC conference in 1987 , as they were well aware of the Soviet and East German support.

All in all, al-Beidh upheld an extreme course of socialist renewal and constantly feared losing his position. After his partly defeat at the CC conference of 1987 , al-Beidh tried to obtain his power through pragmatic concessions. Nonetheless, his leadership appeared indecisive and hesitant. The opposition under Ali Nasir operated from Sana'a, constantly threatening the new regime in Aden, which was planning for Ali Nasir's return as the head of state and secretary-general of the YSP. 33 On top of that, the final years of the PDRY were characterized by even more severe economic hardships. The civil war of January 1986 not only had destroyed much of Aden's infrastructure, central buildings, and factories, but also created instability that repelled any foreign investors who might have had interests in the PDRY. According to East German IM information, Seidel summarized in early

29 | Hadi had been vice-president of unified Yemen from 1994-2012 and was appointed president of Yemen after Saleh's downfall in 2012.

30 | Zusammenfassung der wichtigsten Feststellungen und Gespräche während des Aufenthaltes in der VDRJ am 02. und 03.09.1987, Fiedler HV A III, September 14 1987, in: BStU MfS Abt.X Nr. 234 Teil 1 von 2, $228 f f$.

31 | According to Salem Saleh, Mohammed Al-Beidh's style of leadership was of "anarchic" character. Zusammenfassung der wichtigsten Feststellungen und Gespräche während des Aufenthaltes in der VDRJ am 02. und 03.09.1987, Fiedler HV A III, September 14 1987, in: BStU MfS Abt.X Nr. 234 Teil 1 von 2, 229; 232.

32 | For example his plan to "merge the [PDRY's] KfS and Ministry of Interior." Zusammenfassung der wichtigsten Feststellungen und Gespräche während des Aufenthaltes in der VDRJ am 02. und 03.09.1987, Fiedler HV A III, September 14 1987, in: BStU MfS Abt.X Nr. 234 Teil 1 von 2, 229.

33 | Brief Ali Nasir Mohammed an Erich Honecker, March 16 1987, BStU MfS HA II Nr.28714, 182-188. 
1989: "Practically, the state [is] bankrupt."34 The newly discovered oil reserves close to the Saudi and the North Yemeni border did not offer significant economic relief, as extraction only developed slowly, ${ }^{35}$ but rather fueled conflict between the PDRY and its neighbors. ${ }^{36}$ In this environment of hopelessness, the idea of unity was now gaining speed and offered a supposedly easy way out. There was not much the new leadership could do to prevent the demise of the only "Marxist" state in Arabia.

\section{2. "Soviet Dilemma at the Gate of Tears": 37 Between INFLUENCE, IMPOSITION AND LACK OF CONTROL}

"Life is what happens to you while you are busy making other plans."

(John Lennon, Darling Boy, 1982)

\subsection{Moscow's Role in the Events of 1986: A Comment on Conspiracy Theories}

After Ismail's return from Moscow in 1985, conflict was in the air. Brehony refers to an unnamed member of the Politbüro claiming to have sought for Soviet support in convincing Ali Nasir to give up one of his three posts, but Moscow apparently remained inert..$^{8}$ This at first appears rather surprising, as the disagreement between the factions was not only about Ali Nasir's plentitude of power, but also about his relationship with the Eastern Bloc. Nonetheless, Moscow at this point did not interfere, at least not openly. After the "1986 crisis," international media had been speculating about possible Soviet interference to replace Ali Nasir Mohammed and to "install a less independent mind." ${ }^{39}$ But the Kremlin clearly had had no interest in replacing Ali Nasir at the time, regardless of Ismail's return and even though Ali Nasir aimed for more independence from Moscow and the socialist states. Certainly things were more complex and might be illuminated by asking the right questions.

34 | Abschrift einer IM-Information der HA VII, Abt.1, February 28 1990, in: BStU MfS HA VII $7054,51$.

35 | Information Nr. 70/IV Erdölförderung in der VDRJ, MfAA, June 13 1988, in: BStU MfS HA II Nr.28714, 267.

36 | Zusammenfassender Bericht über die Dienstreise nach der VDRJ vom 25.2. bis 11.3.1988, March 18 1988, in: BStU MfS Abt. X Nr. 234, Part 1 of 2, 165; Information Nr. 70/IV Erdölförderung in der VDRJ, MfAA, June 13 1988, in: BStU MfS HA II Nr.28714, 267.

37 | Landwehr, Andreas, Suedjemen. Das Sowjetische Dilemma am “Tor der Traenen," Januar 1986, in: BStU MfS HA III Nr.5922, 14.

38 | Brehony, 2013, 133.

39 | Kirkpatrick, Jeane, 1986, in: Katz, 1986, 11. 
First: Was Moscow actively involved in the "1986 crisis" by supporting one of the factions?

Ali Nasir had developed the profile of a pragmatist and began to open South Yemen up to Western investments and "encouraged Western oil companies" to search for oil. Moscow sensed the danger of its ally steering away from Soviet influence. ${ }^{40}$ This coincided with calls for Ismail's return from exile in Moscow in 1983 , and while Moscow did not actively promote Ismail, the Kremlin hadn't done much to keep him from preparing his return either. In 1985, Ismail presented himself in public again and was allowed to meet with high-ranking Arab officials during their visits to Moscow. ${ }^{41}$ The very same year Ismail returned to Aden, right on time to chair the preparation committee for the YSP Conference in late 1985. The "new left," now strengthened due to Ismail's return, insisted on again intensifying relations with the Eastern Bloc to finally qualify as a "Socialist state" and become eligible for more economic and military assistance.

The "new left" around Ismail, however, aimed to return to the former policy of "revolution export" to their neighbors and propagated unification of both Yemens under socialist terms as soon as possible by overthrowing Saleh's rule. Ali Nasir, on the other hand, was renowned for his friendly relationship with Ali Abdallah Saleh and a policy of pragmatic cooperation with Sana'a. ${ }^{4^{2}}$ One may agree with Katz that the Kremlin sent "Ismail home to join the Politbüro [as a warning to Ali Nasir] that he could be overthrown if he went too far on a path towards the West by allowing Western corporations into South Yemen."43 Thus, it is highly unlikely that Moscow had tried to get rid of either of the two figureheads. Rather, the Kremlin apparently had aimed to keep both Ismail and Ali Nasir in power and to counterbalance the two competing wings of the YSP leadership and follow its very own agenda in Aden.

Second: How actively involved did Moscow get after the incident?

Even though the Kremlin was likely not involved beforehand, the escalation in the end could not have been a surprise to the Kremlin. In the fall of 1985, Cigar, a US Ministry of Defense officer, predicted: "The jockeying for power [between Ali Nasir and Ismail] is likely to intensify as the Congress [of the YSP in October] approaches." 44 Clearly, Moscow must have been aware of the brewing conflict, though hoping that it would not escalate. Thus, the Soviet Union was able to
40 | Katz, 1986, 9.
41 | Cigar, 1985, 792.
42 | Brehony, 2013, 140ff; Burrowes, 2010, 28.
43 | Katz, 1986, 12.
44 | Cigar, 1985, 790. 
decide quickly on how to react to the "1986 crisis" at the time to suit their best interest. Brehony presents the official version of Soviet non-intervention, which without doubt has to be amended:45 At the instigation of the Soviets, delegates of the opposing Yemeni factions met at the Soviet embassy in Aden as early as January 14, though not much was achieved, as the representatives "lacked the power to implement a cease-fire." ${ }^{\prime \prime 6}$

Within two weeks, Moscow had decided with whom to side. Ali Nasir had retreated to North Yemen and went to Addis Abeba later on to ask for Mengistu's support. On January 28, the GDR embassy in Addis Abeba reported information from the Soviet embassy: "[A]ccording to Soviet assessments immediate danger of Ethiopian interference averted for now. Soviet ambassador will have talks with Mengistu today."${ }^{\prime 47}$ In the end, Ethiopia refrained from intervention - according to MfS reports, this was due to Soviet efforts and personal engagement by Gorbachev..$^{8}$ Furthermore, Moscow appears to have appealed to Syria's Hafez alAssad to "change its original position" and support the new government "to assure the USSR's influence and the influence of progressive Arab forces." ${ }^{\text {"49 }}$ The Kremlin had opted to support the survivors of the coup to stabilize its most important ally in the region and "restore the Marxist order" $5 \circ$ as soon as possible.

All in all, uncertainty over Moscow's part in the power struggle before the "1986 crisis," as well as over the Kremlin's true intentions, remains. However, speculations about Soviet intervention towards the replacement of Ali Nasir are nothing more than that. First of all, a violent putsch resulting in a civil war which endangered the stability and existence of the USSR's closest ally in the region clearly could not have been in Moscow's interest. Furthermore, it has to be doubted that the Kremlin originally wanted to get rid of Ali Nasir. Reconsidering some of the events prior to the coup rather support the argument that the leadership personnel did not matter too much for the Kremlin - as long as the vanguard YSP stayed in power.

45 | Brehony, for instance, quotes Yemeni sources that the Soviet ambassador himself on the 15th of January was instructed to inform Saleh in Sana'a that Moscow would not intervene, in: Brehony, 2013, 154.

46 | Information über die Entwicklung in der VDRJ und internationale Reaktionen, January 1986, No.29/86, BStU MfS HV A Nr. 40, Part 1 of 2, 343.

47 | Telegramm Jagenow Addis Abeba an Axen, Fischer, Sieber ZK IV, König, January 28 1986, In: BStU MfS ZAIG Nr.6725, 8.

48 | Zur Lage in der VDRJ - Stand 27.1.1986 - 22,00 Uhr, January 28 1986, in: BStU MfS ZAIG Nr.6744, 56; Abschrift zur Entwicklung in der VDR Jemen, HA II/14, March 13 1986, in: BStU MfS ZAIG Nr.6725, 84.

49 | Zur Lage in der VDRJ - Stand vom 29.1.1986, January 30 1986, in: BStU MfS ZAIG Nr. $6744,60 f$.

50 | Katz, 1986, 12. 


\subsection{Pushing for a Swift Recovery: Moscow holds on to its Failed Socialist Showcase}

"[N]0 matter which pro-Soviet faction defeated the other, the USSR would retain its influence in South Yemen." ${ }^{51}$

(Contemporary Comment on the January 1986 events by Mark Katz)

At first glace, there was not much to gain anymore in Aden after the Soviet Union's loyal allies were removed from power in one way or the other. The showcase example among the closest Soviet allies in the developing world had failed - for now..$^{52}$ However, after several days of uncertainty, Moscow launched a strategy to stabilize the new leadership and with it socialism in the country: several years before the collapse of the Soviet Union, Moscow displayed a policy change towards the Global South but also the states of the Warsaw Pact. As part of an approximation to its Cold War adversary in Washington, the Kremlin under Mikhail Gorbachev introduced an empowering policy that aimed to create the impression that Moscow was loosening its grip on its dependent allies. And indeed, the Kremlin seemed to grant more maneuvering room and aimed at stimulating more internal and international self-reliance within the respective regimes. In Aden, this policy change could already be felt before the Kremlin reacted to the events of January 13 1986,53 with the crisis causing a "rollback" of this policy towards more direct control over the YSP regime.

In February 1986, the members of the new government prepared to attend the Party Congress of the CPSU. ${ }^{44}$ On month later, the Stasi notes that "the USSR is cooperating with the new leadership" and that Moscow intended to send back their evacuated personnel to Aden as soon as possible..$^{55}$ All in all, the USSR continued all of its projects of economic and technical assistance rather soon after the crisis. ${ }^{56}$

$\mathbf{5 1}$ | Katz, 1986, 7.

52 | Ibid., 12.

53 | McFaul, 2002, 39.

54 | Vermerk, February 18 1986, in: BStU MfS ZAIG Nr.6744, 85f.

55 | Soviet military advisors hadn't been called back to the Soviet Union at all, while some reports claim that even the majority of technical experts had remained in the PDRY during the crisis. This may be doubted. An East German engineer even reports that on January 20, all Soviet colleagues already had been evacuated while he and his delegation were left behind at the construction site in Little Aden. Abschrift zur Entwicklung in der VDR Jemen, HA II/14, March 13 1986, in: BStU MfS ZAIG Nr.6725, 85; Bericht über die Ereignisse auf der Auslandsbaustelle "Bridges Reconstruction in Aden“ im Januar 1986, January 29 1986, in: BStU MfS ZAIG Nr.6725, 246.

56 | Abschrift zur Entwicklung in der VDR Jemen, HA II/14, March 13. 1986, in: BStU MfS ZAIG Nr.6725, 85. 
This clearly aimed at a renewal of Soviet-Yemeni relations. In February 1987, the new leader al-Beidh was invited to Moscow. During the extensive consultations, held in the presence of the East German ambassador, al-Beidh repeatedly was "assured of comprehensive support for the current political course" and new agreements on culture and the cooperation between the foreign ministries of the USSR and PDRY were signed. ${ }^{57}$

As a short-term response to the crisis, the Soviet leadership tried to neutralize the opposing factions so that the regime would be able to survive and thus the "Marxist" state could re-emerge as a stable ally once more. The long-term response, however, has to be considered a reversal of the new empowerment tendencies in Soviet foreign policy mentioned above. Moscow obviously intended to uphold their "unbreakable friendship" with Aden, while drawing the PDRY closer again and intensifying "control over the policies of the junior ally [in the region], ${ }^{58}$ a status Aden clearly had gained by then. Halliday considers the replacement of the Soviet ambassador Vladislav Zhukov, a trained diplomat, by Albert Rachov, a party functionary, a telling indicator for this policy change - or rather policy rollback - towards the PDRY.59 The replacement of personnel on the ground was complemented by more regular visits of party delegations and security advisors. Moscow's efforts to further integrate South Yemen into the Comecon fits into the picture. By offering trade advantages for the PDRY, ${ }^{60}$ Aden on the long run was to increase the share of its total trade and economic cooperation with and thus dependency on the states of the Eastern Bloc.

Regardless of the swift recovery of relations, official Soviet statements on South Yemen's policies suggest a new mistrust toward the PDRY and a certain dislike of the new leadership. This included open critique and the Kremlin's reluctance to further display "expressions of friendship," such as inviting the leaders of the YSP to speak on the occasion of the 7oth anniversary of the October Revolution. But the feelings somewhat seemed to be mutual, at least with regard to al-Beidh. Moscow upheld its plan to open its institute for training and education of the PDRY's KfS cadres in October $1987^{61}$ -

57 | Telegramm (Blitz) Botschaft Moskau an Sieber, Krolokowski, Winter, Steinhofer, Neumann, Betreff: NO-Verwaltung MID zu Besuch AI-Beidh February 9 to 11, February 10 1987, in: BStU MfS HA II Nr.28714, 159 f.

58 | Halliday, 1990, 203.

59 | Halliday considers this replacement policy as a repeated phenomenon, as it had happened in Afghanistan in 1979 and Ethiopia in 1980, Halliday, 1990, 209.

60 | Stellungnahme zur Vorlage für das Politbüro des ZK der SED. "Entwicklung der mehrseitigen Zusammenarbeit der RGW-Länder mit der VDR Jemen," August 18 1986, In: BStU MfS AG BKK Nr.1850 Bd.2, 57.

61 | Zusammenfassung der wichtigsten Feststellungen und Gespräche während des Aufenthaltes in der VDRJ am 02. und 03.09.1987, Fiedler HV A III, September 14 1987, in: BStU MfS Abt.X Nr. 234 Teil 1 von 2, 227-243. 
even though al-Beidh considered the Soviet advisors "supervisors" exerting control. According to Salem Saleh Muhammad, al-Beidh simply detested their presence. ${ }^{62}$

However, the harsher tone was not accompanied by a decline of Soviet engagement. Even though Brehony speaks of a "subtle downgrade of relations," ${ }_{3}$ in praxis this was not the case. ${ }^{64}$ The Stasi summarizes the Soviet position in March 1986:

\begin{abstract}
"The PDRY will remain a country of strategic importance in the future. To maintain [the PDRY"s] socialist orientation is of outmost importance for the distribution of power in the region. To counter all attempts by reactionary circles to stray the PDRY from its progressive path of development, the prevailing conditions in the PDRY have to be obtained and cooperation continued." 65
\end{abstract}

To save its supposedly "failed experiment," the USSR had quickly sided with the new regime and agreed to support Aden against the ploys of Ali Nasir and his adherents to overthrow the new leadership. ${ }^{66}$ In pursuit of this goal, the Kremlin extended its engagement in the field of state security, which was coordinated with the MfS of the GDR. In particular, the increase in financial contributions demonstrates the Soviet Union's continued interest and engagement. Moscow even sent money for new buildings and restoration in Aden. ${ }^{67}$ The new Soviet agenda in South Yemen had "stabilization" on top of its list due to the "significance of the PDRY for the socialist camp." 68

62 | German: Kontrolleure, Salem Saleh Mohammed would urge Soviet and East German advisors to be careful and keep a close watch over al-Beidh and his policies and relations to the YAR, in: Zusf. der wichtigsten Feststellungen und Gespräche während des Aufenthaltes in der VDRJ am 02. und 03.09.1987, Fiedler HV A III, September 14 1987, in: BStU MfS Abt.X Nr. 234 Teil 1 von 2, 232

63 | Brehony, 2013, 169.

64 | In 1988, for example, an Agreement on Health Cooperation and a new Protocol on Economic Cooperation were signed, in: Yemen news items 1988.

65 | Abschrift zur Entwicklung in der VDR Jemen, HA II/14, March 13 1986, in: BStU MfS ZAIG Nr.6725, 85.

66 | Geheim. Übersetzung aus dem Russischen. Auskunft über die Reaktion des Ministeriums für Staatsicherheit der VDRJ auf die Tätigkeit der Anhänger von A.N. Muhammed [sic!] in den sozialistischen Ländern, 1987, in: BStU MfS HA II Nr. 22860, 151-155.

67 | Brehony, 2013, 166 and 169.

68 | Vorlage zum Stand und zur weiteren Gestaltung der Zusammenarbeit mit dem MfS der VDRJ und zu dessen Unterstützung, Januar 25 1988, by Oberst Fiedler, signed by Mielke, HV A III, Jemen, in: BStU MfS Abt. X Nr. 234, Part 1 of 2, 135. 


\section{The Caesura of 1986 and Its Aftermath: SEd State Policy or Honecker-Centered Policy?}

The GDR's high level of engagement in socialist nation- and state-building in South Yemen had survived three more or less violent regime changes since Qahtan. ${ }^{6}$ But the incident of 1986 finally shattered East German belief in the South Yemenis, or at least the idea of modelling a revolutionary state on East German socialism in Aden. The death and exile of the two most prominent figures of the former NLF liberation movement and long-term allies of Moscow and East Berlin, Ismail and Ali Nasir, had corrupted relations and thus the GDR's policy beyond repair: The time of the SED regime was up before relations could fully recover. As a consequence, the last phase of East German engagement in the PDRY became the "Ice Age" of relations between formerly "best friends."7o

\subsection{Best Friends do not Part: Honecker keeps Faith with Ali Nasir}

Once fighting in Aden had ceased, functionaries of the new PDRY leadership approached the remaining diplomatic GDR personnel: “The partners expressed their wish for continuity of the bilateral relations - especially with regard to the security organs." ${ }^{11}$ Statements by East German diplomatic personnel and Stasi reports agree that Ali Nasir had been responsible for the assassination of the Politbüro members on January $13,7^{72}$ and thus the survivors of the coup remaining in the PDRY were considered the rightful leadership. Meanwhile in East Berlin, the MfAA, namely Vice-Minister Winter, supported by the former ambassador to the PDRY, Freimut Seidel, had even established a crisis group immediately to consult on the events in South Yemen and on future action:

\footnotetext{
"We concluded that we could not apply the criteria of 'socialist orientation' or the distinction between progressive/reactionary to these opposing groups [in South Yemen]. These simply were power struggles [...] and one could not support Ali Nasir simply because he symbolized progress." ${ }^{73}$
}

The crisis group identified the East German engagement as an imposition not necessarily fitting to the country and its social realities - regardless of the explicit South Yemeni wish for this support. Furthermore, the group agreed to turn their

69 | Arabic: Qaḥtān Muḥammad al-Shałābĩ.

70 | Interview with Heinz-Dieter Winter July 32012.

71 | Zur Lage in der VDRJ - Stand 27.1.1986 - 22,00 Uhr, January 28 1986, in: BStU MfS ZAIG Nr.6744, 55.

72 I Ibid. Another report refers to an internal report of Syria's Ba'ath Party which concludes that Ali Nasir had organized the liquidation of his opponents himself, in: Zur Lage in der VDRJ - Stand vom 30.01.1986, January 31 1986, BStU MfS ZAIG Nr.6744, 62 f.

73 | Interview with Heinz-Dieter Winter July 32012. 
backs on Ali Nasir and to cooperate with the new regime right away. In addition to the MfS and the MfAA, Moscow also advised Honecker to reconnect with Aden. These instructions confirm the USSR's persisting interest in the country beyond personal or ideological considerations. Aden clearly remained a vital part of Moscow's political strategy in the region. The more surprising response appears the East German reaction: Ignoring internal recommendations, as well as South Yemeni and Soviet wishes, Honecker and the SED hesitated to reestablish cooperation with Aden after the escalation of 1986.

Over the years, Honecker had developed a personal friendship with both the theorist Ismail and the more pragmatic Ali Nasir, as well as several other ministers. These friendships had grown in numerous meetings after the downfall of Salmin. ${ }^{74}$ Confronted with Ismail's exile in 1980, the secretarygeneral of the SED had to focus on Ali Nasir and the personal relations between the two - more or less - sole rulers in their states of "democratic centralism" had even become closer. Demonstrably, Honecker upheld his hopes for Ali Nasir to be reestablished as leader of the YSP until 1987. These personal preferences of Honecker were the major cause for the "Ice Age" of GDR-PDRY relations which then followed: Ignoring Soviet instructions, the majority of experts remained in the GDR after their evacuation during the crisis and the new ambassador Freimut Seidel did not get permission to travel to Aden until half a year later.75 It took more than two years until the GDR sent a new advisor group to Aden, ${ }^{76}$ the FDJ Brigade terminated its activities, and the agreements of 1985 were put on hold. Apart from security and military cooperation, East German engagement was "frozen" for the time being.77 On top of that, East Berlin expressed its opposition to further integration of the PDRY in the Eastern Bloc as frankly as possible under Soviet control. Even the Koko expressed only restrained enthusiasm for the Kremlin's plan. Though the GDR "[did] not raise any objections to a mixed Comecon Commission - PDRY," it clearly signaled its preference for "bilateral agreements" 78 and made clear that "the GDR [would] neither commit to nor

74 | After Ismail had been exiled, Ali Nasser and Honecker had met on an almost annual basis. Informationsmappe für den Besuch des Generalsekretärs des ZK der JSP [...] Ali Nasser Mohammed, November 1984, in: BStU MfS HA II Nr. 28712, 175; Interview with Fritz Balke on May 232011.

75 | Interview with Fritz Balke on May 232011.

76 | Telegramm Seidel an Ost-Berlin, February 8 1988, handwritten notes by Seidel in: BStU MfS HA VII 7054, 92.

77 | Zusammenfassung der wichtigsten Feststellungen und Gespräche während des Aufenthaltes in der VDRJ am 02. und 03.09.1987, Fiedler HV A III, September 14 1987, in: BStU MfS Abt.X Nr. 234 Teil 1 von 2, 237.

78 | Stellungnahme zur Vorlage für das Politbüro des ZK der SED. "Entwicklung der mehrseitigen Zusammenarbeit der RGW-Länder mit der VDR Jemen,” August 12 1986, In: BStU MfS HA XVIII 21008, 57. 
participate in this Comecon framework."79 The East German attitude, that is, Honecker's attitude toward the new South Yemeni leadership, was clear.

\subsection{Badheeb's Asylum and AI-Salami's Amnesty: Honecker's Loyalty brings forth Strange Blossoms}

One of the concrete obstacles on the East German side to a normalization of relations between the two states had been the persecutions and extreme punishments of Ali Nasir's followers. For East Germany these crystallized around two cases: Badheeb, ${ }^{80}$ a confidant of Ali Nasir, and al-Salami, the former minister of education. Badheeb had visited the GDR on several occasions, such as in May 1980 when he met with Hermann Axen. ${ }^{8}$ According to the HV A, Badheeb was "second on the list after Ali Nasser [sic!] Mohammed to be prosecuted," as he was considered "one of the major culprits of the bloody events." ${ }^{2}$ After the failed coup of 1986, Badheeb asked for asylum in the GDR. Backed by the "socialist state community," Badheeb was received as an honored guest "under the condition to abstain from any political activities" ${ }^{3}$ in the GDR. Coming from Damascus, he arrived in East Berlin in July 1986. ${ }^{84}$ The move had been "ordered by Honecker and with the objective to prevent the [...] forces of Ali Nasser [sic!] Mohammed to unitedly change sides to the reactive Arab and imperialist states." ${ }_{5}$ Thus, Badheeb's asylum on the one hand appears to have been in the interest of Moscow and its allies. Al-Salami's case, on the other hand, was quite a different matter.

Personal friendships had developed over the years between al-Salami and several leaders of the SED, first and foremost Honecker himself and his wife Margot. ${ }^{86}$ Al-Salami, the former minister of education, had also been the long-

79 | Vorlage für das Politbüro des ZK der SED. Betreff: Entwicklung der mehrseitigen Zusammenarbeit der RGW-Länder mit der VDR Jemen, August 18 1986, In: BStU MfS HA XVIII 21008, 56.

80 | Arabic: 'Abdallāh al-Razzaq Badhīb.

81 Informationsmappe für den Besuch des Generalsekretärs des ZK der JSP [...] Ali Nasser Mohammed, November 1984, in: BStU MfS HA II Nr. 28712, 168.

82 | Vermerk zur Asylgewährung für [...] Badheeb, HV A/III/AG, August 5 1986, in: BStU HA II Nr. 27366, 2.

83 | Information zum ehemaligen führenden Funktionär der JSP der VDR Jemen, [...] Badheeb, January 141987 (?), in: BSTU MfS HA II Nr. 28714, 131.

84 | Vermerk zur Asylgewährung für [...] Badheeb, HV A/III/AG, August 5 1986, in: BStU HA II Nr. 27366, 2-5.

85 | Ibid., 3.

86 | Interview with Fritz Balke on May 232011. 
time chairman of the East German-Yemeni Society of Friendship. ${ }^{87}$ After the "1986 crisis," he was arrested as traitor who was considered actively involved in the "1986 massacre." 88 With regard to South Yemeni practices, his execution seemed to be inevitable. However, East Berlin not only demanded al-Salami's swift release, but also his amnesty. At first, the new Vice-Secretary-General of the YSP, Salem Saleh Mohammed, merely guaranteed Al-Salami's safety on the occasion of the CC meeting in early February. Al-Salami himself remained in prison, waiting for his trial. ${ }^{89}$

In September 1986, a Stasi MfS delegation travelled to Aden to prepare alSalami‘s safe departure to East-Berlin. At first, the YSP leadership considered the GDR's wish to release al-Salami an "interference in the PDRY's domestic affairs" and that "the PDRY would not accept the GDR attaching Dr. Hassan al-Salami's fate to the cooperation between [the YSP and the SED] and the two countries."9o The relevant MfS report does not go into detail about how the delegation finally achieved the YSP's promise to free al-Salami. But during the five weeks of their stay, the Stasi had contacted the KfS of the USSR and in the end received full support. $9^{1}$ Considering Moscow's initially hesitant stance in the matter, ${ }^{92}$ East Germany's success appears rather surprising. It seems as if the delegation was authorized to even threaten the termination of relations: "For this decision of the [YSP] Politbüro, the PDRY's interest in the normalization and development of relations with the GDR was decisive."93 The report mentions "hard discussions" on the topic of al-Salami and the asylum of Badheeb in the GDR, but assures that

"cooperation remained constructive and never lost its character of friendship

[...] The method to act on the level of long-term personal relations below the official levels [again] proved successful." 94

However, not successful enough at the time. Al-Salami remained imprisoned regardless of the promises given and of considerable improvements in the

87 | Abschrift zur Entwicklung in der VDR Jemen, HA II/14, March 13 1986, in: BStU MfS ZAIG Nr.6725, 83-85.

88 | Zusammenfassung der wichtigsten Feststellungen und Gespräche während des Aufenthaltes in der VDRJ am 02. und 03.09.1987, Fiedler HV A III, September 14 1987, in: BStU MfS Abt.X Nr. 234 Teil 1 von 2, 238.

89 | Vermerk, February 7 1986, BStU MfS ZAIG Nr.6744, 73.

90 | Bericht über die Dienstreise in die VDRJ vom 1.9. bis 3.10.1986, October 10 1986, in: BStU MfS Abt. X Nr.234, Part 1 of 2, 284.

91 | Ibid., 283.

92 | Vermerk Genosse Oberst Fiedler, HV A III, September 5 1986, in: BStU MfS Abt. X Nr.234, Part 1 of 2, $281 \mathrm{f}$.

93 | Ibid. 285.

94 | Ibid. $285 f$. 
relations between the countries. 95 The issue remained top priority on East Germany's agenda. Fritz Balke reports of two meetings between Honecker and al-Beidh on the occasion of the CPSU Party Congress and the $70^{\text {th }}$ anniversary of the Soviet revolution in Moscow that he had witnessed as a translator. "Twice, it was tough bargaining." ${ }^{6} 6$ According to Balke, Honecker at the time even considered terminating relations altogether. Shortly after the CPSU Party Congress, however, al-Salami was released. And while Balke himself did not have an explanation for it, the whole process can be reconstructed with the files of the MfS. A draft on Mielke's line of argumentation for a meeting with the PDRY's minister of state security mentions "the unsolved problems in the relations between our countries (Sallami] [sic!]." 97 Even in February 1989, the topic of the "1986 traitors" was still pressing. Due to Honecker's, wish it was East Berlin's declared goal to achieve an exemption from punishment for alSalami, so that he would be able to live in Aden again. The YSP regime kept raising their demands to grant this wish, $9^{8}$ but in March 1989 finally gave in. Al-Salami was released and allowed to reintegrate into society. Without doubt this was the Stasi's doing on Honecker's orders: Minister of the Interior Saleh Munasser al-Siyeli explicitly added that with freeing al-Salami "he [al-Siyeli] had kept his personal promise to Genosse Minister Mielke."99 In a meeting between al-Salami and an MfS delegate to the PDRY, Oberst Winkler, al-Salami assured Winkler "that he knew about Honecker's share in his [amnesty]" and thanked him repeatedly for the GDR's role in his release.

\subsection{Before and After AI-Salami's Release: Was there an "Ice Age" of Relations in all fields of Cooperation?}

After the "1986 crisis," the majority of new agreements or the renewal of old ones had either been put on hold, or had their provisions pared back. This was even the case for military relations. In 1987, the PDRY's Ministry of Defense had asked for the continuation of South Yemeni military training for another 50 officers in the GDR. ${ }^{100}$ And even though this request was granted, no further steps to

95 | For example an SED delegation attended the YSP Party Congress in 1987 in Aden, Interview with Fritz Balke on May 232011.

96 | Interview with Fritz Balke on May 232011.

97 | Hinweise für das persönliche Gespräch mit dem Minister für Staatssicherheit der VDR Jemen, Saeed Saleh Salem 25.5.1988, in: BStU MfS ZAIG Nr.5119, 6.

98 | Abschrift einer IM-Information der HA VII, Abt.1, February 28 1990, in: BStU MfS HA VII $7054,52$.

99 | Vermerk Entlassung von Dr. Hassan as-Sallami, March 6 1989, HV A III, in: BStU MfS Abt.X Nr.234 Teil 1 von 2, 53.

100 | Estimated costs for the training: 4 million GDR Marks and about 76,000 VM. MfNV (Ministry of National Defence), Minister of Defense Keßler to Honecker, May 18 1987; Honecker's positive response, May 19 1987, BArch, AZN 32673, BI. $12 \mathrm{f}$. 
extend the cooperation were launched. But again this changed in late March 1989:101 Ambassador Seidel reports in a blitz telegram after a meeting with alDhali: "Pleasant circumstances, after obstacles for [relations] have been overcome, steps for revival or continuation [are launched]." ${ }^{102}$ Relations between Aden and East Berlin seemed to be back on track: East Germany finally approved of a new agreement on future military training. ${ }^{103}$

East German non-engagement in the PDRY during this very last phase of foreign policy delivers an outstanding example of East Germany's capacity for double standards in international activities concerning foreign policy and economic interests. On the one hand, the GDR had held back any further political, cultural, or security commitments until al-Salami's release, while economic and security matters were pursued in secrecy nonetheless. The KoKo and IMES, the major tools of the GDR's secret economic policy, were busy doing business with Aden. During the "Ice Age" of relations, their delegations regularly travelled to sell East German and Soviet arms and weapons. East-Berlin presumed South Yemen to dispose of "credit and Valuta from Saudi-Arabia." ${ }^{104}$ And Aden was more than willing to spend these assets on East German arms.

After a visit by the BKK working group, Habenicht reports:

"It's a fact that the North Yemenis dispose of about 600 to 800 T-55 [tanks], an unreal huge amount - and the South probably does not stand back. So both [sides] have no money, but for arms and ammunition they always have money." ${ }^{105}$

101 | Vermerk über ein Gespräch mit Dr. Hassan as-Sallami [sic!], 1989, in: BStU MfS Abt.X Nr.234 Teil 1 von 2, 53.

102 | Blitz Telegramm Seidel an MfAA über eine ausführliches Gespräch mit Ad-dali [sic!], March 20 1989, in: BStU MfS Abt.X Nr.234 Teil 1 von 2, 60.

103 | The two states agreed to extend the time of training to five years and to include military doctors as well, in: Abkommen zwischen der Regierung der DDR und der Regierung der VDRJ über die Ausbildung von Militärkadern der Streitkräfte der VDRJ in der DDR vom 1.6.1989, in: BArch, DVW 1/43671, BI. 171ff.

104 | Bericht über die ADR nach Nord- und Südjemen, Arbeitsgruppe BKK, January 30 1989, in: BStU MfS BKK Nr.95 Teil 1 von 2, 33.

105 | The actual motivation of the visit was to sell a new caliber gun $(5.56 \mathrm{~mm})$ produced in the GDR, "System Wieger," the automatic rifle 940 put together in Wiesa to possibly "establish business with third countries," in: Bericht über die durchgeführte Dienstreise nach Sanaa vom 9.1.-11.1.1989, in: BStU MfS Ag BKK NR.95 Teil 1 von 2, 80; Telegramm Aden an SchalckGolodkowski August 15 1988, in: BStU MfS AG BKK Nr.1661 Bd.2, 125; Erzeugnis 940 Sturmgewehr, August 23 1988, Habenicht, BStU MfS AG BKK Nr.98, 226-229; Telegramm Sanaa an Schlack-Golodkowski, January 2 1989, in: BStU MfS AG BKK Nr.174, 106. 
According to Habenicht, South Yemen "aim[ed] to acquire Soviet T-72 [tanks] and heavy machine guns from Poland" and that he, Habenicht, had "agreed to provide these T-72s, though [the GDR's interest was] to offer used T-55s." the BKK working group planned to expand the IMES trade in the Middle East as "there [was] a lot of money to be made." Habenicht even asked for supporting personnel for the region as he "could not manage the focus areas of West Africa, Yemeni peninsula, and India all by himself." ${ }_{107}$ Clearly, the BKK and IMES were instructed to raise foreign currency in any possible way - even though the trades without doubt violated the GDR's pledge for international peace and their former vows of friendship toward Aden, which was entangled in permanent conflict with the YAR. Even more surprising, these arms deals simply contradicted the current foreign non-policy towards South Yemen. With the IMES trades being the only exemption, East Berlin had terminated its engagement in all fields, including the military.

The security apparatus was another exemption from the rule. Even before al-Salami's release, relations between the secret services improved significantly. Seidel mentions the planned steps by the GDR's Ministry of the Interior and the HV A of February 1988 to send a delegation of the GDR's security apparatus in his telegrams. ${ }^{108}$ Major Wolf and Oberst Fiedler travelled to Aden. ${ }^{109}$ In March, Seidel "inform[s] [...] the PDRY's Minister of the Interior and Vice-President alSiyeli about the principal possibility of assistance." According to Seidel, al-Siyeli considered these decisions a "decisive step to overcome the problems in relations after 1986." ${ }^{110}$ Shortly thereafter, the PDRY's KfS and the Stasi again renewed and even extended their cooperation. ${ }^{111}$ The operational group of about ten advisors and two translators from the MfS was to remain in Aden, ${ }^{112}$ whereas another group for "operative control" of the MfS, as well as several experts on intelligence, surveillance equipment, and vehicles were delegated. Furthermore, the newly

106 | Bericht über die ADR nach Nord- und Südjemen, Arbeitsgruppe BKK, January 30 1989, in: BStU MfS BKK Nr.95 Teil 1 von 2, 33.

107 | Ibid. 33.

108 | A series of telegrams that was submitted to the "Party leadership and Minister Dickel [of thelnterior]," in: Telegramm Seidel an 0st-Berlin, February 8 1988, handwritten notes by Seidel in: BStU MfS HA VII 7054, 92.

109 | Zusammenfassender Bericht über die Dienstreise nach der VDRJ vom 25.2. bis 11.3.1988, March 18 1988, in: BStU MfS Abt. X Nr. 234, Part 1 of 2, 163-170.

110 | Telegramm Seidel an Ost-Berlin, March 9 1988, in: BStU MfS HA VII 7054, 93.

111 | Protokoll über die Maßnahmen der Zusammenarbeit zwischen dem Ministerium für Staatssicherhit der DDR und dem MfS der VDRJ für die Jahre 1988/1989; Zur Lage des MfS der VDR Jemen, in: BStU MfS Abt.X Nr.234 Teil 1 von 2, 10-16 and 96.

$112 \mid \mathrm{Zu}$ den Beziehungen des MfS der VDRJ mit dem MfS der DDR und mit Sicherheitsorganen anderer Länder, in: BStU MfS Abt. X Nr. 234, Part 1 of 2, 101. 
signed protocol granted another delivery of new equipment for surveillance worth 3.5 million East German Marks. ${ }^{113}$

In May, Vice-Minister of the MfS Schwanitz sent a delegation to inspect the condition of the East German telecommunication equipment and new shipments were planned for $1994-95.14$ In June 1988 , the first "delivery of solidarity" since 1986 arrived in Aden. ${ }^{15}$ Half a year later, in January 1989 , a new protocol between the two ministries of the interior amended the agreement of $1980 .{ }^{116}$ Five new experts were promised to be delegated to South Yemen, the head of the delegation and one for the "criminal police, (operative) headquarters, supply services and surveillance" each. Obviously, the GDR's double standard not only included the economy, but also the cooperation on the field of inner security. The protocols of the security and interior ministries, as well as the engagement of the East German security apparatus before al-Salami's release, clearly indicate the GDR's intention to continue its proactive engagement and further guide South Yemen's socialist state- and nation-building.

\subsection{A Fiction of Cooperation: Indicators for Future GDR Engagement}

Speculations about possible different outcomes in history cannot add to final conclusions on the matter. But one may find traces hinting at the possible future behavior of an actor had events turned out differently. Thus in the following section, some of these traces are meant to offer a tentative glimpse at the possible development of relations between German real socialism and Yemeni Marxism after their expiration date. What could have been East German intentions with regard to the PDRY beyond 1990? An extremely interesting case can be found by reviewing the Stasi reports on East German investments in the South Yemeni security apparatus.

Regardless of East Germany's early and intensive engagement in the establishment of the PDRY's security apparatus, the capability and efficiency of the PDRY's KfS did not meet East German expectations. After the "1986 crisis," only about half the cadres of the KfS remained. ${ }^{17}$ Without clear responsibilities

113 | Protokoll über die Maßnahmen der Zusammenarbeit zwischen dem MfS der DDR und dem MfS der VDRJ für die Jahre 1988/1989, in: BStU MfS Abt.X Nr.234 Teil 1 von 2, $12 \mathrm{ff}$.

114 | Maßnahmen zur solidarischen Unterstützung der Sicherheitsorgane der VDR Jemen, May 2 1988, in: BStU Sekretariat Schwanitz 24, 5.

115 | Telegramm Seidel an Ost-Berlin, June 20 1988, in: BStU MfS HA VII 7054, 90.

116 | Protokoll zur Vereinbarung über die Zusammenarbeit zwischen dem Ministerium des Innern der DDR und dem Mdl der VDRJ für den Zeitraum 1989 bis 1991, January 1989, in: BStU MfS HA VII Nr.1094, 12-16.

117 | Zur Lage des MfS der VDR Jemen; Kadersituation des MfS der VDRJ in: BStU MfS Abt. X Nr. 234, Part 1 of 2, 99. 
and the ever-present danger of "deconspiration," that is discovery of clandestine activies, the cooperation between Sections and Units was considered insufficient. Cadres appeared to be underqualified, including the new minister of state security himself, ${ }^{118}$ and the PDRY's KfS could not rely on an extensive net of IMs. As a consequence,

"[t]he operative information and materials [...] handed over by the Yemeni partners were almost non-utilizable (not sophisticated, lack of preconditions to further analyze the material, low level of the Yemeni partners)." ${ }^{119}$

To improve the situation, the MfS emphasized the need to extend the "authority of the MfS as an instrument of the Party to secure and strengthen the Party's leadership role." ${ }^{120}$ Both the GDR's MfS and the Soviet KfS significantly extended their material and cadre support after 1986. ${ }^{121}$ The East German MfS concluded: "Without the technical and cadre support by the [USSR"s] KfS and the MfS of the GDR [the PDRY's KfS] is not functional." ${ }^{122}$ However, the East German security service upheld its goal "to establish a cadre base of the GDR's MfS in the PDRY"123 to facilitate operative cooperation under all circumstances.

Similar observations and decisions were made with regard to East Germany's long-term surveillance project. Regardless of the "Ice Age" of bilateral relations, "Network 3"124 had been continued, though not expanded. This was remedied right after al-Salami's release. In February 1989, Oberst Fischer, deputy head of HA III and Oberstleutnant Tronicke, head of Subsection 9 of HA III, travelled to Aden to assess the condition of the radio station and to hand over

118 | Ibid., $96 \mathrm{ff}$.

$119 \mid \mathrm{Zu}$ den Beziehungen des MfS der VDRJ mit dem MfS der DDR und mit Sicherheitsorganen anderer Länder, in: BStU MfS Abt. X Nr. 234, Part 1 of 2, 103.

120 | Zur Lage des MfS der VDR Jemen; Kadersituation des MfS der VDRJ, in: BStU MfS Abt. X Nr. 234, Part 1 of 2, 97.

$121 \mid \mathrm{Zu}$ den Beziehungen des MfS der VDRJ mit dem MfS der DDR und mit Sicherheitsorganen anderer Länder, in: BStU MfS Abt. X Nr. 234, Part 1 of 2, 105.

122 | Zur Lage des MfS der VDR Jemen; Kadersituation des MfS der VDRJ, in: BStU MfS Abt. X Nr. 234, Part 1 of 2, 98.

123 | Vorlage zum Stand und zur weiteren Gestaltung der Zusammenarbeit mit dem MfS der VDRJ und zu dessen Unterstützung, Januar 25 1988, by Oberst Fiedler, signed by Mielke, HV A III, Jemen, in: BStU MfS Abt. X Nr. 234, Part 1 of 2, $134 \mathrm{f}$.

124 | German: Aktion Netzwerk 3. In the early 1980s, the MfS had signaled its interest in the PDRY's radio surveillance and established a military radio station in 1984, Also See: Ch 13. Phase III: The Phase of Continuity and Consolidation, The GDR in Yemen from 1978 to 1986: German Guidance and Yemeni Emancipation. 
new equipment. ${ }^{125}$ As opposed to the radio surveillance of the South Yemeni's Defense Forces, the MfS radio station was well-equipped with personnel and material.

"The material-technical equipment of the radio surveillance station, financed almost exclusively by East German solidarity allowances, is fully operational and functioning." 126

But Fischer and Tronicke clearly were not satisfied with the condition of the radio surveillance in Aden after "eight years of continuous advice by the [HA III]:" 127 the radio station so far had had "no immediate value for the MfS of the GDR." ${ }_{128}$ The two delegates insisted that this had to change over the period of the next " 4 to 5 [sic!] years." 129 Despite the inefficiency of the station, this decision suggests that the GDR's project was to be continued, just like the MfS' overall engagement in the PDRY and in doing so, to even go beyond the assistance of the 1970 s and early 1980 s.

Furthermore, one can find other indicators for the East German intention to fully rebuild relations: On the occasion of the inauguration of the new ambassador in March 1989, Honecker promised that the FDJ Brigade, evacuated in 1986 , would return to the PDRY.130 Balke reports about the renewal of the party agreement in June 1989 when he travelled with the high-ranking delegation leader, Head of the CC International Relations Section Günter Sieber. Then Balke remembers al-Beidh as the "last foreign guest received by Honecker" in Berlin on the occasion of the GDR's $40^{\text {th }}$ anniversary. ${ }^{131}$ Nonetheless, time was running out for both the PDRY and the SED regime. The process of Yemeni unification gained speed, while in East Berlin foreign policy issues beyond the German question clearly were pushed from the GDR's agenda of survival. Any other conclusion on East Germany's foreign policy plans for the PDRY thus remains speculation.

125 | Reisebericht über eine Dienstreise im Rahmen der Maßnahme "Netzwerk III," in: BStU MfS Abt.X Nr.234 Teil 1 von 2, 26-32.

126 | Ibid., 26.

127 | Ibid., 29.

128 | Ibid., 32.

129 | Ibid., 29.

130 | Interview with Heinz-Dieter Winter July 32012

131 | Interview with Fritz Balke May 232011. 


\section{Conclusion: Belated and Unfortunate Self-Confidence: East-Berlin wanders off the Soviet Course}

As a consequence of the "1986 crisis," Moscow's and East Berlin's closest allies within the Aden regime had been forced out of power. The events of 1986 are an indicator that neither Moscow nor its East German henchman were able to fully control their supposedly homunculus regimes in the Global South. One might reason, though, that these two states drew quite different conclusions. During this last phase of East Germany's engagement in Aden, the GDR moved away from ideologically inspired nation- and state-building to focus on more commensurable benefits, opting for a significant shift in the fields of engagement: The comprehensive state-building approach before had somewhat balanced civil and security measures. Now civil engagement was simply terminated. Over the following years it regenerated at a slow pace, while support for the security apparatus was picked up with considerable speed after 1987.

Moscow on the other hand upheld its high level of engagement in the country to remain the most important partner of South Yemen, with or without Ali Nasir. Though the Marxist experiment "PDRY" appeared to have turned from an "ideological victory" 132 for the USSR to an "ideological Waterloo," the Soviet Union did not end its engagement, but rather changed its policy to a more comprehensive approach: Economic aid and assistance became new fields of engagement in an attempt to stabilize the regime and thus the state. This policy change towards Aden has to be considered part of Moscow's wider regional strategy and the high level of engagement did not wane before the Soviet Union itself began to fall apart.

\section{The GDR and the Kremlin: New Self-Esteem?}

The GDR clearly aimed to decrease its political dependence from Moscow and to prove this not only within the Eastern Bloc, but also on the international stage. Even though the GDR was not able to move beyond the room for action granted by the Soviet Union, it clearly did not fully act in the USSR's best interest anymore by refusing to reconnect with the old ally South Yemen and their new regime after the "1986 crisis." While the Kremlin had sided quickly with the new regime in Aden, Honecker had decided otherwise for the GDR. East German engagement with South Yemen was kept at a political minimum to avoid terminating relations with Aden and thus aggrieving Moscow. Furthermore, Honecker's behavior of individual-centered foreign policy in the "al-Salami issue" clearly brings to mind the bigger picture of his final years as leader of the SED state, when he openly opposed the new course of the Soviet Union and propagated a "Socialism in the colors of the GDR." "133 Moscow had demanded the GDR reengage in the PDRY and

132 | Cigar, 1985, 782.

133 | Honecker, Erich, Report of the Politbüro to the VII. Conference of the Central Committee, in: Neues Deutschland December 21988. 
even the MfAA's findings were pointing in this direction. But Honecker clung to the guidelines of socialist foreign policy and his personal preferences, supporting the former revolutionary Ali Nasir. Clearly, this did not improve al-Beidh's weak political standing among the new YSP leadership either.

\section{Socialist Foreign Policy: Doomed to "Walk the Talk"}

According to Winter, the "Ice Age" of relations had not thawed before a discussion between himself and the PDRY's Foreign Minister al-Dhali in December 1989.134 But as the MfS documents show, the thaw had been underway half a year earlier. Significant investments had been made by the MfS to obtain the release of alSalami in March 1989. Thus, it had been the relations between the two security apparatuses and the active engagement of the MfS that were able to clear the air in the end. This turned out to be one of the few channels of communication that were upheld throughout this "Ice Age" between East Germany and South Yemen. It was also the foundation upon which relations were rebuilt.

After the "al-Salami issue" was settled, East Germany's policy in the end somewhat returned to the inflexible tracks of Socialist state- and nation-building, though with significantly less intensity. East German engagement appears to have taken quite a pragmatic turn after the tentative regeneration of relations between Aden and East Berlin. While East-Berlin refused to reactivate its former high level of engagement in various fields, it rather focused on topics more of interest to the GDR itself. For example, the station "Netzwerk 3" at first had been part of the Soviet strategy in the region, but turned out to be inefficient. Nonetheless, East Germany upheld investments in the station, despite Moscow's retreat from the engagement. Beyond Soviet interest, rumors of huge oil reserves might have kept the GDR on board, ${ }^{135}$ while East Berlin sensed lucrative opportunities for arms deals ${ }^{136}$ and seemed to hope for its very own MfS base in the Middle East.

During the short period after al-Salami's release and before the GDR and the PDRY disappeared from the map, relations seemed to be on their way of recovery. Taking into consideration the high number of renewed agreements and mutual visits of the two states, one may even speculate about further intensification of East German engagement, if German reunification had not got in the way. On the one hand, the last four years of East German-South Yemeni relations after the "1986 crisis" ended the history of cooperation between the two states. However, it has to be regarded a path-dependent outcome of the GDR's foreign policy on the other.

134 | Interview with Heinz-Dieter Winter July 32012.

135 | Despite other agreements, such as with France, the USSR signed the first agreement on oil exploitation in June 1988. In 1990, the Kremlin continued its planned extension of oil production, in: Abschrift einer IM-Information der HA VII, Abt.1, February 28 1990, in: BStU MfS HA VII 7054, 51; Yemen news items 1987.

136 | Bericht über die ADR nach Nord- und Südjemen, Arbeitsgruppe BKK, January 30 1989, in: BStU MfS BKK Nr.95 Teil 1 von 2, 30-36. 
Honecker's extreme reaction contradicted any sensible foreign policy cooperation. Even though he would evoke ideological arguments, such as "solidarity for the revolutionaries," in reality it was his personal preferences that determined his behavior. ${ }^{137}$ To accommodate Honecker's single-handed style of leadership working even against his foreign policy apparatus, a centralized political system like the GDR's was a conditio sine qua non.

All in all, the PDRY too was running out of breath in the end. The decline of Soviet and East German support was a decisive blow for the unstable and insolvent PDRY. However, this withdrawal of the Eastern Bloc was not due to a lack of interest, but rather to a lack of ability to uphold cooperation on this intense level. Moscow's priority was to keep its foothold in Aden - the actual circumstances were merely secondary. Both major YSP leading figures had disappeared from the scene in January 1986 and the few competent cadres remaining were not able to heal South Yemen's political and actual wounds to hold the country together. Just like East Germany, South Yemen was not able to adapt to the changing framework in international relations and drifted into unification as the considerably weaker "half" of Yemen: In newly unified Yemen, the few remnants of the former south bit by bit disappeared under the pressure of the politically and socially dominant north. The experiment of the only Marxist state in Arabia had failed and with it the GDR's "policy of state- and nation-building."

137 | Interview with Fritz Balke on May 23rd, 2011. 



\section{SECTION C. FINDINGS}


The concluding section approaches the central problem of this study on the "limits of foreign policy" in three chapters and revisits the major hypotheses of the analysis. The first concluding chapter summarizes the empirical, concrete limits, both internal and external, of East German foreign policy in general to clarify in what ways the GDR had been subject to internal and external limitations in International Relations in general. The second chapter is occupied with the empirical, that is, the concrete limits of East German foreign policy resources and abilities in the particular case of South Yemen. These two concluding chapters serve as the framework to answer whether the major hypothesis of the study can be upheld: Can the case of South Yemen be considered as both an exceptional case and a model suggesting a Weberian ideal-type of East German foreign policy? Finally, the last "Findings" chapter reconsiders the normative limits of East German foreign policy with regard to the autonomy of the host country South Yemen, while reflecting on the ability of societies to change based on the "degree of responsiveness" of collective identities. 


\section{CHAPTER 15. On the External and Internal Empirical "Limits" of East German Foreign Policy}

\section{External Determinants of East German Foreign Policy}

The GDR's existence can be considered a by-product of the Cold War. Naturally, the continuation of its existence highly depended on the changes in conflicts, alliances, and dependencies, that is, the changes throughout the period of the Cold War. First of all, this meant a significant impact of the relationship between the USSR and the USA on any party involved in the conflict, especially in places home to competing systems, such as divided Germany. As a consequence, the GDR was highly susceptible to the policies and actions of the Soviet Union and Western Germany, the two major determinants of its international scope of action. It was the bilateral relations to these two actors that determined the GDR's relations to all other state actors and alliances. And while Moscow exerted an active role and has thus to be considered a directive determinant, Bonn, on the other hand, remained without direct diplomatic contacts to East Berlin: West Germany, though highly influential on the SED's foreign policy decision-making, upheld its of passive character as a reactive determinant. Due to the limiting nature of these two determinants, the GDR regularly has been denied the quality of an autonomous actor in the international realm and thus a self-directed foreign policy by contemporaries and academia alike - especially when consulting sources from the Western hemisphere. This study now claims that East Berlin was able to find alternative ways within this narrow scope of action to promote its interests, which is the major precondition for the emergence of a state's foreign policy. ${ }^{1}$ Just like Bonn, East Berlin did not merely move within but actively worked with the "limits of its foreign policy."

1 E.g. during the first phase of the CSCE Process in Geneva and Helsinki in the early 1970s, in: Müller, in: DA 4/2010, 610. 
Throughout the GDR's history, any other policy goal was subordinated to the overarching interest of securing its existence as a state while upholding the SED's political autocracy. The SED's strategy to achieve this goal was to create a positive image of the anti-imperialist and "democratic" peace-state of the GDR, as opposed to the imperialist West Germany within the Cold War rivalry. This context threatened the existence of the GDR, the necessity of an "alternative Germany" in the sense of the "discourses of danger." As the SED successfully tied the GDR's state survival to its reign, opposition to the SED was equated to opposition to the GDR and treason. Thus, the East German foreign policy actors had internalized loyalty to the regime itself, as a conditio sine qua non for the state's survival and thus their own.

\subsection{External Limits I: On the Kremlin's "Short Leash"}

Apart from defining East Berlin's boundaries of foreign policy maneuvering room - the concreate "limits of foreign policy" - Moscow also provided the GDR with a promise: To guarantee its existence as a state coupled with the survival of the SED and the continuation of its leadership.

\section{Phase I of East German Foreign Policy: Benefits for East Berlin Despite Full Soviet Control}

During Phase I of the GDR's foreign policy, Moscow laid bare that it would not shy away from direct military control to uphold the SED regime with force - directly when it ended the "June Uprising" in 1953 in the GDR, and indirectly when the SED supported Moscow's intervention in the ČSSR to stifle the reform movement of the "Prague Spring" in 1968. This "guarantee of existence" was combined with an extremely high level of economic and political assistance to uphold a persistent level of control over this new "Socialist Germany." Nonetheless, this control changed over time in intensity and form, from high-intensity direct control to low-intensity indirect control. Also, until its international recognition in the early 1970s, the GDR needed the Soviet Union's active support as a foreign policy proxy for the GDR, as the East German state, not yet internationally recognized, was not able to act for itself. ${ }^{3}$

While East Berlin's foreign policy in the 1950 s and 1960 s mostly "copied" Soviet foreign policy, ${ }^{4}$ the GDR began to advance as an "active junior partner"s of the Soviet Union in the late 196os. In the developing world, the GDR navigated time and space within the Soviet foreign policy framework, but without doubt pursued a policy quite different from Moscow: Moscow neither had the interest

2 | Malycha/Winters, 2009, 184.

3 | Judt, 2008, 501.

4 | Möller, 2004, 330f.

5 | Wentker, 2007, 537. 
nor the capacity to engage with the same intensity everywhere within its own sphere of influence. East Berlin first reacted with a "Fill-in Policy" where the Soviet Union neglected certain policy fields or even states and secondly with a "Policy of Enhancement" where it was initiated or tolerated by Moscow. One concrete example for the latter is East Germany's engagement during the Ethiopian-Somali conflict in 1977, when East Berlin acted on behalf of the Soviet Union to support Addis Abeba. Furthermore, the GDR's engagement in the PDRY as a whole may be grouped under this kind of policy.

\section{Phase II of East German Foreign Policy: From Satellite to Junior Partner?}

The state's survival was always the top priority of the GDR's foreign policy. Thus, it remained a means to an end for internal and external consolidation while increasing East Germany's international prestige and influence. Despite the de facto recognition by West Germany and the establishment of diplomatic relations with a majority of influential states in the early 1970s, the GDR's existence still fully depended on the goodwill of Moscow. As a consequence, the SED aimed to emerge as an indispensable ally and maybe even partner for Moscow. In the words of Egon Bahr: "Being just a satellite probably isn't the most pleasurable condition." ${ }^{6}$ With the "Prague Spring," the GDR finally was able to prove its loyalty and began to establish itself as Moscow's "junior partner." Also, within less than two decades, the GDR had been able to ascend as the second industrial power after Moscow, and developed a new self-confidence. ${ }^{8}$

\footnotetext{
"For sure, in the end [usually] we gave in. Nonetheless one has to say Honecker pushed through the interest of the GDR as early as 1974/75 - even against interventions by Moscow [...]. Sometimes we did not inform Moscow at all - or at least only in rather general terms. Several times [the Soviets] complained. [...]. Sometimes we merely informed them after it was done." ${ }^{9}$
}

In the mid-1970s the mechanisms of consultations between the SED and CPSU had achieved a sufficient level of routine. After Moscow had replaced its former champion Ulbricht with the more loyal Honecker, the Kremlin appeared to have settled for observation of the GDR's activities and considerate "advice" if necessary rather than active intervention. This attitude however, should not be mistaken for Soviet weakness. Rather, it was in the Kremlin's best interest to "steer" East Germany with the least effort possible.

6 | Interview with Egon Bahr February 3 2009, in: Müller, 2009.

7 | Gasteyger, 1976, 38.

8 | Scholtyseck, 2003, 23.

9 | Seidel, 1999, 1. 


\section{New Ways in the Global South End with the International "Wind of Change"10}

While the GDR's narrow scope of action within the framework of the Kremlin's foreign policy did not expand considerably, East Berlin's willingness and ability to become active within this framework increased significantly after the mid-1960s. Over time, a congruency of interests of Soviet and East German foreign policy, especially in the Global South, had emerged. Thus, given limits might not have appeared as restrictive for East-Berlin:

“[Our position] corresponded [with the Kremlin's] in most situations like developmental policies. Not due to the feeling we had to defer Moscow, but due to an identical ideological perspective on the 'Third World' as 'anti-imperialist' allies." 11

Also, the clear "limits of foreign policy" had a rather beneficial side effect for East Berlin: Their inclusion as an important factor of Soviet foreign and security policy offered East Berlin other options to expand its international position. ${ }^{12}$ With the blessing of the Soviet Union, ${ }^{13}$ the GDR became considerably active in certain states in the Global South and within the framework of international organizations and conferences, such as the sub-organizations of the United Nations Organization or the CSCE Process, by acting as the "honest broker."

Moscow's comparably modest reaction to the reformist movement in Poland in 1980 signaled the rise of a new international climate. And even though the GDR kept strictly in line with all questions of Soviet security and armament policies during the 1980s, the inflexible regime in East-Berlin was not able to follow the political changes taking place in the Soviet Union at high speed. Instead, the SED leadership obstinately held on to the ideological truths of Marxism-Leninism and the Cold War. The expansion and increased flexibility of East Germany's "limits of foreign policy" staked out by Moscow overexerted not only its foreign policy in the end, but also its sclerotic state and regime.

\subsection{External Limits II: Competition is Good for Business or how Bonn justified the Existence of a "Socialist Germany"}

Apart from its dependency on Moscow's goodwill, East Germany grew into the role of West Germany's immediate competitor: For political and economic success, international reputation, and especially the German population's support. However, West Germany's economic head start, in combination with better

10 | The Scorpions, Album "Crazy World," Lyrics “Wind of Change” in English and Russian.

11 | Winter Heinz-Dieter, in: DDR-Außenpolitik aus heutiger Sicht, 1994.

12 | Muth, 2001, 24.

13 | Scholtyseck, 2003, 35. 
conditions for reparation payments ${ }^{14}$ and a more flexible economic system, made certain that the venture to beat the competitor through economic success would fail. In addition to that, Bonn hoped to position West Germany as the "shop window of the West"15 to draw the GDR's population, especially the young and qualified, across the border and in doing so, destabilize the GDR's political system. After the national uprising on the June 17 1953, the success of this "Magnet-Theory"16 became more and more a harsh reality for the SED regime. Ulbricht tried to react with his theory of a uniquely socialist way of economic development. The GDR was supposed to follow a supposedly more social, humane and, in the long run, more economically successful path of development. But Ulbricht's famous formula to "outdistance [the FRG] without catching up" ${ }^{17}$ of 1958 never became reality. ${ }^{18}$ The West's economic growth and liberties coincided with mounting pressure on the political opposition and the urge of the disaffected in the GDR to leave.

However, direct competition did not end with direct comparison of the two systems. While the GDR at first aimed for a unified Socialist Germany, Bonn considered itself the only legitimate German government, offering citizenship to all Germans, East and West. With this, Bonn denied East Berlin the recognition as an equal member of the international community of states. As a consequence, it had been the SED's foremost interest to achieve the international recognition of their state to at least internationally legitimize their claim to power. Accordingly, this was the major goal of the GDR's foreign policy endeavors until the early 1970s. In the international sphere, Bonn's claim to exclusive representation was translated into the so-called "Hallstein Doctrine" of 1955: Bonn threatened to cut diplomatic ties with any state which established relations of this kind with the GDR. For more than 15 years, the "Doctrine" barred regular diplomacy for the GDR.

\section{Establishing Itself as a State in Its $\mathbf{0 w n}$ Right}

Even though East Berlin did not have anything at its disposal that could compete with Bonn's financial, economic, or technical resources, the GDR nonetheless was able to emerge as a rising industrial nation in the mid-196os. Especially in the fields of consulting for the governments of the "partner countries," education, and vocational training, East Germany was able to offer support on a considerably high level. Furthermore, East Berlin successfully marketed their own educational system and created an image of "East German culture." ${ }^{19}$ As a consequence, the

14 | Wehler, 2008, 467.

15 | German: Schaufenster des Westens, in: Haftendorn, 2001, 50 and Alisch, in: Timmermann (ed.), 2012, 249.

16 | German: Magnettheorie, West German interpretation in: Abelshauser, 2005, 402; Scholtyseck, 2003, 13; East German interpretation in: Stöver, 2007, 311.

17 | "überholen ohne [sie] einzuholen," in: Schroeder, 2006, 95.

18 | The est. productivity before 1961 was about half of the FRG's, Scholtyseck, 2003, 23.

19 | Das Gupta, in: Wengst/Wentker, 2008, 119. 
GDR was ready and able to emerge as a "normal" international player after the "wave of recognition." Thus on the first glace the de facto recognition by Bonn finally had freed the way for East German foreign policy. But recognition also brought new challenges with it. The second phase of the GDR's foreign policy was predominantly characterized by East Berlin's permanent effort to balance its "rapprochement" to Bonn while keeping the necessary distance from "imperialist Germany" ${ }^{\circ \circ}$ so that the GDR's existence as the "better Germany" could still be justified.

\section{Changing Relations, Changing Challenges}

Apart from its "de facto recognition" by Bonn, the most important outcome of the "Grundlagenvertrag" for East Berlin had been the installation of the "direct line" ${ }_{21}$ between the two Germanys. Until then, any contact between them had been mediated by Moscow and "in accordance with [the Kremlin's own] interests." From then on, the GDR at least tried to realize its own policy without the Soviet's permission for every move. Economic relations with the West in general and the FRG in particular steadily intensified: Between 1970 and 1975, foreign trade with the "capitalist states" doubled and the "West Mark" advanced as the second if not the most important currency. ${ }^{23}$ Not surprisingly, this special treatment of East Germany significantly affected relations with Moscow and the Eastern Bloc.

In this early days of political exchange between the two Germanys, the GDR's dilemma had become obvious: At first international détente, and thus Moscow, had demanded rapprochement with the unloved sibling state; later on it was the SED's economic need that demanded it. Regardless, any relaxation of relations between the blocs, and thus between the GDR and FRG, somewhat questioned the GDR's justification for its existence.

\section{State without People?}

"What kind of state is this which has a territory, people living in it, which has borders but not a state population of its own? “24

(Siegfried Bock, former chief-diplomat of the GDR)

When it had become clear that the GDR wouldn't be able to realize its goal of a unified socialist Germany, East Berlin changed its approach to the German nation and began to propagate the "socialist nation" of the GDR. Two important parts of this policy of "establishment of two German nations" were the abolishment of the "unified German citizenship" advocated by Bonn and the recognition of GDR

20 | Scholtyseck, 2003, 33.

21 | Wentker, 2007, 371ff and 413ff.

22 | Bahr, in: Die zweite gesamtdeutsche Demokratie, 2001, 192.

23 | Haftendorn, 2001, 162.

24 | Interview with Siegfried Bock Sep 18 2008, in: Müller, 2010. 
citizenship. But citizenship was not the only nor the most acute issue questioning facing the GDR's national sovereignty: To finally claim full sovereignty over its territory, East Germany needed to include West Berlin, the West German enclave surrounded by the German Democratic Republic. Securing its existence and liberty on the outside, that is, external sovereignty, remained the major priorities of the GDR's foreign policy. The de facto recognition by the Federal Republic of Germany did not do much to change this: The GDR never had been able to fully acquire all three fundamental prerequisites of a sovereign state introduced by Jellinek. ${ }^{25}$

Even though the SED had erected and secured an undisputable Staatsmacht, its Staatsvolk remained undefined as GDR citizenship was contested by Bonn and its Staatsgebiet appeared to be fragmented with the island of West Berlin in the middle. Thus, while the SED regime was able to establish and uphold state power, it constantly was being questioned - by the government in Bonn, but also by dissidents and opposition from within the GDR. Even though disagreement on power distribution exists in any state of the world, the SED considered it necessary to eliminate any dissident voices and install one of the most intensive systems of state control in Western history over its citizens. One may interpret this policy as the attempt to compensate for the imperfection of the other two characteristics of Jellinek's definition of the state: A state's territory and a state's people.

\section{Internal Limits of Foreign Policy: Between Economic Exhaustion, "Double Standards" and Political Friction}

Compared to Western democracies, the internal structures of the GDR did not only form a very different background for foreign policy activities, but also played quite a different role for foreign policy generation itself.

\subsection{Economic Exhaustion beyond Marxist-Leninist Principles: The "Double Standard" of East German Foreign Policy}

"Considering its limited resources, the GDR had to distribute its support for the developing countries very wisely." 26

(Hans Bauer, MfS resident in Aden in the early 1980s)

Economic welfare in the GDR rather was a secondary foreign policy goal rather than a foreign policy priority: Both the internal economy and foreign trade were policy fields subordinate to the major goal of the SED's internal and external

25 | The three prerequisites are territory, power, and citizens, in: Jellinek, 1900, 393 and 426.

26 | Interview with Hans Bauer June 202011. 
policies: Securing the state's existence and thus the SED's survival. The 1970s had witnessed an economic but illusory boom and major mistakes in economic policies produced an economic crisis in the early 1980 os. $^{27}$ Without doubt, the economic bottlenecks had a significant impact on East Germany's foreign policy, especially in the "developing countries." First, aid and technical assistance from the GDR turned out to be less and less reliable due to supply shortages and a simple lack of money. Thus, East Berlin oftentimes was not able to keep its foreign policy promises and technical projects in particular suffered from parts shortages in the GDR. ${ }^{28}$ As a result, East Germany was not able to compete with other economic actors regardless of its political standing and prestige.

Second, economic need led to the open dismissal of ideological ideals. The need for foreign currency and oil became highly pressing during the 1980 s and created a detectable "double standard" in East German international behavior. While the GDR's foreign policy officially was based on ideological principles, pragmatic reasoning regularly overruled Marxist-Leninist ideals if it was considered beneficial for the GDR: The SED opted for "Realpolitik" whenever it was deemed suitable. The KoKo and its dummy companies acquired the foreign currency desperately needed to keep the GDR and its economy afloat and alive. One of the most striking examples of this "double standard" was the arms trade with both sides of the Iraq-Iran War in the 1980s. According to East German Vice-Minister of Foreign Policy, Heinz-Dieter Winter:

“[The arms deliveries to Iraq and Iran] fully contradicted our neutrality and our advocacy for the termination of the war. Nonetheless, I was informed that these deliveries existed." 29

But as opposed to other contemporary commentators' versions of events, this was not a singular case. A similar decision was made with regard to the two Yemens in the late 1980 s, as was shown in the respective analytical chapter. Furthermore, the "peace state" GDR delivered arms and weapons to terrorist groups like the "Abu-Nidal Group", well aware of who they sold their products to. ${ }^{30}$ This "double standard" was an inherent part of East German foreign policy. Economic need dictated foreign policy action to secure the SED's survival as the leading vanguard of a one-party system. This undeniably demystifies the prevailing notions of East Germany as an advocator for the "small nations," a "peace state," its solidarity with the oppressed, and thus its foreign policy strategy of the "honest broker."

27 | Schroeder, 1999, 199.

28 | See e.g.: Scharfenberg, 2012, 45; Interview with Wolfgang Bator May 272011.

29 | Interview with Heinz-Dieter Winter July 3 2012; On the GDR's arms deals with Iraq and Iran also see: Deutscher Bundestag (ed.), 1994, $191 \mathrm{ff}$.

30 | Deutscher Bundestag (ed.), 1994, $206 f$. 
In the end, and mostly due to economic reasons, the SED regime had to open the GDR to the world - and with it, to ideas of social alternatives and hopes for political change. To assure the survival of an SED-led GDR, the party reacted with increased internal control to curb oppositional forces. Whether the SED leadership had been informed of the looming danger by the MfS but did not have the time to act, ${ }^{31}$ or in reality did not believe in the "inherent dynamics" of the CSCE process ${ }^{32}$ and "rapprochement" with West Germany is of not much importance here. The crucial point is that the SED regime was neither able to shield its society from these influences, nor to react in a flexible way by integrating them. The regime was not able to adjust to political change, not even to prevent its own downfall.

\subsection{Assessment of Friction Losses between Foreign Policy, Ideology, and the Political System}

To be able to reach a final conclusion with regard to East German foreign policy making, the actors of the field have to be taken into consideration. The division of competencies in the field of foreign policy between party and state, and also between political reality and the foreign policy ideals of Marxism-Leninism, caused considerable friction. Muth locates the process of the establishment and consolidation of the GDR's foreign policy apparatus, the evolution and settling down of the system, as well as the recruitment and education strategy for its personnel, in the period from 1949 to about $1972^{33}$ - a time period that coincides with the two phases of foreign policy of the GDR due to the internal and external consolidation of the GDR. The division of responsibilities in the field of foreign policy changed considerably over time due to two factors: First, the development of the efficiency of the complex relation between party and state and second, the personality and power network of foreign policy functionaries. Based on these two factors, three phases of responsibilities in foreign policy making can be identified: The first "Phase of Collective Improvisation," from the founding of the GDR to 1961, the second "Phase of Consolidation and Professionalization," until international recognition in 1971-72, and the third and last "Phase of Establishment Administration," until 1989, when the state, its political system, and the ruling elite were able to act from an established position.

31| Hanisch, 2012, 20.

32 | Müller, 2010, 612.

33 | Muth, 2001, 11. 


\section{From State to Party, from Bottom to Top: Centralization of Responsibilities and the "Second Version" of Foreign Policy}

Over time, and just as in other fields, responsibilities in the field of foreign policy were either withdrawn from constitutional state organs or had not been left with them in the first place. The centralization process of responsibilities and authorities in the field of foreign policy did not stop at the party level, however, but expanded into the party apparatus itself. Over time, the Central Committee of the SED lost authority to the smaller, more elitist circle of the Politbüro. While some individuals were able to overcome the centralized structures of foreign policy making, the reasons for this can be found in a combination of personalities and connections to the "inner circle," and sometimes also within the responsibilities of the organ or institution itself. As a popular means of assuring the functioning of "democratic centralism," this often led people holding similar posts in both the party's CC and the government. Also, the superiority of the party toward the specialized ministries and its technocrats and experts led to the most absurd friction losses of expertise: "The political leadership [of the SED] evaluated the credibility of [foreign policy] analysis less based on their content, but rather on ideological criteria." ${ }^{34}$ In the MfAA, this regularly led to the production of the "second version" of reports and analyses for the SED leadership that was apparently ignorant of political realities.

When Honecker replaced Ulbricht, he furthered this centralization process from state to party, from bottom to top, and actively drew foreign policy authority toward himself. Storckmann even goes so far to consider all party organs irrelevant during Honecker's reign. ${ }^{35}$ However, Honecker was still part of and thus dependent on the party apparatus and the logic of "democratic centralism." Despite his undeniable plentitude of power, one has to recognize the existing limits of human capacity, as he could not be everywhere at the same time, and also had to balance the inherent competition between the various organs included in the process of foreign policy making. In addition, after Honecker had taken power and his confident Fischer was installed at the top of the MfAA, the distribution of responsibilities remained quite stable. Apart from minor changes, the power constellations within the foreign policy apparatus remained surprisingly constant over the years. This continuity in personnel and thus in policy style not only in the field of foreign policy but almost all other fields significantly added to the almost proverbial image of the SED leadership in the late 1980 s as "overaged and overcome." To carve out the more complex layers of foreign policy making below the centralized "primacy of the party" and Honecker's "rule of the Sun King," further research on these structures is needed. For now, one may settle for the image of "party meritrocrats" who, under their "maestro" Honecker, divided the responsibilities for foreign policy making among their small and powerful circle.

34 | Muth, 2001, 22. Muth refers to several diplomats and foreign policy personnel of the GDR.

35 | Storckmann, 2012, 80. 


\section{The Fragmentation of East German Foreign Policy Making}

Clearly, the intertwined foreign policy responsibilities did cause a certain fragmentation of the GDR's foreign policy making. ${ }^{36}$ Even though decision-making itself can be considered quite efficient, as it did not include a democratic process, the ruling party still had to rely on the state apparatus and its functionaries to further elaborate the party's directives and execute them while still constantly demanding full control of the process. In addition to that, the field of foreign policy within the state was not an exclusive matter for the MfAA, so that competition and miscommunication lead to additional friction losses. This setup led to an extremely slow and long-winded process of policy-making. Based on his analysis, Möller concludes that in the field of foreign policy and international relations in particular, the SED's claim to absolute power could not be upheld due to actors' and institutions' self-interests on the one hand, and the incalculable impact of the international environment and its actors on the other. ${ }^{37}$ Without doubt, these two dynamics had a volatile effect on East German policy-making that more often than not opened additional room for maneuver for certain foreign policy actors.

36 | Wippel, 1996, 16.

37 | Möller, 2004, 327. 



\title{
CHAPTER 16. South Yemen as the Model Case of a Possible East German Foreign Policy
}

\author{
"As opposed to the Soviet Union, [the GDR] was a \\ small country, comparable [to South Yemen in size and \\ population.[...] And small countries clearly preferred to \\ follow the example of other small countries." ${ }^{1}$ \\ Hans Bauer, East German advisor to the Yemeni government
}

\begin{abstract}
After the Suez Crisis and the Six-Day War, the Middle East and its major conflict, the Arab-Israeli dispute, were fully included into the wider frame work of Cold War rivalry. The founding of an independent South Yemeni state in 1967 coincided with the first tentative steps taken by the GDR toward a full-fledged foreign policy. This foreign policy included a variety of strategies, such as those of "focus and low-profile," "socialist orientation" and the "strategy of the honest broker." Not entirely coincidental, all of this happened in the middle of the phase of Soviet expansion in the region: ${ }^{2}$ Moscow's policy demanded coordinated action of the Warsaw Pact states under Soviet supervision. ${ }^{3}$ East Berlin readily filled this role, while it had to live with the restraints produced by its dependence on the Kremlin and West German policies. As a consequence, the GDR's policy in the Middle East can be characterized as a "fill-in policy" between its two major foreign policy determinants, Moscow and Bonn. But this policy can nonetheless be considered a very creative one.
\end{abstract}

The following chapter embeds the findings on East German policy in South Yemen into the wider framework of Soviet and East German engagement in the Middle East with regard to the empirical limits of the GDR's policy in Yemen.

1 Interview with Hans Bauer June 202011.

2 | Halliday, 2005, 99.

3 Storckmann rightly decries a lack of sound archival findings on the coordination between Moscow and its political orbit of Warsaw Pact states due to lack of access to the relevant archives in Moscow: Storckmann, 2012, 38. Nevertheless, archival documents of the GDR allow for some insights into the processes and thus general conclusions to a certain extent. 
Based on these findings, the chapter concludes with the question: Can the case of South Yemen be considered both an exceptional case and a model pointing toward a Weberian ideal type of East German foreign policy?

\title{
1. Best Friends with Benefits: Soviet and East German Engagement in South Yemen as Part of a Regional Strategy in the Region
}

\author{
"Now Socialism has taken root on three continents."
}

(Fritz Balke quoting a member of the SED Politbüro)

In the late 1950s, the Soviet Union had opted to join forces with "progressive" regimes in the Middle East and increased the intensity of its engagement successively from "influence" to "involvement" and "intervention." At the time, Moscow did not hide its claim to political and military control over the Arab states. Especially during the period between the Suez Crisis and the decrease of Soviet involvement in the mid-eighties, ${ }^{6}$ the Soviet Union aimed to present itself as a major, if not the dominant, external actor in the region. Motivated by geopolitical considerations of national security, Moscow nonetheless had begun to include ideological justification, such as the concept of "socialist orientation," in its Middle East policy. While Soviet engagement gradually intensified, the rules of the Cold War changed in a way that demanded more restraint with regard to obvious intervention in other's countries affairs.

This change in "Cold War conventions" coincided with the consolidation of the relationship among the allies within the Western and the Eastern Bloc. In case of the Soviet Union, this included the increase of competition among its satellite states for missions and for Moscow's benevolence.7 The financial and material support coming from the Warsaw Pact states not only eased the economic pressure from engagement in the Middle East for the Soviet Union. Most importantly it eased pent-up political pressure due to the change in "Cold War conventions," as the engagement of other states of the Warsaw Pact aimed to veil the actual intensity of Moscow's engagement. This "low-key strategy," in which Soviet

4 | Interview with Fritz Balke on May 232011.

5 | Choueri, 2000, 192.

6 | Halliday even states that as early as 1980 the bloc confrontation as the dominant conflict was supplanted by a regional contention, the Iraq-Iran War, Halliday, 2005, 100.

7 | Until the states of the Warsaw Pact finally agreed on the basic principles of coordination for military relations with the Global South, in: Protokoll 11. Sitzung Komitee der Verteidigungsminister TS des Warschauer Vertrages vom 4 bis 7.12 1978, Ost-Berlin, in: BArch DVW 1/71035, 318-357; Protokoll 12. Sitzung Komitee der Verteidigungsminister des Warschauer Vertrages vom 2 bis 6.12 1979, Warschau, in: BArch DVW 1/71036, sine pagina. 
engagement was sometimes mediated through secondary actors, such as the ČSSR or the GDR, was applied in cases of significant military support and conflict intervention in the region in Soviet interest. Moscow hoped to be able to deny its active involvement if necessary so as to minimize the impact of its on action on the superpower relations. ${ }^{8}$

When Moscow's good relations with Egypt successively deteriorated in the early 1970 s, the Kremlin began to shift its attention to other allies, old and new, to uphold its power status in the region. During this period of consolidation in the Middle East, Moscow also began to expand its footholds, such as Aden, mostly through the advancement of the revolutionary nationalist movements. However, this policy of Marxist-Leninist expansionism in the "Global South" in the end clearly exceeded Moscow's economic abilities: When the Soviet star in the Middle East was on the wane after the mid-1980s, its allies were among the poorest and most isolated in the region. As a consequence, the Kremlin's interests transformed from long-term involvement to "more immediate benefits" 9 - such as the use of military, naval, or political bases at the most important strategic locations.

In Yemen, still one of the poorest countries today, Moscow had made an extraordinary long-term commitment, hoping for a reliable and stable ally that could serve as one of the major Soviet bases in the Middle East. The Kremlin's strategy in South Yemen can be subsumed under its wider policies in the Middle East the Global South in general, as it rather simply aimed at expansion of influence, if possible at a cost to the Western powers. Politically, Moscow's strategy mainly relied on ideological arguments, for the large part the support of "liberation movements" against the "imperialist West," combined with financial and military incentives, either directly or mediated through local henchmen. ${ }^{\circ}$ Even though the support policy of the "liberation movements" and the communist parties became less aggressive and obvious, Moscow did never fully discard the option until the late 1980 s. ${ }^{11}$ The neighboring conservative states in the region were well aware of this role of South Yemen as the original "troublemaker" and a possible duplicate of the Soviet system.

Among all of the Soviet Union's allies in the Middle East, the Aden-Moscow relationship has to be considered a special one. This relationship has long been neglected by analysts or relativized in comparison to Soviet ties with Cairo or

8 | Chubin, Adelphi Paper No.157, 1980, in: The Intl. Institute for Strategic Studies (Ed.), 302. 9 | Yodfat, 1983, 115.

10 | The support of the Popular Front for the Liberation of the Arab Gulf (PFLOAG) and its cause to remove "the monarchies in the Persian Gulf" is one of the major examples of joint foreign policy projects between Moscow and Aden. Chubin, 1980, in: The International Institute for Strategic Studies (Ed.), 301.

11 As the participation of the Saudi Communist Party in the leftist Party Conference in Cyprus of 1985 had shown, in: Cigar, 1985, 784. 
Bagdad. However, Soviet presence in Egypt never reached an extent comparable to that in South Yemen, in what Cigar calls a "qualitative difference": The PDRY's "socio-political system was [...] remolded on a Marxist-Leninist pattern." ${ }^{\text {" In }}$ addition to that, Halliday argues, "[d]espite the undoubted divergences between Moscow and Aden, and the enduring nationalism of the South Yemenis, there had not been the kind of break that had occurred in [...] Egypt and Iraq." ${ }^{13}$ All in all, South Yemen has to be considered "the closest [and most loyal] of [the Kremlin"s] Arab allies."14 Even though there never was agreement on all fields between Aden and Moscow, the common ideological basis and growing dependence on Soviet support and safekeeping without doubt had created a basic congruence of interests.

Commentators at the time described South Yemen an "ideological model," an "ideological victory" 15 for the USSR - a view shared by Moscow. The external view of these witnesses comes close to what can be concluded today, but misses the actual conditions just as often: This perception simply elevates the Soviet-South Yemeni relations beyond their actual significance and exaggerates with regard to Soviet engagement. In 1985 Norman Cigar, an Officer of US Department of Defense, summarizes: “The Soviets have sought to establish their presence in as many sectors as possible." ${ }^{16}$ However, and especially in the beginning, Moscow rather focused on those sectors which immediately benefited its policy in the region. Then, its policy was combined with the GDR's activities: Moscow advanced to become Aden's primary "source of political and socio-economic guidance," while East Berlin served as Aden's "role model" of a socialist state led by a Sovietstyle vanguard party. ${ }^{17}$

Current research on Soviet foreign policy, as well as its goals, reasons, and even the intensity of engagement, remains a mere approximation due to lack of archival access to this day. South Yemen, a country where the GDR intensified its activity on behalf of the Kremlin, is a case study in which at least some features of Moscow's regional policy during this time are revealed through both secondary literature and the archival material. Halliday, not only one of the few researchers who occupied themselves with South Yemen and its foreign relations, but also the only one who also devoted extensive interest to the USSR's presence in the country, advocates for the relevance of the Aden case for the Soviet Union's Middle East policy. And rightly so. Despite the lack of any extra-territorial status, and even though the USSR officially never maintained the number of forces in the PDRY as they did in Egypt and Somalia, ${ }^{18}$ Moscow enjoyed full access to South

12 | Cigar, 1985, 793.

13 | Halliday, 1990, 217.

14 | Ibid. 1990, 178; also see: Brehony, 2013, 81; Cigar, 1985, 775.

15 | Cigar, 1985, 782.

16 | Cigar, 1985, 777.

17 | On the GDR's “model character” for the developing countries, also see: Howell, 1994, 328.

18 | Halliday, 1990, 204. 
Yemen's military facilities and Aden advanced to "the port most frequently visited by the Soviet fleet in the Indian Ocean." ${ }^{19}$ South Yemen provided the USSR with a military base and all necessary privileges in all but name.

All in all, Halliday considers the "alliance with the USSR [...] the most important component of the PDRY's foreign policy" ${ }^{\circ \circ}$ and emphasizes the political benefits and dependencies of both sides: ${ }^{21}$ On the one hand, South Yemen clearly played the dependent part. The Soviet Union promoted itself as South Yemen's external security guarantor in the region. The survival of the radical NF/YSP regime hinged on this Soviet guarantee, just as the SED regime in East-Berlin did. This clear commitment by Aden to the Eastern Bloc only added to the radical state's isolation in the region. At times, Aden even opted against the consensus of the other Arab states in support of the Eastern Bloc. ${ }^{22}$ On the other hand, small, isolated, and unimportant Aden had emerged as Moscow's only Marxist-Leninist “model state” in the Middle East. No wonder the Kremlin was ready to go to great lengths to secure "socialism on three continents," even after the shock of the "1986 crisis," and to keep its incarnated model and symbol of Marxist-Leninist expansion alive and healthy.

\section{Advocacy for an East German Foreign Policy in its Own Right}

For the GDR, the scope of action for its foreign policy was considerably small, as East Germany had to maneuver between three restricting determinants: the Soviet Union, West Germany, and the demands from within the GDR. But to simply consider the GDR's policy in the Middle East as a “residuum of Bonn's action or non-action" ${ }^{23}$ does not do justice to international relations at the time. A comprehensive assessment of East German foreign policy cannot rely on a restricted view that defines East Berlin's policy as a mere reaction to Bonn alone. Rather, one has to acknowledge the fact that - despite Bonn's early internal and external political strength - both Germanys had to maneuver within the determinants of the Cold War. Even though Bonn was able to acquire an actual degree of sovereignty toward the Western allied forces, the FRG was no fully sovereign state either before German reunification in 1990. Thus, the argument

19 | Cigar, 1985, 781.

20 | On the intensifying relationship between Moscow and Aden, See: Halliday, 1990, 178; Dresch, 2000, 134.

21 Similar to other analysts of the time like Cigar, 1985.

22 | E.g., the formal recognition of the Afghan regime opposed the common Arab position.

23 | Wippel, 1996, 27. 
that no East German foreign policy existed due to its restricted sovereignty alone does not hold.

Beyond West Germany, the Soviet Union - the GDR's midwife and the guarantor of its existence - always remained the major determinant of East German foreign policy. However, within the staked out field of international action, the GDR incrementally established itself as an international actor. Regardless of its lack of full sovereignty and thus its limited autonomy in the international sphere, East Berlin had to act on its own accord. At a certain point Moscow was neither willing nor able to watch and guide each and every step of the GDR. Rather, the Kremlin was sure that the SED would act in anticipatory obedience and embrace Soviet interests as part of its own foreign policy. East Germany had to become active itself. In the beginning, this meant copying Soviet policies as far as possible. However, the GDR had to realize that it had very different prerequisites in resources and the GDR's national interests, or at least its foreign policy priorities, were not even close to being identical to the Soviet agenda.

Due to the modest tools at its disposal, East Germany began to create its own foreign policy strategies to further its national interests. East Germany indeed developed several strategies for the Global South in general and the Middle East in particular, which together can be considered a "Middle East Policy." While East Berlin rather passively followed Moscow's orders during the first phase of its foreign policy, it was already beginning to frame bilateral relations where possible. After international recognition of the GDR, Moscow gave assignments rather than orders and left the details to East Berlin. In the 1980s, the Kremlin, due to its own emerging weakness, even tolerated single-handed decisions and strategies like Honecker's aloofness toward the new PDRY regime after the "1986 crisis." Toward Bonn, the GDR tried to react proactively to any blank spots of West German international engagement, with South Yemen being the prime example. Thus, the GDR's policy in the Middle East may be characterized as a restricted "fill-in policy" between the two determinants, Bonn and Moscow. This has to be considered more than a "residuum of Bonn's actions" though. It was a framed foreign policy based on specific strategies to pursue the interests of the state. All three of the determinants mentioned above more or less could turn into either a guarantor for or threat to the existence of East Germany as a separate state under SED leadership. Thus, East Berlin did not simply move within the given limits, but consciously worked with them. East Berlin's engagement in the Middle East in general and in South Yemen in particular clearly show that the SED developed several strategies aiming to first ensure the survival of the GDR as the SED's state and second to secure its acceptance as an international actor by expanding East Germany's international position. 


\section{The GDR in South Yemen: A Phase Analysis of Foreign Policy}

Moscow's official reading of politics in the Middle East had dominated the GDR's foreign policy approach throughout the state's existence. ${ }^{24}$ Not surprisingly, the Kremlin's high times of engagement in the region from the 1970s to the early 1980 s coincide with the GDR's most active phase in the Middle East and its engagement in South Yemen. However, in the very beginning it had been East Germany's initiative THAT promoted the connection to the future leaders in Aden. Just as in other countries of the developing world, this was part of the GDR's "lowprofile strategy" to achieve international recognition through the intensification of contacts "from below the governmental level." The major target countries of the GDR's early policies were often led by strong leftist liberation movements, which were considered promising candidates for "socialist development," especially in the Middle East.

\subsection{Toward Diplomatic Relations: The First Phase of Engagement}

In 1965 , a "fundamental resolution" on the support of the African and Arab people in their struggle for liberation with "non-civilian materials" was presented. ${ }^{25}$ After South Yemen's declaration of independence in 1967, Aden still was merely one piece in this East German foreign policy puzzle, but this was to change soon enough. In the following years, the political measures taken by East Berlin to further its goal of recognition in South Yemen laid the foundation for cooperation. During this first phase of East German engagement, lasting until 1970, East Berlin was able to build upon personal contacts, leading to the establishment of diplomatic relations between East Berlin and Aden in 1969. When the GDR and South Yemen jointly developed a new South Yemeni constitution in 1970, East Germany was able to squeeze "a foot in the door" to get involved in a variety of other policy fields. After delegating its first advisory group to South Yemen to support the draft of a new constitution, East German consultancy became the catalyst for future cooperation. These relations of cooperation, which grew in the early days of South Yemeni state-formation, emerged as the basis of trust for East Germany's policy of socialist state- and nation-building in the years to follow. From then on, East German engagement intensified continuously until the caesura of 1986 .

24 For further elaboration on these concepts see Chapter 8. The GDR and the "Arab World": A Small State's "Fill-In Policy."

25 | Otto Winzer and Willy Stoph, May 28 1965, in: BArch, DC 20/13001, BI.28-33. Also see: Storckmann, 2012, 108; Politbürositzung January 10 1967, Annex 5, in: BArch SAPM0, DY 30/J IV 2/2/1093. 


\subsection{Policy Change toward State-Building: The Second Phase of Engagement}

Until the early 1970s, the dominant motivation of East Germany's foreign policy had been securing international recognition as an equal member of the international society of states. South Yemen is one of the earliest examples where this goal was achieved. As a consequence, the SED was able to leave behind its "policy of recognition" and to introduce a new comprehensive bilateral policy toward South Yemen: With Soviet blessing and at South Yemen's request, the GDR developed a policy of socialist state- and nation-building. Whether East Germany believed itself to be able to introduce its own version of Soviet "system export" at the time is certainly debatable. Nonetheless, this is exactly what East German engagement was to become in scope and intensity: A supportive stateand nation-building policy close to neo-colonialist aspirations. Thus, one may also question whether the GDR truly wanted to serve South Yemeni needs better than Moscow. But South Yemenis apparently tended to see it that way, preferring the small GDR as a role model to the overpowering Soviet Union, as it was more comparable to its own size. ${ }^{26}$ Also, East Berlin had invested more and earlier in its bilateral relations with Aden than Moscow, so when the Soviet Union induced a policy change in the region in the mid-1970s, the Kremlin was able to use the GDR's good relations with the Aden regime for its own purposes: Over the next decade there clearly existed a "division of labour" between the superpower and its "first officer of foreign policy." While East Berlin promoted inner stability of state and society and aimed to secure the rule of the YSP and its "progressive regime" on the inside, Moscow provided for military training and equipment to guarantee security for the future Socialist state on the outside.

During the second phase of East German foreign policy from 1970 to 1978 , the "Phase of Expansion," the GDR diversified its engagement and continuously increased the intensity from "involvement" to "intervention" until the end of the third phase. Through consultancy, East Germany ensured its influence on a wide range of policy fields of the young state: Education, the media, economy, agriculture, even foreign policy and finally the establishment of a jurisdiction and security apparatus, including security policy and South Yemen's secret service, KfS. The latter played a central role in East Germany's policy of socialist stateand nation-building. In Aden, East Berlin cooperated closely with the security services of the USSR, and later on the ČSSR, the People's Republic of Bulgaria, and Hungary, ${ }^{27}$ but the MfS of the GDR considered itself the "the most important partner" of the PDRY's KfS. ${ }^{28}$ From 1970 onwards, the East German Security

26 | Interview with Hans Bauer June 202011.

27 | Zu den Beziehungen des MfS der VDRJ mit dem MfS der DDR und mit Sicherheitsorganen anderer Länder, in: BStU MfS Abt. X Nr. 234, Part 1 of 2, 105.

28 | Ibid.,102. 
Service MfS continuously expanded its engagement and advisory presence in South Yemen, even reaching into other policy fields such as legislation and legal affairs in general.

The GDR's high level of engagement during this time in almost all social and political fields was furthered by two dynamics that appear to contradict on first glance. On the one hand, the PDRY had publicly aligned itself with the Eastern Bloc, while the US and Bonn for the time being had given up any aspirations in South Yemen. In addition to that, the Kremlin not only acquiesced to East Berlin's concrete engagement in South Yemen, but even integrated it into its own, more active policy in the region in the mid-1970s. ${ }^{29}$ On the other hand, the GDR had to cope with other competitors from outside the Eastern Bloc who sought Aden's attention and trust and thus this smallest sphere of influence: Western experts, UN envoys, and representatives of the World Bank and the IMF. This was one of the major reasons why East Berlin would continually work on South Yemen's behalf, such as by presenting itself as the "honest broker" as opposed to the representatives of the Western world: Within GDR diplomacy, but also among the Yemeni public, it was the GDR's declared goal to ward off these "advances of imperialism."

\subsection{Founding of the Vanguard Party and Consolidation: The Third Phase of Engagement}

For Moscow and its East German henchman, the most pressing topic in the PDRY's domestic politics during the 1970s was the establishment of a Sovietstyle vanguard party. Thus, the founding of the Yemeni Socialist Party in 1978 turned out to be the catalyst event that further intensified the commitment of the Eastern Bloc. This event also initiated the third phase of East German activities, the "Phase of Continuity and Consolidation." Moscow clearly had aimed for the establishment of this vanguard party and kept entertaining a high level of engagement. Furthermore, Moscow added technical assistance to its two major fields of activities, military and ideology. The Kremlin's policy was complemented by the highly diversified East German engagement: East Berlin continued its involvement in the crucial civil fields of law, governance, economy, education, and the media and significantly intensified cooperation with the security apparatus. Nonetheless, it was also time for Soviet and East German engagement to yield concrete results. Evaluation of the performance of the KfS, for example, indicated that the secret service so far had not produced much valuable information. Also, the majority of state institutions were not working efficiently, and despite the early successes in installing "democratic centralism" as the major structural principle,

29 | Letter Scharfenberg and Grünheid, Ministry of Planning, January 1 1974, in: PA AA, MfAA, 166276, 79. 
socialist state- and nation-building was far from being accomplished. ${ }^{\circ}$ Personal political conflicts and internal social obstacles seemed to prevent profound improvements and the PDRY's regime was searching for the reasons for failure outside its borders rather than within. Moscow and East Berlin had invested a lot to create a secure foothold and a dependent ally in the region that would follow their guidance. But as the events of 1986 were about to demonstrate, these investments were not to obtain much success.

\subsection{Aden's Crisis and East Berlin's Cold Shoulder: The Final Phase of Engagement}

In January 1986, the GDR's cooperation and steady intensification of relations with South Yemen were brought to an abrupt end. The internal coup among the leadership of the YSP caused the removal of the principle political actors - the leaders and "heroes" of the revolution - from their posts. Both external actors, the Soviet Union and the GDR, had to accept the unpredictability of the PDRY, but drew quite different conclusions. Moscow, on the one hand, picked up right where its engagement had been interrupted by the "1986 crisis," explicitly tightening its grip on its outpost at the Bab al-Mandab and clearly aiming to further increase control over what was left of the PDRY. The GDR, on the other hand, fully terminated its civil activities. Long-term personal friendships had nourished the relations between the GDR and the PDRY, which had yielded advantages such as unofficial channels of communication. These personal relationships were particularly important to the GDR's ties with the PDRY, as foreign-policy-making of the 1980 s was mostly focused on the person of Honecker, who rejected any rapprochement with the new regime right away. The stable base of relations disappeared and left a diplomatic-political vacuum that the rigid political system of the GDR prevented from being filled again in the few years the two states had left. Especially due to Honecker's irrational foreign policy, which followed his personal preferences rather than the GDR's national interest, this fourth and last phase from 1986 to 1990 simply was too short for relations to recover.

30 | Operative Einschätzung des GMS “Leonhardt“ - Vorg.-Nr.XV 3481/82, August 28 1986, HV A/III/AG/018, in: BStU MfS AGMS Nr. 10208-88, 67; Interview with Hans Bauer June 202011. 


\section{South Yemen as the Exceptional Case and an Approximation to the "Ideal Type" of East German Foreign Policy}

"For the GDR, South Yemen was all about erecting a bastion of socialism. Regardless of its size, there was the hope that [the model of] South Yemen would radiate into the Arab world." ${ }^{31}$

(Fritz Balke, East German diplomat assigned to the policies toward both Yemens in the Section Near and Middle East of the MfAA in the 1980s)

The GDR's activities in South Yemen were by no means the rule but were rather the exception of East German foreign policy in the Global South. But due to the intensity and diversity of engagement, this study concludes that this exceptional case can also serve as a theoretical "ideal type,"32 a model case that laid beyond West German restrictions and within a scope of action approved by the Soviet Union. This leads to the major hypotheses of this study: In the sense of a paradox, ${ }^{33}$ the case of South Yemen may not only be the "exception of the rule," but also a model pointing towards the possible "ideal type" of the "general," a "utopia" of East German foreign policy towards the Global South.

Following Kierkegaard's notion of the general, it may be concluded that this exception carries a meaning beyond its own, as the exception defines the normal situation as well as itself. ${ }^{34}$ Only in relation to the "normal condition" we may detect the deviation, the "exceptional case." When reconsidering the "normal condition" of East German foreign policy, two factors, or determinants, create the lion's share of what is considered the scope of action of foreign policy for the GDR: The Soviet Union and the "other" Germany, the Federal Republic in the West. Both major determinants of the GDR's international activities manifested in different ways than they usually did for East German foreign policy: First, South Yemen is one of the few cases where West Germany and West German presence did not play an immediate role in determining the GDR's foreign policy beyond the general question of international diplomatic recognition of East Berlin. Thus Bonn did not have a direct impact on the GDR's activities on the ground and was absent as one of the major determinants of East German foreign policy. Secondly, Moscow

31 | Interview with Fritz Balke on May 232011.

32 | Weber, 2002, 10.

33 | This paradox may be resolved as a "dialectic." "Das reinere dialektische besteht darin, daß von einem Prädicat eine Verstandesbestimmung aufgezeigt wird, wie sie an ihr selbst ebenso sehr das Entgegengesetzte ihrer selbst ist, sie sich also in sich aufhebt," Hegel, 1961, 214. On the benefits and limits of the concept of "dialectic" in modern thought in general and the social sciences in particular, especially with regard to the differences between the "three-step" of Thesis, Antithesis, Synthesis" and the so-called "Hegelian Dialectic" and its misinterpretations, see: Burch, 2004; Mueller, 1958; Popper, 2009 (1963), $180 \mathrm{ff}$.

34 | Kierkegaard, in: Schmitt, 2005 (1922), 15. 
apparently had assigned East Germany to get involved with South Yemen in the $1960 s$, even though the Soviet Union did not develop a special interest in South Yemen until the mid-1970s. By the time Moscow aimed at establishing Aden as its new unofficial military base in the region, East Berlin was a well-acquainted and respected ally of the radical South Yemeni regime. Within the granted room of maneuver, Moscow had left East Berlin to its own devices for almost a decade, during which the GDR had developed a self-confidence different from its typical dwarfed self-perception. In this, South Yemen, without doubt, was the "exception to the rule" of East German international performance.

However, this "exceptional condition" may not only be considered the exception from the norm. The "exceptional case" of GDR foreign policy in South Yemen may also be considered a model case pointing the way towards a Weberian "ideal type,"35 a "utopian" idea of East German foreign policy. With his "Idealtypus," Weber first of all introduced an instrument to analyze singular cases, but at the same time it expands the view of the analyst towards the general phenomenon, formed by the sum of singular cases. By "generating [one or several] 'ideal types' from limited empirical material [one may] compare further empirical material with it" ${ }^{6}$ and draw conclusions from the similarities and differences between material and ideal type. So this "utopia," though it never existed in reality, may be derived from the singular case of East German foreign policy as it was planned and implemented in the PDRY: Aden was one of many possible foreign policy futures that were realized nowhere else.

How does the "exceptional case" of East German foreign policy, the case of South Yemen, point toward an "ideal type" then? On the one hand, the two major determinants of East German foreign policy allowed for foreign policy activities and self-direction well beyond the regular East German scope of action: The Soviet Union assigned East Berlin to actively engage in the stabilization of the new state in south Arabia as well as its regime, while the Federal Republic of Germany was conspicuously absent from Aden. Bonn's foreign policy simply had no immediate impact on East German activities in South Yemen. On the other hand, South Yemen more than welcomed East German help as a fellow "small country," 37 and thus accommodated East-Berlin's intended engagement in any

35 | On the ideal type see: Weber 2002, 10; Swedberg, 2005, 119; According to Weber, limited empirical material is analyzed to generate this ideal type, by an "einseitige Steigerung eines oder einiger Gesichtspunkte und durch Zusammenschluss einer Fülle von diffusen und diskreten, hier mehr, dort weniger, stellenweise gar nicht, vorhandenen Einzelerscheinungen, die sich zu jenen einseitig herausgehobenen Gesichtspunkten fügen, zu einem in sich einheitlichen Gedankenbilde," in: Weber, Max, Die "Objektivität” sozialwissenschaftlicher und sozialpolitischer Erkenntnis, in: Weber, 1991, 73.

36 | Pohlig, 2013, 304.

37 | Interview with Hans Bauer June 202011. 
imaginable way. Clearly, East Germany's diversified activities made the difference for Soviet engagement, such as in Iraq or Syria. In Bagdad and Damascus, East Germany also served as an immediate supporter of Soviet military and technical engagement, as well as the security apparatus. However, activities never achieved a comparable level of intensity or diversity, not in the realm of security, and especially not in the civil sphere: Due to lack of willingness of the host states, in this case Iraq and Syria, no policy could be implemented that approached the level of engagement of the socialist state- and nation-building policy in Aden.

In conclusion, conditions in South Yemen were as close to "ideal conditions" 88 for East German foreign policy making as they could ever be under the rules of the Cold War: An exceptional room for East German maneuver allowed for a high intensity of engagement. South Yemen advanced not only as one of the few East German focal countries, but also achieved one of the highest levels of East German foreign policy engagement outside the Eastern Bloc. ${ }^{9}$ Thus Aden is one of the few, if not the only case, where the GDR was able to design and apply an at least partly self-directed comprehensive foreign policy. Based on this observation, one may consider the policy designed for South Yemen a model policy, a kind of blueprint suggesting a theoretical "ideal type" of East German foreign policy toward states of the Global South. In other words: If East Germany had had the autonomy, scope of action, and the resources to do so, its foreign policy towards other countries in the Global South could have looked pretty much the same way as it did in Aden - if the host state cooperated.

38 | "Ideal conditions" in this context means the most positive conditions imaginable. The meaning of "ideal" in the term "ideal conditions" does not correspond with Weber's idea of the "ideal type" as a theoretical notion in any respect.

39 | Apart from Cuba and Nicaragua, other intense engagement usually was focused on certain phases and did not increase continuously from the mid-1960s as it did in South Yemen. 



\title{
CHAPTER 17. Moscow, East Berlin and the "Hawks of Hadramawt": 1
}

\author{
Nation-Building or Neo-Colonialism in Southern Yemen?
}

\begin{abstract}
"The essence of neo-colonialism is that the State which is subject to it is, in theory, independent and has all the outward trappings of international sovereignty. In reality its economic system and thus its political policy is directed from the outside. [...] The result of neo-colonialism is that foreign capital is used for the exploitation rather than for the development of the less developed parts of the world." ${ }^{2}$ KWAme NKRUMah, 1965
\end{abstract}

\section{How to explore the "Limits of Foreign Policy"}

Based on Kwame Nkrumah's monograph "Neo-Colonialism: The Last Stage of Imperialism," the notion of "neo-colonialism" 3 has been used to describe the perpetuation of relations of dependence between post-colonial states and their former colonizers, as well as external powers that replaced the former colonizer. ${ }^{4}$ And while according to Nkrumah, "neo-colonialism" is considered to be an immediate consequence of colonialism and imperialism, recent research based on discourse analysis ${ }^{5}$ expanded the meaning of the term. Here, the concept has also been applied in studies concerned with newly emerging relations of dominance between external powers and formerly colonized states, as well as newly forming or reforming states in the sense of state- and nation-building, such as Iraq or

1 | Title changed for spelling consistency. Alfree, The Hawks of Hadramaut, 1967.

2 | Nkrumah, Neo-Colonialism: The Last Stage of Imperialism, 1965, ixff.

3 | Definition “Neo-Colonialism," in: Stanton/Ramsamy/Seybolt/Elliott, 2012, 332-334 and Young, 2001, Chapter 4.

4 | Nkrumah, 1965, $x$.

5 | Holzscheiter, 2014; Torfing, 2005. 
Afghanistan, ${ }^{6}$ often under the umbrella of "humanitarian intervention" 7 and the "responsibility to protect" (RtP). ${ }^{8}$ What all of these interpretations of "neocolonialism" have in common is an outright critical stance towards external engagement in domestic politics of another state, while some would recognize the external actors' intention as a qualifying factor and others wouldn't.

Nkrumah's approach, however, has not only been selected for the reflection on the limits of foreign policy due to its reception and eventual transformation, but because of its direct connection to Marxist-Leninist ideology that is discussed later on in this chapter. All of the approaches inspired by Nkrumah in the end question the basis of international action in the current world system of nation states: A state's national "sovereignty" and how to interpret it. As introduced in Part A of this analysis, this study approaches "sovereignty" in nominalist terms to be able to differentiate between internal and external state sovereignty. 9 Internal sovereignty is defined by Francis Harry Hinsley's interpretation of sovereignty, that is, the "final and absolute authority in the political community" where "no final and absolute authority exists elsewhere" ${ }^{10}$ in the respective territory. ${ }^{11}$ External sovereignty, on the other hand, is regularly defined in legal terms and based on the sovereign equality of states in the international state system and the nonintervention clause in Chapter 1, Article II(7) of the UN Charter. ${ }^{12}$ According to this principle of "non-intervention," every sovereign state has the right "to conduct its affairs without outside interference." ${ }^{{ }_{13}}$ This ties in with the major criterion used to distinguish between coercive intervention and "humanitarian intervention" before the introduction of RtP: Any intervention had to be justified by consent of the host state. ${ }^{14}$

6 | See e.g. Welch, 2008. For a critique on "Humanitarian Intervention" see, e.g. Nardin, Humanitarian Imperialism, 2006 answering Tesón, 2006.

7 | For a wider discussion on the topic of "humanitarian intervention" as a justification for military and other interference in domestic affairs, see: Welsh, 2004; Wheeler, 2000.

8 | On the origins of the RtP see: Walzer, 1977. Major document that introduced the RtP to be discussed as a new norm in international law: Report of the International Commission on Intervention and State Sovereignty (ICISS), 2001.

9 | The argument follows Georg Jellinek, 1900.

10 | Hinsley, 1986 (1966), 26.

11 Hinsley's definition rests on the essentialist understanding of sovereignty as it had been introduced by Jean Bodin and Thomas Hobbes. For a discussion of Bodin's and Hobbes' understanding of "sovereignty" see: Schmitt, 1922, 33. Furthermore, Hinsley includes Max Weber's definition of the state as the agent claiming and owning the "monopoly of the legitimate use of [physical] violence within a certain territory," Weber, 2004 (1919), $310 \mathrm{f}$. 12 | UN Charter of October 24th 1945.

13 | "Case Concerning the Military and Paramilit. Activities in and against Nicaragua (Nicaragua v. United States of America)," Sep. Opinion of Judge Nagendra Singh President, 1986.

14 | On the question of consent in military intervention see e.g. Lieblich, 2011. 
Now, one may transfer this divide used for "rightful military intervention" to nonmilitary intervention in domestic affairs: "Consent of the host state" may serve as a criterion to judge whether the GDR's foreign policy in South Yemen, and actually any other foreign policy as well, transgressed the "limits of foreign policy," in the sense of "imposition" or "neo-colonialism." In more concrete terms, this distinction is occupied with the question of whether it is only the external actors' interests that determine their engagement or if the "neo-colonized" or "host" state actually demanded or needed this intervention. East German engagement in South Yemen is reconsidered with a focus on the motives for this engagement, that is, its foreign policy intent. In so doing, this analysis explicitly differentiated between intensity and intention of action, as opposed to Prados' approach, ${ }^{15}$ and includes an assessment of possible South Yemeni agency, the "receiving side" of this foreign policy.

As shown above, the notion of "neo-colonialism" as it is applied in current debates also encompasses the more problematic side of external support for stateand nation-building, and thus is considered extremely useful to interpreting the GDR's foreign policy of socialist state- and nation-building in the PDRY in normative terms. In addition to that, the notion of neo-colonialism developed by Nkrumah is based on Lenin's "Imperialism, the Highest Stage of Capitalism"16 and thus on the socialist ideal of international relations, socialism's own standard of comparison, so to speak. As a consequence, "neo-colonialism" might turn out to be an intriguing basis for normative judgment.

\section{The GDR's Policy of Socialist State- and Nation- BuIlding: Motives and Strategies}

\footnotetext{
"We, [the MfAA working group on the 1986 crisis] already concluded at that time that our support [for Aden] with the constitution and everything else had merely been superimposed on South Yemen. But this was not only because we wanted it. [The South Yemenis] wanted it themselves, the party wanted it."17

(Vice-Minister of Foreign Affairs of the GDR Heinz-Dieter Winter in 2012)
}

The first question to be answered is about the possible motives of the GDR, that is, its foreign policy intent, separating these motives from any considerations about the intensity of the GDR's engagement. While the first phase in South Yemen was clearly focused on the full diplomatic recognition by the Aden regime, the following engagement was part of East Germany's attempt to further strengthen its international status. After the establishment of diplomatic relations in 1969 ,

15 | Prados, 2005.

16 | Lenin, 1963 (1917).

17 | Interview with Heinz-Dieter Winter July 32012. 
South Yemen became one of the few countries of intense East German involvement following its "strategy of focus." One of the highest levels of East German foreign policy engagement outside the Eastern Bloc was accomplished in Aden.

\subsection{The Determinism of Socialist State-Building}

From that time onward, East Berlin emphasized assistance with the establishment of a functional state apparatus in the sense of state-building, while following its own socialist state model. Apart from constitutional law and administration, this also included the promotion of the armed forces in general, as well as the establishment of a state security apparatus to support and secure the rule of the Yemeni counterpart of the GDR's SED, the YSP. East Berlin also intended to promote the integration of society in the sense of its own "homogenization of society" and the creation of the "new human." In this regard, East German foreign policy activities focused on the "third sphere" of foreign policy making outside party and state: Cooperation between East German society actors and the Yemeni population, such as the media and friendship societies, but especially the field of education. Last but not least, in the case of socialist nation-building in South Yemen, the "integration of society" necessarily was supported by the communication and acceptance of an integrative ideolog $y .^{18}$

All in all, the GDR's particular interpretation of Marxism-Leninism offered both the motivation and the goal for this "superimposed" As the SED shared this ideology with a majority of political actors of the YSP, ${ }^{\circ}$ "ideology" not only served as the basis for building trust between South Yemen and East Germany, but also served as the point of departure for Soviet and East German political. Especially during the 1970s, East Germany was considered the young South Yemen's role model, as Aden's functionaries never ceased to emphasize. ${ }^{21}$ Due to the GDR's activities during Phase I and II of its foreign policy in Aden, South Yemen's years of state-building offer numerous examples of the GDR's long-term influence in almost any political field. Apart from the determined and intensive creation of South Yemen's security apparatus, the biggest impact was on the genesis of the PDRY's constitution and legal system, which from the very beginning followed a noticeable path-dependency of East German development. The justification behind East Germany's nation-building policy first of all was an ideological one: In the socialist version of state- and

18 | East-Berlin for example was highly influential in this respect on the training of NF/YSP Party cadres in the GDR and the PDRY.

19 | Interview with Heinz-Dieter Winter July 32012.

20 | Meaning after Salmin was removed from office in 1978.

21 Stenografische Niederschrift der Beratung mit der Delegation der NLF Südjemen am 2.11.1970 im Hause des ZKs, in: BArch SAPMO/DY 30/11407. 
nation-building, all three elements of nation-building intertwine and doubleback on each other in such a way that the ideology's logic appears as an inevitable outcome, defying any critical scrutiny.

\subsection{A New Perspective on Nature and Interests of East German Activities in the Global South}

The majority of analyses occupied with the GDR's policies in "developing countries" focus on the economy and the military as the major "fields of engagement." This study explicitly included a differentiation of the "fields of engagement" in its analysis, which leads to fundamentally different conclusions on the nature of East German activities and interests in the Global South: Despite the sometimes considerable substantial financial and material support provided to the economy and the military in Aden, it was other fields in which the GDR's involvement had been the most intense. This involvement also developed a considerably higher impact on the receiving country: Administration and state institutions, legal affairs and the media, and above all education. Thus, modest military support and economic aid were merely used as a means to an end: To strengthen the bonds with the supposedly socialist or socialist-friendly regimes of the host countries and to stabilize their position. At the end of the day, the SED aimed for the policy fields most relevant for state- and nation-building to have an impact on the regimes with "socialist orientation" - to guide them towards the East German interpretation of the "planned development of socialism." ${ }^{22}$

Socialist state-building had been one of the major strategies of Soviet engagement in Eastern Europe to multiply its political system led by a vanguard party of "the new type." Thus, East Germany's foreign policy in South Yemen can be interpreted as a copy of the Soviet approach toward the GDR itself: The creation of a proxy state by providing the plans and the means necessary to establish a socialist state very much like its own. However, by applying this comprehensive policy approach, the GDR also felt competent enough to mimic Soviet foreign policy toward its so-called satellite states and even toward Eastern Germany of the 1940 a and 1950 s on a lower scale of intensity, though no less ideologically dedicated. However, East Berlin had clearly aimed not just to reproduce the Soviet model, but the East German interpretation of it. East Berlin tried to transfer its own experiences of the socialist path of development to South Yemen. In the process, the GDR applied a rigid, intrusive foreign policy to further its national interest, while at least some of its foreign policy actors clearly believed in a "higher purpose" of their engagement in South Yemen in the sense of "solidarity" and

22 | Schroeder, 1999, 119ff; Schroeder, 2013, $110 \mathrm{ff}$. 
"socialist internationalism," ${ }_{23}$ presenting a socialist version of Kipling's "The White Man's Burden.”24

The GDR's "policy of socialist state-building" has to be considered an "imperial variant of external nation-building" that demonstrated the temptation "to create one's counterpart in one's own image." 25 This reveals that the GDR's attitude toward the Global South was based on the assumptions of "modernization theory": ${ }^{26}$ The "underdeveloped" states of the "Third World" should and could "catch up" with the states of the developed world by imitating their process of development. ${ }^{27} \mathrm{As}$ a mélange of rational national interest and ideology, Walzer would summarize the GDR's intentions in Aden as "mixed motives" of the intervening state. ${ }^{28}$ Armed with the belief of bringing "socialism" to an underdeveloped country, South Yemen above all served East German national interests. Examples like the PDRY were meant to fulfill the SED's hunger for international prestige: Publications of the time presented the GDR as a progressive, industrialized nation state, granting generous support and assistance to build a "Socialist Civilization" in a developing country. ${ }^{29}$ Without doubt, East German intentions in South Yemen had a "neocolonial" tinge to them and thus transgressed the boundaries of foreign policy acceptable under international law.

\title{
3. The Impact of Socialist Nation-Building on South Yemen and its Society: A Truly Marxist State in the Arab World?
}

\author{
"[M]aking the socialist revolution means transforming existing relations." ${ }^{30}$ \\ The NLF in Mukhalla before the British Pullout in 1967
}

The main questions that now needs to be answered to reach a normative conclusion on East German policy are whether the YSP regime was able to react to East German and Soviet engagement and direct it in its own interest, and whether the socialist approach in the end was embraced by Yemeni society or not. The actual impact of an external "policy of state-building" may be rather difficult to assess. In case of South Yemen, and with the benefit of hindsight, the analyst can, for example, ask for the

23 | KI. Polit. Wörterbuch, 1973, Außenpolitik, in: 86; Also see: Scholtyseck, 2003, 36.

24 | Kipling, 1899.

25 | Hippler, 2005, 177.

26 | On "modernization theory” see: Badie/Berg-Schlosser/Morlino, 2012, 1609-1613.

27 | On the emergence of "Developmentalism" and "Modernization Theory" as part of US Foreign Policy due to the perceived threat of Communism during the Cold War see: Baber, 2001; For a critique on "Developmental Theory" see for example: Berberoglu, 1992.

28 | Walzer, 1977, 101ff.

29 | See e.g.: Gambke/Jacob/Mätzig, 1974 and Schußter, 1987.

30 | Dresch quotes the Mukalla NLF before the British pullout, in: Dresch, 2000, 120. 
reasons why the policy failed in the end. The following subsection seeks the reasons for the PDRY's failure as a state to approach the questions outlined above.

\section{Yemeni Traditions Trump "Socialist Revolution"}

The outcome of South Yemen's process of nation-building can be connected to the notion of collective identities' degree of responsiveness to change: While the success and failure of establishing stable state institutions has been a major focus of analysis in studies on the emergence of states, ${ }^{31}$ the other two elements regularly receive less attention. This shortcoming could be remedied by including the degree of "responsiveness" of collective identities as an additional explanation for success or failure of the state-and nation-building process. This hypothesis of the correlation between social change and the character of collective identities was merely introduced and interpreted very briefly, due to the framework of this study, but was included nonetheless as it without doubt supports the argument for the failure of the YSP regime to impose its ideology on the Yemeni population.

In the process of nation-building, ideology often, though not always, turns out to be the most influential source of social power, contributing to the process in three major ways: First, by legitimizing political measures taken; second, by mobilizing support for the new system and its implications; and third, to facilitate the "integration of society." The claim made here is that the fulfillment of the last two "functions" of ideology in the nation-building process ultimately depends on the characteristics of the collective identities exposed to this ideology. Ideology can support the formation of a national consciousness and construct national identity if, and only if, the prevailing identities are receptive to this ideology. Ideally, this consciousness will facilitate the integration of society by increasing political participation in the political sphere in scope and intensity and allow the mobilization of political action - from below or above.

In the mid-1980s, SED officials claimed that the YSP had "little impact on the population and [the party's] efforts to expand its basis in society remain insufficient." ${ }^{2}$ The Soviet Union and GDR had identified "tribalism" as the major obstacle to socialist nation-building by the NF/YSP-regime. ${ }^{33}$ But while the newly emerging state could only rely on weak state structures, this fact cannot not be equated with a lack of social or political structures. Yemen is an example of the

31 Hippler describes three intertwined elements as the preconditions for successful nation building: Effective and stable state institutions, the integration of society, and an attractive ideology, Hippler, 2003.

32 | Informationsmappe für den Besuch des Generalsekretärs des ZK der JSP [...] Ali Nasser Mohammed, November 1984, in: BStU MfS HA II Nr. 28712, 150.

33 | In 1982, a Soviet research mission even began "compiling a tribal and ethnographic map of the Hadramaut and Socotra" which potentially could provide extensive knowledge on the power distribution among the tribes, in: Cigar, 1985, 779 and October 14th, Daily South-Yemeni newspaper, April 91984. 
most complex social relationships, which have grown and stabilized over hundreds of years. During the "Socialist revolution" in Aden, these traditional social structures and identities turned out to be extremely sound and rigid:34 Despite the implementation of radical measures to abolish tribalism and tradition as early as the late 196os, traditional social structures clearly withstood the policies of the YSP regime. Even within the lower ranks of the YSP, people first and foremost followed the local and tribal leaders according to the established patronage system, pretty similar to the socio-politico conditions in other Arab states of the time. 35

But while the Marxist-Leninist ideology and its values had proven to be alien to the South Yemeni people and their social reality, even the radical political leaders had a hard time escaping their collective identities. Even though the figureheads of the NF propagated the dissolution of tribal affiliations, they mostly drew their political power from their tribal ties. ${ }^{36}$ These affiliations explain why it was mostly "tribeless" Ismail from the north who advocated convincingly for a profound change of society towards socialism. But even the chief ideologue Ismail appears to have recognized the lack of coherence between his ideological aspirations, the imposed political system, and the actual society on the ground: One of his final decisions was to abolish the enumeration of the provinces and give them back their traditional names in March 1980.37 Ideological principles apparently had never reached the degree of entrenchment within the population that was needed for a social transformation of socialist connotation in South Yemen. In addition to that, the fundamental encroachments into peoples' everyday lives driven by the YSP regime not only caused displeasure, but also outright rejection of the political system. Just as in the GDR before 1961 , there was a "constant stream of people leaving, mainly the best-educated and most talented." ${ }^{8}$

In this study, nation-building has been identified as a policy that can be pursued from the inside and from the outside, in which the latter can "make nationbuilding easier or harder." Hippler concludes that even though some developments can be initiated or promoted from the outside, others "are very difficult or even impossible to furnish from [there]," 39 especially ideology. This is where one may find an explanation for the failure of the YSP and its Marxist state in the end: Even though the regime may have invited socialist state- and nation-building, most of the effort came from outside Yemen's society. The YSP regime was only a very

34 | Na'ana, Hamida, 1988, in: Dresch, 2000, 120.

35 | Brehony, 2013, 36.

36 | "The tribal chiefs had gone, but were in fact replaced by the NF officials from the tribe," in: Brehony, 2013, 70.

37 | BBC Summary of World Broadcasts, ME/6365 (8 March 1980), in: Brehony, 2013, 121.

38 | Brehony, 2013, 59.

39 | Hippler, 2005, 9. 
small part of South Yemen's "inside" and clearly had not been able to rally the support of the majority of the Yemeni population.

\section{South Yemen: Subject or Object of Foreign Policy?}

"Our relations are not merely multifaceted. They are characterized by completeness, by their "totality." Do you understand what I mean? They are all-embracing."

Valery Sukhin, a Soviet Foreign Ministry official on Soviet-South Yemeni relations in 1984

"[I consider the Yemenis] a very proud people who were fully convinced of their own importance. [...] We felt the independence of the South Yemenis at all times - which they understandably wanted to maintain." ${ }^{\text {11 }}$

(Hans Bauer, consultant and MfS resident of the GDR to the PDRY)

Halliday argues that both superpowers refrained from direct involvement in the Middle East, though both got involved in proxy conflicts. ${ }^{4^{2}}$ Taking into consideration the results of the "levels of engagement approach," this judgment has to be questioned - at least for the Soviet Union. In South Yemen Moscow's actions constantly hovered between the levels of "involvement" and active "intervention." The intention behind these actions furthermore must be reconsidered in the light of this study with regard to the GDR's involvement in the PDRY: With the GDR as vicarious agent, the Kremlin apparently aimed to "impose" its own political system on South Yemen. Hence, one may see the Soviet Union's ultimate goal in Aden as the inclusion of the PDRY in its sphere of influence - and thus clearly to exceed the limits of foreign policy.

However, the Arab countries may not be considered helpless with no agency at all during the Cold War, as Halliday rightly summarizes:

"[T]he elites of Turkey, Israel, Iran and Saudi Arabia were not simply tools of Washington, any more than were the radical leaderships of Egypt, Syria, Libya, Iraq or the PDRY agents of Moscow." ${ }^{43}$

Halliday's statement can be expanded by concluding that the bipolar structure of the Cold War enabled rather than restricted actors of the Global South in general and of the Middle East in particular: Between 1946 and 1990, the "developing world" was able claim a certain power in the international sphere, by either using the permanent

40 | Al-Thawra, September 22 1984, quoted in: Cigar, 1985, 781.

41 | Interview with Hans Bauer June 202011.

42 | Halliday, 2005, 125.

43 | Halliday, 2005, 128. 
competition between East and West to strike the best bargain for themselves, or, as in the case of radical South Yemen, to opt for the "alternative" in the international system. ${ }^{44}$ As a consequence, one has to take into consideration South Yemen's actual interests and behavior towards Moscow and East Germany to be able to conclude first on Aden's agency in the relationship, and second to be able to unmask the doublemoral standard of East German foreign policy engagement.

Security, that is securing its existence as a state, was the foremost priority of the newly independent South Yemeni state after the British withdrawal in 1967. Naturally, this led to a certain paranoia towards any foreign interference and a possible return of "imperial" powers. This mindset may serve as an explanation for Aden's initial rejection of Western support, the leadership's extremist political position, and the resulting close relationship with Moscow and East Berlin, who readily offered material support and consultancy. As opposed to other post-colonial states, however, the colonial power hadn't left behind a fully functional administrative apparatus in South Yemen. Due to Britain's focused interest in the harbor, "administrative resources" 45 in 1967 were restricted to Aden and its vicinity, and thus the bigger part of South Yemeni territory was not fully integrated into the state apparatus in the sense of a "modern nation state." ${ }^{\prime 6}$ As a consequence, the Aden regime was confronted with the task of building a new state almost from scratch. Even though British administration was expanded over the South Yemeni territory successfully, functioning state organs and institutions, above all police and military forces, had to be established. For this effort, the impoverished country needed financial and technical assistance, and above all, due to the lack of education in leadership and population, know-how and training.

In retrospect, the PDRY not only consented to Soviet engagement, and especially the East German policy of socialist state- and nation-building, but explicitly demanded this kind of support, based on the ideological approach offered by Moscow and East Berlin. This analysis repeatedly revealed the South Yemeni belief in Lenin's three inseparable elements, ${ }^{47}$ as references to all three of them can be found in the Party Program of the YSP of $1978.4^{8}$ Without doubt, this ideology served as a comprehensive and cohesive blueprint for nation-building in South Yemen, and Moscow provided the assistance it considered necessary for its implementation. The GDR advanced as the most active and influential Soviet ally in this undertaking. This included the integration of South Yemen in a wider

44 | See for example, Howell, 1994.

45 | On the role of “imported” administration for "post-colonial states" see: Giddens, 1983, 272.

46 | Giddens, 1983, 255; Also: Weber's def. of the state as the agent claiming and owning the “monopoly of the legitimate use of [physical] violence," in: Weber, 2009 (1919), sine pagina.

47 | Schroeder, 2013, 716.

48 | JSP - Avantgarde des jemenitischen Volkes. Auszüge aus dem Programm der JSP (I) und (II), in: horizont No.50/51 1978, in: BStU MfS HA II Nr.27368, 9. 
community of states, that is the Eastern Bloc and its allies, clearly an upside of Aden's close ties to Moscow for the otherwise isolated radical regime of South Yemen. Cigar even speaks of "a sense of acceptance" and the "reassurance [for the PDRY regime] that it [was] on the right path."49 Thus, apart from rational considerations of security and economic development, Soviet acknowledgment also meant moral confirmation and support for the young Yemeni regime.

On first glance, the Aden regime appears as the weaker part of this unbalanced relationship to Moscow and East Berlin. East German reports and minutes from meetings even describe PDRY functionaries as naïve and heady, ignorant of time frames and the political and economic capabilities of South Yemen. ${ }^{50}$ However, the "1986 crisis" somewhat showed that neither Moscow nor East Berlin had full access to all spheres of politics and communication in South Yemen, not to mention control of the YSP and its cadres. On top of that, South Yemeni actors without doubt were able to develop a certain political self-confidence..$^{51}$ Supposedly small political gestures during the years that followed the founding of the YSP hint at the Yemenis' intention to emancipate themselves from Soviet and East German "guidance" and their policy of active nation-building: In 1983, the KfS awarded the "Medal of Friendship" to Mielke and the "Medal of Loyalty" to OibE "Marquardt," $5^{2}$ claiming political agency for themselves with this act. And only a few years later, a delegation of the GDR's Ministry of the Interior reports that the PDRY wished for a change in terminology for the next Protocol on Cooperation [between the security apparatuses]. Instead of consultants, the GDR was supposed to send "delegates" which clearly indicated that the YSP regime strived for more autonomy and independence. 53

Taking into consideration the mounting drive toward more agency within the relationship between Aden, Moscow and East Berlin, as well as the impact of the "1986 crisis" on this relationship, the most decisive phase of East German presence was, without doubt, the 1970s: East Berlin's policy of socialist state-building was in full swing and the intensification of engagement worked toward the manipulation

49 | Cigar, 1985, 786.

50 | Brief Scharfenberg an Willerding, July 25 1973, in: PA AA, MfAA, C 1555/76, 52; Also see: Brehony, 2013, 81.

51 | Like the South Yemeni "Vo," the liaison officer of the KfS in the GDR; German: Verbindungsoffizier, V0, in: Bericht über die erste Zusammenkunft des neueingesetzten V0 des KfS der VDR Jemen beim MfS, Mohammed Abdo Mohammed, August 21 1986, in: BStU MfS, Abt. X Nr.234 Teil 1 von 2, 262-265.

52 | Brief Botschaft der VDRJ in Berlin, January 19 1983, in: BStU MfS Abt.X Nr. 234 Teil 1 von 2 438. "Marquardt" is Major-General Jänicke, ibid. 441/2.

53 | Bericht über die Reise einer Delegation des Mdl in die VDRJ, January 1986, in: BStU MfS HA VII 7954, 62. 
of the "internal affairs or foreign policy activities." 54 In correspondence with Soviet involvement, one may even speak of a drift towards "imposition," as the continuous existence of South Yemen as a state of "socialist orientation" depended largely on Moscow's protection. Clearly, this foreign policy aimed at changing the conditions in South Yemen in East German and Soviet interest. On the other hand, any policy steps taken by the two foreign powers happened with the explicit consent of the Yemeni regime. East German and Soviet intensive activities would not have been possible if not for the willingness of the South Yemeni political elite, that is, from the "power actors" on the inside.

The Aden regime's decisions at times clearly were not fully autonomous: A relationship of dependency had emerged with Moscow as an economic 55 and military guarantor of survival. A survival which was contested by its neighbors and the major actors of the region. Both Moscow and East Berlin pursued a policy based on an attitude one may easily describe as "neo-colonial," based on material and ideological superiority with regard to the Marxist-Leninist ideal of development. However, the attitude of merely one side of a relationship does not define the ultimate character of it. Even though the GDR first of all served its own interests when fulfilling South Yemen's requests, the Aden regime presented itself as a proactive player with clear motives. East German archival sources and contemporary witnesses agree that most of the time it was the South Yemenis who initiated further cooperation and sought for concrete support from East Berlin. Also, the PDRY apparently tried to use the GDR to feel less pressured by Moscow and to diversify its dependencies, and succeeded in doing so.

Socialism had come as an "alien arrival [to South Yemen], tied up for a time, then passed on. ${ }^{56}$ What can be witnessed today in Yemen's South, a movement with an appetite for separation based on a separate Yemeni identity, clearly is not the re-emergence of a Marxist-Leninist state of Soviet and East German making, but rather the memories and mentalities of a very Yemeni interpretation.

"Yemen is a happy country, the people die standing tall: they will not cower, will not surrender their identity." 57

(Mansur Rajih, “The Fatherland”, 1958)

54 | Prados, 2005, 4.

55 | In December 1989, Aden's debt to Moscow was estimated at about 4 billion, AlAshmali, in: Brehony, 2013, 169.

56 | Mackintosh-Smith, 1997, 171.

57 | Rajih, Mansur, The Fatherland, 1958. Born in northern Yemen in 1958, Rajih was imprisoned for murder from 1983-1998. Amnesty International condemned trial and sentence as politically motivated. 
ANNEX 



\section{Bibliography}

\section{Monographs, Anthologies, and Articles}

Abebe, Ermias, The Horn, the Cold War and Documents from the Former East-Bloc: An Ethiopian view, in: Russian \& East German Documents on the Horn of Africa, 1977-78, Cold War International History Project Bulletin Issues 9-10, New East-Bloc Evidence on the Cold War in the Third World and the Collapse of the Détente in the 1970, Woodrow Wilson International Center for Scholars, Washington, D.C., Winter 1996, 40-45, Retrieved from http://www.wilsoncenter.org/sites/default/files/CWIHPBulletin8-9_ tableofcontents.pdf.

Abelshauser, Werner, Deutsche Wirtschaftsgeschichte seit 1945, Bundeszentrale für Politische Bildung, Bonn, 2005.

Abu Samra, Dalia, Deutschlands Außenpolitik gegenüber Ägypten. Abbruch und Wiederaufnahme der diplomatischen Beziehungen 1965 bis 1972, Dissertation Freie Universität Berlin, 2002.

Adelman, Jonathan R./Palmieri, Deborah Anne, The Dynamics of Soviet Foreign Policy, Harper \& Row Publishers, New York,1989.

Adler-Nissen, Rebecca/Gammeltoft-Hansen, Thomas, (ed.) Sovereignty

Games. Instrumentalizing State Sovereignty in Europe and Beyond, Part I Theoretical Perpectives, Palgrave Macmillian, New York, 2008.

- Chapter 1: Adler-Nissen, Rebecca/Gammeltoft-Hansen, Thomas, An Introduction to Sovereignty Games, 1-20.

- Chapter 3: Bartelson, Jens, Sovereignty Before and After the Linguistic Turn, 33-46.

Adra, Najwa, Dance and glance: Visualizing tribal identity in Highland Yemen, in: Visual Anthropology: Published in Cooperation with the Commission on Visual Anthropology, 2010, 55-102.

Al-Dawsari, Nadwa, Tribal Governance and Stability in Yemen, Middle East, April 2012, Retrieved from http://carnegieendowment.org/files/yemen_ tribal_governance.pdf. (latest access May 5 2013) 
Al-Enazy, Askar Halwan, The International Boundary Treaty (Treaty of Jeddah) Concluded between the Kingdom of Saudi Arabia and the Yemeni Republic on June 122000 , in: 96 American Journal of International Law, No.96, $2002,161-172$.

Alisch, Steffen, Die (West-)Berlinpolitik der SED zwischen Mauerbau und Mauerfall im Spiegel der Verhandlungen mit dem Berliner Senat, in: Timmermann, Heiner (ed.), Die DDR zwischen Mauerbau und Mauerfall, Lit Verlag, Münster, 2012, 249-260.

Al-Rasheed, Madawi, A History of Saudi Arabia, Cambridge University Press, New York, 2002.

Al-Rasheed, Madawi/Vitalis, Robert (ed.), Counter-Narratives: History, Contemporary Society, and Politics in Saudi Arabia and Yemen, Palgrave McMillian, New York, 2004.

Blumi, Isa, Shifting Loyalties and Failed Empire: A new Look at the Social History of Ottoman Yemen, 1872-1918, 103-118.

Willis, John M., Leaving only Question-Marks. Geographics of Rule on Modern Yemen, 119-150.

Vom Bruck, Gabriele, Evacuating Memory in Postrevolutionary Yemen, 229-246. Weeden, Lisa, Seeing Like a Citizen, Acting Like a State: Exemplary Events in Unified Yemen, 247-283.

Al-Shishani, Murd Batal, The Geopolitical Importance of Yemen and Oil for Al-Qaeda, 17th January 2007, The Emirates Center for Strategic Studies and Research, Retrieved from http://www.grc.net/?frm_module=contents\&frm_ action=detail_book\&frm_type_id=\&op_lang=en\&override=Article $\mathrm{s}+\% 3 \mathrm{E}+\mathrm{The}+$ Geopolitical+Importance+of+Yemen+and+Oil+for+Al-

Qaeda\&sec=Contents\&frm_title=\&book_id=26062. (lates access: July 20 2013). Agoston, Gabor/Masters, Bruce (ed.), Encyclopedia of the Ottoman

Empire., Facts on File, New York, 2009, Retrieved from Modern World History Online, Facts On File, Inc. http://www.fofweb.com/activelink2. asp?ItemID=WE53\&iPin=EOE571\&SingleRecord=True (accessed September 11, 2013)

Anderson, Benedict, Imagined Communities. Reflections on the Origin and Spread of Nationalism, Verso, 1983.

Anter, Andreas, Max Weber's Theory of the Modern State, Origins, Structure and Significance, Palgrave Macmillian, New York, 2014.

Antonius, George, The Arab Awakening. The story of the Arab national movement, The Kegan Paul Arabia Library, 2000, (1938)

Applebaum, Anne, Iron Curtain : the crushing of Eastern Europe, 1944-1956, Anchor Books, Random House Inc., London, 2013.

Ashton, Nigel J. (ed.), The Cold War in the Middle East. Regional Conflict and the Superpowers 1967-73, Routledge, London and New York, 2007. Atkinson, David/Dodds, Klaus, (Ed.), Geopolitical Traditions, Routledge, 2002. 
Auerbach, Thomas/Braun, Matthias/Eisenfeld, Bernd/von Prittwitz/Vollnhals, Clemens, Hauptabteilung XX: Staatsapparat, Blockparteien, Kirchen, Kultur, >>politischer Untergrund<<, MfS-Handbuch, BStU, Berlin, 2008.

Augustin, Anne-Linda Amira, „Erhebe deinen Kopf, du bist en freier Südaraber“ - Gesungene Slogans und Sprechgesänge der Bewegung des Südens, JemenReport, Jg. 46/2015 Heft 1 von 2,49-54.

Augustin, Anne-Linda Amira, Der Südstaatler Ali Salim Al-Beidh, in: Zenit $10 / 2013,13$.

Aust, Stefan, Der Baader-Meinhof-Komplex, Hoffmann und Campe, Hamburg, 2008 (1985).

Auswärtiges Amt (ed.), 40 Jahre Außenpolitik der Bundesrepublik Deutschland. Eine Dokumentation, Clausen and Bosse, Bonn, 1989.

Ayubi, Nazih N. Over-Stating the Arab State: Politics and Society in the Middle East, I.B.Tauris, New York, 1995 (2006).

Baber, Zaher, Modernization theory and the Cold War, Journal of Contemporary Asia, 31/1, 2001, 71-85.

Baumgart, Winfried (Hg.), Quellenkunde zur deutschen Geschichte der Neuzeit von 1500 bis zur Gegenwart, Darmstadt, 1977.

Baynard, Sally Ann/Newhouse Carter, Laraine/Lieff Benderly, Beryl, Krieger, Laurie, Historical Setting, in: The Yemens. Country studies, Area Handbook for the Yemens, Foreign Area Studies, United States Government, Washington D.C., 1986.

Baring, Arnulf, Machtwechsel. Die Ära Brandt-Scheel, Deutsche Verlags-Anstalt, Stuttgart, 1982

Bender, Peter, Deutschlands Wiederkehr. Eine ungeteilte Nachkriegsgeschichte 1945-1990, Bundeszentrale für Politische Bildung, Bonn, 2008.

Berberoglu, Berch, The Political Economy of Development: Development Theory and the Prospects for Change in the Third World, State University of New York press, Albany, 1992.

Berlin, Isaiah, (Hardy, Henry, ed.), Freedom and Its Betrayal: Six Enemies of Human Liberty, Princeton University Press, New Jersey, 2014 (2002).

Berggötz, Sven Olaf, Nahostpolitik in der Ära Adenauer, Möglichkeiten und Grenzen 1949-1963, Droste Verlag, Düsseldorf, 1998.

Bialas, Wolfgang, Politischer Humanismus und "verspätete Nation":

Helmuth Plessners Auseinandersetzung mit Deutschland und dem

Nationalsozialismus, Vandenhoeck \& Ruprecht, Göttingen, 2010.

Bierling, Stephan G., Die Außenpolitik der Bundesrepublik Deutschland. Normen, Akteure, Entscheidungen, Oldenburg Verlag, München, 2005. Bippes, Thomas, Die Europäische Nahostpolitik, Peter Lang Verlag, Frankfurt am Main, 1997.

Blasius, Rainer A., „Völkerfreundschaft“ am Nil: Ägypten und die DDR im Februar 1965, in: Vierteljahreshefte für Zeitgeschichte 46/1998. 
Blasius, Rainer A, Erwin Wickert und die Friedensnote der Bundesregierung vom 25.März 1966. in: Vierteljahreshefte für Zeitgeschichte, Vol.43, July 1995, 539-553.

Blumi, Isa, Chaos in Yemen. Societal Collapse and the New Authoritarianism, Routledge Verlag, London, 2011.

Bock, Siegfried, Die Beziehungen zur SFRJ, 233-252, in: Bock, Siegfried/Muth, Ingrid/Schwiesau, Hermann, DDR-Außenpolitik im Rückspiegel. Diplomaten im Gespräch. Band 2, Lit Verlag, Berlin, 2004.

Bonnefoy, Laurent/Poirier, Marine, Civil Society and Democratization, in: Contemporary Yemen, Knowledge Programme Civil Society in West Asia, Amsterdam, 2009, Retrieved from http://www.hivos.net/content/ download/32633/209388/file/WP3Bonnefoypoirier.pdf. (latest access May 10 2014) Borchert, Jürgen, Die Zusammenarbeit des Ministeriums für Staatssicherheit (MfS) mit dem sowjetischen KGB in den 7oer und 8oer Jahren. Ein Kapitel aus der Geschichte der SED-Herrschaft, Lit Verlag, Berlin, 2006.

Brandt, Marieke, Sufyaān's “Hybrid” War: Tribal Politics during the Đūthī Conflict, in: Journal of Arabian Studies, June 2013, 120-138.

Braun, Ursula, Nord- und Südjemen im Spannungsfeld interner, regionaler und globaler Gegensätze, Forschungsinstitut der Deutschen Gesellschaft für Auswärtige Politik e.V., Bonn, 1981.

Braune-Steininger, Franz, Die Nahost-Politik der Bundesrepublik Deutschland von 1965 bis 1982, Phil. Diss., Gießen, 1988.

Brehony, Noel, Yemen Divided. The Story of a Failed State in South Arabia, I.B. Tauris, New York, 2011.

Bringmann, Tobias C., Handbuch der Diplomatie 1915-1963: auswärtige Missionschefs in Deutschland und deutsche Missionschefs im Ausland von Metternich bis Adenauer, Saur Verlag, München, 2001.

Brubaker, Rogers, Ethnicity, Race, and nationalism, Annual Review of Sociology, No. 35, 21-42, 2009, Retrieved from soc.annualreviews.org (latest access January 292013 )

Brünner, Thomas, Public Diplomacy im Westen. Die Presseagentur Panorama DDR informiert das Ausland, Peter Lang Verlag, Frankfurt am Main, 2011. Bücking, Hans-Jörg, (Ed.) Entwicklungspolitische Zusammenarbeit in der Bundesrepublik Deutschland und der DDR, Duncker und Humblodt, Berlin, 1998.

- Graewe, Wolf Dieter, Entwicklungspolitische Zusammenarbeit in der DDR, 81-94.

- Schleicher, Hans-Georg, Entwicklungszusammenarbeit und Außenpolitik der DDR, 95-110.

Budde, Gunilla/Freist, Dagmar/Günther-Arndt, Hilke, Geschichte. Studium Wissenschaft, Beruf, Berlin, 2008.

von Bülow, Bernhard, Denkwürdigkeiten, 4 Volumes, Vol.1, Berlin, 1930. 
Burch, Robert, Dialectic, in: English Studies in Canada; Vol. 30, No. 4, 2004, 16-20. Burkhardt, Martin, Arbeiten im Archiv. Praktischer Leitfaden für Historiker und andere Nutzer, Paderborn, 2006.

Buthmann, Reinhard, Die Arbeitsgruppe Bereich Kommerzielle Koordinierung (MfS-Handbuch), BStU (Ed.), Berlin, 2004.

Campell, David, Writing Security. United States Foreign Policy and the Politics of Identity, University of Minnesota Press, 1998.

Chelkowski, Peter J./Pranger, Robert J. (Ed.), Ideology and Power in the Middle East: Studies in Honor of George Lenczowski, 1988.

Choueri, Youssef M., Pensée 2: Theorizing Arab Nationalism,International Journal of Middle East Studies, Vol. 41, No.1, February 2009, 13-15.

Choueiri, Youssef M., Review Article. The Middle East: Colonialism, Islam and the Nation State, in: Journal of Contemporary History, Vol. 37, No. 4/2002, p. 649-663.

Choueiri, Youssef M., Arab Nationalism. A History, Blackwell Publishers, Oxford, 2000.

Cigar, Norman, South Yemen and the USSR: Prospects for the Relationship, in: Middle East Journal, Vol.39, No.4, 1985, 775-795.

Clark, Victoria, Yemen. Dancing on the heads of Snakes, Yale University Press, New York, 2010.

Courtois, Stéphane (Ed.). Das Handbuch des Kommunismus. Geschichte. Ideen. Köpfe, Piper Verlag, München, 2010.

Cox, Michael, Fred Halliday, Marxism and the Cold War, in: International Affairs Vol.87, No.5, 2011, 1107-1122.

Crome, Erhard (Ed.), Die Babelsberger Diplomaten Schule. Das Institut für Internationale Beziehungen der DDR, WeltTrends, Potsdam, 2009.

Dagne, Haile Gabriel, The Commitment of the German Democratic Republic in Ethiopia. A study based on Ethiopian sources, Lit Verlag, Berlin, 2006.

Dahlgren, Susanne Traditions and modernities in Aden (Yemen). On studying complex Middle Eastern societies, The fourth Nordic conference on Middle Eastern Studies: The Middle East in a globalizing world, Oslo, 1998, Retrieved from http://www.org.uib.no/smi/pao/dahlgren.html (latest access 10 July, 2014)

Dahlke, Matthias, „Nur eingeschränkte Krisenbereitschaft.“ Die staatliche Reaktion auf die Entführung des CDU-Politikers Peter Lorenz 1975, Vierteljahreshefte für Zeitgeschichte, ifZ München, No.4, Oldenburg Verlag, München, 2007, Retrieved from http://www.ifz- muenchen.de/ heftarchiv/2007-4-4_dahlke.pdf.

Day, Stephen W., Regionalism and Rebellion in Yemen. A Troubled National Union, Cambridge University Press, New York, 2012.

Dennis, Mike, The Rise and Fall of the German Democratic Republic 1945-1990, Pearson Education Limited, Essex, 2000.

Derrida, Jacques. Of Grammatology, Baltimore: JHU Press, 1997 (1976). 
Deutscher Bundestag (ed.), Bericht des 1.Untersuchungsausschusses des

12. Deutschen Bundestages, Werkzeuge des SED-Regimes, Der Bereich Kommerzielle Koordinierung und Alexander Schalck-Golodkowski, Zur Sache 2/94, Bonner Universitätsdruckerei, Bonn, 1994.

Diedrich, Torsten/ Ehlert, Hans Gotthard/ Wenzke, Rüdiger (ed.), Im Dienste der Partei: Handbuch der bewaffneten Organe der DDR, Christian Links Verlag, Berlin, 1998.

D'Mello, Bernhard, What is Maoism?, in: Economic and Political Weekly, Vol.44, No. 47, 2009, 39-48.

Dresch, Paul, A History of Modern Yemen, Cambridge University Press, Cambridge, 2000.

Dresch, Paul, Tribes, government, and history in Yemen, Clarenden Press, Oxford, 1993 .

Döring, Hans-Joachim, >>Es geht um unsere Existenz $<<$. Die Politik der DDR gegenüber der Dritten Welt am Beispiel von Mosambik und Äthiopien, Christian Links Verlag, Berlin, 1999.

Doernberg, Stefan/Hänisch, Werner/Schirrmeister, Helga/Spröte, Wolfgang, Außenpolitik der DDR, Staatsverlag der Deutschen Demokratischen Republik, Ost-Berlin, 1979.

Douglas, Leigh J., The Free Yemeni Movement 1935-1962, The American University of Beirut, 1987.

Eder, Klaus/ Giesen, Bernd/Schmidtke, Oliver/Tambini, Damian, Collective Identities in Action. A Sociological Approach, Ashgate Pub Ltd, Hampshire, 2003.

Eisenberg, Avigail/Kymlicka, Will, (ed.). Colonial and Postcolonial States. In Identity Politics in Public realm. Bringing Institutions back in, Vancouver University Press, Vancouver, 2011.

- Berman, Bruce J. "Knowledge and the Politics of Ethic identity and Belonging”, 52-78.

- Nobles, Melissa, “The Challenge of Census Categorization, 31-51.

Eckart, Gabriele, The GDR and Anti-Semitism?: A Comparison of Jan Koplowitz' Novel Bohemia, mein Schicksal (1979) and Horst Seemann's FilmHotel Polan und seine Gäste (1981),in: Shofar, An Interdisciplinary Journal of Jewish Studies, Volume 26, No. 3, Spring 2008, 68-86.

Elie, Serge, Soqotra: South Arabia's Strategic Gateway and Symbolic Playground, in: British Journal of Middle Eastern Studies, Vol. 33, No. 2, November 2006, 131-16o. Engel, Ulf/ Schleicher, Hans-Georg: Thesen zur Afrikapolitik der beiden deutschen Staaten, Focus Afrika. I AK-Diskussionsbeiträge 8, Hamburg, 1997. Engelmann, Roger/Florath, Bernd/Heidemeyer, Helge/Münkel, Daniela/Polzin, Arno/Süß, Walter, Das MfS-Lexikon. Begriffe, Personen und Strukturen der Staatssicherheit der DDR, Der Bundesbeauftragte für die Unterlagen des Staatssicherheitsdienstes der ehemaligen Deutschen Demokratischen Republik, Christian Links Verlag, Berlin, 2011. 
Erler, Peter, >>Moskau Kader<< der KPD in der SBZ, in: Wilke, Manfred (ed.), Die Anatomie der Parteizentrale. Die KPD/SED auf dem Weg zur Macht, Berlin, Akademie Verlag, 1998, 229-291.

Fahmy, Khaled, The era of Muhammad Ali Pascha, 1805-1848, in: The Cambridge History of Egypt, Daly M.W. (Ed.), Cambridge University Press, 1998, (online publication 2000), Retrieved from http:// universitypublishingonline.org.ezproxy.library.uvic.ca/cambridge/histories/ chapter.jsf?bid=CBO9781139053341\&cid=CBO9781139053341Aoo9. (latest access June 12 2013)

Fanon, Frantz, The Wreched of the Earth (1961), Grove Press, New York, 2004. Faroughy, Abbas, Introducing Yemen, Orientalia Inc., New York, 1947.

Ferris, Jesse, Soviet support for Egypt's intervention in Yemen 1962-1963, in: Journal of Cold War Studies, Vol.10, No. 4, Fall 2008, 5-36.

Flade, Florian, Assad droht dem Westen mit einem Dschihadisten, in: Die Welt, 14th of February 2013, Retrieved from http://www.welt.de/politik/ausland/ article13867763/Assad-droht-dem-Westen-mit- einem-Dschihadisten.html. (latest access Sep 20 2013).

Fischer, Bernd, Als Diplomat mit zwei Berufen. Die DDR-Aufklärung in der Dritten Welt, Verlag das Neue Berlin, Berlin, 2009.

Foucault, Michel, Society Must Be Defended. Lectures at the Collège de France 1975-1976, Picador, New York, 2003.

Foucault, Michel, Discipline \& Punish: The Birth of the Prison, Random House Inc., New York, 1995 (1975).

Fricke, Karl-Wilhelm/Steinbach, Peter/Tuchel, Johannes, Opposition und Widerstand in der DDR. Politische Lebensbilder, C.H. Beck, München, 2002. Freedman, Robert O., The Soviet Union and the Middle East in 1986, Rabinovich, Itamar/Shaked, Haim (ed.), Middle East Contemporary Survey, Vol. X, 1986, Westview Press, Boulder \& London, 1988, 33-50.

Fulbrook, Mary, Anatomy of a Dictatorship. Inside the GDR 1949-1989, Oxford University Press, New York, 1995.

Gaddis, John L., The Long Peace. Inquiries into the History of the Cold War, Oxford University Press, New York, 1987.

Gambke/Jacob/Mätzig (ohne Vornamen), Sultanspaläste in Volkes Hand. Die Volksdemokratische Republik Jemen, Dietz Verlag, Berlin (Ost), 1974.

Gareis, Sven Bernhard, Deutschlands Außen- und Sicherheitspolitik, Verlag Barbara Budrich, Opladen, 2006.

Gavin, R.J., Aden under British Rule 1839-1967, C. Hurst \& Co. Pub. Ltd. London, 1975 .

Gellner, Ernest, Nations and Nationalism, Cornell University Press, New York, 1983. Gerlach, Daniel, Die doppelte Front. Die Bundesrepublik Deutschland und der Nahostkonflikt 1967-1973, Lit Verlag, Berlin, 2006.

Glaeßner, Gert-Joachim, Sozialistische Systeme. Einführung in die Kommunismus- und DDR-Forschung, Westdeutscher Verlag, Opladen, 1982. 
Giddens, Anthony, Die Konstitution der Gesellschaft, Grundzüge einer Theorie der Strukturierung [The constitution of Society. Outline of the Theory of Structuration], Campus Verlag, Frankfurt/ New York, 1988 (1984).

Giddens, Anthony, The Nation State and Violence, Blackwell, New York, 1983.

Gieseke, Jens, Die hauptamtlichen Mitarbeit der Staatssicherheit.

Personalstruktur und Lebenswelt, Christian Links Verlag, Berlin, 2000.

Gieseke, Jens, Der Mielke-Konzern. Die Geschichte der Stasi 1945-1990,

Deutsche Verlagsanstalt, Stuttgart/München, 2001.

Gieseke, Jens, Die Stasi 1945-1990, Pantheon Verlag, München, 2011.

Gieseke, Jens, The History of the Stasi. East Germany's Secret Policy, 1945-1990,

Random House, Munich, 2014.

Gilbert, Alan, Marx on Internationalism and War, in: Philosophy \& Public

Affairs, Vol.7, No.4, 1978, 346-369, Retrieved from http://www.jstor.org/ stable/2264962 (latest access March 18 2014).

Giordano, Ralph. Die Partei hat immer Recht..., Kiepenheuer \& Witsch, Köln, 1961. Glaeßner, Gert-Joachim, Die Ost- und Deutschlandpolitik,. in: Glaeßner, GertJoachim/Holz, Jürgen/Schlüter, Thomas (Ed..), Die Bundesrepublik in den siebziger Jahren. Versuch einer Bilanz, Leske und Budrich, Opladen, 1984.

Goerner, Martin G./Kubina, Michael (1995): Die Phasen der Kirchenpolitik der

SED und die sich darauf beziehenden Grundlagenbeschlüsse der Partei- und Staatsführung in der Zeit von 1945/46 bis 1971/72. in: Deutscher Bundestag (Ed.): Materialien der Enquete-Kommission „Aufarbeitung von Geschichte und Folgen der SED-Diktatur in Deutschland“. Baden-Baden [u.a.] 1995, Bd. VI, 615-874.

Golz, Hans-Georg, Das Wirken der Freundschaftsgesellschaft DDR-

Großbritannien und der Britain-GDR Society - Möglichkeiten und Grenzen, Universitätsverlag Leipzig, 2003.

Gorbatchev, Michael, Memoirs, Doubleday, New York, 1996.

Görtemaker, Manfred, Geschichte der Bundesrepublik Deutschland. Von der

Gründung bis zur Gegenwart, Fischer Taschenbuch Verlag, München, 2004. Greiner, Bernd/Christian Th. Müller/Weber, Claudia (Ed.), Ökonomie im Kalten Krieg, Bundeszentrale für Politische Bildung, Bonn, 2008.

- Dangerfeld, Martin, Sozialistische Ökonomische Integration, der Rat für gegenseitige irtschaftshilfe (RGW), 348-369.

- Kanet, Roger E., Vier Jahrzehnte Sowjetische Wirtschaftshilfe, 45-61.

- Scheben, Thomas, Wachstumsstrategien im Nahen Osten während des Kalten Krieges, 124-162.

Greiner, Bernd, Krisen im Kalten Krieg. Bilanz und Ausblick, in: Greiner, Bernd/Müller, Christian Th./Walter, Dierk (Ed.), Krisen im Kalten Krieg, HIS Verlag, Hamburg, 2008, 7-23.

Griffiths, Martin/Roach, Steven, Scott, Solomon. Fifty Key Thinkers in International Relations, Routledge, London, 1999. 
Haass, Richard N./O’Sullivan, Meghan L., (ed.). Honey and Vinegar: Incentives,

Sanctions and Foreign Policy. Washington: Brookings Institution Press, 2000.

Hachicho, M. Ali, Die Verfassungsentwicklung der Volksdemokratischen

Republik Jemen (1839-1970), in: Die Welt des Islams, XVII, 1/4, 1976, S.78-

103, Retrieved from www.jstor.org/stable/1570341.

Hacke, Christian, Weltmacht wider Willen. Die Außenpolitik der

Bundesrepublik Deutschland, Klett-Cotta Verlag, Stuttgart, 1988.

Hacker, Jens, in: 40 Jahre innerdeutsche Beziehungen, Haendcke-Hoppe,

Maria, Lieser-Triebnigg, Erika (Ed.), Schriftenreihe der Gesellschaft für

Deutschlandforschung, Bd. 29, Dunker und Humblot Berlin, 1989, 33-88.

Haftendorn, Helga, Sicherheit und Stabilität. Außenbeziehungen der

Bundesrepublik zwischen Ölkrise und NATO-Doppelbeschluß, Deutscher

Taschenbuch Verlag, München, 1986.

Haftendorn, Helga, Außenpolitische Prioritäten und Handlungsspielraum. Ein

Paradigma zur Analyse der Außenpolitik der Bundesrepublik Deutschland,

in: Politische Vierteljahresschrift, 1. Ausgabe, 1989, 32-49.

Haftendorn, Helga, Kontinuität und Wandel des außenpolitischen

Entscheidungsprozesses in der Bundesrepublik Deutschland, in: Ellwein,

Thomas/Holtmann, Everhard, 50 Jahre Bundesrepublik Deutschland,

Westdeutscher Verlag, Opladen/Wiesbaden, 1999, 246-257.

Haftendorn, Helga, Deutsche Außenpolitik zwischen Selbstbeschränkung

und Selbstbehauptung. 1945-2000, Deutsche Verlags-Anstalt, Stuttgart/

München, 2001.

Haftendorn, Helga, Coming of Age: German Foreign Policy Since 1945, Rowman and Littlefield, Oxford, 2006.

Hahn, Gerhard/Hänisch, Werner/Busse, Hartwig/Linger, Klaus, Außenpolitik der DDR. Für Sozialismus und Frieden, Staatsverlag der Deutschen

Demokratischen Republik, Ost-Berlin, 1974.

Halliday, Fred, The Middle East in International Relations. Power, Politics and Ideology, Cambridge, University Press, 2005.

Halliday, Fred, The Formation of Yemeni Nationalism. Initial Reflections, in:

Gershoni, Israel/Jankowski, James, Rethinking Nationalism in the Arab

Middle East, Columbia University Press, New York, 1997, 26-47.

Halliday, Fred, Revolution and Foreign Policy. The Case of South Yemen 1967 -1987, Cambridge University Press, New York, 2002, (1990).

Halliday, Fred, The Cold War as Inter-system Conflict: Initial Theses, in: Bowker, Mike/Brown, Robin (ed.), From Cold War to Collapse: Theory and World Politics in the 1980s, Cambridge University Press, Cambridge, 1993, 21-34. Halliday, Fred, Aspects of South Yemen's Foreign Policy 1967-1982, Doctoral Thesis, London School of Economics, April 1985, Retrieved from http:// etheses.1se.ac.uk/430/1/Halliday_Aspects\%2oof\%2oSouth\%2oYemen's\%20 foreign\%2opolicy.pdf (latest access April 11 2014). 
Halliday, Fred, The Arc of Revolutions: Iran, Afghanistan, South Yemen,

Ethiopia, in: Race \& Class, No. 20, 1979, 373ff.

Halliday, Fred, Arabia without Sultans, Pelican, New York, 1974.

Halm, Heinz/Haarmann, Ulrich, Geschichte der Arabischen Welt, C.H. Beck

Verlag, München, 2004.

Hänisch, Werner/Linger, Werner/Mardek, Helmut/Morgenstern, Peter/Eckstein,

Eva, (Ed.), Konflikt Naher und Mittlerer Osten, Institut für Internationale

Beziehungen an der Akademie für Staats- und Rechtwissenschaft der DDR

Potsdam-Babelsberg, Staatsverlag DDR, Berlin (Ost), 1982.

Hanisch, Anja, Die DDR im KSZE-Prozess 1972-1985: Zwischen

Ostabhängigkeit, Westabgrenzung, Oldenburg Verlag, München, 2012.

Hanna, Sami A., Gardner, George H., Islamic Socialism, in: The Muslim World,

Volume 56, Issue 2, April 1966, 71-86.

Hartewig, Karin, Jüdische Kommunisten in der DDR, Zuckermann, Mosche,

Zwischen Politik und Kultur. Juden in der DDR, Wallstein Verlag, Göttingen, 2002, 48-62.

Hathaway, Oona A./Brower, Julia/Liss, Ryan/Thomas, Tina/Victor, Jacob,

Consent-Based Humanitarian Intervention: Giving Sovereign Responsibility

Back to the Sovereign, Retrieved from Cornell International Law Journal, Vol.

46, 2013 and Yale Law School, Public Law Research Paper No. 503.

Healy, Sally/Hill, Yemen, Somalia, Terrorism, Shadow-Networks and the

Limitations of State-Building, Chatham House Briefing Paper, October 2010,

Retrieved from https://www.chathamhouse.org/sites/default/files/public/

Research/Africa/bp1o10_yemensomalia.pdf.

Hechter, Michael. Containing Nationalism. Oxford and New York: Oxford

University Press, 2000. See pages 15-17, Retrieved from http://www.

nationalismproject.org/what/hechter.htm.

Hegel, Georg Friedrich Wilhelm, Sämtliche Werke III, (Glockner, Hermann, ed.), Frommann Verlag, Stuttgart, 1961.

Hertle, Hans-Hermann/Stephan, Gerd-Rüdiger (ed.), Das Ende der SED: Die letzten Tage des Zentralkomitees, Christian Links Verlag, Berlin, 2012 (1997).

Hinsley, Francis Harry, Sovereignty, Cambridge University Press, Cambridge, 1986 (1966).

Hippler, Jochen, (Ed.), Nation-Building. A key concept for peaceful conflict transformation?, Pluto Press, New York, 2005.

Hippler, Jochen, Gewaltkonflikte, Konfliktprävention und Nationenbildung Hintergründe eines politischen Konzepts, in: Hippler, Jochen (Pub.), NationBuilding - ein sinnvolles Instrument der Konfliktbearbeitung?, Dietz Verlag, Bonn, 2003.

Hobbes, Thomas, Leviathan, Felix Meiner Verlag, Hamburg, 1996 (1651). Hobspawm, Eric, Introduction: Inventing Traditions, in: Hobspawm, Eric/ Ranger, Terrence, The Invention of Tradition, Cambridge University Press, London, 1983, 1-14. 
Hoffmann, Dierk/Schwartz, Michael/Wentker, Hermann, Vor dem Mauerbau:

Politik und Gesellschaft in der DDR der fünfziger Jahre, Oldenburg Verlag,

München, 2003.

- Wentker/Schwartz/Hoffmann, Einleitung, 7-20.

- Ritter, Gerhard A., Traditionen und Brüche. Die DDR in den fünfziger Jahren, 21-38.

- Foitzik, Jan, Sowjetische Hegemonie und Ostintegration der DDR, 39-58.

- Wentker, Hermann, Die gesamtdeutsche Systemkonkurrenz und die durchlässige innerdeutsche Grenze, 59-76.

Holden, David, Farewell to Arabia, Faber and Faber, London, 1966.

Hölscher, Wolfgang, Abschied vom Konzept der gemeinsamen Außenpolitik.

Zur parlamentarischen Auseinandersetzung über die neue Ostpolitik in den Jahren 1969 bis 1972. Abandoning the Concept of a Mutual Foreign Policy, Vol. 290/2, April 2010, 347-385.

Holzscheiter, Anna, Between Communicative Interaction and Structures of

Signification: Discourse Theory and Analysis in International Relations, in:

International Studies Perspectives No.15, 2014, 142-162.

Honecker, Erich, Aus meinem Leben, Dietz Verlag, Berlin, 1980.

Hourani, Albert, Die Geschichte der arabischen Völker. Von den Anfängen des

Islam bis zum Nahostkonflikt unserer Tage, Fischer Taschenbuch Verlag,

Frankfurt am Main, 2003.

Howell, Jude, Ride and Fall of G.D.R. Aid, in: The Jounal of Moddern African

Studies, Vol. 32, No.2, June 1994, 305-328.

Hudson, Valerie M., Foreign Policy Analysis. Classic and Contemporary Theory,

Rowman and Littlefield Publishers, Plymouth, 2007.

Hünseler, Peter, Die außenpolitischen Beziehungen der Bundesrepublik

Deutschland zu den arabischen Staaten von 1949-1980, Peter Lang Verlag,

Frankfurt am Main, 1990.

Huntington, Samuel, The Clash of Civilizations? in: Foreign Affairs, Vol. 72, No.

3, 1993, 22-49. Retrieved from http://www.jstor.org.ezproxy.library.uvic.ca/ stable/20045621.

Huntington. Samuel, The clash of civilizations and the remaking of world order,

Simon \& Schuster, New York, 1996.

Ismael, Tareq Y., The Communist Movement in the Arab World, Routledge, New

York, 2005 .

Ismael, Tareq Y./ Ismael, Jacqueline S., The People's Democratic Republic of

Yemen. Politics, Economics and Society, Marxist Regimes Series, Boulder

Publishers, London, 1986.

Ismail, Sharif, Unification in Yemen. Dynamics of Political integration 1978-2000. Jesse, 2007a, Jesse, Eckhard, Die Ursachen des RAF-Terrorismus und sein

Scheitern, in: 1977 und die RAF, Aus Politik und Zeitgeschichte, No.40/41, 2007, 15-23. 
Joas, Hans, Social Theory: Twenty Introductory Lectures, Cambridge University Press, 2011.

Johnson, Gregory D, How we lost Yemen. The United States used the Pakistan playbook on Yemen's terrorists. It didn't work, August 6th 2013, Retrieved from www.foreignpolicy.com/articles/2013/08/06/how_we_lost_yemen_al_ qaeda (latest access August 31 2013)

Judt, Matthias (ed.), DDR-Geschichte in Dokumenten, Bundeszentrale für Politische Bildung, Bonn, 1998.

Jessen, Ralph, Partei, Staat und 'Bündnispartner': Die Herrschaftsmechanismen der SED-Diktatur, 27-43

- Judt, Matthias, Deutschland- und Außenpolitik, 493-507.

- Neubert, Ehrhart, Kirchenpolitik, 363-381.

- Segert, Astrid/Zierke, Irene, Gesellschaft der DDR: Klassen - Schichten Kollektive, 165-181.

- Trampe, Andreas, Kultur und Medien, 293-314.

Kaminski, Lukasz/ Persak, Krysztof/Gieseke, Jens, Handbuch der kommunistischen Geheimdienste in Osteuropa 1944-1991, Vandhoeck \& Ruprecht, Göttingen, 2009.

- Gieseke, Jens, Deutsche Demokratische Republik, 199-264.

- Hilger, Andreas, Sowjetunion (1945-1991), 43-142.

- Werth, Nicolas, Sowjetunion (1917-1945), 15-42.

Karner, Stefan, Der „Prager Frühling“ - Moskaus Entscheid zur Invasion, in: Prag: 1968. Aus Politik und Zeitgeschichte, Vol.20, May 2008, 6-12.

Karpat, Kemal H., The Politicization of Islam: Reconstructing Identity, State, Faith, and Community in the late Ottoman State, Oxford University Press, New York, 2000.

Katz, Mark N., Civil Conflict in South Yemen, Middle East Review, Vol. 19, No. 1, fall 1986, 7-13.

Kelsen, Hans, General Theory of Law and State, Lawbook Exchange, New York, 2007 (1945).

Kelsen, Hans, Theory of International Law, Lawbook Exchange, New York, 2005 (1952).

Kipling, Rudyard, The White Man's Burden: A Poem, Doubleday and McClure Company, New York, 1899.

Klein, Manfred: In Verantwortung für den Hörfunk - versuche und Versagen, in: Spielhagen, Edith, So durften wir glauben zu kämpfen ... Erfahrungen mit DDR -Medien, Berlin, Vistas Verlag, 1993, 83-91.

Kleßmann, Christoph, Zwei Staaten, eine Nation. Deutsche Geschichte 19551970, Bundeszentrale für Politische Bildung, Bonn, 1988

Kopp, Horst (Ed.), Länderkunde Jemen, Reichert Verlag, Wiesbaden, 2005. Kostiner, Joseph, The Struggle for South Yemen, St. Martin's Press, New York, 1984.Kotz, David/Weir, Fred, Revolution from Above. The Demise of the Soviet System, Routledge, New York, 1997. 
Kowalczuk, Ilko-Sascha, Stasi konkret. Überwachung und Repression in der DDR, Bundeszentrale für Politische Bildung, Bonn, 2013.

Kramer, Martin, Arab Awakening and Islamic Revival: The Politics of Ideas in the Middle East, Transaction, New Brunswick, 1996. (Kramer, 1996a)

Kramer, Martin, Fundamentalist Islam at Large: The Drive for Power, Middle East Quarterly, Vol. III, No.2 June 1996, 39-49. (Kramer, 1996b)

Kramer, Martin, Arab Nationalism: Mistaken Identity, Daedalus, Bielefeld, 1993, pp.171-206.

Krause, Jürgen, Das DDR-Namibia-Solidaritätsprojekt „Schule der Freundschaft“. Möglichkeiten und Grenzen interkultureller Erziehung, BIS Verlag der Carl von Ossietzky Universität Oldenburg, Oldenburg, 2009.

Kostiner, Joseph, South Yemen's Revolutionary Strategy, 1970-1985, Jaffee Center for Strategic Studies, Westview Press, Boulder, 1990.

Kuehn, Thomas Empire, Islam, and Politics of Difference: Ottoman Rule in Yemen, 1849-1919, Koninklijike Brill, Leiden, 2011.

Küntzel, Matthias, Die Deutschen und der Iran. Geschichte und Gegenwart einer verhängnisvollen Freundschaft, WjS Verlag, Berlin, 2009.

Kupper, Siegfried, Die Tätigkeit der DDR in den nichtkommunistischen Ländern. VI. Arabische Staaten und Israel, Deutsche Gesellschaft für Auswärtige Politik, Bonn, 1971.

Kutschera, Chris, L'étoile rouge pâlit-elle à Aden ? in: Le Monde Diplomatique,

October 1982, 22f, Retrieved from http://www.monde-diplomatique. fr/1982/10/KUTSCHERA/36979

Lackner, Helen, (ed.) Why Yemen matters. A Society in Transition, SOAS Middle East Issues, 2014 .

Lackner, Helen. P.D.R. Yemen. Outpost of Socialist Development in Arabia, Ithaca Press, London, 1985.

Lamm, Hans/Kupper, Diegrfried, DDR und Dritte Welt, Oldenburg Verlag München, 1976.Lang, Andrew, The Arabian Night's Entertainment, Longmans, Green and Co., London, 1898.

Lapid, Yosef/Kratochwil, Friedrich (ed.), The Return of Culture and Identity in IR Theory, Lynne Rienner Publishers, Boulder, 1996.

Lee, Dwight E., The Origins of Pan-Arabism, The American Historical Review, Vol. 47, No. 2, 1942, Oxford University Press, 278-287.

Legvold, Robert, Iron Curta in: The Crushing of Eastern Europe, 1944-1956, in: Foreign Affairs, Vol.g2 Issue 1, Jan/Feb 2013, 198-199.

Lemke, Michael, Prinzipien und Grundlagen der Außenbeziehungen der DDR in der Konstituierungsphase des DDR Außenministeriums 19491951, in: Sowjetisierung und Eigenständigkeit in der SBZ/DDR (1949-1953), Zeithistorische Studien 13, Köln, 1999, 233-274.

Lenin, Wladimir Iljitisch, Werke (in 40 Bänden), Vol.22. Institut für MarxismusLeninismus beim ZK der KPdSU (Ed.), Berlin-Ost, 1959 (1960). 
Lenin, Wladimir Iljitisch, Werke (in 40 Bänden), Vol.31. Institut für MarxismusLeninismus beim ZK der KPdSU (Ed.), Berlin-Ost, 1959 (1966).

Lenin, Wladimir Iljitisch, Imperialism, the Highest Stage of Capitalism. A popular Outline, in: Lenin's Selected Works, Progress Publishers, Moscow, 1963 (1916), Vol. 1, 667-766.Leonhard, Wolfgang, Die Revolution entlässt ihre Kinder, Kiepenheuer und Witsch, Köln/Berlin, 1961.

Lewis, Alexandra, Security, Clans and Tribes. Unstable Governance in Somaliland, Yemen and the Gulf of Aden, Palgrave McMillian, New York, 2014.

Lewis, Jim, People's Democratic Republic of Yemen: Struggle for survival, In Geography, Vol.72, No.4, 1987, 360-363.

Lichtenthäler, Gerhard, Power, Politics and Patronage: Adaption of Water Rights among Yemen's Northern Highland tribes, in: Études rurales, N. 155/156, Prégancedu droit coutumier (Jul. - Dec. 2000), 142-166, Retrieved from www.jstor.org/stable/20122832. (latest access June 26 2013).

Lieblich, Eliav, Intervention and Consent: Consensual forcible interventions in internal armed conflicts as international agreements, in: Boston University International Law Journal, Vol. 29, No. 2, 2011, 334-383.

Linde, Gerd, Moskau und Aden: Partner stürzen, Bastionen bleiben, Berichte des Bundesinstituts für ostwissenschaftliche und international Studien, 371987 , Köln, 1987.

Löbner, Sebastian, Semantik. Eine Einführung, Walter de Gruyter, Berlin, 2002. Lockman, Zachary, Contending Visions of the Middle East. The History and Politics of Orientalism, Cambridge University Press, Cambridge, 2010.

Lyons, Jon, Einführung in die modern Linguistik, C.H.Beck Verlag, München, 1995 (1st edition 1968).

Mackintosh-Smith, Tim, Yemen. Travels in Dictionary Land, John Murray, London, 2007 (1988).

Maeke, Lutz, Vom Zauber des Anfangs: Die Palästinensische Befreiungsorganisation und die DDR, Tribüne, Vol. 51 No.203, 2012, 155-164.

Malycha, Andreas/Winters, Peter Jochen, Geschichte der SED. Von der Gründung bis zur Linkspartei, Bundeszentrale für Politische Bildung, Bonn, 2009 .

Manea, Elham M., La tribu et l'Etat au Yémen, in: Mondher Kilani (ed): Islam et changement social,205-218, Editions Payot, Lausanne, 1996, Retrieved from http://www.al- bab.com/yemen/soc/manea1.htm. (2oth of November 2012)

Manea, Elham M., Am Anfang war der Stamm, in: Jemen. Zerrissene Einheit, inamo 62/16, summer 2010, 4-8.

Mann, Michael, A Political Theory of Nationalism and its Excesses, in: Periwal, Sukumar (Edit.), Notions of Nationalism, Central European University Press, Budapest, 1995, 44-64.

Mann, Michael, The Sources of Social Power, Cambridge University Press, 1993. 
Marantz, Paul/Steinberg Blema S. (Ed.), Superpower Involvement in the Middle East. Dynamics of Foreign Policy, Westview Special Studies in International Relations, Westview Press inc. London, 1985.

- Macfarlane, S.N., The Soviet View of the Utility of Force in the Third World, 3-30.

- Rome Spechler, Dina, Soviet Policy in the Middle East: The Cruicial Change, 133-173.

- Steinberg, Blema S., The Dynamics of Superpower Involvement in the Middle East: Retrospect and Prospect, 283-291.

Marx, Karl/Engels, Friedrich, The Communist Manifesto, Oxford University Press, 1998 (1848).

März, Peter (ed.), Die zweite gesamtdeutsche Demokratie. Fragen und Fundamente, Band 1, Bayrische Landeszentrale für politische Bildungsarbeit, München, 2001.

Maslow, Abraham Harold, Motivation and Personality, Harper and Row, New York, 1954 .

Masters, Johnathan/Laub, Zachary, Al-Qaeda on the Arabian Peninsula (AQAP), on Foreign relations, Retrieved from http://www.cfr.org/yemen/al-qaedaarabian-peninsula-aqap/p9369. (latest access September 12 2014).

Mc Faul, Michael, Russia's unfinished Revolution. Political Change from Gorbatchev to Putin, Cornell University Press, New York, 2001.

Meining, Stefan, Kommunistische Judenpolitik. Die DDR, Die Juden und Israel, Lit Verlag, Hamburg, 2002.

Meisner, Maurice, Marxism, Maoism, and Utopianism. Eight Essays, The University of Wisconsin Press, London, 1982.

Melamid, Alexander, New Oil from Arabia, in: Geographical Review, Vol. 78, 1/1988, 77f, Retrieved from www.jstor.org/stable/214307.

Meneley, Anne, Living Hierarchy in Yemen, Canadian Anthropology Society, Anthropologica, Vol. 42, No. 1, 2000, p.61-73.

Meuschel, Sigrid, Legitimationsstrategien in der DDR und in der Bundesrepublik, in: Kleßmann, Christoph/Misselwitz, Hans/ Wichert, Günter (ed.), Deutsche Vergangenheiten - eine gemeinsame Herausforderung. Der schwierige Umgang mit der doppelten Nachkriegsgeschichte, Ch. Links Verlag, Berlin, 1999, 115-127.

Modrow, Hans (Ed.), das große Haus, Berlin, 1994.

Möller, Harald, DDR und Dritte Welt. Die Beziehungen der DDR mit den Entwicklungsländern - ein neues theoretisches Konzept, dargestellt anhand der Beispiele China und Äthiopien sowie Irak/Iran, Berlin, 2004.

Mueller, Gustav E., The Hegel Legend of 'Thesis-Antithesis-Synthesis,' in: Journal of the History of Ideas, Vol. 19, No. 3, June 1958, 411-414. Müllenmeister, Uwe, Die Nahostpolitik der sozial-liberalen Koalition 1969-1982, Peter Lang Verlag, Frankfurt am Main, 1988. 
Müller, Miriam, Papiertiger auf Beutezug. Über die Schlussakte von Helsinki und ihre Bedeutung für das geteilte Deutschland [On the Final Report of the CSCE and the role of divided Germany], in: Deutschland Archiv, Bertelsmann Verlag, Bielefeld, 43. Jahrgang, 4/2010.

Müller, Miriam, Zwischen Ost und West liegt Helsinki - Die Bedeutung des KSZE-Prozesses für DDR und Bundesrepublik bis $1975 \mathrm{im}$ Vergleich unter besonderer Berücksichtigung der innerdeutschen Beziehungen, DiplomaThesis at Free University Berlin, 2009.

Müller-Enbergs, Helmut, Hauptverwaltung A (HV A). Aufgaben - Strukturen Quellen, Teil des MfS Handbuch, Anatomie der Staatssicherheit. Geschichte, Struktur und Methoden, Der Bundesbeauftragte für die Unterlagen des Staatssicherheitsdienstes der ehemaligen Deutschen Demokratischen Republik, Köster,Berlin, 2011.

Müller-Enbergs, Helmut/Wielgohs, Jan/Hoffmann, Dieter (Ed.), Wer war wer in der DDR? Ein biographisches Lexikon, Bundeszentrale für Politische Bildung, Bonn, 2000.

Müller-Enbergs (Ed.), Inoffizielle Mitarbeiter des Ministeriums für Staatssicherheit. Teil 2: Anleitungen für die Arbeit mit Agenten, Kundschaftern und Spionen in der Bundesrepublik Deutschland, Ch. Links Verlag, Berlin, 1998.

Müller-Enbergs (Ed.), Inoffizielle Mitarbeiter des Ministeriums für Staatssicherheit. Richtlinien und Durchführungsbestimmungen, Links Verlag, Berlin, 1996.

Muth, Ingrid, Die DDR-Außenpolitik 1949-1972, Inhalte, Strukturen,

Mechanismen, Ch. Links Verlag, Berlin, 2000.

Nardin, Terry, Humanitarian Imperialism, in: Ethics \& International Affairs, Vol. 19, No. 2, 2006.

Naumkin, Vitaly, Red Wolves of Yemen, Cambridge University Press, New York, 2004 .

Neubert, Erhart, Geschichte der Opposition in der DDR 1949-1989,

Bundeszentrale für politische Bildung, Bonn, 2000 (1997).

Neusüss, Arnhelm, Marxismus. Ein Grundriß der großen Methode, Wilhem Fink Verlag, München, 1981.

Niebuhr, Carsten, Travels through Arabia and other countries in the East, Vol.2, Morison and Son, London, 1792.

Nietzsche, Friedrich, Vom Nutzen und Nachteil der Historie für das Leben 1873/74, Insel Verlag, Leipzig, 1937.

Nitsche, Rudolf, Diplomat im besonderen Einsatz: Eine DDR-Biographie, GNN Gesellschaft für Nachrichtenerfassung und Nachrichtenverbreitung, Schkeuditz, 1994 .

Nkrumah, Kwame, Neo-Colonialism. The Last Stage of Imperialism, Thomas Nelson and Sons, London, 1965 . 
Nohlen, Dieter/Nuscheler, Franz (Ed.), Handbuch der Dritten Welt, Band 6:

Nordafrika und Naher Osten, 1993, Dietz Verlag, Bonn, 2003.

Nolte, Ernst, Deutschland und der Kalte Krieg, R.Piper \& Co.Verlag, München, 1974.

Onuf, Nicholas, World of Our Making: Rules and Rule in Social Theory and International Relations, Routledge, New York, 2013 (1989).

Orford, Anne, Reading Humanitarian Intervention: Human Rights and the Use of Force in International Law, Chapter 3: Localizing the other: the imaginative geography of humanitarian intervention, Cambridge University Press, Cambridge, 2003.

Ostermann, Christian F., East Germany and the Horn Crisis: Documents on SED Afrikapolitik, in: Russian \& East German Documents on the Horn of Africa, 197778, Cold War International History Project Bulletin Issues 9-10, New East-Bloc Evidence on the Cold War in the Third World and the Collapse of the Détente in the 1970, Woodrow Wilson International Center for Scholars, Washington, D.C., Winter 1996, 47-49, Retrieved from http://www.wilsoncenter.org/sites/default/ files/CWIHPBulletin8-9_tableofcontents.pdf. (latest access July 12 2014)

Ostow, Robin, The Shaping of Jewish identity in German Democratic Republic 1949-1989, in: Critical Sociology, Vol.17, No.47, 1990, 47-59.

Paget, Julian, Last Post. Aden 1964-1967, Faber and Faber, London, 1969.

Palmer, Monte, The United Arab Republic: An Assessment of Its Failure, in:

Middle East Journal, Vol. 20, No. 1, Winter, 1966, pp. 50-67.

Peri, Oded, Christianity under Islam in Jerusalem: The Question of the Holy

Sites in early Ottoman Times, Koninklijike Brill, Leiden, 2001.

Periwal, Sukumar, (Edit.) Notions of Nationalism, central European university

Press, Budapest, 1995.

Philbrick, Yadav, Stacey, Antecedents of the Revolution: Intersectoral Networks and Post-Partisanship in Yemen, in: Studies in Ethnicity and Nationalism, Vol.11, No.3, 2011, 550-563.

Phillips, Sarah, Yemen's Democracy Experiment in Regional Perspective. Patronage and Pluralized Authoritarianism, Palgrave McMillian, New York, 2008.

Petouris, Thanos, in: Review: Stephen W. Day. Regionalism and Rebellion in Yemen. A Troubled National Union, The Middle East Journal, Vol. 67, No. 3, Summer 2013, 487-489.

Pfeiffer, Otto, Nur das Meißner Porzellan. Das Auswärtige Amt übernahm keine DDR-Diplomaten, in: epd-Entwicklungspolitik, No.6/7, 1997, in: Verband für Internationale Politik und Völkerrecht e.V. Berlin, Retrieved from http:// www.vip-ev.de/texto6.htm (latest access March 6 2014).

Pfeil, Ulrich (Ed.), Die DDR und der Westen. Transnationale Beziehungen 19491989, Ch. Links Verlag, Berlin, 2001.

- Howarth, Marianne, Die Westpolitik der DDR zwischen internationaler Aufwertung und ideologischer Offensive (1966-1989), 82-98.

- Lemke, Michael, Die Außenbeziehungen der DDR (1949-1966), Prinzipien, Grundlagen, Zäsuren und Handlungsspielräume, 63-80 
- Sywotteck, Arnold, Die Bundesrepublik Deutschland als gesellschaftspolitische Herausforderung der DDR, 151-164.

Pohlig, Matthias, Vom Besonderen zum Allgemeinen? Die Fallstudie als geschichtstheoretisches Problem, in: Historische Zeitschrift 297 (2013), 297-319.

Popper, Karl, Vermutungen und Widerlegungen: das Wachstum der wissenschaftlichen Erkenntnis, Kapitel 15 - Was ist Dialektik?, Mohr Siebek, Tübingen, 2009 (1963).

Prados, Edward. The United States and Yemen: A Half Century of

Engagement. Occasional Papers. Center for Contemporary Arab Studies.

Georgetown University, 2005, Retrieved from http://ccas.georgetown.edu/ document/1242772109439/CCAS_Occasional+Paper_15.pdf.

Pridham, P.R. (Ed.), Contemporary Yemen. Politics and Historical Background,

Crom Helm Ltd, Sydney, 1984.

Quandt, William B., Soviet Policy in the October 1973 War, Office of the Assistant Secretary of Defence /International Security Affairs, 1973,

Retrieved from http://www.rand.org/content/dam/rand/pubs/reports/2006/ R1864.pdf.

Rabenhorst, Ernst-Peter, Die VDR Jemen auf sozialistisch orientiertem

Entwicklungsweg. in: Einheit, Vol. 32 (1977), No. 1, 111ff.

Read, Christopher, Lenin. A Revolutionary Life, Routledge, London and New York, 2005. Ritter, Gerhard A., Hans-Dietrich Genscher, das Auswärtige Amt und die deutsche Vereinigung, C.H.Beck Verlag, München, 2013.

Rogers, Joshua, Yemen's First Civil War offers Lessons for ending the Country's current conflict, Al-Muftah, April 21st 2015, Retrieved from http://muftah. org/yemens-first-civil-war-offers-lessons-for-ending-the-countrys-currentconflict/\#.VTfCZaY-bg2. (latest access April 22 2015)

Rogler, Lutz, Jemen versus Südarabien? Zur Entwicklung der “Bewegung des

Südens”, in: Jemen. Zerrissene Einheit, inamo 62/16, summer 2010, 24-29.

Rosenau, James N. New Directions and Recurrent Questions in the Comparative

Study of Foreign Policy, in: Hermann, Ch.F./Kegley, C.W./Rosenau, J..N., (ed.). New Directions in the Study of Foreign Policy, Allen \& Unwin Inc., Boston, 1987 .

Rothmann, Jay, Resolving Identity-Based Conflict In Nations, Organizations, and Communities, Jossey-Bass Inc., San Francisco, 1997.

Sabrow, Martin, Historisierung der Zweistaatlichkeit, in: APuZ 03/07, 2007, 19-24. Said, Edward W., Culture and Imperialism, Random House, New York, 1993. Said, Edward W., Orientalism, Pantheon Books, New York, 1978.

Saha, Santosh, The Politics of Ethnicity and National Identity, Peter Lang, New York, 2007.

Salter, Mark, Barbarians and Civilizations in International Relations, Pluto Press, London, 2002. 
Scharfenberg, Günther Scharfenberg, Jahre am Bab el-Mandeb. Als Botschafter in der Volksdemokratischen Republik Jemen, Publikationen des Verbandes für Internationale Politik und Völkerrecht e. V., Blaue Reihe Vol.41, 2012. Scheider, Christian, Der südliche Jemen und die Sowjetunion.

Großmachtengagement und politische Radikalisierung in der Dritten Welt, Deutsche Orient Institut, Hamburg, 1989.

Schleicher, Hans-Georg/Schleicher, Ilona, Die DDR und Afrika, Lit Verlag, Berlin, 1993 .

Schmeitzner, Mike (ed.), Löwenthal, Richard. Faschismus - Bolschewismus -

Totalitarismus. Schriften zur Weltanschauungsliteratur im 20.Jahrhundert, Vandenhoeck \& Ruprecht, Göttingen, 2009.

- Löwenthal, Richard, Die totalitäre Diktatur, 546-563. First published in: Gegenwartskunde. Zeitschrift für Wirtschaft und Schule, No.15, 1966/3, 199-212.

- Löwenthal, Richard, Jenseits des Stalinismus, 389-402.

- Löwenthal, Richard, Messianism, Nihilism and the Future, 458-474.

Schmidt, Siegmar/Hellmann, Gunther/Wolf, Reinhard (ed.), Handbuch zur deutschen Außenpolitik, VS Verlag für Sozialwissenschaften, Wiesbaden, 2007. Schmidt, Andreas, Hauptabteilung III: Funkaufklärung und Funkabwehr, Anatomie der Staatsicherheit, Geschichte. Struktur und Methoden (Handbuch), BStU (ed.), Berlin, 2010. Retrieved from http://www.nbnresolving.org/urn:nbn:de:0292-97839421300667.

Schmitt, Carl, Political Theology, University of Chicago Press, 2005 (MIT Press, $1922 / 34)$

Schneckener, Uwe, States at Risk. Fragile Staaten als Sicherheits- und

Entwicklungsproblem, SWP- Studie, 43/04, November 2004, Retrieved from http://www.swp-berlin.org/de/common/get_document.php?asset_id=1708.

Scholtyseck, Joachim, Die Außenpolitik der DDR, Enzyklopädie Deutscher Geschichte, Band 69, Verlag Oldenburg, Oldenburg, 2003.

Schroeder, Klaus, Der SED-Staat, Der SED-Staat. Geschichte und Strukturen der DDR (überarbeitete Auflage), Bayrische Landeszentrale für Politische Bildungsarbeit, München, 2013.

Schroeder, Klaus, Kompaktwissen Die DDR. Geschichte und Strukturen, Reclam Verlag, Stuttgart, 2011.

Schroeder, Klaus, Das Neue Deutschland. Warum nicht zusammen wächst, was zusammen gehört, wjs Verlag, Berlin, 2010.

Schroeder, Klaus, Der SED-Staat. Geschichte und Strukturen der DDR, Bayrische Landeszentrale für Politische Bildungsarbeit, München, 1999. Schulze, Hage, Kleine Deutsche Geschichte, Verlag C.H. Beck, München. Schußter, Hans-Jörg, VDR Jemen - Land am Golf von Aden, Friedrich-SchillerUniversität, Jena, 1987. 
Schwartz, Hans Peter (ed.), Die Bundesrepublik Deutschland: eine Bilanz nach $6 \circ$ Jahren, Böhlau Verlag, München, 2008.

- Wengst, Udo, Weichenstellungen in der Besatzungszeit, 121-134.

- Alisch, Steffen, Die DDR von Stalin bis Gorbatschow. der sowjetisierte deutsche Teilstaat 1949-1990, 135-156.

- Staadt, Jochen, Deutsch-deutsche Beziehungen von 1949-1989, 157-180.

- Hacke, Christian, 6o Jahre Außenpolitik der Bundesrepublik Deutschland, 487-510.

Schwartz, Howard, Tree of Souls: The Mythology of Judaism: The Mythology of Judaism, Oxford University Press, Oxford, 2004.

Schwartz, Seth J./ Luyckx, Koen/ Vignoles, Vivian L. (Ed.), Handbook of Identity

Theory and Research, Vol. 1 Structures and Processes, Springer, New York, 2011

Schwarzenbach, Rudolf, Formulierungshilfe als Entwicklungshilfe, Deutschland Archiv, 11/1971.

Seale, Patrick, The Break-Up of the United Arab Republic, in: The World Today, Vol. 17, No. 11, 1961, 471-479.

Shakespeare, William, The Tempest, Macmillian and Co., London, 1894 (1611).

Shearman, Peter (ed), Russian Foreign Policy since 1990, Westview Press,

Colorado, 1995,

- Shearman, Peter, Soviet Foreign Policy, 1917-1991, 1-22.

- Malcom, Neil, Russian Foreign Policy Decision-making, 23-52.

Sicherman, Harvey, Aden and British Strategy 1839-1968, Research Monograph

Series (12), Foreign Policy Research Institute Philadelphia, 1972.

Siebs, Benno-Eide, Die Außenpolitik der DDR 1976-1989. Strategien und

Grenzen, Schöningh Verlag, Paderborn, 1999.

Silsby, Susan, George Antonius. The Formative Years, in: Journal of Palestine Studies, Vol. 15, No. 4, 1986, 81-98.

Sindermann, Horst, Frieden und Sozialismus - Staatsdoktrin der DDR, Dietz Verlag, Berlin (Ost), 1980.

Sitton, John F., Marx Today. Selected Works and Recent Debates, Palgrave Macmillian, New York, 2010.

Slaughter, Cliff, Marx and Marxism. An Introduction, Longman Inc, New York, 1985. Soutou, Georges-Henri, La guerre de cinquante and. Le conflit Est-

Ouest 1943-1990, Fayard, Paris, 2001 (2011).

Spivak, Gayatri Chakravorty, A critique of postcolonial reason: Toward a history of the vanishing present, Chapter 4 - Can the Subaltern Speak?, Cambridge, Harvard University Press, 1999.

Spruyt, Hendrik, The Sovereign State and Its Competitors: An Analysis of Systems Change, Princeton University Press, New Jersey, 1996 (1994). Stalin, Jossip, V., Über die Grundlagen des Leninismus. Zu den Fragen des Leninismus, Verlag Neuer Weg, Berlin, 1946. 
Steinberg, Guido (Edit.), Deutsche Nah-, Mittelost- und Nordafrikapolitik. Interessen, Strategien, Handlungsoptionen, SWP-Studie, May 2009, Retrieved from http://www.swp-berlin.org/common/get_document. php?asset_id=5977 (October 10 2012).

Steiner, André, Von Plan zu Plan. Eine Wirtschaftsgeschichte der DDR, Deutsche Verlagsanstalt, München, 2004.

Steininger, Rudolf, Der Kalte Krieg, Fischer Taschenbuch Verlag, Frankfurt/Main, 2004.Stenslie, Stig, „Decisive Storm“: Saudi Arabia's attack on the Houthis in Yemen, Norwegian Peacebuilding Resource Centre, April 2015, Retrieved from https://www.academia.edu/11927469/_Decisive_Storm_Saudi_Arabia_s_ attack_on_the_Houthis_in_Yemen. (latest access April 15 2015)

Storckmann, Klaus, Geheime Solidarität. Militärbeziehungen und Militärhilfen der DDR in die $>>$ Dritte Welt<<, Christian Links Verlag, Berlin, 2012.

Stookey, Robert W., South Yemen. A Marxist Republic in Arabia, Westview Press, Boulder, 1982 .

Suckut, Siegfried (Ed.), Das Wörterbuch der Staatssicherheit. Definitionen zur politisch-operativen Arbeit, (Dictionary of State Security. Definitions of political-operative service) GVS JHS o01400/81, JHS Potsdam-Eiche, April 1985, in: Analysen und Dokumente - Wissenschaftliche Reihe des Bundesbeauftragten der Unterlagen der Staatssicherheit der DDR, Band 5, Christian Links Verlag, Berlin, 2001.

Suckut, Siegfried, Die Entscheidung zur Gründung der DDR. Die Protokolle der Beratungen des SED-Parteivorstandes am 4. Und 9. Oktober 1949, in: Vierteljahreshefte für Zeitgeschichte, 39/No.1, 1991, 125-175.

Süß, Walter, Staatssicherheit am Ende: warum es den Mächtigen nicht gelang, 1989 eine Revolution zu verhindern, Christian Links Verlag, Berlin, 1999. Svensson, Birgit, Presidential Election in Yemen. An Experiment in Democracy, February 2012, Retrieved from http://en.qantara.de/An-Experiment-inDemocracy/18524c19293i1p1405/index.html.

Tapper, Richard. "Anthropologists, Historians and Tribespeople on the Tribe Formation the Middle East", in: Khouri, Philip S/ Kostiner, Joseph, (ed.). Tribes and State Formation in the Middle East, Oxford, University of California Press, 1990.

Taylor, Charles, The Politics of Recognition, in: Multiculturalism of Recognition, Princeton University Press, Princeton, 1994, Retrieved from http://ow.ly/dtgm4. Tesón, Fernando R., Ending Tyranny in Iraq, in: Ethics \& International Affairs, Vol. 19, Issue 2, 2006.

The International Institute for Strategic Studies (Ed.), The Geopolitics of the Middle East, Adelphi Papers, Routledge, London/New York, 2006.

- Chubin, Shaharam, Soviet Policy Towards Iran and the Gulf, Adelphi Paper No. $157,1980,272-323$.

- Hunter, Robert E., The Soviet Dilemma in the Middle East Part II: Oil and the Persian Gulf, Adelphi Paper No. 60, 1969. 
Tibi, Bassam, Arab Nationalism between Islam and the Nation State, Palgrave McMillian, New York, 1997.

Tillmann, Heinz, Deutschlands Araberpolitik im zweiten Weltkrieg, VEB

Deutscher Verlag der Wissenschaften, Berlin (Ost), 1965

Timm, Angelika, The Burdened Relationship between the GDR and Israel, Israel

Studies, Vol. 2, No.1, 1997, 22-49. (Timm, 1997a)

Timm, Hammer, Zirkel, Davidstern. das gestörte Verhältnis der DDR zu

Zionismus und Staat Israel, Bonn. (Timm, 1997b).

Timmermann, Heiner (ed.), Diktaturen in Europa im 20. Jahrhundert - Der Fall DDR, Dunker und Humblot, Berlin, 1996.

- Tantzscher, Monika, Die Stasi und Ihre geheimen Brüder. Die international und geheimdienstliche Kooperation des MfS, 595-621.

- Timmermann, Heiner, DDR Außenpolitik als Instrument, 583-593.

Toal, Gerard (Ó Tuathail, Gearóid), Critical Geopolitics: The Politics of Writing

Global Space, Minnesota University Press, 1997.

Torfing, Jakob, Poststructuralist Discourse Theory: Foucault, Laclau, Mouffe, and Zizek, in: Janoski, Thomas/Alford, Robert R./Hicks, Alexander M./ Schwartz, Mildred A., Handbook of Political Sociology, The: States, Civil Societies and Globalization, Cambridge University Press, Cambridge, 2005.

Transfeld, Mareike, The NDC, Federalism, \& Violent Conflict: What's Next for Yemen?, February 15 2014, Retrieved from Muftah, http://muftah.org/end-ndcfederalism-violent-conflict-whats-next-yemen/ (latest access March 14 2014).

Unger, Oswald, Die Verfassung für die national-demokratische

Entwicklungsetappe der Volksdemokratischen Republik Jemen, in: Staat und Recht, Nr. 20, 2/1971, 1158-1173.Unger, Oswald, DDR-Erfahrungen gefragt, in: Horizont 23/71, 1971, 28-29.Vincent, R. J., „Non-intervention and International Order", Princeton University Press, Princeton, 1974.

Walker, R.B.J., After the Globe, Before the World, Routledge, London, 2010. Walker, R.B.J., Inside/Outside, Cambridge Studies in International Relations

(No. 24) Cambridge University Press, Cambridge, 1992.

Walker, R.B.J., Security, Sovereignty, and the Challenge of World Politics, in:

Alternatives: Global, Local, Political, 15(1), 1990, pp. 3-27.

Waltz, Kenneth, Man, the State, and War: A Theoretical Analysis, Columbia

University Press, New York, 2001 (1959).

Walzer, Michael, Just and Unjust Wars, Basic Books, 1977.

Weber, Max, Wirtschaft und Gesellschaft. Grundriß der verstehenden

Soziologie, Mohr/Siebeck, Tübingen, 2002 (1922).

Weber, Max, Politics as a Vocation, Essays in Sociology, Routledge, London, 2009, (1919)

Weber, Max, Schriften zur Wissenschaftslehre, Reclam Verlag, Stuttgart, 1991. Wehler, Hans-Ulrich: Deutsche Gesellschaftsgeschichte. Bundesrepublik und DDR, 1949-1990, Band 5, C.H.Beck Verlag, München, 2008. 
Weidenfeld, Werner/Korte, Karl-Rudolf (Ed.), Handbuch zur deutschen Einheit. 1949 - 1989 -1999, Bundeszentrale für Politische Bildung, Berlin, 1999.

Weingardt, Markus A., Deutsche Israel- und Nahostpolitik. Die Geschichte einer Gratwanderung seit 1949, Campus Verlag, Frankfurt a. M., 2002.

Weinhauer, Klaus, Terrorismus in der Bundesrepublik der Siebzigerjahre. Aspekte einer Sozial- und Kulturgeschichte der Inneren Sicherheit, in: Archiv für Sozialgeschichte 44, Verlag J.H.W. Dietz, 2004, 219-242, Retrieved from http://www.zeitgeschichte-online.de/sites/default/files/documents/afs-2004219.pdf_-_afs-2004-219.pdf. (latest access September 20 2014)

Welch, Michael, Ordering Iraq: Reflections on Power, Discourse, \&

Neocolonialism, in: Critical Criminology, 12/2008, Vol. 16, No. 4, 257-269.

Welsh, Jennifer M., (Ed.), Humanitarian Intervention and International

Relations, Oxford University Press, Oxford, 2004.

- Shue, Henry, Limiting Sovereignty, 11-28.

- Wheeler, Nicholas, The Humanitarian Responsibilities of Sovereignty, 29-51.

Wengst, Udo/Wentker, Hermann (Ed.), Das doppelte Deutschland. 40 Jahre

Systemkonkurrenz, Bundeszentrale für politische Bildung, Bonn, 2008.

- Das Gupta, Amit, 1965. Ulbricht am Nil. Die deutsch-deutsche Rivalität in der Dritten Welt, 111-134.

- Wirsching, Andreas, 1989. Die Mauer fällt. Das Ende des doppelten Deutschland, 357-374.

- Wenner, Manfred W., The Yemen Arab Republic. Development and Change in an Ancient Land, Westview Press, Boulder, 1991.

Wentker, Hermann, Außenpolitik in engen Grenzen. Die DDR im

internationalen System, 1949-1989, Oldenburg Verlag, München, 2007.

Westad, Odd Arne, The Global Cold War. Third World interventions and the making of our times, Cambridge University Press, Cambridge, 2005.

Wettig, Gerhard, Sowjetische Deutschland-Politik 1953 bis 1953. Korrekturen an

Stalins Erbe, Chruschtschows Aufstieg und der Weg zum Berlin-Ultimatum, Oldenburg Verlag, München, 2011.

Wettig, Gerhard, Bereitschaft zur Einheit in Freiheit? Die sowjetische Deutschlandpolitik von 1945 - 1955, Olzog Verlag, München, 1999. Wheeler, Nicholas J., Saving Strangers: Humanitarian Intervention in International Society, Oxford University Press, Oxford, 2000.

Wilson, Mary C. The Hashemites, the Arab Revolt and Arab Nationalism, in: Khalidi, Rashid/Anderson, Lisa/Muslih, Muhammed/Simon, Revva S., The Origins of Arab Nationalism, Columbia University Press, New York, 1991, 204-221.

Whitaker, Brian, The Birth of Modern Yemen, 2009, Retrieved from www.albab.com/yemen/birthofmodernyemen.

Wien, Peter, Preface - Relocating Arab Nationalism, in: International Journal of Middle East Studies, Vol.43, Special Issue 02, May 2011, 203-204.

Winkler, Heinrich August, Der lange Weg nach Westen: Deutsche Geschichte vom „Dritten Reich bis“ zur Wiedervereinigung, C.H.Beck Verlag, München, 2000. 
Winter, Heinz-Dieter, Von Hanoi bis Damaskus - Stationen eines Diplomaten der Deutschen Demokratischen Republik, Publikationen des Verbandes für Internationale Politik und Völkerrecht e. V., Blaue Reihe Vol.43, 2013

Winzer, Otto, Über einige Hauptfragen der Außenpolitik der DDR. Reihe

Vorlesungen und Schriften der Parteihochschule Karl Marx, Berlin (Ost), 1972.

Wippel, Steffen, Die Außenwirtschaftsbeziehungen der DDR zum Nahen Osten: Einfluss und Abhängigkeit der DDR und das Verhältnis von Außenwirtschaft zu Außenpolitik, Das Arabische Buch, Berlin, 1996.

Wolf, Christa, Im Dialog. Aktuelle Texte, 1994, München, „Unerledigte Widersprüche. Gespräch mit Therese Hörnigk, June 1987“, excerpt in: Judt, 1998, 59f.

Wolf, Markus, Spionagechef im geheimen Krieg. Erinnerungen, List Verlag, München, 1997.

Womersley, David (Ed.), Decline and Fall of the Roman Empire, Penguin, New York, 1994.

Wünsche, Renate, in: Hahn, Gerhard/Hänisch, Werner/Busse, Hartwig/Linger, Klaus, Außenpolitik der DDR. Für Sozialismus und Frieden, Staatsverlag der Deutschen Demokratischen Republik, Ost-Berlin, 1974.

Wunschik, Tobias, Die Aufnahmelager für West-Ost-Migranten. Öffentliche Darstellung und heimliche Überwachung nach dem Mauerbau, March 2013, in: Deutschland-Archiv Online 2013, Retrieved from http://www.bpb.de/ geschichte/zeitgeschichte/deutschlandarchiv/wunschik20130802/

Wunschik, Tobias, Baader-Meinhoff international, in: 1977 und die RAF, Aus Politik und Zeitgeschichte, No.40/41, 2007, 23-29.

Yodfat, Aryeh Y., The Soviet Union and the Arab Peninsula. Soviet Policy towards the Persian Gulf and Arabia, Routledge, New York, 2011 (1983).

Young, Elisabeth, Unifying History: An examination of official national narratives in the Republic of Yemen, 2009, Irmgard Coninx Foundation, Retrieved from http://www.irmgardconinxstiftung.de/fileadmin/user_ upload/pdf/Memory_Politics/Workshop_2/Young_Essay.pdf.

Young, Robert J.C., Postcolonialism. An Historical Introduction, Blackwell Publishers, Oxford, 2001.

Zubok, Vladislav Martinovič., A Failed Empire. The Soviet union in the Cold War from Stalin to Gorbachev, University of North Carolina Press, Chapel Hill, 2007.

\section{Essays, Newspaper Articles and the Media}

Al-Azm, Sadek, Arab Nationalism, Islamism and the Arab Uprising, Lecture at the London School of Economics, December 2011, Retrieved from http:// blogs.1se.ac.uk/mec/2011/12/07/arab-nationalism- islamism-and-the-arabuprising. (latest access January 10 2013)

Agafinov, Vladimir, 2008, Retrieved from http://www.socotra.info/sovietmilitary-base-on-socotra-the-myth-and- reality.php\#.U8kB3ZWWBBo. 
Avenarius, Tomas: Stellvertreter Krieg in Jemen. Unglückliches Arabien. in: Süddeutsche Zeitung, March 26 2015, Retrieved from http://www. sueddeutsche.de/politik/jemen-unglueckliches-arabien-1.2411264. (latest access March 27 2015)

Blog - The GDR Objectified. The Red Woodstock: 1oth World festival of Youth and Students East Berlin, no author, Retrieved from http://gdrobjectified. wordpress.com/2013/03/01/the-red-woodstock/, (latest access April 10 2014).

Deffarge, Claude/Troeller, Gordian, Sud-Yemen: Une révolution menace?, in: Le Monde Diplomatique, April 1971, 6-8, Retrieved from http://www.mondediplomatique.fr/1972/04/ DEFFARGE/ 30853.

Der gescheiterte Taktiker Bethmann Hollweg”, Retrieved from http://www. bundesarchiv.de/oeffentlichkeitsarbeit/bilder_dokumente/01107/index-18. html.de. (latest access May 26 2014)

Ein-Gel, Ehud, Why did they liquidate Salmin? Beduin Socialism with a Human Face, 1981, pub. in Ein-Gel, Ehud, Milestones on the Road to Hadhramaut., Appendix, 2004, Retrieved from Mazpen. The Socialist Organization in Israel, http://98.130.214.177/index.asp?p=english_salmin-eng

Erika Wildau, in: Der Spiegel, No.49, 1988, Retrieved from http://www.spiegel. de/spiegel/print/d- 13531065.html. (latest access May 10 2014)

Kein Tapetenwechsel: Kurt Hager beantwortete Fragen der Illustrierten Stern, in: Stern, April 9 1987, Retrieved from http://germanhistorydocs.ghi-dc.org/ pdf/deu/Chapter13Doc8.pdf. (latest access May 20 2014)

Lorenzentführung: Nur die Generalprobe? Der Spiegel, 10/1075,

Retrieved from http://wissen.spiegel.de/wissen/image/show.

html?did=41560944\&aref=image035/E0534/PPM-SP197501000190027. pdf\&thumb=false. (latest access February 27th o14)

Müller-Marein, Josef, Abstimmung mit den Füßen. Die große Flucht in Deutschland, in: Die Zeit, July 21 1961, No. 30, Retrieved from http://www. zeit.de/1961/30/abstimmung-mit-den-fuessen.

Coker, Margaret, Tribal Tied Impede Yemen's War on Al-Qaida, Wallstreet Journal, November 2nd 2010, http://online.wsj.com/article/SB100014240527 $48704865104575588121894056984 . h t m l$ latest access March 5th 2013.

Drepper Danile/Hülsewig, Sola, Waffengeschäfte. Waffen für die Welt: Retrieved from Der Westen - Portal der WAZ-Mediengruppe, http://stasi.derwesten. de/14-o-Die-Waffengeschfte.html (latest access March 10 2014)

Festschrift. 30 Jahre Wiederaufnahme Diplomatische Beziehungen und 30 Jahre Entwicklungszusammenarbeit zwischen Jemen und Deutschland, Press- und Informationsamt der Bundesregierung (Ed.), Deutsche Botschaft, Sana'a, 1999.

Feuer der Revolution nicht zu löschen, in: Der Spiegel, No.10, 1980, Retrieved from http://www.spiegel.de/spiegel/print/d-14315762.html (latest access April 20 2014). Gender Inequality Index 2011, United Nations Development Reports, Retrieved from http://hdr.undp.org/en/statistics/gii/, (latest access March 5 2013). 
Gould, Jack, Radio Free Europe: A Unique Private Enterprise is set up to pierce Russia's Iron Curtain Channels St-Up Craftsmanship Unity, in: New York Times, July 9 1950, X9, Retrieved from http://search.proquest.com.ezproxy.library.uvic. ca/docview/111663579?accountid=14846 (latest access March 18 2014).

Honecker, Erich, Report of the Politbüro to the VII. Conference of the Central Committee, in: Neues Deutschland December 21988.

Hayden, Thomas, It's the Tribes Stupid, 4th of November 2010, poliquicks, Retrieved from http://poliquicks.com/2010/11/04/it\%E2\%80\%99s-the-tribes-stupid-2/

Interview with Faruq Mustafa, member of the CC of the Democratic Youth Organization of Yemen, in: Neues Deutschland, Nov 301972.

Kaufmann, Sylvia-Yvonne (Ed.), Partei des demokratischen Sozialismus, DDRAußenpolitik aus heutiger Sicht. Politikwissenschaftliche Konferenz der PDS am 16. April 1994 in Berlin, Bundesvorstand der PDS, Berlin, 1994.

Kifner, John, Battle for Southern Yemen: How the Fury Began, in: The New York Times, January 30 1986a, Retrieved from http://www.nytimes. com/1986/01/30/world/battle-for-southern-yemen-how-the-fury-began.html. (latest access April 15 2014)

Kifner, John, Massacre over Tea: Southern Yemen Conflict, in: The New York Times, February 9 1986b, Retrieved from http://www.nytimes. com/1986/02/o9/world/massacre-with-tea-southern-yemen-at- war.html. (latest access April 15 2014)

Lebanon's men of letters. The Christian scholars who let Arabic literary revival of the 19th century, in: Al-Jazeera, Retrieved from http://www.aljazeera.com/ focus/arabunity/2008/01/2008525173546578323.html (26th of December 2012). Lenon, John, Beautiful Boy, 1982, Retrieved from http://www.thebeatles.com. hk/john/lyrics/lyrics.php?lyTitle=Beautiful+Boy+(Darling+Boy). (latest access April 15 2014)

Lieven, Anatol, review: Paperbacks: Iron Curta in: The Crushing of Eastern Europe 1944-56 by Anne Applebaum, in: The Guardian, June 15 2013, 19. Madabish, Arafat, Divisions within Yemen's Al-Hirak delay announcement of Southern independence, Al-Sharq Al-Awsat, December 12014 , Retrieved from http://www.aawsat.net/2014/12/article55339051/divisions-withinyemens- al-hirak-delay-announcement-of-southern-independence-sources. (latest access December 15 2014)

Management and conservation of renewable marine resources in the Red Sea and Gulf of Aden region, UNEP Regional Seas Reports and Studies No.64, 1985, Retrieved from http://www.unep.org/regionalseas/publications/reports/ RSRS/pdfs/rsrso64.pdf. (latest access May 10 2014)

Miller, Dorothy, Iraq extends full diplomatic relations to the GDR, May 5 1969, Radio Free Europe Research. Communist Area, Retrieved from Open Society Archives, http://osaarchivum.org/files/holdings/30o/8/3/text/25-5-246.shtml (latest access March 19 2014) 
Moskauer Strafexpedition am Horn von Afrika, in: Der Spiegel, No. 7, 1978,

Retrieved from http://www.spiegel.de/spiegel/print/d-40616402.html. (latest access April2o 2014).

Rajih, Mansur, The Fatherland, 1958. Retrieved from worldswithoutborders.org/ article/the-fatherland, (latest access March 5 2013).

Rupp, Rainer, Interview with Hans Bauer, "Strafvollzug in der DDR zielte auf vollwertige Wiedereingliederung”, in: junge Welt, June 21 2012, 3

Schiavenza, Matt, Yemen's Wily Puppet Master. Ali Abdullah Saleh, ousted in the Arab Spring protests, has re- emerged as the country's most influential man. March 29 2014, The Atlantic, Retrieved from http://www.theatlantic. com/international/archive/2015/03/yemens-wily-puppet-master/388973/. (latest access September 28 2014).

Temlali, Yassine, The "Arab Spring" - Rebirth or Final Throes of "PanArabism”?, Heinrich-Böll- Stiftung (Ed.), 2011 Retrieved from http:// www.boell.de/sites/default/files/assets/boell.de/images/download_de/ Perspectives_02-06_Yassine_Temlali.pdf. (latest access Febuary 1oth 2014) Trigor, Yehoshua, Untenable position for the DDR, in: Jerusalem Post, May $7^{\text {th, }}$ 1991.Political Parties weigh in on who is, is not advantageous to National Dialogue success, in: Yemen Times, October 22 2012, Retrieved from www. yementimes.com.

Who represents the South?, in: Yemen Times, October 24th 2012, Retrieved from www.yementimes.com, (latest access March 5 2013).

Southern Movement pressured to join National Dialogue, in: Yemen Times, November 17th 2012, Retrieved from www.yementimes.com.

Al-Beidh: Southern state will help "fight regional instability”, December 15th 2012, Retrieved from http://nationalyemen.com/2012/12/15/al-beidh-southern-statewill-help-fight-regional-instability (latest access March 8th 2013).

Scorpions. "Wind of Change” zum Mauerfall, in: Spiegel Online, October 27 1999, Retrieved from http://www.spiegel.de/kultur/musik/scorpions-windof-change-zum-mauerfall-a-49545.html

Seidel, Karl, in: Protokoll der Arbeitsgemeinschaft Geschichte im Verband Internationale Politik und Völkerrecht e.V., February 4 1999, Berlin, 1999, 1.

South Yemeni Protest in Washington, You Tube Photography and Comments July 72009 , Retrieved from https://www.youtube.com/ watch?v=6sKTFHOIRAc (latest access, July 10th 2013)

Soviet military base on Socotra - Myth and Reality, Retrieved from http://www. socotra.info/soviet- military-base-on-socotra-the-myth-and-reality.php , (latest access March 20 2014)

Steinvorth, Daniel: Kollision zwischen Riad und Teheran. in: Neue Züricher Zeitung, March 26 2015, Retrieved from http://www.nzz.ch/international/ naher-osten-und-nordafrika/drohende-kollision-zwischen-tiad-undteheran-1.18510531. (latest access March 27 2015). 
The Scorpions, Album "Crazy World", Lyrics "Wind of Change” in English and Russian, Retrieved from http://www.the-scorpions.com/german/discography/ records/crazy_world.asp\#WIND_OF_CHANGE, (latest access March 10 2014).

UN Data, Former Democratic Yemen, Retrieved from http://data.un.org/ (latest access May 10 2014).

UN Office of the High Representative for the Least Developed Countries, Landlocked Developing Countries and Small Island Developing States (UNOHRLLS), Retrieved from http://www.unohrlls.org/en/ldc/related/59/ (latest access July 10 2014).

\section{Dictionaries, Encyclopaedias and IntRoductory Literature}

Badie, Bertrand/Berg-Schlosser, Dirk/Morlino, Leonardo, International Encyclopedia of Political Science, Sage Publications, Inc., Thousand Oaks, 2012.

Anheier Helmut K./Juergensmeyer, Mark, Encyclopedia of Global Studies, Sage Publications, Inc., Thousand Oaks, 2012.

Burrowes, Robert D., Historical Dictionary of Yemen, Scarecrow Press Inc., Plymouth, 2010.

Encyclopedia of Yemen (Arabic), Alafif Cultural Foundation (ed.), 4 Volumes, 2003, Sana'a, Yemen.

Ginsburg, George, A Calendar of Soviet Treaties. 1974-1980, Martinus Nijhoff Publishers, Dortrecht, 1987.

Kleines Politisches Wörterbuch, Dietz Verlag, Berlin (Ost), 1973.

Mattar, Philip (Ed.), Encyclopedia of the Modern Middle East and North Africa, Palgrave \& Macmillan (Macmillan Reference), New York, 2004.

Stanton, Andrea L./Ramsamy, Edward/Seybolt, Peter J./Elliott, Carolyn M., Cultural Sociology of the Middle East, Asia, \& Africa: An Ecyclopedia, Sage Publications, Los Angeles/Washington D.C., 2012.

Putzger Historischer Weltatlas, Cornelsen Verlag, Berlin, 2001.

van Waarden, Frans, Insitutionen zur Zentralisierung und Kontrolle politischer Macht, in: Schubert, Klaus/Bandelow, Nils, Lehrbuch der Politikfeldanalyse, Oldenburg Verlag, München, 2003, 257- 287.

Wörterbuch der Außenpolitik und des Völkerrechts, (Dictonary of Foreign Policy and International Law), 1980, Berlin.

Woll, Artur, Allgemeine Volkswirtschaftslehre, Verlag Vahlen, München,1990. World Heritage Encyclopedia, Retrieved from http://cdn.worldheritage.org/ articles/National_motto\#Y. (latest access September 9th 2014). 


\section{Archival Documents}

\section{Legal Documents, Treaties, Speeches and other Primary SOURCES}

Adenauer, Konrad, Erste Regierungserklärung von Bundeskanzler Konrad Adenauer, 20.September 1949, Retrieved from http://www.kas.de/wf/ de/33.820/ (latest access March 13 2013)

Ban, Ki Moon, Implementing the Responsibility to Protect. Report of the Secretary General, January 12 2009, Retrieved from http://responsibilitytoprotect.org/ implementing\%2othe\%2ortop.pdf (latest access July 10 2014)

Bericht des ZK der SED an den XI. Parteitag der SED, April 17 1986, 31-101. in: Protokoll der Verhandlungen des XI: Parteitags im Palast der Republik in Berlin 17. Bis 21. April 1986, Berlin (Ost), 1986.BVerfGE 36,1, vom 31.Juli 1973, Grundlagenvertrag, Retrieved from http://www.servat.unibe.ch/dfr/ bvo36001.html. (latest access June 15 2013)

Brezhnev, Leonid, November 22 1978, Opening the session of the Political Advisory Committee of the Warsaw Treaty Organization, The Intervention in Afghanistan and the fall of Détente - A Chronology, in: The Carter-BrezhnevProject, The National Security Archive, Retrieved from http://www2.gwu. edu/ nsarchiv/carterbrezhnev/ (latest access March 30 2014)

"Case Concerning the Military and Paramilitary Activities in and against

Nicaragua (Nicaragua v. United States of America)", Separate Opinion of Judge Nagendra Singh President,1986, Retrieved from http://www.cajpe.org. pe/terro/casonica.htm. (latest access, April 20 2014)

Chruchill, Winston S., The Sinews of Peace, March 5 1946, Retrieved from http://www.nato.int/docu/speech/1946/s460305a_e.htm, (latest access March 30 2014).

Constitution of the PDRY of October 31st 1978, published by the Foreign Ministry of the PDRY, 14 October Corporation Aden, 1981.

Das Grundgesetz, in: Staats- und Verwaltungsrecht Bundesrepublik

Deutschland, C.F. Müller Verlag, 2007, 8-69. 
Dertinger, Georg Minister for Foreign Affairs of the GDR, in: Neues Deutschland, Vol.4, No.250, October 25 1949, Retrieved from www.www. diplomatieglobal.de. (latest access April 12 2014)

Grundgesetz für die Bundesrepublik vom 23. Mai 1949, Retrieved from http://www. documentarchiv.de/brd/1949/grundgesetz.html. (latest access June 20 2013)

Final Act of the Conference on Security and Co-operation in Europe (CSCE), Retrieved from http://www1.umn.edu/humanrts/osce/basics/finact75.htm, (latest access May 11 2013)

International border treaty between the Republic of Yemen and the Kingdom of Saudi Arabia 12 June, 2000. Unofficial translation by Brian Whitaker of Arabic text published in al-Hayat newspaper on 22 June, 2000. Preamble omitted, Retrieved from http://www.al-bab.com/yemen/pol/int5.htm, (latest access October 10 2015).

Konferenz über Sicherheit und Zusammenarbeit in Europa. Schlussakte, Helsinki 1975, Retrieved fromhttp://www.osce.org/documents/ mcs/1975/08/4044_de.pdf (latest access July 20 2015).

Report of the International Commission on Intervention and State Sovereignty (ICISS), International Development Research Centre, Canada, December 2001, Retrieved from http://responsibilitytoprotect.org/ICISS\%20Report.pdf (latest access September 19 2014)

Stasi-Records Act (Act regarding the records of the state security eservice of the former German Democratic Republic, Issued by The Federal Commissioner for the Records of the State Security Service of the former German Democratic Republic Berlin, 2012, Retrieved from http://www.bstu.bund.de/DE/ BundesbeauftragterUndBehoerde/Rechtsgrundlagen/StUG/StUG_e nglisch/ StUG_englisch_pdf.pdf?_blob=publicationFile, (lastest access: April 12 2014). Statistisches Jahrbuch der Deutschen Demokratischen Republik 1973 and 1979, Staatliche Zentralverwaltung für Statistik (ed.), Staatsverlag der Deutschen Demokratischen Republik, Berlin (East), 1973 and 1979.

The Responsibility to Protect. Report of the International Commission on Intervention and State Sovereignty. December 2001, Retrieved from http://responsibilitytoprotect.org/ICISS\%2oReport.pdf, (latest access January 10 2014)

The Tripoli Declaration, 2 to 5 December 1977, in: Letter dated 5 December 1977 from the Permanent representative of the Libyan Arab Jamahiriya to the United Nations addresses to the Secretary-General, Annex, A/32/411, 6 December 1977, Retrieved from unispal.un.org (latest access April 8 2014). Treaty on Juridical Assistance April 1st 1971, in: BStU MfS HA IX Nr. 13694. Treaty on the final settlement with respect to Germany of September 12 1990, Retrieved from http://www.auswaertiges- amt.de/cae/servlet/ contentblob/37316o/publicationFile/153328/ZweiPlusVierVertrag.pdf, also see: PA AA MULT 781.

Verfassung der Deutschen Demokratischen Republik vom 7.Oktober 1949, Retrieved from http://www.documentarchiv.de/ddr.html. (latest access April 2 2013) 
Verfassung der Deutschen Demokratischen Republik vom 6. April 1968, Retrieved from http://www.documentarchiv.de/ddr.html. (latest access April 6 2013)

Verfassung der DDR, vom 7. Oktober 1974, Retrieved from http://www. documentarchiv.de/brd.html. (latest access April 6 2013)

Verordnung über das Statut des Ministeriums für Auswärtige Angelegenheiten vom 14.Dezember 1959, in: Gesetzblatt der DDR, Part I, No.18, March 23 $1960,160 f f$.

Verordnung über das Statut des Ministeriums für Auswärtige Angelegenheiten vom 18.Februar 1970, in: Gesetzblatt Teil II, Nr.23, March 3 1970, 173.

Verordnung über das Statut des Ministeriums für Auswärtige Angelegenheiten vom 14.Dezember 1959, in: Gesetzblatt der DDR, Part I, No.18, March 23 $1960,160 f f$.

Vertrag zwischen dem Allgemeinen Deutschen Nachrichtendienst, der Nachrichtenagentur der DDR, und der Aden News Agency, der Nachrichtenagentur der Volksrepublik Südjemen, über Zusammenarbeit auf dem Gebiet des Nachrichtenwesens, in: BArch DC 900/920.

Vertrag über die Beziehungen zwischen der Bundesrepublik Deutschland und den Drei Mächten ("Deutschlandvertrag") vom 26. Mai 1952 in der Fassung vom 23. Oktober 1954, Retrieved from http://www.documentarchiv.de/brd. html. (latest access May 24 2013)

Vertrag über die Grundlagen der Beziehungen zwischen der Bundesrepublik Deutschland und der Deutschen Demokratischen Republik ("Grundlagenvertrag") December 21 1972, Retrieved from http://www. documentarchiv.de/brd/grundlvertr.html. (latest access January 6th, 2014)

Völkerrechtliche Vereinbarungen der Deutschen Demokratischen Republik. Eine Zusammenstellung der internationalen Verträge, Abkommen und sonstigen Vereinbarungen der Regierung der Deutschen Demokratischen Republik, ihrer Organisationen und Institutionen seit 1949: Jemen (demokratischer), Gesamtdeutsches Institut - Bundesanstalt für gesamtdeutsche Aufgaben (Ed.), Stand 1987, 139-140-4.

Weißbuch zur Sicherheit Deutschlands of 1994 and Weißbuch zur Sicherheitspolitik Deutschlands of 2006 , Retrieved from http://www.bmvg. de/portal/a/bmvg/!ut/p/c4/DcapDYAwDAXAWVgg7unYAuicYCVP-Qrnsz7 omqObfoUnPHfUwolOuhx2u4zNoxuFC_IGQddWEzqi4eLFii7mqXFkKfWQNUOF6jFY_sAY_7e5g!!/. (latest access July 10 2014).

Yemen news items of Al-Bab, Retrieved from http://www.al-bab.com/yemen/ chron/yem87.htm. (latest access April 30 2014).

Yemen Transition Agreement, Retrieved from http://www.albab.com/arab/docs/ yemen/yemen_transition_agreement.htm. (latest access March 10 2013.)

Zhdanov, Andrej, answering Stalin's and Truman's „declarations of war“ on September 22 1947, Retrieved from http://www.ena.lu/shdanow_bericht_22_ september_1947-3-833.pdf (latest access July 10 2014). 


\section{Edited Documents and Document-Collections}

Akten zur Auswärtigen Politik der Bundesrepublik Deutschland (AzAP-BRD) 1969 - Vol.1 1.Januar bis 30.Juni

- Carstens, Karl. Runderlass 18.Juni 1964, Dok. 171. 688-69o.

- Aufzeichnung des Ministerialdirektors Frank, April 15 1969, 478-481.

- Aufzeichnung des Ministerialdirektors Bahr, July 1 1969, 751-760. 1969 - Vol.2 1.Juli bis 31.Dezember

- Aufzeichnung des Ministerialdirigenten Gehlhoff, July 9 1969, 798-801. 1974 - Vol.1 1.Januar bis 30.Juni

- Botschafter Held, Sanaa, an das Auswärtige Amt, June 3 1976, 807-809. 1981 - 1.Januar bis 31.Dezember

- Staatssekretär van Well z.Z. in Riad an Auswärtiges Amt, 28. April 1981, 650-654. Bator, Wolfgang und Angelika (Ed.), Die DDR und die arabischen Staaten.

Dokumente 1956-1982, Staatsverlag der Deutschen Demokratischen Republik, Berlin (Ost), 1982.

Die Kabinettsprotokolle der Bundesregierung, Vol. 22, 1969, Das Bundesarchiv,

Hollmann, Michael/Naasner, Walter/Seemann, Christoph (ed.), Oldenburg

Verlag München, 2012

- 172. Kabinettssitzung am Mittwoch dem 2.Juli 1969.

Die Kabinettsprotokolle der Bundesregierung, Das Bundesarchiv Online,

Retrieved from https://www.bundesarchiv.de/cocoon/barch/o00o/k/k1969k/

kap1_2/kap2_25/index.html. (latest access 2.Febraur 2014)

- 50. Kabinettssitzung, am Mittwoch dem 13. Februar 1974.

Dokumente zur Außenpolitik der Regierung der Deutschen Demokratischen

Republik Staatsverlag der Deutschen Demokratischen Republik (DzAPR-

DDR), Rütten \& Loening, Berlin.

Vol.I, 1954

- Abschluss eines Abkommens über den Waren- und Zahlungsverkehr mit Ägypten am 11.März 1953 durch den Sonderbeauftragten für den Nahen Osten, Herrn Koch, 505 f.

Vol. III, 1956

- Besuch des Kronprinzen des Königreichs Jemen 1956 in Ost-Berlin, in: Kronprinz des Königreichs Jemen, Emir Seif el-Islam Moahmmed el-Badr, vom 25. Juni bis 2. Juli 1956, 687 .

- Unterzeichnung eines deutsch-jemenitischen Kommuniqués, 696.

Vol. IX, 1962

- Besuch des Ministers für Post-, Telegrafen- und Telefonwesen des Königreiches Jemen, Qadi Abdulla Ben Ahmend el Hagri, 1961, $45^{2}$. Vol. XV/1, 1970

- Kommuniqué über die Konferenz der Außenminister europäischer sozialistischer Staaten vom 19. bis 21. Dezember 1967 in Warschau zur Entwicklung der Lage im Nahen Osten“, $567 f f$. 
Dokumente zur Deutschlandpolitik, Oldenburg Verlag, München

21. Oktober 1969 Bis 31. Dezember 1970, Band 1 (2002)

- Nr.111 - Gespräch des Ministerpräsidenten der DDR Stoph mit

Bundeskanzler Willy Brandt, Erfurt 19.März 1970, 398-435.

Jaeger, Kinan/Tophoven, Rolf, (Ed.) Der Nahost-Konflikt. Dokumente.

Kommentare. Meinungen, Bundeszentrale Politische Bildung, Bonn, 2011.

Lautemann, Wolfgang / Schlenke, Manfred (Ed.) Die Welt seit 1945. Geschichte

in Quellen, Bayerischer Schulbuchverlag, München, 1980.

Materialien der Enquete-Kommission „Aufarbeitung von Geschichte und Folgen der SED-Diktatur in Deutschland“, 12. Wahlperiode des deutschen Bundestages, Deutscher Bundestag (Ed.), Vol. VIII: Das Ministerium für Staatssicherheit : Seilschaften, Altkader, Regierungs- und Vereinigungskriminalität, Baden-Baden, 1995.

President of the GDR Otto Grothewohl signs the Warshaw Pact on May 15

1955, Picture: Beitritt der DDR zum Warschauer Pakt, in: BArch Va 75468.

(Retrieved from online archive of the Bundesarchiv: https://www.bundesarchiv. de/oeffentlichkeitsarbeit/bilder_dokumente/oo827/index-8.html.de)

Russian \& East German Documents on the Horn of Africa, 1977-78, Cold War International History Project Bulletin Issues 9-10, New East-Bloc Evidence on the Cold War in the Third World and the Collapse of the Détente in the 1970, Woodrow Wilson International Center for Scholars, Washington, D.C., Winter 1996, 50-219, Retrieved from http://www.wilsoncenter.org/sites/ default/files/CWIHPBulletin8-9_tableofcontents.pdf.

Additions to 2 February 1977 Report by Third African Department, Soviet

Foreign Ministry, on "Somalia's Territorial Disagreements with Ethiopia and the Position of the USSR," apparently in late May-early June 1977, 63.

Conference of Deputy Chairman of the State Council of Cuba Carlos Rafael

Rodriguez with U.S. Secretary of State Alexander Haig, in Mexico, 23

November 1981, "Year of the 2oth Anniversary of Victory at Playa Giron", 207-215.

Third African Department, Soviet Foreign Ministry, Information Report on

Somali-Ethiopian Territorial Disputes, 2 February 1977, 52 f.

Soviet Ambassador to Ethiopia A.P. Ratanov, Memorandum of Meeting with Mengistu, 10 September 1977, 78 f.

Soviet Foreign Ministry and CPSU CC International Department, Background Report on the Somali-Ethiopian Conflict, 3 April 1978, 92-94. 


\section{Quoted Archival Material}

Abkommen zwischen der Regierung der DDR und der Regierung der VDRJ über die Ausbildung von Militärkadern der Streitkräfte der VDRJ in der DDR vom 11.6.1981, in: BArch, DVW 1/54328.

Abkommen zwischen der Regierung der DDR und der Regierung der VDRJ über die Ausbildung von Militärkadern der Streitkräfte der VDRJ in der DDR vom 1.6.1989, in: BArch, DVW 1/43671, Bl. 171ff.

Abschrift einer IM-Information der HA VII, Abt.1, February 28 1990, in: BStU MfS HA VII 7054, 51-53.

Abschrift zur Entwicklung in der VDR Jemen, HA II/14, March 13 1986, in: BStU MfS ZAIG Nr.6725, 83-85.

Aktennotiz über den Besuch der Delegation des Aden Trades Union Congress beim Bundesvorstand des FDGB, from 24 February to 1 March 1965, in: PA AA, MfAA C 1226/71,125-129.

Aktenvermerk zum Besuch des Innenministers der VDRJ in Berlin, Sekretariat des Ministers, October 8 1969, in: BStU MfS Abt. X Nr.234 Teil 1von 2, 365.

Aktenvermerk über eine Gespräch mit Herrn Alaini, Vertreter der Aden-TUC im Allarabischen Gewerkschaftsbund (ICATU) am 4.Dezember 1961 in den Räumen des Büros des Bevollmächtigten der DDR in der VAR, in: PA AA, MfAA, C 1224/71, 145-147.

Anlage - Abrechnung und Nachweisführung der Baumaßnahmen für das Objekt „Freund“ im Jahre 1986, in: BStU, MfS, Abt. Finanzen Nr. 85, 29.

Bericht Besuch des IM „Klaus Winter“, 1989, in: MfS HA VII 7054, 54-58. Bericht des ZK der SED an den XI. Parteitag der SED, April 17 1986, 41ff, in: Protokoll der Verhandlungen des XI: Parteitags im Palast der Republik in Berlin 17. Bis 21. April 1986, Berlin (Ost), 1986.

Bericht über den Aufenthalt einer Delegation des MdI in der VDRJ, July 25 to August 1 1989, in: BStU MfS HA VII7954, 43ff.

Bericht über den Aufenthalt der Studiendelegation des Ministeriums der Justiz in der VDR Jemen in der Zeit vom 14. - 25.2.1988 [sic!], February 26 1988, in: BStU MfS Abt.X Nr.234, Teil 1 von 2, 189-198.

Bericht über den Besuch des Ministers für Auswärtige Angelegenheiten der VDRJ, Mohammed Saleh Aulaqi in der DDR in der Zeit vom 1. bis 5.Februar 1972, PA AA, MfAA, C 156276, 55-61.

Bericht über die ADR nach Nord- und Südjemen, Arbeitsgruppe BKK, January 30 1989, in: BStU MfS BKK Nr.95 Teil 1 von 2, 30-36.

Bericht über die Dienstreise in die VDRJ vom 1.9. bis 3.10.1986, October 10 19786, in: BStU MfS Abt. X Nr.234, Part 1 of 2, 283-286.

Bericht über die durchgeführte Dienstreise nach Sanaa vom 9.1.-11.1.1989, in: BStU MfS Ag BKK NR.95 Teil 1 von 2, 79 - 82.

Bericht über die Ereignisse auf der Auslandsbaustelle „Bridges Reconstruction in Aden“ im Januar 1986, January 29 1986, in: BStU MfS ZAIG Nr.6725, 245-251. 
Bericht über die erste Zusammenkunft des neueingesetzten VO des KfS der

VDR Jemen beim MfS, Mohammed Abdo Mohammed, August 21 1986, in:

BStU MfS, Abt. X Nr.234 Teil 1 von 2, 262-265.

Bericht über die finanzökonomische Anleitung in der Ministerratsgruppe der

Volksdemokratischen Republik Jemen in der Zeit vom 3.7. bis 5.7.1987, BStU

MfS Abt. Finanzen Nr.85, 6o-66.

Bericht über die Reise einer Delegation des MdI in die VDRJ, Januar 1986, in:

BStU MfS HA VII 7954, 59-63.

(Bericht „Carlos“, February 10 1981) Bericht über die Tätigkeit terroristischer

Organisationen, unter besonderer Beachtung der „Organisation

Internationale Revolutionäre“, die vom bekannten Terroristen „CARLOS“

geleitet wird, February 10 1981, BStU MfS HA XXII Nr.20004, 28-40.

Bericht über eine Dienstreise in die VDRJ vom 22.3. bis 3.4.1977 by Scheidig, in:

PA AA, MfAA, C 1874, 60-74.

Bericht über eine Dienstreise zum Komitee für Staatssicherheit der

Volksdemokratischen Republik Jemen, 14.Februar 1984, Stellv. Leiter der

Abt.N. Oberst Albrecht, in: BStU MfS Abt.N Nr.120, 19-31.

Bericht ueber eine Reise der Genossen Karl Wildau und Wolfgang Unger auf

Einladung des MfAA in die 5.Provinz der VSRY, Aden, December 4 1968, in:

PA AA, MfAA, C 122571, 69.

(Bericht „Carlos“, January 10 1980) Bericht über politisch-operative Erkenntnisse

zur Herausbildung, Stellung, ideologischen Positionen, Plänen und

Absichten, Mitgliedern, Verbindungen der „Carlos“-Gruppierung und der sich daraus ergebenden Gefahren und Sicherheitsrisiken für die DDR und die anderen sozialistischen Staaten, January 10 1980, in: BStu MfS HA XXII Nr.11, 231-275 232.

Beschluß des Politbüros, Protokoll Nr. 49/77, December 20 1977, in: BArch,

SAPMO, DY JI 2/2 1705.

Beschlußvorlage [sic!] zur Konzeption Entwicklung der politischen,

ökonomischen und kulturellen Beziehungen zur VDRJ 1968 ausgearbeitet

durch MfAA und MAW, in: PA AA MfAA C 1219/71.

Beziehungen der Polizei und innerer Organe zu Südjemen 1968-1970 (Relations

of Police and Inner Security to Southern Yemen 1968-1970), in: Political

Archive of the German Foreign Office, PAAA MfAA C $760 / 73$.

Blitz Telegramm Seidel an MfAA über eine ausführliches Gespräch mit Ad-dali

[sic!], March 20 1989, in: BStU MfS Abt.X Nr.234 Teil 1von 2, 60-62.

Brief Ali Nasir Mohammed an Erich Honecker, March 16 1987, BStU MfS HA II Nr.28714, 182-188.

Brief an HA I Kommando Landstreitkräfte Unterabteilung Stab, November 28 1984, in: BStU MfS HA I 13551, 26.

Brief Botschaft der VDRJ in Berlin, January 19 1983, in: BStU MfS Abt.X Nr. 234 Teil 1 von 2, 438.

Brief Bollmann an Sittig, December 4 1978, in: PA AA, MfAA, C 1874, 143. 
Brief Bollmann der HA IV Abt.II an Kopp, Oct 17 1977, in: PA AA, MfAA, C 1874, 94. Brief Bollmann (Botschaft Aden) an Sittig, Oct 31 1971, in: PA AA, MfAA, C 1874, 141. Brief HA XX Kienberg an HV A Stellvertreter, January 28 1982, in: BStU MfS AP Nr.68777-92, 27f.

Brief Lugenheim an Scharfenberg zu Scharfenbergs Jahresbericht, 29 April 1973, in: PA AA, MfAA, C 1555/76, 2-3.

Brief Oskar Fischer an Joachim Herrmann, Mitglied des Politbüros und Sekretär des ZK der SED, 1979, in: PA AA, MfAA, C 4959, 21-27.

Brief Scharfenberg and Grünheid, Ministry of Planning, January 11974 , in: PA AA, MfAA, 166276, 78f.

Brief Scharfenberg an Rost, December 20 1973, in: PA AA, MfAA, C 1555/76, $116 \mathrm{f}$. Brief Scharfenberg an Scholz, December 5 1972, in: PA AA, MfAA, C 1556/6. Brief Scharfenberg an Willerding, Aden, July 25 1973, in: PA AA, MfAA, C $1555 / 76,52$.

Brief Scharfenberg an Willerding, Aden, March 20 1974, in: PA AA, MfAA, C $1555 / 76,4 \mathrm{f}$.

Brief Stellvertreter HVA an MfS Abt. Finanzen Oberst Hennig, November 30 1977, in: BStU MfS Abt.Finanzen Nr.1419, 161-163.

Brief Wildau an Kämpf January 23 1969, in: PA AA C 1125/71, 63-65.

Brief Winzer an Dickel, December 1968, sine diem, Beziehungen zur Polizei und innerer Organe der Volksrepublik Südjemen, PA AA, MfAA, C 76073, $15 \mathrm{ff}$.

Brief Winzer an Minister für Landwirtschaft und Bodenreform Ahmed Saleh al-Shair, June 1968, in:PA AA, MfAA, C 1226/71, 37.

Briefe Winzer an Stoph, Weiß, Sölle, Schürer, August 1968, in: PA AA, MfAA, C $1219 / 71$.

Brief Winzer an W. Stoph und Prof. K. Hager, June 12 1969, Berlin, in: PA AA, MfAA, C 1219/71, sine pagina.

Brief Zscherpe an Winzer, August 21 1968, in: PA AA, MfAA, C 1219/71, sine pagina.

Bulletin des Presse- und Informationsamtes der Bundesregierung, Nr. 112, September 7 1968, in: PA AA MfAA C 753/73, 13.

Der außerordentliche und bevollmächtigte Botschafter der DDR in der Volksrepublik Südjemen Wildau an Generaldirektor des Allgemeinen Deutschen Nachrichtendienstes Genossin Deba Wieland, March 9 1970, in: BArch DC 9oo/410.

Der Generalsekretär Robaya Ali, June 22 1971, in: PA AA, MfAA, C 1555/76, 169 . Dertinger, Georg, stenographisches Protokoll der Tagung der Chefs der Missionen der DDR, 3.Tag, March 9 1951, in: PA AA, MfAA, A 15465. Direktive für die Reise einer Delegation des Ministeriums für Volksbildung in VDR Jemen [March 1 to April 24 1977], in: PA AA, MfAA, C 1874, 49-51. Einschätzung der Ergebnisse der bisherigen DDR-Regierungsberatertätigkeit mit Schlußfolgerungen für das weitere Vorgehen auf diesem Gebiet in der VDRJ, June 27 1972, in: PA AA, MfAA, C 156276, 33-52. 
Einschätzung über Mohammed Saleh Yafai, Minister des Innern der

Volkrepublik Südjemen, in: BStU MfS Abt.X Nr.234 Teil 1 von 2, 331.

Erzeugnis 940 - Sturmgewehr, August 23 1988, Habe nicht, BStU MfS AG BKK Nr.98, 226-229.

Fragen für die Fragestunden der Sitzungen des Deutschen Bundestages am Mittwoch, dem 14. September 1977 und am Donnerstag, dem 15. September 1977, Deutscher Bundestag, 8.Wahlperiode, Drucksache 8/885, September 9 1977, in: http://dipbt.bundestag.de/doc/btd/o8/008/080o885.pdf.

Geheim. Übersetzung aus dem Russischen. Auskunft über die Reaktion des Ministeriums für Staatsicherheit der VDRJ auf die Tätigkeit der Anhänger von A.N. Muhammed [sic!] in den sozialistischen Ländern, 1987, in: BStU MfS HA II Nr. 22860, 151-155.

Gesprächskonzeption über die am 16.8. - 17.8.1979 durchzuführende Beratung mit Vertretern der CSSR-Sicherheitsorgane in der CSSR-Hauptstadt - Prag, August 14 1979, BStU MfS HA XXII Nr.20004, 9- 27.

Glückwunschschreiben Saeed Saleh Salem an Erich Mielke, February 5 1989, in: MfS BStU Abt.X 234 Teil 1 von 2, 34f.

Hilfeleistungen gegenüber jungen Nationalstaaten auf nichtzivilem Gebiet. Übersicht über Ausgaben [...] von 1967 bis 1976, Abt. Fianzen an HV A/III, 26.April 1977, in: BStU MfS Abt. Finanzen Nr. 1393, 151- 161 (166 including notes).

Hinweise für das persönliche Gespräch mit dem Minister für Staatssicherheit der VDR Jemen, Saeed

Saleh Salem 25.5.1988, in: BStU MfS ZAIG Nr.5119, 1-10.

IM „Dieter Gerlach“, in: BStU MfS HA VII 5012, 4 ff.

Informationen zu einigen inneren und äußeren Problemen der VDRJ, Aden, February 6 1973, in: PA AA MfAA C 1555/76, 100.

Information Nr. 70/IV Erdölförderung in der VDRJ, MfAA, Jun 13 1988, in: BStU MfS HA II Nr.28714, 267.

Informationsbericht über die Lage in der VDRJ, January 25 1986, in: BStU MfS ZAIG Nr.6725, 238-243.

Informationsmappe für den Besuch des Generalsekretärs des Zentralkomitees der Jemenitischen

Sozialistischen Partei [...] Ali Nasser Mohammed, November 1984, in: BStU MfS HA II Nr. 28712, 131-184.

Informationstelegramm Wildau to the MfAA, October 30 1968, in: PA AA C 1125/71, 118-120.

Information über die Entwicklung in der Volksdemokratischen Republik Jemen und internationale Reaktionen, January 1986, No.29/86, BStU MfS HVA Nr. 40, Part 1 of 2, 338-343.

Information über die Entwicklung in der Volksdemokratischen Republik Jemen und internationale Reaktionen, February 1986, No.77/86, BStU MfS HVA Nr. 40, Part 1 of 2, 178-186. 
Information über die Entwicklung in der VDR Jemen, in: BStU MfS HVA 81, August 1978, Part I of I, Nr. 35/78, 110ff.

Information über die innen- und außenpolitischen Probleme in der JAR (Nordjemen) und der VRSJ (Südjemen), September 1970, No.983/70, BStU MfS HVA Nr. 172, Part 2 of 2, 360-367.

Information über die Lage in der Volksrepublik Südjemen, 1969, in: BStU HVA Nr.151, 172-177.

Information über die politisch-militärische Lage der Volksdemokratischen Republik Jemen (VDRJ), 1972, in: BStU MfS HVA 388, 277-280.

Information über einige innen- und außenpolitische Entwicklungstendenzen in der VDR Jemen, September 14 1976, in: BStU MfS HVA Nr. 125, 19-26.

Information über die Zusammenarbeit der „Carlos“-Gruppierung mit der VDRJ, in: BStU MfS HA XXII Nr.17191, remnant, sine anno, sine pagina.

Information zum ehemaligen führenden Funktionär der Jemenitischen

Sozialistischen Partei der VDR Jemen, Abubaker Abdulrazzag Badheeb, January 141987 (?), in: BSTU MfS HA II Nr. 28714, 131-133.

Instructions for the Soviet ambassador in Cairo, May 16th 1969. in: BArch

SAPMO, DY 30/3524, 108- 111.

Jahres- und Quartalsberichte der AV in Südjemen 1966-1970 (Annual Report

Aden Consulate 1966-1970), in: PA AA MfAA, C 744/73.

JSP - Avantgarde des jemenitischen Volkes. Auszüge aus dem Programm der

Jemenitischen Sozialistischen Partei (I) und (II), in: horizont No.50/51 1978,

in: BStU MfS HA II Nr.27368, 4-11.

Lieferungen von Waffen und Ausrüstungen in die Demokratisch Volksrepublik Jemen, in: BStU MfS Sekretariat des Ministers 668.

Konzeption für die Durchführung einer Dienstreise im Rahmen der Aktion „Netzwerk 3“, in: BStU MfS HA III Nr.8, 212-215.

Konzeption für die Durchführung eines Sonderlehrganges zur Ausbildung von

Mitarbeiter des MfS VDR Jemen, Section X to Section XXIII May 4 1988, in: BStU MfS Abt. X Nr. 234, Part 1 of 2, $125 \mathrm{f}$.

Konzeption für ein Gespräch mit dem Vorsitzenden des MfS der VDR Jemen zur Fragen des Terrorismus, November 12 1980, in: BStU MfS HA XXII Nr.20004, 51-54.

Korrespondenz Oberst Kempe (Abt.X) und Oberst Machts (HV A),

Zusammenarbeit mit den Sicherheitsorganen der VDRJ, February/March 1989, in: BStU MfS Abt.X Nr.324 Teil 1 von 2, 23-25.

Landwehr, Andreas, Suedjemen. Das Sowjetische Dilemma am “Tor der

Traenen”, Januar 1986, in: BStU MfS HA III Nr.5922, 14.

Letter to Dickel, July 12 1978, in: BStU MfS AGM Nr.430, 63.

Maßnahmen zur solidarischen Unterstützung der Sicherheitsorgane der VDR

Jemen, May 2 1988, in: BStU Sekretariat Schwanitz 24, 5.

MAW Brief von Clausnitzer, Ministerium für Außenwirtschaft,

Direktionsbereich Übersee, in: PA AA, MfAA, C 121971. 
MfNV (Ministry of National Defence), Minister of Defense Keßler to Honecker,

May 18 1987; Honecker's positive response, May 19 1987, in: BArch, AZN 32673, Bl. $12 \mathrm{ff}$.

Korrespondentenbüro/Ausland an Direktion Genosse Wieland, Berlin, July 9 1969, in: BArch 900/537, sine pagina.

Neiber an Mielke, April 25 1984, in: HA III 11099, 121.

Oberst Fiedler HV A III an MfS Abt.X Geberalmajor Damm, May 13 1980, in:

BStU MfS Abt.x Nr.234 Teil 1 von 2, 392.

Operative Einschätzung des GMS “Leonhardt"-Vorg.-Nr.XV 3481/82, August 28 1986, in: BStU MfS AGMS Nr.1020-88, 66-68.

Operativ-Information zu Gesprächen der „Carlos“-Gruppierung mit einem Vertreter des irakischen Geheimdienstes, March 10 1980, in: BStU MfS HA XXII Nr.20004, 1-6.

Ordnung für die Koordinierung und Abrechnung der Hilfeleistungen der

DDR gegenüber Entwicklungsländern, in ökonomischer Hinsicht weniger entwickelten sozialistischen Ländern, Beschlüsse des Sekretariats, Oktober 1988, in: BArch, SAPMO, DY 34/13551.

Otto Winzer an Willy Stoph, May 28 1965, in: BArch, DC 20/13001, Bl.28-33. Planvorschlag 1986 und Plankorrektur 1985, Ministerrat der DDR an MfS Leiter der Abteilung Finanzen, July 18 1985, in: BStU MfS Abt. Finanzen Nr.3492, 45. Plenarprotokoll 8/50 Deutscher Bundestag, Stenographischer Bericht, 50.

Sitzung, Bonn, Donnerstag, den 20 . Oktober 1977, Retrieved from http:// dipbt.bundestag.de/doc/btp/08/08050.pdf.

Politbürositzung January 10 1967, Annex 5, in: BArch SAPMO, DY 30/J IV $2 / 2 / 1093$.

Programm für den Besuch S.E. MfL der VDRJ Herrn Achmed Salem Ashair [sic!] am 12. Und 13. Juli 1968 in Berlin, in: PA AA, MfAA, C 753/73, 14-16. Protokoll der Verhandlungen des V. Parteitages der SED, 10th-16th July 1958,

Dietz Verlag, Ost-Berlin, 1959.

Protokoll Nr.8/63 der Sitzung des Politbüros, March 27 1983, Annex 5, in: BArch SAPMO, DY30/JIV 2/2 A 953.

Protokoll Nr.23/87 der Sitzung des Politbüros, June 9 1987, BArch, SAPMO, DY $30 / J$ IV 2/2/2224.

Protokoll Politbüro Nr.49/77 12 December 1977, Annex 13, Bl. 156, in: SAPMO BARCH, DY3O J IV2/2 1705.

Protokoll zur Vereinbarung über die Zusammenarbeit zwischen dem des Innern der DDR und dem Ministerium des Innern für den Zeitraum 1989 bis 1991, January 1989, in: BStU MfS HA VII Nr.1094, 12-16.

Protokoll über die Maßnahmen der Zusammenarbeit zwischen dem Ministerium für Staatssicherheit der DDR und dem Ministerium für Staatssicherheit der VDRJ für die Jahre 1988/1989, in: BStU MfS Abt.X Nr.234 Teil 1 von 2, 10-16. 
Protokoll über die vorgesehenen Maßnahmen der Zusammenarbeit zwischen dem MfS der DDR und dem KfS der VDRJ im Jahre 1980, November 17 1979, in: BStU MfS Abt. X Nr. 1767.

Protokoll über Maßnahmen der Zusammenarbeit zwischen dem MfS der DDR und dem KfS der VDRJ für das Jahr 1983, in: BStU MfS Abt.X Nr. 1811.

Protokoll zwischen dem MfS der DDR und dem KfS der VDRJ vom November 17 1979, in: BStU MfS Abt X Nr.1763.

Protokoll 1.Sitzung Kommission zur Koordinierung der ökonomischen, kulturellen, wissenschaftlich-technischen Beziehungen und der Tätigkeit im nichtzivilen Bereich der Länder Asiens, Afrikas und des arabischen Raumes („Mittag- Kommission“), Januar 5 1978, in: BArch, DE 1/54880.

Protokoll 11. Sitzung Komitee der Verteidigungsminister TS des Warschauer Vertrages vom 4 bis 7.12 1978, Ost-Berlin, in: BArch DVW 1/71035, 318-357. Protokoll 12. Sitzung Komitee der Verteidigungsminister TS des Warschauer Vertrages vom 2 bis 6.12 1979, Warschau, in: BArch DVW 1/71036, sine pagina.

Quartalsbericht I/69, Volksrepublik Südjemen, Abt. Arabische Staaten, in: PA AA, MfAA, C 744/73.

Quartalsbericht III/69, Volksrepublik Südjemen, Abt. Arabische Staaten, in: PA AA, MfAA, C 744/73.

Quartalsbericht IV/69, Volksrepublik Südjemen, Abt. Arabische Staaten, January 20 1970, in: PA AA, MfAA, C 744/73.

Redaktion für Auslandssendungen an Korr-Büro Ausland, HA Kader/Bildung, Betr. ADN-Mitarbeiterin in der Volksrepublik Südjemen, August 21 1970, in: BArch DC 9oo/410.

Reisebericht über eine Dienstreise im Rahmen der Maßnahme „Netzwerk III“, in: BStU MfS Abt.X Nr.234 Teil 1 von 2, 26-32.

Report on Carlos‘ future moves, dated probably before 1981, in: BStU MfS HA XXII Nr.17191, 51-54.

Schreiben Horst Männchen Abt. III an Stellvertreter des Ministers, Bruno Beater: Konzeption zum Aufbau einer Funkabwehr in Äthiopien und Jemen (VDRJ), February 23 1978; BStU, MfS, HA III 11787, 312-314;

Schreiben Horst Männchen Abt. III an den 1. Stellvertreter des Ministers, Generalleutnant Bruno Beater, Meldung zur Aktion „Netzwerk 3“, November 3 1978: BStU, MfS, HA III 680, 29.

Schwab, Sepp, in: Department for the work in the countries of Africa, Southeast Asia and Latin America on the occasion of a joint consultation of the MfAA and the Heads of the GDR's diplomatic representations on 19th and 2oth of December 1960, in: PA AA, MfAA, A 15489.

Sendungen 1965-1982, in: BStU MfS BCD Nr.20802, 93.

Sharabi, Al-Thaura Journalist, People's Republic of Southern Yemen, in: PA AA, MfAA, C 122571, 110-123. 
Sofortinformation AG Ausländer an HA II, February 26 1979, in: BStU MfS HA II Nr. $27850,46$.

South Yemen-USSR: Outlook for the Relationship, Secret, National Intelligence

Estimate, CIA, April 5 1984, Retrieved fromhttp://www.foia.cia.gov/sites/

default/files/document_conversions/89801/ DOC_oooo681975.pdf

(published 2001; latest access September 12 2014).

Stellungnahme zum politischen Fehlverhalten des Genossen [geschwärzt], March 17 1986, Verband der Journalisten der DDR, in: BStU MfS HA XX Nr.13169, $179 f$.

Stellungnahme zur Vorlage für das Politbüro des ZK der SED. „Entwicklung der mehrseitigen Zusammenarbeit der RGW-Länder mit der VDR Jemen“, August 18 1986, in: BStU MfS HA XVIII 21008, 57.

Stellvertreter Operativ: Konzeption zur Vorbereitung und Durchführung der Aktion »Netzwerk 4 « in der Abt. III in Zusammenarbeit mit der HV A, March 31 1980, in: BStU, MfS, HA III 11787, 371-389.

Stenografische Niederschrift der Beratung mit der Delegation der NLF

Südjemen am 2.11.1970 im Hause des ZKs, (Minutes of Consultations with

NLF Delegation on 2nd Nov 1970), in: BArch SAPMO/DY 30/11407.

Stenografische Niederschrift der Beratungen der Partei- und

Regierungsdelegationen der DDR und der VDRJ im Hause des ZK der SED in Berlin, 1. Beratungstag: Freitag: den 28. Juli 1972, Minutes of Consultations with NLF Delegation on 28th July 1972), in: BArch SAPMO/ DY $30 / 11408$.

Stenografisches Protokoll. Offizielle Gespräche zwischen dem Generalsekretär des ZK der SED und Vorsitzenden des Staatsrates der DDR, Genossen Erich Honecker, und dem Generalsekretär des ZK der Jemenitischen Sozialistischen Partei, Vorsitzenden des Präsidiums des Obersten Volksrates und Vorsitzenden des Ministerrates der Volksdemokratischen Republik Jemen, genossen Ali Nasser Mohammed, am 9.11.1984, in: BArch, SAPMO/ DY $30 / 11408$.

Strukturen des MfS der VDR Jemen; Zur Lage des MfS der VDR Jemen; Kadersituation des MfS der VDR Jemen in: BStU MfS Abt. X Nr. 234, Part 1 of 2, 93-107.

Telegramm Aden an Schalck-Golodkowski August 15 1988, in: BStU MfS AG BKK Nr.1661 Bd.2, 125 .

Telegramm (Blitz) Botschaft Moskau an Sieber, Krolokowski, Winter, Steinhofer, Neumann, Betreff: NO-Verwaltung MID zu Besuch Al-Beedh February 9 to 11, February 10 1987, in: BStU MfS HA II Nr.28714, 159-161.

Telegramm Jagenow Addis Abeba an Axen, Fischer, Sieber ZK IV, König, January 28 1986, In. BStU MfS ZAIG Nr.6725, 8.

Telegramm Krauße, Aden an König, Sieber, Bunkert, Winter, Jaunary 17 1986, in: BStU MfS ZAIG Nr.6725, 159. 
Telegramm Sanaa an Schlack-Golodkowski, January 2 1989, in: BStU MfS AG BKK Nr.174, 106.

Telegramm Seidel an Ost-Berlin, February 8 1988, handwritten notes by Seidel in: BStU MfS HA VII 7054, 92.

Telegramm Seidel an Ost-Berlin, March 9 1988, in: BStU MfS HA VII 7054, 93. Telegramm Seidel an Ost-Berlin, June 20 1988, in: BStU MfS HA VII 7054, 90. The Department of the Head Deputy of the Section International Relations at the Central Committee of the SED, Training of Party Secretaries of diplomatic representations from August 11 to 18 1967, in: BArch, SAPMO, DY 30/IV A 2/20/1141

Talks between GDR diplomats and functionaries of third countries 1965-1969, in: Political Archive of the German Foreign Office, PAAA, MfAA, C 1224/71. Vereinbarung über die Zusammenarbeit zwischen dem Ministerium für Staatssicherheit der Deutschen Demokratischen Republik und dem Komitee für Staatssicherheit der Volksdemokratischen Republik Jemen, November 25 1980, in: BStU MfS Abt. X 1789.

Vermerk, February 7 1986, BStU MfS ZAIG Nr.6744, 73.

Vermerk, February 18 1986, in: BStU MfS ZAIG Nr.6744, 85f.

Vermerk Entlassung von Dr. Hassan as-Sallami, March 6 1989, HV A III, in:

BStU MfS Abt.X Nr.234 Teil 1von 2, 53.

Vermerk Genosse Oberst Fiedler, HV A III, September 5 1986, in: BStU MfS Abt. X Nr.234, Part 1 of 2, 281f.

Vermerk Telegramm aus Aden vom 20.8.1979 an Neiber, Roscher, HV A/III, August 20 1979, in: BStU MfS HA XXII Nr.20004, $7 f$.

Vermerk über die Einstellung der inoffiziellen Zusammenarbeit mit dem GMS „Leonhardt“ Reg. Nr. XV 3481/1982, October 11 1988, HA XX, in: BStU MfS AP Nr.36630-92, 48 .

Vermerk über die Aktivitäten der Anhänger Ali Nasser Mohameds [sic!] in der DDR und Ersuchen der Leitung des MfS der VDRJ zur Unterstützung des MfS/der Regierung der VDRJ bei der Bearbeitung derselben, September 8 1987, in: BStU MfS HA II Nr.22860, 156-159.

Vermerk über ein Gespräch des Genossen Kiesewetter mit dem sowjetischen

Gesandten, Genosse K.P. Kusnezow, June 11 1969, in: PA AA, MfAA, 1223/71, 64-71.

Vermerk über ein Gespräch des Genossen Kiesewetter mit dem sowjetischen

Gesandten, Genosse K.P. Kusnezow, February 1969, no day in: PA AA, MfAA, C 1223/71, 30-34.

Vermerk über ein Gespräch des Ministers für Auswärtige Angelegenheiten,

Genossen Otto Winzer mit dem Minister für Landwirtschaft und Bodenreform der VRSJ, Ahmed Saleh As-Shair [sic!], June 25 1968, in: PA AA, MfAA, C 1223/71, 27.

Vermerk über ein Gespräch mit einem Mitglied der Regierungsdelegation der Volksrepublik Südjemen, June 26 1968, in: PA AA, MfAA, C 1223/71, 3f. 
Vermerk über Hilfsleistungen, July 18 1978, in: BStU MfS AGM Nr.430, 1.

Vermerk zur Asylgewährung für Abubakr Abdulrazzaq Badheeb, HVA/III/

AG, August 5 1986, in: BStU HA II Nr. 27366, 2-5.

Volksdemokratische Republik Jemen, zur Entwicklung des Landes, 1973, in:

BStU MfS Allg. S. Nr.332/73, 6-16.

Vorgaben für die Berichterstattung zum Studien- bzw. Schuljahresabschluß [sic!] 1977/78 der Kader des Ministeriums für Volksbildung der DDR in der VDR Jemen (Anlage), 1978, sine diem, in: PA AA, MfAA, C 1874.

Vorlage für das Politbüro des ZK der SED. Betreff: Entwicklung der mehrseitigen Zusammenarbeit der RGW-Länder mit der VDR Jemen, August 18 1986, In. BStU MfS HA XVIII 21008, 56.

Vorlage zum Stand und zur weiteren Gestaltung der Zusammenarbeit mit dem MfS der VDRJ und zu dessen Unterstützung, Januar 25 1988, by Oberst Fiedler, signed by Mielke, HV A III, Jemen in: BStU MfS Abt. X Nr. 234, Part 1 of $2,134-138$.

Vorschläge für auslandsinformatorische Maßnahmen anlässlich des Besuchs einer hochrangigen

Delegation der DDR im Sozialistischen Äthiopien und in der VDRJ vom 11.Oktober 1979 der Abteilung Auslandsinformation, in: PA AA, MfAA, C 4959, 1-6.

Vorschlag für das Gespräch mit dem Innenminister der VRSJ (Oberst Jänicke), October 8 1969, in: BStU MfS Abt.X Nr.234 Teil 1 von 2, $329 f$.

Vorschlag zur Verschlüsselung [suggestion for coding; handwritten note], 1980, in: BStU MfS BCD Nr.20802, 59.

Wertmäßige Übersicht über Lieferungen in die VDR Jemen 1971-1977, Berlin, November 2 1977, in: BStU MfS BCD Nr.2854, 134f.

WTZ-Protokoll 74/75 by HA FTZ Entwicklungsländer HA-Leiter Sachse, November 6 1974, 70-72.

Wildau und Serauky zur Reise der VDRJ Delegation in arabische Länder 1972, in: PA AA, MfAA, C 1555/76, 176.

Wissenschaftlich-technische Zusammenarbeit zwischen der DDR und der VDRJ und wissenschaftlich-technische Hilfeleistung der DDR gegenüber der VDRJ in Form des Einsatzes von DDR-Beratern in zentralen Staatsorganen und im Bereich der Wirtschaft der VDRJ 1971-1974 [Abschlussbericht], in: PA AA, MfAA, C $156276,1-32$.

Ziffern-Code, GVS MfS 031-944/76, 1976, BStU MfS BCD Nr.2854, 114-116.

$\mathrm{Zu}$ den Beziehungen des MfS der VDRJ mit dem MfS der DDR und mit

Sicherheitsorganen anderer

Länder, in: BStU MfS Abt. X Nr. 234, Part 1 of 2, 101-116.

Zum Gespräch [der AASK Delegation] mit dem Leiter des Büros der PFLOAG in Aden, Youssuf Taher, March 6 1973, in: PA AA, MfAA, C 1555/76, 86.

Zur Lage in der VDRJ - Stand vom 24.1.1986, January 25 1986, in: BStU MfS

ZAIG Nr.6744, 45-50. 
Zur Lage in der VDRJ - Stand 27.1.1986 - 22,00 Uhr, January 28 1986, in: BStU MfS ZAIG Nr.6744, 54-57.

Zur Lage in der VDRJ - Stand vom 28.1.1986, January 29 1986, in: BStU MfS ZAIG Nr. 6744, 58f.

Zur Lage in der VDRJ - Stand vom 29.1.1986, January 30 1986, in: BStU MfS ZAIG Nr. 6744, 6of.

Zur Lage in der VDRJ - Stand vom 30.01.1986, January 31 1986, BStU MfS ZAIG Nr.6744, 62f.

Zusammenfassender Bericht über die Dienstreise nach der VDRJ vom 25.2. bis 11.3.1988, March 18 1988, in: BStU MfS Abt. X Nr. 234, Part 1 of 2, 163-170. Zusammenfassung der wichtigsten Feststellungen und Gespräche während des Aufenthaltes in der VDRJ am 02. und 03.09.1987, Fiedler HV A III, September 14 1987, in: BStU MfS Abt.X Nr. 234 Teil 1 von 2, 227-244.

Zusammenstellung des MfS für Hilfeleistungen an junge Nationalstaaten 1978 , December 15 1978, in: BStU MfS Abt. Finanzen Nr.1393, 149. 